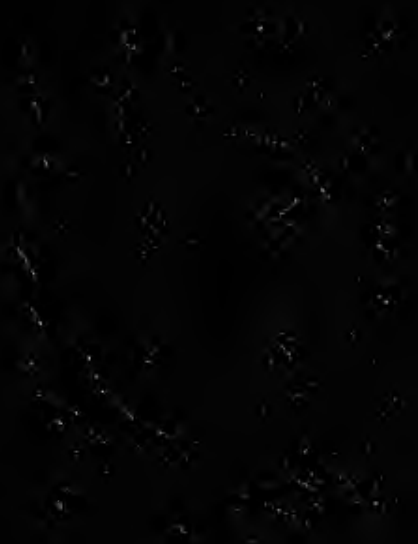


Digitized by the Internet Archive in 2007 with funding from Microsoft Corporation 


\section{AN INTRODUCTION TO THE STUDY OF \\ INTERNATIONAL ORGANIZATION}




\section{THE CENTURY \\ POLITICAL SCIENCE SERIES \\ EDITED BY \\ FREDERIC A. OGG, \\ University of Wisconsin.}

Introduction to American Government. By Frederic A. Ogg, University of Wiseonsin, and P. Orman Ray, Northwestern University.

American Parties and Elections. By Edward M. Sait, University of California.

State Government in the United States. By Walter F. Dodd, Chicago, Illinois.

Municipal Government. By Thomas H. Reed, University of California.

Constitutional Law of the United States. By Edward S. Corwin, Princeton University.

Constitutional History of THE. UNITED Btates. BJ Andrew C. MeLaughlin, University of Chicago.

The Conduct of american Foreign Reuations. By John M. Mathews, University of Illinois.

Outuines of Worid Politics. By Herbert Adams Gibbons, Princeton, New Jersey.

European Diplomacy, 1914-1921. By Charles Seymour, Yale University.

Introduction to the Study of INTERnational Organization. By Pitman B. Potter, University of Wiscon. sin.

American Interests aNd Policies in the Far East. By Stanley K. Hornbeck, Washington, D. C.

Latin Amerioa aNd the United States. By Graham H. Stuart, University of Wisconsin.

Recent and Contemporary Political Theory. By Francis W. Coker, Ohio State University.

Elements of International Law. By Charles G. Fenwick, Bryn Mawr College.

other volumes to be arranged. 


\title{
AN INTRODUCTION TO THE STUDY OF
}

\section{INTERNATIONAL ORGANIZATION}

\author{
BY \\ PITMAN B. POTTER, Pн.D. \\ ASSISTANT PROFESSOR OF POLITICAL SCIENCE, \\ UNIVERSITY OF WISCONSIN
}

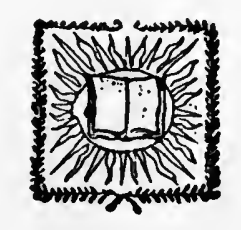

NEW YORK

THE CENTURY CO.

1922 
Copyright, 1922, by

The Century Co.

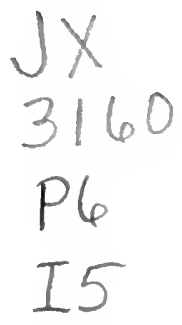

Printed in U. 8. A. 
To

MY MOTHER

LOUISA A. POTTER

GRATITUDE AND RESPECT 



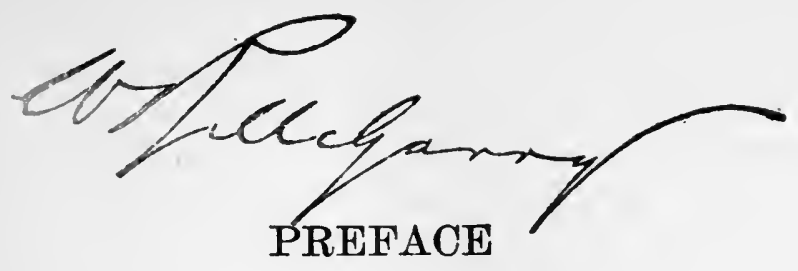

In the pages which follow I have attempted to do three distinct things. First, I have tried to show that international organization is not a new thing in world history,nor a reform proposed for the future,-but a political system of long standing which deserves to be studied as such. Second, I have tried to show how this standing system of international organization has expanded and developed, particularly in the past century, and to set forth the causes which will probably lead to a continuation and intensification of that process in the future. Finally, I have expressed the conviction that such a process is salutary, in that it meets a real need of the world today, and have attempted to make some suggestions regarding steps which might profitably be taken in the improvement and development of the existing institutions of international government.

The task of recording and explaining existing international institutions and practices becomes daily more diffcult, because of the rapidity with which activities in this field are being expanded. In every branch of international organization dealt with in this volume, particularly in Parts V, VI, and VII, new steps are constantly being taken, and it is almost impossible for the student to keep himself informed of these advances, to say nothing of digesting and recording all the information relating to these matters which comes pouring in through official documents, current newspapers and periodicals, and private writings.

For this reason I hope that where the account given appears to be inaccurate or out of date the reader will remember that my object is not to describe exhaustively vii 
and finally the international organization of the world, but to provide an introduction to the study of that subject, by describing basic institutions and analysing the principles underlying them. For this reason also I have not tried to bring the record in Part VIII down to the last minute, but have left it at a juncture where one movement - that of the League-reached a definite point in its development, and a new one-the Washington Conferencebegan.

The League of Nations has been taken as the culmination of international constitutional growth in the past, and the treatment of certain subjects in various chapters has been arranged with this in mind. Thus, the development of international organization has been carried down only to 1918 in Parts I-VI, with the exception of certain materials in the later portions of Chapters IV, XVI, and XXI; the League is presented as the last stage in the process of creating world government; and the events of 1920-21 have been treated mainly in their relations to the League. For this there seems to be ample justification. In its essential character, and in the magnitude of the effort which it represents, the institution of the League of Nations is comparable in world history only with the adoption of the Constitution of the United States in the history of the American nation. Defective it is, and final in its present form it most certainly is not; but whatever is done in the future in the direction of general international organization will be done by way of modification of, or additions to, the present League. If the importance of the League is to be minimized at all, it is not because of anything directly connected with its own organization and methods, but only by recalling the great amount of international organization of the simpler types, such as diplomacy, treaties, and conferences, which exists apart from the League.

My object being to provide a volume useful to college students and to general readers, I have, with a view to 
making reference work simpler for the student, confined my references to general and secondary materials; references to relatively inaccessible materials and to works in languages other than English have been reduced to a minimum. I am particularly indebted to certain writersfor example, Hershey, Phillipson, and Satow,-because of the serviceableness of their works as reference books. Ample introduction to the more highly specialized materials will be found in the books cited in the special sections in Appendix B.

The frequent references to works on international law, as well as the professional feeling of some persons who are interested in that subject, may raise a question concerning the propriety of such a work as this, distinct from a treatise on international law. To such a question my reply would be as follows: Two distinct types of material are included in the ordinary treatises on international law, namely, material descriptive of the institutions for regulating and conducting international relations, and of their methods of operation in practice, and material stating the recognized rights and duties of states. The latter, and only the latter, is international law proper. The former is political science, descriptive and analytical. International law proper should be handled by lawyers as law; it should be purified of non-legal materials. When that is done it will not be so likely to appear to the legal profession as near-law, or imitation law. International organization will also profit in its turn by receiving due attention in its own name. The vast stretches of material in the works of international law descriptive of the machinery of world government are no more in place in such works than would be a description of the courts in a treatise on private law. These materials should, however, be brought together in a work such as I have here tried to produce.

I am happy to have this opportunity to express to Pro- 
fessor James Wilford Garner, of the University of Illinois, my appreciation of the opportunity to work into this particular field of study, as distinct from international law, which he was the first to give me, and to Professor Frederic Austin Ogg, the editor of the series in which this volume appears, for a laborious and exceedingly helpful revision of the text. I am glad, also, to have the chance to record my thanks to my wife, Jessie Dalton Potter, for the patience with which she has served as audience for a perpetual lecture on this subject, and for her many sympathetic suggestions as I have worked out the subject in my own mind, during the past few years.

Pitman B. Potter.

University of Wisconsin,

Christmas, 1921. 


\section{CONTENTS}

CHAPTER
PAQE

I Introductory: Terms and Principles . . . . . . 3

PART I. ORIGIN AND NATURE OF THE MODERN STATE-SYSTEM • . • • . • • • • . • . . 21

II State-Systems of ANtiquity . . • . • . • . . . 23

III Mediefal State-Systems . . • . . • . • . . . 33

IV Rise of the System of National States . . . . . . 42

PART II. MODERN DIPLOMACY . . . . . . . 61

V Origin and Developaent of the Consular System . • . 63

VI Organization and Functions of the Consular Service • 71

VII Origin and Development of Modern Diplomacy . • • 84

Vili Organization and Practice of Diplomact . . . . 100

IX Criticism or Modern Diplomacy . . . . . . . . 123

PART III. 'TREATIES AND INTERNATIONAL LAW • 139

$X$ Treaty Negotiation . . . . . . . . . . . . 141

XI The Modern Treaty System . . . . . . . . . . 156

XII Treaties and the Development of International LaW 172

PART IV. INTERNATIONAL ARBITRATION . . . 191

XIII Good Offices and Mediation; Commissions of Inquiry - 193

XIV History and Theory of International ARbitration before 1899 . . . . . . . . . . . . . . . . . 210

XV The hague Arbitration System . . . . . . . . 228

XVI Proposed International Courts . . . . . . . 243 
CHAPTER

PART V. INTERNATIONAL ADMINISTRATION $\quad . \quad 267$

XVII Official Unions, Commissions, and Bureaus • • • • $\quad 269$

XVIII Private International Associatrons . • • . • . 289

XIX Modern CosmopolitanisM . . . . . . . . . 302

PART VI. INTERNATIONAL CONFERENCES AND CONGRESSES . . . . . . . . . . . . . . . 315

XX International Conferences in Time of Peace; the Hague Conferences . . . . . . . . . . . . . 317

XXI Peace Conferences; the Conference of Paris . . . . 336

XXII The Problem of Peace and Its Relation to International Organization

PART VII. INTERNATIONAL FEDERATION • . . 377

XXIII The JURistic Theory of International Federation • 379

XXIV Eupire, Defensive Aluiances, and the Balance of Power 396

XXV The Holy Alifance, the Concert of Europe, and Methods of International Control . . . . . . . . . . 417

XXVI Projects for International Federation . • . . . 438

XXVII The Leaque of Nations, 1919 . . . . . . . . . 456

PART VIII. INTERNATIONAL ORGANIZATION IN 1920-1921

XXVIII The Establishment of the League of Nations aND the RESUMPtion OF INTERNATional GOVERnMENT • • • . 479

XXIX International Organization in 1921 . . . . . . . 498

Appendix A: Documents Illustrating the Development of International Organization . . . . . . . . . . . 511

1. Consular Convention between the United States and Sweden, 1910511

2. Regulations of Vienna, 1815, and Aix-la-Chapelle, 1818, Concerning Diplomatic Rank . . . . . . . . . . . . 519

3. American Foreign Service and Foreign Diplomatic and Consular Representatives in the United States in December, 1916 . $~ . ~ 520$

a. Diplomatic Service of the United States . . . . . 520

b. Foreign Diplomatic Representatives in the United States . 522 
c. Consular Service of the United States

d. Foreign Consular Officers in the United States

4. Arbitration Convention between the United States and Great Britain, 1908, with Marginal Analysis and Supplementary Documents

a. Resolution of the Senate of the United States Consenting to the Ratification of a Treaty by the President . . . . .

b. Act of Ratification of a Treaty . . . . . . . 536

c. Protocol of an Exchange of Ratifications . . . . . . 537

d. Proclamation of a Treaty by the President . . . . 538

5. Treaty of Peace, signed at Paris, 30 March, 1856, and Declaration of Paris, Adopted by Signatories Thereto

a. Treaty of Paris, 30 March, 1856 . . . . . . . 538

b. Declaration of Paris, 1856 . . . . . . . . . 543

6. Convention for the Pacific Settlement of International Disputes, Signed at The Hague, 1907

7. Convention for the Creation of an International Institute of Agriculture, 1905

8. Proposals for The Hague Conference of 1907 . . . . . 568

a. Memorandum from the Russian Embassy in Washington, Handed to the President of the United States, 13 September, 1905, Proposing a Second Peace Conference at The Hague .

b. Note from the Russian Ambassador to the Secretary of State, 3 April, 1906 . . . . . . . . . . . .

c. Note from the Russian Ambassador to the Secretary of State, Proposing the Program of the Second Peace Conference, 12 April, 1906

9. Final Act of the Second Hague Peace Conference, 1907 . . 572

10. Regulations Governing the Organization and Work of the Peace Conference of Paris, 1919 .

11. Treaty of Alliance for the Preservation of the Balance of Power, 1814

12. Act of the Holy Alliance, 26 September, 1815 . . . . . . 581

13. Program of the Concert of Europe in the Greek Question, in a Treaty of 6 July, 1827 .

14. Convention of the Concert of Europe Providing Guarantees for the Kingdom of Greece, 7 May, 1832 . . . . . . . .

15. Covenant of the League of Nations, 1919 is sos . . . . . 589 
xiv CONTENTS

PAGE Appendix B : Bibliography . . . . . . . • . . . . . 602 General . . . . . . . . • . . . . 603

Special; Reading ReFErences . . . . . . . 607

INDEX . . . . . . . . . . . . . . . . . . . . 637 


\section{AN INTRODUCTION TO THE STUDY OF INTERNATIONAL ORGANIZATION}


$+$ $\therefore$ 


\section{AN INTRODUCTION TO THE STUDY OF INTERNATIONAL ORGANIZATION}

\section{CHAPTER I}

\section{INTRODUCTORY: TERMS AND PRINCIPLES}

D

URING the past twenty-five years a new phrase has come into common speech and into the formal literature of political science: international organization. The rise of the idea which this term expresses is no less significant than was the emergence of the idea of "international law," or a "law of nations," at an earlier time. A new field of study has been opened up which is quite as definite as municipal government, state government (in the United States), or national government, and which is no less important for both layman and professional political scientist. All of these subjects of study are readily designated by reference to the community whose institutions are to be considered. It is time that we devoted more attention to the aggregate of institutions and usages for governing the modern world, in so far as the world is governed as a unit. However, it is better, for various reasons, not to employ the obvious phrase "world government," but to use a title which indicates, to some extent, the nature of the chief process by which the world has come to enjoy some measure of unified government, namely, "international organization."

The materials for this study must be drawn from widely scattered sources. Moreover, on account of the newness of the subject, there is certain to be a good deal of confusion 
as to the materials which do and those which do not properly relate to the subject in hand. Nevertheless, for the very reason that we are mapping out a field for study which is new, but which will demand increasing attention as time goes on, it is necessary to establish definitions and concepts with some care at the beginning.

A distinction ought to be made at once between international intercourse and international organization. The former term denotes the whole body of non-political and nonlegal activity among the nations. Such activity is commercial and financial and cultural, in a very general sense, and includes the many activities and practices in the development and maintenance of trade and travel and communication, and in the exchange of information and of artistic and scientific knowledge, which lie outside the field of official legal and political practice. This body of international intercourse forms the foundation upon which legal and political international organization is built, and the two systems react one upon another in many ways. But they are not identical, and they must be kept distinct in one's thought.

The most obvious way in which this body of international intercourse may be affected by legal and political action is by the formulation of rules governing it by people engaged in it. This has been done, to a certain extent, during the past three centuries, and we have a set of principles and rules adopted by common consent and covering more or less directly and more or less in detail the whole field of international life. This set of principles and rules is called international law, and must itself be distinguished from international organization. The rules of international law are abstract formulæ. They describe and prescribe the relations and behavior of nations, and of their official representatives, in contact one with another, rather than the actions of private individuals, and they bear upon actual international intercourse in the economic and cultural 
sphere only indirectly, through state action upon the individuals participating in that intercourse. These rules are to be sought in unofficial treatises by private scholars, in public documents of various sorts (especially treaties), and in judicial and arbitral decisions in which they are embodied.

Rules of law, however, are of scant effect if unsupported by organs of government. It is here that international organization proper comes into view. The system of institutions and practices for the creation and enforcement of these rules of international law which govern the body of international intercourse constitutes the existing international organization. Various institutions have grown up among the nations, having certain forms and following certain regular modes of operation, for the execution, administration, and revision of the rules of international law and the regulation of international life by reference to these rules and to the principles of equity. The structure of these institutions, their functions, and their modes of procedure deserve examination and careful understanding.

It has long been customary, in the study of national government, to speak of legislative, executive, and judicial organs and functions, and these designations and the concepts back of them are so familiar that they can well be employed in dealing with the development of international governmental institutions. The analysis, however, will not come out as sharply in this field as in that of domestic government, for various reasons. International institutions, moreover, frequently combine in one organ two or more of these functions, perhaps as often as is the case with national governmental institutions.

It may be said, in the first place, the international system contains organs of the judicial function. These appear very early in the history of international government. Their task is to apply rather clearly recognized and firmly accepted legal rules and principles of equity to specific con- 
flicts of national interests. The rules so applied are the rules of international law and justice already worked out more or less unconsciously in international life. The court is interested, first, in finding and setting out the law applicable to the case in hand, turning more or less upon the formal rules of law and more or less upon equitable considerations arising out of the particular facts of the case itself. In doing this, the court adds to the existing law by interpreting its provisions and describing their application in a novel set of circumstances. Finally, the tribunal sometimes acts in an administrative capacity and issues orders for the execution of the judgment or the working out of the solution suggested in the premises.

Likewise, there are found international executive and administrative organs, which act upon the basis of existing international law and carry on the work of international intercourse on behalf of the members of the community of nations. These bodies make judicial decisions of a minor character, but only as incidents of their administrative work; and they lay down rules of law in a legislative capacity, though only within the discretion granted them in their executive duties. They serve in a humbler capacity than the judicial tribunals, but they provide a mechanism for doing much useful, if prosaic, day-by-day work among the nations.

Just as the administrative organs seem to develop at a stage in international evolution later than that at which the judicial organs appear, so at a still later stage certain international legislative organs come into prominence. These legislative organs have as their task the codification, revision, and amendment of existing international law and the creation of new law. This is done by a process of contract in the earlier stages, and by a process of legislation proper at a later stage. The law of nations, applied as found by tribunals dealing with international cases in the first instance, applied largely as found by international ad- 


\section{INTRODUCTORY: TERMS AND PRINCIPLES 7}

ministrative bodies in the second instance, is here revised and renewed by agreements among the nations, either in the form of bargains one with another or in the form of general rules adopted as statements of legal right.

Thus in the international field we find the same sort of political organization and operation that we find in local and national life.

For the appearance and growth of international organization, however, favorable conditions are necessary. ${ }^{1}$ Certain circumstances have powerfully stimulated, others have equally retarded, development in this direction. In the absence of some very simple conditions, indeed, it has been quite impossible for international intercourse itself to spring up, for a legal system to be developed, or, finally, for an institutional system to be devised for the accommodation of that intercourse. Under differing conditions, international life has developed a richness and intensity calling for an extensive legal system and a complicated set of governmental organs to take care of it. The principal prerequisites of international organization must, therefore, be noted at the outset.

First, there must be in existence certain states or nations or national states. ${ }^{2}$ That is, there must be available certain potential members of the community of nations. There could be no international intercourse, law, or organization if and whenever there should cease to exist in the world a number of free states. The existence of independent nations is indispensable.

Two nations might conceivably develop such relations. ${ }^{3}$ But a multiplicity of units is desirable, rather than a bare plurality, for, just as a multiplicity of specimens gives opportunity for the development of general principles of law

${ }^{1}$ Hershey, $\S 16$; Hill, I, 1; II, 1; III, 1; Walker, $\S 20$. For full titles of all references see, below, Appendix $B$.

The exact relations between these concepts is discussed below, p. 50, and following.

Marriott, 27. 
in the field of natural science, so the multiplication of independent states, resulting in decreased size of the individual states and in an inevitable tendency to interstate equality, is conducive to a rapid and equable growth of the law of nations. The body of the law is enriched with new and rapidly increasing materials, while a more urgent demand is created for some international organization to supervise and foster, on governmental lines, the increasing bulk of international intercourse.

One of the most beneficial results which could be expected from the reduction of the existing nations to something like a condition of equality would be the removal of the difficulties to international cooperation. The greatest obstacles to such cooperation now are, on one side, the feeling of the larger states that they have more to gain by "going it alone" and preserving a free hand than by joining in a world federation and that, if any organization is to be created, they are entitled to control it, and, on the other side, the fear of the smaller states that any international organization will prove merely a device for their enslavement, seeing that they cannot control it. A multiplication, and consequent equalization, of the states would tend to remedy these difficulties.

This conclusion, it is true, runs counter to recent protests against the "Balkanization" of central Europe and Western Russia." Unquestionably, the multiplication of states makes the task of international cooperation more complicated, and to that extent more difficult; and the creation of artificial states by the powers that be, if for ulterior purposes, is to be condemned on all grounds. But the protest arises chiefly from people who cling to the old diplomacy as a means of settling international questions and do not wish to see it replaced by judicial and legalistic methods, because they hope to profit by skillful maneuver-

${ }^{2}$ New York Times, 14 December, 1919, § 2, p. 1, column 8; Mowrer, entire, especially Chap. I; for application to China see Dewey, J., "Balkanization of China" in New Republic, XXVIII, 176, 178 (12 October, 1921). 
ing, by fishing in troubled waters. This is more difficult if the number of states is multiplied, while the legalistic method would be encouraged thereby. The protest springs also from a realization of the inadequacy of existing international governmental machinery as a means of holding the many new states in order. The remedy here, obviously, is not to destroy the new states, but to provide a sufficient world government.

In so far as a multiplication of states involves only a subdivision of homogeneous units, the increase of materials in international law would be merely quantitative. Todivide the British Empire into a dozen units for the purpose of international representation would assist the growth of international law and government, from a qualitative point of view, only in so far as there already existed a substantial variety of conditions among the component parts. Variety of resources, of needs, and of policies among the states in the community of nations is conducive to the rapid and extensive internal development of international law and practice. If the nations become, and in so far as they become, monotonously identical in character, the law produced will, and in actual fact does, become common law rather than anything else.

At the same time, a certain degree of homogeneity is equally necessary. It is a familiar paradox of political science that homogeneity is indispensable as a basis for law among units of any order, while perfect homogeneity removes the occasion for any law except a system of common law. Some common denominators among the nations must be found in the intercourse among them. If there are no common interests and standards there can be no legal community. General recognition of this principle is evidenced by the idea of restricting the application of international law to the European nations, to the "civilized" nations, to Christian nations-a thought which persisted as long as it seemed that the differences between the members 
of these groups and states outside were so profound as to render impossible a common life between them. The idea that there is a peculiar "American" international law, testifies to the same thing."

The foregoing conditions are fundamental. ${ }^{2}$ There could be very little international law or practice in a world of one great state, of a restricted number of states, or of states either monotonously alike or immeasurably at variance in character. Retardation in the growth of international law and organization in the past can often be traced directly to the suppression of independent states, to the limited number of precedents available on a given point, to the fact that a given proposition has been too generally accepted to need mention, or, more often, to the fact that national practices and views have differed so widely that agreement was impossible.

Beyond these fundamental requirements lie certain others of less importance, which nevertheless have a considerable bearing on the growth of international law and government. Such are the conditions of stability, equality, territorial possessions, and political character in the states of the world.

Thus, if the rise and fall of states in the world is too rapid, it is clear that intercourse and the elaboration of legal and institutional connections among the states will be rendered increasingly difficult. New states now appear, in the ordinary event, only by the modification of older ones. If this process of modification is too swift, it becomes difficult to determine at any one time the degree of independence, of separable existence, enjoyed by a given, socalled, state. Too much of flux and flow, too rapid change in the political map of the world, is not conducive to the

1 Alvarez, Droit International Americain.

${ }^{2}$ Compare these historical conditions with the so-called fundamental rights of states at international law as set forth in Hershey, $\$ \S 131-149$. All these conditions or rights are logically involved in the simple proposition that to have international law and organization we must have states or nations to start with. 
INTRODUCTORY: TERMS AND PRINCIPLES 11

development of an orderly international system. As in all periods of great revolutionary disturbances, international chaos is the disastrous result.

Furthermore, it is exceedingly desirable that every state shall be able to manage its own affairs in its own way. If the peculiar individuality of each nation is to find due expression, independent action is, indeed, essential. For this reason such an equality among states is needed as will eliminate domination on the part of some over the free actions of others. When powerful empires control the discretion of weaker neighbors, the latter contribute little to the growth of the law of nations. Recognition of the unwholesomeness of such a situation has led to the adoption of the fiction of state equality. It is maintained that, irrespective of relative areas, populations, resources, and power, the nations are, as concerns the law of nations, equal among themselves. The smaller nations must have freedom to live their own lives and to receive satisfaction for their national rights in the face of the more powerful members of the international community.

Commendable as this fiction may be as a means of obtaining by an artificial ruling something which is felt to be desirable but not actual fact, it is still far from effective in any final sense. Equality in any mere physical characteristics is, of course, unimportant. As a comparison between the positions occupied by Belgium and by China in recent international relations will show, area, population, natural resources, and wealth, as such, count little in determining the degree and quality of importance and power in international affairs. But equality of aggregate power -economic, cultural, and political-is certainly to be desired. In so far as preponderant empires give place to independent national states theretofore held in subjection we shall have a better balanced community of nations.

That a nation must possess a certain territorial domain in order to be a state at all seems to be generally admitted. 
Conceivably, a system of nomadic or non-territorial states might give rise to a body of international law and a set of international governmental organs. Throughout all history, however, states or other organizations of people lacking a territorial basis have failed to contribute greatly to international life, or, indeed, have totally failed to hold a place in that life. To deprive a state of its territorial basis, and of the population sustained by that territory, means to deprive it of existence. Modern international law and diplomacy are the products of a system of territorial states, in contrast to an earlier system of personal jurisdictions.

Finally, if the law and practice of the nations is to reach its fullest fruition, the states must be political in character. That is, they must be general, or comprehensive, in their activities and aims, and not exclusively religious, industrial, scientific, or æsthetic. In so far as states have only special interests, relations with other states are more difficult, being dependent on the chance that there will be other states with like special interests. The path is not long to a condition of direct opposition between such states. What could a proletarian state find in common with a capitalist state? Members of the family of nations with only special interests would contribute little to the law of nations outside of their own interests; Switzerland has not contributed to the development of maritime law nor Bolivia to that of the law of cable control.

Given these characteristics on the part of the potential members of the society of nations considered within themselves, certain external historical conditions are also requisite to the growth of any considerable system of international relations and government. First, there must be a sufficient degree of contact among the existing states, and, second, a science of international relations must be developed to explain existing conditions and suggest the elaboration of new legal and political institutions. 
Of these, the first is more fundamental. Unless two states make contact, they can have no economic, political, or legal relations one with another. National isolation results in paralysis of international growth. In proportion as means of communication-commercial, personal, scientificincrease among the nations, the intercourse upon which the whole system is founded grows in quantity and complexity. More needs arise for, and more facilities are provided for creating, an international legal and governmental system.

However, the importance of the second condition ought not to be underrated. For want of a mature science of international relations, the Greek state-system went down before Macedon and Rome. For want of an adequate science and art of international government, seven million men died on the plains of Europe in the years 1914-18. With all the materials for international organization present,-a numerous group of fully developed states, with a rich international intercourse on the non-political side,the world still lacked a statesmanship equal to the tasks of ensuring justice and keeping peace.

International organization, it should be understood, is not the only possible type of world government, nor the only process by which some degree of unified government has been attained in the past. Two other forms of world government are always to be reckoned with, namely, empire and cosmopolitanism. The relations among these several types and their bearing upon the concept of the state may be briefly stated.

The national state is the basic unit upon which all discussion must proceed. That state is largely the product of the fifteenth and sixteenth centuries, although the list of such political systems has been steadily growing down to the present time. Its salient characteristic is the binding together in a single political organization of a group of people kindred in race, ideals, manners, religion, language, or 
customs, and living in a definite territory, under a formal constitution and government. ${ }^{1}$

On one side of the national state we have empire, which is the forcible union and subjection in one state of the people of otherwise independent nations. The imperial unit is more or less extensive, more or less world-wide. The need of an autocratic government to dominate the structure usually brings into being a monarch, an emperor; and at the heart of the empire stands the master nation which has subjugated the remainder. The logical maximum of empire is a world state resting on conquest and domination.

On the other side we find cosmopolitanism, which is the merging of the individuals of otherwise distinct nations in one state on the basis of interests common to them apart from nationality. The logical outcome of this process would be a world state erected by voluntary action; and in its form of government it would tend toward anarchy, because of its emphasis upon the individual, and because of the elimination of intermediate authorities between the individual and a possible world government. We thus have here, within the field of world politics, the conflict between authority and liberty which is so familiar within the national state.

Standing between empire and cosmopolitanism, we have international organization, which takes the national state as a permanent unit, and expects neither its subjugation nor its disappearance by the sublimation of its elements. International organization proceeds by the voluntary cooperation of separately organized nations. The result is a unity similar to that obtained by empire, but based on free consent and the preservation of national identity; or it is the unity attained under cosmopolitanism, but based on the conscious action of national groups. Autocracy and anarchy lie on either side; but national liberty-positive and nega-

${ }^{1}$ On nature of the state and law of jurisdiction see Garner, Introduction, $38-85$, and Wilson and Tucker, $\$ \S 20,34,46-66,68$. 
tive, the liberty to exist and to resist,-may be secured only under the legal order here described.

Examples of empire, or attempted empire, can be cited from Alexander to William II. Examples of cosmopolitanism, or of tendencies toward it, extend from the Greek religion to the modern Roman Catholic Church. Both programs are more or less discredited today as plans for world organization. But, historically, these modes of world order have ruled the scene with fully as much power and prestige and over periods fully as extensive as has international organization. It therefore, might seem more accurate to regard these types as coördinate with international organization, as permanent forms of world government, available for use here and there along with the latter. It will be found, however, that they both come in conflict with a certain modern social force, and that this conflict dooms them to defeat so long as that force operates, while international organization may be freely promoted without any conflict of the same sort.

The rock upon which both empire and cosmopolitanism come to grief is nationality. So long as there was no feeling of nationality, conquest and empire, on one side, were considered perfectly legitimate; and, on the other side, a somewhat amorphous cosmopolitanism,--a cosmopolitanism by default, - was widespread. But so long as the newer nationality holds sway, neither empire nor a cosmopolitan world will be easily feasible. If, and when, nationality loses its grip on man, both cosmopolitanism and empire will be possibilities to be reckoned with. As things now stand, people will not, if they have the power to prevent it, consent to an alien domination; and they cannot, so long as human psychology and culture is what it is today, forget their national kinships and national traditions in a universal brotherhood. Whether this is cause for rejoicing or regret is irrelevant; the point at present is simply that it is true. Resistance to international organization itself springs 
chiefly from these same motives, from fear of foreign domination and reluctance to mingle with the world's people indiscriminately. It also arises from the apprehension of plotters of empire that such a system is calculated to check their schemes, and from the fear of cosmopolitan enthusiasts that it will be accepted as a substitute for their creed. Both are right. The only feasible form of world government, and the one which is at once feasible and safe, is international federation.

The possible modes of world organization just described are not, of course, entirely incompatible at any one time. Cosmopolitan society may develop within an imperial unit and still not develop so far as to threaten the stability of the empire as against outside influences. Indeed, the development of cosmopolitanism within an imperial state tends to remove internal sources of disruption. AustriaHungary broke up because this process had not taken place within her territories. Similarly, cosmopolitanism may develop under an international system without going so far as to threaten to obliterate national lines. In fact, the cause or sanction of internationalism is the previous development of a certain degree of cosmopolitan unity, calling for some measure of political and legal accommodation.

In like manner, the methods of imperialism and of cosmopolitanism-force on one side and natural growth on the other-are not wholly absent from the field where an international federation is developing. Even in the case of empire there may be voluntary coöperation of distinct national units, as in the British Empire today; although it is doubtful whether under these circumstances the concept of "empire" is truly applicable. Such development is most likely to take place, not in compact continental empires, but in transmarine colonial empires, whose geographical structure lends itself to political decentralization. A more perplexing problem is encountered on the his- 
INTRODUCTORY: TERMS AND PRINCIPLES 17

torical, or evolutionary, side of the subject. On one hand, it is certain that a condition of social homogeneity immediately preceded the present condition of national differentiations. Medieval Europe knew a greater degree of social solidarity, at least in the legal and political aspects of life, than does contemporary Europe. On the other hand, there seems to be evidence today that cosmopolitanismwith or without imperialism-is developing, by a natural evolutionary process, as a condition to follow the nationalistic era; and, of course, Medieval cosmopolitanism was itself preceded by a period of nationalistic rivalries and con- $\checkmark$ flicts which, in turn, followed the cosmopolitanism of the Roman Empire, even as the latter followed a previous condition of national independence and competition in Italy and throughout the Mediterranean basin. There has been no permanent transition from one of these forms to the other. Neither can be classed, on the record alone, as primitive, and neither as ultimate. They would appear to be two modes of human life and might be expected to persist indefinitely. We do not have here a case of alternate progress and reaction-which, then, would be the progress and which the reaction? We have, rather, a case of more or less conflicting impulses toward variety and uniformity which are permanent conditions of life. And for their reconciliation, for preventing the constant oscillation from one to the other, from a too great unity, perhaps a forced unity, of the nations, to a too great degree of conflict, even to destructive war, international organization provides the best mechanical device.

An effective international federation would neutralize the more active tendencies toward either empire or cosmopolitan unity. The case of empire is specially clear. In spite of the easy assumption that "there have always been empires and there will always be empires," there is reason for hoping, and tentatively believing, that we have seen the end of the age of empire. Since 1789 nationality has become 
an unconquerable force. The memories of St. Helena and Amerongen are not reassuring to aspiring imperialists. The burdens-political and administrative-of far-flung empire are unsupportable. There is, indeed, today, no great, powerful, and close-knit empire. The future-the near future, at least-belongs to the national state of medium size; it is the unit in the present problem of world order.

This leaves the future of cosmopolitanism uncertain. Is it to be a permanent aspect of human life on this planet, existing side by side with internationalism, as already suggested, or is it, like empire, to pass? Despite a certain suggested parallelism with the case of empire, and notwithstanding things already said which tend to suggest the conclusion that cosmopolitanism will persist but that nationalism will persist also, it seems that the outcome will be still different. Cosmopolitanism seems likely to increase and finally supplant internationalism. Both empire and international federation are forms in the process of unifying the human race in one state. One form is defective in being positively repulsive to nationality. The other is adequate to the final result when, but only when, it is gradually transformed, by the constant modification of its internal structure, so as to leave fewer and fewer matters to national jurisdiction and to expand the world jurisdiction more and more.

In the past the process of cosmopolitanization, if it may be so called, has been retarded by inadequate means of communication, by the political effects of sudden shifts of great masses of people from one section of the earth to another, and by the survival of primitive instincts of combativeness derived from tribal experience. Attempts to create a world state by voluntary federation or imperial compulsion have failed either because of the coercion employed or because the cosmopolitan basis was still inadequate. Within the past hundred years, however, the factors 
making for cosmopolitanization have multiplied and have been developed intensively to a degree never before known. Means of communication have increased enormously; population has became more mobile and at the same time-and largely for this very reason-less likely to shift suddenly and violently; theories and ideals of coöperation have tended to supplant those of rivalry and dissension. One might almost say that the cosmopolitanizing process has become conscious and deliberate. The modes and conditions of international life and relations have received so much attention that one may dare hope that the collapses of earlier days-the disruption of the Roman empire, the anarchy of the fourteenth century, the catastrophe of 1914 due largely to sins of neglect and unconsciousness-will be avoided in the future.

Whatever may be the ultimate form of the world state, however, and as we look back to the past, international federation is for all present purposes the one form of world order demanding study. To this we may now turn. Attention must be given, first, to the economic and social basis of international relations in modern times and to the nature of the national state-system, and afterwards to the institutions and methods of international organization, directly considered. Under the last heading are to be studied the institutions of modern diplomacy, treaties and international law, arbitration and judicial settlement, international administrative bureaus and unions, international congresses and conferences, and, finally, attempts to bring together all of these partial forms of international government under one federal league.
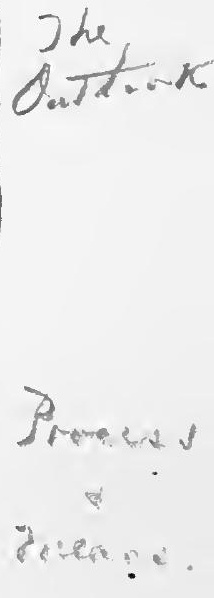
rin 


\section{PART I \\ ORIGIN AND NATURE \\ OF THE \\ MODERN STATE-SYSTEM}




\section{CHAPTER II}

\section{STATE-SYSTEMS OF ANTIQUITY}

THE form which international organization has taken 1 from time to time in the past has been controlled partly by the nature of the state-system upon which it was based and partly by the character of the international economic life of the day. Contemporary international organization is likewise controlled by these factors. To understand present world government it is necessary to understand present world intercourse and the nature of the modern state-system.

Regarded by itself the modern state-system, however, cannot be completely understood; for latent within it, and determining its nature and behavior in many critical junctures, are elements derived from ancient and Medieval political systems. In order to obtain a full understanding of the modern state, and of the modern system of national states, it is necessary to study the life history of the modern national state as such.

In recently recovered historical materials there is evidence of arbitration and treaty-negotiation among the nations of western Asia as early as 4000 B. C. ${ }^{1}$ Both opponents of the League of Nations, who protest against rash adventures upon new and untried paths, and enthusiastic supporters, who hail the League as opening a new era in international life, ought to be sobered by the reflection that the problem of international federation is at least five thousand years old. It is not, however, worth our while to try to reconstruct the theory of things international as ${ }^{1}$ Tod, 170-71. 
they stood prior to the dawn of European history. Considering the data available, the results achieved in their own time, and their contributions to the problem here and now, the Greeks were the first to develop a state-system commanding our serious attention. The Mediterranean basin was the cradle of our system of independent states and international organization.

From as early as 600 B. C., the Greek world was made up of many independent states: Athens, Sparta, Megara, and Thebes, on the mainland of the Greek peninsula; Delphi, Syros, and Naxos, on islands in the Aegean; Ephesus, Priene, and Miletus, on the Asiatic mainland; Sinope, Cyrene, Alonae, Agathe, and Elea, located in what are now the Black Sea region, Africa, Spain, France, and Italy. Literally hundreds of independent states studded the shores of these inland seas. In this community of states there were at least ten times as many distinct units as we find in the modern society of nations. ${ }^{1}$

The resources and needs of these states varied greatly. On the Greek mainland were industrial and commercial centers of great activity. In the western Mediterranean were pastoral towns and mining settlements. In the Levant were centers for the Oriental trade. The Nile valley and the Euxine area provided cereal exports, and the states of Attica and Bœotia offered household wares in exchange. Gold, salt, and various raw materials came from Iberia and Gaul. ${ }^{2}$

As a natural result, a lively maritime trade animated the Greek scene from Cilicia to the Pillars of Hercules. Rugged hills somewhat obstructed the development of communication by land. But the sea, with its thousands of estuaries and bays, provided ready means of contact and united all of the members of this lusty family of nations in active and constant commercial intercourse. Even the compara-

${ }^{1}$ Shepherd, 10-17; Walker, $\S \S 20,23$.

Zimmern, 39-51, 251-272, 391-396. 
tively remote states beyond the Bosphorus and in Southern Gaul were but slightly isolated. ${ }^{1}$

Moreover, these many states were of a measurable equality one with another. No great states dominated the political scene. If it seems somewhat magniloquent to call these independent urban communities with their encircling farm lands "states"-if it appears that we ought to call them simply "cities" -it is still much more true that the Athenian and Spartan "empires" enjoy in that term a glory and importance derived in part from modern experience, not from their own character. The balance of power was always very delicate and unstable. National safety was sought in a numerous array of allies rather than in subjection to a great protector. Each state could hope to play a substantial part, and to be entitled to real consideration, in interstate relations.

On the other hand, the relations among these states were made the more cordial by participation in a common body of culture; their cultural homogeneity was as marked as was the variety of resources and capacities among them. The Greek religion, the mother tongue, and community of race and thought and feeling, gave Dorian and Ionian, and, indeed, all the Greek peoples, a bond of sympathy and understanding which provided a firm foundation for more formal political and legal relations. Already the world could clearly distinguish the characteristic quality of Greek culture and the Greeks themselves were conscious of their kinship. ${ }^{2}$

Nothing was lacking but a theory of international relations. With the materials for such relations so rich and plentiful, it would be natural to expect a great development in the science and art of international government. Nothing of the kind happened. There grew up, it is true, a set of institutions and practices-consular, diplomatic, and

Same, 308-318; Francotte, 132-159; Huet, entire.

2 Fairbanks, 13-29, 148.164; Murray, Part I. 
arbitral-among these states, which was extraordinarily complete, in view of the fact that they were largely naïve and unconscious. But there was no deliberate and explicit theory of interstate relations to explain what was happening, what was being done, what might take place, and what might be done in the future. There is a curious absence of any deliberate theory of interstate relations in Greek thought. ${ }^{1}$

The result was, in the end, disastrous. So long as conditions remained constant and auspicious, the customary practices could go forward, albeit not by deliberate design but as a natural result of those conditions. If the experience had continued long enough the Greeks might have become conscious of it and rationalized it. As it was, they failed to do so, and therefore when the attack of imperialism came they succumbed. The potentialities of free international coöperation had not been explored to a point from which steps to resist the conqueror could be taken. Not having recognized and learned the art of international organization and practice, the Greek states lost their statehood.

There had been warnings in ample time. Long before the rise of Macedon and Rome there had appeared intimations of empire to threaten the free life of the Greek states. ${ }^{2}$ Sparta and Athens had been tempted to convert positions of leadership, which they enjoyed among allies and confederates by virtue of their power and intelligence, into positions of domination. Sparta, fearing the spread of democracy, ${ }^{3}$ used her military predominance to interfere in the domestic affairs of the Peloponnesian states in support of the principle of oligarchy in national government. Athens employed her naval power and the funds of her allies to establish her own domination over certain of the Agean states. ${ }^{4}$ The Athenian empire was maritime, and it rested on democ-

${ }^{1} \mathrm{On}$ international organization in ancient Greece and Rome see, in general, the works cited in this chapter, especially Freeman, Phillipson, and Tod, and also Egger, Monceaux, and Raeder, as cited, below, Appendix B, $\$ 1$.

'Ferguson, 1-5, 65-78, 79-97, 142-148.

Same, 21, 89; Fowler, 290; Greenidge, 114-115.

- Ferguson, 65-78; Fowler, 287-289; Greenidge, 190-204. 
racy at home; but for the dominions it was a true empire. The Thebans sought and obtained a hegemony which developed into a firm control of the Bœotian states. ${ }^{1}$

All of these events followed from attempts to erect interstate federations, and they followed because those attempts were undertaken without adequate knowledge of, or skill in, the business in hand. ${ }^{2}$ The attempt to do more than contemporary political science justified induced the abuses practiced by Athens and Sparta; once those abuses began, the same cause prevented the victims from making an effective resistance. In view of the inability to go through to a complete international organization, it would have been better to preserve the primitive, but real and resistant, virtues of national independence.

The result was to put a blight upon the free life of the Greek states. They seemed never to regain their vitality. The state-system of 500 B.C. had begun to pass into something unlike itself. ${ }^{3}$

The characteristic defect of the Greek state-system, was not, however, that the individual states were, on the whole, too prone to schemes for combination, but that they were too fond of their independence. ${ }^{4}$ From the beginning there had been a keen, and often fanatical, spirit of jealousy among them which prevented any lasting and effective cooperation, and their bitter experiences with Athens and Sparta confirmed their feeling of opposition to international federations. They had been willing to combine for defence against Persia in 480 B.C., but their confidence had been abused and imposed upon. Henee, when a new threat of invasion and conquest came from the North there was no trusted leadership to rally them into an effective league of defence. ${ }^{5}$

Not that efforts in this direction were lacking. Sensing

1 Ferguson, 26-27; Fowler, 292-293.

Phillipson, II, Chaps. XVI, XVII.

Fowler, 274-279.

Phillipson, I, 34, 38.

- Fowler, 294-295, 300. 


\section{INTERNATIONAL ORGANIZATION}

the impending danger, the members of the Athenian, Spartan, and Bœotian leagues, as groups, sought to draw closer together. The independence of the individual state was a thing of the past. ${ }^{1}$ But the effort failed. The groups could not effect a coöperation, just as, earlier, individual states had failed in the same task; and resistance was really weaker than it would have been had the Macedonian been compelled to deal with a hundred states waging defensive war independently against him. ${ }^{2}$ As it was, Philip and Alexander took advantage of the unstable balance of power among the rival leagues, played off one against another, and at the battle of Chrronea, in 338 B.C. put an end to Greek independence. The peninsula was conquered and-appropriately enough-the leagues, which had failed to save the Greek state-system because of their incompetence in international coöperation, were dissolved. This included the Achran league, the most effective then existing. ${ }^{3}$ Empire came to take the place of national independence. Greece was henceforth united, but united in subjection, along with Egypt and Syria and unheard of barbarian regions beyond, in the empire of the Macedonianhimself a barbarian. ${ }^{4}$ ?

Somewhat the same course of events followed in the years 338-146 B.C. The Macedonian imperial domination weakened and disintegrated after Alexander's death in 323. His successors in Greece were not able to maintain a unified control of the Greek states, and during the third century B.C. the individual states behaved about as they pleased. ${ }^{5}$ Further, the practice of international federation reached its highest point at this time. ${ }^{6}$ But when the test again came the result was a second failure. Rivalry between

1 Fowler, 294, 301.

Same, 295.

Same, 302.

- Shepherd, 18-19.

- Fowler, 302, 312. 26-28.

-Same, 302-305; Ferguson, 33-34, 242-243; Hart, 31-32; Phillipson, II, 
the Achæan League and Sparta and Athens and enmity between the Actolian League and its neighbors across the Gulf of Corinth made Greece an easy prey for Rome. ${ }^{1}$ Once more the free state-system of Greece was brought into subjection to empire, ${ }^{2}$ and for the same reason that had been operative in 338. The states could not organize and cooperate, even in self-defence. Insisting over much upon independence, they lost all independence, Refusing or failing to create a voluntary union, they were compelled to accept empire.

The experience of the states of Italy and of the Mediterranean world in general had not been dissimilar.

In the beginning, the Italian peninsula was divided among Etruscan, Umbrian, Samnite, and other tribal states. $^{3}$ Carthage, Phœnicia, Macedon, and other kingdoms were arrayed upon the coasts of Europe, Africa, and Asia. ${ }^{4}$ The same variety of economic resources, the same maritime means of communication, and, in general, the same homogeneous Greco-Latin culture was to be found in this larger community as had been present in the Greek society of states. ${ }^{5}$ In addition, the Romans, masters of law and political government, might have been expected to provide an adequate theory of international law and relations. With approximately the same rich materials that existed in the Greek age, there were now present the greatest jurists of antiquity. ${ }^{B}$ A science of international government of great moment in the history of the world might have been expected.

The course of events did not fulfill that expectation. Rome developed a motive or policy which prevented any such development. Rome chose the path of empire.

${ }^{1}$ Ferguson, 240 and following, 246-248; Fowler, 305; Freeman, 339 and following, 374; Hart, 32-33.

Pelham, 153-154.

- Shepherd, 26-31.

- Same, 32-33; Walker, § 32, at 44.

Resources: Oliver, 9-14, 19-21, 41-51, 134-139; commerce: Davis. 80-95; culture: Mahaffey, Chaps. V-VIII, X-XVI.

- Muirhead, §§ 61-63.
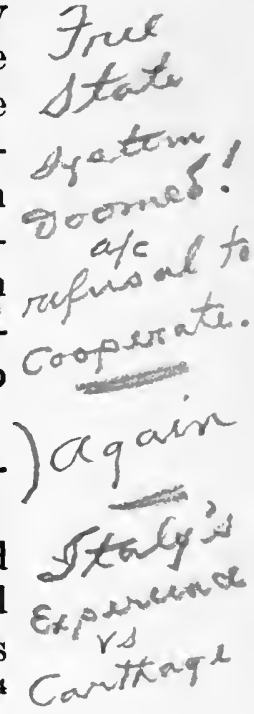
To begin with, the Italian states did not develop their system of international relations in the early period as far as did the Greeks. The Italian states were much more elementary. They attempted, it is true, to combine in confederations for defense against attack. Rome herself appears as a member of the Latin League, of some thirty cities, united on a semi-religious basis. ${ }^{1}$ But these unions were very simple in comparison with the Greek leagues, and they did not succeed in resisting Rome herself for any length of time. ${ }^{2}$ Athens and Sparta had met greater resistance from rival leagues and confederations. In the end the Italian states were conquered and subjected to Roman dominion.

This process was applied, successively, to the Latin League itself, to other coalitions in Italy, ${ }^{3}$ and to the independent states in the Western Mediterranean outside of Italy. Rome now-in the first half of the second century B.C. ${ }^{5}$ - extended her sway over the remnants of the Macedonian Empire outside of Greece proper: Unable to assist each other in any way, Italy, Spain, Carthage, Egypt, Syria, and Macedonia fell into the new empire. Finally, as we have seen, the Greek states constituted a fitting sacrifice, in 146 , to signalize the eclipse of independent national statehood in antiquity and the advent of world empire.

For five hundred years the Roman Empire stood fast in its power and majesty, and for that period the state-system was exceedingly simple. One world state had swallowed up the multitude of independent states and blotted out the attempts at international federation. Gaul, Asia Minor, Britain, and many outlying areas were added to the Empire. ${ }^{6}$ From Gibraltar to the Syrian desert, from the hot

1 Frank, 4, 13-17; Hart, § 22 ; Phillipson, II, 33-42.

2 Frank, Chaps. II, III.

Date: 266 B.C.; Hart, $\S \S 21,23$; Shepherd, 29.

Spain: 205 B.C.; Carthage: 238, 201, 146 B.C.; Pelham, 114-139. herd, $\mathbf{3 3}$.

Syria: 190; Egypt: 181; Macedon: 168 B.C.; Pelham, 140-152; Shep-

'Shepherd, 34-35; 42-43. 
wastes of the Sahara to the ice and snow of the Baltic there prevailed one system of law and one official religion, there was felt the power of one imperial city. ${ }^{1}$ Governor and priest and even god, the Emperor had supplanted free consent as the basis of national authority, and there were no more national states, but a world empire. ${ }^{2}$ World unity had been attained by the suppression of state independence.

During this period some measure of authority was delegated to what before had been independent nations. But the basis of authority was merely the discretion of the imperial master, ${ }^{3}$ and interstate diplomacy became constitutional government, not international practice. Emissaries from the imperial Senate were governmental agents assuming diplomatic guise for tactical reasons. ${ }^{4}$ Free interstate life was dead.

Likewise, such cosmopolitan unity as was attained under Rome was largely counterfeit. The unity of religion, of speech, of manners, so far as it came about at all, was not altogether a spontaneous growth, gradual and slow, and taking origin in the life of the people itself, but was in large part a servile imitation of the capital city or obedience to imperial commands. ${ }^{5}$ Peace and unity obtained, to a large extent; but it was the peace and order of subjection, not of natural repose. It was the peace and order of dishonor.

For these very reasons, if for no others, the maintenance of the fabric of empire depended upon control from Rome. When, therefore, the heart and mind of Rome gave way, toward the end of the fourth Christian century, the nations tended to drop out of the picture into their natural places. The stones of the mosaic stood in their places dissevered, as the substance which had bound them dissolved and disappeared. Before this process was completed, however, those
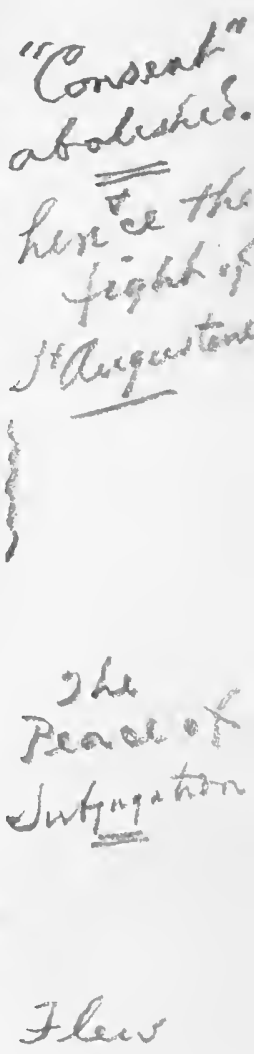

$\cos$

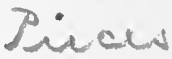

1 Eryce, 5-7; Fowler, 323-331; Hill, I, 1-3, 15.

'Greenidge, 252; Hill, I, 3-7, 12-15; Walker, $\S \S 36,37$.

" Hart, $\$ \S 21,23$; Tod, 179-182.

Bouché-Leclerq, 105, 196, 202.

Hill, I, 18. 
in power in the Empire made a last attempt to preserve the structure by dividing the government into two parts, Eastern and Western, seated at Rome and Constantinople. What could not be saved as a whole was to be saved in parts. In so far as this step was successful, the condition of the state-system was not changed and the step itself would deserve no special attention. In point of fact, the effort ultimately failed. The Empire was finally divided in 395 A.D., at the death of the Emperor Theodosius, only to fall prey to still greater anarchy. The process was not unlike that which took place in the Alexandrian empire after 323 B.C. And once more, as at that time, it seemed possible that independent national states would regain the stage. After seven centuries of submergence in empire, the nations might reorganize the European state-system on its earlier lines.

Such was the situation when the ancient period closed. The political map of Europe showed the result of a thousand years of state practice at least in this, that either independent nations or autocratic empire might then reasonably count upon mastery.

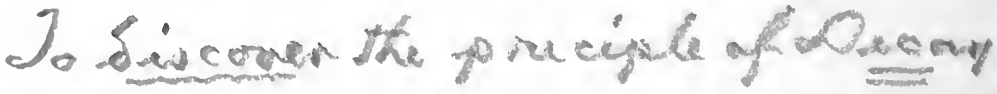

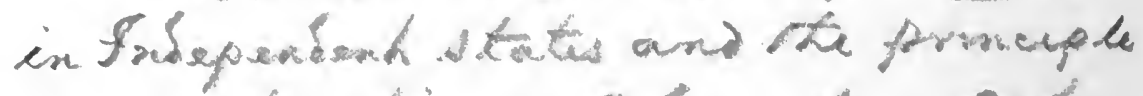

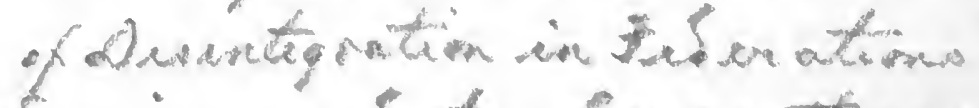

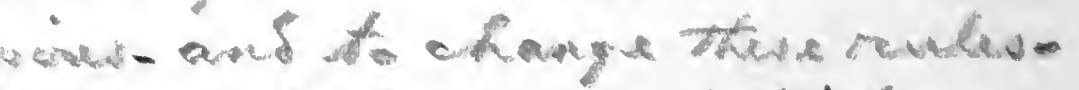

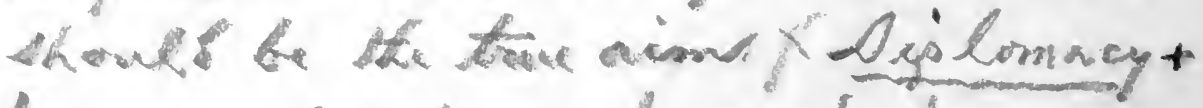
Lespecion - Enamety - peal ane y - hate -

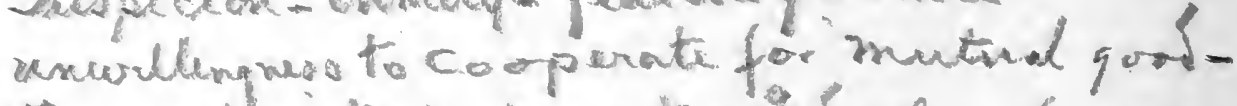

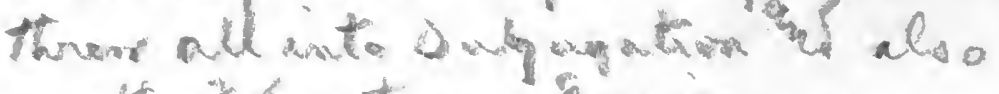
broxka

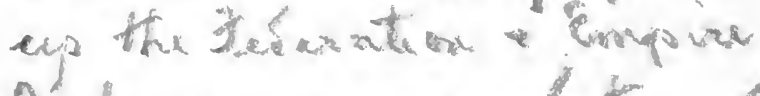

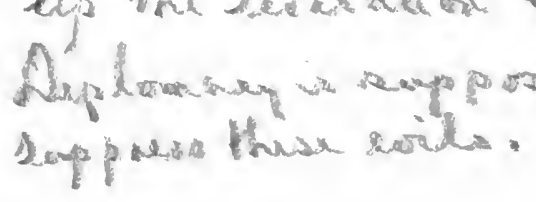




\section{CHAPTER III}

\section{MEDIEVAL STATE-SYSTEMS}

7 HE definitive formation of the European state-system was, however, delayed again, after the disintegration of the Roman Empire, for another thousand years. Not until the fifteenth and sixteenth centuries did the national state regain the center of the stage.

For this there were two principal causes. First, powerful attempts were made to renew and to recreate imperial states on the plan of Macedon and Rome, and, second, the political organizations which actually developed in the various parts of Europe were not able to act as free and independent states. The obstacles to the formation of a system of national states were, chiefly, the medieval empire on one hand and the feudal state on the other.

As a result, Europe from 395 to 1453 displayed not so much a coherent system of states and a system of international organization and practice as the lack of both. The period is instructive because of the fact that in its records can be studied all of the elements which tend to destroy or render ineffectual international organization. By contrast, it throws light on the character of the state-system of our own day. And out of it actually came, at the end, the modern national state.

The break-up of the Roman Empire was attended by two sharply contrasted events. On the one hand, new national forces invaded the Empire from the North, and, on the other, the Church of Rome attempted to uphold the theory of imperial unity throughout Western Europe. The barbarian invasions led to feudalism and the development of the feudal states, and the feudal states developed later into 
the national states of modern Europe. But before that process could be completed the other force, the imperial idea, the heritage of Rome, had also played its part. ${ }^{1}$

From the fourth to the fourteenth century the idea of universal empire almost completely dominated formal European political thought. ${ }^{2}$ There were other elements in the actual experiences of men, but the theory of the state was largely a theory of empire. This is traceable to very definite causes, and the power of the imperial idea in Europe to the time of the Renaissance must be sought in those causes.

The prestige of imperial Rome lingered in men's minds. The contemporary situation was felt to be an interruption, a temporary accident in the natural course or condition of things. Five centuries of Roman power dominated men's memories. $^{3}$

Moreover, the Roman imperial religion, now Christian, remained to perpetuate the idea of world unity. Life had disintegrated and collapsed on the material side, but the spiritual realm was comparatively untroubled. The idea of unity gained power as the physical fact of unity disappeared. At once a consolation for and a bold defiance of the actual world roundabout, the evangel of the unity of the faith was of peculiar power in the troubled times after 395.4

Finally, the greatest chaos was felt in the realm of politics and law, and the doctrine of empire attacked this problem on its own ground. The nature of the world's trouble and the source of its distress was felt to be political disorganization. Obviously, the remedy lay in rebuilding the fabric of Augustus and the Cæsars. ${ }^{5}$

These forces found several distinct manifestations.

1 Fisher, I, Chap. I; Hartung, entire.

Bryce, Chap. V; Carlyle, III, 170-171; Hartung, as cited; for contrary view see Carlyle, III, 178-180; Thorndike, v.

Bryce, 89-90, 102, 273-274.

- Bryce, 31, 93-97, 100; Hill, I, 92 ; Walker, § 42.

- Bryce, 96-97; Gierke, 95-96. 
First, there was an attempt to carry on the Roman tradition at Constantinople. Comparatively free from barbarian invasions, an Eastern Empire rose rapidly on the shores of the Bosphorus. ${ }^{1}$ An attempt was made to reconquer Italy and Northern Africa. ${ }^{2}$ The Empire was to be reunited. ${ }^{3}$ As an element in the program of reconstruction and restoration, the great Justinian issued the Corpus Juris Civilis, the definitive compilation of the principles and rules of the law of Rome, her greatest gift to posterity. ${ }^{4}$ And in some measure these efforts succeeded. In Europe East of the Adriatic the empire of Rome was carried down to the invasion of the Turks in $1453 .^{5}$

Another power rose in the East to make a bid for world empire. In 622 the Mohammedan forces began their conquest of nearer Asia and Northern Africa. Stretching out to the Atlantic coast of Africa, they crept up into Europe and held control of enormous portions of the ancient Roman dominions down to the period of the Crusades. ${ }^{6}$

In the heart of Europe itself, in what had been Roman Gaul, there rose, beginning early in the eighth century, the new Frankish empire. ${ }^{7}$ The secular ruler was to act as protector of the Church of Rome, and to this end he founded a Papal domain in the center of Italy in 751 and took the formal Imperial title in 800 under Papal auspices. ${ }^{8}$ By the end of the ninth century the empire of Charlemagne extended over all Western central Europe and Northern Italy.

Meanwhile the Church itself, waxing strong under Imperial protection and encouragement, and exerting a power-

${ }^{1}$ Bryce, Chap. XVII; Thorndike, 71-72, 76-80, 86-87, 128-153; Walker, $\S \S 43,44,54$.

Thorndike, 135-138.

Same, 131, and map at 137.

- Same, 141-143.

- Same, 553-559; maps in Shepherd, 52, 59, 89.

Thorndike, Chap. $X$, and map at 180; Shepherd, 53; Walker, $\S \S 45$, 46, 55-58.

Thorndike, Chap. XI, and map at 201; Shepherd, 55; Walker, $\$ 47$.

B Thorndike, 147. 
ful sway over the minds of men, developed a temporal power and dominion far greater than that of the Carolingian emperor. From 751 to the fourteenth century, and especially from the eleventh century onward, the Papacy was a sturdy rival of the leading secular claimants for the imperial legacy of Rome. ${ }^{1}$ In one way the Church had a great advantage in this struggle, for the Pope spoke from the imperial city itself and spoke as a lineal descendant and legal instrument of the former state. In a special sense, the Church was "Rome" to Medieval Europe.

Finally, later Germanic emperors built more or less directly and completely on Frankish foundations, just as Charlemagne had built in part on Papal support, and reared the most pretentious claim of all to European empire. The Holy Roman Empire was a rival of, and at the same time a partner with, the Papacy, and it boldly claimed the rights, titles and glories of the Roman Empire as it was in the hands of Augustus and Diocletian. It constituted at once the most vivid, the most complete, and the latest attempt to carry the Roman world-state down into modern Europe. ${ }^{3}$

In these successive surges of empire ${ }^{4}$ there are certain essential ideas which determine its nature and constitute its significance for the history of the European state. ${ }^{5}$ Surpassing the Greeks, the Romans had developed a theory

Thorndike, Chaps. IX, XV, XXIII, XXIV.

Hill, I, 92.

Walker, $\$ 49$.

- Bryce, entire, especially 89-90, and Chaps. VIII-XIII and map at 180;

- Chronological tables:

I. Eastern Roman (Byzantine) Empire. 395 Empire established at Constantinople.

1453 Constantinople conquered by the Turks.

II. Mohammedan Empire.

622 The Hegira; beginning of Mohammed's career.

1036 End of the Caliphate of Cordova.

III. Frankish (Carolingian) Empire.

717 Accession of Charles Martel.

888 Death of Charles III.

IV. The Papacy.

751 Foundation of the States of the Clurch.

1309 Removal to Avignon.

Bryce, Chaps. VII, XV, especially 116 and following. 
to explain their state, their empire and its activities; the Medieval imperialists now began with a theory and tried to carry it out in practice. The plan was so pretentious that the attempt was bound to be largely unsuccessful. Even though the Empire was chiefly an idea, however, it did, as an idea, undermine for the time being that other idea, the principle of national independence, which was indispensable for a rebuilding of the European state. The fact that it was not completely realized in practice, therefore, is of less importance than the content of the idea itself.

There was to be a universal church and a universal state, and the two were to coöperate harmoniously-over all of the temporal life of men, the Emperor; over all of their spiritual life, the Pope. No local independence, ecclesiastical or political, was contemplated. Local rulers, such as made their appearance in different sections of Europe, were to be subject to the Emperor and the Pope in matters legal, political, and religious. ${ }^{1}$

The result was a paralysis of national spirit. The center and final resting place of authority was not the national sovereign but the Emperor or the Pope. The peoples were not national units in their own names, but members in the Church and the Empire.

A further result was to stifle and discourage interstate relations. In so far as the emperors succeeded in the attempt to carry on the tradition of empire, which had now held sway sirce the time of Philip of Macedon, and which was to last until the Renaissance, the nations of Europe were submerged and denied independent life. Such interstate action as existed was, as in Roman times, the distorted activity of imperial control masquerading as international diplomacy, or, at best, international diplomacy prostituted to the service of imperial domination.

Most of this imperial activity, be it noted, was carried ) on in the field of theory, of philosophy, of speculative

${ }^{3}$ Bryce, 183-191 and 256-266; Thorndike, Chap. XXIV. 


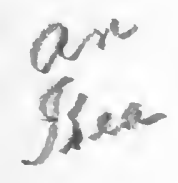

thought. Rome had been a mighty physical fact; the Medieval empire was largely an idea. The actual governmental condition of the period, tested where government must always be examined in order to yield reliable conclusions, namely, in application to the daily life of society, was a matter of local feudal authority rather than of central control by the Emperor or Pope. Far below the levels on which were erected the doctrines of empire the real Medieval state, the feudal principality, assumed its place. ${ }^{1}$

However, the effect of the development of the feudal state was the same as that of the development of empire. The Empire overshadowed and suppressed the national state; the feudal state undermined the possible national organization from below. In the end, the feudal state, enlarged and developed in scope and power, was to provide the effective substitute for the imperial state; and, on the other side, it reached back to barbarian invasions which had constituted the first powerful attack upon the ancient imperialism of Rome. But from the eighth century to the fourteenth the effect of feudalism upon the state-system was simply to intensify the effect of empire.

When the Roman defense gave way, in the latter part of the fourth century and the early part of the fifth, sundry nations of barbarians came marching into the imperial dominions. Goths, Franks, Vandals, and Lombards invaded Italy, Spain, and Gaul, and established more or less transitory kingdoms in one place and another. ${ }^{2}$ Europe seemed about to be occupied by these new nations in the place of the Empire.

Unfortunately, these peoples lacked political experience and skill. Their instincts were those of nomads. Destructive and not constructive, politically, they consumed and did not produce, and they built no enduring political structures. The Greeks had lacked a science of international

1 Thorndike, Chaps. V-VII, XIV.

'Same, especially Chaps. V, VII; map in Shepherd, 50; Walker, § 40. 
relations but had developed government within the individual state to a high degree of perfection; the Romans surpassed the Greeks in domestic government and added a fine power of world dominion; the Germanic nations had neither skill at self-government nor skill in international relations. A condition of mobility, of instability, of legal and political chaos, lasted until the rise of the Papacy and the Frankish empire as already described. ${ }^{1}$ During this period there could hardly be said to exist a system of definite and independent states. At the collapse of the Frankish empire in the ninth century another series of barbarian invasions took place, which a second time suggested the appearance of a group of independent states. ${ }^{2}$ But here again the promise did not materialize, and no solution of the problem of providing Europe with a permanent state-system was forthcoming.

In such a period there could be little regular and formal interstate organization or activity. Order was lacking, knowledge was deficient. A rude diplomacy was practiced, it is true. ${ }^{3}$ Two isolated cases of arbitration are found. ${ }^{4}$ Certain rules bearing upon interstate relations appear in law codes compounded by the barbarians out of their own customs and local Roman laws. ${ }^{5}$ On the whole, the barbarian nations contributed nothing to the development of European international relations in their own time.

One thing, however, the barbarians accomplished: they established certain political units which eventually helped greatly to solve the problem. The violence of the earlier inroads of Goths and Franks, as well as of the second series

${ }^{1}$ Period of the Barbarian Kingdoms.

376 Admission of East Goths into the Empire.

774 End of the Lombard Kingdom in Italy.

It will be noted that the development of the Frankish and Anglo-Saxon kingdoms in Northern Europe are excluded from consideration here. When these cases are considered we are in a distinct period and a distinct historical movement.

Hill, I, 135; Thorndike, Chap. XII, and map at 225.

Hill, I, 36-41.

- Scott, Conferences, I, 202.

Hill, I, 39-40. 
of invasions, in the end of the ninth century, in conjunction with the economic disorganization of the time, led to the formation in Southern Europe of local groups of people of various ranks and abilities for mutual assistance, military and economic. The center of the group was usually a landholder, a military leader, a person possessing some sort of power which could be utilized for purposes of protection in a troubled age. In the eighth and ninth centuries (especially in the latter), upon the break-up of the Frankish empire, these groups developed into formal feudal statesduchies, principalities, and fiefs of various grades. A congeries of such units covered all Western and Central Europe. ${ }^{1}$

Here is to be found, in combination with the barbarian kingdoms, the actual particularity of conditions in Europe beneath the ideal unity of the empires. Teutonic pluralism underlay the Latin monism. The feudal units were connected more or less completely in a hierarchical system, and even in federal systems, in the kingdom or the empire. ${ }^{2}$ But the hard facts of the situation were the manor, the parish, the village, the county. ${ }^{3}$

The result was anarchy. Power was hideously decentralized. No national units could develop. Local armies, local courts, local taxes, local laws, and, worst of all, local spirit,-even Greece in the days of the city-states presented no such picture as this. The authority of the central ruler-king or emperor-was a myth. And, finally, the weightiest factor in the situation is to be found in the nature and source of feudal power. The local prince held his power by a grant of authority from a superior. $\mathrm{He}$ enjoyed no inherent sovereignty, nor did he derive his power from his own people in the state itself. The result was that relations with other feudal rulers of like station

' Hill, I, 135-136; Thorndike, 232-233; Walker, § 48.

Carlyle, III, 75-76; Gierke, 20-21, and notes, especially note 64 .

Davis, 87-100; Thorndike, Chap. XIV, and map at 271; also maps in Shepherd, 62-63. 
were legally impossible except through some common superior. The defects of the feudal state-system, from the point of view of the development of European international relations, were, thus, too great independence and at the same time too great interdependence. $x$ The local states were too numerous and too petty; they were too closely fettered in the gigantic feudal web. The interstate life of the time was, accordingly, barren, impoverished, and largely confined to the activities of feudal superiors in wielding control over their subject princes. ${ }^{1}$

The Renaissance and the dawn of the modern age therefore found the question posed at the close of the ancient period still unanswered. The barbarian nations had been unable to give Europe a permanent state-system; the empires were, somehow, unreal and unconvincing; the feudal states did not promise well. The long interlude passed, leaving conditions approximately where they had been in the fourth century. The great differences were that in the fourteenth century the over-pretentious and dangerous character of imperialism was more definitely suspected than when the prestige of Rome still dazzled the minds of men, and that the materials available for the building of local states of independent and secure power were far superior to those existing at the end of the Roman age. The dream of empire wavered and flickered; the independent state knocked once more at the door of Europe.

${ }^{1}$ Hill, I, 365-366; Thorndike, as cited, especially at 259.
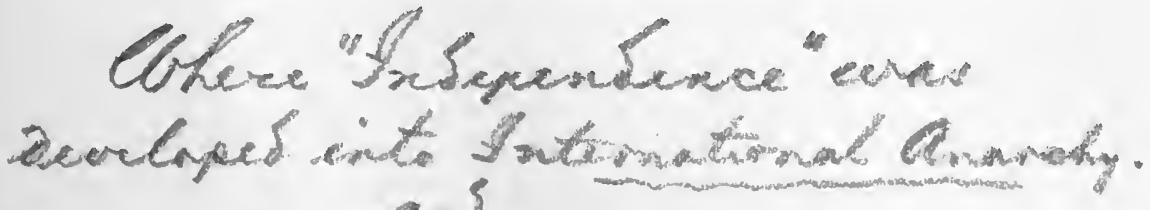

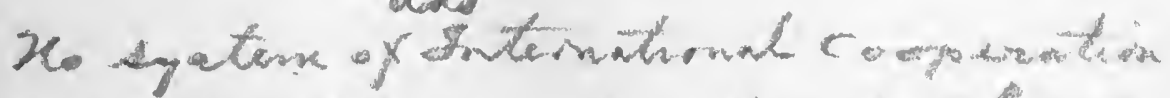

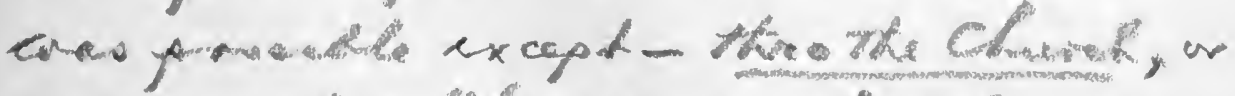
Le promateme Grothed L. S" of E endo 


\section{CHAPTER IV}

\section{RISE OF THE SYSTEM OF NATIONAL STATES}

DERHAPS by pure coincidence, perhaps by virtue of a common cause, the decay of empire and the maturity of the feudal state in Europe came at a time when conditions in the world of commerce and science were altering in such a way as to encourage a radical change in the existing state-system. By a dual process of disintegration on the one hand and aggregation on the other; the Medieval empires and the feudal principalities gave way to the national state; and the process was facilitated by a change in the conditions of European intercourse in the realms of trade and culture. The political events may be regarded as, in large measure, effects of the revival of commerce and learning; the former encouraged and in part made possible the latter. The fundamental causes of the changes which came over the Western World in the fourteenth century are to be found in the evolution of Medieval society itself, and the progress of those changes was largely the story of their mutual reactions one upon another. Both aspects of the development deserve close scrutiny.

Beginning in the thirteenth century, Europe witnessed a complete economic revolution in the disappearance of Medieval practices and the revival of active commerce by land and by sea. ${ }^{1}$ In Greek and Roman times the traffic of the Mediterranean basin formed the basis for interstate political organization and practice. The succeeding eight centuries witnessed a gradual decay of commerce in the

' Day, Chaps. V-XIV. 
RISE OF THE SYSTEM OF NATIONAL STATES 43

South of Europe, and the effect of the imperial efforts which have just been reviewed was thereby intensified. In an age when political practices tended to discourage national life and international intercourse, the decay of commerce had been quite natural, and had in turn contributed to the same result. Now came a change which was to last in its original form for three centuries, and which was to be continued and completed by the industrial revolution of modern times and by the enormous development of commerce resulting in the past century from the use of steam and electricity. The revival of commerce in the thirteenth and fourteenth centuries was the first step in the development of modern world intercourse.

The causes of this revival are difficult to discover and to measure. The Crusades (1095-1270) furnish the most obvious explanation of the new life in the traffic of Southern Europe. ${ }^{1}$ Through them Western European traders came in touch with new wares for the European markets, which were obtainable in the Levant,-fruits and spices and silks and other luxuries,-and became aware of new markets for the products of the European guild industries. Shipbuilding and the art of travel were encouraged, from Genoa and Venice to Alexandria and Syria.

Another fact, however, affords a still fuller explanation. After a long period of decay, ${ }^{2}$ towns were reviving and town-life was reappearing. The cities of ancient Greece and Rome had fallen into decline with the barbarian invasions, and the barbarians were not themselves builders of cities. The result was the absence of much of that sort of energy and activity which makes for vigorous economic and political life. Now came a revival of the older cities and the emergence of new towns and cities in all parts of Western Europe, and with this a quickening of the pulse of commercial and financial life.

${ }^{1}$ Day, $\$ \S 97-99$.

Day, $\$$ 43-51; Thorndike, Chaps. XVII-XIX. 
moted by various means, including the removal of price regulations and market rules. The convenience of outside purchasers and of travelers was considered, and local merchants were given means of trading with strangers through the development of national currencies providing more practicable mediums of exchange than the many feudal currencies of the preceding centuries. And to supply this expanding trade, and as a factor which in itself made the farther expansion of trade necessary, the manorial and monastic industries continued to expand and spread into individual cottages and open towns.

While these events were taking place on land similar e processes were afoot on the seas. Certain new forces made their appearance in the maritime world, certain old forces disappeared. As a result, the land traffic of Europe was supplemented by an active coasting trade and by maritime transport outward to distant shores. The compass was introduced into western Europe about 1200 and made longer sea voyages possible. New sea routes had been learned during the Crusades, old routes had been rediscovered, and now the Oriental trade was revived to cater to tastes acquired in Byzantium and Palestine. The building of larger and better vessels was encouraged. Venice rose to her height as a commercial empire (1200-1400). Between 1400 and 1500 came discoveries and explorations in America, Africa, and Asia which revealed the extent of the modern world. The area of commercial and political activity widened, the horizon disappeared, the spirit of adventure, of inquiry, of achievement replaced the defeatism, preoccupation, and timidity of the Middle Ages.

The results in the world of commercial organization were of great significance. The new national states encouraged industry and trade for fiscal purposes, whether for royal profit or for public prosperity. Commercial organizations of various sorts made their appearance. Wholesalers, commission agents, and factors became fa- 
miliar figures. Postal systems were created, developed, and finally thrown open for general use. Joint stock companies were organized. Credit machinery and methods of accounting were worked out by the Italians and taken over by Northern Europe. In the first half of the sixteenth century, bills of exchange were invented, and credit exchanges appeared in Antwerp, Lyons, Frankfort, London, and other towns, for the use of the European merchant community. Thus was provided a transition from the older system to the new.

This was the origin of modern Europe. With these forces in operation, the existing political system must necessarily have proved inadequate. A distant Emperor could not control or properly foster the growth of local $\checkmark$ industry and trade; local feudal princes could not adequately support the national economic life about to be realized. As a matter of fact, the state-system had already changed, or begun to change, to keep pace with the eco$\checkmark$ nomic transformations. Both effects were products of psychological and technological evolution too subtle, too obscure, and too complex to be easily detected or set out here; again it is the effect with which we are chiefly concerned. To the conversion of the European state-system, in point of fact, from a multitude of feudal principalities and a hope of empire to a system of national states, we therefore turn. ${ }^{1}$

When the gods quarrel the demi-gods profit thereby. In the thirteenth century the Holy Roman Empire and the Papacy fell into acrimonious dispute concerning the proper relations to be maintained between the secular and the sacred powers, and sharply contended for the mastery of Italy. In the struggle both Emperor and Pope found it necessary to secure support from lesser kings, nobles, cities, ecclesiastics of high degree, and the rising burgher

${ }^{1}$ Rise of national states: Hill, I, Chap. VIII; II, Chaps. I, VI (Part III), VII; Muir, 57-64. Disruption of Empire: Bryce, 204-213, and Hill, as cited. Fall of Papal Power: Hill, II, 27-44; Walker, § 52. 
class. ${ }^{1}$ At the same time, they were led to put forward excessive claims to power themselves. ${ }^{2}$ The result was to strengthen the kings and to weaken both the Emperor and the Pope, and to provoke the national rulers to resistance against the excessive claims of Emperor and Pope to control them. The two processes interacted; the national rulers were incited to resist imperial domination and were able, by playing Pope against Emperor, and Emperor against Pope, to secure the means of resistance.

This process may be studied in the culminating acts of the drama which led to the final break-down of both Papacy and Empire and the emergence of the first national states. Frederick II, Holy Roman Emperor from 1210 to 1250, vainly tried to conquer and control Lombardy and Sicily and to free himself and his possessions from Papal opposition and interference. He was met with repeated excommunications, in 1227, 1239, and 1245. To outdo the Pope in religious zeal and win his favor, Frederick embarked on the Fourth Crusade, only to see the princes of the Empire, on whom he relied to keep the peace in his absence, repudiate his claims to authority over them. While he was still in Palestine anarchy and rebellion broke out afresh in Lombardy and Sicily, not without the connivance of Papal agents in those regions. French and British forces were invited by the Pope to intervene in the peninsula. Frederick was unable to make headway against his foes, and when he died in 1250, the last of the Hohenstauffen, he left his sons and grandsons to be killed or captured, in 1254, 1266, and 1268, and the Empire to be overwhelmed by its enemies. ${ }^{3}$ The revolt of the feudal princes went on; the outside powers invoked by the Pope intervened; and complete confusion resulted.

The Papacy, in its turn, broke down under pressure from the same forces. Too many concessions had been

1 Thorndike, 471-472.

${ }^{2}$ Hill, I, 396-398. (
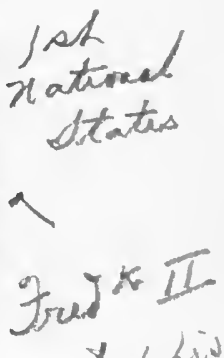

Thorndike, 462-463, 467-471.

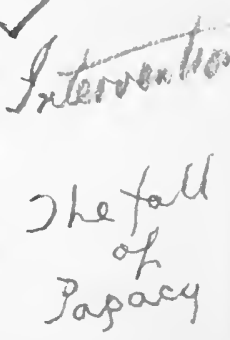


made with a view to securing support against the Empire, and further weakness arose from excesses resulting from the victory over the Emperor. Pushing to extremes his pretensions to international authority, the Pope encountered fatal opposition from those very powers which he had helped to call into play against the Emperor. The culmination of this process may be observed in events at the end of the thirteenth, and in the early fourteenth, century.

In the bull "Clericis laicos," of 1296, Pope Boniface "VIII presumed to deny the power of the newly arisen national sovereign of France to tax the clergy without Papal consent. Both French and English rulers promptly put forward the doctrine of the divine right of kings in opposition to such a contention. Philip IV of France was sustained in his attitude by the French people in Parliament assembled and was thus fortified in resisting the Papal encroachment upon his jurisdiction. Naturally, he was threatened with the penalty so vigorously used by the Pope against the Emperor Frederick, namely, excommunication and deposition, involving a release of his subjects from their allegiance. As a matter of fact, such a decree probably would not have had much effect upon Philip's position, for his people were well disposed toward him in this particular situation and would not, probably, have acted upon such a release. Moreover, Philip had already established with considerable firmness his authority over the people of France, including-and this is the main point, a matter to receive additional attention later-the erstwhile independent feudal nobility. In the event, Philip did not wait on the Pope, but sent his agents to Italy; and these agents unceremoniously took Boniface prisoner at Anagni in 1303 and held him until he was rescued by friends. He returned to the Vatican only to die, a month later, broken and vanquished. Through the influence of the French cardinals, the Archbishop of Bordeaux was elected, in 1305, to succeed the beaten pontiff, and, as 
RISE OF THE SYSTEM OF NATIONAL STATES 49

Clement V, he decided, more or less voluntarily, not to go to Rome, but to remain resident at Avignon, in France. This was the end of Papal imperialism on the temporal side. ${ }^{1}$ France, and to a lesser degree, England, had captured Pope and Papacy, and had broken up the Papal system, as the German princes and Italian cities had broken the power of Frederick II.

On the purely ecclesiastical side the Papacy met the same defeat at the hands of nationalist forces after the return to Rome in the last quarter of the century. The French members of the College of Cardinals became involved with the Italian group in disputes regarding church management, particularly the subject of Papal elections. The Great Schism, as it came to be called, dragged on for a generation, Italian Pope and French anti-Pope, or the reverse, contending for the throne of Peter. In no way could harmony in the Church be finally restored except by reconciling the conflicting national groups, which met together in 1417 in the Council of Constance. Here the schism was formally ended, but only by a recognition, in the composition of the Council by reference to "national" delegations, of the new force of nationality now risen to deny the hierarchical unity of the Church. And, though solidarity once more formally prevailed, the ancient Papal prestige was gone forever. ${ }^{2}$ Af $/ \mathrm{h}$ is arreng

A century later the Protestant Reformation carried the process of disruption into the field of doctrine. The orting Hapsburg monarchs attempted vainly to prevent the result, which was more or less clearly foreseen. Charles $\mathrm{V}$, taking by inheritance from Ferdinand and Isabella the Spanish domains, acquired the Imperial power by election in 1519 and attempted once more to revive the Holy Roman Empire, and to fight the battle of the Church as well. In vain did he and his successors labor at this anachronistic
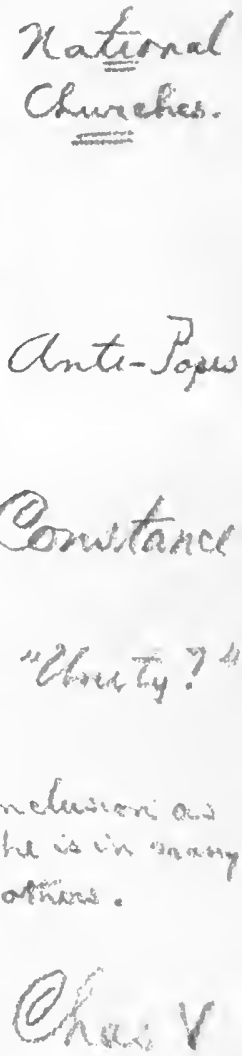

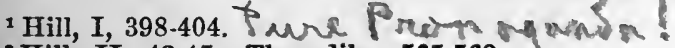

Hill, II, 42-45; Thorndike, 565-568. 
$\sqrt{\text { task. }}{ }^{1}$ Already in 1356 Charles IV had definitely recognized the new powers of the Imperial princes by his Golden Bull, ${ }^{2}$ and the national kings of western and northern Europe were in no mood to resume their former positions of subjection. The Peace of Westphalia, in 1648, confirmed the fact that universal empire in Europe was a thing of the past. ${ }^{3}$

(* In vain, likewise, did the forces of Rome attempt to preserve the doctrinal control of the Pope over local rulers, and in the Peace of Augsburg in 1555 local religious autonomy was recognized (cujus regio, ejus religio). Similar attempts in France failed, and the end of the Wars of Religion saw a pretty general recognition of that fact. One last struggle was made, in the Thirty Years War, to restore the Faith in Central and Western Europe, but quite apart from the natural disintegration of the issues which came about in the course of the war, the end saw the original purpose abandoned. The Peace of Westphalia signalized not only the end of the Empire for it also registered, on the part of the states of Europe, the end of European religious unity under the Pope. ${ }^{4}$

Through all of these events the outstanding political factor was the new national state, under a powerful national sovereign. In the promotion of commerce and in the disruption of the Empire and of the Papacy the national states had led the way, and in some cases nationalist feelings operated with much the same effect, even in the absence of a unified state. France, England, and Sweden had already achieved national statehood. Others were passing over the threshold. From one point of view,

1 Hill, II, Chaps. V-VII; Walker, $\S \S 72,76,77,79$.

Thorndike, 532-534; also Hill, II, 38.

Walker, $\$ 81$. All of the various other attempts at empire in the Middle Ages as reviewed in Chap. III had come to eventual failure, as indicated in the table, note 4, p. 36. See Thorndike, 187-189, 212-213, 554-558. For an extreme view regarding the early supersession of the imperial idea by the narional principle see Carlyle, III, 178, 179.

*Hill, II, Chap. VI, especially 602; Walker, §§ 73-75, 77, 78. 
RISE OF THE SYSTEM OF NATIONAL STATES 51

these states came into being by the breaking up of the Empire. ${ }^{1}$ It remains to note how they had come to independence by the amalgamation of many formerly independent feudal units.

There had long been growing up, beneath the figment of empire and within the ecclesiastical fold of Rome, a group of national unities which now merely burst into plain view. In England and France this might be traced back even to the ninth and tenth centuries. The Frankish Empire was divided by the Treaty of Verdun in $1843,{ }^{2}$ and never afterward did France form an integral part of the Holy Roman Empire. England was in some degree unified under Canute and, more significantly, in the eleventh century under Alfred. These, however, were anticipations of later events, and it is to the twelfth, thirteenth, and fourteenth centuries that we must go to witness the birth of French and English nationality.

The ultimate or original causes for the appearance of nationalities in Europe are elusive to the point of almost completely evading description. Nationality may be taken to mean a certain spiritual unity observable among a group of people, usually arising from a greater or lesser degree of racial unity and from community of language, art, religion, economic interests, and ethical ideals, although at times it is manifested by groups not very clearly possessing any of these bases for their apparent spiritual unity. This factor in European life appeared slowly after the fall of Rome. There had been some feeling of this kind in antiquity, and the barbarian peoples seem to have had some degree of national consciousness at the time of the Invasions. But nationality, as we know it, came into being only after the settling down of the peoples in the fifth and sixth centuries.

After the wanderings of the invaders were over, the

${ }^{2}$ Hill, I, 366-380.
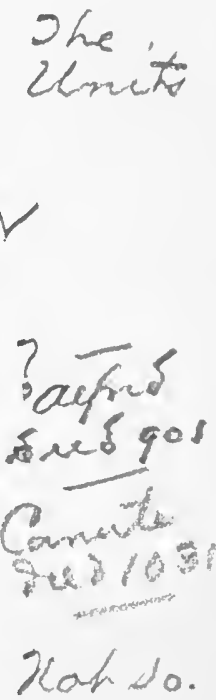
various migrating peoples settled down in definite local areas and worked out, or, as we might say, worked up, from their own customs and languages and those of the peoples among whom they settled and with whom they became completely mingled, common bodies of culture more or less peculiar to the different areas where they settled." With the growth of these "national" culture units came a consciousness, on the part of the peoples among whom they developed, of their actual existence, a self-consciousness, a realization of their own unity and of their diversity from their neighbors. All this was encouraged by the awakening of the human consciousness which came with the Renaissance. ${ }^{2}$ Through living together in more or less separated sections of the continent, the peoples of Europe came gradually to feel that they were divided into groups in cultural matters.

It has been the habit to say that antiquity knew no such thing as "nationality" " and that the barbarian "nations" constitute the earliest prototypes of modern nations." To a degree this is true. But such statements must be made with a great deal of caution. Certainly the Greeks and Romans and Phœnicians were, and felt themselves to be, distinct nationalities. ${ }^{5}$ No little pride of national spirit was manifest among them. On the other hand, the barbarian tribes, even when they were of different racial stocks and had distinct political organizations, formed no highly distinctive or specially developed bodies of culture. When the field is carefully surveyed, it appears that there was, in truth, such a thing as "nationality" before 1789 , but that it had not developed very far. The final divergence between ancient and modern national states lies not only in the intensity of development of the national spirit but particularly in the correlation set up between

${ }^{2}$ Hill, $\mathrm{Y}, 41-42$.

Muir, 33, 126-127.

'Same, 37; Rose, 2-5.

- Hill, as last cited.

Phillipson, I, 30-31, 40, 122, 123, 213, 230; Walker, §§ 24-29. 
national cultural unity and political unity and independence. The latter, the correlation of nationality and statehood, was not to be found in antiquity except by accident. The Greek city states were mainly subnational, the Roman Empire was supernational. During the Medieval period this condition persisted; the feudal states were morsels of national masses, the empires conglomerate superstates. In the collapse of feudalism the correlation between nation and state began to be established in the early modern period. ${ }^{1}$

The concentration of political power in the hands of national sovereigns began with the Crusades, which put a premium on the relatively greater ability of the kings to raise larger forces of men for the enterprize than could be raised by the lesser nobles. Professional standing armies could be maintained by them and set over against the temporary and amateur feudal levies of the barons. ${ }^{2}$ Under such conditions the titular superiority of the supreme over-lord, of no great importance in ordinary times, became important and significant. ${ }^{3}$ fule, of cruze

Meanwhile there were developed within the national kingdoms certain legal and political institutions which in effect strengthened the hands of the national sovereigns against foreign foes and helped to weld the nations into compact entities. ${ }^{4}$ In the first place, a centralized administrative machine was built up in France which rendered

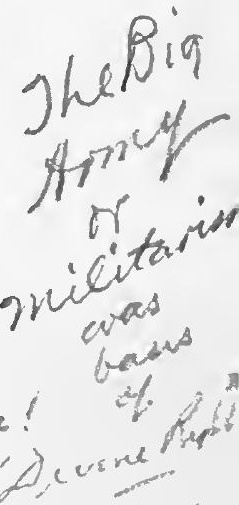

1 This correlation is, of course, not yet perfect. Many modern states have diverged widely from the type of national unity. The real difference between the modern and the Medieval state might seem to be merely that the former is independent of imperial and feudal leading strings whereas the latter was not. However, notwithstanding all the exceptions, the test of nationality seems to be the most significant one.

On the other hand, Marriott goes too far in denying that international diplomacy existed at all before the appearance of the "national" state (Marriott, 22-25). As Phillipson says (II, 122, 123) such a contention results from too great deference to words and names. Before 1500 A.D. there were very active interstate relations between the existing political entities, and these are properly studied, even prior to 500 A.D., as being of the same character as the "international" relations of later times.

Hill, I, 373.

Same, I, 367-368; Thorndike, 491.

- Thorndike, Chaps. XXV, XXVI. 


\section{INTERNATIONAL ORGANIZATION}

the royal power effective in all corners of the dominion. ${ }^{1}$ In England the legal system was unified by judges of the Crown who, as they moved about on circuit, heard appeals from local and feudal courts, thus carrying the king's justice to all sections of the realm. ${ }^{2}$ Royal power and the central state authority were everywhere strengthened by new activity in the study and teaching of the law of Rome. Beginning with the rediscovery of certain texts of the classical jurists, and the dissemination of them from the now flourishing schools of law in northern Italy, the science of the Roman state spread through Europe, with the effect of providing everywhere a new theoretical justification for the authority of the national government. ${ }^{3}$ National parliaments were, finally, convened in England and France and

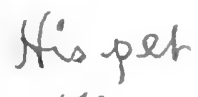
served to body forth the state as a political whole. ${ }^{4}$ I

Powerful personalities in royal station were not wanting to take advantage of these tides in the affairs of Europe. Philip Augustus (1180-1223), Louis IX (122670), Philip IV (1285-1314), and, later, Louis XI (146183), in France, and Henry II (1154-89), Edward I (12721307), and, later, the Tudors in England, made strong and largely successful efforts to weld their subjects into coherent bodies politic. ${ }^{5}$ The royal dynasties took advantage of their relatively greater continuity in the face of the many feudal successions to gather into the royal domain by escheat various pieces of feudal territory whenever the person holding them in fief died without heir. ${ }^{6}$ The Crown also found allies against the feudal nobility in the growing town citizenry which desired emancipation and protection from the nobles and could be persuaded to support the king politically and individually against the barons in

1 Thorndike, 491-492.

Same, 475-476.

Hill, I, 374-375.

Thorndike, 483-484, 500-502, 519-521.

- Same, 475-479, 483-485, 492-494, 495-496, 498-510, 623-627; see also Hershey, §52, and note 87 .

- Hill, I, 368; Thorndike, 491. 
exchange for increased freedom for themselves. ${ }^{1}$ As defenders of the faith in crusades against the infidels and heretics, the national sovereigns found added prestige and influence. ${ }^{2}$ The doctrine of divine right, which had been invented to combat the Imperial and Papal claims to control over national affairs, was in part made over by the lawyers, working always with the Roman law in mind, into a doctrine of absolute sovereignty within the state, especially against noble and ecclesiastic. ${ }^{3}$. fill !

Wars between the newly developing national states contributed to the movement. After England and France had contended with one another in the long struggle called the Hundred Years War the peoples of the two countries could hardly fail to realize that they formed distinct national groups. The struggle was in origin purely dynastic, but in each country it went far to complete the process of unification by establishing the king as a paramount sovereign over all the feudal nobles. ${ }^{4}$ For France, an alien power was expelled from the national territory; ${ }^{5}$ for England, the distracting foreign holdings were cut off and the country was turned back on itself. In both cases the familiar effect of foreign war in rousing a spirit of national unity was manifest. Finally, the long Italian wars of France at the turn of the fifteenth and sixteenth centuries affected that state in a similar manner. ${ }^{6}$

Hill, I, 371; Walker, 90.

Walker, 89.

3 Hill, I, 374-375; Walker, 89, end.

'Hill, II, 20, 72; Muir, 58; Rose, 11, 13-15. England had already achieved a measure of national unity, although it is not safe to declare, as Mr. Marriott does (27), that she attained national unity three centuries before France. The process was completed in the fifteenth century. The same process in France, begun more recently, was not completed until the opening of the sixteenth century; after the expulsion of England from Gascony it remained for Charles the Bold to be expelled from Burgundy before the monarchy could feel safe in its territorial supremacy in France. Marriott, 23; Thorndike, 616-621, 624-626. Nevertheless, because of her position on the continent amid the other states, France stands out as the leading figure in this movement.

Thorndike, Chap. XXVII; on the anti-alien character of the war see Marriot, 23.

- Hill, II, 372. 
Thus were the first modern national states made out of the fabric of imperial and feudal Europe, by a breaking down of the greater imperial unity and an aggregating of the lesser feudal states. ${ }^{1}$ These states were incomplete fulfillments of the national idea as it was to work itself out later, but they were radically different from anything that had gone before, with the possible exception of the transitory barbarian kingdom. They were not weakly grandiose, as were the Medieval empires, nor meanly petty, as were the feudal principalities. Moreover they had psychological, social, and economic foundations that were more stable.

The processes just described have gone steadily forward to the present day. The results may be summed up briefly at this point.

The emergence of France and England as national states was followed by the appearance of the Portuguese, Spanish, Swiss, and Dutch national states, substantially as we know them today. Before 1648 had also appeared the Danish, Norwegian, Swedish, Polish, and Russian nations, independent of the processes of feudal amalgamation and imperial disintegration just studied. During the last three centuries the state-system has been expanded by the addition of other European national states, formed either by the unification of scattered national elements into one state or by the disintegration of empires holding in subjection diverse national groups. Such are Germany, Italy, Hungary, Greece, and others. In addition, there have been added many states developed from transmarine colonial settlements made by the European states, and also several non-European states of independent origin. Such are all of the independent American nations on the one hand, and China, Japan, and Turkey on the other. ${ }^{2}$

As new states emerge from the preëxisting state-system

${ }^{1}$ Compare the sharp statement of Nys (Origines, 166) who says that what appeared in fourteenth-century Europe was "the state" itself (lo stato, l'état).

'For other nations than England and France see Muir, 59-64. 
RISE OF THE SYSTEM OF NATIONAL STATES 57

through the stages of insurgeney and civil war, they demand, and, under proper circumstances, receive, recognition from the existing states. The new state must possess a real existence at the time, must be prepared, if recognized, to submit to the aceepted rules of international law, and must hold out some prospeet of permanence or stability. Recognition may be aceorded by each state for itself or by several states acting in concert, and such action may take the form of either a direct proclamation or steps from which the intention to recognize may be clearly inferred. Once recognized the new state succeeds to all the rights and duties of states at common international law. ${ }^{1}$

The result is a group of some seventy independent political organizations holding in their jurisdiction certain portions of the earth's surface and certain portions of the earth's peoples, beasts and things. ${ }^{2}$ Most of them exhibit a fair degree of national unity; and among them has developed an elaborate system of international organization and coöperation. In recent years changes have come over the commercial relations of these states which have profoundly influenced the development both of the statesystem itself and of the political and legal relations among the members thereof. In the period since 1648, also, the old struggle between empire and nationality, as fought out in Europe between 1250 and 1450, had to be gone through again. But the upshot was merely to confirm and extend the results of the earlier contest; St. Helena and Amerongen have ratified the teachings of Canossa and Anagni. ${ }^{3}$

${ }^{1}$ For law and politics of rebellion and recognition see Goebel, entire, and Wilson and Tucker, $\S \S 22,28,29$.

${ }^{2}$ On territorial and personal jurisdiction in the legal sense see Wilson and Tucker, $\S \S 46-68$.

Chronology of the rise of the national state-system: 1095-1270, The Crusades; Clermont to death of Louis IX 1154-1189, Reign of Henry II in England 1180-1223, Reign of Philip Augustus in France 1250-1268, End of the Holy Roman Empire of the Hohenstauffen

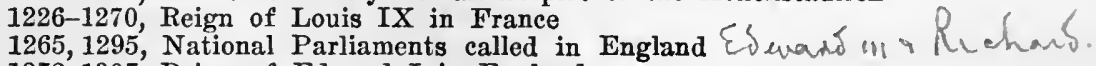
1272-1307, Reign of Edward I in England 1285-1314, Reign of Philip IV in France 1302, 1308, Estates General called in France 
We may, therefore, take the state-system of 1648-1918, with its implications for the institution of national statehood and international relations as the foundation for the study of modern international organization. ${ }^{1}$

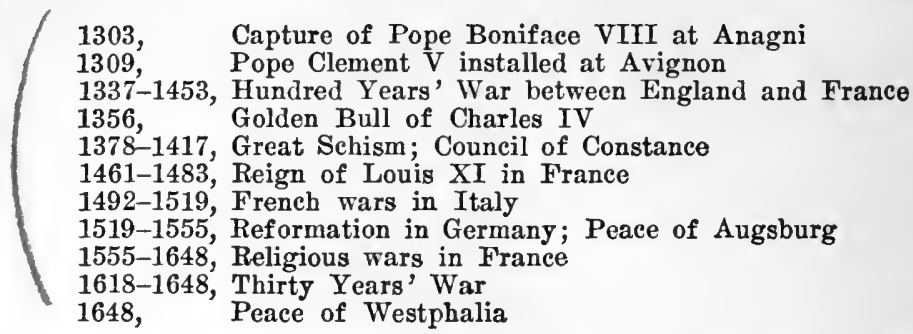

${ }^{1}$ Disregarding, at this stage of the discussion, the questions of diplomatic recognition and of limited sovereignty, the principal members of the international state system of the world as of 1 January, 1922, grouped with reference to their modes of origin, were as follows:

A. States formed in Europe by aggregation of feudal units or several national groups and by disintegration of supernational empires:

$\begin{array}{lll}\text { Albania } & \text { Germany } & \text { Lithuania } \\ \text { Austria } & \text { Great Britain } & \text { Netherlands } \\ \text { Belgium } & \text { Greece } & \text { Portugal } \\ \text { Bulgaria } & \text { Hungary } & \text { Roumania } \\ \text { Czechoslovakia } & \text { Italy } & \text { Spain } \\ \text { Esthonia } & \text { Irish Free State } & \text { Switzerland } \\ \text { Finland } & \text { Jugoslavia } & \\ \text { France } & \text { Latvia } & \end{array}$

B. North European states formed independently of such processes:

$\begin{array}{lll}\text { Denmark } & \text { Sweden } & \text { Russia } \\ \text { Norway } & \text { Poland } & \end{array}$

C. States developed in America, Australasia, Asia, and Africa from colonies of European states, with native elements:

$\begin{array}{lll}\text { Argentina } & \text { Dominican Republic } & \text { Panama } \\ \text { Australia } & \text { Ecuador } & \text { Paraguay } \\ \text { Bolivia } & \text { Guatemala } & \text { Peru } \\ \text { Brazil } & \text { Haiti } & \text { Salvador } \\ \text { Canada } & \text { Honduras } & \text { South Africa } \\ \text { Chilo } & \text { India } & \text { United States } \\ \text { Colombia } & \text { Mexico } & \text { Uruguay } \\ \text { Costa Rica } & \text { New Zealand } & \text { Venezuela } \\ \text { Cuba } & \text { Nicaragua } & \end{array}$

D. Native states in Africa and Asia:

$\begin{array}{lll}\text { Abyssinia } & \text { China } & \text { Liberia } \\ \text { Afghanistan } & \text { Far Eastern Republic } & \text { Muscat } \\ \text { Armenia } & \text { Georgia } & \text { Nepal } \\ \text { Azerbaijan } & \text { Hedjaz } & \text { Persia } \\ \text { Bhutan } & \text { Japan } & \text { Turkey }\end{array}$


RISE OF THE SYSTEM OF NATIONAL STATES

59

E. Surviving feudal principalities:

Andorra

Luxembourg

Liechtenstein

Monaco

San Mario

In addition to the above, there are some thirty autonomous colonies, protectorates, and other self-governing dependencies, which are not states in the strict sense of the term but which participate more or less directly in international relations. For a full discussion of this matter see Willoughby and Fenwick, especially 5-13, and Fenwick, Wardships, entire.

From AD 1095 to En of a sa year's lar by Sixty of thetphate in 1648 . or 553 years- aratrepuneí to value the modern

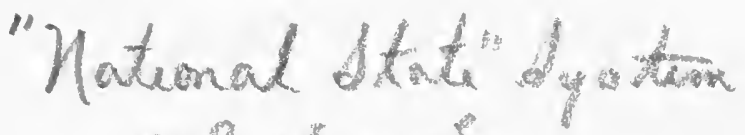
eon ck ma se

Diplomacy pow ide as Reorganization NECESSARY

an knowles Chain! From Lear are to Lane The race of man is born! 



\section{PART II}

MODERN DIPLOMACY 

, 


\section{CHAPTER V}

\section{ORIGIN AND DEVELOPMENT OF THE CONSULAR SYSTEM}

STUDY of modern international institutions and pracA tices must logically begin with an examination of the origins and development and the present status of the consular and diplomatic systems. The classification of international governmental institutions as legislative, executive, and judicial cannot be applied with any success until a comparatively late stage in the evolution of international relations. Such a classification depends upon the idea of the regulation of international relations according to law. This law is to be made by legislative bodies, administered by executive agencies, or applied in litigation by judicial organs. Nothing of that character is found in seventeenth century Europe; not until the nineteenth century did such concepts enter the field of international affairs. Meanwhile international relations, not to be oonducted: by a legalistic method, were carried on by the method of personal negotiation, through diplomatic and consular officers. And, as

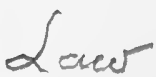
romer

between the two sets of agents, diplomatic and consular, the latter must take precedence in the history of the growth of international organization. In this early epoch of government not by laws but by men, of government by personal negotiation, the consul was the pioneer.

The essential cause which has produced the modern consular system is the need for some official governmental assistance to, and supervision over, the conduct of international commerce by the private citizens of the various na- 
tions. The Greek city-states found it necessary to secure representation in each other's ports and markets for the protection and assistance of their merchants abroad. The representative in question held court on board visiting vessels of the state which he represented, and settled disputes between the master and members of the crew, on one hand, or, on the other, merchants having business relations with him in relation to the cargo of the vessel. The Greek consul was a citizen and officer of the state in which he resided and constituted a much more important figure in international relations than did the transient and fugitive diplomatic agents of the same period. ${ }^{1}$ Rome likewise employed a system of commercial representation abroad, and modern nations, in working out their consular services, are thus merely responding to a natural need which has been felt since the dawn of international relations. Indeed, this need is the most elementary and unescapable in the whole range of those relations. Consular representation is the original and most fundamental form of official international intercourse.

When overseas commerce, after its long period of stagnation during the centuries from 400 to 1100 A.D., began to revive and expand once more in the twelfth century, the office of consular representative reappeared also. Or, to state the result entirely afresh, the nations which aspired for shares in the new commerce found it advantageous to adopt the device of foreign consular representatives. Two centuries, at least, before the establishment of diplomatic representation as we know it, the states along the Mediterranean were led,into the practice of sending consular officers out to distant parts for the service of their merchants abroad. In particular, the Western Mediterranean city-states, such as Genoa, Valencia, and Amalfi, began to send such officers into Levantine ports in connection with

${ }^{1}$ On the consular system of Greece see Monceaux, entire; also Phillipson, I, 154, and elsewhere. 
the trade growing out of the Crusades. This was the origin of the modern consul. ${ }^{1}$

It is still difficult to trace definitely the steps by which the consular office was created. The records are incomplete, confused, and contradictory. Conditions and practices varied greatly, even within the comparatively limited Mediterranean world. It would be misleading and futile to attempt to do more than reconstruct the general process, taking note of all the important steps and the principal varieties of consular activity. The account must be inclusive, not exclusive. ${ }^{2}$

There were two principal currents of practice leading to the final result. ${ }^{3}$ French, Spanish, and Italian maritime city-states had long been in the habit of appointing special judges to deal with commercial matters, especially maritime disputes, in their courts. ${ }^{4}$ These judges, who took the name of consules maritimi (signifying magistrates with authority over maritime affairs), or their deputies, began to go on board the vessels of citizens of the state for which they were acting, to perform their functions while the ship lay in the home port, or was at sea, or rested in a foreign harbor. ${ }^{5}$ Soon these travelling judges found it convenient to go on shore during the stay of the vessel in the foreign port, and to remain there, even while the vessel sailed back for other cargoes, performing their functions for the benefit of any of their fellow-nationals who were at the time present in the foreign city, and for the protection of their

${ }^{2}$ For literature on the origin of the consular service see works cited in Appendix B, $\$ 5$ especially Ravndal. For evidence of consular practices in China and nearer Asia as early as the eighth century see Capello, 161.

${ }^{2}$ For a treatment seeking to find a single all-sufficient theory of the origin of the consul see Pradier-Fodéré, IV, 430.

II, 397 .

Compare the version in Sheppard, at 394, with that in Martens, Traite,

Twiss, Black Book, IV, xcr. This official resembled the Greek "arbiter of the port" ' Capello, 155.

B Twiss, as cited, III, 183 (text of Chapter LXXIV of the Consolato del Mare, and note 1): also Nys, Droit, II, 398. 
ships and property. ${ }^{1}$ The prevailing doctrine that an alien was subject only to the law of his home state, and not to the jurisdiction of the foreign state where he happened to be located, made all this quite natural and feasible. ${ }^{2}$

On the other hand, in the absence of any judge from the home city, ${ }^{3}$ groups of alien traders, living in "foreign quarters" of maritime cities in the Levant, were led to elect commercial judges from their own numbers. These commercial judges likewise came to be called "consuls" and, by the home governments, "consuls in foreign parts." Later, they were sent out by the home governments, on the request of the foreign community, to maintain the law of the city over the citizens and their property abroad. ${ }^{4}$

These two lines of procedure tended to coalesce. One form of action inevitably became mingled with the other. Elected consuls and consuls sent out from the home state alternated with one another from place to place and from time to time. The common factor constituted the positive result achieved: foreign consular representation became a fact in Southern Europe in the twelfth century; and during this century and the succeeding one the practice spread throughout the whole Mediterranean world.

The activities of these consul-judges resulted in the production of a body of rules of commercial law more or less common to all trading cities. The laws of the home state were, naturally, respected so far as they applied, but the consular law served to supplement and harmonize the local legal systems and to create something of a body of common law up and down the commercial world. This body of rules and principles as found in practice in the Mediterranean

${ }^{1}$ Twiss, as cited, IV, 539 (Article 25 of the Maritime Ordinances of Trani); also Capello, 160 .

'Sheppard, 395.

'Capello, 160; Martens, as cited, II, 97. On this side the practice may be traced back to the sixth century, or earlier; Nys, Droit, II, 397; PradierFodéré, IV, 432. This officer resembled the elective judges of the guilds in Greece; Capello, 155.

-Capello, 156, 158, 160. 
area was, apparently, compiled at some time near 1300 in what is known as the Consolato del Mare, ${ }^{1}$ and constituted in its day the most important legal monument since Justinian, with the possible exception of the still incompleted compilation of the Canon Law.

The Consolato del Mare marks the beginning of the modern period in this field, just as the Peace of Westphalia, over three centuries later, marks the recognition of the establishment of the modern state-system and diplomatic representation. The first book of the Consolato dealt with consul judges, setting forth their duties and powers, and giving a full description of the judicial office from which the foreign consular representative was derived. ${ }^{2}$. By this time, in other words, practice in this field had reached the mature stage of codification.

As has been suggested, the consul-judges were carried into the Levant by the Crusades. ${ }^{3}$ The fact that the regions visited by the Crusaders were ruled by Jews and Mohammedans led the Christians to demand the right to establish consular jurisdictions in Palestine and Syria. The Western merchants demanded this right also from the kingdoms set up by the Christian Crusaders themselves. Elaborate charter permits were obtained exempting trading factories and shipping from local laws and permitting the establishment of local consular courts. These "capitulations" were not always grants by Levantine powers to Western European states for the benefit of their citizens, but were commonly grants to private corporations of quasi-public rights. A merchant guild or foreign colony was often accorded, in its own name, the right to elect consul-judges and, in gen-

1 The term is used here to refer to the first part of the Book of the Consulate, as of the edition of 1494; see Twiss, as cited, II, lix-lxx; III, xxv-lxxxii; also Pardessus, I, 21-34, 206, 209.

${ }^{2}$ For text of the Valencian Regulations which form the first treatise or book in the Consolato, see Twiss, as cited, IV, 450-495.

${ }^{3}$ Capello, 161; Sheppard, 399-400. For those who take the consuls elected in foreign ports as the source of the consular office, as does Martens, the office originated in the Orient and was brought to the West later; Martens, as cited, II. 397 . 
eral, to govern itself. ${ }^{1}$ By 1226 such establishments were to be found not only in Palestine but in Asia Minor, Byzantium, and Egypt. ${ }^{2}$ The differences of religion and social customs and legal practices operated in all these regions to expand the privileges of exterritoriality granted to the alien merchants.

However, similar practices sprang up in the North of Europe where the same religious differences did not exist. In the Hanseatic cities British, Dutch, Scandinavian, and German traders were led to the establishment of such consular magistrates in each other's territories. ${ }^{3}$ Semi-autonomous merchant "colonies" were to be found, at the opening of the fifteenth century, at many points on the North Sea and the Baltic. In 1438 Henry VI of England secured for his consular judges a renewal of their privileges "for one hundred years back, to do justice between the King's liege subjects and merchants at all Hanseatic towns beyond the sea." 4 The same treaty in which this privilege was granted recognized the authority of the second part of the Consolato as applicable in Northern Europe. This part of the Consolato dealt with the substantive rules of maritime law. Thus the consular law of Europe was to a degree unified. By the natural process of development to meet the needs of the commercial community the office of consul had not only come into being but had secured formal recognition and systematization by the new states of Europe.

Since the fifteenth century there have been several striking changes in the nature of the consular office. Of these changes three deserve notice at this point.

First, selection by the home state, always the more authoritative method of choosing consular representatives, has come to supplant entirely the practice of election by a foreign colony. Consuls are now almost universally sent

${ }^{1}$ Hershey, $\$ 51$, note 86 .

'Sheppard, 401.

Same, 402-404.

- Sheppard, 405. 
out from the state securing representation abroad, and where the consul is chosen from persons residing abroadeither citizens of the local state or of the state to be represented-the choice is made by the latter in its official capacity.

Second, the doctrine that the alien carries the law of his home state with him has given place in all Western states to a doctrine that when abroad the alien is mainly subject to the jurisdiction of the state in whose territory he is for the moment domiciled. There is still a large measure of exterritorial consular jurisdiction in the Orient. But the Western world has adopted the feudal concept of exclusive territorial jurisdiction in its full import. The result is that national sovereigns, whether royal or popular, have refused to continue to allow the foreign consul to exercise any considerable jurisdiction over the alien. As a further result, the judicial character of the office has greatly diminished. ${ }^{1}$ During the sixteenth century this effect was very important, for the consul was not at that time charged with the collection of information for the home state and the performance of ministerial functions in its name, as he now is. As a result of this fact, and under the influence of the continuous wars of the next two centuries, the office declined greatly in importance. The present consular system is, therefore, largely the product of the nineteenth century.

Finally, the growth of a complete diplomatic system, side by side with the system of consular representation, has drawn off from the consular service many of the diplomatic functions once attached to it. ${ }^{2}$ The external prestige of the office has consequently fallen. These changes, however, have not touched the essential quality of the consular function: the promotion and control of international commerce. Hence they have not destroyed the office, but have

1 Hershey, §51; Martens, as cited, II, 100.

2 For diplomatic qualities of the consular office in earlier periods see Sheppard, 392-402. 
merely altered the circumstances under which it is to be conducted. The central principle of the consular function has remained constant from the fime when it first appeared in the period of the Crusades and the commercial revival of the Renaissance. 


\section{CHAPTER VI}

\section{ORGANIZATION AND FUNCTIONS OF THE CONSULAR SERVICE}

AL'sorts of variations appear among the forms given A by modern nations to their consular representation abroad. The organization and methods of operation of no two national consular services are exactly alike. Therefore, to be accurate a description of the consular system must deal only in those fundamental matters where there is substantial uniformity among the nations. ${ }^{1}$ Moreover, it would be impossible to give anything but a very general survey of the consular system except by setting out at great length a mass of detailed material which has no significance in the abstract, and which could mean nothing apart from the circumstances and actions of the consular representatives in individual cases. Leaving the detailed regulations of the different national consular services aside, therefore, we may turn to the principal elements in modern international consular representation as we know it.

It should be noted at the outset that every nation of political and, especially, of commercial, importance, maintains consular representatives in the territories of the other members of the community of nations. Under normal circumstances there is no state or quasi-state, whether it be able to claim and exercise diplomatic representation or not, whose business interests are willing to see it go without consular representation in the important markets and harbors of the world.

${ }^{1}$ On the consular system in general see Stowell, Le Consul, as cited in Appendix B, $\S 6$; there is no equivalent work in English. For literature on the consular services of various nations see references in same, 319-345; on the American consular service see the references in Griffin, Consular Service. 
These consular representatives reside in the various ports and other commercial centers of the nations to which they are accredited. Wherever industry and trade are active there are to be found representatives from all other parts of the world; meanwhile, representatives have gone out from that state to the regions from which raw materials are to be obtained or where finished products may find a market.

Each nation decides for itself upon the method to be followed in choosing persons to exercise consular representation abroad on its behalf, and some mode of selection is regularly provided for by law. The work naturally calls for an acquaintance with the various branches of international commerce, together with commercial and international law. Command of the language in common commercial use in the region to which the consul is to be sent is indispensable. In view of these facts it has been found advisable in several countries to establish schools for the preparation of candidates for the consular service or to make arrangements with private educational institutions for this work. ${ }^{2}$ The suitable candidates are then selected more or less by means of a series of technical examinations determining the fitness of the applicants for entrance into the lower and middle ranks of the service. ${ }^{3}$ The recruitment of the higher posts is generally left to promotion from the lower ranks, or to selection, on grounds not readily made the subject of formal examinations, outside of the existing personnel.

Consular agents are grouped, for administrative purposes, into various classes. These naturally differ from one national service to another, yet, on the whole, there is a measure of uniformity here as in other phases of the system. Among the titles most frequently used are: Consul

1 Report, 30; Stowell, Consul, 186.

Jones, 93-99.

-Stowell, 188; for the United States see U. S. Consular Regulations, §32, and Report, 21-31. 
General, Consul, Vice Consul, Deputy Consul, and Consular Agent. ${ }^{1}$ There are many consular clerks, often so called, and many consular representatives of no special title and rank or, on the other hand, of very special title and rank created to meet special circumstances. ${ }^{2}$

Each consular office abroad has its proper territorial jurisdiction, which results in a districting and redistricting of each of the important nations, on the part of all the others, for this purpose. ${ }^{3}$ The idea that the United States, for example, is so parcelled out, on the books of the British French, Italian, and Japanese governments, may be a novel idea to an American citizen, but it is a commonplace of actual practice. ${ }^{4}$ The importance of the consular officer depends to a greater extent upon the importance of the district in which he is stationed than upon his rank or his relation to the other consular representatives from his own nation who are stationed in the same country. At the same time, the rank of the consular representative in charge will correspond, under ordinary circumstances, to the importance of the consular area. Finally, some effort is made to organize the consular representatives abroad into a more or less complete hierarchy among themselves and in relation to the diplomatic service. The several districts and their representatives are not left to depend individually upon the home office. ${ }^{5}$

Ordinarily, the field service is controlled by either the department of the national government dealing with foreign relations or the department of commerce. ${ }^{b}$ At one time or another, in one or another nation, the national consular agents have, however, been controlled by colonial departArt. I.

' Foster, 217-218; Hershey, § 284 and notes; U. S. Consular Regulations,

2Regulations, $\$$ 23-29.

Same, § 30 ; Register, Table XI.

Register, 186-217.

- Stowell, 194, 203; for United States see U. S. Consular Regulations, Arts. VI-VIII. title.

- Stowell, 197; Hershey ( $\S 284)$ is too dogmatic here; ef. Ferguson, by 
ments or departments of the government dealing with naval affairs. ${ }^{1}$ This is due to the fact that consuls have sometimes been regarded by the country sending them out as colonial agents,- especially in the case of consuls sent into African and Oriental countries,--or as naval officers. Early Venetian and Genoese consuls were, in fact, colonial governors. ${ }^{2}$ The control of the consul is still in an ambiguous position for the reason that his position as foreign representative of his national government would imply control by one department of that government, while his work in connection with the foreign trade of his country would make it advantageous for him to be controlled by another department.

In like manner, the degree of control exercised by diplomatic officials over the consular representatives from their own country who are stationed in the territory of the state to which the former are accredited varies greatly. In general it may be said that a certain amount of control exists, having been conferred upon the diplomatic representatives by the home government. ${ }^{3}$ On the other hand, no diplomatic representative, at all events none but the very highest, and then only under instructions from the home government, could dictate to consuls in the same country the proper action for them to take on matters on which standing instructions have been provided. ${ }^{4}$

Consular representatives are coming to be paid mainly by salary. ${ }^{5}$ In earlier times they were frequently regarded as private commercial adventurers, sojourning abroad, who could be utilised and prevailed on to perform certain functions for their governments, or they were regarded as agents and representatives of private business interests or of the merchant community itself. They.are now pretty

1 Stowell, 198.

Capello, 179.

${ }^{3}$ For United States see Regulations, Arts. I, II, VI-VIII.

- The attempt of a Mexican confidential agent in the United States in 1920 to do this met with failure; New York Times, 23 November, 1920, p. 15.

Foster, 217 ; Regulations, Art. XXV. 
generally regarded as public officers, representatives of the state, and in no way private merchants. As a result, they are not required to perform their consular services out of a sense of honor or duty while supporting themselves by private business. Nor are they dependent for their pay, as was the case for many years, upon fees collected in the performance of their duties, although fees are still collected and go in part to the consul as pay. In so far as fees are still used, the government provides, for the convenience of the consul-and his clients,-tables of the fees which may be legally charged, in order that there may be no misunderstanding and hard feeling between the consul and his fellow nationals who come to him for his services. ${ }^{1}$ Similarly the consul is provided with fee stamps, the use of which prevents misunderstandings between him and the home government. Even with all precautions, however, the fee system is a source of constant annoyance to those who should receive nothing but help from the consul. It would be illogical to place the charge for consular service entirely upon the national treasury and to make no provision for special payments by those who in actual fact receive the special services of the consul. But the regulation and administration of the charges to be made is a perplexing problem. ${ }^{2}$

As in the matter of recruitment, so in the matters of promotion, retirement, and pensions, each nation follows its own bent. Other members of the international community are not interested except to obtain additional light on the best methods of managing their own consular services. ${ }^{3}$ These problems are wholly within the field of administrative technology and impinge upon the international field only indirectly.

The difficulty of securing suitably equipped persons to accept consular posts, particularly some of the subordinate

${ }^{1}$ Register, Table XII.

Regulations, Art. XXVI; also Jones, 19-22,

Stowell, 192, 
posts in the service, has led various nations to resort to the devices of merchant consuls and native consuls. ${ }^{1}$ The former are consuls who perform their official functions while engaging at the same time in trade for their private interest. As has been seen, this practice was at one time the normal form of consular representation. Similarly, the native consul, a person selected by a foreign state to act as its representative in the territory of his own nation, was a familiar figure in ancient times and was used, apparently, in the Middle Ages. To a certain extent the practice constitutes an independent historical source of the modern consular office. ${ }^{2}$ However, the native consul was always totally inadequate to the purpose in many parts of the world, as, for example, the Orient; and, even with all the exceptions to the doctrine of territorial sovereignty which modern states are accustomed to make in the interest of international coöperation, it is not to be expected that a nation will be content to entrust the protection of its interests abroad to an alien, particularly an alien who is a citizen of the country in which he is to perform that service. Accordingly, the nations are willing to incur the additional expense involved in sending out their own citizens for purposes of consular representation abroad, and they strive to avoid the handicap incident to the employment as a consul of a person who is subject to all the local regulations of his home country and city by confining their slight use of the native consul to the lowest ministerial and clerical posts in the service. Similarly, the merchant consul, who is likely to confuse public office and private busniess, or to sacrifice one to the other, or to utilize official position-unconsciously, perhaps,-for personal profit, is eliminated as far as possible. These traces of more primitive forms of consular representation are gradually disappearing. ${ }^{3}$

1 Foster, 217 ; Hershey, $\S 284$, notes 2 and 3 ; Regulations, $\S \S 28,37,42$.

Schaube, 525, 526, 528, 531, 533, 536, 538, 542, 545, 553-556. elsewhere.

Foster, 219-220; Jones, 91-93; Moore Digest, §697; Report, 66-69, and 
The consul is concerned in his daily work with a multitude of affairs relating to the state on whose behalf he acts. To perform this work he is given a certain measure of authority by the state which appoints him, and this authority is defined in a commission with which he is provided at the beginning of his mission. ${ }^{1}$ On the other hand, the permission to exercise the powers committed to him by his home government comes from the government of the state within whose jurisdiction he expects to exercise his functions and is embodied in a document called an "exequatur." The reception of individual consular representatives from other states is a purely voluntary matter on the part of each nation. However, consular intercourse has been so generally accepted by modern nations that refusal to participate in such interchange could fairly be regarded, and could only be explained, as a manifestation of an unfriendly disposition. At the same time, it is useful, and it is a matter of common practice, for the nations to agree specifically one with another in consular conventions or in special consular clauses in general commercial treaties upon the terms under which they will exchange consular representatives. The consular convention is thus the immediate foundation and legal basis of all consular intercourse. ${ }^{2}$

Once commissioned by the home state and officially received by the foreign state the consul carries on his work under several sets of rules. ${ }^{3}$ The terms of his commission and his exequatur, together with the instructions from his home government in amplification of the former, are of most immediate importance to him in defining his powers and duties. Back of these stand the laws of the two nations concerned; these, in turn, must be read in the light of

${ }^{1}$ Hershey, § 285; Stowell, 207-209; Regulations, $\S 35$, 48.

'Regulations, Appendix III, especially 552, 564, 570; for a typical consular convention see, below, Appendix A, Document No. 1.

${ }^{3}$ Regulations, Arts. IV and $\mathrm{V}$ and Appendices II-IV. 
existing treaty agreements between the two states; in case of conflict the former must be followed by the individual consul rather than the latter. Finally, back of all stands the system of common international law to which the consul will often turn for information regarding his rights and obligations. The fact that the consul carries on his activfity in the field of private interests, real and personal, results in his being subjected to minute regulation by both the sending and receiving state. In practice, as can well be inferred, the individual consul is largely relieved of the necessity of referring to these different sets of legal principles and rules by having such matters cared for by the department of foreign affairs of his home government. $\mathrm{He}$ will receive from that source, either in general or special instructions, or in response to his inquiries, any information on these questions which he may desire.

The activities of a consul may be variously classified. ${ }^{1}$ $\mathrm{He}$ has certain duties relating to the persons and property of his clients, his fellow-nationals who happen to be present within his consular area. ${ }^{2}$ He must keep a record, ordinarily, of such as are permanently resident there, and of transients who apply for services at the consulate. For all of these he must endorse or "visé" passports, certify to births, marriages, and deaths, and even, if so authorized, perform marriages and draw up and attest wills. He may extend assistance to travelers who are out of funds, to the sick, to the poor. He aids in securing the burial of deceased fellow-nationals or in having their remains transported to the home country. He assists stranded sailors and wanderers of all sorts to return home. He must protect his

1 The analysis given in the text is based on Stowell; for a detailed statement of the duties of American consular representatives abroad see Moore, Digest, Chap. XVI; also Carr, W. J., "What Your Consul Does," in American Consular Bulletin, IV, 1 (January, 1922), and, below, appendix A, Document No. 1 , as cited.

"Stowell, 24-78; also Regulations, Arts. X-XIX. "Fellow-national" is used here to mean a person who, by virtue of citizenship or domicile, is entitled to the protection of the consul. 
clients, individuals or business concerns, from injustice in the local courts, in respect either of their persons or their property. This function is the modern version of the original power of the consul to determine litigation between fellow-nationals in the local district, a power of which a few traces remain in the West, and considerable portions in the East. He is called on to secure, if possible, the release of fellow-nationals from unjust detention or compulsory military service, a duty which has fallen with special weight upon American consuls because of the number of returned naturalized Americans resident in all sections of Europe. ${ }^{1}$

The consul is also of much service to fellow-nationals who are not present in his consular area but resident in the home country. ${ }^{2}$ Their property within his jurisdiction is in his general care; property interests acquired by inheritance will, for example, likewise be protected by him. The relevant and necessary evidence, both documentary and testimonial, must be secured by him, and, if need be, title must be proved before local probate courts. In all sorts of litigation connected with the local interests of business concerns at home the consul is called on for work in the courts in his consular district. Finally, and perhaps most important of all, the consul collects, compiles, and transmits to the home government all possible information regarding local export and import markets and, working with and through the diplomatic representative of his nation stationed in the capital of the country to which he is accredited, information regarding political events and conditions. This service of information is, as far as it goes, the foundation for international commerce as fostered by the official activities of the nations. ${ }^{3}$

On behalf of the home government, as such, the consul

${ }^{1}$ Regulations, $\S 168$, and Appendix IV, 669, 680 .

Stowell, 90-96.

- For the United States see the Commerce Reports; also Regulations, Art. XXVIII. 
performs certain quasi-diplomatic duties. ${ }^{1} \mathrm{He}$ is called on to watch over and insist upon the execution of commercial treaties and other international agreements with the state to which he is accredited, in so far as these depend for their execution upon the local authorities. He is called on to act in demands by his government for the extradition of fugitives from justice, under existing extradition treaties. In case of inability on the part of the diplomatic representative from the home country to carry on his work a consular officer of higher rank may be temporarily and specifically charged with such work. ${ }^{2}$ Finally, the original condition of things, where the consul was in full power as a diplomatic representative, is reflected in a few cases today where diplomatic and consular representation is united in one officer. ${ }^{3}$

The consul, it must be admitted, is a national official, commissioned to act for the state, not accredited to another government, but, at the very least, the consul is an official of the state from which he is sent, in spite of the attempt still made in some quarters to interpret his position as that of a private representative of the national business interests ${ }^{4}$-and as such he may be called on to take quasi-diplomatic action at times.

In his administrative capacity the consul has a very burdensome list of duties. He must endorse cargo-manifests, crew lists, and other documents for merchant vessels about to sail for ports in his home state. He must inspect, often at great labor, emigrants about to depart from their home country for settlement in his state, enforcing the national immigration laws as far as possible at that stage. Finally, he acts as a judicial officer in many petty maritime cases and commercial disputes, and takes depositions of

1 Stowell, 111-129.

- Regulations, $\$ \S 500,501$.

- Same, $\$ \S 20,21,23$.

Jones, 87-89; Sheppard, 444; Stowell, 177-181; and, for the contrasting views, Le Deux and Patau. 
evidence for use in the courts of the home country. Within limits the consul performs duties in this connection which seem to run counter to the principle of territorial sovereignty, and which go straight back to the age of the Crusades for their origin.

To enable him to perform his duties unhindered the consul is accorded certain immunities of person and property. ${ }^{1}$ These include unrestricted communication with his home government and his colleagues in the consular and diplomatic services of his country. This freedom of communications extends to the right to have access to his fellow-nationals at the time in the country, especially, when they are under arrest. He is frequently held to be immune from taxes on his person and his personal property and from detention or prosecution for either civil or criminal offenses except criminal acts of a very serious nature. ${ }^{2}$ He may maintain an office and archives which are inviolable, and he may extend this inviolability to property of deceased nationals by sealing it up. The degree of immunity enjoyed by the consul, in such matters as taxation and military and jury duty, for example, depends largely on whether he is a merchant and a native or a bona fide consul with no local interests except his official work. In the latter case he is free from control by the local authorities in all respects pertinent to the conduct of his consular duties. It is, however, one of the disadvantages of the merchant consul and the native consul that such immunities cannot readily be secured by them. ${ }^{3}$

To guide the consular representative through the maze of law defining his powers and duties and also his official privileges and immunities his home government usually provides him with certain forms of consular literature, in addition to his commission and instructions, ${ }^{4}$ although he

'Stowell, 139-168; also Regulations, §§ 79-84.

- For variant treatments see Hershey, 289.

Stowell, 169-175; also Regulations, §\$ 83-84.

- Regulations, ii. 
may, of course, provide himself with this material. $\mathrm{He}$ should have a working library on the various subjects of international commerce and law, commercial law and general international law, and the law of the nation where he is stationed. He should have reliable manuals or guides upon consular law, or those portions of public and private international law likely to be of special service to consuls. ${ }^{1} \mathrm{He}$ may profitably possess published collections of consular precedents and cases. He will find useful a formulary for consular officers, in addition to the table of forms given in his instructions. He should have a set of the general instructions issued to the diplomatic service of his own country. Finally, the consulate, which should be maintained permanently by the state whose representative is to occupy it, and maintained, thereby, on a higher level than would be possible if it were left to each succeeding representative to provide a consular establishment, should be equipped with the ordinary geographical and statistical materials such as maps, tables of values, weights, and measures, and dictionaries and encyclopedias indispensable to effective office work.

The tenure of office of the consul may come to an end in various ways. ${ }^{2}$ He may resign and his resignation be accepted. Death may terminate his work. On the other hand, outside causes may bring his stay to a close, temporarily or permanently. Such, for example, is the effect of recall by his home government or the cancellation of his exequatur by the receiving government. The outbreak of war between the two nations will ordinarily lead to one or both of these steps, although it is conceivable that neither nation might move to terminate consular representation between them. Even in that case the effect of war would be to suspend the treaty on which that intercourse rested. This is of critical importance. International organization in the form of consular representation is

${ }^{1}$ See literature cited, below, Appedix B, $\S 6$.

Stowell, 217-222. 
continuous in normal times; in time of war it is entirely suspended. It might be contended, with some reason, that the very time when official international communication is most needed is in a period when disputes arise between nations, and that in time of war there are many subjects which need settlement between the belligerents in the course of the war. All of this reasoning will be found to apply with greater force to diplomatic representation. As matters stand, however, and particularly in the consular field, the legal nature of war, with its stoppage of trade, is held to preclude the continuation of international communication of this type.

Surveyed as a whole, the consular system suggests several conclusions. The total result is an enormous and elaborate web of official representation connecting the various members of the international community. ${ }^{1}$ That we is growing in complexity and in toughness with each $\checkmark$ year. Further, the basis of the service is to be found in the quite simple desire for private commercial profit, for personal profit and convenience. The simple and plain facts of international commerce and international travel are the reasons for consular representation, not any sophisticated and fine spun theories of international relations. The creation, maintenance, and improvement of the consular service is a result of the demand of the commercial and travelling public, and any substantial curtailment of it would meet emphatic protest from that quarter. Since the dawn of international relations, in ancient, Medieval, and modern times, the nations have found it useful and even indispensable to provide themselves with some such arrangements. Any system of international organization to be established in the future must take care of the interests now entrusted to the consular service or carry the present system along with itself. No. 3.

${ }^{1}$ Register, Tables XIV and XXXIX, and, below, Appendix A, Document 


\section{CHAPTER VII}

\section{ORIGIN AND DEVELOPMENT OF MODERN DIPLOMACY}

4 ROM time to time in the course of international relations the forms and methods of international diplomacy are severely criticized by intelligent lay observers and are evidently the cause of a great deal of indignant perplexity. Some of the criticisms levelled against modern diplomacy have just reasons for their existence and deserve a respectful hearing. Much of this perplexity and hostility, however, is due to a failure to understand the nature of the diplomatic office and the character of diplomatic representation. These matters can be understood only by a study of how the present system came into being, for the nature of the diplomatic function is determined directly by the way in which it has been worked out in immediate connection with the development of the modern national state.

A single example may be briefly related. In the end of 1920 the Ambassador of the United States in Paris refused to meet the German Ambassador to France at a social gathering attended by both. To the layman this might seem to be silly nonsense and impractical formalism of some mysterious kind. In point of fact, it is to be explained by the circumstance that as diplomacy originated and has been carried down through modern times it has been universally confined to states in peaceful relations. To resume diplomatic relations with a nation with which we have been at war, prior to the conclusion of a formal treaty of peace, would, under the historic rules of international law, bring 
into operation the rule of uti possidetis as applicable to the termination of war. The result might have cost this country hundreds of millions of dollars. What appears, viewed only in the light of the present, as impractical formalism, turns out, in the light of the standing rules of international relaThe tions and intercourse, to be in the highest degree practical. It behooves us, therefore, to examine the historic nature of modern diplomacy by means of a brief review of the status of international diplomatic intercourse in various historical periods in the past.

The Greeks and Romans practiced a sort of diplomacy, semi-religious, semi-commercial in character, but entirely episodic and discontinuous. ${ }^{1}$

With the fall of the Empire in the West the invading barbarian nations were compelled by circumstances to carry on certain rather elaborate negotiations with one another and with the Eastern Empire. Roman formulas were taken up and employed as far as possible. It also appears that persons who had participated in imperial diplomacy before the collapse of Rome were pressed into service. ${ }^{2}$ Missions were dispatched to the courts of neighboring tribal states and to Byzantium, as occasion demanded. There was much display and ceremony accompanying all this activity, and, apparently, the messengers were well entertained in the course of their journey and upon their arrival. At all events, the principle of the personal inviolability of the emissary was clearly recognized. ${ }^{3}$ It was not for lack of proper forms that the barbarian states failed, as they did fail, to carry the development of diplomacy very far. It was because they did not themselves develop, as states, to the point of stability and fullness of political life where the need for a complete diplomatic system would be felt.

1 On diplomacy in the ancient period see Phillipson, in general.

' Hill, I, 36-41.

Same, 39. 
During the feudal period, likewise, there was much going to and fro of messengers of various kinds. These messengers were dealing with the sorts of questions which we ordinarily consider as diplomatic, such as war and peace, princely marriages, and succession to posts of political power. They employed very elaborate diplomatic forms and were careful to claim, in an age of turmoil and violence, the protection of the law of embassy. ${ }^{1}$ However, these agents were only semi-public in character, because of the dependent legal and political position of the feudal princes among whom, for the most part, they moved. ${ }^{2}$ They were representatives of rulers who did not possess, in strict law, or in actual political fact, wherever the suzerain could be present in power, the right to deal freely one with another upon any important matters of state. Likewise, the "diplomatic" representatives received by the feudal rulers from the Emperor were in legal theory and, to a certain extent, in actual effect, constitutional officials within the Empire. ${ }^{3}$ They carried the commands or requests of the supreme feudal authority to the subject princes. The latter were, moreover, under a general obligation to refrain from alliances and diplomatic relations in their own name. Their representatives were subjected to interference and control and a monopoly of the power of 7 carrying on foreign relations was claimed by the Emperor as against subject rulers and by the national kings as against local barons. ${ }^{4}$ Diplomacy could hardly develop when the units of international life were still so widely interlocked and when independent state life had developed to such a slight degree.

By the Emperor himself various classes of agents were sent on political and diplomatic missions, both in the time

${ }^{1} \mathrm{Hill}, \mathrm{I}, 365,367$; on Medieval diplomacy in general see literature cited, below, Appendix B, §7.

'Hershey, 148, note 11 .

Hill, as cited, 367.

- Same, II, 155, 156. 
of Charlemagne and in the later period of the Holy Roman Empire, in efforts to render the Emperor's will effective at the courts of feudal princes of various grades. ${ }^{1}$ The true nature of these missions has already been commented upon. Of more importance were the pretentious missions dispatched to Rome, to Byzantium, and to the Saracenic capitals. $^{2}$ These embassies moved with pomp and circumstance; they followed definite formulas of procedure; and in many cases they took up matters of the utmost importance internationally. Yet the development of Imperial diplomacy was slight. The reasons for this are to be sought partly in the fact that the internal diplomacy of the Empire, so to speak, was held back from any great development by the feudal character of the Empire, as already described. In part it was due to the circumstances that, on the external side, the Empire embraced so much of the active political world of the day that there were few important neighboring states in Europe with which to carry on relations. As in the Roman period, the extension of the Empire in the Middle Ages caused the disappearance of states with which the relations of diplomacy might have been developed. Finally, the Medieval sovereign was given to much personal diplomacy; he moved about his dominions and about the world in general-as the world was then known-and in many cases he was his own foreign representative. ${ }^{3}$

The Papacy developed the device of foreign representatives more fully, for it was engaged in continual negotiations for alliances and treaties with the princes and cities of Italy and Western Europe. ${ }^{4}$

Cardinals, often close friends of the Pope, were sent on the more important special missions. Their coming frequently caused resentment on the part of those rulers to whom they were sent. The reason is not far to seek.

${ }^{1}$ Hill, I, 366, 367; Thorndike, Chap. XXVI, entire.

Hill, I, 183-186; Walker, §61.

Hill, I, 177-179; Walker, §60.

- Hill, I, 360, note 1 to p. 359 . 
These agents attempted to dictate to the rulers of Europe the will of the Supreme Pontiff and to influence them in relation to what were to all appearances purely domestic questions, such as church regulation and the taxation of ecclesiastical persons and property. In other words, they were not acting upon those assumptions regarding state independence upon which alone any elaborate and stable system of international negotiations can be built. They also were attempting to claim constitutional authority over subject princes on behalf of the Holy See.

The highest grades of standing Papal representatives were the legati a latere, or Cardinals representing the Pope personally in a given court, and the legati missi or nuntii, special messengers dispatched from time to time on definite errands. ${ }^{1}$ From the last we have today the Papal nuncio, the single class of modern Papal diplomatic representative. There were various grades of Papal agents traversing Europe in the later Medieval period on all sorts of errands. There were local ecclesiastical officials who had been given representative capacity in their own jurisdictions, the so-called legati nati. These were concerned largely, of course, with church matters. Yet there was to be observed here a more pretentious and stable system of interstate negotiation than had appeared elsewhere. Of particular significance, in retrospect, was the use by the Papacy of resident ecclesiastics with diplomatic powers. In point of historic continuity the present Papal nuncio descends from the most fugitive and transient figures in the Medieval diplomatic service of the Holy See, the "nuntii ;" but the Papacy did discover the need for permanent diplomatic representation and acted upon that discovery. Europe was on the verge of modern diplomatic organization.

It is to the city states of Italy in the time of the Renais-

${ }^{1}$ Hill,. I, as eited; also Satow, $\S 265$, quoting Ferraris. 
sance that we must actually turn for the definite beginnings of the present diplomatic system. ${ }^{1}$ The state-system existing in Italy in the fourteenth century was reminiscent of that of classic Greece. ${ }^{2}$ A number of substantially independent city states were to be found located in Northern Italy,-Sienna, Florence, Genoa, Milan, Venice, and others, -all striving in keen competition for profit and advantage one over another. Secret correspondence, alliances, intrigue, espionage, subtle negotiation,-such were the practices in vogue in that age. ${ }^{3}$ The term ambaxiator or ambasciator made its appearance to supplant the old orator which had been carried down from the days of ancient Rome. ${ }^{4}$ Various rules of procedure and practice were worked out, especially by the Venetians, for the guidance of diplomatic agents abroad. It was required that the ambassador should take no wife with him on his mission, lest she indulge in gossip and betray his cause; he must take his own cook with him, lest he be poisoned by his hosts; he must accept no gifts during the period of his mandate. Venice required formal detailed reports from all persons who had been sent on official missions. Strict limits were set upon the duration of a stay abroad, lest loyalty to the homeland and her institutions be weakened-a principle not unfamiliar to students of the American and British foreign services. Conversation with strangers until an official report had been made was forbidden. ${ }^{5}$

As the system of independent national states arose in Northern Europe these practices spread in the fifteenth century into France and other countries. ${ }^{6}$ Italians were frequently employed in the diplomatic services of the North-

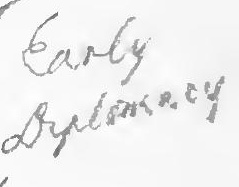


ern states, especially by France. ${ }^{1}$ Diplomacy was, indeed, more or less of an Italian institution and product at this time. The new national monarchs sought to make use of the fine Italian hand of the countrymen of Machiavelli in the promotion of their own interests.

Now the distinguishing feature of modern diplomatic intercourse,- the feature which clearly sets it off from the diplomacy of antiquity and the Medieval period,-is the institution of the permanent resident diplomatic representative. For centuries diplomatic missions were special and temporary things, moving to their destination and terminating with the performance of a given assignment. Modern diplomatic organization, on the other hand, is based upon permanent bonds of representation among the nations. And it was precisely the Italian situation here described which produced the permanent embassy. The city states of Italy were sufficiently numerous, sufficiently active politically, and sufficiently stable, to support a more pretentious practice of diplomacy than Europe had ever known before. In 1450 Milan and Florence each established resident embassies in the territory of the other. ${ }^{2}$ Ten years later a similar exchange was made by Milan, Venice, and Naples. ${ }^{3}$ In the last quarter of the century began the Italian resident embassies to France, so important during the French wars in Italy.4 A new organ of government had appeared in Europe.

Several aspects of this movement deserve special notice.

The resident diplomat was not unlike the resident consul who had already established himself, two centuries before, in the cities of the Levant. Indeed, when it is recalled that the consul of that period possessed and exercised extensive diplomatic privileges it might appear that this was the origin of the modern diplomatic office. 5 In point of fact,

1 Hill, II, 152.

Same, 154.

- Same; also Nys, Diplomatie, 1, 15.

- Hill, as cited, 153; Nys, 16.

- Nys, 20. 
however, modern diplomatic representation can be traced back to the Italy of the fifteenth century, while it is not clear that any connections ean be made with the consular representation of the thirteenth century. The Italian diplomacy may, in turn, be traced in a vague fashion back through Venice to Byzantium and Rome, but in those remoter periods no permanent embassies are found.

The establishment of permanent representation seems to have been due to the quite understandable desire on the part of the governments of the city states not to go unrepresented at any time at the seats of government of each other. There was such a continuous involvement of interests and polieies among them that nothing but continuous representation could serve their needs. Part of the task of the new diplomat was to aet as an observer on behalf of his master. The other part was to act as mouthpiece; it was still true that a good orator made a good ambassador. ${ }^{1}$ For both purposes, continuous activity was greatly superior to temporary missions.

On the other hand, the burden of expense and labor connected with the constant and steadily increasing use of special diplomatic missions was mounting rapidly. Disputes over ceremonial and procedure increased in proportion. Special missions must, ordinarily, be entrusted to distinguished citizens, and this accentuated these inconvenient features. It appeared better, therefore, to eut down the expenses of diplomatic representation, to simplify the procedure and ceremony attending such representation, and, at the same time, to secure a greater amount of representation in point of quantity, by employing less elevated personages in a less pretentious office and rank, but permanently stationed at a neighboring court. ${ }^{2}$ In later years this set of forces operated simply to keep down diplomatic rank long after permanent diplomatie representation had become an established fact.

1 Theory in Nys, 1, 10. Permanent ministers are almost always spies, said Bynkershoek; Heatley, 17.

SSatow, § 267. 
Finally, this whole movement should be regarded with special sympathy and understanding by American students. Three hundred years afterwards America passed through this same series of stages in the development of her diplomatic service. The United States made use of special embassies entirely in the years 1776-89, embassies usually entrusted to distinguished eitizens, and surrounded with as much pomp and circumstance as republican tastes and funds would permit. These tastes were not very highly developed, however, and by the end of the Revolution our people were quite ready to get along without the expense and the show attendant upon this activity. Already American missions abroad had come to appear to be all too permanent. The reaction went to the point where Adams was about ready in 1783 to "recall every minister from Europe" and rely on special missions to be sent out as the occasion demanded. As it was impractical to go without continuous representation, however, permanent posts were reluctantly created by the government under the new Constitution. At the same time, the rank and ceremony employed and the expense incurred were kept down to a minimum. This American experience faithfully recapitulated the general European experience on the same point three centuries earlier. ${ }^{1}$

Meanwhile there had developed in the individual national states certain public services which aided materially in the practice of diplomacy. Postal facilities were created for the use of the state. The king's couriers, an institution which by itself was as old as ancient Babylon, were employed anew in constantly increasing numbers to carry dispatches to all corners of the kingdom. They were now adapted to the needs of the diplomatic service and were sent upon distant journeys with dispatches for diplomatic representatives abroad. ${ }^{2}$ Cipher writing, hitherto largely a pastime, was given serious attention and drawn into the

${ }^{1}$ Foster, Century. Chaps. I-III, V.

2 Hill, as eited, 155-156, especially note 2 to 155. 
service of the state. Under the political circumstances of the age this mechanical development was just the sort of thing needed to promote the spread of the new diplomacy. The national languages, first used by national sovereigns in correspondence with their own agents, began to make their appearance in international negotiations and to present a serious challenge to the primacy of the Latin. ${ }^{1}$ All of these factors made for greater mechanical freedom and ease of official international communication.

With all due credit to these internal developments, however, the principal causes for the expansion of European diplomacy are to found in the changes taking place in the state-system itself. These have already been reviewed. To them are to be attributed the steps taken in Italy and France to work out a new method of interstate negotiation. With Pope and Emperor fallen as imperial overlords, the now independent states began to employ a new system of political organization and practice in their relations one with another, and modern diplomacy was born. ${ }^{2}$

During the next two centuries, from 1450 to 1650 , the new practice grew apace. ${ }^{3}$ The ambassadors in ordinary, permanently stationed near friendly courts, were long under suspicion as spies. For what other purpose could they be hovering about? Nevertheless, they met a real need, and hence they increased steadily and soon outnumbered the ambassadors extraordinary on special missions. A whole group of such representatives appeared in each capital. The ordinary type of special ambassador under the older system became rarer, and the new type became the "ordinary" representative, so-called, and took the stage in force. ${ }^{4}$

This led to the development of a more or less articulate and complete code of diplomatic etiquette, and also a for-

Hill, 157; Satow, $\S 89,90$.

Hill, 158.

- Nys, as cited, 21-32.

-Walker, §94; also Satow, 269.

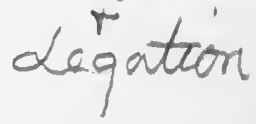


mal law of legation. The mere multiplication of various classes of diplomatic agents made necessary not only a system of procedure in the actual conduct of negotiations but a set of rules firmly and carefully defining the legal rights and privileges of foreign representatives.

This diplomatic etiquette was visualized almost wholly in terms of precedence. Papal agents, being veteran diplomats and possessed of a peculiar influence and prestige, received precedence over the representatives of secular. rulers. In view of the historical and theoretical primacy of the Empire, the imperial representatives took rank above those of the rising national kings. Royal representatives took precedence over the agents of republican states and cities, claiming a superior dignity and prerogative. Many violent disputes inevitably arose in these matters, and the literature of early diplomacy abounds in anecdotes concerning them. The classic example of this sort of thing is to be found in the Peace of Westphalia, in 1648, which was the work of a conference held in two distinct sections meeting contemporaneously in two distinct cities, partly because it was impossible to reconcile the claims to precedence put forward by France and by Sweden.

These claims and pretensions are not, however, to be regarded as entirely lacking all substantial foundation or explanation. The age was an age of awakening spirits and the new nations were keenly sensitive on the score of their title to respect. The preceeding period had been characterized by too much confusion and doubt regarding national identity and state independence; it was wholly desirable that these matters should now be dealt with vigorously and carefully. For this reason the external marks of state independence and national authority were given great attention and the details of reception and precedence took on new significance. ${ }^{2}$ It was natural that this should lead to silly

1 Walker, $\S 95$.

- Same, §§95-96; also Bernard, Lecture I. 


\section{DEVELOPMENT OF MODERN DIPLOMACY 95}

excesses. But the exorbitant claims and disputes were silly not because they arose over matters of no importance, but because they distorted the realities which were present behind all these questions of diplomatic etiquette. Each state was entitled-as had not been true in another ageto due consideration, and to consideration in proportion not to mythical imperial authority or legendary feudal titles but to real power and consequence in the new Europe. This remained true even when the eager ruler tried to reverse the process and secure added political power and consequence by obtaining some formal diplomatic advantage over his rival. The new states were with difficulty finding themselves in a new political world.

The more serious problems of diplomatic procedure were being worked out at the same time by the efforts of private scholars to arrive at a just definition of the rights and duties of diplomatic representatives in the territory of the state to which they were accredited. ${ }^{1}$

A beginning in the elaboration of the law of legation was made by an Austrian scholar, Brunus, who had once been a diplomatic agent of Charles V, by going back to the rules of Roman law on this subject. The ancient regulations regarding credentials, instructions, and the reception of diplomatic representatives were revised with a view to use in the sixteenth century. ${ }^{2}$ There followed the work of the Oxford professor Gentilis, who dwelt upon the historical evolution of the institution of embassies as a preface to a thorough examination of the public character of diplomatic representation. He made a strong case against the continuing efforts of subject feudal princes to deny in practice the monopoly of the national sovereign over the control of foreign relations. Gentilis then proceeded to classify missions with reference to the character of the state represented, and to define the legitimate diplomatic im-

1 Walker, $\S \S 131,135,143$; also Nys, 33-55.

Walker, § 131 . 
munities for each class, and closed his brilliant study with a critical examination of the right to send and receive ministers and ambassadors, which led him gradually back to his principal theme. ${ }^{1}$

Finally, Grotius dealt with the subject in his great work on the general law of nations. He likewise insisted upon the principle that only independent states possessed the right to send and receive diplomatic representatives, and upheld the right of rulers to refuse to receive as the representatives of foreign states individuals not personally acceptable to them. ${ }^{2}$ Grotius, however, went even further, and was led by his caution in the rapidly moving events of his time to ascribe the same right to the national rulers in regard to all the distasteful "permanent legations" which were "now in use." For the greater part of the time these agents had no negotiations to carry on. Why, then, should they be entertained in the state? The great jurist also defined the basis and extent of diplomatic immunities by reference to the quality of the sovereign represented, thus following the opinion of his age. Not until two centuries later was the true standard found in the purpose and function of embassy as such.

The close of the Thirty Years War thus found both a diplomatic ceremonial and a law of legation ready at hand to serve the needs of the new independent states emerging in the Peace of Westphalia. ${ }^{3}$ Brunus and Gentilis and Grotius were followed by other scholars, such as Wicquefort, Callières, and Bynkershoek, to mention only the greater ones among the host of writers on diplomacy prior to the French Revolution. ${ }^{4}$ The territorial state, authoritatively recognized by the great mid-century settlement, adopted the Italian diplomatic institution as its own,

1 Walker, $\S 135$.

Same, p. 302.

- Same, § 81. 363-379.

Heatley, 151-160, and Appendix I (extracts); Satow, I, x, and II, 
worked out its implications, called into life historic practices and legal rules to amplify the same, and set out on a career of competitive international relations which is only now being slowly closed and converted into something else.

Since 1650 there have been few vital changes in the system of diplomacy as then recognized. The consular system has changed far more. However, certain developments must be reviewed briefly at this point. ${ }^{1}$

During the period of Louis XIV the French ascendancy set a stamp upon the still plastic diplomacy of Europe which has never completely disappeared. ${ }^{2}$ The Grand Monarque inherited an already well developed system of diplomatic representation from Richelieu and Mazarin, and he proceeded to expand and to employ this service to the utmost. In personal interviews he gave the French agents abroad detailed instructions before they set out on their missions. These priests of the Most Christian King-true missionaries of Gallic culture-were fired with a zeal to carry French prestige to the ends of Europe. Under constant and careful supervision, they made detailed reports on political and social events and conditions in all quarters of the diplomatic field, and, as a result, Louis was in touch with every faction in every high intrigue in all the capitals of Europe. These French agents were indeed indefatigable. They travelled night and day, and they amassed enormous stores of documentary material. From a pecuniary point of view they were poorly paid, but they were devoted apostles of the Sun King, and they found in the royal approval and the reflected glory of France ample recompense for their labors. Through their efforts mainly, Paris became the political center of Europe and diplomacy a French institution.

1 There is no history of modern diplomacy as such. Fragmentary materials for such a history are to be found in Hill, Satow, and the other works cited in this and the succeeding chapter.

Hill, III, 52-55. 
The following century was a time of colonial rivalry, alliances, and wars. ${ }^{1}$ Diplomacy was consequently employed for all sorts of devious purposes and in all sorts of ugly situations. The culmination came in the partitions of Poland in the later part of the century-actions which were brought on by causes deeply embedded in the European state-system itself, but carried through in characteristic fashion by the diplomats of the day. It would be grossly inaccurate to attribute the evil transactions of this period to the institutions and methods of diplomacy in use at the time. The system, as it had grown up since the Renaissance, was greatly enlarged in point of numbers and extent, and this tended to make it weak in principle and ideal. But, after all, the determining factors are to be sought in the vicious policies of the rival sovereigns who employed personal diplomacy in the pursuit of their personal satisfaction and aggrandizement. ${ }^{2}$ At the same time, it would be futile to deny that the accomplishment of their sinister purposes was facilitated by the existence and employment of a method of international negotiations which lent itself readily to these purposes.

The great expansion of diplomacy in the eighteenth century was followed by the tremendous international disturbances of the Revolutionary and Napoleonic periods. As a result, the rulers participating in the Congress of Vienna found it necessary to attempt to reorganize, in part, the diplomatic system of Europe and to standardize the ranks of diplomatic representatives. ${ }^{3}$ An official reclassification of diplomatic agents was adopted which, as amplified in 1818, is still in use today. ${ }^{4}$ Despite the latent growth of forces which may soon supplant the historic institutions of diplomatic representation with newer forms of national representation in international bodies of one

1 Hill, III, Chaps. V-VIII, especially 673-676.

${ }^{2}$ Satow, II, 360-362; see also Bernard, Lecture III, entire.

Satow, $\S \S 263,271$; see, below, Appendix A, Document No. 2.

- Hershéy, $\$ 261$. 
sort or another, there have been during the past century almost no changes in the diplomatic system as it stood in 1815 , except a further cutting down of the use of form and etiquette, a weakening of the force of procedure and custom. Diplomacy has now become very much more businesslike and unceremonial, and perhaps we are to see still farther steps in that direction. Notwithstanding all the changes in manners, however, the fundamentals of diplomatic intercourse are essentially what they were during the seventeenth and eighteenth centuries; what we have to deal with is a long established, and, in a measure, a fixed, international institution. 


\section{CHAPTER VIII}

\section{ORGANIZATION AND PRACTICE OF DIPLOMACY}

THE term "diplomacy" is employed by many writers to mean many different things. So diverse are the ideas back of this common term that no possible progress can be made in the present discussion until some understanding has been reached upon the sense in which we shall use it.

Sir Ernest Satow, a leading authority on the subject, goes so far as to include in his treatise on "Diplomatic Practice," in addition to his consideration of the simpler forms of diplomacy, a description of the forms and procedure of international congresses and arbitral tribunals, much international law pure and simple, and the subject of treaty negotiation proper. ${ }^{1}$ At the same time he omits all mention of the consular system. It does not seem best to follow such a plan here. The last topic has, indeed, already been studied in its own name and may now be left out of further account. Furthermore, we shall consider international courts, commissions, and conferences separately at a later point, as institutions standing by themselves. For our purposes, therefore, the field is narrowed to the subject of negotiation by diplomats acting individually. This is a strict interpretation of the term "diplomacy," and might be called diplomacy proper, in contrast to various forms of diplomatic activity which, by reason of their complexity and formality, become something distinct from simple diplomacy, deserving attention in their own names.

Even with this affirmative definition of the subject, it ${ }^{1}$ Satow, Bk. III. 
is well to take notice of two or three things which ought to be carefully set off from diplomacy proper. One is foreign policy and another is foreign relations or foreign affairs. The former phrase refers to national programs of action in international relations, to national purposes or objectives or motives to be carried out through the existing framework and procedure of the national foreign service. In formal terms it is, as has been said by a recent writer, the application of mind and means to current conditions for an object more or less distant. The phrase "foreign relations," on the other hand, refers to the totality of events and actions transpiring among nations or between one nation and the other members of the existing state-system. Neither of these things is diplomacy proper; the phrases diplomatic policy or diplomatic relations may be used in the place of "foreign policy" and "foreign relations," but the simple term "diplomacy" should be reserved for use in referring to the organs and practices whereby the nations carry on their political affairs one with another.

There is one topic, however, which is commonly omitted from discussions of the general subject of diplomacy, but which should be noted in this connection. This is the Foreign Office, or that department of the national government which has control of the nation's foreign service, consular and diplomatic. ${ }^{1}$ The department of foreign affairs ordinarily has the control of the consular service, although this may be shared with the department of commerce or some other department of the central government. Invariably it has control of the diplomatic service, and as such it deserves to be included in any review of the machinery of diplomacy. Foster, a leading American writer on diplo-

${ }^{1}$ Commonly called the "Ministry of Foreign Affairs," or "Ministry of Foreign Relations," or the "Foreign Office"; in the United States the "Department of State." The old term "chancellory" or "chancellories" is occasionally used for literary effect, as in a news item by Barry, R. T., in Milwaukee Journal, 26 November, 1921, p. 4. 
matic practice, does not include the Department of State in his treatment of American diplomacy, as Satow insists should be done; ${ }^{1}$ on the other hand, Foster does devote a chapter to the consular service. ${ }^{2}$ Both topics deserve to be treated under the general head of "diplomacy."

It is the function of the department of the national government dealing with foreign affairs to recruit, classify, instruct, and control the field force of the foreign service; and a monopoly of this control is ordinarily created on its behalf by national law. Thus the Logan Act, in the statutes of the United States, forbids unauthorized American citizens to consult with foreign governments or their representatives regarding any question in which the United States is interested. ${ }^{3}$ Similarly, the Japanese Foreign Office in 1921 disclaimed any responsibility for utterances of military officials in Korea relating to foreign affairs, and held that they did not bind the Government. ${ }^{4}$

Moreover, it is the task of the Foreign Office to provide such a mechanism of administrative divisions or sections or bureaus at the capital of the nation as can take care of the various sorts of business arising in the course of a nation's foreign relations. ${ }^{5}$ The members of the field force must rely very largely, for the success of their efforts, upon the equipment and ability of the department of foreign affairs. The field force depends for its original composition and the constant maintenance of its personnel and equipment upon this department of the home government. As the standard rises or falls in the department, so will the . standard of ability and service rise or fall in the field. Defective organization and defective administration at home mean ineffectiveness and failure abroad. Many of the failures and blunders and positive sins in diplomacy

Satow, $\$ \S 4,13-20$.

2 Foster, Chap. XI.

- Revised Statutes, § 5335.

*New York Times, 28 January, 1921, p. 15.

Satow, § 20. 
which are attributed to diplomatic representatives abroad are really due to causes beyond their control, in the Foreign Office at home.

To go into a study of the department of foreign affairs here, however, is both unnecessary and impossible. Suffice it to say that the standard principles of administrative organization and practice are defied only at the peril of the national interest. There must be unity of control over, and consistency of action among, the various bureaus of the department. There must be ample provision of distinct administrative units to care for the distinct varieties of work to be done. There must be a clear demarkation between the determination of policy and routine administrative work, and unqualified employees must be prevented from interfering in discretionary business of the former variety. In short, the national government must provide an adequate administrative machine to support the consul and the diplomat abroad.

The task of recruitment likewise belongs entirely to the national authorities. Each nation adopts the means which it prefers to secure competent diplomatic representatives. $^{1}$ The diplomats form part of the national civil service and may be regulated as all other parts of the civil service are regulated with respect to methods of selection, treatment,-including salary and pension,- -and retirement. Whether an examination system is to be used in judging candidates for admission to the diplomatic service is to be decided by each nation for itself. Whether adequate salaries are to be paid, and whether any provisions are to be made for retirement and pensions, is likewise to be decided by the national governments. The nations observe the experiences of one another as various methods are tried from time to time, and a process of imitation is going on whereby the procedure followed in all countries tends

${ }^{1}$ Foster, Chap. III; Satow, § 221. 
to become the same. But in all cases the source of changes is the national policy of each state.

Certain general reflections, however, may well be set forth here.

It is obvious, for example, that the principal diplomatic representatives of a nation must be in political sympathy with the officials in control of the national foreign policy at home. The diplomatic representative abroad largely determines the success or failure of the national policy. No set of instructions can possibly be so complete as to dispense with the need for discretion and judgment on the part of the representative in the foreign capital; and in the exercise of this discretion and judgment it is essential that the diplomat be in harmony with his superior officer as to the foreign policy to be pursued. The success of the national policy for the time being, whatever it may be, requires consistency and unity above and below in the foreign service, for it is an elementary rule of administrative science that control must be effective from above. Nothing can insure that result in the field of personal diplomatic negotiations except subtle and delicate personal and political sympathy between the foreign office chief and the diplomatic representative abroad. It would be disastrous for the United States to have an Anglophobe President in Washington and an Anglophile Ambassador in London. Whether the desired result is to be attained more readily by a system of appointments at discretion or by appointment as a result of technical examinations is another matter. ${ }^{1}$

It is none the less desirable that heads of missions should possess those qualities of tact and manner which are conducive to smooth diplomatic negotiations. ${ }^{2}$ The bearings of a machine are not improved by being rough and

1 There is also the question whether it is desirable to create an entirely professional diplomatic service or to retain a number of popular. leaders, amateurs, in posts of importance. Report, 50 .

${ }^{2}$ Satow, $\S 223-226$. 
unpolished. The appearance of strength and integrity is superficial, and the smooth and effective operation of the machine is retarded. Diplomatic representatives who have the task of actually conducting conversations and negotiations of various sorts are engaged in a form of personal intercourse, and certain personal qualifications are therefore pertinent in their selection. The ability to subordinate feelings and prejudices and personalities to considerateness and reasonableness and common decency is indispensable. We do not want weak or insincere or dishonest diplomats, however polished they may be. Equally, we do not want egregious boors for diplomats (sic) however strong and sincere and honest they may be. Honesty and sincerity can be found in combination with decent manners and considerateness.

Below the grade of the principal diplomatic representatives personally engaged in negotiations there are, however, large numbers of diplomatic agents to whom rules almost the opposite of those just stated apply. Personal manners and political beliefs are of little consequence in a mere secretary or a law clerk in an embassy. The task of the members of the staff in a diplomatic establishment is to supply information to the head of the mission and to carry out administrative details. They are engaged in impersonal work, and have no political or discretionary power. Expert training in history, law, economics, and, above all, the technique of government and diplomacy, is the thing required in such persons. Candidates for these posts may best be selected by a system of technical examinations, ${ }^{1}$ a procedure which would be intolerable for heads of missions. ${ }^{2}$ Likewise, it is in regard to such positions that permanence of tenure, experience in the service, promotion for merit, and other salutary administrative prac-

Register, 1919, 188-192.

${ }^{2}$ Compare Satow, $\S 224$, with Report, 18, and a quotation in latter, at 262 , from minority report of British Commission on the Civil Service. 
tices may be, and ought to be, adopted. ${ }^{1}$ With respect to heads of missions, these practices have little or no value, and under certain circumstances would be clearly injurious. When questions of policy and of discretion no longer arise in the work of the diplomat he may be made a purely technical administrative officer; that is not the condition today and the diplomat at the head of a mission must continue to be a personal political representative. For technical members of the establishment, however, the opposite is true.

The future may see a considerable change in the relations between these two classes of diplomatic representatives. This depends upon what happens to international relations in general. If international organization develops very far, so that international assemblies or councils for the regulation of international relations are created, in which the nations are represented by persons who are sent there to debate and vote rather than to negotiate, then only routine administrative details will be left to the resident diplomat. In that case he might well be merely a legal clerk or agent. Furthermore, if and in so far as the development of telegraphic communication narrows the discretion of the foreign representative and gives the home office control over him, the same result will follow. National representatives in the new international legislative bodies would enjoy the national confidence such as is accorded to elected representatives, and in the second case legal and business ability would be desirable. But in neither case would political attachment to a personal superior be in point. Thus it is required that members of the Permanent Court of Arbitration at the Hague shall be "persons of known competence in questions of international law," 2 and the Senate of the United States was inclined in 1919 to require that any American representatives in the Assem-

1 Report, 58-59, 61, 288-294.

Below, Appendix A, Document No. 5, Art. 44. 
bly or Council of the League of Nations be elected by the Senate, in the event that the United States should join the League. Such requirements are thoroughly consistent with the nature of the situations in which they are invoked, but they leave little room for the diplomat of the old style. A purely international aspect of the question of the selection of diplomats arises in the requirement that diplomatic representatives must be personally acceptable to the governments to which they are to be accredited. ${ }^{1}$ This leads to the practice of obtaining the consent of a foreign government to the appointment of a certain individual as diplomatic agent to that power before making the selection definitive and before dispatching him upon his mission. ${ }^{2}$ The United States did not always follow this practice, but, on the contrary, contended that any American citizen must be acceptable to any foreign power which consented to enter into diplomatic relations with us. In part, that attitude was an expression of national pride and sensitiveness which was not entirely dignified and considerate; in part, however, it was a premature attempt to minimize the personal element in diplomacy. ${ }^{3}$ It has been largely abandoned now, because it is seen that the rule of personal acceptability is in harmony with the actual nature of diplomacy, whether we like it so or not, and because the equalitarianism and excessive nationalism of an earlier day has yielded to common sense. Here, as in the problems just discussed, the future of the rule depends upon the course of events in general international relations. In the case of national representatives in the Assembly of the League of Nations personal acceptability is an irrelevant consideration.

Just as a state will at times employ natives or citizens of a foreign country for consular representation on its behalf in the territories of their own country, so various

${ }^{1}$ Foster, 36-45; Satow, Chap. XIV.

2 Satow, \$230.

${ }^{3}$ Foster, as cited, especially 37, 38, 40-43; Satow, §§ 232-234. 
nations have from time to time employed foreigners as diplomatic representatives either in the foreigners' own country or in a third country. The latter case raises only one question, namely, the ability of an alien to act loyally and effectively on behalf of the state. The former practice raises, further, and in an acute form, the question of conflicting loyalties to native land and client state. Most states now refuse to receive their citizens as diplomatic representatives of foreign powers, and except for backward states with a dearth of diplomatic talent, the practice has generally gone out of use. ${ }^{1}$

After the foreign service force has been recruited the next task is that of classifying the members.

Broadly speaking, the foreign service as a whole must itself be subdivided and the first step is the establishment of separate consular and diplomatic services. This separation is not wholly logical or satisfactory, and presents many difficulties. The line between the commercial and legal work entrusted to the consul and the political work of the diplomat is hard to locate in the abstract and is in practice rather vague and imaginary. In the result, consuls, as has already been pointed out, participate in quasidiplomatic work in comnection with treaties and extradition proceedings, while diplomats are deeply concerned with commercial and financial relations among the nations. Further, we find cases where the consular and diplomatic offices are combined, as in the instance of the American Minister Resident and Consul General to Liberia. ${ }^{2}$ There exists just enough confusion between the two branches of the foreign service to show its latent unity, and indications are not wanting to suggest that the two branches may in the future be brought together in one service. ${ }^{3}$

The diplomatic service proper, like the consular service,

1 Foster, 49 ; Satow, $\S 236$.

Diplomatic and Consular Service of the United States, 1920, Table I.

'Grew, J. C., "Danish Foreign Service Reorganized,' in American Consular Bulletin, III, 2-4 (October, 1921), and speech of Hon. J. J. Rogers in (U.S.) House of Representatives, 27 January, 1921. 
is classified into several ranks corresponding roughly to the regulations adopted by the European nations in 1815 and 1818 at Vienna and Aix-la-Chapelle. ${ }^{1}$ The principal ranks are those of Ambassador (with which are to be classed the nuncios and legates of the Pope), Envoys Extraordinary and Ministers Plenipotentiary, Ministers Resident, and Chargés d'Affaires. ${ }^{2}$ In addition, there are various special diplomatic representatives called Agents, Attachés, Secretaries, Counsellors, and what not. The typical diplomatic establishment consists of a chief of mission holding one of the four principal ranks, together with a varying number of Secretaries, Attachés, and clerks. There is more freedom in the use of titles and styles for the subordinate positions than for the principal offices, and there is nothing to prevent a nation from inventing its own nomenclature for its subordinate diplomatic agents.

The respective rank of the principal diplomatic representatives formerly had an important bearing upon their powers and upon their ability to conduct their business; rights of representation and of negotiation hinged upon the formal status of the foreign representative. At present this is still true but to only a very limited extent. Ambassadors and Ministers are accredited to heads of states, while Chargés are accredited to the Secretary of Foreign Affairs. Ambassadors alone are held to represent the sovereign personally. But all this signifies little in practice. The rank of a diplomat relates chiefly nowadays to ceremony and precedence. ${ }^{3}$ Indirectly, the effect on the real business of diplomacy since priority in precedence often means an advantage in negotiations. The surface effect and appearance also in matters of ceremony and) precedence is not without importance also.

Furthermore, the relative rank of the diplomatic representatives resident in a given capital depends in part upon

${ }^{1}$ Foster, Chap. II.

2 Text below, Appendix A, Document No. 2.

${ }^{3}$ Foster, 22, 23, 25, 26. 
the standing of the states which they represent. This is largely a result of the rule of reciprocity in rank whereby two states entering into diplomatic relations-and the establishment of such relations is always the result of a bilateral international agreement-arrange to exchange diplomatic representatives of equal rank. ${ }^{1}$ Thus in Washington the Great Powers are represented by Ambassadors, generally speaking, and the smaller powers by Ministers. The effect of this rule or procedure is, however, sometimes curiously adverse to its intention. The Great Powers will not send diplomats of first rank to the very small nations and therefore accept merely Ministers or Envoys from them in return. It is a case of reducing the rank of the representatives exchanged to correspond to the level of the lower of the two powers. But the small nation may be exchanging diplomats of first rank with another small nation which regards it as an equal. The result is to place the Great Powers in a position of equality with the secondary powers, in the capitals of many small states, a result precisely the opposite from that aimed at by the rule. ${ }^{2}$

What this means is evident. Rank alone tells little about the significance of the representative to the government to which he is accredited. The power behind the representative, not his official title, determines his influence. On the other hand, rank, having lost ground as a factor in determining the legal powers and political influence of diplomats, has come to mean more in a ceremonial way as the doctrine of state equality has gained ground. If the states themselves are to be considered formally as equals, the only ground for precedence among their representatives is the relative rank of the latter. ${ }^{3}$ It is not surprising to find that salutes and all sorts of social privileges are standardized on this basis. ${ }^{4}$

2 Foster, 20 ; Satow, $\S \S 218,219$.

See, below, p. 122, note 2 .

Foster, as cited; Satow, Chap. IV, especially $\S \S 32,40$, and 273, 371.

`Satow, §§81, 88. 
The present tendency is to get away from these discriminations as far as practicable. To avoid disputes over precedence, rather than to work out a system of precedence accurately reflecting some scale of real power and influence, ${ }^{1}$ seems to have been the principal object of the nations since 1815. The most important step in that direction is the adoption and spread of the twin devices of the alphabet and the alternat in actions involving several nations or their representatives. According to these forms of procedure, the nations involved take their places in a roll call, a seating plan, or a table of signatures by virtue of the position occupied in the alphabet by the initial letters of their names. ${ }^{2}$ In the case of a signed document it is arranged that each power shall retain that copy on which it appears at the head of the list of signatories, the various copies having been signed in such manner that each power signs once in the first position, once in the second position, and so on. ${ }^{3}$ The order of signing may be settled by lot equally well, and the alternat employed in connection therewith. The motive and the net result of all this is, of course, to eliminate considerations of rank among representatives and among nations, so far as any effective application of it goes. The world seems to be tending toward the goal marked out by America, namely, the abolition of discriminations in rank among nations and diplomatic representatives and the employment of one uniform diplomatic title or office by all nations. ${ }^{4}$ It need hardly be pointed out that

${ }^{1}$ Opening words of the declaration made at Aix-la-Chapelle, below, Appendix A, Document No. 2; Satow, §39.

Same, $\S \S 32,33,273$.

If Argentina, Brazil, Chile, and Denmark were to sign a document in English by alphabet and alternat, the result would be as follows:

\begin{tabular}{|c|c|c|c|}
\hline $\begin{array}{l}\text { Copy retained } \\
\text { by Argentina: }\end{array}$ & $\begin{array}{l}\text { Copy retained } \\
\text { by Brazil: }\end{array}$ & $\begin{array}{l}\text { Copy retained } \\
\text { by Chile: }\end{array}$ & $\begin{array}{l}\text { Copy retained } \\
\text { by Denmark: }\end{array}$ \\
\hline Argentina & Brazil & Chile & Denmark \\
\hline Brazil & Chile & Denmark & Argentins \\
\hline Chile & Denmark & Argentina & Brazil \\
\hline Denmark & Argentina & Brazil & Chile \\
\hline
\end{tabular}

- Foster, Chap. II, end. 


\section{2}

\section{INTERNATIONAL ORGANIZATION}

in the Assembly of the League of Nations this result is already actually achieved.1

The diplomatic representative receives his authority from his appointment by the home government and his reception by the government to which he is accredited, His letter of credence is the formal evidence of his appointment to the representative office at a certain capital. In addition, a "full-power" may be provided for the ordinary work of the office or for special tasks committed to his charge. These documents are for the information of the foreign government and form the basis for the relations which are to be set up with the newly arrived diplomat. ${ }^{2}$ (If all is agreeable to the power in question he will be formally received by the sovereign, the chief executive, or the Foreign Minister, and diplomatic relations between the two states will be thus established. ${ }^{3}$

The diplomat receives oral instructions from his home government before setting out on his mission, and he carries with him general regulations and special instructions in writing. Furthermore, he receives from his foreign office a constant stream of advice and instructions which control his actions in the conduct of his office. These documents constitute his version of the credentials handed to the foreign government, and correspond to the latter in scope and authority. Needless to say, perhaps, they are fuller and more precise than the latter.

The work of the diplomat at his post defies precise or complete definition. He must conduct negotiations with the government to which he is accredited; he must observe and report what is going on about him; and he must perform certain functions on behalf of his own state toward fellow-nationals who apply to him for passports, for the inspection and endorsement of passports which they already hold and, in general, for services not unlike those performed by the consul. This is all that can be said, and it

${ }^{1}$ Covenant, Art. III, below, Appendix A, Document No. 15.

3 Examples in Satow, $\$ \S 119$, 126-128.

${ }^{3}$ Foster, Chap. IV; Satow, §§ 244-262. 


\section{Personality not "techugece"counts.}

\section{ORGANIZATION AND PRACTICE OF DIPLOMACY 113}

leaves the main work of the diplomat to be covered by those Carysare vague phrases "diplomatic negotiations" and "observations" which are filled out by each observer of international relations according to the dictates of his own imagination. What is to be negotiated and what is to be observed cannot be defined in advance, yet they constitute the heart of the problem.

In the actual conduct of negotiations the diplomat enters a complicated and delicate field of action. Some efforts may be made to instruct him concerning the "manner of negotiating," but the business is too complicated and too subtle to be completely reduced to formal rules. The diplomat must rely upon his own tact, his own feeling, his own common sense to help him in his work. Much has been written cautioning the young diplomat against haste, against the use of flattery and bribery and falsehood and other cheap and therefore ineffective methods of action. Such advice is sound enough. The difficulty is to apply the principles when needed, and to recognize the exigencies when they are needed; in this nothing but the sound judgment and instinctive wisdom gained by experience in dealing with persons and politics can serve. So long as international relations are conducted by personal representation this is bound to be true. ${ }^{1}$

The same must be said concerning the whole matter of style and ceremony. Not all of the mannerisms and rules of the etiquette of diplomacy are essential. Not all of them are, on the other hand, superfluous or irrelevant. ${ }^{2}$ The amount of such formalism has greatly decreased in the past century, and particularly in the past generation. With the advent of republican states and civilian diplomats the use of ceremonial costume, long deprecated by the United States, has declined perceptibly; there were practically no ceremonial costumes visible among the members
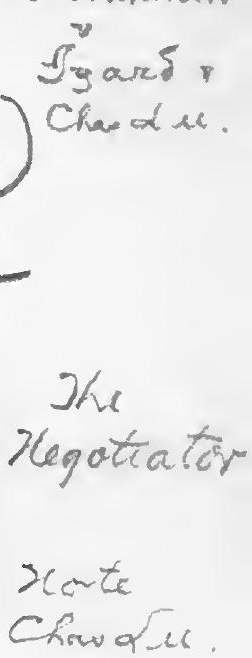
. 
of the Assembly of the League of Nations when that body met in Geneva in 1919, and no military uniforms at all, in striking contrast to things as they used to be. ${ }^{1}$ The greater part of the punctiliousness and formality which does remain is due to an effort for precision and accuracy in a field where the materials dealt with and the issues involved are very complex and indeterminate and where the competitive national interests involved are great in magnitude and at the same time ill-defined. At the Conference of Paris President Wilson merely neglected to put on record the intention of the United States to reserve certain rights of discussion concerning the disposal of the island of Yap in the Caroline group; the ultimate result in 1920 1921 was a very bad situation all around and particularly between Japan and the United States. ${ }^{2}$ Propriety and form are an integral part of substantive right especially where procedure is still in the stage of personal negotiation.

The matter of written documents is similarly important; the art of literary composition constitutes an intimate part of diplomacy. Indeed, the term diplomacy is derived from diploma, which was a document in the form of a sheet of paper folded into two leaves; a certain famous collection of early treaties has the phrase "containing diplomas (continens diplomata)" in its title. The written record remains, once it is made, and it behooves the signers of a document to exercise the most scrupulous care about its wording. To say that two powers "are not prepared to act" (now) is not to say that they "will not act" (next year), and many apparent euphemisms and circumlocutions in diplomatic documents reflect what are often very laborious attempts to say just what is meant, and no more and no less. ${ }^{3}$ It is undeniable that diplomatic writing contains much bombast, and is often guilty of evasion, and worse.

1 New York Times, 17 November, 1920, p. 12, column 1.

Same, 24 February, 1921, p. 1.

: Satow, $\S 89-95$; compare also de Clereq et Vallat, Formulaire, entire. 
But it is equally true that much of the criticism of diplomatic diction is due to shallow inattentiveness to exactness in detail and to childish lack of thought upon the subject.

Some part of the difficulties attendant upon the composition of satisfactory documents in diplomacy is due to the question of language. So long as Latin could be used by all diplomats the situation was relatively simple. ${ }^{1}$ To some extent this situation was perpetuated by the general adoption of French in the seventeenth century in the place of Latin as the international diplomatic language. French possesses qualities of range, accuracy, and flexibility or delicacy which make it valuable on its intrinsic merits as a diplomatic medium, and the language of Louis XIV has therefore never lost its position in the world of international relations. Matters of this sort change, however, in response to considerations of what appear to be practical utility. The French is now being abandoned by certain nations and English or Spanish or some other common language is being employed, even where English and Spanish are not hative tongues. Thus Germany and Austriaploy German in dealing one with another, Japan and Russia employed English at Portsmouth in 1905, and the South American states commonly employ Spanish in negotiations among themselves. Documents are sometimes drawn up in two or more languages in parallel columns. In such cases one of the versions may be regarded as the standard text or, indeed, two texts may be accorded equal authority and potential discrepancies left for adjustment as they appear. ${ }^{3}$ In many cases the merits of the French have been foresworn without commensurate convenience and benefit. It is absolutely impossible to produce two texts of a given document, one in Spanish and one in

${ }^{1}$ Some use is still made of Latin, of course, as in Papal documents, but the chief reminder of its once universal sway is to be found in the retention of certain words or phrases in use in diplomacy, such as ultimatum, casus belli, casus focleris, and others; Satow, $\S \S 168-193$.

See the amusing Bismarck story in Satow, $\$ 96$.

Treaty of Versailles, Art. 440, in Sen. Doc. 49, 66 Cong., 1 Sess. 
English, with identical meanings. Even single texts yield to varying interpretations; how much greater the difficulty when two or more national tongues are used!

The outcome of this question of language cannot be foretold, but the solution may partake of three elements. The leading national languages are likely to continue to compete one with another for preference in international dealings and to be recognized by different nations at different times according to present practice. By the generous use of translators and interpreters this way of doing business may be made to yield results which, if not wholly satisfactory, will at least be tolerable. Secondly, the study and use of foreign languages by people in general is likely to increase with the increase of international travel and communication. Along with this, we may see important changes as a result of the incorporation into one language of words and phrases in use in another; a process of amalgamation is steadily going on which tends to make the different languages more nearly alike. Finally, we may well see some serious effort to develop an artificial international language. To historically-minded persons such a suggestion seems ridiculous and in some way or other weak and futile. It bears on its face the appearance of artificiality. Notwithstanding all this, the circumstances of the case seem to justify the conclusion. If telegraphic codes, scales of weights and measures, signal systems, and other artificial media of communication have been successfully devised and put into use under similar circumstances the course of events is not likely to be different in the field of diplomacy.

The individualdiplomat is not alone in the foreign capithi he is a member of a group of representatives from all countries who, collectively, form the "diplomatic corps" at that capital. His relations with his colleagues will depend

${ }^{1}$ Satow, Chap. XXIII. The term is sometimes used to refer to the diplomatic representatives of one state, as, for example, "the diplomatic corps of 
somewhat upon his position in the corps; if he is a newcomer he will be expected to defer, socially and diplomatically, to his colleagues; if he is an older member he will enjoy some influence in matters properly of concern to the corps as such.

The standing and powers of this somewhat amorphous body depend upon local court or governmental regulations. ${ }^{1}$ The diplomat of highest rank and longest tenure is commonly the "dean" of the corps; but he does not exercise any substantial authority over the other members. ${ }^{2}$ Questions of diplomatic privilege form the chief concern of the corps as such, and its dean and the members would protest as a unit against any mistreatment of one of their number. At times, joint action is taken by the ministers present in a certain capital on some substantive point in international relations, as when the diplomatic agents in Peking protested in 1921 against any interference by the Chinese Government in the administration of the customs revenues in China according to the standing agreements between China and the Powers. ${ }^{3}$ In such a case, however, it is not the diplomatic corps which is acting but the nations there represented. The Council of Ambassadors which sat in Paris in 1919-20 and dealt with various questions connected with the peace was not acting as the diplomatic corps proper. The chief concern of the corps, in other words, is diplomatic procedure, etiquette, the privileges and immunities of its members, and social intercourse. ${ }^{4}$

In certain important commercial cities the foreign consuls act together from time to time as a "consular body" in a manner similar to that of the diplomatic corps. Thus the consular body at Vladivostok in 1920-21 took counsel concerning the maintenance of local order and safety for the United States." This is bad usage; the expression should be "the diplomatic service of the United States."

'Satow, \$377. 'Same, §369. 'New York Times, 4 February, 1921, p. 1.

- For lists of members of the diplomatic corps in all capitals in 1921 see Annuaire Général, 1920-1921, 740, 759, 767, etc. For example of a small corps see, below, p. 122, note 2 . 
foreigners. ${ }^{1}$ There exists in Madrid an Association of American Consuls, comprising the entire consular service of North, Central, and South American states in that capital, and engaged in promoting Spanish-American trade generally. ${ }^{2}$ This is, however, rare. The whole subject of the diplomatic corps is rather fugitive and formal. The corps is so loosely organized that it hardly deserves to be regarded as an international governing body.

As in the case of the consular system, the result of this practice of international exchange of representatives is to cover the world with a web of bilateral bonds running among the capitals of all the nations. These bonds are less numerous than in the case of the consular system, but they are of greater legal and political significance. They have for centuries in the past constituted the main form of existing international organization, and for some time to come they will remain the principal avenues of international intercourse. ${ }^{3}$

Given this diplomatic system, it remains to be noted that international law attempts to define in some measure the powers and privileges attaching to the members thereof. The rules already reviewed, relating to diplomatic amenities and the forms of diplomatic procedure, are part of what might be called the technique of diplomacy. The law of legation, on the other hand, deals with the right to send diplomatic representatives in the first place, and with the very practical question of the rights of diplomatic representatives in relation to the law and officials of the state where they are stationed. The law of legation is principally international law, though national laws, statutory and administrative, deal with the subject also.

The primary rule to be noted is that, as a general thing, only an independent state may send or receive diplomatic

${ }^{1}$ New York Times, 21 January, 1921, p. 15; 29 January, 1921, p. 4; 17 February, 1921, p. 15.

'Same, 11 November, 1921, p. 4.

${ }^{8}$ See the tables, below, Appendix A, Document No. 3. 
agents $;^{1}$ indeed, the right of legation is frequently used as the supreme test of a state's independence. ${ }^{2}$ There are, however, many cases which are difficult to deal with on this assumption. Certain states of the German Empire held a limited right of legation previous to $1918 .^{3}$ Bavaria even attempted to deal with Berlin by diplomatic note as with a foreign power at one time in 1920-21. ${ }^{4}$ Canada has been accorded the privilege of sending a Minister to Washington if matters can be arranged between Ottawa and Washington and between Washington and London. ${ }^{5}$ The Pope exercises a right of legation in certain states of Europe and Latin America, and in February, 1921, there appeared the novel sputacle of the Papacy appealing diplomatically to the League of Nations on certain international questions ${ }^{\circ}$ Yet on the whole the principle is sound, and what we should do in the above cases is to admit that the German states, Canada, the Papacy, and the League are independent members of the existing state-system to the degree in which they act freely in international relations.

The members of the community of nations, however, do not exchange diplomatic representatives upon the basis of the principles of common international law alone. Each exchange is based upon express consent in the form either of a treaty or some simpler agreement. ${ }^{7}$ The reception of diplomatic representatives from other states is a legal obligation resting upon each member of the community of nations, and refusal would constitute a valid ground for complaint and a demand for commensurate reparation. But the manner, and even the simple fact, of discharging that obligation is commonly decided by special agreement

\section{Sras bur
Stati}

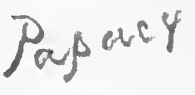 \\ Papacy}


between the interested parties. The further step of agreement upon the individual diplomat to be sent and received has already been noted.

Once received by the foreign power, the diplomat is accorded certain concessions of jurisdiction in view of his position and functions. ${ }^{1}$ International law defines the immunities which the receiving state is bound to accord to the foreign representative, and the national laws set forth these rules with a view to their application in the courts of the nation. These immunities include the ancient privileges of personal inviolability and independence of personal action, including freedom from arrest for acts under civil or criminal law. ${ }^{2}$ The diplomat enjoys the same relief from customs duties and personal taxes, witness duty and other similar burdens, as does his colleague, the consul, but in a more definite manner and to a greater extent. ${ }^{3}$

The original view of these immunities seems to have been that they were necessary in view of the impropriety and discourtesy of enforcing upon a foreign sovereign or his agent the local law, and to the fact that no state was entitled to enforce its own will upon another state, equally sovereign, or its head or diplomatic representative. It is now seen that these privileges are essential to the effective operation of the system of diplomatic representation, and that they must be supported and defined with a view to that desirable end, irrespective of any theory of sovereignty.

One result of this change of view as to the foundation of diplomatic immunities is seen in the alteration of the rules of the law of nations on the subject of asylum in legations and embassies. The right of extending asylum to fugitives, formerly claimed by foreign representatives and reluctantly conceded to them in view of the doctrine that the embassy was foreign territory enjoying exterritorial

* On immunities in general see Hershey, Diplomatic Agents, Part II.

2 Foster, Chap. VIII; Satow, Chap. XVIII, $\S \S 279-300$ (inviolability and independence), and Chap. XXII (passage through third states).

${ }^{8}$ Satow, $\$ \$ 308-311$, and Chap. XIX. 
status, has been curtailed in various ways. Particularly significant is the principle that a foreign representative must not receive and accord asylum to fugitives from justice, coupled with the rule that the grounds and buildings of the embassy are inviolable, even when so used. ${ }^{1}$ The reasons for this ambiguous position are found in the conflict between the desire to accord as much immunity to the diplomatic establishment as is necessary for its effective operation and the unwillingness to accord any unnecessary immunity to it. Likewise, the diplomat may worship his own God in his own way in his own chapel, and fellow nationals may join him in this worship; but he must not make this a cause of disturbing the public peace. ${ }^{2}$

All these privileges are regulated, as has been said, by local law. The home government of the diplomat will instruct him regarding the immunities which he is to claim for himself and these will correspond to the privileges accorded by his own government to foreign representatives in its territory, including those from the state to which he is accredited. By this process of reciprocity, practice on diplomatic immunities is generalized until the common rules of international law on the subject appear as a summary of the practices of all the nations. Meanwhile the diplomat is controlled exclusively by his own government in respect to the special costume which he shall wear, if any, the way in which he shall conduct the internal affairs of the cmbassy, and the reception of gifts and decorations at the hands of the government to which he is accredited. ${ }^{3}$ The result is that the rules governing the operations of the diplomatic system are found in general international law, written and unwritten, and in the national legal systems of all the states, including in the last the various codes of administrative regulations issued for the guidance of the national civil servants. The diplomat, hardly less than

${ }^{1}$ Satow, Chap. XX.

${ }^{2}$ Same, Chap. XXI.

${ }^{2}$ He is commonly prohibited from receiving such gifts. Foster, 141-155; Satow, §§306-406. 
the consul, needs to be provided with manuals and guides wherewith to inform himself on the vast amount of law and procedure connected with the conduct of his office. ${ }^{1}$

Finally, a diplomatic mission may be terminated in several ways. The person holding the mission may die, retire automatically by virtue of age, resign, or be recalled to make way for a new appointee. These are entirely matters of national law and have no bearing on international relations. Of real importance in the international field, however, is the recall of the head of the mission, leaving affairs in charge of a subordinate-here the mission is not interrupted-or a discontinuance of the mission entirely by withdrawal of all diplomatic representatives. So much a part of normal international relations is the exchange of diplomatic representation that such action is construed as unfriendly and is the usual prelude to war. More striking and emphatic in tone, but of less consequence internationally, is dismissal of a diplomat by the receiving state. In such a case, although continuance of diplomatic representation between the two countries is not interrupted, diplomatic relations between them is bound to be gravely disturbed. It is of some significance that the institution of international representation is stable enough to persist through an episode of this kind. ${ }^{2}$

- For example: Martens, Guide, entire.

- Diplomatic corps at Warsaw in 1921 (Annuaire Général, 1058; for abbreviations see, below, Appendix A, Document No. 3, note 2):

Germany: Ch. Oberndorff.

America: E. E. \& M. P. Gibson.

Belgium: E. E. \& M. P. van Ypersele.

Spain: Ch. Contréras.

Finland: Ch. Gyllenbogel.

France: E. E. \& M. P. de Panafieu.

Great Britain: E. E. \& M. P. Rumbold.

Hungary: Ch. de Zsombolya.

Italy : E. E. \& M. P. Tommassini.

Norway: E. E. \& M. P. Eyde.

Roumania: E. E. \& M. P. Froreseu.

Holy See: Nuncio Ratti.

Jugoslavia: Ch. Taditch.

Sweden: Ch. Danielson.

Czechoslovakia: Ch. Radinsky. 


\section{CHAPTER IX \\ CRITICISM OF MODERN DIPLOMACY}

T $\mathrm{T}$ is impossible to give any attention to the conduct of 1 modern diplomacy without realizing that there has developed in recent years a very serious body of criticism directed against the historic diplomatic institutions. That criticism dates back at least to the end of the eighteenth century, but it has increased in recent years, especially since 1870 and, further still, since 1914. The collapse of international comity in 1914 is attributed to the failure of the diplomats, when it is not attributed to their positive machinations. The appalling sorrows and burdens of the past six or seven years are ascribed to the incapacity and the peculiarly vicious character, as it is felt, of modern diplomacy. ${ }^{1}$

Such a school of thought,-if anything so popular and spontaneous can be so formally described,-Deserves attention and a considered reply. To have deliberately brought on the events of 1914-18, or the lesser events of 1870-71, or even to have allowed them to transpire by ineptitude, would be too serious a crime to be excused or defended merely by ignoring the accusation. The circumstances are such as to demand some defense or explanation of the relations between the diplomacy of the past century and the results in the field of international relations proper.

One reason for the current feeling of hostility and critical suspicion toward diplomacy will be discovered when one contrasts the practice of diplomacy with consular practice. The external style and manner of the consul is

'See literature cited, below, Appendix B, § 9. 
of much less importance and attracts much less attention than the substance of his work. On the contrary, the style and manner of the diplomat are striking and spectacular, and in many ways they are characterized by traits found outside of diplomacy only in a bygone age; while the substance of the work of diplomacy is not apparent on the surface and is sometimes carefully hidden. ${ }^{1}$ In any case, the major work of the diplomat eventuates in the field of international political relations, not in the ordinary affairs of daily life. As we have seen, it is practically impossible to give a statement of the work of a diplomat comparable to the analysis which can be made of the work of the consul. This is to be considered in connection with the fact that the effects of the activity of the diplomat, although less in quantity than the work of the consul, are often far greater in magnitude and more significant in kind. An alliance concluded by diplomatic representatives outweighs in importance and consequence the work of many consuls for years. The effect of all this is to disturb public confidence in diplomacy. What is this thing which is so ceremonious, so pretentious, so powerful, and yet so elusive in its real operations? And are its inherent capabilities, and the capabilities of those engaged in it, equal to its pretensions?

Closely allied to this, of course,-if, indeed, it is not the principal factor in the case,-is the question of secrecy in diplomacy. Much of the criticism of diplomacy is based upon ignorance of what the diplomat is really doing. More is based upon resentment at being compelled to remain in ignorance. Still more arises from the fact that the defense of secrecy on the part of the diplomats has been notably incomplete. As in the consideration of so many of these questions, it has seemed to the accused sufficient to shrug the shoulders and-remain silent. That may conceivably

1 Attempted statements in Foster, Chaps. V, VI, and Satow, $\S \S 147,148$. It will be noted that these statements relate more to the manner and form of diplomatic work than to its substance. 
be justified, all things considered; but it does not allay suspicion or meet criticism or instil confidence.

It must be noted, at the start, that much of the criticism of diplomacy is a reflection of opposition to the substance of certain policies which certain diplomats happen to be pursuing at a given time. Diplomacy is criticized because of the purposes of the heads of states who are represented by the diplomats. Yet in the main these purposes are decided upon at home, by those who control the diplomatic agents abroad. The pernicious policy which is the real cause of complaint is formed in the Foreign Office, in the Cabinet, in the Court. The principal responsibility does not lie at the feet of the representative abroad; in many cases he is compelled to carry out a policy with which he radically disagrees. Not infrequently the behavior of the home government nullifies the best that the diplomat can do in the cause of international friendship and justice.

It may be objected here that diplomatic agents are ordinarily in sympathy with their home governments by reason of their spirit of loyalty to the nation which they represent, by reason of their dependence upon these governments for retention in office and for good treatment as to salary, advancement, and perquisites. It is said also that the diplomatic representative is not infrequently chosen precisely because he is in sympathy with the ideas and purposes of the government in power and can be relied on to carry on the policies of this government in good faith. This is all true to the extent that, even where there is no special prior agreement between the home government and its foreign representative on a given question of policy, the diplomat in the field may make or mar the success of that policy by his behavior in carrying it out. Beyond this it can be maintained up to a certain point that the diplomat, by remaining in office and carrying on a policy with which he disagrees, becomes a participant in the crime. But it should be noted that even in these situations,-even where 
the diplomat and the home government are hand in glove as to policies to be pursued,- the question of policy is distinct from the question of diplomatic practice. What we object to in many cases is a certain foreign policy, not the manner of organizing and conducting the diplomatic service. And yet it is the latter institution as such that is criticized in the result. It is as if a man should criticize a motor vehicle because it carried him into a ditch. The driver and the driving would more likely be the proper objects of criticism, not the vehicle.

Turning to the mechanism of diplomacy, there are still various criticisms to be made, and criticisms which are, in practice, actually made, against the service. It can be, and is, said, for example, that diplomats are frequently unrepresentative. That is, they are personal friends or political supporters of the official holding the appointing power, not persons enjoying any measure of public confidence. There were few evidences of any marked public appeal or influence on the part of Davis, Wallace, or Johnson, prior to the time when these gentlemen were sent from Washington to London, Paris, and Rome. If these representatives were to act merely in an administrative capacity, this might make little difference. But, entrusted as they are with the work of political representation,-work which it is mechanically impossible to control completely by instructions,- they should be persons in whom the public confidence has been clearly placed for the purposes of their missions.

On the other hand, the members of the service in the lower grades are frequently drawn from the ranks of "society" with little else to recommend them. The manners of the salon of the eighteenth century, and of the drawing room of the nineteenth, seem of such importance in diplomacy that dilettantes in silk hose and top hats are preferred to lawyers or clerks. People who are in actual fact triflers and incompetents are sent out in place of men 
with real ability and enterprise. Now this sort of person may be useful in one position, that of secretary, where he will be entrusted with the ceremonial business of the legation or embassy, and where he will be called on to take up, as chargé, the business of personal negotiations in the absence of the head of the mission, without, however, being entrusted with the power of making decisions on questions of policy. In such a position there is no need of a representative character and no great need for legal or executive ability. The remaining members of the staff, however, while not requiring representative credentials, do need to possess some of the sterner talents and should not be "pink tea fellows," as General Dawes said, and nothing more."

Complaint has likewise been directed against the manner in which the service is organized or, rather, is left unorganized. Diplomats themselves have lamented the extent to which one legation is out of touch with another and with the home office. ${ }^{2}$ It is often a case of one diplomat not knowing what another is doing or what the home government is doing. In an earlier day that was inevitable, and the individual representative of his sovereign was expected to stand alone, but in view of the possibilities of communication today, and in the absence of a true representative character in the diplomat, such a condition ought not to be tolerated. The chief effect upon diplomacy of the development of telegraphic communication ought to be a diminution of the element of personal discretion on the part of the many distant agents and a stabilization and standardization of national policy. That effect is largely lost by failure to take complete advantage of modern means of communication.

Furthermore, the individual legation office is badly equipped in comparison with government offices at home and with private business agencies abroad. Hardly a

${ }^{1}$ On eriticisms of recruitment: Ponsonby, Chap. VI and Appendix III.

- Brailsford, 152, 153, 215. 
nation has realized the need for adequate equipment for its diplomatic establishments abroad, and the result is that the staff has to struggle with equipment entirely inferior to that enjoyed by the bureaus of the national government with which it is dealing and by local private concerns. Clerical assistance, filing apparatus, maps, and tables of statistics, commercial and legal literature are wanting. In the case of the consul this is particularly unfortunate, in the competition with local business houses.

Finally, the consular and diplomatic arms of the service are not closely coordinated. Both deal more or less with commercial and economic questions, and both deal with legal and political questions and often with the same commercial and political questions. Yet they are not completely unified except through the home government. The consul does not always report to the diplomat, nor does the latter have all the help he might derive from the former. Indeed, as things are organized now, the diplomatic offices would be physically unable adequately to supervise and control the consular establishments in the territory where they are stationed, even if they had that legal power. ${ }^{x}$

Coming to the foreign office, it is said that the cus-

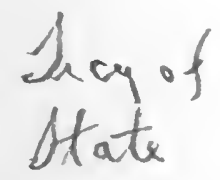
todians of national foreign policy are, like the diplomats, out of touch with the people who must in all common sense be regarded as their constituents. There is a dogma, very popular in some quarters, to the effect that "the conduct of foreign affairs is essentially executive in character." To this no one can object, inasmuch as the conduct or actual administration of any business is executive in character. When, however, this formula is made a basis for conferring upon the executive,-or, worse, the administrative,-offcials of the government the power to determine foreign policies it cannot command hearty assent. It must be

${ }^{1}$ On conditions in the American foreign service: Regulations, Art. VII, Instructions, $\$ \S 189-199$. 


\section{Our Palecy?}

recognized that the formulation of foreign policy is more vital than its execution and that the former ought not to be entrusted to bureau chiefs or appointive department heads. These men may love their country, feel responsible for what they do, desire to leave a successful reputation behind, and all the rest. But the long and the short of it is that only representative officials possess the requisite authority to formulate public opinion into formal policy and law.

The phenomenon just described would not cause such great evil as it does were it not for two incidental causes. On the one hand, there are those specially interested in questions of foreign affairs who do not fail to bring influence to bear in the offices of the foreign affairs department to control the formulation of policy there. The reserve of the Foreign Office is not impenetrable to Mexican oil interests nor to Russian concessionaires. ${ }^{1}$ On the other hand, the public pays little or no attention to the whole business, once a set of officials is installed in the Foreign Office. The bureau chiefs and department heads are left pretty much alone by the people of the state at large. ${ }^{2}$ The result is not only an absence of public control but also a persistent private control over non-representative officials in the formulation of public policy.

Finally, so far as the Foreign Office goes, there is a well-founded belief that the head of that office is commonly out of touch with the other members of the government. ${ }^{3}$ These latter are concerned with affairs within the national territory, he with things preponderantly outside the national frontiers. The effects of foreign policy and foreign affairs on home conditions are not obvious enough to change this to any marked degree. The Treasury, the Army, and the Navy departments are in measurable degree
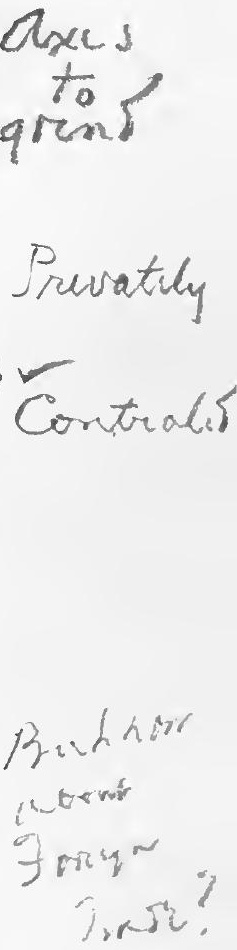

1 Brailsford, 208 and following.

2 Ponsonby, Chap. II, especially 47; Young, Chap. I, beginning.

3 Ponsonby, 46. 
ignorant of the course of events which may cause them to be called on for support later. The benefit of criticism from persons who have a collateral interest in the subject is lost. And the Foreign Office comes to expect the continuation of this treatment, and to resent scrutiny, critical examination, and any attempt to control it. The department is a region of mystery, silence, and awe-or, at least, it tries to be. ${ }^{1}$

- Much of the responsibility for this situation lies with the representative bodies in the state and the members thereof. The members of national legislative bodies commonly know little of international relations, care less, and make no effort to learn. ${ }^{2}$ When such topies come up for debate the seats in the legislative chamber empty and the smoking rooms fill up. Foreign politics, international relations, and diplomatic policy suffer at the hands of local politics in competition for the attention and time and efforts of representatives. The local post office is of more importance politically to the representative from the thirteenth district than is the Anglo-Japanese alliance. The reason for all this, of course, is lack of interest on the part of the constituents. It is not only the representative who is more interested in the local post office than in the various questions of foreign relations before the country; the folks at home are not interested in the latter at all! If they were, the representative would change his views regarding the relative importance of "abroad" and "back home." And, so long as peace is maintained, it may be admitted that there is much reason for the view that the welfare of the individual citizen depends infinitely more upon domestic economic and political questions than upon events in the field of foreign relations. Whatever the ex-

\footnotetext{
${ }^{1}$ Summary view, extremely denunciatory, in Ponsonby, 10-21, 45-48, made up from utterances of famous men.

'Remarks of Mr. Lloyd George in House of Commons on 16 April, 1919, in New York Times, 17 April, 1919; Ponsonby, Chap. V, extracts; Young, 15-16.
} 
planation, however, this situation is the source of all the results just reviewed. ${ }^{1}$

It is not certain that any change could be made imme. diately in this matter of public control of public policy, even if there should occur a change in public interest. Not many national legislative bodies are so organized and equipped with committees and rules of procedure as to be able to study foreign affairs adequately or review the actions of those in charge of foreign policy. It was true until very recently that neither the House of Commons nor the Italian Chamber of Deputies possessed any committee to deal with foreign affairs. ${ }^{2}$ In addition, the individual members refrain, in practice, from exerting an effective scrutiny over the action of the Foreign Office and the diplomatic service. They yield with apparent willingness to the view that foreign affairs are to be treated with fear and trembling and as far as possible left alone. The divine right to ask questions is surrendered in awe before the "official statement." Public debate is onerous in any case; here there is a tradition which advises against it; the net effect is a deep silence, having the appearance of being sanctioned by most profound reasons of state.

Improvement could more readily be made in the field force of the diplomatic service. The selection of the chief diplomatic representatives might well be made dependent upon approval by national representative bodies, as is done in the United States at present. That would at least provide an opportunity for an alert legislative body, anxious and competent to use its constitutional power, to control the character of the national representation abroad. On the other hand, the lower and middle ranks of the service should be filled by competitive technical examinations and a system of automatic selection and promotion for

\footnotetext{
For analysis of control of foreign relations in various nations see Myers, 681-684; fragmentary materials in Heatley, 263-282.

Ponsonby, Appendix II.
} 


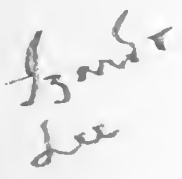

merit. ${ }^{1}$ Persons designed for such positions as clerks, or members of the research and administrative staffs, need none of those elusive personal qualities which make the use of formal examinations difficult or undesirable for the higher posts. It is stoutly maintained in some quarters that even chiefs of missions ought to be so chosen. Such a view goes upon the assumption that it is possible to exert a complete control over foreign policy from the Foreign Office itself and that it is not necessary to rely upon the individual diplomat for a loyal and sympathetic support of the policy with the execution of which he is entrusted by the foreign secretary, or, if it is necessary, that representatives chosen apart from personal or political beliefs are more reliable than others. The former view simply does not meet the facts of the case; the latter seems to depend on an artificially impersonal idea of the way men work in public office.

Changes in the mechanism of diplomacy, however, are of less importance than changes in its spirit; changes in the larger features of structural organization are of less importance than changes in practice, in the manner of carrying on foreign relations, and in foreign policy itself. And this brings us back to the national legislature. After all, the origin of all improvement must be found there, if anywhere. The character of the diplomatic representatives chosen-both in subordinate and superior ranks-may be subjected to control by the elected representatives in point of legal fact. But if such a control is established, it must be exercised actively and intelligently to be of any effect. That is, the choices for chiefs of missions would have to be made with care and discrimination, and the system established for the selection of subordinates would have to be constructed and operated with care and infinite patience. So for the internal organization of the legislative body: the success of any effort on the part of the legislature to

'Report. 11, 19. 
control foreign policy and the conduct of diplomacy must depend upon whether the representative bodies take the pains to provide themselves with adequate committees and bureaus and commissions and rules of procedure to make such work possible.

rowit

Back of all of this, of course, the question rests with the constituents for final solution. So long as the people neglect foreign relations and tolerate ignorance and neglect of them by their representatives, just so long will the latter ignore and neglect this group of public questions, and fail to exert any supervision and control over the Foreign Office and the diplomatic service. Such changes as have come about in the extent to which national representative bodies interest themselves in foreign affairs in recent years are due to the fact that, with war and international maladjustment bearing as they do more widely upon all people in society than ever before, more people are insisting upon some greater control of foreign policy than has hitherto been exerted by their representatives. ${ }^{1}$

Behind this movement lies still another question, namely, how far, as a matter of practicality, could such a change be carried out if people really wished to bring it about? How far could public control of foreign policy be carried, in the very nature of the case? This question is not, strictly, equivalent to the question as to how far publicity is possible in the control of foreign policy, for responsibility might be exacted and enforced in various ways without public debate upon the substance of questions at issue in foreign relations. Nevertheless, the two questions come very close together and may be so treated here, especially as it must be borne in mind that the constituents themselves are not loath to participate in this process of supervision and control, and in many cases desire to control the controllers, the committees on foreign relations.

Much time might be spent in speculating abstractly

${ }^{2}$ Ponsonby, Chap. VIII; Young, 48-76. 
upon the feasibility of publicly conducted diplomatic negotiations. Such speculation is of no great value in such a case. We shall never know what can be done until we try, and the two most important conclusions to be drawn in this matter as it now stands are that, whatever we think or prefer, the days of secrecy are vanishing, in actual practice, and that, after all, it does not appear to make much difference in the result.

In the circumstances of today, with the multiplication of the number of parties interested in every international question and the number and activity of newspaper correspondents serving publics who are increasingly eager for international political news, the possibility of maintaining secrecy simply does not exist. Add to this the fact that the spread of popular government has led the statesman and politician to a position where he also desires to utilize public interest in these questions to secure support for himself, and the plea for secrecy is hopeless. Diplomatic representatives recognize this and, by means of "press conferences," arrange to divulge everything that transpires in the secret conference. ${ }^{1}$ All this may be good or evil, but inevitably it is so. ${ }^{2}$

In actual observation the results do not seem to be very decisive one way or the other. Great danger has been predicted from open discussion of international political questions. When tried extensively in the United States in 1919-20, no such results followed. The discussion became a terrible bore. For one thing, people did not know enough about the background of the various topics discussed to have any interest in them. Teschen and Fiume meant little

New York Times, 22 November, 1921, p. 8.

2 See resolutions of representatives of the press in Paris, as handed to the Supreme Inter-Allied Council, 17 January, 1919, and reply of 18 January, 1919; New York Times, 18-19 January, 1919. There is a striking discussion of this matter, in connection with the Adriatic problem, in same, 16-20 February, 1920. See also accounts of conditions in Washington in November and December, 1921, in same, 17 November, 1921, p. 1, and editorial comment in New Republic, XXVIII, 332 (16 November, 1921). 
to people with no special interest in Central Europe and the Adriatic. This, indeed, is the safeguard contained within the procedure in question: so long as people know little about foreign affairs they will not be dangerously excited by the news which means little to them, and as they begin to learn more the capacity to discount and assess sensational items at their true value increases. ${ }^{1}$

This phenomenon should be examined further, in the light of possible future developments. Let us suppose for a moment that diplomatic conferences were held in public, or that verbatim reports were published daily as, indeed, was done in Washington in November and December, 1921. The conferees would expect, and fear, great excitement and annoyance and interference with their work. In reality most people would lack both time and interest to read steadily the verbatim reports, and the conference would be less the object of excited attention than at present, when, in speculation, the outsider imagines that all sorts of sensational things are going on behind the closed doors. But this also means that, even with full publicity, the task of securing public control would still have to be met, for unless people read the reports no results would come from their publication. Thus we get back, as before, to the real difficulty and the real problem, namely, the failure of the public to interest itself in international affairs. Until that condition changes no great results can be expected either in opening up the procedure of diplomacy or, more important still, in taking advantage of such open methods to exert a public control over national foreign policies.

One of the chief difficulties encountered here is to be found in the fact that it is not with conditions of perfect secrecy or perfect knowledge that we have to deal. If it

${ }^{1}$ Again in 1921 a public conference was held in which representatives of two Balkan states actually engaged in hostilities were called on to state their cases to the world, in order that European public opinion might be brought to bear on the subject, yet no great attention was given to the case; New York Times, 17 and 18 November, 1921, pp. 5 and 17. 
were possible to preserve a condition of perfect secrecy about the discussions of international affairs the result might be tranquillity, at all events, - at least until diplomacy broke down and war came upon us, - unless, indeed, that too could be kept secret. As a matter of fact, complete secrecy is simply not possible today, and what results from an attempt to preserve secrecy is a series of intermittent and spasmodic revelations than which there is nothing better calculated to excite speculation and high feelings and to give a false basis for conclusions. ${ }^{1}$ Moreover, here as in other cases of a similar kind, the restrictions bear unequally upon different people, and what public representatives are prevented from discussing in parliament is discussed freely in the smoking room of the club and at the directors' meeting; again it is a question not between no secrecy or total secrecy, but between public knowledge of public affairs and private knowledge, the public remaining ignorant.

Finally, the danger or inconvenience of public control of foreign policy depends largely upon the character of the policy to be followed. If a fair and honest policy is pursued, it can stand-and will profit by-exposition and revelation; the policy that will not stand discussion is the policy of rascality and greed. In a similar way, politicians who resent scrutiny in this field of politics do so almost invariably because of political or personal prestige, not national interest. Therein they do not differ, of course, from politicians in other fields of public life; but here the argument is raised into the front rank and made one of principle, just as it was formerly maintained that public discussion of any sort of state questions would be disastrous. ${ }^{2}$

${ }^{1}$ Compare excellent statement in editorial in same, 25 February, 1921; also episode in Washington conference in same, 29 November, 1921, p. 2, column 7.

" "Strangers" (the public-!) were formerly rigidly excluded from the Halls of Parliament and publication of debates was held to be a crime; and these rules are still in effect and may be invoked at any time; Mray, 74, 189. The Congress of the United States has, in times past, and still might, legally, meet and legislate in secret; Miller, Secret Statutes. 
As for partisanship in foreign affairs, the same group of criticisms is to be applied to the current dogmas. In actual fact artificial bi-partisan unity on such questions is breaking down as people become more interested, and interested to the point of disagreement, in such problems. And there are no catastrophic results. Inconvenience and delay and bother ensue; but inconvenience and delay are the results of all lack of perfect accord among men. Partisanship is inexpedient in these matters, but so it is in domestic matters. On the other hand, sincere opposition and debate are as useful in one field as in the other. If possible, by all means let there be unity within the nation among all factions on foreign policy; likewise, unity or continuity among successive governments in power. But let this not be obtained at the expense of honesty. To hold that a nation must go on making a mistake because a mistake has been begun is hardly politics, it is some subtle form of superstition. After all, the curse of international politics in the past has been too little discussion, too little investigation, too little competition in ideas and policies, too much monopoly of public power by private interest or, at teast, too much neglect of public interest by official representatives. ${ }^{1}$

As has already been said, the reason for this is the lack of public interest; when people insist on a different way of doing things that different way will be adopted. And the sum of the whole thing is that such a change is now being brought about. It is not now a question whether such a thing shall be done, but what is being done and why. For the results we shall have to "wait and see." They are not likely to be cataclysmic, although doubtless they will mark considerable changes over the conditions of a century ago. ${ }^{2}$
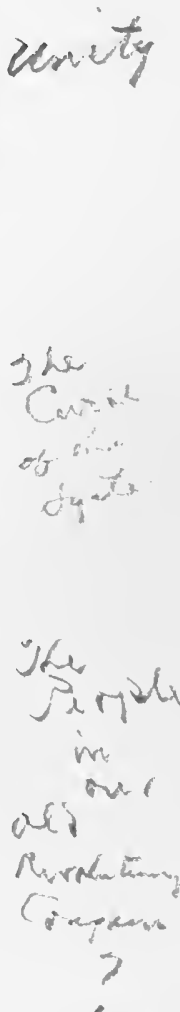

${ }^{1}$ Further materials in Heatley, 52-76; Young, Chap. III.

'A careful study of the mechanical aspects of this problem is badly needed. In the text the attempt has been made merely to point out some of the more vital angles of the problem. The studies of Neilson, Ponsonby, Young, etc., do not attack the problem in its most important part, namely the feasibility of publicity in diplomatic negotiations, as a problem of the technology of politics, as a problem of engineering. 
. 
PART III

TREATIES AND INTERNATIONAL LAW 


\section{CHAPTER X}

\section{TREATY NEGOTIATION}

$7 \mathrm{HE}$ ordinary work of the diplomatic representative 1 consists in the conduct of negotiations relating to current questions at issue between his own state and the state to which he is accredited. These negotiations may be conducted orally, in conversations with the Foreign Secretary of the state to which the representative is sent, or in writing, by exchanges of diplomatic notes. In the former case the element of personal intercourse is predominant, and the action is transitory and leaves little trace of itself behind, unless a memorandum of the agreement reached in the negotiations is drawn up and signed by the participants. In the latter case the correspondence remains to serve as a record of the transaction; though here also, in the absence of a signed statement summarizing the exchange of views, the chance for disagreement as to the real results of the negotiation is great, and the degree of inconclusiveness and impermanence in this form of action is therefore also considerable. This is all the more inconvenient when the negotiations have concerned, not some special case, as, for example, the citizenship of a certain individual, but a general question, such as the principles which the two states agree to follow in the future in settling disputed cases of citizenship.

For these reasons-namely, the unstable and impermanent character of purely personal diplomatic negotiations - this primitive form of international government was supplemented at a very early stage of international development with the device of the formal written agreement. 
An elaborate practice of treaty-negotiation sprang up among the Greek and Roman states of Antiquity. ${ }^{1}$ Such a result followed naturally from the desire and effort to leave a permanent record of diplomatic agreements behind, and, in its simplest form, constituted merely a final stage of personal diplomacy. Indeed, the noun "treaty" seems to have been formed on the basis of the verb "to treat," used to describe diplomatic negotiations; when diplomats treat with one another for peace a treaty of peace is the result. The treaty is of such a distinctive character, however, and has developed to such an extent on its own account, apart from its parent practice, that it deserves study by itself. The negotiation of treaties and their analysis and generalization among the states is a distinct branch of modern international government. ${ }^{2}$

It is to be noted, first, that the usual object of the formal treaty today is to provide for certain and definite action in the future whenever a given type of question shall arise-a question of citizenship, of commercial privileges, of extradition-without the necessity for special diplomatic agreement every time upon the merits of the case. So far as the process of treaty negotiation is successfully extended, therefore, the practice of personal diplomacy is rendered superfluous. The greater the number of questions which are settled in advance by treaties, the fewer will be left for settlement by diplomacy as they arise, assuming, of course, that the treaty is faithfully executed on both sides.

This elaborate extension of treaty negotiation is preceded by a much simpler stage where the treaty itself has for its object merely the settlement of a concrete case. Such, for example, is the treaty providing for the sale of a given piece of territory. This simplest type of treaty is hardly more than a compact ad hoc, or a contract promis-

${ }^{1}$ On treaties in Antiquity, see, beside Phillipson, Egger, entire.

2 For literature on treaty negotiation see, below, Appendix B, § 10. 
ing a specific performance, in contrast to the treaty negotiated upon a general subject to operate continuously into the future. The latter treaty approaches legislation in its nature, especially when it is concluded among several states and deals with subjects in a general and comprehensive way. Thus the treaty, which begins within the range of simple personal diplomacy, ends in the most advanced and final stage of international government.

Under ordinary circumstances treaties are negotiated by the regular diplomatic representatives permanently accredited between or among the states concerned. ${ }^{1}$ For such a purpose the standing powers and instructions of the diplomatic representatives are often adequate; a regular diplomatic representative would not hesitate, if a sufficient occasion demanded, to enter into treaty negotiations with the Foreign Secretary even if his standing instructions said nothing upon the matter. In most cases, however, special authorization and instructions are needed by the representative abroad; and, even if he enters into negotiations for a treaty with the state to which he is accredited, he will communicate with his home government for authority and instructions to continue the discussion, and he will be able to sign an agreement, in the absence of such special authority, only ad referendum, that is, upon the understanding that the agreement is to be referred to the home government for approval. ${ }^{2}$ In these days of swift communication and when treaties must commonly be submitted for approval to representative bodies before being effective, the diplomat finds few occasions for such unauthorized action, while, on the other hand, all treaties are, in actual fact, signed ad referendum.

When special "powers" are issued to diplomats for the negotiation of treaties, these documents perform the function performed by the credentials of the diplomatic repre-

U. S. Diplomatic Instructions, $\S \S 242,243$.

Satow, § 189. 
sentative in ordinary cases. The "full-power" serves to identify the diplomat personally, and to describe the scope of his authority for the current negotiation. ${ }^{1}$ It ordinarily authorizes him to sign on behalf of his state. Indeed, it is of little value if it does not do so, as was evidenced at one time in 1920 when Russian representatives refused to enter into peace discussions with the Poles so long as the latter had no powers to sign a treaty of peace. ${ }^{2}$ The fullpower pledges ratification by the state, provided the agreement made does not exceed the limits of discretion entrusted to the agent. ${ }^{3}$ But there would be no obligation resting upon a state which had given authority to its agent merely to arrange for an exchange of prisoners, to ratify an agreement for, let us say, the exchange of territory.

While the negotiation of ordinary treaties may be left to members of the regular diplomatic service, special treaties of great importance, such as treaties of peace and general international conventions among more than two powers, are ordinarily concluded by delegates or commissioners specially chosen for the negotiations in hand or for representation at the conference where the convention is to be drawn up. The press of business upon the regular diplomatic service and the fact that specially qualified agents are, or are not, available, are considerations which determine whether or not special agents shall be utilized for the purpose. Thus, on owe hand, the American Ambassador in Paris was left entirely aside in 1918-19 when it came to the negotiation of a treaty of peace at the close of the World War, while several smaller powers made use of their representatives in Paris rather than send special agents from Asia or South America. Where special agents are used they are given diplomatic rank for the time being to facilitate their work, and are provided with

Examples in Crandall, 635, and Satow, $\S \S 126-138$; seo also Moore, Digest, § 739 .

Crandall, § 3 ; Moore, as cited, $§ 743$.

Moore, $\$ 744$. 
credentials and instructions in diplomatic form. They become, for the time and the purpose, diplomatic agents, even where they are acting as delegates to an international conference or congress.

The term "negotiation" should properly be confined to the first stage in the making of a treaty. In this stage of the proceedings the proposals of the negotiating parties are put forward, discussed, harmonized, and tentatively agreed upon. The next step, and a crucial one, is to draft a treaty or convention embodying the agreements in substance already reached, and to do this in such manner that the text will be satisfactory to the parties. Finally, the treaty must be signed. This completes the preliminary work of the diplomats and includes everything that can possibly be considered part of the negotiation of the treaty; even the drafting and signing of the agreement might well be excluded from the concept of negotiation. The treaty now passes to the home government for further disposition.

Treaties negotiated by diplomatic representatives are now almost universally submitted to representative bodies for approval before becoming effective. ${ }^{1}$ Whether this needs to be done is purely a matter of national constitutional law in each state, although things are in such a position now that states are not likely to feel great confidence in the binding effectiveness of treaties not so submitted; and in the near future international law may hold that such action is necessary, just as it now holds that treaties may be concluded on behalf of the states only by duly authorized persons, and just as ratification by the formal head of the state is held to be necessary, whether based on the consent of a representative body or not. Few treaties fail to provide, in one of their articles or clauses, for ratification within a given period of time.

\footnotetext{
${ }^{1}$ Satow, $\S 606$; also Ratification of Treaties, a compilation in Sen. Doo. 26, 66 Cong., 1 Sess.
} 
The original object of this ancient rule requiring rati. fication by the head of the state was to protect the latter against the errors of a diplomatic agent, primarily as to action in excess of the legal power conferred upon the agent, but also as to mistakes of policy. ${ }^{1}$ Hence this power of ratification, like the power to select diplomatic representatives on behalf of the state in the first place, and the power to consent to ratification, if such a step is required by the national constitutional law, is conferred by the provisions of national law upon one of the national organs of government. ${ }^{2}$

Finally, limits are ordinarily set by national laws and constitutions upon the range of subjects upon which treaties may be concluded by the government, or upon the disposition which may be made of certain subjects by the government in treaty agreements. Thus the government may be forbidden to alienate national territory by treaty, or to change the form of national government, or to contract liens upon the national revenue without consent of the popular chamber. ${ }^{3}$ This whole matter-the range of the powers enjoyed by the government and the permissible modes of exercising these powers, the so-called "treatymaking power"-is ordinarily dealt with quite fully in the national constitution. In addition, it is the subject of a vast deal of scientific-and pseudo-scientific-speculation and writing. ${ }^{4}$

The step of ratification has taken on a new significance in recent times as a result of the action of public representative bodies in seizing upon that occasion as an opportunity to exercise control over the Foreign Secretary and the diplomatic representatives of the state. For such action raises immediately the question of the duty to ratify.

1 Moore, as cited, 185, quoting Vattel and Martens.

For United States see Foster, Chap. XIII, Moore, §§ 743-758.

Crandall, §§ 33-46, 116, 124, 133-135; Moore, \$§ 737, 738. entire.

- See literature cited, below, Appendix B, $\$ 10$, especially Treaty Power, 
The utterances of certain recent Presidents and Secretaries of State of the United States, criticizing the Senate for refusing to consent to the ratification of treaties which had been negotiated by them, may be recalled. Secretary Hay went so far as to say that the only certainty in the matter was that once a treaty was sent into the Senate it would not come out alive. Switzerland has recently adopted a constitutional amendment whereby all treaties concluded with foreign powers for a period of more than fifteen years shall be submitted to public referendum upon the demand of a certain number of voters. ${ }^{1}$

It may be stated definitely at once that there is no obligation of ratification where the agreement actually signed exceeds the powers of those who signed it, be they diplomatic representatives or Secretaries of State or Presidents. More than that, there is a constitutional inability and a duty not to ratify in such circumstances. Where there has been no excess of power in a legal sense there is some room to maintain that a state, in selecting a diplomatic agent commits its advantage or disadvantage to his judgment, discretion, and skill. In actual practice, all states, having this second opportunity to reflect upon the policy involved in the proposed agreement, do not hesitate to take it and to reject treaties on grounds of policy. This most frequently happens, of course, when the Executive who negotiated the treaty and the Legislature or representative body to which the treaty is submitted for approval have divergent views as to the desirable national policy. In such cases the only thing to be said is that the ordinary rules of representation in government must be applied. If the Executive is not at the time representative in theory or in fact or neither, while the Legislature is so, no one can complain if the latter will not accept treaties drawn by the former, unless the principle of public responsibility

${ }^{1}$ Brooks, R. C., "Swiss Treaty Initiative," in Amer. Pol. Sci. Rev., XV, 423-425 (August, 1921). 
in government is to be given up. If both arms of the government are in theory representative, yet disagree in policy, it is evidently a case where the mechanism of representation is defective, leaving divergent mandates standing to conflict with one another. If the conflict be due to changes of public opinion in the passage of time, the case is the same, but it must also be recognized, in such cases, that reconsideration of policy is not, by itself, a procedure which can be condemned. In none of these cases can it reasonably be argued that the action of the representative body deserves to be ignored, or that it would be better if that were possible.

In view of the very real difficulty of this problem, whatever the cause of that difficulty may be and however natural the cause of events leading up to it, attempts are made to take care of the situation in advance. The agents chosen to negotiate the treaty are at times selected with the advice or consent-tacit and implied or explicit-of the body which is later to be called upon to ratify the treaty. Thus some degree of accord between the home government and its agents is assured, not only in point of law, but in point of policy. Such a procedure is wholly desirable. Second thoughts are useful, and the value of two independent judgments upon a treaty is unquestioned, but this gain must not be sought at the expense of consistency and effectiveness in state action. If the public assembly is to have the final word on the treaty, the first word ought not to be said in indifference to or defiance of the policy of that body. And the whole situation is greatly alleviated by the insertion in the text of the treaty of a provision stipulating ratification at discretion by the home government. In view of the fact that the ratifying body can hardly hope to control foreign representatives in practice, even though their appointment be subject to its approval, in view of the fact that their instructions must naturally come from the executive, such a solution seems to be inevitable. ${ }^{1}$ Control

${ }^{1}$ Corwin, 58-70; Crandall, $\S 37-38$. 
by the legislature of the selection of representatives to negotiate treaties would undoubtedly have some effect, but not a great deal. The practice of subjecting international agreements to public approval is not going to decrease; on the contrary, it is going to increase; and it remains to adjust matters in view of that movement by a device in the mechanism of treaty negotiation to take care of it. ${ }^{1}$

A similar line of reasoning is to be applied to "reservations" to treaties on the stage of ratification. ${ }^{2}$ Reservations which merely interpret the provisions of the treaty text present no difficulties; but this is merely to raise the question whether a given reservation is merely interpretative, that is, whether it serves merely to bring out the agreed meaning of the text, or whether it constitutes a change in the agreement as understood at the time by one or more of the parties. ${ }^{3}$ The net result is that if a state desires to make reservations it does so at its peril, while, if the consignatory allows the reservation made to stand, it, in turn, may suffer thereby. It is impossible to say either that a reservation made has no effect unless explicitly agreed to by the other parties or that, if allowed to stand unchallenged, it has the effect of altering the obligations of the treaty for the state making the reservations. The law of nations has not reached a point where these detailed problems are settled. The test to be applied is the test of joint agreement or mutual consent between or among the parties to the treaty; just what will constitute evidence of consent in the matter of ratifications with reservations remains to be settled in the special circumstances of the case, checked and reënforced by the risk of counterclaims and refusals to perform the obligations of the treaty in the future. Where reservations or amendments, including changes in the text and essential modifications of meaning,

${ }^{1}$ Crandall, $\S 49$; Moore, work cited, $\S 743$, p. 185 ; example, below, in Appendix A, Document No. 4, $a$ and $b$.

Wright, Amendments, 16-17.

${ }^{8}$ Moore, § 750 . 
are stated by one party and accepted by the other, all difficulty is removed.

After ratification by the parties severally, ${ }^{1}$ evidences of this action are exchanged. ${ }^{2}$ This exchange of ratifications is the definitive step in the conclusion of the treaty and gives it binding force upon the contracting states. ${ }^{3}$ A publication or promulgation of the treaty usually follows and renders it binding, subject to the constitutional law of each state and common international law, upon the citizens of each of the contracting states and, so far as may be by international law, upon third states. ${ }^{4}$ It will be noted that the range of binding effect of the treaty increases at each stage, from signature through ratification and exchange to promulgation. Signature binds the government, ratification and exchange of ratification binds the state, promulgation binds the people of the state individually.

The effect of treaties upon third states or states not parties to the agreement varies with the nature of the treaty and the action or inaction of these states. On the one hand the doctrine of the legal independence of states forbids any two states to impose legal obligations upon a third state without its consent. On the other hand, outside states may become parties to a treaty by giving such consent. Between the two extremes, and especially in the binding effect of these acts, there are many variations.

States not parties to a treaty may be asked to adhere to the agreement or to accede to its terms, ${ }^{5}$ and this invitation may be extended by separate diplomatic action or in the text of the treaty or in both ways. ${ }^{6}$ The distinction between accession and adhesion is slight, and the two terms are often confused. So far as there is any distinction, it

${ }^{1}$ Examples in Crandall, 636, and Satow, $\S \S 607-612$, anā, below, Appendix A, Document No. 4.

2 Example in Crandall, 637, and, below, Appendix A, as cited.

Treaty of Versailles, Arts. 438-440, in Sen. Doc. 49, 66 Cong., 1 Sess.

- Crandall, §50.

S Satow, §§613-618.

- Treaty of Versailles, Art. 1, as cited. 
lies in the fact that by accession a state becomes a party to the treaty, while by adhesion it simply recognizes the terms as agreed to by others and pledges to respect them. ${ }^{1}$ This distinction is of importance where the treaty is of such character that accession would involve the new state in obligations to do certain things, as, for example, to participate in an exchange of military or economic statistics among the signatories. Where a cession of territory by one state to another is involved, third states could hardly, in the nature of the case, do more than adhere to the treaty.

In the absence of accession or adhesion, third states are merely under obligation to take notice of the existence and effect of the treaty between the contracting powers. The results, in point of fact, are the same in the end, in the casse of treaties such as those for the cession of territory, as though the state had formally adhered thereto. Likewise for treaties embodying and declaring rules or codes of international law; third states may be compelled to accept them as evidences of the common law of nations in spite of the fact of not being signatory thereto, as in the case of the Declaration of Paris of 1856 . Further, nonsignatories may by independent action adopt the rules of law embodied in such treaties without joining in the signature of the treaty itself, as did the United States, in part, with respect to that same Declaration of Paris. It is hardly too much to say that the effect of treaties upon non-signatory states depends more upon the contents of the treaty in question than upon the formal action or inaction of these states. With the great increase of the number of treaties of a law-making character, this is doubly true. Treaty-making is becoming increasingly legislative in character, both within the individual states and in their relations to one another. It is a far cry to the age when treaties were merely contracts between personal sovereigns nego-

${ }^{1}$ Satow, $\S 614$; specimens in $\S \S 615-618$. 


INTERNATIONAL ORGANIZATION
tiated on their behalf by personal agents, and could in the
nature of the case bind only the signatory parties.
Several questions arise in connection with international
treaties which are of an essentially legal nature, as, for ex-
ample, the rights of states signatory to the treaty by virtue
of the terms of the agreement. These questions lie in the
field of abstract or pure law, rather than in that of inter-
national governmental practice. Nevertheless, certain ques-
tions of this sort arise directly out of the process of treaty
negotiation, and these problems cannot therefore be over-
looked in any study of that process.
As has already been suggested, the scope of the treaty
signed by the agents of the states must conform to the scope
of the powers entrusted to them. Any agreement in ex-
cess of the powers conferred upon them can have no bind-
ing force unless it is conferred by some additional action
of the state, such as ratification in spite of the extended
scope of the agreement. The agent cannot commit his
principal to obligations which are beyond his powers, al-
though the latter may make good the defect by himself
accepting those obligations.
Again, the principal cannot be held bound by agreements
made by his diplomatic agent where the latter has, in the
course of the negotiations, been subjected to fraud or
duress to compel him to sign." The state as such may
be "compelled" to accept a treaty at great disadvantage
to itself by reason of the fact that the only alternatives
open to it are still greater disadvantages or sufferings.
But in such a case the state has lost its freedom of choice
as a matter of fact at an earlier point of time, by allowing
itself to be put in such a position that it can be confronted
with the alternatives of eonquest or agreement to pay an
indemnity; as a matter of law, its choice is still free as be-
tween the alternatives presented. In the case of the agent,
"Hall, 108.


he has no choice when confronted with fraud or a threat of death; or, even if it is insisted that the same freedom to choose exists in his case as it exists in the case of the state whose territory and capital have been occupied, the only choice that he actually has is between his own interests and those of the state. For this reason he is not capable of binding the state by such a choice.

Finally, the treaty as negotiated cannot violate the accepted rules of international law. Treaties may be concluded with the direct purpose of revising the accepted rules of international law, and two states may agree to act in their relations with one another in a manner at variance with these rules. But such a treaty can have no binding effect in the eyes of third states, nor will the rules of international law be revised for them without their consent as a result of that treaty. The utmost to be gained in such cases is that third states will recognize that its obligations exist as between the signatories. This they need not do, but may, on the contrary, enter a legitimate protest where their rights are adversely affected by a treaty contrary to commonly accepted international law. ${ }^{1}$

The validity of treaties is affected not only by the manner and conditions under which they are negotiated, but also by the course of subsequent events. And these may easily lead to the total disappearance of the treaty or its replacement in whole or in part by a new agreement.

The simplest mode in which a treaty may pass out of the system of effective international agreements is by the fulfillment of its terms or expiration according to a time limit set in those terms. ${ }^{2}$ By such a process treaties are lapsing continually, and if this were the only force operating in the field the existing treaty system would be seriously depleted with the passage of time, and only such treaties would remain as stipulated obligations which were still

' Hall, § 108; Roxburgh, §§ 24, 25, 71.

${ }^{2}$ Hall, $\$ 116$. 
unperformed or were permanent and continuous in their nature.

Such a result is forestalled by the constant replacement of expiring treaties by new agreements. ${ }^{1}$ Old treaties are constantly revised, in whole or in part, and thus the treaty nexus is carried along continuously. The multiplication of state rights and obligations as a result of the repeated negotiation of single treaties leads to a condition of confusion and complexity which in itself calls for a process of constant revision and consolidation. ${ }^{2}$ States are from time to time compelled by this factor to pause, take stock of their outstanding treaties and treaty rights and obligations, and attempt to consolidate these rights and obligations and render them uniform and consistent. Such, in part, was the motive which led Japan, in 1894-96 to undertake a wholesale revision and simplification of her treaties granting exterritorial privileges to Western Powers on behalf of their nationals residing in Japan. This leads to a renewal or revision of old treaties; and it may also lead to the abandonment of old treaties by mutual agreement without any further steps, as well as to the replacement of old treaties by entirely new ones.

Treaties or parts of treaties may likewise come to an end by the action of the beneficiary in renouncing rights accorded by the terms thereof. This would not of itself give a right to release from obligations incurred by the treaty and could only take place under ordinary circumstances in connection with unilateral treaties. These are rare, and the case where a state is willing to renounce treaty rights while not securing a release from the corresponding obligations is rare. Hence this mode of terminating treaties or treaty obligations is unusual. A recent example is to be found in the surrender by Great Britain of certain rights

${ }^{2}$ Hall, § 117.

- Compare situation in which China found herself at the end of 1921; New York Times, 18 November, 1921, p. 3. 
over German property in British territory under the Treaty of Versailles.

Finally, treaties may be terminated by a process of denunciation. ${ }^{1}$ One of the parties may denounce a treaty according to provisions made in the text of the instrument itself. Or one of the parties may denounce the treaty according to the rules of common international law. This may take place when it is discovered that there are defects in its original validity due to action by the negotiators in excess of their powers or due to duress applied to the negotiators. The proper stage at which to act upon such facts is that of ratification, and ratification may be taken to cover any such facts as these which are known at the time. But newly discovered facts of this nature will probably justify and - what is more important for our purposes - probably lead to denunciation later. Beyond this, denunciation will be likely to follow upon the failure of one party to perform its obligations under the treaty, and also such a change in circumstances in either of the states parties to the agreement or in general international relations as to make the treaty dangerous to the existence of one of the parties or to invalidate the exchange of benefits upon which it is based. The denunciation in such a case will give a right to compensation to the other party for benefits actually conferred and for loss of compensating benefits, but no state can hope to hold another to treaty obligations apart from some substantial degree of mutual benefit or in circumstances endangering the safety of the state. Indeed, it is this very reason, turned in the other $v$ direction, that entitles the second party to compensation $\checkmark$ upon denunciation by the first.

By these processes treaties are made, revised, abandoned, replaced, and extended, and the web of international treaty obligations is kept in constant repair and effectiveness.

${ }^{1}$ Hall, $§ 116$. 


\section{CHAPTER XI}

\section{THE MODERN TREATY SYSTEM}

THE negotiation of treaties according to the processes 1 just described has gone on steadily and with an ever accelerating frequency during the past four or five centuries. The results appear in the enormous mass of treaties and treaty obligations existing at any one time, a body of material which is constantly renewed, constantly revised, and which is constantly increasing in extent and in its internal complexity. Each decade sees an increase in the number of treaties concluded, the number of subjects taken up for settlement by the process of treaty negotiation, and the degree to which the states are involved in this system of relations.

The treaty nexus may be studied as it stands at any given point in time; and an analysis of existing treaty rights at any given point in the past gives a fairly adequate understanding of the existing state system and the existing system of international practice at that time. Moreover, despite the fact that, with each advancing decade, and almost with each new treaty made, some old treaty passes out of effective existence as a statute of binding obligation,so that the vast majority of all the treaties on record are now obsolete, and only the more recent ones, such as have not expired and have not been superseded or abrogated by succeeding compacts, are directly effective,- these older treaties are not of merely historical interest. For the provisions which they contain furnish evidence regarding the principles upon which the nations may be presumed to desire to regulate their relations, in the absence of any conventional agreements in effect to the contrary. In other 
words, they provide the materials from which the rules of the historic common international law may be inferred by a process of induction. Finally, it is with the external aspects of this net-work of treaties in which the modern states of the world are and have been constantly enlaced that we are chiefly concerned, and not with the contents of those treaties; for this purpose the treaty system of a decade ago is as useful for study as that of today.

Probably the best way to realize the nature and extent of the treaty system is to examine some of the greater treaty collections which have been made in the past, and some of which are maintained continuously at the present time. These collections are either official or unofficial; they are made, that is, either by the states themselves or by private scholars. Each state, of course, keeps a record of the treaties to which it is a party and which are still in effect. ${ }^{1}$ Very few states, if any, however, maintain systematic collections of old treaties. When a treaty becomes obsolete it is relegated to "the archives," and in many cases to oblivion. It remains for private scholars, assisted, at times, by public aid, to collect and edit and publish complete collections of international treaties. And the relative rapidity with which treaties accumulate, are rendered obsolete, or are revised or amended makes the task a gigantic one. All sorts of physical, legal, and personal difficulties are involved. ${ }^{2}$ Nevertheless, such collections are made, and they provide the best exhibits of the treaty system that are available. ${ }^{3}$

In a collection of treaties published at Amsterdam in the years 1726-39 Jean Du Mont assembled several hundreds of international agreements contracted by European states between 800 A.D. and the eighteenth century. ${ }^{4}$ The collection fills thirteen huge volumes, in one or two parts

${ }^{1}$ Outline, 77.

'Am. Hist. Rev., V, 436 (April, 1900) ; VI, 395 (January, 1901); IX, 452 (April, 1904).

Klüber, Supplément, §§ 6-23; Tentative List, 7-12.

4 Klüber, as cited, $\S 6 ;$ List, 8; full title: Corps Universal Diplomatique du Droit des Gens, 8 vols. 1726-1731, 5 vols. 1739. 
each, and bears testimony to the manner in which the practice of treaty negotiation grew with the appearance and early development of the modern state-system.

The collection of Du Mont was later supplemented by a collection of the European treaties concluded in the eighteenth century prior to 1772 , which was published at Leipsic in the years $1781-95$ by Friedrich A. W. Wenck. ${ }^{1}$ The number of treaties for these three quarters of a century is greater than that of the treaties in Du Mont for any preceding century, just as, in Du Mont, the earlier centuries are surpassed by the later ones. These two great collections provide a very satisfactory introduction to the modern treaty system.

The true measure of the body of treaties concluded among modern states is to be found, however, in the monumental collection begun by G. F. de Martens and bearing his name in its entirety. ${ }^{2}$ This series has been continued to date since 1791 and in 1920 numbered just over one hundred volumes. The series has been published in Göttingen and Leipsic in French, and is divided into the Receuil, Supplément, Nouveau Receuil, Nouveaux Supplémens, and other parts. ${ }^{3}$ It is, for this reason, and for other mechanical reasons, somewhat difficult to use; but there is no difficulty in realizing the significance of its contents, even from an inspection of the Tables Générales published from time to time. ${ }^{4}$ The treaties included date mainly from 1761, although one group of volumes in the series includes

${ }^{1}$ Klüber, as cited; List, 12; full title: Frid. Aug. Guil. Wenckii... Codex juris gentium recentissimi.

${ }^{2}$ Klüber, as cited; List, 10-11; full title of first group: Receuil des principaux traités d'alliance, de paix, de trève... conclus par les puissances de l'Europe.

${ }^{3}$ Receuil, 7 vols., 1791-1801; Supplément, 10 vols., 1802-1828; Receuil, $2^{\circ}$. ed., rev. et aug., 8 vols., 1817-1835; Nouveau Receuil, 16 vols., 1817-1841; Nouveaux Suppleméns, 3 vols., 1839-1842; Nouveau Receuil Général, 20 vols., 1843-1875; Nouveau Receuil Général, $2^{\mathrm{e}}$ gér., 35 vols., 1876-1908; Nouveau Receuil Général, 3 ${ }^{e}$ sér., vols. 1-8, etc., 1909-1915, etc.

'In 1837-1843, 2 vols., covering the materials published prior to 1843 ; in 1875,2 vols., covering all materials published prior to 1875 ; in 1900 and 1910,2 vols., covering the " 2 e série." 
treaties dating between 1494 and 1760 which do not appear in Du Mont or Wenck. ${ }^{1}$

The treaties in Martens prior to 1920 number over five thousand. These treaties involve over one hundred independent states, some of which, like most of the treaties recorded in these volumes, have passed into history. They deal with all possible subjects of international negotiation.

Finally, the treaties of American states are to be included in this review. The treaties concluded up to 1913 by the United States with other states have been collected and edited by W. M. Malloy and Garfield Charles, and were published in three volumes in 1910 and $1913 .^{2}$ There are on record about six hundred treaties and other international agreements between the United States and other Powers prior to 1920. Carlos Calvo has performed the same service, in part, for Latin America, by publishing a collection of all treaties concluded by Latin American states from 1493 to $1822 .{ }^{3}$ This collection runs to sixteen volumes and 500 Trias $\checkmark 100$ Dra Jkates. must be supplemented by collections of treaties concluded by Latin American states in the past century. ${ }^{4}$

In addition to these five great collections, which are duplicated in part by collections of other scholars, such as Garden, Koch, Lamberty, and others, ${ }^{5}$ there are many collections for individual nations and for individual conferences where treaties have been produced. Such are the collections of De Clercq for France, of Rymer and of Hertslet and others for Great Britain, of Lagemans for the Netherlands, on one hand, ${ }^{6}$ and the many collections of the conventions signed at the Peace Conference at the Hague in 1899 and 1907. ${ }^{7}$

\footnotetext{
11 The first volumes of the Supplement.

${ }^{2}$ Sen. Doc. 357, 61 Cong., 2 Sess., and Sen. Doc. 106, 62 Cong., 3 Sess.

List, 7.

"Colección de tratados celebrados por la República Argentina, Publicación oficial, 1863, List, 22 ; Colección de tratados celébrados por la República de Chile, 1853-1875; List, 26, et cetera.

${ }^{5}$ List, 8, 9.

- Same, 34, 44, 45, 66.

Tame, 13-19.
} 
From an inspection of these collections ${ }^{1}$ it appears that modern states have concluded somewhat over ten thousand treaties with one another since the dawn of international relations. ${ }^{2}$ In view of the nature of the material, it is, of course, impossible to render such data precise within two, or even three, figures. All of the collections contain many national statutes, decrees, and other acts besides treaties proper. There are many duplications, and doubtless not a few treaties have been entirely lost from their pages. Nevertheless, the general result is sufficiency reliable to be dependable for the simple inferences which may be made from it. And the mere fact of bulk deserves attention if nothing clse could be said. Here is a vast body of treaty $\checkmark$ practice and treaty law which forms a solid element of international organization on its own account.

The existing body of international conventions may be analyzed in several ways. The agreements among the nations may be classified according to form and also according to subject matter, and each method yields its own peculiar results. Of the two, the former classification is simpler and reveals more regarding the mechanics of international practice. ${ }^{3}$

The "treaty" proper is the basic type of international agreement and is an agreement in full form and style between two or more states, independent at least for the purposes of that particular treaty. ${ }^{4}$

There is, however, great confusion in actual practice in the descriptive terms used to refer to various international compacts. Thus the agreement between Venezuela and the Powers in 1903 providing for the arbitration of claims held against Venezuela by the latter is in form a treaty proper;

${ }^{1}$ And the finding lists of Tétot and Ribier for the collections of Dumont, Wenck, Martens et cetera.

${ }^{2}$ Over three thousand international agreements concluded between 1814 and 1918 are listed in the Catalogue of Treaties published in 1919 by the U. S. Department of State, 3-445.

Satow, Chaps. XXVII-XXXI.

- Specimens in same, $\S \S 503-527$; and, below, Appendix A, Document No. 4. 
in the text it is called an Agreement; in the acts of accession a Protocol; we should be inclined, along with Professor Wilson, to call it a compromis for arbitration. ${ }^{1}$ The usage of daily practice cannot be accepted uncritically. The term treaty may be used either generically, to refer to all sorts of international agreements, or, more specifically, to denote the typical, formal, international compact. It is in the latter sense that it is used here.

A treaty, or, rather, the text of a treaty,--although there is no such thing as an unwritten treaty, and the term refers to the document in which the agreement is recorded rather than to the agreement itself-may be analyzed into various parts. ${ }^{2}$ First comes the preamble, which declares that the parties named have, through their agents, as named, agreed to the following articles for a certain purpose, also named. Then follows the body or text of the treaty, usually divided into articles, and even, on occasion, into chapters, sections, clauses, paragraphs, and so on, giving the substance of the agreement. Articles dealing with the general principles of the agreement come first, followed by special articles which apply these principles. At the end are often found articles dealing with the way in which the agreement is to be carried out, and, perhaps, articles providing for guarantees of execution. At the end also come provisions concerning ratification and the exchange of ratifications and the date when the agreement shall be effective. This completes the body of the treaty, and the statement follows that this agreement has been made at a certain place and on a certain date and has been signed by the participants. Finally come the signatures and seals of the agents. There may be annexed to the treaty any number of appendices or schedules containing details of rates or similar material which operate in execution of the principles of the treaty,

1 See text in Wilson, Cases, 12. below.

'Satow, $\S 500$; see marginal analysis of Document No. 4 in Appendix A, 
but which it has not been thought best to include even among the special articles.

Much labor has been spent upon the art or science of interpreting treaties. But such work is part of the science of logic rather than of international relations and, in any case, refers to the subject matter of the treaty rather than to the form. Regarding the latter, as just described, the chief difficulty concerns the act of signing and sealing the document. The giving of guarantees is rapidly disappearing now, ${ }^{1}$ but the problems connected with the powers of the signers are not diminishing in numbers or in complexity. As greater care is now taken in the assumption of international obligations by treaty, and as opposition to secret treaties increases and likewise the demand for public ratification of treaties concluded by the executive arm of the government, this question is rendered more difficult than ever. The rules regarding the power to sign are partially principles of constitutional law and partially principles of international law pure and simple. What we have to note is the procedure in the case.

The negotiators are identified and their powers defined by their credentials and full-powers. The identification and declaration of powers in the preamble must lie within the limits of the former. Further, the treaty itself must lie within the limits of these full-powers. And, finally, the signatures and seals must correspond with the declarations of personal identity contained in the credentials. The seals used by the signers are not state seals, but private personal seals used for purposes of identification. ${ }^{2}$ Needless to say, they are not necessary in a day when personal signatures are adequate for these purposes, but they repay attention because they reveal the fact that the negotiators sign primarily as individual persons, and only

${ }^{1}$ Crandall, $\S 7$.

${ }^{2}$ See amusing discussion as to the use by President Wilson of his personal signet ring as a seal in signing the Treaty of Versailles in New York Times, 29 June, 1919 , pp. 3, 5 . 
indirectly as state officials. The question of due powers may, therefore, always be raised, and if raised must be settled by reference to the credentials and full powers just described.

There are many varieties of international agreements beyond the "treaty" proper. ${ }^{1}$ The term "convention" has been used in various ways in modern treaty practice to describe international agreements. On the one hand, it has been used in reference to international agreements of minor importance, such as postal conventions, and therefore of somewhat informal style-sub-treaties, if they may be so termed. On the other hand, the term has been used to refer to great international agreements signed by several nations, in full form, such as the Hague Conventions. ${ }^{2}$ Evidently there is some confusion here. The real distinction seems to run between agreements upon subjects of a political character and agreements upon subjects of a governmental or administrative character. Thus we always have "treaties" of peace, of alliance, of cession, but "conventions" regarding postal service, and "conventions" for the exchange of consular representatives. Even that distinction is not consistently followed, and the two terms are often used interchangeably.

Various other forms of international compact are in use. A "declaration" is a joint statement of international law as it is understood by the parties or a statement of the policy which they intend to pursue on a given subject, or a mixture of both. ${ }^{3}$ Such was the Declaration of Paris of 1856 relating to the rules of naval warfare. A "compromis" is an agreement to arbitrate on certain terms a certain dispute which has arisen between the parties; ${ }^{4}$ it is to be contrasted with the "treaty of arbitration" which provides for the use of arbitration by the parties in disputes which

1 See the examples in Catalogue of Treaties, 3-445, as cited.

Satow, § 499 .

same, §§ 535-544.

"Properly a "compromis d'arbitrage"; same, $§ 597,598$. 
shall arise in the future." The term "protocol" is used to describe either memoranda or records of discussions, articles drawn up in explanation of the terms of the main body of the treaty, or records of an exchange of ratifications to a treaty. ${ }^{2}$

It will appear that some of these distinctions are distinctions of substance as well as of form. Other classes of international agreements are definable in the same way. Thus a "capitulation" is a military agreement for surrender of one of the parties, and "the capitulations" are, or were, treaties between Western Powers and Turkey and other Eastern states relative to privileges of citizens of the former while in the East. ${ }^{3}$ The connection between the substance and the form of international agreements is not arbitrary, even including the distinction between treaties and conventions. The more important subjects are dealt with in formal treaties and conventions, while agreements upon questions of minor importance are embodied in less formal pacts called by various names, such as "agreement," "arrangement," "exchange of notes," procès verbal, "additional article," and modus vivendi. ${ }^{4}$

One important aspect of this practice is found in the fact that such informal agreements, where the participants feel free to rely on them, may be concluded by executive officials, even subordinate executive officials, with less ostentation than would be involved in the conclusion of a full treaty, and even, perhaps, without that process of parliamentary ratification which is necessary in the latter case. Thus, the Postmaster-General of the United States may enter an "agreement" with the British Post Office relating to Money Orders between the two countries. ${ }^{5}$ Presidents

${ }^{1}$ Example, below, Appendix A, Document No. 4.

2 Same, 4c, and Satow, $\S 559-578$.

a Foster, Chaps. XII, XIII.

- Same, and Satow, $\$ \$ 530-534,545-558,579-596,599-605$. The "exchange of notes" and the "modus vivendi" are hardly more than written memoranda of simple diplomatic negotiations.

'Crandall, $\$ \S 56-61$; Moore, Digest, $\$ 752$. 
and Secretaries of State of the United States have not failed to take notice of this and to act upon it, as in the case of the "preliminaries of peace" concluded with Spain in 1898 and the "protocol" at the end of the Boxer affair in 1901." The Senate has protested against such a practice, but to no great effect. ${ }^{2}$ Where legislation is necessary for the execution of the agreement the check of the representative body exists in that form, of course. Still, the loophole is and must be very large under the circumstances. ${ }^{3}$

Two other forms of international agreements remain to be noted, one a very minor form and one a very significant form.

The executive agreement without posterior ratification deserves to be compared with the executive agreement based upon prior national statute. ${ }^{4}$ In all states today there has grown up a practice of enacting statutes dealing with matters arising in international relations, such as tariff laws and postal service legislation, while providing in the text of such legislation for discretion by the executive authorities in applying the law to goods or mail coming from other states. Agreements are thereupon made with other states for reciprocal remission of tariff duties or the division of postal charges by the parties. This practice constitutes a fertile source of international agreements.

Lastly, the "final act"' is the supreme treaty form. ${ }^{5}$ This term refers to the concluding agreement reached in an international conference where several treaties or conventions have been signed and which recites the circumstances and objects of the conference, indicates the course of events in the conference, and lists the results achieved in the form of separate conventions. The final act does not

${ }^{1}$ Crandall, § 56; Malloy, 2006.

${ }^{2}$ Corwin, 116-125, 168-204.

${ }^{3}$ Same, 120, note 47; Crandall, $\S \S 70-104$.

* Crandall, $\S \S 62-65$; Moore, as cited, $\S \S 753-755$; also Copyright Proclamation of President Harrison, 1894, in Malloy, 105.

- Final Act of Second Hague Peace Conference, below, Appendix A, Document No. 9. 
contain a minute record of the proceedings of the conference and merely lists by name the agreements concluded, and it does not add anything in substance to what has already been accomplished, but, in point of form it is the most striking and solemn international agreement.

Before reviewing the various classes of international treaties by reference to the subjects with which they deal, it will be well to set aside entirely two great classes of "treaties," so-called.

All of the leading European and American states have concluded agreements with native tribes or semi-civilized people dealing chiefly with the cession of territory, but also with such matters as the payment of tribute, the render"ing of services of one sort or another, and commercial relations. The United States concluded some five hundred "treaties" of this kind with the Indian nations prior to 1871, when the practice came to an end. ${ }^{1}$ These compacts deserve to be called treaties only in a formal sense. ${ }^{2}$ They have been so regarded in our jurisprudence and constitutional government, but clearly they do not rest upon the essential assumption of treaty negotiation, namely, the independence of the contracting parties. The treaty form was used for tactical purposes, to save the faces and consciences of the European settlers and to assimilate the process of dispossessing the Indian nations to the accepted system of the European law of nations, and also for the superior moral and psychological effect in the eyes of the Indian of this form of action in contrast to a simple notice to him to vacate. The pretense of free consent was considered, apparently, to have a certain argumentative value and the question of constitutional jurisdiction was avoided, while placing the immediate burden of enforcement upon the Indian chiefs who had signed the "treaty."

${ }^{1}$ Crandall, $\S 66$; Moore, as cited, $§ 756$.

${ }^{2}$ Last of such treaties, between the United States and the Klamath and other Indian nations, dated 1870, in 17 Statutes at Large (Treaties), 383. 
In the second place, notice should be taken of the "Concordats" concluded by the Papacy with various states with the purpose of protecting the interests of the Catholic Church in the territories of those states. While these agreements take the form of treaties or conventions they deal almost exclusively with religious and ecclesiastical matters and hence do not relate to the normal subject matter of international relations. And we cannot, in view of all the facts of the case, regard the Papacy as a state in the full meaning of the term; such agreements are to be regarded rather as agreements between states and a private, or, at most, a quasi-public organization than as treaties in international law. ${ }^{1}$

With the subject matter of the great majority of individual treaties neither the student of diplomacy nor of law has much concern. The cession of this piece of land, the granting of this or that commercial privilege, the settlement of this or that claim are not, in themselves, of more importance for common international law or the elaboration of international governemnt than are the contents of private contracts for the private or public law of the state where they are made. Given the methods of diplomatic negotiation and the legal rules concerning consent, interpretation, and termination, and the nations may agree with one another upon tariffs or territories at their pleasure. Of course, the student of law is interested in the classification of treaties as executory, executed, declarative, and so on, according as they provide for future performance, create a new legal status, or declare a given rule of law or line of policy. ${ }^{2}$ This, however, relates rather to legal form than to subject matter, and does not alter the conclusion stated. This is all the more true because of the fact that as yet there seem to be no bars to the conclusion of individual treaties between the members of individual pairs of states

${ }^{1}$ On concordats see Calvo, $\S \S 1605-1615$.

${ }^{2}$ Hershey, § 296 . 
contrary to common international law. In only two familiar cases have the nations pledged themselves not to conclude new treaties at a later date in conflict with earlier agreements, namely in the negotiations of 1856 at Paris and in the Treaty of Versailles in 1919.

While not interested in the specific content of given treaties, however, the student of law and diplomacy finds it convenient to classify treaties according to the general nature of the subjects dealt with. ${ }^{1}$ They may be classified as treaties of peace, treaties of alliance, treaties of cession, boundary treaties, treaties of commerce, consular conventions, and so on through dozens of titles, covering all conceivable aspects of international relations. ${ }^{2}$ For few questions arise among the nations which have not been the subjects of international treaty agreement. Or, on the other hand, treaties may be grouped into two great classes, namely, treaties dealing with legal and governmental subjects and those dealing with concrete topics having no implications for international law or organization. Of the former class are treaties declaring rules of international law and conventions establishing international courts or commissions or conferences; ${ }^{3}$ of the latter class are those ceding a piece of territory for a certain purchase price. ${ }^{4}$ The former are of vital significance for the student of international government, the latter have little more to do with

${ }^{2}$ Catalogue of Treaties, as cited.

2 Treaty of peace between the United States and Mexico, 1848, in Malloy, 1107; treaty of alliance between the United States and France, 1778, in same, 479 ; treaty between the United States and Spain for the cession of Florida to the United States by Spain, 1819, in same, 1651; treaty between the United States and Great Britain regarding boundaries, 1846, in same, 656; treaty of commerce between the United States and Spain, 1888, in same, 1685; consular conrention between the United States and Colombia, 1850, in same, 314. Text of one of the most important of modern treaties of peace is given, below, Appendix A, Document No. 5a. 1856 3 vete of Pars.

'Declaration of Paris, of 1856, below, in Appendix A, Document No. 5a. Hague Conventions of 1907 setting forth the rules of war and establishing courts for arbitration and commissions of inquiry, and providing for further international conferences on these subjects, in Malloy, 2220, 2269, 2389.

"Treaty between the United States and France for cession of Louisiana, 1803 , in same, 508; treaty between these states, for payment of money, of even date, in same, 511. 
that subject than a private horse trade has with national constitutionallaw.

It is, of course, difficult to draw the line between these two classes of treaties with complete precision. It is still more difficult, in many cases, to classify a given treaty, because of the mixture of elements to be found in its provisions. The treaty of arbitration is easy to classify, and likewise the treaty agreeing to the cession of a given piece of territory. The treaty of commerce, however, may include provisions for the remission of tariff duties and also provisions for the exchange of consular representatives, and while the former have no special significance for international law or government, the latter have. ${ }^{1}$ Even the treaty of cession, the purest type of non-governmental or non-legal treaty, may contain statements of the grounds for the cession in point and thereby take on an added significance. ${ }^{2}$

It would be of no special service to recite here a list of the different varieties of treaties by subject matter. Among the more important, beside those already named, are treaties of guarantee, treaties of navigation, treaties dealing with laws of copyright and patent, the settlement of claims, the protection of property, and jurisdiction over aliens, including the related subjects of naturalization and citizenship and extradition..$^{3}$ In the past century and a quarter there has, however, been a notable change in the predominating character of treaties, so far as their subject matter is concerned. A collection of treaties of the early

${ }^{1}$ Treaty of commerce and navigation between United States and France, 1800, Arts. VI, IX, X, in same, 498, 499.

${ }^{2}$ Treaty between the United States and Mexico for cession of territory and payment therefor, Art. IV, in same, 1123.

Treaty of guarantee between the United States and Panama, 1903, in same, 1349; treaty of navigation between United States and Denmark, 1857, 380 ; treaties on patent and copyright between the United States and Japan, in same, 1037; treaty on settlement of claims between the United States and France, 1880, in same, 535; treaty of amity and commerce between the United States and China, 1844, Art. XIX, in same, 201; treaty on naturalization between the United States and Ecuador, 1872, in same, 434 ; treaty of extradition between the United States and Bavaria, 1853, in same, 58. 
eighteenth century bears the title "collection of treaties of alliance, of peace, of truce." Of late years there have been fewer such political treaties or treaties dealing with personal and formal diplomatic questions and more treaties dealing with legal, economic, and governmental affairs. ${ }^{1}$ There have been fewer treaties of alliance, marriage treaties, and treaties relating to the privileges of rulers and princes, and more agreements dealing with questions of international law, providing for the extradition of fugitives from justice, the settlement of pecuniary claims, the exchange of commercial and postal facilities, and the establishment of international judicial or administrative organs.

A secondary result is to be seen in the increase in the number of treaties signed by more than two powers, or what may be called general international acts. This is due to the fact that it is natural for several states to combine in law-making treaties while it was not natural to expect them to combine in treaties of the older type, creating special and exclusive privileges, or establishing special ties of marriage or alliance against hostile dynasties between friendly royal houses. The more recent international agreements are of a broadly coöperative character in contrast to the narrow competitive agreements of an earlier age.

The character of the treaty nexus is thus being altered within itself. Not only is the web of treaty obligations growing greater in magnitude and internal complexity; it is also growing firmer and more stable in quality. Bargains on concrete questions of no permanent significance are being superseded by what looks very much like international legislation on legal and governmental matters of general and continuing interest. Just as personal diplomacy is converted into something far more significant for the problem of international government by its metamor-

${ }^{1}$ Wright, Treaties, 243-245. 
THE MODERN TREATY SYSTEM

171

phosis into treaty negotiation, so the latter takes on a new and far more significant nature by the reorientation of its outlook as to subject matter. To this is to be added the changing character of the process of treaty negotiation, whereby treaties between two parties are increasingly supplemented by treaties concluded in international conferences among several nations. The transition from personal contract to public legislation is here seen in all its detailed steps.

1.D.1928: Unilateral Treaty to" Outlaw

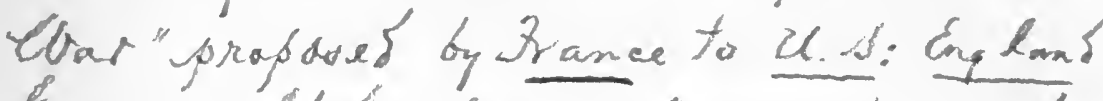
Germany, Italy. He an. "Never to go to cover" against either or the athens.

cohan Protects them from -

Russia - Turkey- Norway- Levered.

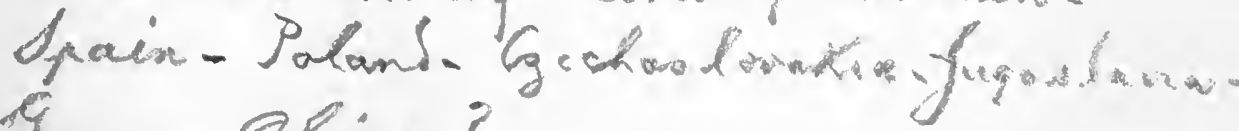
Truce - China? 


\section{CHAPTER XII}

\section{TREATIES AND THE DEVELOPMENT OF INTERNATIONAL LAW}

T HEN the contents of the treaties concluded among the nations are examined more closely the relations between provisions found there and the whole body of national and international law appear to be very ambiguous. Treaties have been classified in the preceding

$\gamma<$ chapter as legal and governmental, on the one hand, and latter class henceforth, it remains to define the processes by which the provisions of a treaty stating a rule of law to which the signatory parties have agreed becomes effective. This investigation leads in two directions. On the one hand, it leads to an inquiry into the relation between the law of treaties, if it may be so called, and national law; on the if other side it leads to the problem of the relation between treaties and international law, or, more broadly still, to the origin, nature, and development both of international law itself and of the science of international law.

It is obvious from an inspection of the text of many international treaties that their provisions, although stated as rules of law, and sometimes precisely because they are stated in that form, need further action in order to be effective. The general principles, and even the comparatively detailed rules, of a treaty may need elaboration in statement and in the explanation of their precise meanings. In any case they need to be carried into practical execution. Treaties sometimes relate merely to the state as such; thus, a treaty recognizing the independence of one of the 
contracting parties would need no elaboration upon that point, and it would call for no direct application in actual life. The effect intended is an effect in the field of theory and abstract law, and it is accomplished by the very act of concluding the treaty. In the case of a treaty providing for reciprocal commercial rights for citizens of the contracting states, however, there is a need for further legal statement and also for practical application in actual life. After all, the individual is the ultimate unit of political and legal action, and most treaties call for results in the realm of the individual citizen. In this great range of cases additional action is necessary in national law and government to carry out the treaty. Let us note those cases carefully and in detail. ${ }^{1}$

Certain types of treaties may be carried out by the simple action of executive officials without further coöperation from other governmental bodies and without any change in the national law. A treaty signed by the United States recognizing the independence of the consignatory state would automatically constitute such recognition. Furthermore, even if the agreement contained also a pledge to receive diplomatic or consular representatives from that state, it could be carried into execution by the President alone, in the exercise of his Constitutional power to conduct the foreign relations of the nation.

Where, however, the action needed must be taken by subordinate officials who have no discretion and who must act solely in accordance with instructions from superior officers, such a procedure is impossible. In such cases some further action is necessary in order to set the machinery of the national government in operation.

In certain of these cases, again, the chief executive might carry the treaty into execution by issuing the necessary instructions to subordinate officials. This would be true,

1 On the relation of treaties to national law see literature cited, below, Appendix B, \$12. 
for example, where no statutory or constitutional provisions existed to control executive and administrative action in that field. Such situations are relatively rare and can be found in the United States only in the field of foreign relations. Thus the President could instruct the Secretary of State to issue an exequatur to a certain individual in execution of a consular convention with a given state, without reference to any statute or other legal standard.

In most of these cases, however, action by subordinate administrative officials depends on authorization from the legislature, because the chief executive is unable to issue new instructions to his subordinates for the execution of the treaty in the face of national legislation to the contrary or in the absence of appropriate legislation. Even in the United States, where treaties become an integral part of the law of the land, and where a treaty acts to repeal previous statutes in conflict with it, ${ }^{1}$ this is true, especially as regards the payment of money from the treasury, and in the case where legislation contravenes a prior treaty. ${ }^{2}$ In these cases favorable or supporting legislation by Congress is needed, or, at the very least, careful abstention from hostile legislation.

If the executive is somewhat dependent upon the legislature for its power to act in execution of national treaty engagements, the judiciary is doubly dependent upon both the legislature and the executive branches. What the "political" departments of the government do or say as respects

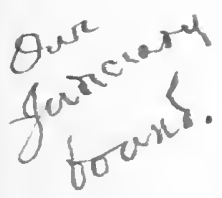
the nature and extent of the obligations of a treaty will be accepted by the judicial department as final in many cases, particularly as to the effectiveness or ineffectiveness of the treaty as a whole, the annexation of territory by treaty, and, as above, the actual administrative operations under the treaty. ${ }^{3}$ In another sense, however, the courts

${ }^{1}$ Constitution, Art. IV, §2; Moore, Digest, § 2; Head Money Cases, 112 D. S. 580 .

Crandall, §§ 74-89.

Terlinden v. Ames, 184 U. S. 270. 
have more opportunity and power to carry into execution treaty obligations than do the other two departments of the government. Thus, where the requisite action has been taken by these departments it is to the courts that the matter comes in the last instance if there be any doubt or dispute about it. Again, where no such action is necessary the courts are free to act upon the treaty directly, in a number of nations, applying the treaty in litigation between private parties wherever it is in place. This is true especially in the United States, because of the constitutional position of treaties in the national legal system, as already defined. ${ }^{1}$ It is not true, however, that this posture of affairs is wholly exceptional, and it seems fairly certain that the drift of things is toward this solution of the problem of the application of treaties. French courts apply treaties directly as they do statutory law to private interests affected thereby; Belgian courts, apparently, may do the same. ${ }^{2}$ With the growth of this practice of subjecting treaties to national representative bodies for approval in legislative form, as has been done recently in England and in the new German constitution, this method of action is bound to spread. ${ }^{3}$ Thus all branches of the national government will gain increased authority in carrying into execution the national treaty obligations.

Such a result is earnestly to be desired. As matters now stand in the field of international government, a treaty depends for its execution upon the national governments of the signatory parties. Whether it is executed or not, and the terms on which it may be executed, are matters of comparative national constitutional law and government.

${ }^{1}$ Foster and Elam v. Neilson, 27 U. S. 253; Wright, Enforcement, 15, 223.

${ }^{2}$ Crandall, § 70.

${ }^{3}$ Heretofore Parliament has denied the legislative power of the Crown acting through treaty agreements, in defending the powers of Parliament over the public funds and the public welfare in general; Crandall, as cited, $\S 71$. For the new practice of legislative ratification in England see Act of $25 \mathrm{July}$, 1919; in Germany: Constitution of the German Commonwealth (trans. by Munro, W. B., and Holcombe, A. N.), Art. 45, in League of Nations, Vol. I, 365 (December, 1919).
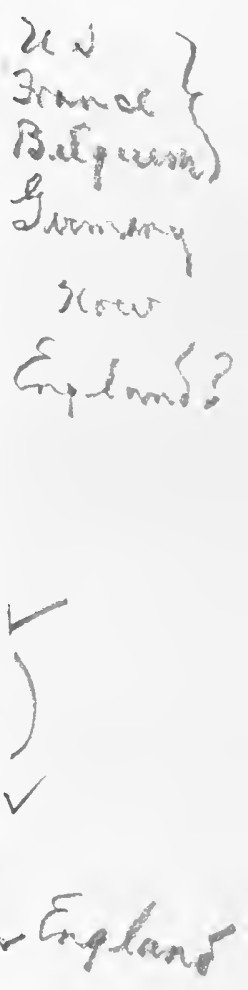
Failure of a national government to act means that the treaty fails of execution. ${ }^{1}$ There is, of course, a distinct moral obligation to act, ${ }^{2}$ and this obligation is not only moral but also legal, in the sense that it is supported by the accepted principles of international law. It is not, however, enforceable by a signatory state in any judicial tribunal, national or international, and it therefore lacks a perfect binding force in operation. The national courts cannot attempt to compel the legislature to act in execution of the treaty. ${ }^{3}$ The legislature could usually compel the executive and the judiciary to act by the processes of statutory legislation or impeachment, but if the legislature, the repository of the national discretion, sees fit to refuse to carry out the national obligations, no legal or governmental redress is available to the other state. In default of execution the signatory state not satisfied with the performance of the other party to the treaty may legitimately put forward diplomatic protests and seek compensation for value received and for any losses incurred. ${ }^{4}$ But the fact remains that in order to be finally effective a treaty must be incorporated into the national legal systems of the signatory states and thus made binding and operative in the hands of the executive, legislative, and judicial organs of the state.

Such is the relation between treaty law and national

- law. It remains to be seen whether the relation between treaty law and international law is as intimate and, if so, whether it is of the same type or form.

That relation may be stated tentatively and in general terms at the start by adopting a mathematical form of expression. As diplomacy is to treaty negotiation so treaties are to international law. The latter is a higher stage in the process of evolution of international governmental prac-

${ }^{2}$ Wright, work last cited, 17, 218-220, 227, 228; this work is authoritative on the general subject.

Moore, work cited, $\S 758$.

McChord, v. L. \& U. R. R. Co., 183 U. S. 483.

New Orleans v. Abbagnato, 62 Federal Reporter, 240; also Moore, work cited, § 1026. 


\section{TREATIES AND INTERNATIONAL LAW 177}

tice. The former develops into the latter, but is superseded by it in so far as the latter expands to cover more and more of the territory of international relations. The second stage is entered from the first because of a desire to secure a more general and more permanent form of regulation for those relations. It is a case of developing general law out of a system of more or less specific contractual agreements in order to pass, and with the result of passing, beyond the stage of contract to the stage of legislation in international life.

The processes by which the materials of treaty agreements enter into the composition of general international law vary in their simplicity and directness. Certain treaties or joint international declarations set forth international law directly and expressly, and leave no additional act necessary to this result. Such was the Declaration of Paris of 1856 which ended by declaring that, in naval war, "blockades, to be binding, must be effective." On the other hand, international law can be derived from certain economic or political pacts only by a process of induction, of inference, by indirection, and by a somewhat hazardous generalization from the specific instance to a common principle. Thus many treaties ceding territory in exchange for money payments imply that, in international law, territory may be properly acquired by purchase. A single case of the kind would not, however, be of any legalistic value. Thus, the guarantee by the United States of the territorial integrity of Panama in connection with the acquisition of the use and occupation of the Canal Zone could not be relied on as proving that states receiving concessions of that sort must guarantee the territorial integrity of the ceding state.

The same is true of treaties apparently in conflict with commonly accepted international law. So far as binding at all, they constitute exceptions to, not evidences of, the rules of the international common law, as national statutes 
make exceptions to the national common law. In the international field, however, the repetition of such a treaty by many states will lead to an alteration in the rules of the common law itself, based on the evidence afforded by these treaties. ${ }^{1}$

The names and numbers of the parties to a treaty are, however, of as much importance in the discussion of treaties as are the provisions of the treaty itself. Thus, the legalistic value of treaties and their effect on common international law depends to a great extent upon the number and importance of the signatory powers. A treaty between Siam and Haiti would not have much effect on the law of nations, even if it pretended to declare international law directly and in express terms. A treaty signed by ten or twelve leading states of the world would be decisive on the subject with which it dealt, even if not cast explicitly in the form of a law-making treaty. According to the doctrine of independence, no state can be legally bound without its consent, and a given state could by express declaration refuse to be bound by the rules set forth in or deducible from the last-named treaty. But in the absence of such specific and explicit action or, what is the same thing, by common international law, other states would be presumed to agree to the rules accepted by the powers signatory to that treaty. It would be almost conclusive evidence upon the content of the current accepted law of nations on the subject with which it dealt. Not only would the doctrine of state independence be ignored in so far as it is not covered by the theory of presumptive and tacit consent; the doctrine of state equality, likewise involved in the case, would also be passed by in silence. The injured state may be partially conciliated and satisfied by the proposition that, while states may be equal in the right to enjoy such legal rights as they possess under common or conventional international law, they are not entitled to equal political

${ }^{1}$ Atherley-Jones, 7-42; Quigley, 7-29. 
power in the making of law or the control of international government. Leaving these problems of legal theory for farther attention later, it may be tentatively concluded that treaties among several of the Great Powers specifically declaring rules of international law would contribute most effectively to the formation of general international law, even if these Powers did not through their agreements exercise any recognized international legislative authority. ${ }^{1}$

It may be well, however, to turn aside at this point to review the origin and development of international law on an independent footing, before completing the study of the relations between that system of law and international treaties.

Antiquity, so it has been declared, knew no international law. Yet elaborate treatises have been compiled upon "the international law and custom of ancient Greece and Rome" and "international law of antiquity." The doubt arises from the fact that the European state-system was, as we have already seen, in such a dubious condition during much of the period prior to the end of the fourth Christian century, especially in comparison with the modern statesystem, that, although there was much public law of state relations it hardly seems proper to regard it as true international law, judging it by what we have today. ${ }^{2}$

The same is true for the Medieval period, down to the end of the thirteenth century, at the very least. There was much public law of state practice on the books and in practical use, but even less than in antiquity did it measure up to any logical standard of true international law. Modern international law did not appear before the break-up of the feudal-imperial state-system and the formation of the society of free national states at the end of the Medieval period. ${ }^{3}$

1 Hershey, §§ 14, 15; Nippold, § 3 .

'On international law in Antiquity see Phillipson, entire, and literature cited therein.

Nys, Origines, 7-12, 95-139. 


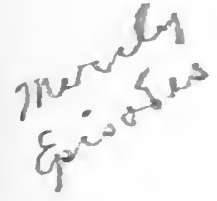

All of this is predicated of Europe and the West. In the Orient there seem to have been many usages and not a few writings which related to interstate rights and practices just as there seem to have existed in these regions certain institutions of diplomacy and treaty negotiation, prior to, and independent of, the development of the European system of international law and diplomacy. ${ }^{1}$ It is of no general use to dwell upon these facts here, however. They serve to gratify a curiosity about the East; they furnish an isolated episode in the story of world political development; but they did not contribute to the formation of the existing system of international law and practice. The states of Asia are members of that system not by virtue of having entered it in the formative period as charter members contributing to its original constitution, but by virtue of admission at a later time, at the hands of the already existing members of the European family of nations. Only in the past century have China, Japan, Siam, Persia, and Turkey been admitted to any thing like full membership in the family of national states among whom run the principles and rules of international law. ${ }^{2}$

The process by which modern international law and the science of international law has been formed is somewhat curious. $^{3}$ It reminds one of the man who was made a physician in spite of himself. International law as now practiced by the states of the world is largely the product of private scholarship, taken over later by the states more or less in spite of their natural instincts. Unlike the man in the story, however, the states have come to see to some extent the real value of what they have been persuaded to accept.

When the modern state-system made its appearance in Europe there was great interest among scholars in the legal

${ }^{1}$ Hershey, $\S$ 20-24.

2 Turkey was admitted in 1856, Japan and China in the last decade of the last century; Oppenheim, I, $\S 28$.

Hershey, $\S \S 54-62,86$, and citations on p. 90 . 
problems it presented. There was on foot at the time a notable revival in the study of law, particularly the law of Rome, as a result of the rediscovery of certain texts of that law and of the increased interest in classical antiquity characteristic of the period of the Renaissance. There was current, moreover, a spirit of inquiry and a taste for philosophizing and theorizing which, in combination with some of the better elements of the thought of the Medieval period, served well for the new task. Private jurists and philosophers proceeded to construct a theoretical legal system to describe and regulate the new independent states in their relations one with another.

In doing this the early writers drew upon two sources of supply, namely, the philosophy of nature, or their own sense of right, of reason, and of justice, on one side, and, on the other, certain more concrete materials, old or new, of a legal and governmental character. ${ }^{1}$

Among the older bodies of law now called on for new service was the law of Rome, reviewed and revised for use in the field of international relations-where it could be applied in some cases directly and in some cases only by a very liberal re-interpretation. Along with the law of classic Rome went the more recent civil and canon law developed in Medieval Europe on a basis of the classical law. Secular lawyers and ecclesiastical jurists alike contributed their work in the new field. ${ }^{2}$

In the same group are to be placed the commercial law, -continental and maritime, private, public, and mixed-of the period of the Renaissance; feudal law; and English law 7 and equity. From the commercial codes of the period of revival came much law relating to the rights of merchants and persons dealing with them, and many matters now covered, into the field of admiralty law proper. From English law and equity came little at first; in later decades

Oppenheim, I, § 42.

2 Walker, $\S \S 85-87,113-120,126-128,130-134$. 
the spirit of legalism on one side and the spirit of practical justice on the other, as they have developed in English jurisprudence in contrast to either unstable philosophizing or to rigid doctrinalism, have influenced international law perceptibly. Most important of all, as far as materials from older legal systems are concerned, the concept of territorial sovereignty and territorial jurisdiction was drawn from Medieval feudal law. Under the distinct statesystem of Greek and early Roman antiquity territorial sovereignty was not an unfamiliar concept. But with the confusion of the centuries from the establishment of cosmopolitan Rome to the end of the era of the invasions and the wanderings of the peoples the concept had been lost. Now it was resurrected as a prime element in the legal theory of the modern state. ${ }^{1}$ It had been developed anew, all over again, as it were, by the feudal states, and was ready to be taken up where Rome had weakened it and the invasions destroyed it. Political society in Europe had dissolved and then reformed again about new politicoterritorial units; the feudal system, curiously enough, thus contributed to modern public law one of its two or three principal ideas.

The materials employed by the earlier writers on international law were not entirely of a legal character. There was a growing body of state practice which could be utilized to illustrate and support the principles derived from the philosophy of nature and the law of Rome and, more clearly still, the law of maritime commerce and war. The consular system was expanding rapidly and was serviceable not only in illustration and elaboration of rules and principles derived from other sources but as a source of new principles devised upon consular practice as a basis. So for the rapidly developing practice of diplomacy proper, and the operations of the new permanent embassies. This was true also for the frequent interstate wars being waged with a

1 Wilson and Tucker, 16. 
new spirit of formalism and regularity of procedure by the new professional standing armies in place of the old informal levies. ${ }^{1}$ In addition to the more abstract theoretical and legal materials, the scholars of the period of the origins of international law were thus in a position to draw upon current state practice for additional data. Modern international law, therefore, runs back to the law of nature or the sense of reason and justice and right in man, on one side, and to various legal and governmental foundations, on the other, such as civil and canon law, feudal law, consular law and practice, the history of international diplomacy, and the conduct of war.

To review these elements in a series is of less importance, however, than to examine their relationship one to another within the field where they operate. These being the historical sources from which the materials embodied in international law have been drawn, what are the philosophical foundations of that law which make possible the employment of these materials? ${ }^{2}$

The ultimate foundation of international law is justice. However imperfect the vision which men have gained of what constitutes justice in general or justice among the nations in particular, and however imperfect the statements given to that principle as it is visualized, and the applications made of the rules as stated, no other conclusion is possible than that the law of nations intends to give every state its due. To intend otherwise were to undertake what in the long run would be impossible, and to undertake the unnatural. Over no considerable period of time is it possible for a state to secure a greater share of this world's benefits than it is entitled to on a basis of its natural capacities and rights; all states must be assumed to desire to act under the natural conditions of the world in which we live.

1 Oppenheim, as last eited.

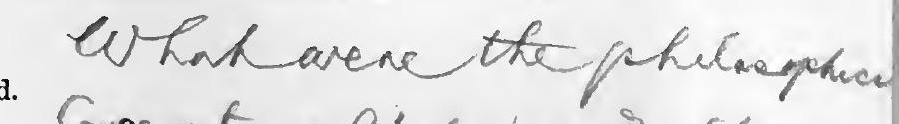

'Same, $\$ \S 15,16$.

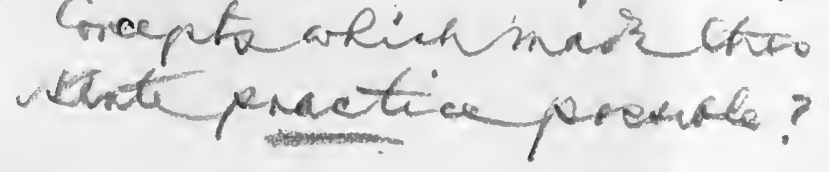


On the other side of the problem we have the facts of state practice, constituting the imperfect applications, the imperfect statements, and the imperfect visions of justice already mentioned. In actual life and in the actual operations of states it is state practice which seems to be decisive. What rights are accorded to a state depend definitely upon the rights recognized by fellow states in treaties and other interstate agreements.

The divergence which seems to be possible between justice and practice as sources of the authority of international law is to be bridged only by means of the doctrine of interstate consent. Justice being an abstract ideal of right and state practice being simply the operation of concrete fact, the basis of the law of nations would be a void, a gap, if no connection could be observed between the principles of justice and the rules of practice. In point of fact, the students of international relations may be perfectly clear on this point: if justice is to be the source of international law it must be formulated by the members of the international community, and where these members do not formulate it expressly they do give expression to it in practice and there it may be discovered. ${ }^{1}$ The express provisions of international treaties declaring the law of nations and the incidents of international practice embody what the states of the world agree constitutes justice in their relations one with another. Not that there are three sources of authority - justice, consent, and practice-but that these three are one. As a typical preamble to an international treaty runs: "considering that justice demands a change in the boundary between the two states, the High Contracting Parties have agreed to the following articles."

This synthesis of justice and practice in the doctrine of consent makes the historical dissension between the philosophical school and the positivist school of international jurists unreal and uninteresting. ${ }^{2}$ There have been those

' Compare Hershey, $\S \S 13,14$; Oppenheim, $\S \S 16-19$.

'Hershey, $\$ \S 60,61$; Holland, Jurisprudence, 31-40, 63, 71. 
who have considered that the law of nations ought to rest entirely upon justice and reason and have thereupon set forth their ideas as to what justice and reason demanded in international relations. There have been those who have held that the law of nations could only be found in positive state practice and that considerations of abstract justice and reason were irrelevant. The former have forgotten that it is not their law on international relations which is sought, but the law of the nations upon their own relations one with another. The latter have forgotten that the nations believe that they are acting upon the dictates of justice in that very state practice which seems to be so purely pragmatic and cynical in the result. Where practice on a given point appears uniform for some time among many states,-the only situation which would, in sheer logic, permit generalization as to the rule of law involved, -we may, moreover, be sure that the states have been accurate in their judgment.

The desirable synthesis of the views of the positivists and those of the philosophers has been made only in recent times, and as yet very imperfectly. In earlier days individual writers, such as Pufendorf, went to extremes in the direction of philosophical speculation, while others, such as Moser, repudiated too completely all considerations of justice. Certain writers, not necessarily later in time than either or both of these, who have been called "the eclectics," tried to carry both views without repudiating either. ${ }^{1}$ The attempt was not successful, for two mutually exclusive views cannot be retained simultaneously. The two views must be reconciled and harmonized, not tolerated or propounded side by side. Where there is an express declaration of law by the nations the difficulty vanishes: the rule embodies justice as agreed upon in law by the signatories. Where there is an established general practice the same thing is true; positivists and philosophers must agree

${ }^{1}$ Hershey, $\S 62$. 
that such is the law, as the states evidently think that it should be. Where there is neither express declaration nor established practice the individual jurist is free to use his own judgment, but his conclusion must be based on the same elements, so far as they are present in the premises, and the only valid conclusions are that the law is unsettled, that there is no (settled) law, that it is tending to become this or that, or that it ethically ought to be this or that.

Such a position was that of Grotius, the great Dutch jurist who is commonly regarded as the father of modern international law. ${ }^{1}$ Grotius was not the earliest writer on the modern law of nations nor yet the last; nor are his writings the source of all subsequent international law, nor are they above criticism in point of form or substance. Grotius was pedantic at times, academic at times, uncertain and not entirely clear at other times. But he possessed the true approach to the field he chose to cultivate. International law was needed to reduce to order the chaos of current international practice and to provide a standard to be used in measuring and restraining certain of the more unbridled practices of the day. In discovering that stand(ard, he said, therefore, that what the student could not deduce from established ethical principles by a process of logical deduction and yet was found everywhere observed in practice must be understood as arising from the free consent of the nations. ${ }^{2}$ Thus Grotius, albeit imperfectly, set forth the proper foundations for the science of international law. Modern scholarship, while it has tended to repudiate the ethical element on the side of which Grotius committed some slight degree of error, has not thereby improved upon his position. The perfect synthesis of justice and practice in international law remains to be worked out by some jurist not too enamored of his own

${ }^{1}$ Walker, $\S \S 141,142,144,148$; the best edition of Grotius for American readers is still that by Whewell, now out of print.

${ }^{2}$ Law of War and Peace, Preliminaries, $\S 40$, end. 
TREATIES AND INTERNATIONAL LAW 187

ideas of right and wrong nor too cynical of state motives in general.

For practical purposes it is necessary to have some clearer statement of the documentary sources from which a knowledge of current international law may be gleaned. ${ }^{1}$

For the historical materials such as Roman law and past state practice, the texts of that law and of international acts in the past are used. Not even the documents of civil and canon law or the texts of early commercial codes are without value. These materials at once supply information upon the history of international law and contribute to a knowledge of current law.

More directly in point, of course, are documents embodying modern state practice, such as national legislative acts and records of national judicial decisions on questions of international relations. When taken from one nation they may show practice divergent from commonly accepted international law; when collected from many nations they reveal the consensus-or lack of any consensus-of opinion on the points of law dealt with. This is equally true of instructions issued to national diplomatic representatives.

Of greatest value and weight, however, are the texts of international diplomatic settlements of various types, including the awards of international arbitral tribunals and international treaties. The perfect documentary source is the text of a treaty signed by many powerful states declaring international law on a certain point or series of points.

The law developed by international practice according to these processes presumes to cover the whole field of international relations. There are to be found in the law of nations the most general principles regarding the nature of the state and the nature of war and of neutrality, and likewise the most detailed rules regarding the enjoyment by diplomatic representatives of the recognized diplomatic immunities. $^{2}$ The relations of states are treated as they

${ }^{1}$ Hershey, § 16.

' Same, §§ 131, 249. 
exist in time of peace, in time of war, and under conditions of neutrality. ${ }^{1}$ The nature and attributes of the persons of international law, their rights and obligations, and the modes of action available for vindicating these rights and obligations are set forth. ${ }^{2}$ The nature and powers of the instruments of international government-consuls and diplomats, courts and commissions and congresses-are described. $^{3}$ On one hand, much attention is given to international diplomacy, rather than to substantive rights in the abstract. Thus there is much material descriptive of the methods whereby the international governing bodiescourts, commissions, and congresses-are created and operated. ${ }^{4}$ The presence of these subjects in works on international law is due to the absence of works dealing specifically with international government such as the one now in the hands of the reader, and it is bad both for international law and for international organization, for it detracts from the strictly legalistic character of the former and it obscures the independent existence of the latter. On the other hand, very little attention is given to international economic and cultural intercourse by comparison either with the amount of attention given to these matters in national law or with the amount given to purely political matters in international law. Of recent years there has been a considerable change in this respect, but tariff legislation and the regulation of immigration, for example, are still left entirely to national discretion. ${ }^{5}$

Naturally enough, the multiplication of the documentary records of international law produces some confusion. As has been seen, this leads individual states to attempt to simplify matters by reducing the number and the complexity of their outstanding obligations. It also leads to

${ }^{1}$ Wilson and Tucker, Parts III, IV, V.

'Same, Parts I, II.

a Same, Chaps. XIII, XIV, XV.

- Hershey, Chap. XIX.

-Wilson and Tucker, $\S 3$, end (briefly). 
efforts on the part of states or private individuals to digest or codify the law of nations for scientific convenience. In a sense, all the writing of private scholars in the field is merely an effort at codification, for these scholars cannot make law, they can only record it and summarize it and reduce it to system and ordered statement. Some among them have recognized this by the titles adopted for their works; thus Fiore calls his last treatise "International Law Codified," and Field and Internoscia expressly call their complications "codes" of international law." Since 1870 the number of such compilations has increased enormously. ${ }^{2}$

Official codification has followed at a leisurely pace. After three centuries of private efforts in this direction, the states are beginning to make up in part for their indifference to international law in the past. The "Digest of International Law" by James Bassett Moore, compiled from the documentary records of the practice of the United States and published by authority of Congress, is a semiofficial code, ${ }^{3}$ as are several of the compilations made and published by the Department of State in 1918-19.4 For fully official codes and codes which rest not merely upon the authority of one nation, we must turn to the great international conventions adopted by the states of the world in tion.

${ }^{1}$ Below, Appendix B, $\S 12$ especially Root, Function of Private Codifica-

${ }^{2}$ Number of general treatises on the substantive rules of public international law published before and after 1870, by decades:
$1600-1649 \ldots \ldots \ldots \ldots 2$
$1650-1699 \ldots \ldots \ldots \ldots 3$
$1700-1749 \ldots \ldots \ldots \ldots 6$
$1750-1799 \ldots \ldots \ldots 66$
$1800-1809 \ldots \ldots \ldots \ldots 0$
$1810-1819 \ldots \ldots \ldots \ldots 3$
$1820-1829 \ldots \ldots \ldots \ldots 2$

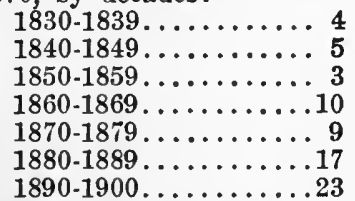

This table does not include reëditions, works on the history of international law, monographs on special topics-including the vast number of theses written by students in Europe and America in recent years on special topics in the field of international law, -nor case books; it does not include works on international private law.

3 Full title below, Appendix B.

- Martin and Baker, Maritime Warfare; Baker and Crocker, Land Warfare, below, Appendix B, § 12 . 
formal congresses and conferences, such as the Geneva Convention of 1864 setting forth the rules of law regarding the treatment of the wounded in the field. ${ }^{1}$ Such acts have multiplied rapidly since the opening of the present century. ${ }^{2}$ Thus we return, in the last stage in the formation of international law, to the practice of treaty negotiation.

From such acts of codification it is a slight step in point of form, although a tremendous stride in point of principle, to the action of legislation or the making of new law. The existing law is not only codified but also revised. Finally, entirely new law is adopted to supplement preexisting law. This law relates to fundamental constitutional arrangements in the society of nations, such as the neutralization of Switzerland or Belgium, ${ }^{3}$ and also to the details of international procedure, such as the rules adopted at the Hague in 1907 for the conduct of war on land. ${ }^{4}$ In the former action we reach the highest stage of international government. Lawmaking is the final process in the development of political organization and practice. We reach it thus early in the study of world government because it has developed in point of form out of diplomatic negotiation pure and simple, which is a very primitive form of international practice. And although international lawmaking is beginming to pass out of the form of treaty negotiation, it still retains that form as regards several vital features, such as the necessity for unanimous consent and the contractual form of the law produced. To these aspects of the case we shall have to turn later in connection with international conferences and congresses.

${ }^{1}$ Oppenheim, $\$ 560$. decades:

Number of general international law-making treaties since 1800 by
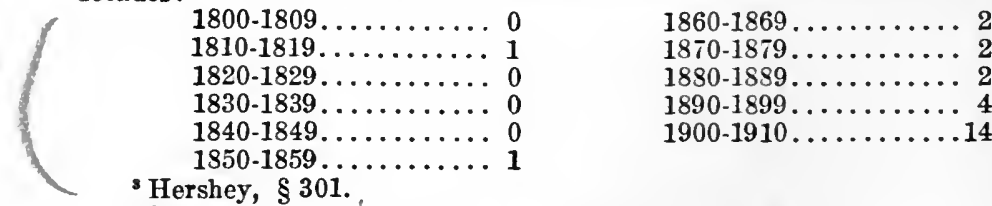

2

$1800-1809 \ldots \ldots \ldots \ldots 0$

$1820-1829 \ldots \ldots$

$1830-1839 . \ldots \ldots \ldots \ldots 0$

$1850-1859 \ldots \ldots \ldots \ldots 1$

s Hershey, §301.

‘Same, \& 83. 


\section{PART IV}

\section{INTERNATIONAL ARBITRATION}


$$
\text { . }
$$ 


\section{CHAPTER XIII}

\section{GOOD OFFICES AND MEDIATION; COMMISSIONS OF INQUIRY}

T $\mathrm{T}$ is conceivable, perhaps, that international relations 1 might proceed smoothly from month to month and from year to year merely by means of the practices of diplomacy and treaty negotiation. If no other complicating factors were introduced in the problem these forms of international organization might be sufficient. As a matter of actual experience, however, they are not sufficient to meet all the needs of the situation. The reason for this is the appearance of what may be called the international dispute. The international dispute arises precisely because the procedures of diplomacy and treaty negotiation are inadequate to provide for the management of all future and contingent relationships between nations, and, in turn, once the dispute has made its appearance, the inadequacy of diplomacy and treaty negotiation to resolve the difficulty and settle the dispute is accentuated at each succeeding stage.

Direct personal diplomatic negotiation is not always inadequate to settle an international dispute, and, where successful, it constitutes the first and simplest method of removing the trouble which its own negligence or incapacity has allowed to develop. What happens here is that the machinery and practice of diplomacy as it is ordinarily $2 n+4 m a$ conducted catches up with its task. It removes the dispute by securing a diplomatic agreement of one sort or another, including, as one of the possible forms of settlement, an international treaty.

This simple method of dealing with the international 
dispute is not, however, capable of resolving the more difficult and complicated questions which arise between nations. The technique of such a method is too primitive; it does not possess resources of procedure and treatment adequate for the task. There is nothing left to the contending parties but to continue to put forward their own views of the facts and the principles and to urge their claims and try to secure satisfaction of their interests by bargains and demands, persuasions, threats, or arguments. What is needed is an entirely new approach to the questions in dispute, and, particularly, an approach from a point of view, a right, and an interest, radically different from that of either of the two contending parties. That method and that approach have been found in the practices of mediation and arbitration, or, to speak in still broader terms, in the judicial settlement of international disputes.

There are two forms of diplomatic practice which serve to prepare the way for arbitration or judicial settlement proper. These are mediation and the still milder form of international regulation of international disputes, good offices. ${ }^{1}$ Each of these preliminary stages has its peculiar nature and function, and it is worth while to exert some care to draw clearly the distinctions between them. Thousands of newspaper readers in the United States were misled and confused in April, 1921, as to what was happening between the United States and Germany, in connection with the dispute between Germany and the Allies over the reparations question, by failure to understand the differences between good offices, mediation, and arbitration.

Both good offices and mediation begin within the field of simple diplomacy, but in the end they go very far beyond that field and get well over toward arbitration. On the other hand, both stop short of true arbitration, and good offices stop very far short of that point. The use of

${ }^{2}$ See literature cited below, Appendix B, $\S 13$. The treatment in this and the succeeding chapter covers the subject to the end of 1918 . 
one or the other may pave the way for arbitration. Equally well, the use of one or the other may achieve a settlement of the dispute and render a resort to arbitration unnecessary.

The proper occasion for the exercise of good offices or mediation is the existence of a dispute between two nations respecting their rights and duties toward one another. ${ }^{1}$ War may be impending, and may possibly be averted by these means. Or a war which is already being waged may be brought to a close by securing an agreement between the parties. This agreement may be an agreement on the merits of the case,- the most definitive result which can be hoped for,-or it may be an agreement for arbitration on the merits, pending which, or in view of which, hostilities are to be postponed or suspended or even terminated entirely. In any case the result will almost certainly take the form of a treaty, since a dispute so important as to have reached the stage of mediation or arbitration can hardly be settled in any less formal manner. In the circumstances described the resulting treaty will very often be a treaty of peace or an arbitration convention. Mediation in time of peace is, naturally, the commoner of these forms of action, but there are many examples of good offices or mediation in the termination of wars, as when France used her good offices to bring Spain and the United States together in 1898.2

Whether the action in question is to be called "good offices" or "mediation" depends upon the distance to which the parties to the dispute are invited to go in adopting a new method for settling their quarrel. For what really happens is that the nations in dispute are invited to compose their dispute for the good of the general peace. This invitation comes from a state or states not party to the dispute, and whether it amounts to good offices or media-

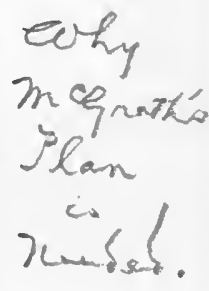


(tion depends upon the extent to which the third party goes in offering assistance in the premises.

Good offices consist merely in offering to provide a meeting place where representatives of the disputing nations may meet together to discuss anew, perhaps under the presidency of the third party, the subject matter of the dispute, or in offering to receive and transmit to the other party written proposals and counter-proposals dealing with the question in dispute. In such a case the third party refrains from giving any opinion or advice upon the substance of the question, and confines its activities to the mechanical steps just described. ${ }^{1}$ From this point on, therefore, good offices do not possess any resources beyond those of ordinary diplomatic discussion. It does, however, serve to renew discussions when the parties themselves have drawn apart, and in this way may affect the future course of the dispute considerably. It is undertaken in the hope that renewed or continued discussion may result in some agreement. It is based on the supreme truth that conference is indispensable in such situations and that the more conference the better, so long as any issues remain open between nations.

In mediation we reach an entirely different sort of thing. Here the third party takes up for consideration the substance of the dispute itself and attempts to discover a solution. This is, of course, of far more significance and, potentially, at least, is of far more service, than merely inviting the parties to continue trying to find a solution themselves. The mediator enters into much more intimate relations with the nations in dispute than does the party who merely offers good offices. The mediator must therefore possess the confidence of the parties in greater measure. ${ }^{2}$ There must be no suspicion that the mediator is attempting to secure a certain solution for motives of

${ }^{1}$ Hershey, $\S 306,307$; Mélik, 15-28, 52-57; Satow, §§619-623, 626-629.

'Satow, $\$ \$ 619,631$. 
immediate self interest in that particular solution. The mediator must necessarily enter into discussion with both parties; or, if the parties meet face to face for discussions between themselves, the mediator must, in the very nature of the case, meet with them and enter into the discussions, whereas in the case of good offices the third party may never meet the disputants or either of them. The mediator may even sign the treaty which embodies the settlement reached, as did the American Secretary of State, "in the character of mediator," in the settlement of the war between Spain and Peru, Chile, and Ecuador in 1871. The mediator may thus become, to a greater or less degree, perhaps merely by implication, a guarantor of the settlement. ${ }^{1}$

It is worthy of note that in good offices and mediation, and especially in the latter, there appears, for the first time, the case of a mandate or grant of authority resting upon international, rather than national, bases. Diplomatic representatives are purely national agents. Even the diplomatic corps is, at best, a composite of national agents. Except for the general international consent back of the existence of the diplomatic service as a whole, no truly international authority is exercised by the diplomats. The power whose good offices or mediation are accepted by other states, however, acts as an agent or official representative of two or more nations directly.

Good offices are, very naturally, offered more easily and accepted more readily than mediation. Once begun, however, good offices may develop into mediation, if the third party is led to take up the substance of the question at issue between the parties. ${ }^{2}$ Thus President Roosevelt began in 1905 by merely extending his good offices to bring Japan and Russia together at Portsmouth to try to reach

${ }^{1}$ Satow, $\S 634$; text of treaty of 1871 in Martens, Nouv. Rec. Gén., $z^{\circ}$ série, III, 475 .

${ }^{2}$ Hershey, $\S 306$, note 4 ; Satow, $\S 619$, end. 
an agreement for a settlement of the conflicting interests at stake in the war. At a later point he was led to interest himself in the terms of the settlement, and in the final event he practically dietated the terms of the settlement. Similarly, in the following year he began by persuading France and Germany to go into conference on their claims concerning Morocco, and ended, in 1906, by drafting the settlement reached at Algeciras. ${ }^{1}$

As in all other fields of international relations, the terminology of this body of procedure is somewhat unsettled, even after three centuries of practice. Thus the formula "good offices" is occasionally used to describe the diplomatic action of one state toward another for a certain purpose apart from any dispute between the latter and a second or third state. Likewise a power exercising "good offices" is sometimes spoken of as an "intermediary" in the case. ${ }^{2}$ Finally, the two sorts of action are at times confused for sheer want of knowledge or want of care in the use of terms, as in the above-mentioned case of the German-American exchange of 21 April, 1921. ${ }^{3}$

To be of any service the mediator must be neutral and impartial. The parties to the dispute are naturally very suspicious of any outsider who enters the scene and undertakes to find a settlement of their quarrel. Only in the rare case where the mediator very clearly gains nothing by the result, and where both parties are and remain equally satisfied with the settlement, will the mediator escape all suspicion and insinuation. The gratitude of the parties will only be earned where both feel that they have secured the better of the settlement. "What is probably the most remarkable case of mediation on record, when all the circum-

${ }^{1}$ Bishop, I, 382 and $410 ; 467,477$, and 490 .

Satow, $\S 626$.

- New York Times, 22 April, 1921, p. 1; Germany really asked the United States to act as arbitrator, and America declared herself willing to extend her good offices and pass on the rroposals of Germany to the Allies; yet headlines and sub-heads wandered widely in interpreting the exchange.

- Satow, §631, end. 
stances are borne in mind, came about when, in 1918, Germany, through Swiss good offices, in effect asked the United States, an enemy state, to act as mediator to secure mutually acceptable terms for an armistice and preliminaries of peace with the Allies.

The mediator will not, of course, be led to undertake such an ungrateful task without reason, and yet that very reason may well affect the formula of settlement proposed to the parties. As a rule, the third state is led to act in such cases by national interests which demand protection. Indeed, it would hardly seem proper for a third state to take action in the premises unless it had some substantial interests to defend. Mere idle meddling would be intolerable and entirely void of that essential basis of all legitimate diplomatic action, the necessity of defending substantial interests of the state. Such a requirement today, however, means primarily that these interests are first of all the interests which all nations have at stake in seeing the general peace preserved and war averted. Nations which may, as prospective neutrals, expect to see their commerce injured if war breaks out and nations which fear that they will themselves be drawn into such a potential war have every reason for promoting a settlement on those general grounds. This is the common basis for joint international action to mediate a quarrel likely to lead to war. In such a case, also, the action may be affected because one possible solution rather than another is desirable in the interests of peace. Thus President Roosevelt, because he was primarily interested in seeing Japan and Russia reach any solution which would end the war, was interested almost as much in seeing that the solution reached was just in order that it might really end the war and not be merely temporary. That meant that at the time of the settlement he was compelled to oppose first the Russian views and then those of the Japanese.

Beyond its interest in the restoration and maintenance 
of peace, however, a nation may very well be interested in seeing one solution rather than another adopted by the parties because of the indirect advantages to be had by that nation from one solution and not from the other. In the case of neighboring states such a condition is almost certain to exist. And if it does exist the third nation will commonly regard that desired solution as just on general grounds and feel free and even "compelled" to promote sueh a settlement for the sake of all eoncerned.

It is not to be assumed that the contending parties are unaware of this situation. Indeed, in earlier times all efforts at mediation were regarded as nothing but indirect efforts at self-aggrandizement. They were therefore viewed with grave suspicion by the parties in dispute. With the growth of the cost of, and consequent desire to avoid, international war, and with that development of closer international relations which, in actual fact, has made the just solution of a given dispute that solution which accords most with the interests of third states, this instinctive hostility has somewhat diminished. Nevertheless, the action is not so simple and natural and free from suspicion that it can be admitted without a careful definition of its legitimate scope and procedure.

To begin with, the third party normally possesses no jurisdiction over the question in dispute or over either of the parties. They eannot, therefore, be summoned to meet and settle the dispute by discussion, nor can any solution be imposed upon them. Even where the action is to be taken by two or more third parties, or by the family of nations in general, no such jurisdiction exists at common international law. Granted that, in the interest of the general peace and of general justice, or in its own special interests in peace and justice, a third party or a group of third parties has a right to attempt to secure a settlement under such cireumstances, precisely what may be done with that end in view remains to be seen. 
The simplest case of all occurs where both parties to the dispute request a third state to extend its good offices or to act as mediator. Nothing then remains but to accept the request and perform the task as skilfully as may be. ${ }^{1}$ In rare circumstances, as where no peaceful or just solution seems possible and the attempt at mediation can lead only to further embitterment and to the useless involvement of the third power, the latter may decline the request.

An intermediate stage is found-and in many ways this is the most natural form of procedure-where only one of the disputing parties requests good offices or mediation, in view of its own inability to secure satisfaction either by diplomacy or war. The third party still has no jurisdiction over the other disputant or over the issue. Assuming that the request of the first disputant is to be acceded to, the third party may only turn to the party of the second part and offer to extend good offices or to act as mediator in accordance with the request of the first party. The second party is under no obligation to accept such an offer, and will accept or reject the offer as circumstances dictate. Here are to be considered the possibility of securing satisfaction by persisting in direct diplomacy or war, the desirability of getting some settlement at once, and of conciliating the opponent and the would-be mediator. If the offer be rejected there is nothing more to be done. If it be accepted the subsequent course of events is clear from the previous case.

The third case arises where there is no request from the disputants. Here the would-be mediator may, if circumstances seem propitious, as already outlined, offer to both parties at once or to first one and then-if accepted-to the other, to furnish good offices or to act as mediator. The offer may be accepted by both disputants or rejected by one or by both. In either of the last two cases the effort fails. Thus President Roosevelt's first attempt to extend

${ }^{2}$ Examples of failure in Satow, $\$ 638$. 
his good offices to Russia and Japan was balked by the attitude of Japan alone. In all of these cases mediation may be offered, accepted, or undertaken, upon certain conditions previously stipulated by the disputants, or by the third party, and these conditions must then be observed in all future negotiations unless repealed. ${ }^{1}$ In the same way, the disputants and the mediator alike may, at any stage of the proceedings, lacking an agreement to the contrary, withdraw and terminate the whole affair.

Under certain circumstances these normal principles may be varied considerably, apart from any specific international treaty agreements touching the matter. In cases of civil war or colonial revolt the request of the rebellious group for mediation may not be accepted as freely as that of a state whose independence has already been recognized. The quarrel is in law a domestic matter, and in most cases the very issue is that independence the establishment of which could alone make mediation by a third power legitimate and even an offer of mediation welcome to the mother country. Napoleon III was suspected of desiring to promote the separation of North and South when he suggested mediation during the Civil War in the United States. This does not entirely preclude the use of good offices and mediation in such situations, but it does mean that their range of application and their value is strictly limited. ${ }^{2}$

On the other hand, there are situations where the "third party" possesses a basis for action which gives greater authority to the "offer" than inheres in such action in ordinary circumstances. Such a situation exists where a common superior possesses a right to come forward and invite, or to come forward and compel, the parties to accept good offices or mediation to settle their dispute. Such action was taken in times past by Rome, by the Papacy, by the Emperor, and, in modern times, by the great powers of

1 Mélik, 31-32.

'Satow, §§ 632, 638, 639; Mélik, 4-51. 
Europe. ${ }^{1}$ This is not free international practice at all but, so far as admitted or tolerated, is constitutional government. Where not admitted voluntarily and justified on that basis, but imposed by force, it is intervention. In that case it must be justified, as any intervention must be justified, not by reference to any general right of intervention but to the special circumstances of each case, the necessity of self-defense or equally cogent interests; of "armed mediation" there can be none in normal circumstances. ${ }^{2}$

It will be noted that, under ordinary conditions, acceptability, not justice, is the quality sought by the mediator in the formula of settlement. The object is peace; the mediator is not a judge. For the higher form of settlement other procedure is needed, namely, arbitration. ${ }^{3}$ Yet it may be suggested that immediate justice between the parties may result as frequently from the attempt to find a settlement acceptable to both parties as from the decision of an arbitrator who knows that his award must be accepted, right or wrong, but who has a very inadequate body of legal principles to guide him in his action.

In the history of modern international relations good offices and mediation have passed through various stages as far as their organization and practice are concerned.

In the early decades of the modern period the keen and jealous rivalry of the new national states caused these devices of international conciliation to be regarded, for reasons already described, with great suspicion and even with resentment. As late as 1905 Japan was inclined to resent American interference as calculated to prevent her from obtaining all that she hoped to obtain from a prosecution of the war with Russia. As a consequence, nations were reluctant to undertake such a work of pacification and preferred to stand by and allow the rivals to weaken each other by fighting it out, taking care, if possible, to prevent

1 Mélik, 37-41, 136-147.

Satow, §631.

Hershey, § 306; Mélik, 58-66; Satow, §641; Vattel, § 328. 
a too decisive victory for either side by intervention or mediation of a narrow type at the strategic moment. ${ }^{1}$

As a further consequence, the practice of good offices and mediation was left unorganized, and also unrecognized, as far as formal approval goes. A spontaneous offer, followed by rejection or acceptance, was the only means by which these practices could be put in play. Moreover, not a great deal of encouragement was given to the making of such an offer. Outside interference in private international quarrels was discouraged.

Not until the middle of the nineteenth century was this opinion expressly repudiated. Then, with the growth of a body of sounder and less febrile opinion on the various questions of international relations, and with the spread of the desire for the maintenance of peace and the settlement of disputes in some more permanent way than by war, on the only basis likely to be permanent, namely, of justice, things began to change. ${ }^{2}$ In a treaty signed at Paris in 1856 at the end of the Crimean War there was inserted a declaration in favor of the general resort to good offices for the settlement of international disputes. ${ }^{3}$ Turkey was, moreover, required by the peace treaty signed in the same year to request the joint mediation of the Powers in future disputes in which she should be involved, thus incorporating mediation into the conventional international constitutional law of Europe. ${ }^{4}$ Again in 1885 the Powers pledged themselves to have recourse in the future to mediation before appealing to arms in matters relating to the Congo. ${ }^{5}$

The final stage in the development of the organization of good offices and mediation is found in the Hague Convention dealing with the pacific settlement of international disputes, drawn up in 1899, and revised in $1907 .{ }^{\circ}$ In that

1 Kamarowsky, 95-97.

'Same, 81.

Satow, \$ 624.

- Below, Appendix A, Document No. 5.

- Mélik, 118-126.

- Same, 215-251; text, below, Appendix A, Document No. 6. 
Convention the signatory powers agreed to have general recourse to the good offices and mediation of friendly powers in future disputes of a serious character, endorsed the practice of offering good offices and mediation in suitable cases, even during hostilities, and attempted to provide for a special form of mediation designed to settle a dispute and prevent war by a process approaching arbitration in its nature. ${ }^{1}$

Thus, good offices and mediation were, in 1914, already in a relatively high stage of perfection, so far as their organization is concerned. One link, however, was missing in the system, namely, the automatic commencement of the process. There was nothing to bring these practices into operation without a delicate and complicated process of offer or invitation and acceptance. With things moving as fast and as furiously as they did in July, 1914, there was not time to get these practices into play, not time, that is, to persuade or compel the German war party to accept conference on the issue at stake. This lack of time may be traced back further to the determination of Prussia to have war on the issue at the time. In that view of the matter it is no defect in the practices of good offices and mediation which is responsible for the occurrence of hostilities. For these practices are limited in their efficacy by the essential stipulation that they may operate only where both parties are willing to accept them of free will. What the events of July, 1914, show is that good offices and mediation, so limited, are not enough, and that other methods of settling international disputes are needed.

Another method of dealing with such disputes which serves as a preliminary to arbitration, and which should be examined together with the exercise of good offices and mediation, is the use of a commission of inquiry. ${ }^{2}$

The commission of inquiry is based in theory upon two

${ }^{2}$ Arts. 2, 3, 8; on joint mediation as such see Hershey, $\S 307$, Kama. rowsky, 91-102; Mélik, 70-80; Satow, $\S 619$, end.

Sec literature cited, below, Appendix B, § 13. 
phenomena familiar to all who have studied international relations. ${ }^{1}$ On the one hand, it is undeniably true that much of the difficulty of settling international disputes amicably derives from the initial difficulty of establishing a statement or version of the facts to which both parties will agree. On the other hand, this difficulty perpetuates itself by allowing passions to be roused on either side which not only obstruct agreement between the parties on points of principle but also prevent a clear settlement of the facts in the case in preparation for agreement on points of principle. Given goodwill in point of principle to start with, it would still be of little avail, and would often be destroyed very shortly, by claims and counter-claims on questions of fact.

Thus the first task of the mediator is often that of allaying international tension and getting agreement upon the facts. It may then appear that, the facts being what they are, the solution follows almost automatically because of the spontaneous agreement of the parties on the law and equity of the case. Seeing that such a task is useful when performed by a mediator, the nations have in very recent years developed the commission of inquiry to perform the same function, while abstaining from any treatment of the substance of the dispute in principle. The commission is to take over the function of ferreting out the facts and providing time for passions to cool and for inquiry to be made into the real merits of the case.

Here for the first time we meet an international governmental body, an organ made up of several members representing several states. The diplomatic corps would constitute such a body if it were more closely organized and enjoyed an international mandate. In the commission of inquiry there is no doubt on this score. Here we have a body of persons acting as a unified international governmental institution.

${ }^{2}$ Beaucourt, 11, 12; Bokanowski, 1-9, especially 7 . 
The commission of inquiry originated in the "mixed commission," which had been extensively used since 1794, when the institution was adopted by Great Britain and the United States for conducting certain arbitrations provided for in the Jay Treaty of that year. ${ }^{1}$ These commissions were created to settle the amount of damages done to property, to evaluate losses incurred by claimants, to carry out investigations and hearings chiefly upon questions of fact, and to report their findings to the nations appointing them, as a basis for such action as was thought fit in settlement of the claims. In such cases the principles had usually been agreed upon in advance, and the work of the commission consisted merely in the application of the principles already agreed upon in the location of a boundary or in fixing the amount of a claim. ${ }^{2}$

The commission of inquiry is organized, as was the mixed commission, by the appointment of representatives by the disputing parties, with or without an umpire, with provisions for majority votes or unanimous consent as the parties may prefer. The questions examined are questions of fact, and the final settlement and political considerations are removed from the scene. The members of the commission are chosen primarily for their expert scientific ability, rather than from the diplomatic forces. The atmosphere of the commission is, therefore, more conducive to calm and able discussion than it might otherwise be. For that reason a surprising degree of unanimity can be obtained in the decisions of the commission.

Following the report of the commission on the facts, the parties are free to settle the questions of principle or of honor, and to act upon the application of the latter to the facts as found. The fact that the report of the commission is known may make difficult an agreement upon the principles or law to be applied, since the outcome would be a

${ }^{1}$ Beaucourt, 18-47; Bokanowski, 11-31.

Examples in Beaucourt, 36-47; Moore, Arbitrations, especially Chap. XI. 
foregone conclusion. This situation may be avoided only by prior agreement upon the principles. This step, however, is, in turn, likely to influence the decisions or discussions of the commission in the same way, although not to the same extent. In the former case the report of the commission leaves the definitive settlement open, and there may be a need for good offices or mediation or arbitration on top of the work of the commission. For that matter, mediation may be used to induce the disputants to accept a commission of inquiry or arbitration in the first place. Still further, in the second case the commission may amount to a court of arbitration, as did many of the mixed commissions." The "questions of fact" and "questions of law" are not, of course, always distinct or even distinguishable in these cases, and the commission inevitably tends to include legal questions in its work. In this manner a "commission of inquiry" which sat in Paris in 1905 upon an Anglo-Russian dispute over the action of a Russian fleet in firing on English fishermen in the North Sea during the Russo-Japanese War found on the facts and also upon the liability of the parties arising out of the facts. ${ }^{2}$ Such action serves to show the relation between the commission of inquiry and arbitration, but is likely to bring suspicion on the commission of inquiry as a court in disguise. ${ }^{3}$

Not until the end of the nineteenth century was there any general international recognition and organization of the commission of inquiry. ${ }^{4}$ Then, in the Hague Convention already mentioned, the nations endorsed the institution for its proper purpose and defined the procedure to be followed in making up the commission and in its operation. ${ }^{5}$ The experience of the Commission which dealt with the Anglo-Russian dispute served to provide information thereto.

'Beaucourt, 30-36; Bokanowski, 33-40; denial in Hershey, § 308, note 9.

Beaucourt, 105-109; Bokanowski, 61-89; Hershey, § 309 and note 15

Beaucourt, 175, 176; Bokanowski, 86-89.

- Scott, Conferences, I, 265 and following.

Text, Arts. 9 and 10-36, below, Appendix A, Document No. 6. 
GOOD OFFICES, MEDIATION, AND INQUIRY 209

according to which the embryonic clauses relating to the subject in the Convention in 1899 were greatly elaborated in 1907.1 The result was a procedure adequate, if invoked, to deal fairly and comprehensively with the most complicated problems of fact. Here again the weak point is the voluntary character of recourse to the commission.

A great improvement has since been made by the United States in this regard in concluding some thirty-five treaties with different nations providing for commissions of inquiry to be appointed in advance of the occurrence of any dispute between the parties. The commission is given power to act upon its own initiative, when such a dispute arises, to investigate the facts and report upon them. A period of one year is allowed for this investigation and report, and for diplomatic settlement upon the basis of this report, before hostilities may be begun. ${ }^{2}$ This is about as far as the institution could well be developed without passing over into something quite different.

${ }^{1}$ Beaucourt, 192-224; Bokanowski, 91-97.

See editorial comment, giving facts and interpretation, in Am. Jour. Int. Law, VII, 566, 823; VIII, 565; IX, 175; X, 882; and Scott, Treaties, entire.

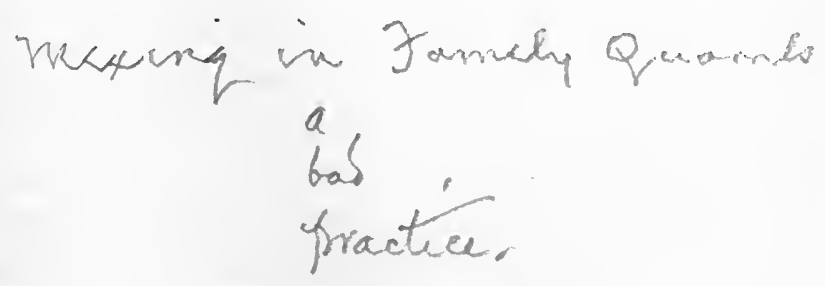




\section{CHAPTER XIV}

\section{HISTORY AND THEORY OF INTERNATIONAL ARBITRATION BEFORE 1899}

EITHER good offices nor mediation provide a means
of settling international disputes unless the solution worked out in conference or proposed by the mediator is acceptable to both parties, and it will command the assent of both parties only if it appears to offer to them the maximum of advantage obtainable in that particular case at that particular time. The parties may conceivably take account of the advantages of a peaceful settlement instead of war. They may take account of any indirect or remote advantages to be derived by the acceptance of a settlement of the current dispute which is less favorable on its merits than they would desire to accept. In international relations, however, with the constant rise and fall of national power and advantage and the constant shifting of support to one party or another in the diplomatic game, the nations are not prone to seek these indirect advantages which might come by the support of legal principles calculated to bring a general benefit in the long run. They are prone to seize the immediate advantage and take a chance on being able to do the same thing in whatever circumstances may arise in the future. Thus it is that the formula proposed by the mediator must be acceptable, not so much because in conformity with general principles which might be acceptable in themselves for constant application to all cases at all times, but because it represents concrete benefits at the time in the case in hand.

The result is to diminish considerably the value of 210 
mediation as an international practice. Mediation is the sort of task which, being performed, may easily have to be performed all over again at once, not because of any change in the subject matter of the dispute but because of the relative positions of the two parties and their abilities and courage to demand greater things for themselves. Each mediation is a new task, not to be performed by reference to any preceding act of the same sort or any principles or rules of law, unless the results of the application of such rules or the rules themselves appeal at the time to the parties as desirable. This prevents the use of artificial or antiquated legal rules or principles, just because they have once been established, and irrespective of their intrinsic justice. In this way, as has been pointed out, mediation may secure greater substantial justice and equity in certain cases than a more legalistic settlement. The result in the total number of cases, however, is to produce instability, uncertainty, and disorder, and to allow free reign to capricious political claims which take no account of any general principles of law.

This is partly accountable for the reluctance often felt by third states to undertake the task of mediation. The mediator has no fixed rules which he is free to follow in proposing a settlement. Not that there are no such rules of law or equity in existence which could be called on to settle the dispute. There may not, indeed, be any such generally accepted rules applicable to the case; many aspects of international relations are still in that position. Even where such rules are available, however, the mediator dares not depend upon them for fear that the parties will not agree with him or with each other on the merit of the rules or the results of their application. To the world in general, interested in seeing a peaceful, a permanent and, to that end, a just settlement, this objectionable fact presents itself even more sharply.

The attempt to remedy this defect in the practice of 
mediation leads to the use of arbitration. The mediator, anxious to be free to devise a solution which shall avoid war at the present and avoid it for good and all if possible, so far as this particular case is concerned, may ask to be freed from the necessity of too solicitously conciliating the particular demands put forward at the time by the parties. He may then be authorized to apply existing principles of law and equity to the case by a prior agreement of the parties to accept the result of his mediation. Agreed mediation results in setting up the mediator as judge of the dispute. This is arbitration in all but name. Indeed, at one time in the history of arbitration the judges were called indifferently "arbitrators" and "amicable mediators." 1

Arbitration ${ }^{2}$ may be formally defined as the settlement of international disputes by judges chosen by the parties. ${ }^{3}$ Several elements in this concept deserve special notice.

Arbitration is judicial settlement. That is to say, it is settlement by a person or group of persons acting in a judicial capacity, attempting to settle the dispute by reference, not to the claims of one or the other of the parties, for those conflicting claims, indeed, constitute the dispute itself, but by reference to some standard common to both parties and external to the particular dispute. That standard may be merely one of general convenience-convenience to the parties and to the community at large-or it may be one of philosophical justice, as conceived by the arbitrator and as presumed by him to be conceived by the parties. Where the arbitrator is able to discover legal rules, rules, that is, which have actually been accepted at some time in the past as such by the parties, which are applicable to the case in hand, he will not hesitate to

${ }^{1}$ Bishops acting for Louis XI of France and Edward IV of England under treaty of 1475 were called "arbitrators or amicable mediators"; Moore, Arbitrations, V, 4831.

On arbitration see literature cited, below, Appendix B, § 14.

Scott, Conferences, I, 188. 
HISTORY AND THEORY OF ARBITRATION 213

utilize them, even where those rules have not been accepted generally by the family of nations. For the arbitrator, although acting on the basis of a pledge by the parties to accept his award, knows that the award must in fact be accepted and carried out by the parties if it is to be effective. It would, therefore, injure his standing with the parties to hand down an award not capable of being justified by reference to previous declarations made by them. Whether the arbitrator decides the case by equity or by law, he is acting in a judicial capacity, and where legal foundations are not used in the process it is because they do not exist. The deficiencies of the system of international law, however, should be kept distinct from the supposed deficiencies of arbitral procedure.

Note may be profitably taken at this point of the fact that judicial settlement is a more primitive form of international government than legislation, or even administration. Logically, perhaps, the making, the administration, and the explanation or interpretation of law would seem to follow in that order. Historically it has been otherwise. Judicial settlement began in international law while yet there was available merely the customary law and special compacts between individual states. The revision of the law and its codification have come much later. Meanwhile, of course, the law of nations has been somewhat revised, digested, and codified by the judicial process. But the deficiencies of the law continue to operate as a handicap upon the arbitrator. ${ }^{1}$

The arbitrator is not, ordinarily, left to his own resources respecting the standards to be applied in settling the case submitted to him. The parties to the dispute commonly agree at the time of the submission on the principles to be applied in the case, and this provides the arbitrator with his necessary basis of settlement. Where the parties simply agree to a settlement "according to the

${ }^{1}$ Goodnow, 9, 72, 73; Holland Jurisprudence, 56-57; 65-67. 
principles of international law and equity" the arbitrator is left free to do very much as he pleases. On the other hand, if the bases of settlement are closely specified by the parties, the arbitrator will depart from them at his peril, even where the bases agreed upon seem to him to be out of accord with common international law. For settlements according to common international law a submission on general grounds is preferable.

Implicit in these conditions regarding the basis for the decision of the arbitrator lies the most significant principle governing the practice of international arbitration, namely, the principle that the jurisdiction of the arbitrator and all that this involves is derived from the special consent of the parties, exercised in a choice of a particular judge for a particular case to be decided at a particular time and place. ${ }^{1}$ There exists no general arbitral jurisdiction based upon general agreement of the community of nations, covering all the issues, or even any special group of issues, submitted in advance of their appearance to any court of continuous sessions. The arbitrator is chosen by the parties at the time, and the issue to be settled by him, as well as the time and place of the trial and the standards to be applied in reaching the decision, are defined at the same time. This is the essence of arbitral settlement.

Endless variation is possible among the methods adopted in making up the arbitral tribunal. A single arbitrator may be chosen by agreement. Each party may first select one or more judges and then an umpire may be chosen by agreement. The umpire may be chosen by lot or by the judges already named, or by third and fourth powers who have been named by the parties. All of this procedure is settled in the agreement for submission. ${ }^{2}$

In each case submitted to arbitration, therefore, the critical legal step is the agreement to submit the case. This agreement is ordinarily embodied in what is called

1 Moch, $\$ 8$.

Examples in Wilson, Cases, 3, 42, 67, 82, 329. 
a compromis d'arbitrage, one of the minor forms of international treaties. It is in this document that provisions are made controlling the choice of arbitrators, the scope of the question, the time and place of the trial, the procedure at the trial,-including the languages to be used, the forms of argument and counter-argument to be permitted, the submission of evidence, and whatever else is necessary. ${ }^{2}$ The bases of the award are here specified and the document closes with provisions for the rendering of the award, provisions for carrying out the decision and, perhaps, for guaranteeing execution. This is the simplest and most primitive basis for an arbitral trial. ${ }^{1}$

Where a dispute involves several nations the compromis for arbitration may, of course, be signed by more than two parties. In that case the relative positions of the parties in the trial will be defined in the text.

Very different from the compromis for the arbitration of a dispute which has arisen, and providing the machinery and rules for this arbitration, is the arbitration treaty proper, which provides for the submission in the future of disputes between the parties as they arise. Such an agreement may cover all varieties of disputes, or it may cover only a certain list of disputes described in general terms, or it may cover all disputes outside of a certain specified list of exceptions. In any case, the object is to provide in advance for the submission of a question to arbitration without leaving for discussion, at the time when the dispute arises, the question whether it shall be submitted or not. When a dispute has actually arisen between two nations, the atmosphere is not suitable for the conclusion of an agreement to arbitrate, even though the question be such that in general-apart from the current case-there would be no hesitation to submit it to arbitration.

${ }^{1}$ Wilson, Cases, 83, for compromis between France and Germany in Casablanca case.

${ }^{2}$ Same, Arts. I, II, III, V, IX, and compromis between United States and Venezuela, 1909, Arts. IV, VI, in same, 212; also Hershey, § 311. 
The agreement in advance to submit certain questions to arbitration upon occurrence may take several forms. The earliest form was the arbitral clause, a clause inserted in a treaty dealing with commercial or territorial or any other subjects, providing that if disputes should arise in the future over the meaning of terms of the treaty or any questions arising out of the treaty, these disputes should be submitted to arbitration. ${ }^{1}$ The arbitral clause was in use in ancient Greece, was not unknown in early modern times, ${ }^{2}$ and was revived in the treaty between the United States and Tripoli in 1796. ${ }^{3}$ Since 1875 it has been in common use. ${ }^{4}$

The arbitral clause was followed by the bi-lateral permanent arbitration treaty as just described, covering different questions of one sort and another, apart from any particular treaty. This is the prevalent type of arbitration treaty today. Examples of such treaties are to be found dating back to Medieval and even Greek and Roman times, ${ }^{5}$ but the full use of agreements for future arbitration came only in the modern period, chiefly after $1875 .^{6}$

The third stage is the multi-lateral or general arbitration treaty, providing for the submission to arbitration in the future of all disputes of a certain sort arising among

1 Hershey, as cited.

${ }^{2}$ Treaty of Münster, 1648, Art. VIII; Peace of the Pyrennees, 1659, Arts. CVIII-CX; Treaty of Riswick, 1679, Art. VIII; in Moore, work cited, V, 4832 and following.

Art. XII; in Malloy, 1787.

- Hershey, as cited, note 23 ; the clause may extend to disputes arising outside of the treaty in which it is found; same, note 24.

- Treaty of 1238 between Genoa and Venice; treaty of 1321 between Brittany and England; Moch, $\$ 27$, and Moore, as cited, 4831.

'Hershey, §312; Mérignhac, 206; Moch, \$ 86; "Historical Light on the League to Enforce Peace," in W.P.F., Pamph. Ser., Vol. VI, No. 6, 8-9 (December, 1916). Example in Malloy, 290. Treaties for arbitration are naturally less numerous than arbitral cases, since several cases may be submitted under one treaty. The following table, based on the data given in Darby, Lafontaine, Mérignhac, and other works, represents approximately the multiplication of permanent treaties of arbitration from 1845 to 1914 :

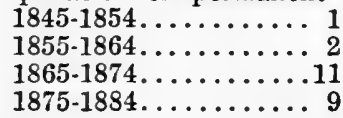

$1885-1894 \ldots \ldots \ldots \ldots 10$

$1895-1899 \ldots \ldots \ldots \ldots 25$

$1900-1906 \ldots \ldots \ldots \ldots 656.66$

$1907-1914 \ldots \ldots \ldots \ldots 100$ 


\section{HISTORY AND THEORY OF ARBITRATION 217}

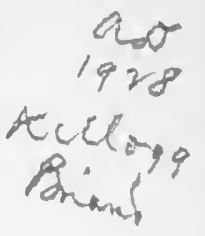

the parties, and signed by a large number of states. This type of arbitration treaty is a little in advance of general usage today. Examples of general arbitration treaties may be found in Medieval Europe ${ }^{1}$ and in Greek times, but the device has never been widely adopted. Such examples as may be found all date from 1890 onward. ${ }^{2}$ There exist a few such treaties today, notably the Hague Convention relative to the collection of contract debts among nations ${ }^{3}$-and even here the result is accomplished by indirection,- - but attempts made to secure the adoption of such treaties on a wide scale failed in 1899, 1907, and again in $1920 .{ }^{4}$

For this, in the technical language of diplomacy, is "obligatory" arbitration. By this it is meant that, once such a treaty is concluded, the signatory states are under legal obligation to submit certain cases to arbitration when they arise. Of course, this obligation arises from a sovereign act of consent made at an earlier time, and is therefore a self-assumed obligation. In that sense it is not obligatory but voluntary. But at the time of the dispute the legal obligation is real and-what is, perhaps, more important-is felt very keenly in the state of opinion existing at the time of the dispute.

On the other hand, even the existence of such a treaty does not avoid the necessity for a special agreement at the time of submission. This is due to the fact that the issue must be defined more precisely than can ever be done in advance by a general treaty, that judges must be chosen, times and places for the hearings selected, and all the many details of procedure arranged. No general standing arrangements of this kind exist. There are no standing

${ }^{1}$ Moch, $\S 26$.

2 Hershey, § 313.

${ }^{8}$ Text in Malloy, 2248.

"Hershey, \$313. A qualification should be made to cover the very recent action of some fifteen states in accepting such an arrangement in connection with the new Court of Justice established under the League of Nations; see below, Chap. XVI, end. 
courts, no forms of action, no sufficient code of procedure; and no way exists for making good these deficiencies except by special agreement at the time. ${ }^{1}$ This means that a large part of the force of any agreement in advance to arbitrate certain cases as they appear is destroyed. Not until, in addition to the promise in advance to arbitrate a specified set of cases as they arise, there exists a standing court, a prearranged method of initiating the action, and a previously established code of procedure ready for instant use, will the need for the special agreement at the time disappear.

The questions specified for submission to arbitration vary greatly. No question is incapable of submission to a mediator, of course, for he may devise a formula of settlement in reliance solely upon his own ideas of convenience and expediency, apart from any law or formal equity, so long as he can secure its acceptance by the parties. Where legal standards are to be used in the settlement, however,and agreements to arbitrate generally specify that such standards are to be so used,- the range of questions capable of submission is immediately restricted to those on which there exist accepted rules or principles of law or equity, namely justiciable questions. ${ }^{2}$ Such are questions of treaty interpretation, which, as has been pointed out, was the earliest type of question submitted to arbitration. Such, likewise, are questions arising under national statutes and accepted rules of international law. Yet the great difficulty here resides in the number of questions of large importance which arise in international relations, for whose settlement there are no legal standards available.

Turning to the other side of the question, there are certain types of questions which have commonly been excepted from the scope of pledges to arbitrate future dis-

1 Hershey, § 313.

'Same, \$319; also text of Art. I of proposed treaty of arbitration between Great Britain and the United States, signed in 1911, in $A m$. Jour. Int. Law, V, Supp., 253 (1911). 
putes. ${ }^{1}$ These are questions of honor and of vital interest, and questions affecting the national independence or the rights of third powers. These exceptions may, of course, be used as disguises for a reluctance to arbitrate based on other grounds. "National honor" may be employed to cover anything which it is desired to withhold from arbitration. The terms are so general that they are-like all general terms-subject to abuse. Yet they do mean something, and their abuse can usually be detected. The terms as properly used merit examination.

The exception of national honor explains itself. ${ }^{2}$ No nation could bring itself to submit to arbitration a question imputing to it dishonor and shame, for the simple reason that the very admission of the possibility that the nation had acted dishonorably would itself be a dishonor to the state. What is to be treated as a question of national honor is, of course, a question of fact with which the law does not deal. The law merely says that such questions as are in fact felt to be questions of national honor may justifiably be withheld from arbitration. The more important fact is that conceptions of what affects the national honor are changing. The national sensitiveness of the early modern period, of the seventeenth and eighteenth and early nineteenth centuries-which made so much ado about questions of diplomatic precedence, which cast suspicion on the offer of good offices and mediation-is dwindling to a more prosaic and sensible tone. This is not true, of course, among the new states of eastern and southeastern Europe; and the exception proves the rule. Nations with secure prestige are not likely, in this unsentimental age, to hold out on this ground very long.

Similarly with questions which affect the vital interests, the independence, the very existence of the state. No state could submit to arbitration a question which might

1 Hershey, as cited, notes.

' Perla, entire, especially Part I. 
result in a decision that it had no right to exist. The logic of such a step would be questionable, and such a loss of sovereignty could only be tolerated, on any accepted theory of international relations, as the result of a direct consent on the part of the state, just as it is well established that in the interpretation of treaties no loss of sovereignty and independence may take place by implication or indirection. Again the important thing is not to try to deny the principle itself, for the principle is sound, but to notice that its consequences are not as extensive in application as they once were. As the state system becomes more and more stable, and the nations are more and more firmly established, the questions which in reality do affect their vital interests are fewer and fewer. With the development of a legal system defining national rights more fully, less is left to political manœuvering. With the continued existence of certain states side by side, relationships spring up which cut down the zone of undefined potentialities between them. A new state may have its existence menaced, and, what is more, may feel that its independent existence is menaced, by questions which an older state would accept as arbitrable with far more safety and equanimity. ${ }^{1}$ This is not merely speculative. The new states of Europe are conspicuously apprehensive about events and actions in the territories of their neighbors which are not of sufficient importance in the eyes of the older and more firmly established states to justify in the eyes of the latter the feelings of the weaker states.

As for questions affecting the rights of third parties, the case is somewhat different. Such questions are likely to increase rather than decrease as time goes on; at the same time, it is well agreed that the rights of third parties may not, as a matter of principle, be settled by decisions between others. The solution lies, apparently, in two directions. The third parties may be invited to join in the case,

${ }^{1}$ Bernard, 99, bottom. 
or may even be brought in under standing treaties of arbitration, as was done in the Venezuelan controversy in 1903. ${ }^{1}$ Or secondary arbitration cases may be instituted to settle issues derived from the decision in the first. After all, this is an exception relating not to the subject matter of questions submitted to arbitration but to the parties to the cases submitted. It argues a defect, not in the nature of arbitration, but in the existing mechanism of conducting cases.

In actual practice several states have agreed to arbitrate all international questions. ${ }^{2}$ There is revealed in such action a curious mixture of cynicism and idealism, of practicality and romanticism. Considerations of national honor and pride are put aside for the sake of getting a settlement without the expense and waste of war. In the enthusiastic support of the peace ideal, the limitations of arbitral practice due to the insufficiency of the legal materials available are overlooked. At all events, the tendency seems to be to eliminate the traditional exceptions as described and to take care of the real interests formerly covered by those exceptions in some other way. It may be added that the preliminary question of the propriety of submission may itself be arbitrated. ${ }^{3}$

Finally, as regards the questions submitted to arbitration, it should be recognized that there is a vast difference between the questions of public law submitted to arbitral tribunals and private claims submitted to international commissions. ${ }^{4}$ The former are the questions which attract attention. The latter bulk large in actual practice. Even in the latter case, of course, the nations whose citizens have claims against each other and against the governments act on behalf of their citizens and make these claims their

${ }^{1}$ Wilson, Cases, 12-39, especially $34,35$.

${ }^{2}$ Hershey, as cited, note 55 , examples.

${ }^{3}$ Moch, § 7.

Public questions: Casablanca case; private claims: Canevaro case; in Wilson, as cited, 89, 239. 
own in arranging for the creation of mixed commissions to evaluate them and often to adjudicate upon them. Moreover, the principles of national liability determining the settlement of the various claims presented are principles of public law. Without the latter, and the action of the states as such, no hearing and settlement could be had on the claims. But, granted the provision for hearing and settlement, the claims actually settled are claims of private individuals.

In practice there is often a close intermixture of public and private law in cases submitted to arbitral courts. ${ }^{1}$ In the end the commission is led to try to settle the cases coming before it by any law applicable-public or private international law, Anglo-American or Civil law, or what not. $^{2}$ And the further we go in that direction the more evident does it become that arbitration is, whenever circumstances permit, judicial settlement.

Once the arbitral award is rendered, it is subject to no appeal. The reason is to be found in two facts. There is no other tribunal to which, as of right, the case may be carried. There is no superior court; all arbitral courts are supreme courts. In the second place, the parties have pledged themselves to accept the award, duly made according to the convention of submission. The pledge of acceptance having been given, the rendering of the award makes it part of the treaty itself and of final effect, pending any action having legal power to alter the obligations of the treaty.

In point of fact, few arbitral awards have been rejected by the participants. ${ }^{3}$ One reason is to be found in the fact

${ }^{1}$ On relation between arbitration at public and private law see remarkable document in Scott, Conferences, I, Appendix V, giving picture of arbitration in early English law; also see Redman entire, especially the forms in Appendix for future submission, submission of a dispute which has actually arisen, et cetera.

3 Decision in Caneraro case rested on international law, Italian law, and the law of Peru; Wilson, 243-259.

'Hershey, §312, and note 49 thereto; Moore, Digest, $§ 1081$. 
that by the time a state is willing to submit to arbitration the chief desire is to secure a settlement of some sort or other, and this is the chief reason for that willingness. This leads to the mutual pledge of acceptance and to its almost automatic observance, especially among AngloAmerican peoples, whose respect for judicial decision is naturally strong.

In order for this rule to operate, however, the award must have been duly made. An award made in excess of the authority conferred by the parties submitting the case is not binding; nor is an award touching questions not submitted, or based upon considerations not open to the court acting under the convention of submission. Likewise, an award obtained by coercion or fraud, the use of threats or of dishonest documentary or oral evidence, would have no binding force. It is commonly said that in such cases the parties may ask for a revision of the award. It would be more to the point to say that the case may be resubmitted to a new tribunal for a new decision. The original award has no legal existence. It is not appealed, revised, or overruled. It is of no further importance at all. ${ }^{1}$

This whole general theory of arbitration has been worked out through twenty-five hundred years of international practice. ${ }^{2}$ In the course of that development much has been done to bring the practice to the high state of perfection in which we find it today.

As long ago as the time of classical Greece, four or five centuries before the Christian era, interstate arbitration was extensively employed among the Mediterranean citystates, ${ }^{3}$ and a system of procedure was elaborated which compares favorably with anything put forth in Europe until the later nineteenth century. With the advent of the Macedonian Empire, of the Leagues, and of Rome,

1 Hershey, § 312; Moore, Digest, § 1081; Nippold, § 16.

On history of arbitration see literature cited, below, Appendix B, § 14 .

'On arbitration in Antiquity see, beside Phillipson, Raeder and Tod, entire. 
Greece, however, saw a decline in the practice of free international arbitration. The submission of interstate questions to arbitral tribunals continued, indeed, and even increased in frequency for a time, but the basis was the action of Alexander, the federal Leagues, and imperial Rome, in compelling subject cities and provinces to settle their disputes by submitting them to arbitrators-often named by the Emperor or the League-instead of by fighting them out. It had come to be a device of constitutional government, not a form of free international practice. Later, as Rome increased the pressure for complete control over all sections of the empire, and sought to perfect the unity of the state, even this disappeared.

During the period of the barbarian kingdoms there came a slight revival of arbitration, only to die away again by the eighth century. ${ }^{-}$With the development of feudalism there came another movement, lasting to the end of the Medieval period, which had some appearance of international arbitration. ${ }^{2}$ Here again, however, appearances are deceptive, and on closer inspection the arbitraments of the Middle Ages turn out to be cases where the Pope, the Emperor, or some superior feudal ruler rendered an award in a dispute between parties over whom he claimed a constitutional authority. Again the device was being used for the convenience of the superior, not for its merits in the eyes of the parties. ${ }^{3}$

It is, therefore, to the period of the Renaissance that we are compelled to turn for the definite revival of interstate arbitration and to the cradle of the Renaissance, the Italian peninsula. The same state-system which gave rise to modern diplomacy produced like results in another field." Between 1200 and 1300 there occurred some one hundred cases of interstate arbitration among independent Italian

${ }^{1}$ Scott, Conferences, I, 202.

2 Moore, Arbitrations, V, 4825-4851 (translated from Mérignhac).

- Scott, as cited, 203, 208.

- Moore, as cited, 4825, 4826, 4831. 
cities and principalities. ${ }^{1}$ From Italy the practice spread to Northern and Western Europe, and during the three centuries from 1200 to 1500 interstate arbitration spread rapidly and grew greatly in prestige. ${ }^{2}$

The development of interstate arbitration in the modern period was, however, retarded somewhat by the development of the national monarchies after $1500 .^{3}$ The new absolute sovereigns would no longer yield to the arbitraments of Emperor and Pope, and the organization of free international relations was still so feeble as to offer nothing in the place of the earlier form of procedure. Arbitration by free agreement was still in the most elementary stage. The kings would brook no checks and legalistic hindrances upon their power. The ready appeal to arms was too simple and natural to be put aside for such an elaborate and eonsidered device as arbitration. The high temper and excessive national sensitiveness of the period quite prevented the further growth of international arbitration until well into the nineteenth century. Less use, it clearly appears, was made of arbitration from 1500 to 1800 than in the three centuries preceding.

The year 1794 is frequently taken as the date from which the history of modern international arbitration is to be traced. ${ }^{4}$ In a sense this is accurate, for the Jay treaty of that year, between Great Britain and the United States, made provision for three arbitrations and thus inaugurated that Anglo-American practice of arbitration which has been the leading factor in promoting the development of arbitration since that time. Things moved rather slowly, however, until the Napoleonic period had passed, and the period of the revolutionary movements of the early decades of the last century. ${ }^{5}$ By 1850 a noticeable increase in the number

Moch, § 26 ; Moore, as cited, 4829.

Moore, 4828 .

- Moch, § 29.

- For example, by Scott, as cited, 210, 216, 224.

- Moch, 41; Moore, 4851; Scott, 224.

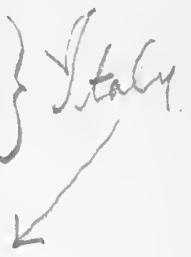


of arbitrations had set in. In 1872 came the celebrated Geneva Arbitration between Great Britain and the United States, and the effect of this demonstration of the feasibility of arbitration for complicated, delicate, and highly contentious questions between great states was soon evident. ${ }^{1}$ There was a rapid increase in the number of arbitrations down to 1899 , and after that a still more rapid increase. $^{2}$ In the years from 1899 to 1914 arbitration assumed the proportions of an international fad, with the United States and Great Britain still leading the movement, but with all states of the world joining in the vogue. ${ }^{3}$ The Latin-American states-for reasons better left to conjecture-have adopted the practice with acclaim, have incorporated provisions relating to arbitration in their national constitutions, and have even pretended to regard it as a peculiarly American institution. ${ }^{4}$

By 1899 it became evident that something might well be done to place international arbitration upon a more secure footing than that of bi-lateral agreements for the submission to special tribunals of cases as they arose.

1 Moore, Arbitrations, Chap. XIV; Digest, § 1330.

2 The following table, constructed on the basis of the data given by Darby, Lafontaine, and others, represents approximately the number of cases submitted to arbitration from 1794 to 1914 :

$\begin{array}{ll}1794-1800 \ldots \ldots \ldots \ldots .4 & 1861-1880 \ldots \ldots \ldots \ldots .44 \\ 1801-1820 \ldots \ldots \ldots \ldots & 1881-1900 \ldots \ldots \ldots \ldots\end{array}$

$1841-1860 \ldots \ldots \ldots \ldots . .19$

Compare Scott, 224-226; also Hershey, § 80, notes; W.P.F., Pamph. Ser., Vol. VI, No. 6, as eited, 7-8.

The following table, constructed as were the tables above, shows approximately the relative frequency with which different nations have submitted cases to arbitration from 1794 to 1914 :

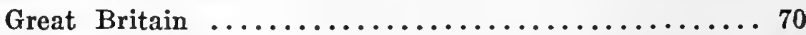

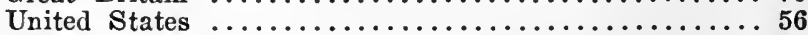

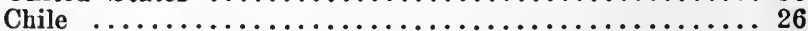

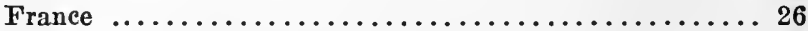

Peru ............................... 13

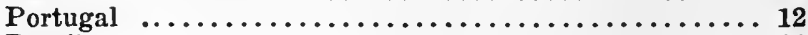

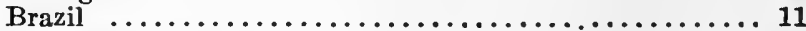

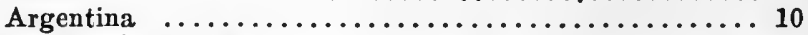

Compare Lafontaine, 4, 5.

Alvarez, 255; Constitution of Venezuela, Art. 120, in Rodriguez, I, 230; Quesada, xi, 125. 


\section{HISTORY AND THEORY OF ARBITRATION 227}

There had been a constant development, as has been seen, in the basis or foundation of international arbitration in the past. ${ }^{1}$ Accordingly, an effort was made in 1899, at the first Hague Peace Conference, to provide a yet broader and more stable foundation; and this attempt was reviewed and revised at the second Conference in 1907.2 As a result, there came into existence what may be called the Hague system of arbitration, including certain institutions and certain methods of practice adopted for use by the nations participating in the establishment and maintenance of the system. Down to 1920 this Hague system constituted the highest development of general international arbitration, and as such it deserves special attention.

${ }^{1}$ Hershey, $\S \S 311-313$, and notes.

2 Text in Appendix A, below, Document No. 6. 


\section{CHAPTER XV}

\section{THE HAGUE ARBITRATION SYSTEM}

A $\mathrm{S}$ far as international arbitration was concerned, the Hague in May, 1899, had a fairly obvious task before them. Arbitration was an institution of long standing among individual nations. It needed, therefore, not approval in principle, but such practical reorganization as would improve its effectiveness in operation. Specifically, what was needed, as every student of the problem knew, whether he desired to see that need satisfied or not, was a permanent court of arbitration, always available to all the nations, as member states in an arbitral union, so to speak, ${ }^{1}$ and competent to deal automatically with certain types of cases defined in advanee. If the commencement of proceedings in the court could be facilitated by the elimination of the need for special consent by the parties in each case submitted to arbitration, so much the better. Some of these results were, after a fashion, obtained; and the Hague system of arbitration must be regarded as, up to the year 1920, a thing standing by itself and entitled to full consideration in its own name. ${ }^{2}$

In the process of reorganizing international arbitration on broader foundations, the Conference began, as has been seen, by reorganizing the practice of good offices and mediation. These topies constitute the subject matter of the opening articles of the First Convention, known as the Convention for the Pacific Settlement of International Disputes, signed at The Hague in July, $1899 .^{3}$

' On Hague system see literature cited, below, Appendix B, $\$ 15$.

- Text of the Convention, as revised in 1907, below, in Appendix A, Docu. ment No. 6, with italics showing portions changed since 1899 . Cited hereafter as "I H.C. '07."

Schücking, by title. 
Passing on to arbitration proper, the Convention provided for a panel of judges and a code of procedure ${ }^{1}$ and that is about all. The "court" created is permanent only in the sense that there is constantly on file a list of persons in the various states participating in the plan who may be chosen by the parties to a dispute to act as arbitrators between them. Such a choice, however, must be made in the same way as before, namely, by an arbitration agreement, or compromis, which defines the issue, indicates the place and date of trial, and names the judges or provides for the method of selecting them from the membership of the "permanent court." It is true that it is not as necessary as it once was to provide in the compromis a detailed plan of procedure for the arbitration, inasmuch as the Hague Convention itself attempts to do this. There is, however, nothing to prevent the parties from framing a special code of procedure in each case.

This is the essential defect of the Hague court. It does not even obviate certain mechanical steps which must be taken in submitting a case to arbitration unless the parties to the case are affirmatively desirous of following the procedure of the First Convention. Even then they must consume a certain amount of time in the formation of a special tribunal. The procedure-on mere mechanical grounds-is far from automatic.

This is still further true regarding the questions which are or are not to be submitted to arbitration. There is no list of questions or types of questions previously agreed upon as suitable for arbitration and to be referred to arbitration in one way or another-by action of one party or by action of the court-without special consideration and discussion at the time. In other words, the court has no continuous jurisdiction over a succession of cases; its jurisdiction is episodic and intermittent.

This has ordinarily been described by saying that there

${ }^{2}$ I H.C. '07, Arts. 44, 51-85 (I H.C. '99, Arts. 23, 30-57). 
is no obligatory arbitration under the Hague Convention. Attempts were, indeed, made to secure the acceptance of various schemes for submitting eases to arbitration automatically as they arose. No headway could be made in this direction in 1899. Hence it is said that obligatory arbitration failed of acceptance. As has been suggested, this form of statement leaves much to be desired. No arbitration founded upon previous agreement-as this would becan be called obligatory in any absolute sense. On the other hand, arbitrations on special agreements are fully obligatory, once the agreement is signed. ${ }^{1}$ Moreover, the essence of the procedure which is so desirable is not the imposition upon reluctant states against their will of lists of cases suitable for arbitration, but merely the agreement upon suitable types of eases in advance, to save time and exasperation when a dispute actually arises.

Of course, the resistance put forward by the opposition has its own explanation. The nations desired to retain the power to block the impartial arbitration of cases which they did not feel confident of winning and were not willing to risk losing. ${ }^{2}$ In addition there was a vague feeling of opposition to this sort of thing in general, that is, to international courts and the attempt to create a permanent jurisdiction in this way. The opposition developed a still more detailed set of arguments at the Second Conference at The Hague, when an effort was made to carry farther the movement for obligatory arbitration.

The First Conference also created a Bureau to administer the First Convention, including the articles dealing with good offices and mediation; this Bureau is placed under the supervision of the diplomatic corps stationed at The Hague, converted for this purpose into a Permanent Administrative Council. ${ }^{3}$ In a sense this supplies the greatest

Taft, 96-98, 112-114.

Same, 112, 126.

I H.C. '07, Arts. 43, 49 (I H.C. '99, Arts. 22, 28). 
element of permanence and continuity which the Court possesses. The records of the Court are kept in the Bureau, and business is conducted through the Bureau at the time of arbitral trials before the Court and during the intervals between cases.

It may well be wondered, however, whether the bare facts thus related tell the whole story of the action of 1899 and of the Court itself. A large part of the work of 1899 is to be found in the effect on public opinion and the public imagination. Ideas are dynamic things, and the expectations aroused by the efforts of the Conference could not be entirely suppressed even by the failure of the Conference to satisfy them. They remained to operate in the years after 1899. Indeed, the results of 1899 were for this reason estimated more highly than they deserved, and a steady practice of arbitration at The Hague was expected. When these expectations were deceived, and the defects of the scheme of 1899 were made manifest, the same force of opinion and desire was converted into a demand for reorganization and improvement.

The Second Conference held at The Hague to deal with these matters met in June, 1907, and took up at once the task of revising the Convention for the Pacific Settlement of International Disputes. ${ }^{1}$ During the years 1899-1907 four cases, all of great importance and complexity, had been submitted to arbitration at The Hague, ${ }^{2}$ and this body of experience served, along with the general desire for a system of arbitration stronger than that provided in 1899 , as the foundation for changes made and attempted to be made in the First Convention. The changes actually made indicate both the nature of the Hague system as it stood in 1920 and, indirectly, the nature of the difficulties encountered in the establishment and operation of the Hague Court.

Deuxième Conférence, I, 399-454.

'Wilson, Cases, ix, 1-81. 
Certain changes were made in the rules governing the organization of the Court. ${ }^{1}$ Thus, a limit was placed upon the selection by parties to a dispute of nationals as members of the trial tribunal. ${ }^{2}$ Likewise, members of the Court were forbidden to act as agents or counsel before the Court except on behalf of the state appointing them. ${ }^{3}$ A process of drawing lots was adopted for settling disputes between the parties over the choice of the umpire on the tribunal. ${ }^{4}$ Provision was made whereby one party to a dispute might notify the Bureau of its willingness to submit a dispute to arbitration and the Bureau was authorized thereupon to notify the other disputant. ${ }^{5}$ By these steps the character of the tribunal was elevated somewhat, the element of diplomatic negotiation and of good offices and mediation in the preliminary procedure was cut down, and a means of getting the case before the Court was adopted which might facilitate matters when a dispute arose. An attempt to eliminate all national representatives from the trial tribunal failed of acceptance. ${ }^{6}$

The code of procedure of the Court was altered at many points. ${ }^{7}$ The subjects to be settled in the compromis were defined in great detail. This was due to the fact that some difficulties had arisen in the period since 1899 because parties to cases to be submitted to arbitration had failed to settle at the beginning of the trial all of the manifold points of procedure involved. Power to frame the compromis was even conferred upon the Court, or, in effect, upon the tribunal selected to try the case. The chief function of the compromis, the choice of arbitrators, would in such cases be committed to a previous agreement, a sort of pre-compromis, providing for submission and naming

${ }^{1}$ I H.C. '07, Arts. 44-46.

2 Same, Art. 45, Par. 3.

"Same, Art. 62, Par. 3.

- Same, Art. 45, Pars. 4-6.

- Same, Art. 48, Pars. 3, 4.

- Deuxième Conférence, I, 419.

'I H.C. '07, Arts. 52, 53, 61, 63, 64, 67-74. 
the tribunal, but leaving the details of procedure to be fixed by the tribunal itself. This is a weak suggestion of what might be done to allow the Court to take jurisdiction in proper cases on its own initiative.

Provisions were inserted dealing with difficulties which had arisen in regard to the languages to be used before the tribunals and the periods of time allowed in the various stages of the trial. ${ }^{1}$ The mechanical ease and consequent smoothness with which arbitration may be conducted has great influence upon the willingness of parties to resort to arbitration and upon the soundness of the result. New powers were conferred on the Court to secure evidence from the parties or in the territories of third states. ${ }^{2}$ Disputes regarding the interpretation and execution of awards were to be submitted to the tribunal which made the award. ${ }^{3}$

Finally, a new chapter of five articles was added to the Convention providing a simpler, less tedious, and less expensive method of arbitration "by summary procedure." 4 It was hoped that this would encourage smaller and poorer states to use the Court more, and that it would, in general, speed things up. Just as in national jurisprudence the cost and delay of litigation may well be prohibitive to some potential parties to a trial at law, so here the cost and delay of arbitration was felt to be a serious obstacle to more frequent recourse to the Court at The Hague. ${ }^{5}$

With all these modifications, however, the essentials of the Hague system stand as in 1899. There is a panel of names from which tribunals for the trial of special cases may be selected at will by parties agreeing upon the submission of a given dispute to the Court for arbitration. The parties agree in advance to accept the award and proceed to plead their cases by written and oral arguments

${ }^{1}$ I H.C. '07, Arts. 61, 63.

Same, Arts. 75-76.

- Same, Art. 82.

- Same, Arts. 86-90.

- Scott, Conferences, I, 302. 
before the tribunal. ${ }^{1}$ The tribunal decides the questions submitted to it by a majority vote, ${ }^{2}$ renders an award, and gives the reasons which had led to the decision; and from this award there is no appeal. ${ }^{3}$ There is a provision whereby non-signatory states may join the Hague system, ${ }^{4}$ and in 1914 there were some thirty members. ${ }^{5}$ From 1907 to 1914 some twelve cases were submitted to the Court under treaties, among states which were members of the Hague system, providing for arbitration of disputes between the parties as they arise. ${ }^{6}$ The Hague system does not, of course, supplant such treaties; on the contrary, it stimulated the formation of such treaties between 1899 and 1907.7

What, then, are the conclusions to be drawn from the arrangements made at The Hague in 1899 and 1907 for the promotion of international arbitration?

In the first place, the conclusion is inevitable that the Hague system constitutes an accomplished fact in the organization of international arbitration which must naturally be taken as a starting point for anything to be done in the future in that field. The system exists today; cases may be submitted to the Court at any time, indeed, are again being submitted and tried at the present time. In so far as international organization, in general, centers about the development of international judicial settlement, the system installed by the conferences at The Hague must be the starting point for future efforts of this sort. 8 As a matter of fact, the soundness of this conclusion has already been demonstrated. In formulating plans for an international

${ }^{1}$ I H.C. '07, Arts. 37, 63.

'Same, Art. 78.

Same, Arts. 79, 81.

- Same, Art. 93.

"Myers, D. P., " Record of the Hague," in W.P.F., Pamph. Ser., Vol. IV, No. 6, Part iii (Óctober, 1914), Appendix.

-Wilson, Cases, ix-x, 83-445.

'I H.C.' '07, Art. 40; see data given in note 6, p. 216, above.

- See the views of Dr. James Brown Scott in Carnegie Endowment, Fear Books, 1920, 111, and 1921, 103. 
court to be set up under the League of Nations, recourse was had in the first instance to the First Convention of the Hague Conferences. The work went forward as a revision of that Convention. ${ }^{1}$

In the second place, it is noticeable that all events from 1899 to 1907 tended to strengthen the Hague system, and that everything about the debates in the Second Conference pointed in the same direction. The number of cases submitted increased in the years just before 1907 and went on increasing down to $1914 .{ }^{2}$ All of the changes made in the Convention in 1907 strengthened the Court and tended to expand its usefulness. Other efforts to expand it still further were put forward and failed for want of unanimous consent, although they commanded a majority support and even general approval in most cases. ${ }^{3}$ Thus it was with the question of obligatory arbitration, or the definition in advance of cases for submission to arbitration as they arose. The progress made toward securing acceptance of some such plan was much greater than in 1899. And, it may be added that in 1920 the proposal to confer "compulsory jurisdiction" on the new court of the League of Nations got much further still. ${ }^{4}$

This matter of jurisdiction may well be regarded as the test question for progress in the organization of international judicial settlement. Other questions are, indeed, significant. Thus, giving the tribunal authority to settle questions as to its own competence under the compromis, as was done in $1907,{ }^{5}$ is a step of vast potentialities. ${ }^{6}$ But, after all, the central issue just now is how to get cases be-

${ }^{1}$ League of Nations, First Assembly, Document 44, 21-24, being reports to the Council of the League of Nations relating to the proposed Permanent Court of International Justice; below, Chap. XVI.

Wilson, Cases, ix-x.

Hershey, § 313, note 27.

"Fenwick, C. G., "Meeting of the Assembly of the League of Nations," in Am. Pol. Sci. Rev., XV, 102 (February, 1920); below, Chap. XVI.

'I H.C. '07, Art. 73. 105.

- Compare debates on this point in 1899: Conférence de la Paix, Ptie. I, 
fore the Court. It is well, therefore, to note the nature of the opposition in 1899 and 1907.

The opposition to obligatory arbitration in 1899 and 1907 came chiefly from Germany and Austria. ${ }^{1}$ Other states-Italy, Japan, and some others-joined the opposition from time to time, but the leadership came from Germany. This position was undoubtedly part of a general German policy of resistance to this sort of thing, to international control and coöperation in general, unless she could use it for her own advantage. Thus in 1905 she had demanded an international conference on Moroceo, expecting to use it to control French action for her own benefit. But three years later the demand for a conference on the Bosnian question was defeated by Germany and Austria for the simplest of reasons, namely, fear that such a conference would not approve of the Austrian annexation. More specifically, Germany was pushing a program of expansion and making her way forward again in the diplomatic world. She believed herself strong and entitled to more of the good things of the earth than she then possessed. She was determined to get them, and that not by general consent but, if need be, in defiance of standing law and equity. She therefore opposed the development of the sort of international organization planned at the Conferences at The Hague.

One may profitably pause at this point and reflect upon the motives, in general, which lead to opposition to international organization. A strong nation which is hungry for more of the good things of earth than it has will desire to remain free for independent action. On the other hand, a nation which is in possession of all it can well expect, or even desire, to secure; will be satisfied to see the existing situation legalized and provided with guarantees. The rigid maintenance of the established order is always desired by the beneficiaries thereof; the needy are the revolution-

${ }^{1}$ Hershey, as cited. 
aries. Again, the smaller powers have more to gain by the protection afforded by an international organization, in so far as conquest is thereby prevented, and hence they very generally support such schemes. On the other hand, these smaller powers constantly stand in fear of the use which the larger powers may make of the organization which they will more or less completely control, and this tends to lead the former to hesitate to commit themselves to membership in, and the jurisdiction of, such a union unless provision is made for equality of representation. They may even wreck the whole plan unless this demand is granted. Better no coöperation, they are likely to feel, than coöperation between superiors and subordinates.

As things stood in 1907, Germany was bound to go into the opposition. She wanted more than she could hope to get by free common consent; she probably dreamed of more or less universal empire, and she felt strong enough to stand alone. In 1914 the bid was made-for colonies, for commerce, for world hegemony. It failed. The opposition of 1907 is thus discredited. Defiance of common international consent, as the issue was formulated in 1907 and 1914, is not regarded as profitable after the events of 1914-18. It would appear that the issue had been clearly raised and clearly settled. No nation or alliance of nations, it would seem, can safely defy common international law and opinion.

Yet the suggestion to give the court to be created under the League of Nations compulsory jurisdiction was rejected in 1920 as it had been in 1907 . The opposition came no longer from the small states, for a plan of representation or membership was worked out to satisfy the large and small states alike. The opposition came from Great Britain, France, Italy, and Japan. ${ }^{1}$ It was not due to lack of satisfaction with the existing situation in the diplomatic world. It was not due to fear of being dominated by others. It was probably due, in part, to a disinclination to see the

${ }^{1}$ Fenwick, as cited. 
political hegemony over the diplomatic world enjoyed by the victors of 1918 in any way restricted, and to a disinclination to risk seeing any of the items of the settlement of 1919 called in question. It was probably due also to a sincere feeling of caution and a sincere doubt whether the nations were ready for such a step. It was officially defended on technical grounds to be discussed later.

The final conclusion to be drawn from a study of the Hague system as it was left in 1907 is that there is still much room for improvement. It will be worth while, in completing this survey, to summarize the chief defects of that system.

The Court is weak in not being permanent; for, in spite of its title, the "Permanent Court of Justice," it is not permanent. Indeed, there is no court, properly speaking. ${ }^{1}$ There are many courts or tribunals which are made up from a panel of "judges" and these tribunals come and go from time to time with no necessary connection one with another. The panel is the only thing permanent about the Court, and the members of the panel never meet as a body. There is a lack of continuity and of corporate spirit which weakens the institution as a whole. Moreover, the practical difficulty of getting a tribunal selected from the panel and getting the members together each time is not negligible. What is needed is a small court in substantially continuous session, in which a body of practice may be developed by the constant operation of the same body of judges.

The second weakness of the Court is its lack of continuity as to jurisdiction. As has been said, this jurisdiction is intermittent, not continuous. The only remedy, of course, is to define in advance the cases to be taken before the Court as they arise. This, however, gets over into "obligatory arbitration" and has been given full treatment already.

As it stands in the First Convention the definition of

${ }^{1}$ Hershey, § 316. 
cases proper for submission to arbitration upon agreement by the parties is ambiguous. In one place it is said that any sort of dispute may be submitted to arbitration. ${ }^{1}$ In another place it is pointed out that certain types of questions - the interpretation of treaties, for example-are especially suited to this method of treatment. ${ }^{2}$ This implies some uncertainty as to the true nature of arbitration. There are certain questions which, if submitted to arbitration would undoubtedly be settled, and would almost necessarily be settled, on the basis of existing law. There are others which, if submitted to an arbitral tribunal, would have to be settled as the members of the tribunal thought best in the interest of all concerned, on grounds of common justice. The nations in committing cases of the latter type to arbitration neglect the necessary task of laying down more fully the principles and rules which are to be followed in the conduct of international relations and make of the arbitral tribunal in part a diplomatic conference or a legislative body. When it is borne in mind that the tribunal usually contains one "representative" of each of the parties, the result is obvious. The Hague system does not carry arbitration far enough in the direction of judicial settlement by law. ${ }^{3}$ The members of the Court have not universally been jurists, but, have too frequently been diplomats. Furthermore, the procedure of the Court itself has not served well the purpose of giving the trial the character of a judicial settlement. Altogether, the legal elements in the institution are not given the prominence which they deserve.

Finally, the complexity and expense of the procedure under the Hague system are too great. This is partly because the Court must be organized anew for each case. It is partly because the use made of the Bureau in the actual

1 I H.C. '07, Art. 42.

'Same, Art. 38.

"Lansing, R., "Some Legal Questions of the Peace Conference," in Am. Jour. Int. Law, XIII, 636, 638 (October, 1919). 
trial of cases is small. It is partly because there is no provision for spreading the expense of the Court, or, rather, of the trial tribunals, over all the members of the system. The parties to the case pay all the expenses. ${ }^{1}$ That means that almost none of the expense of the system is carried as an overhead charge. The result may be estimated by imagining that the salaries of judges were included in the costs of litigation in national jurisprudence. For great states this factor is not of supreme importance. But where the parties bear equal shares of the expense of the trial the smaller state may well find the cost prohibitive.

As has been seen, efforts were made in 1907 to remedy some of these defects. Between 1899 and 1907 some thirty treaties were' concluded among states which were members of the Hague system providing for obligatory arbitration in certain cases. ${ }^{2}$ The Conference voted, in commission; on several proposals of this sort, and in all cases the proposals commanded a majority of the votes-in several cases threefourths of those voting. The conference finally adopted by unanimous vote a resolution in favor of obligatory arbitration in principle, and of its extension by bilaterial conventions. $^{3}$ In addition to this, provisions were adopted for inducing arbitration by action of member states not parties to the dispute in reminding the parties of the possibility of having recourse to the Hague Court, ${ }^{4}$ and provisions whereby one party to a dispute may notify the Bureau and, through the Bureau, its opponent, of its willingness to submit the dispute to arbitration. ${ }^{5}$

Two or three other decisions were taken at The Hague in 1907 which deserve special attention in this connection. There was adopted as the Second Convention of the Conference in 1907 an agreement providing against the use

1 I H.C. '07, Art. 85.

'Hershey, §313.

- Final Act of Second Conference, Pars. 19-21, below, in Appendix A, Document No. 9.

I H.C. '07, Art. 48, Par. 1.

Same, Pars. 3, 4. 
of force in the collection of contract debts, ${ }^{1}$ the agreement being subject to the proviso that the debtor state should not refuse arbitration on the question. ${ }^{2}$ By this agreement and counter-agreement obligatory arbitration was, in effect, provided for upon this subject. In the debates in the Conference the advocates of obligatory arbitration sought the adoption of this Convention on its own merits, being careful, prior to its adoption, not to put it forward as an agreement for obligatory arbitration. Likewise the opposition solemnly maintained that they were voting, not for obligatory arbitration, but against the use of force in the collection of international contract debts. After the Convention was adopted there was no doubt about what had been done.

The Conference of 1907 likewise adopted a Convention for the establishment of an International Prize Court. ${ }^{3}$ It was provided that certain cases could be carried to that court by parties under certain circumstances as they arose. ${ }^{4}$ Here also, in effect, was automatic or obligatory jurisdiction. In the event the Convention was not put into operation, but the reason does not lie directly in the feature just mentioned, which was accepted by all parties.

Similarly, the Conference drew up a convention for a new Court of Arbitral Justice, ${ }^{5}$ and provision was made in this Convention for what amounts to obligatory arbitration in default of affirmative action of one party to a dispute where the other has taken the case to the Court. ${ }^{\circ}$ This Convention also has failed of adoption, but likewise for reasons only remotely connected with the feature of obligatory arbitration.

Mention of the proposals for new courts which were

1 Scott, Conferences, II, 356, Art. 1, Par. 1.

Art. 1, Par. 2.

- Scott, Conferences, II, 472.

- Arts. 3-5.

- Scott, Conferences, II, 291.

- Art. 19. 
made in 1907, however, leads to an entirely new field. Attention must now be given to proposals for new international courts which were brought forward between 1907 and 1920. Already in 1907 it was suggested that the situation demanded not a revision of the old plan, but the creation of a new one $;^{1}$ and, as has been seen, two attempts were made at The Hague to bring this about. Finally, in 1920 an attempt was made to create a new court which should operate under the League of Nations, albeit as a distinct body. To these successive efforts we must now turn.

${ }^{1}$ Scott, Conferences, I, 423-464. 


\section{CHAPTER XVI}

\section{PROPOSED INTERNATIONAL COURTS}

T $\mathrm{N}$ the course of the criticism of the Hague system of international arbitration, and as a result of the same movement for an improvement in the methods of the judicial settlement of international disputes which led to the revision of the Hague Convention in 1907, three outstanding efforts have been made to create new international judicial bodies. A study of these efforts, and a comparison of the arrangements proposed with those of 1899 and 1907, will throw much light on the present status of international judicial organization and upon the place of judicial settlement in international organization as a whole.

The first effort was the signing, at the Second Conference at The Hague, in 1907, of a convention for the creation of an International Prize Court. ${ }^{1}$ In some ways this is the most radical step ever taken in the field of international organization. ${ }^{2}$

The International Prize Court was to be composed of fifteen jurists ${ }^{3}$ appointed by the participating nations according to a plan ${ }^{4}$ whereby the judges appointed by the eight Great Powers-as things stood in 1907-were to sit at all times on the court, while those appointed by the lesser powers were to be present in rotation, in such a way that judges chosen by powers of secondary rank would appear less frequently than those chosen by the Great Powers, but more frequently than those chosen by powers of third rank,

${ }^{1}$ Scott, Conventions, 188-203, eited hereafter as XII H.C. '07.

'Higgins, 431-444.

XII H.C. '07, Art. 14.

- Art. 15. 
and so on. Nations were always to be represented on the bench in cases arising from a war in which they had participated, but judges who had been parties to cases in national courts were debarred from hearing those cases in the International Prize Court, and the judges in general were barred from appearing as advocates before the court. The general expenses of the court, including the salaries of the judges, were to be paid entirely from a general fund contributed by member states. The Bureau and Administrative Council created by the Hague Convention of 1899 were to serve this court as well as the Court of Arbitration. ${ }^{1}$.

In matters of procedure equally radical steps were taken. The court was given control over the use of languages in pleadings, with provision for the use in all cases of the language of the national court where the case had first appeared. Supplementary evidence might be called for, or even taken directly by, the court. The discussion of cases before the court was to be public, subject to the right of either party to the case to demand privacy. Even in such an event minutes of the discussion were to be kept, signed, and published with the judgment. Costs of the trial were to be borne by the unsuccessful litigant. ${ }^{2}$

In the matter of jurisdiction the Prize Court Convention went still further. The cases which might be brought before the court on appeal were defined in advance. The parties capable of bringing appeals were so defined as to include not only neutral states but neutral individuals, and even citizens of belligerent enemy powers. Normally, cases might be carried to the court only after final judgment in the national courts. But if this were delayed over two years the case might be taken direct to the international court. ${ }^{3}$

In either event action was to be brought in the inter-

Arts. 16, 17, 20, 22, 47.

Arts. 24, 36, 39, 45, 46.

Arts. 1-6. 
national court by written declaration in the national court, followed by transmission of the record of the case by the latter tribunal to the former, or notice to the Bureau, followed by a call from the Bureau to the national court for the record of the case, and, apparently, notice to the other parties. Judgment might be given against a party cited to the court in spite of failure to appear or failure to comply with rules of procedure in the court, and the decision was to be notified to such a party. ${ }^{1}$

The basis for the adjudication by the court was to be international law-conventional or treaty law if there were any treaties applicable to the case, common or customary law otherwise, and justice and equity in the absence of any recognized rules that were applicable. The court was given power to disregard national belligerent enactments contrary to justice and equity. ${ }^{2}$

The decision of the court was to be given in the form of an affirmance of the decision of the national court or, in the contrary case, an order for restitution of the prize property or a judgment of damages, or both. The participating states agreed in advance to accept and execute the court's decisions. ${ }^{3}$

The radical character of some of these provisions is evident, yet the Convention was actually signed by thirtythree states. ${ }^{4}$ Reservations were made by ten of these,on the whole, the less important ones,-relating to the. method of choosing the judges. ${ }^{5}$

It will be noted, especially, that "obligatory" adjudication was here provided for, and that the court was to be continuously available without any special agreement or discussion. ${ }^{6}$ The method provided for bringing the appeal

Arts. 28, 29, 40, 41.

Art. 7, especially Par. 5.

Arts. 8, 9.

Scott, work cited, 208.

- Same, 539; also Art. 15 of the Convention.

- Arts. 28, 29. 
through the Bureau served to emphasize this feature of the plan, as did the rule allowing decisions to be given in the absence of one of the parties.

Giving individuals the right of action in cases before the court was, furthermore, an indication that the stage of true international federation had been reached, for it has always been held that one of the marks of a true federation is to be found in the power of the organs of government of the federation to act upon individual members of the federated states and not merely upon or through those states as such. ${ }^{1}$ Conversely, it has been held that international law ran only between states pleno jure. ${ }^{2}$ As a matter of fact, of course, prize cases always affect private individuals directly and states as such only indirectly. It would have been possible to require action by the states in all these cases on behalf of their nationals. Provision is indeed made that the neutral state may act on behalf of its national, or even merely forbid him to act, ${ }^{3}$ and this might have been required in all cases. But it appeared more convenient to adopt the simpler, though more revolutionary, method. Some precedent for this step is found in the right often accorded to private individuals to appear before claims commissions established by treaty to act on behalf of two or more states. ${ }^{4}$ Likewise, international administrative bodies occasionally operate directly upon national citizens of the member states, as will appear later. When individuals who are citizens of a belligerent state are allowed to carry the enemy nation into court the significance of the procedure becomes greater still.

Some concessions were, indeed, made to the established crder of things. Such was the provision that belligerents should be represented on the bench in all cases affecting them. Such, too, was the provision putting special conven-

${ }^{1}$ Garner, Introduction, 151, 196-197.

${ }^{2}$ See Wilson and Tucker, Chaps. V and VI, for conflicting views.

Art. 4, (2).

4 Example in Malloy, 594-595. 
tional agreements ahead of general international law among the grounds of decision by the court. A still greater concession was made some three years after the signing of the Convention, a concession which related to the mode of bringing actions in the court and to the form in which the decisions were to be rendered. These changes, while they derogated from the significance of the plan in one limited particular, enlarged the meaning and consequence of the Convention in another direction. This whole matter may best be discussed in connection with the subsequent history of the Convention.

The Convention was not ratified and the court was not established. To understand why this is so is to understand much of the problem of internationl judicial organization.

It will be remembered that the court was to proceed upon international treaty law, common international law, and equity, in its adjudications. This provision fell far short of satisfying all the Powers, particularly Great Britain and the United States. In the first place, treaty agreements cover a relatively insignificant proportion of the field of prize law. Notwithstanding the mass of treaty agreements which exist, and it has been seen that that mass is very great, the court would by no means be able to find in treaties between the parties to cases brought before it rules to cover all the points of law arising in the course of the pleadings. In the second place, there is little "common" international law in matters of prize which really is "common," that is, little law which is generally or universally accepted. The law of prize badly needs standardization. Indeed, that is precisely why such a court as was here proposed is needed at all, and why international courts are needed in general. But the lack of agreed law is the greatest obstacle to the creation of courts to remedy that very defect. For, in the absence of precise and recognized law, the court must go upon "the principles of justice and equity," and, in the eyes of Anglo-American jurists, at 
least, that is dangerous. In England and America it is, of course, assumed that the law will be, and is, in the long run, substantially in accord with ethical justice and social equity. It is held, however, that whether this be true at a given time or not, the court must apply the law as it stands and leave to others to whom it properly belongs- the legislative body-to make the law to conform to the standards of justice." The motto "let justice be done though the heavens fall," has been revised to read "let the law be enforced though justice be slain in the process." In England and America ethical right and legal rights are not necessarily synonymous. The civilian or continental jurist of France or Germany sees no such distinction between the two sorts of right, between justice and law. But to American and English jurists "equity"-particularly in the hands of continental jurists,-may well be merely a means through which personal or political preferences and prejudices express themselves. In Britain this was a particularly serious consideration, in view of what some continental legal critics had been saying from time to time regarding certain rules of British prize law. Indeed, there is little doubt that the German sponsors of the International Prize Court had something of this in mind in proposing the scheme. ${ }^{2}$

At all events, Great Britain determined not to ratify the Convention until the law to be applied by the court should be defined. ${ }^{3}$ In this she was supremely right, quite apart from motives of self-defense and self-interest. The lack of agreed law lies at the very threshold of the backwardness of international judicial organization. Accordingly, a Naval Conference was held under British auspices in London in 1909, and a convention called the Declaration of London was signed which consisted of a code of the law

${ }^{1}$ Bertholf v. O'Reilly, 74 N. Y. 509.

2 Hall, 1-5; Higgins, 431-432, 438.

Garner, World War, § 19. 
of prize. ${ }^{1}$ Incidentally, it may be noted that this code pretended to be, not new law created by the Naval Conference, but the existing law, and that in its substance it was exceedingly liberal to neutral commerce, reaching, indeed, the high-water mark of the American campaign for the freedom of the seas for neutral commerce in time of war. And it was so primarily because Britain yielded so largely to the continental views of her guests.

The Liberal Ministry of the day was, however, unable to carry the plan through Parliament. A bill to enable the Government to adopt the Declaration and proceed with the establishment of the International Prize Court, after having been passed in the Commons, was defeated by Navy and Empire people in the House of Lords. ${ }^{2}$ In the minds of the peers other political issues were connected with the Declaration. Mr. Lloyd George's budget and taxes were bad enough, the reform of the House of Lords was worse, and the Declaration was, taken on top of it all, too much entirely. The first two measures were accepted, but the third was refused. After the reform of the House of Lords had been accomplished in 1911, and its power to defeat Government measures which had passed the Commons thereby largely taken away, a new bill was prepared to render the Declaration and the Convention effective. The outbreak of war, in 1914, prevented final action, however, and there the matter rests today. ${ }^{3}$

Meanwhile no other state had ratified either the Declaration or the Prize Court Convention. The Senate of the United States consented to ratification in 1912, but the President, acting as had all the other signatory parties, waited upon the decision of Great Britain. ${ }^{*}$ The reason for this is simple, even if it be not obvious upon the surface. Britain, having a maritime supremacy not questioned by

1 Text in Malloy, III (Charles), 266.

${ }^{2}$ Garner, World War, § 21.

"Myers, D. P., "Record of The Hague," 17, note 4.

${ }^{4}$ Garner, as cited, 29, end. 
any other power, could and did write the law of prize. It would have no effect for a weak naval power to try by itself to reform that law. Nor would it have been of any real effect for all naval powers in defiance of Great Britain to attempt to change prize law by agreement. Other nations could expect to be neutrals in most cases and subject to British belligerent rights. And if they anticipated belligerency themselves they could not afford to resign belligerent rights which, as neutrals, they would have to concede to Britain in her belligerency. In the course of a century they would make few captures, while Britain would make many. The law enforced by Britain would be ruling prize law. Prize law has been, in the past, nothing but a measure of British self-restraint in naval war. As in so many fields of international law, the progress of the law is fixed by the minima set by the least advanced state. There being no balance of power at sea, this was inevitably the case in prize law. What is to happen in the future is less certain.

As a matter of general gain and loss, it is probably a good thing for the cause of international law and organization that the Declaration and the Convention were not ratified. The Declaration was unsound in the extent to which it restricted belligerent rights at sea. ${ }^{1}$ If the Court had existed during the World War, and had attempted to apply the rules of the Declaration, one of two results would have followed. Either the Central Powers, who had been the greatest opponents of the development of international organization in the years before the war, and who were undertaking their adventure of conquest in the same spirit, would have been successful in the war, or the Allies would have been induced to repudiate the Declaration and the Court. Either event would have been disastrous to the general cause of international law and organization. The whole episode well illustrates how dangerous it is to attempt to organize society-national or international-

${ }^{2}$ Garner, as cited, $\S 23$. 
on the basis of law if perchance that law happens to be unsound, and also how unwise it is to attempt to reform international practices-such as the practice of capture and condemnation of property at sea in time of war-from the outside, without attacking the causes at the bottom, namely, the freedom to make war.

A second event in the history of the Prize Court Convention must be noted. In 1910 there was signed at The Hague a protocol ${ }^{1}$ revising certain provisions of the Convention so that appeals to the court should take the form of actions against the nations for damages, not of appeals in the original cases as tried in the national courts. ${ }^{2}$ Other changes were necessitated by this principal alteration, and it was provided that the international court should not pass on the validity of captures under national prize law, nor act in any way upon decisions of the national courts. ${ }^{3}$ The court was not to act upon the subject matter of the original cases or order restitution, but to award damages against the nation. 4 So far, the significance of the Convention seems to have been diminished, although more because of the obstacles raised to further international organization in the future than because of any obstacles to the securing of substantive justice in the prize cases contemplated by the Prize Court Convention.

Even so, the protocol of 1910 introduced other changes which in some ways more than make up for these revisions. All cases thereafter were to be carried to the international court by notice to the Bureau, the governments of the participating nations were always to be made the defendants in actions before the court, and the decisions of the court were always to run against these governments. Here is obligatory adjudication and consent to be sued, with a vengeance!

Of course, these changes tended to destroy the strictly

${ }^{1}$ Scott, work cited, 204-208; cited hereafter as Protocol.

Protocol, Art. I.

Same, Art. II.

- Art. I. 
federal character of the union created by the Prize Court Convention and to reduce this union to a confederation. The alleged ground was the constitutional inability of the diplomatic representatives of the individual nations to involve the latter in an arrangement whereby judicial procedure by the national constitutional law was altered by adding a stage of international appeal. ${ }^{1}$ Such an objection, if pressed in all its logical applications, would absolutely prevent international organization of any kind. All international arrangements modify to some extent, by adding further steps of procedure, the national constitutional systems of the participating nations, some more, some less. There is some difficulty in accepting the conclusion that a constitutional agent of the state is incapable of committing the state to an arrangement which would alter the nature and world-position of the state merely because of the magnitude of the consequences, providing, of course, that the agent acts otherwise within the limits of his constitutional powers. Such a contention was dealt with for America pretty conclusively in 1803. If diplomatic representatives and the treaty-making organ are to be denied such a power, then there is an end to the process of international federation. The obvious answer is that nothing of the kind is going to happen, if the experience of the past century is any guide. Sudden and radical steps, such as the Prize Court Convention undoubtedly was, will lead to gasps, hesitation, and even, perhaps, steps backward. Progress in this work must be graduated to the rapidity with which public opinion and feeling develops throughout the world. But the work has gone on so long and so far as to make it inconceivable that it will suddenly come to an end, especially in view of the persistence and intensification of the forces which in the past have caused that work to be undertaken.

A second effort made at The Hague in 1907 to create ${ }^{1}$ Higgins, 443, and Scott, as cited, 204. 
new international tribunals was the drafting of a Convention for the establishment of what was to be called a "Court of Arbitral Justice." 1 As this Draft Convention was not signed, a brief examination of its provisions will suffice.

As in the case of the Prize Court, the tribunal proposed by this Draft Convention was to be small in size, strictly judicial and legalistic in character, and was to be continuously available for cases proper to be submitted to it. In most respects, indeed, it was a duplicate of the proposed Prize Court. ${ }^{2}$

In one particular the two proposals were similar in conception, yet experienced widely different treatment in the outcome. This was in the matter of composition of the court, the choice of judges, and their service on the bench. As always, the smaller states demanded equal representation. This might conceivably have been granted by the Great Powers, on the assumption that the work of the court would be purely judicial in character, based upon previously established law, and that hence, so long as competent jurists were secured, it would make no difference whether or not they, the Great Powers, were "represented" on the bench in proportion to their power and responsibility; or it might have been granted on the assumption that the judges appointed by the Great Powers would exert a controlling influence in the work of the court in spite of mere numbers or the lack of them. Both of these assumptions would be true, in the main, and would, of course, in so far as they were true, similarly undermine the force of the demand of the smaller states.

But the Great Powers were not willing to concede equality of representation. The law is so unsettled that the court would in many cases be called upon to decide according to the opinions of the judges as to what was right and just-or agreeable-to the family of nations, and to their

${ }^{1}$ Higgins, 31-39.

${ }^{2}$ Arts., I-VI, XIV. 
own nations among the rest. The court would often have to make the law which it applied. In such circumstances the Great Powers felt entitled to representation in proportion to their responsibility and their power, and, if an opinion upon the merits of the problem be in place here, it would appear that they were thoroughly justified in such a position. Nations must receive equal treatment as litigants before the court-equality before the law as to the enjoyment of recognized rights-if any stable international system is to exist at all. ${ }^{1}$ To maintain, on the other hand, that they should be equal in political power in making law, that the two million people of Haiti and the one hundred million people of the United States are entitled to the same influence, and no more, in the determination of the content of the law of nations, especially upon constitutional and political questions, because they happen to be organized in two, and only two, independent states, is to become the victim of some subtle form of legalistic superstition. In addition, to have created a court containing one judge from each state would have been to create a court too large for all practical purposes. ${ }^{2}$

A solution of this difficulty had been sought in the case of the Prize Court through the plan already described, whereby the judges named by the Great Powers were to sit constantly, and those named by the lesser powers only for a part of the time, in rotation. This plan had been accepted by fifteen of the lesser powers signatory to the Prize Court Convention, including such states as Argentina, Belgium, Bolivia, Denmark, and Sweden, ${ }^{3}$ but rejected by ten of the signatory states, including Chile and Turkey, but including also Guatemala, Haiti, Persia, and Salvador. ${ }^{4}$

This solution was rejected entirely by the lesser states in regard to the Court of Arbitral Justice. ${ }^{5}$ The Great

1 Dickinson, 335.

${ }^{2}$ Scott, Conferences, 456-457.

Scott, Conventions, 208.

- Same.

- Scott, Conferences, 459. 
Powers, it was admitted by some, might be entitled to a preponderant control of the bench of the Prize Court, in view of the probability that they would most frequently be belligerents whose interests would have to be passed on by the court. But in regard to the great range of questions under the law of nations, outside of prize law, and arising in time of peace, no such considerations were admissible. To consent to inequality here meant to abandon the principle itself. Hence the plan which was accepted in one Convention was rejected in the other.

It may well be admitted that the lesser powers were right in feeling that surrender here meant surrender for good and all. It is not obvious, however, that they were well advised in admitting the relevancy of belligerent strength and interest in distinguishing the Prize Court from the Arbitral Court. After all, that is the principle for which the Great Powers stand throughout this whole problem, namely, that their greater physical power and interest and responsibility entitle them to greater legal power in international government. If this be true in the case of the Prize Court, it is true in some measure in the case of any international court.

Opportunity was provided again in 1920 for the lesser powers to pass upon this question. The same problem of the composition of the bench arose in connection with the third attempt to create a new court, this time under the auspices of the League of Nations. To this we now turn.

When the Covenant of the League was drawn up in 1919 attention was considerably removed, for the time being, from projects and plans for judicial organization such as those adopted in 1899 and 1907 at the conferences at The Hague. There were three or four principal reasons for this. The Hague system still stood and was available at any time. Moreover, what was now needed was, not machinery for applying existing law to the details of international disputes after they arose, but machinery to make law or to devise formulas for settling international prob- 
lems as they appeared and developed, and before they reached the stage where they presented a joinder of issue susceptible of judicial treatment. Third, technical problems such as the organization of a court were very generally left for the future, the Covenant merely laying down the main principles of international organization. Finally, it is clear that the diplomats and political leaders who made up the Peace Conference of Paris attached comparatively little importance to law and lawyers, to judges and judicial settlement. As a result, the first draft of the Covenant contained simply a provision ${ }^{1}$ for the later formation of a court, and the final text contains nothing further except a provision for advisory opinions by the court when it shall have been established. ${ }^{2}$

This episode raises the broad question of the value of judicial settlement in the organization of the international community. The League has been severely criticised in the United States by leaders of the legal profession and by those who have supported the development of international arbitration because it is intended to operate so largely by means of diplomatic conferences, political recommendations, and military or economic intervention. It is maintained that international peace and order depend on doing justice to all nations and that the only reliable method to be followed with that object in view is that of judicial settlement. The more careful students of international organization who feel this way go on to couple with the demand for judicial settlement a demand for international law-making conferences to codify, revise, and amplify the system of international law. ${ }^{3}$

Without such an additional demand the view just stated is, indeed, extremely inadequate. It goes on the assumption that the existing system of international law is sufficiently complete to cover all cases arising for submission

Art. XIV of first draft, in Sen. Doc. 46, 66 Cong., 1 Sess., 18.

${ }^{2}$ Covenant, below, Appendix A, Document No. 15, Ärt. XIV.

- This view is well set forth in Oppenheim's Future of International Law. 
to arbitration or judicial settlement, or that the court will be able to evolve the necessary legal rules in the course of the proceedings on a case, by reasoning from analogy or by the application of the principles of equity, or in some other way. As a matter of fact, the existing system of international law is, as has been seen, very incomplete; it fails to cover the whole of the field of international relations and it fails to treat in sufficient detail even those portions which it does cover. Moreover, to reason by analogy and to base decisions upon the judicial notion of what is just and right is especially dangerous in this field, where fundamental principles and first premises are so largely in dispute. It is to demand a respect for the courts as makers of the law which continental peoples do not share, accustomed as they are to regard the courts largely as administrative organs of the state. And it is to open the door to political opinion, personal judgment, and national prejudice on the part of the judges in a way which should be particularly obnoxious to precisely those people who are advocating this step.

Even where the additional demand is made for legislative conferences, the view in question is in some measure defective. It assumes the feasibility of reducing international relations at once to general rules and defining in a form applicable in courts of law the rights and duties of nations. Such an assumption appears overbold and oversanguine. The extreme difficulty of finding acceptable formulas of settlement for application in the crises of international relations is well known. The outbreak of a war is usually attributed to the desires and demands of one or both of the parties, with the implication that these demands are irreconcilable. With equal propriety it might be attributed to a failure on the part of the belligerents, and the other members of the family of nations, to find a formula of settlement acceptable to the disputants. ${ }^{1}$

${ }^{1}$ Examples in New York Times, 21 April, 1918, §5, pp. 1-2, and 26 November, 1921, p. 1, column 6, end. 
We know but little about the inherent nature and the essential rights and wrongs of international life. Even the basic principles are hardly fixed as yet. The Civil Law of private relations is over ten centuries old, the English Common Law about as old; the science of international relations, dealing with a subject-matter far less stable and far narrower and more uneven in the foundation which it offers for the development of fixed rules, is only three centuries old at the outside. It is, by comparison, in its infancy. Hence the difficulty of the task; hence the impossibility of rapidly expanding the code of the law of nations; and hence the need for just such conferences and arrangements and bargains in the diplomatic and political field as are opposed by the lawyers and the jurists. In the pre-legalistic and pre-legislative stage in which international society still largely finds itself these deliberative agents are indispensable.

In time, the promise of the Covenant that a new court should be created was made good. A committee of private jurists was asked by the Council of the League to meet at The Hague in 1920 to devise a plan for the court; ${ }^{1}$ and on June 16 of that year the jurists of ten leading powers met and proceeded to the task. ${ }^{2}$ A Draft Scheme for the Establishment of the Permanent Court of International Justice was completed in July. ${ }^{3}$ This Draft, modified in one important respect by the Council, was submitted by the Council of the League to the League Assembly at its first meeting, at Geneva, in November, ${ }^{4}$ and was approved by the Assembly, with some alterations. ${ }^{5}$ It constitutes the last effort down to 1921 to reorganize the Hague system, and deserves attention as such. The actions of the Council

${ }^{1}$ League of Nations, First Assembly, Document No. 14, as cited, 21.

${ }^{2}$ Same.

Same, 7-17.

- League of Nations, First Assembly, Procès-Verbaux of Committees, No. 3, p. 3 .

${ }^{5}$ League of Nations, First Assembly, Provisional Verbatim Record, Monday, 13 December, 1920, afternoon session, 4 P.M., p. 13. 
and of the Assembly are also not without significance in themselves. ${ }^{1}$

The principal problems faced in the formation of the new court were the composition of the tribunal, its jurisdiction-both as to what cases were proper for submission and the method to be used in bringing cases before itand the bases of the decisions to be rendered by the court. On all other points the court resembles the Court of Arbitral Justice proposed in 1907. Thus, the bench is to be occupied, not by diplomats, but solely by jurists, chosen, it is expected, upon the advice of the highest national courts and faculties of law in the individual nations. ${ }^{2}$ The court is a court of "justice," not even a court of " arbitral justice"; we are beyond arbitration. Continuity in the sessions of the court is provided for ${ }^{3}$ and the general expenses of the tribunal are to be borne by the League. ${ }^{4} \mathrm{~A}$ majority vote is to be decisive ${ }^{5}$ and the decision is to be accompanied with reasons. ${ }^{6}$

Only one important concession was made to the old order of things. After it was provided, in the beginning, that the judges shall be chosen without regard to nationality - a new step in advance-it was also provided that in each case tried by the court the parties should be represented on the court by one means or another. ${ }^{7}$ The reason assigned is that not only must impartiality be assured in the operations of the court but also the appearance of impartiality. ${ }^{8}$ So long as nationalism remains as strong as it is today it is probably impossible to find a better solution of the difficulty.

1 For account of the whole matter by one of the participants see Scott, in Carnegie Endowment, Year Books, 1921, 104-131.

Draft Scheme, Arts. 5, 6, in Document No. 44 of First Assembly of League of Nations, 108.109.

Same, Arts. 24, 26.

Art. 30.

- Art. 54.

- Art. 55.

Arts. 2, 7, 28.

Bocument No. 44, as cited, 43-44. 
The Draft Scheme diverges further from the precedents in the handling of the three central problems involved, namely, the composition of the court, its jurisdiction, and the bases of its decisions.

As finally created, the tribunal is to be composed of fifteen judges, nominated, to the number of four each, by the national groups in the panel of the Hague Court of Arbitration, and elected by majority votes by the Assembly and Council of the League, voting independently, provisions being made for reconciling divergent elections by the two bodies and for filling the bench in spite of failure on the part of these bodies to elect. ${ }^{1}$ Thus the question of state equality is avoided, or ignored, or transmitted to the electoral bodies. The solution has been hailed as a recognition of the principle of state equality, in that it does not specifically provide for representation of the powers according to size and strength. ${ }^{2}$ It is doubtful, however, whether such an interpretation is sound. It is expected, naturally, that in the elections in the Council, where they predominate, the Great Powers will choose their own representatives and that the lesser powers will control the choices made by the Assembly. The result will be the necessity for a compromise between the Council list and the Assembly list. That compromise is to be made at the start by a joint conference committee ${ }^{3}$ and, failing this, the judges already chosen are given power, if and when entrusted with that task by the Council, ${ }^{4}$ to fill the bench by election.

It will be seen that the settlement of the problem of equality of representation is simply postponed and disguised. The issue is not posed in its obvious form, and several steps are provided for its treatment. The smaller powers represented in the Assembly at Geneva, therefore,

1 Draft Scheme, Arts. 3-12.

Verbatim Record of First Assembly, as cited, p. 8.

Draft Scheme, Art. 12, Pars. 1, 2.

-Same, Par. 3. 
felt safe in accepting the Draft Scheme on this point. Nevertheless the problem is latent in the Draft Scheme, and will have to be met whenever the elections take place. Moreover, as the rules stand, the Council of the Great Powers may block the elections until assured of what they consider their due share of the judges, while the smaller powers are without similar power except likewise to block the elections by refusing to give the Great Powers that "due share." Thus the deadlock of 1907 may reappear. If it does so, it will be the direct result of a continued refusal or inability to face and settle by agreement the critical problem of state equality in international representative bodies. ${ }^{1}$

The Draft Scheme attempted to define the bases of decision of the court in explicit terms. The court is to apply, in order, the following: international conventions between parties to the case before it, international custom, recognized general principles of law, national judicial decisions, and the writings of publicists. ${ }^{2}$ Contractual agreements are put in advance of common law, law in advance of abstract justice. National judicial decisions and private juristic writings are naturally placed last. With most of this no fault can be found.

The problem of jurisdiction was more troublesome. The questions proper for submission to the court were defined by the committee of jurists as questions concerning treaty interpretation, questions "of international law," questions of fact under the preceding legal obligations, the nature and extent of reparation due under the same, and the interpretation of its own decisions. ${ }^{3}$ The last class of cases calls for no comment. The fourth constituted a great step in advance; the court was thereby empowered to fit the penalty to the offense at its own discretion. The third

${ }^{2}$ For elections in 1921 see, below, Chap. XXIX.

Art. 35.

Art. 34 of original text, Document No. 44, p. 12, 
class referred back to the second and the first, and here it is seen that international contracts were to take precedence of common law questions, as might be expected, but that common law questions were to be turned over to the court wholesale, despite the unsettled state of the law. The court was given the further power to deeide whether a given case fell within any of these classes. This was tantamount to reviving all of the difficulty connected with the Prize Court of 1907, especially when the method of bringing action in the court and the ambiguities in the choice of judges are recalled.

For action was to be brought in the court by one party at will, without previous agreement with the opponent, and a decision was to be rendered, if justified on the merits, in default. ${ }^{1}$ In other words, compulsory or obligatory jurisdiction was provided for. The committee was somewhat divided within itself as to the advisability of this step, and, indeed, as to the power of the committee to in. clude such a proposal in their plan under the provisions of the Covenant governing their action. ${ }^{2}$ Nevertheless, in reliance upon the sovereign power of the states which were to adopt or reject the plan to establish such a court as they saw fit, and in reliance on the progress made at The Hague in 1899 and 1907, the proposal was made.

The recommendations of the jurists on these matters were too radical for the Council of the League, to which body the plan was first referred. Before passing the plan on to the Assembly for approval, the Council therefore revised the Draft, deleting all definition in advance of cases to be brought before the court, and all provisions for action by one party to a dispute-in short, all obligatory jurisdiction. The jurisdiction of the court was made to depend upon special consent of the parties to a case, either

${ }^{1}$ Same, Arts. 33, 52 of original text. $7,11$.

${ }^{2}$ Procès-Verbaux of Committees of First Assembly, as cited, No. 5, pp. 
in a compromis concluded after a dispute had arisen or in a treaty of obligatory arbitration previously concluded between them. ${ }^{1}$ The Council felt compelled to rely upon those provisions of the Covenant which create obligations for the members of the League to resort to arbitration in international disputes of a justiciable nature, without accepting a mechanism such as proposed by the jurists for making those obligations easily effective. ${ }^{2}$ It was deemed impossible to accept a scheme which varied from the rules of the Covenant at two or three points. The Covenant envisaged arbitration only by mutual consent of "the parties"; it authorized one party to a dispute to withhold a case from arbitration if the dispute was not "suitable" for submission to that process; and it held out the alternative of subjecting the dispute to inquiry by the Council. ${ }^{3}$

The Draft Scheme definitely varied from these rules, as has been seen. It was suggested that to accept and recommend the. Draft Scheme as drawn was outside the power of the Council, acting under the Covenant, inasmuch as this would be to propose something in violation of the Covenant. If the Covenant was to be amended, it must be done in the prescribed manner, not by indirection. Even assuming that the members of the League possessed legal power to adopt the Draft and so, in effect, to modify the Covenant without amending it formally, it was felt that it would be bad policy to begin the practice of alteration so soon in the life of the League. It was also felt that many states would object to the substance of the change and would refuse to accept the obligation as stated, no exceptions being made for national honor or vital interests, and -with escape by submitting to inquiry by the Council thereby cut off. ${ }^{4}$

${ }^{2}$ Draft Scheme, with alterations by Council, in Document No. 44, 112-113 (Arts. 33, 34, italies).

${ }^{2}$ Procès-Verbaux, as cited, No. 3, pp. 3-4, and No. 5, p. 8.

Covenant, Arts. XII-XIV; below, Appendix A, Document No. 15.

'Procès-Verbaux, as cited, No. 5, pp. 8-11. 
To these suggestions no adequate replies were given. In the committee, the Japanese and Italian delegates were strongest in their objections; in the Council the British and French. An attempt was made to show that the term "parties" in the Covenant might be taken to mean "one or more of the parties," but this was felt to be a strained interpretation. Again, it was maintained that the difficulties might well be passed on by the Council to the members, and that if they actually accepted the Draft these difficulties would themselves disappear. The trouble with such an argument was that the Council desired, above all, to present a scheme which would stand a good chance of being accepted. Besides, the members of the Council were not themselves, in all probability, ready to accept such a drastic scheme. At all events, the Council took the decisive action described.

The Assembly at Geneva approved the Draft as revised by the Council, with a few changes. ${ }^{1}$ Many members desired to restore the provisions for obligatory arbitration. ${ }^{2}$ To do so would have been to court the opposition of the Great Powers in control of the Council-Great Britain, France, Italy, and Japan. For the acceptance by the Assembly was not to be definitive. The Covenant provided for the creation of the court by the "Members of the League." 3 Approval by the Assembly was of no legal effect, ${ }^{4}$ and only acceptance and ratification by the members of the League acting as sovereign states could create the court. If the Assembly had restored obligatory jurisdiction to the Draft, the Great Powers would, it may be feared, have failed to ratify. The changes in the Draft Scheme which the Assembly pretended to make derive their authority. only from the fact that they are acceptable to the members

${ }^{1}$ Documents Nos. 216, 199 of the First Assembly, especially Document No. 199 , pp. 5-6, 14-15.

Verbatim Record, 13 December, 1920, morning and afternoon sessions.

- Covenant, Art. XIV.

- Procès-Verbaux, No. 15, p. 4, M. Leon Bourgeois speaking. 
of the Council, some of whom assisted in the work of the Assembly.

The Assembly did, however, provide a means whereby members of the League, by a special protocol, might accept the Draft Scheme with the provisions for obligatory arbitration included. This protocol was eventually accepted by some fifteen states, which thus carried the process of international judicial organization considerably beyond anything previously attained. The more important states, however, have chosen to stand upon the more conservative decision of the Council.

Comment on this action is hazardous. The Great Powers, that is, the Allies, who were in control of the Council, took a very definite action, an action characteristic of Germany as she appeared at The Hague in 1907. A public explanation has been given of that action as outlined above, yet we are free to form our own opinions upon the matter. In the first place, these Powers are amply protected in the method of selecting the judges. Secondly, the Covenant provides an obligation upon the members of the League to submit disputes to arbitration in the cases named by the jurists in the original version of the Draft Scheme, even if it leaves actual submission to depend upon special agreement at the time or some previously existing treaty. Whether the Council could not have, and might not better have, supplemented these provisions by accepting the Draft; whether the Great Powers acted upon reasonable and honorable grounds; whether the Draft Scheme as revised means much or little in the development of arbitration, time alone can tell. Certain it is that Great Britain, France, Italy, and Japan blocked a step which would have meant vastly more in the cause of international organization than anything done so far by either the Council or the Assembly or the two together. 

PART V

INTERNATIONAL ADMINISTRATION 



\section{CHAPTER XVII}

\section{OFFICIAL UNIONS, COMMISSIONS, AND BUREAUS}

T $\mathrm{N}$ addition to the international institutions already ex1 amined, there has appeared in recent years another device for use in world government, namely, the international administrative bureau. ${ }^{1}$ This institution fills a special place in the international constitutional system and yields rich results when carefully examined in comparison with the simpler forms of international organization.

We have seen that the outstanding defect of arbitration or judicial settlement is that such a process can be applied only when a dispute has arisen between nations. It is, therefore, a relatively uneconomical mode of caring for the maladjustments, the abnormalities, the breaks, in international life. An institution is needed to take care, now and in the future, of the normal, current, day by day business of international relations, the great bulk of which goes forward without contention, dispute, or interruption.

Simple personal diplomacy cannot perform this task. The established diplomatic representatives attempt to carry along the relations between the nations in the field of public law and high politics; and within that field the accredited diplomatic representatives possess a great advantage over the administrative bureau because they possess a measure of legislative power, a power to change the very conditions of their own work, while the bureau has no such power. But the great body of international intercourse concerns private individuals, and not so much high politics as travel,

On international administrative bureaus see literature, cited below, Appendix $\mathrm{B}, \S 17$. 
commerce, and business. For the supervision of these forms of international activity something is needed unlike a court of arbitration and unlike a diplomatic representative. Some public official or governmental body with fixed personnel is needed to work in the field now occupied by the consul, but which will be free from the limitations of a national mandate and a restricted consular district. Such is the international bureau or commission.

The international administrative bureau has not, until very recently, received the attention which it deserves. For this there are several reasons. The institution is comparatively new; it is rarely spectacular in its operations; and it is hidden among the petty events of daily life, instead of being placed conspicuously out in the glare of high politics. Speaking broadly; the bureau does not affect national policies or international politics, and its work is done unostentatiously and silently in the world of business and private affairs.

The international bureau proper has for close neighbors in the general field of world intercourse the private international organizations such as the International Association of Medicine. Such bodies lead off into the highly fascinating subject of modern cosmopolitanism, to which attention will presently be turned. We are here concerned only with official international bureaus or commissions, of which there were, in 1915, some forty-five. ${ }^{1}$

1 This figure is based upon a comparison of data given by Reinsch, Sayre, Woolf, and others, and certain primary materials. It includes only bureaus and commissions and omits all conferences or associations not possessing such bureaus. It does not include several bureaus which had been ereated prior to 1914 but which had passed from the scene in one way or another. The complete list on which the conclusions of this chapter are based is given herewith:

International Administrative Bodies in Operation in 1915 Central Rhine Commission, 1804

Douro River Commission, 1835

Sanitary Council at Constantinople, 1838

International Sanitary Council of Tangier, 1840

Danube Commission, 1856

Universal Postal Union, 1863 
These agencies may be examined from several points of view, such as their historical development, the subjects with which they deal, the functions performed by them, or the jurisdiction enjoyed in the performance of these functions, and their forms of organization.

Administrative bureaus made their appearance in international affairs much later than arbitral courts. Indeed, no such administrative machinery existed before the beginning of the nineteenth century; down to 1804 international governmental practice remained entirely in the field of politics and diplomacy.

International Geodetic Union, 1864

Universal Telegraphic Union, 1865

Lighthouse at Cape Spartel, 1865

Pruth River Commission, 1866

International Penitentiary Union, 1872

International Metrical Union, 1875

Financial Commission for Turkey, 1878

Union on Railway Freight Transportation in Europe, 1878

Financial Commission for Egypt, 1880

Union for Publication of Customs Tariffs, 1880

Union for Protection of Industrial Property, 1880

Union for Protection of Literary and Artistic Property, 1880

Sanitary Council for Egypt, 1881

Council of Sanitation for the Danube, 1881

International Maritime Conference, 1889

Pan-American Union, 1889

Union for Suppression of African Slave Trade, 1890

International Sanitary Union, 1892

Financial Conmission for Greece, 1897

Hague Arbitration Convention, 1899

Union for Regulation of African Liquor Traffic, 1899

Council for Exploration of the Sea, 1899

International Labor Office, 1900

Maritime Customs Board for China, 1901

Plague Surveillance in China, 1901 ( $($ )

Conference on Unification of Formulas of Potent Drugs, 1902

Pan-American Sanitary Convention, 1902

International Sugar Union, 1902

International Association of Seismology, 1903

International Institute of Agriculture, 1905

Wireless Telegraphic Union, 1906

Pan-American Scientific Congress, 1907

International Office of Public Health, 1907

Central American Union, 1907

Union for Standardization of Electrical Units, 1908

International Opium Commission, 1909

International Commission on Map of the World, 1909

South American Postal Union, 1911

Inter-American High Commission, 1915 
The Central Rhine Commission set up in the year mentioned seems to have been the first such bureau. ${ }^{1}$ In the next sixty years seven bodies of this sort were formed, an average of one for every nine years. These early cases included, beside the Central Rhine Commission, the Danube Commission (1856) and the Universal Postal Union (1863). In the next twenty-five years, extending down to 1890 , some fifteen bureaus were established, an average of one about every twenty months. These included the Universal Telegraphic Union (1865), the Union for the Protection of Industrial Property (1880), and the Pan-American Union (1889). Between 1890 and 1914 some twenty-three such organs were set up, an average of one for every thirteen months. Among these newer administrative bodies are the Sugar Union (1902), the Institute of Agriculture (1905), and the Wireless Telegraphic Union (1906).

This record reveals much. ${ }^{2}$ The absence of any such bodies prior to 1804 is significant. The slow growth of such bodies until after the middle of the century deserves notice. Finally, the rapid increase, and the acceleration of the rate of increase, in the last years before 1915, reveal a fundamental change in the scope and nature of international relations which must be borne in mind in the future.

The subjects handled by these international bureaus vary widely. Moreover, as time has passed there has been some change in the subjects treated. Both matters may be reviewed together.

The earlier international administrative bodies dealt with questions of international communications, such as river navigation and the exchange of postal matter. Such were the Central Rhine Commission (1804), the Danube

'Sayre, 132.

'In tabular form:

Period

1648-1803

1804-1864

1865-1889

$1890-1915$
Bureaus formed

0

7

15

23
Bureaus per year

0.0

0.11

0.60

0.92 
Commission (1856), the Postal Union (1863), and the Telegraphic Union (1865). This may be compared with the familiar fact that, historically, the individual states have taken public control of the roads and bridges of the country at a very early stage. The provision, maintenance, or supervision of the means of communication marks the beginning of the extension of the scope of the power of government.

The international bureaus next to appear were those dealing with health and morals. Such were the Sanitary Council of Constantinople (1838), the Sanitary Council for Tangier (1840), and the Penitentiary Union (1872). Apart from the elementary matter of communications, health and safety are the primary concerns of government.

A third group of bureaus includes several that have been created to deal with commercial and financial questions. Such are the Union for the Publication of Customs Tariffs (1880), and the Financial Commission for Greece (1897).

In recent years bureaus have been created to deal with general scientific matters in all the special fields of international life. Such are the Committee for the Exploration of the Sea (1899), the International Institute of Seismology (1903), and the Pan-American Scientific Congress (1907).

The bureaus dealing with commercial matters seem to have multiplied most rapidly, while the bureaus dealing with purely scientific questions are least numerous. The bureaus dealing with questions of health and the bureaus dealing with communications are more constant in their early appearance, their later expansion, and their continued multiplication, even in recent years.

It is not out of place to raise an inquiry at this point concerning the reason or reasons which determine whether a given subject shall or shall not be included in the list of matters to be handled through an international bureau. The test is not the importance to state life, national and 
international, of the subject in question, for many subjects, such as immigration and armaments, which are of superlative concern to the individual states and to the international community at large, are left untouched by this movement. Nor is the test the absence of importance, or even the absence of contentiousness, as the Postal Union and the Sanitary Union amply demonstrate. The subject may be purely national in its incidence, but impossible of adequate treatment without international coöperation; so for the matter of health and sanitation. Or it may be purely international, such as the question of maritime law and international railway transport in Europe.

The fact is that there is no simple objective test which can be applied in answering this question. We are dealing with the old generic problem of the proper scope of governmental action. The nations will get as much international government as they want, and no more. The danger of too much government may be faced with equanimity. Complete internationalization is a remote bogey. When it seems best to the nations to provide a bureau to care for a given subject that step will be taken, and not before. There is no formal necessity for such action, and only the real needs of the case will lead to it. On the other hand, there is no formal limit to such action, and the expansion of international administration is subject to no a priori limitations as we move into a future bound, in the very nature of things, to call for more activities of the sort here described.

The international bureaus and commissions created since 1800 vary greatly in form and function. To attempt to study these organisms is like gathering some fifty pebbles at random from the beach and attempting to classify them and to reach general conclusions concerning pebbles as such. The highest authority on the subject almost despairs at the task-as an introduction to what turns out to be, in the event, a masterly treatment of the matter. ${ }^{1}$ The reason

${ }^{1}$ Reinsch, 143. 
for this degree of variation is that the bureaus have come into being spontaneously, independently, and according to no concerted plan, and have developed in the same free and independent fashion. Only in recent years has the movement become conscious of its own place in the world; only of late has a deliberate practice of comparison and imitation sprung up in this field. The bureaus have, in the past, been created to meet certain needs and have been given duties according to the need in each case, and a form calculated to support the functions assigned to the organization. We have examined the needs which have led to the creation of these bodies. It remains to examine their functions and their forms.

The simplest task intrusted to an international bureau is that of gathering and distributing information. This task is not, however, as is sometimes suggested by the cynic, so simple and innocent as to be wholly unimportant. International discord and waste frequently arise from no other cause than a lack of data upon all phases of a question upon which different nations are each acting from their detached positions in the international community. With adequate data, the possibility of obtaining harmonious action by all interested nations is considerably greater, whether that result is left to chance or to informal and wholly voluntary coöperation. On the other hand, the states are not always willing to interchange such data directly; nor are they pleased to have requests for such data made, nor to have diplomatic and consular officers and attachés active in collecting such information on their own initiative. For these reasons the collection and distribution of information is not to be despised, when it is intrusted to an international bureau, quite part from the fact that such work can be done more effectively by joint action through a common central office. With the increased use of statistics and statistical methods in government in recent years, the number of informational bureaus has multiplied rapidly. 
The bureaus performing informational services have a threefold task, namely, to collect data, to assemble and print such data, and to distribute the results to the nations, or, if authorized to do so, to others interested in the information. The publications of the Geodetic Union, the PanAmerican Union, and the Institute of Agriculture are constantly in great demand from all parts of the world. This service of information is also performed, of course, as an incident in the performance of their main work, by several international bodies whose chief functions are of another sort.

Closely related to the collection and distribution of information is the action of several administrative bodies in serving as clearing houses for the exchange of opinions and views regarding matters of common or concurrent interest. In this capacity the bureau is both a little more and a little less than a permanent international conference, for the speakers remain at home and exchange views at long range, without meeting face to face, yet the Bureau serves to raise the process of conference above the level of that ordinarily maintained in international gatherings for oral discussion and debate. Such bureaus, moreover, prepare the programs and the materials for discussion at the international conferences which are frequently held to deal with the same subjects. The ultimate object is concurrent national action, but action apart from any formal convention or agreement. Such service is performed by the International Labor Office.

The similar, though not identical, function of keeping a record of facts and acts communicated to the bureau by member states may be mentioned in this connection. The bureau of the Labor Office, for example, becomes a depository or registry for laws or treatises in force in the territories of member states.

The turning point is reached when the bureau begins to concern itself with the subject matter under discussion. 
The members of the bureau now examine the data available and the views put forward by different states and decide upon the action which should be taken by member states. This decision may take the form of a model statute, or a draft convention, or rules of practice less formal than a convention. Such is the work of the Metrical Union (1875).

When this has been done the work of the bureau is, in most cases, finished. The results of its deliberations are referred to the member states for consideration and action as recommendations, but only as recommendations. Action still depends upon voluntary coöperation by the states themselves. This is indicative of the fact that international organization at present rests upon what may be described as the level of immediate consent. Just as in the field of arbitration, so here the states are unwilling to bind themselves indirectly, and in advance, to obey the rulings of an administrative body. A rehearing is demanded at each stage of the process; the decision is kept open as long as possible, and is taken in the last resort only by the state acting for itself, not through a delegated body of representatives.

Before concluding, however, that the whole work of such bodies is ineffective, one should remember that, assuming, as we must assume, that the states would not tolerate a supernational legislature, the highest and the very valuable service which is called for from any international organ is precisely that of inducing voluntary coöperation. Given the conditions of the problem,- the unwillingness of the states to submit to supergovernment, such bureaus perform the highest possible international governmental function in this field. If such a function appears to be unimportant the trouble is in the conditions of the problem which limit international action to that type.

In a few instances, indeed, more significant action has been provided for. In the cases of some ten or more international administrative bodies the bureau is given power to 
fix rules binding upon member states or their nationals, and even to carry out these rules in application to the daily business of the world through its own staff of employés. Such, in general, are the sanitary councils and the commissions dealing with river navigation. Such, notably, is the International Sugar Union (1902).

Part of this actual administrative work which is at times conferred upon international bureaus consists in the collection of moneys, the keeping of accounts, the payment of expenses, the distribution of surpluses and other varieties of fiscal duties. ${ }^{1}$ In some cases this is the chief work of the bureau, in others it is done simply by way of paying the expenses of the organization. Certain of the bureaus are supported in part by private funds, but for the most part the expenses are paid by the member states, either by equal contributions or by contributions proportioned in amount to the size, population, or wealth of the member states, and in either case the collection and expenditure of the funds rest with the bureau itself. ${ }^{2}$

Another somewhat special variety of work conferred upon the international bureau, but a function which is in reality only a phase of the power of administration proper, is the power to settle by arbitration disputes which arise in the course of operations of the bureau. ${ }^{3}$ Such power is conferred upon either the bureau itself or a special committee or office attached thereto. Such work is not, of course, administrative, but judicial, and must be understood by reference to the nature of arbitration as such.

The international bureaus to which actual authority over member states of their nationals is given may operate entirely in a local area and confine their work to the actions of individuals, or they may operate in the international field at large, and act upon the member states as

${ }^{1}$ Reinsch, 162.

'Same, 163.

Same, 164. 
such. ${ }^{1}$ There appears to be no essential difference between these two forms of jurisdiction. In both cases the bureau, by prior international agreement, is given authority which at the moment supersedes that of the state, either to act itself or to act through or upon its citizens.

It hardly needs to be said that bodies with authority of the sort just described are relatively few in number, and that the bureaus performing services of information are most numerous. Likewise, the major part of the work of each existing bureau is of the first or unauthoritative type.

It is rather surprising to find that the order of historical development does not correspond with this difference of type. The earliest international administrative organs were prevailingly of the class having authority over member states and their citizens. Such were the Central Rhine Commission and the Sanitary Council at Constantinople (1804 and 1838 respectively). The bureaus created since 1875 provide, relatively, a greater number of purely informational bureaus than do those created prior to 1875 . Again, it is not always the bureaus enjoying administrative authority which are most useful. The Universal Postal Union, for example, is extremely serviceable to the nations, yet its bureau has no discretionary powers at all. Discretionary bureaus are, perhaps, the most useful in dealing with situations demanding direct and immediate action; yet even that is not always the case.

An explanation of these phenomena is discoverable in two directions. The earlier bureaus and commissions were created in response to very urgent needs for joint action. Things had been allowed to drift so long that nothing short of an organ of real authority would meet the needs of the case. Later organs have been created to minister to less urgent needs, and a less decisive action is felt to be sufficient. Furthermore, the nations have never been unwilling to create international organs of government of real power

${ }^{2}$ Sayre, 14-15. 
when convinced of the necessity for such action, and what counts is not so much the degree of authority exercised as the field in which the activity of the bureau falls. The need for joint international action is not always made clear to the national governments by those interested in one variety or another of the world's work. And a great deal more can at times be accomplished simply by the collection and publication of information than would be expected. The underlying reason is the same in both cases. When a real identity or community of interests makes itself felt by the nations neither will they hesitate to act and act decisively, nor will it make a great deal of difference whether formal international action is taken or not, for the community of interest will dictate a spontaneous community of action apart from any joint bureau with discretionary authority.

Apparently, also, the form and structure to be given to an international administrative organization is little influenced by the functions to be performed by the organization after it has been established. Perhaps it would be more accurate to say that the fundamental principles on which such organizations are based are so firm that, in spite of variations of duties, the framework of the international organization is inevitable.

The essential element in all of these organizations is the standing bureau or commission. ${ }^{1}$ In several cases the expression "international union" is employed. This is because in all such action there occurs a banding together of the nations, a loose international confederation for limited purposes. The bureau is merely the organ of the confederation or union, and it derives its international mandate from the act of confederation, the formation of the union, as a result of which it is created. The bureau is the admin-

${ }^{1}$ Reinsch, 155; for illustration see Convention for the Creation of an International Institute of Agriculture, Arts. II and VI, below, Appendix A, Document No. 7, cited hereafter as "Conv. Inst. Agr." The bureau is called a "permanent committee" in this case. 
istrative body proper and derives its authority from a treaty or "convention" which is the constitution of the union. This convention, supplemented by certain "regulations" or by-laws, controls the activities of the bureau in all subsequent practice although the "regulations" are sometimes drawn up or amended by the bureau itself. ${ }^{1}$

Beyond these essential elements, there are two others deserving mention. The treaty or convention in question is concluded, ordinarily, by means of an international conference or congress. ${ }^{2}$ This conference may reassemble from time to time to revise the constitution of the union, and it may select a body of delegates to meet during the intervals between the sessions of the conference for the purpose of supervising the work of the bureau, and, perhaps, revising the "regulations." Where such a body exists it is ordinarily called a commission, and the final administrative body a bureau. ${ }^{3}$ Neither the conference, the convention, nor the commission is administrative in character. As has been seen, the convention or treaty is an international contract and, as will appear shortly, the conference and commission are constituent and legislative bodies. Where the conference does not so much as create a permanent bureau, but confines itself to the conclusion of an international convention providing for concurrent national legislative or administrative action, the case is not one of international administration at all, and should be carefully excluded from this field of discussion. The same is true of a general federation or league providing opportunities for lawmaking conferences of one sort or another; this is merely a case of treaty negotiation as already described. Even where a bureau exists, the conference itself has no administrative character; while the union as a whole is an international federation or confederation of high or low degree. The bureau alone is the administrative organ.

${ }^{2}$ Reinsch, 153; Conv. Inst. Agr., Article V, Pars. 2 and 3.

"Reinsch, 150; called the "general assembly" in the case of the Institute of Agriculture; Conv., Art. II.

Reinsch, 153. 
The contrast in form between the conference or commission and the bureau is sharp. The former is a large diplomatic body meeting periodically to perform constituent or legislative, but no administrative, functions. The bureau is a small body of technical experts acting continuously in the administration of the principles laid down by the conference, or in the formulation and administration of detailed rules for the application of these principles. In the former body the rule of unanimous consent is very generally applied, while in the bureau, and even in the commission, this is not always the case. Indeed, the whole action of voting is rather unimportant in the bureau.

It should be mentioned that there is at times a fifth wheel to these administrative systems, namely, the Directing Government, as it has been called, the government of the state in which the bureau is located. ${ }^{1}$ Such functions of supervision are occasionally intrusted to the local government as would be conferred upon an interim commission of the conference if such a body existed.

Certain conclusions may now be formed upon the basis of the facts just reviewed.

As was said at the beginning, the administrative bodies here discussed, particularly the bureaus having administrative authority, such as the organs for supervising river navigation, constitute to a peculiar degree an application of international government to daily life, continuously, at the instant moment, and directly in contact with the ultimate units of international life, the citizens and subjects of the nations engaged in international intercourse of one sort or another. Other forms of international government, notably arbitration, operate upon international life intermittently, retrospectively, and indirectly, through the national units. The former, it need hardly be said, is much more useful where it is feasible.

The statement has often been made that such organs

${ }^{1}$ Reinsch, 155. 
as are here discussed deal merely with non-political subjects, subjects not likely to cause international disputes or war in any case, because they are non-contentious. As has been shown elsewhere, this is simply not accurate as a statement of fact, when it is considered that such matters as quarantine regulations and postal charges and sugar bounties, all direct manifestations of national sovereignty, have been dealt with by these bodies. Furthermore, the record reveals several sharp contentions among the nations in connection with the work of such bodies. ${ }^{1}$ What is undoubtedly true is that such bodies tend to remove a given subject from the field of political discussion and diplomatic contention. Once a subject is committed to the care of a bureau upon the basis of rules agreed upon in conference, it is removed from the arena of international politics. It is denatured, depoliticalized, so to speak. Not that the bureaus necessarily deal with non-political subjects, but that they deal with whatever subjects are intrusted to them in a non-political way. ${ }^{2}$ When the conference meets there is another story. The sharp disputes just mentioned took place, in point of fact, in conferences. If once a convention can be concluded and a subject referred to a bureau and kept there, there is some prospect that it will be dealt with on its merits and not by reference to what are often fictitious or artificial "national policies." The great danger, indeed, is that politicians will seek to withdraw the subject to the field of political discussion again and to interrupt the scientific treatment of the subject by the expert commission. It would be a curious thing, however, to disparage the work of the bureaus because of the success with which they keep subjects from becoming involved in heated political wrangling.

It is precisely this effect of closing off discussion on the

1 Woolf, 189, 195, 213, 227.

"Similarly, the operation of courts of arbitration, once they are established, passes unnoticed; so for the present (1921) activities of the Hague court. 
case, for the time being at least, which makes the nations so reluctant to commit themselves to such action as the creation of a bureau. International relations being as unstable and variable as they are, the nations hope to gain more by a constant watchfulness and a readiness to take advantage of each turn of the wheel, each chance for advantage and benefit as it arises, than by securing permanent arrangements of general benefit and going ahead to live under them. Only where such a catch-as-catch-can policy is fraught with too much risk, or costs more than it could possibly yield, is the other form of action likely to be taken.

Specifically, the nations have been willing to commit themselves to international administration only where national action must needs be ineffective to prevent injury, or where the international action is positively more economical. The adoption of the Sanitary Convention is an example of the former; national quarantine measures were ineffectual to prevent epidemics and plagues, and international action was needed. ${ }^{1}$ The creation of the Union for the Publication of Customs Tariffs is an example of the latter.

The persons in each nation who are interested in the sort of work undertaken by these bureaus and commissions are more eager for such a development than the public officials themselves. In spite of attempts to prove the contrary, it clearly appears that the states are less active in the formation and promotion of such bodies than are private individuals. ${ }^{2}$ That is, most of the public international administrative unions originated in private movements and were more or less willingly taken over by the states later. There is a regular series of steps in the process of conversion whereby private international activities pass into public activities. A private association or bureau is first given approval, then coöperation, then diplomatic status, and,

1 Woolf, 221-242.

Reinsch, 144. 
finally, it is supplanted entirely by an official union and bureau. ${ }^{1}$ Safety and economy for the state have not been as powerful in bringing forth and sustaining such bodies in the past as private professional interest and loyalty.

This is reflected further in the divergent attitudes taken by the technical officials connected with the bureaus and the diplomatic representatives in the conferences and commissions. $^{2}$ The former, laymen in diplomacy, have their attention and interest centered in their work on its technical side-statistical work, research and publication, administrative technique. The latter, laymen in real life, are constantly fussing about state sovereignty and independence and national interests. The former have in mind the positive achievement of results in the field of action of the proposed bureau; the latter, the negative aim of protecting and defending national sovereignty. In many cases the establishment of the bureau is the work, not of the foreign offices at all, but of the postal, commerce, labor, or other departments of the national governments, acting in international relations for the time being. So far as sovereignty and independence are real considerations in this day and generation, and in the special fields where these bureaus operate, the diplomats can only be praised for guarding the holiest of holies and the experts only regarded as dangerously indifferent to the greater things of life. So far as this assumption is unsound, however, the reverse is true. It is unquestionably true that the unions have arisen chiefly to satisfy the social and economic needs of men, and not the political requirements of the states.

One of the rules most sacredly guarded by the diplomats is that of state equality, together with its corollary, the rule of unanimous consent. All states, as such, are equal in law, irrespective of size and power, and therefore none can lay down a rule for another. There are no a priori

${ }^{2}$ Reinsch, 145-147.

'Same, 146. 
foundations of international jurisdiction, and the consent of each state is necessary for giving force to any rule which is to be binding upon that state. This is no place to discuss the rule of state equality, nor yet the rule of unanimity. 1 They are calculated to prevent unjustifiable dictation by the Great Powers to the smaller states and to secure a fair hearing for the established rights of each. But when these rules are used to give the small power an equal voice in the control of decisions upon the content of law in the making, they are glaringly unjust; a citizen of Panama cannot fairly be given two hundred times the power of a citizen of the United States in the making of conventional international law. This conclusion is all the more inevitable and natural in view of the fact that unions of this sort are generally open to all nations that care to join,--unconditionally in most cases, upon conditions in others. If such a procedure is to be followed, and it is eminently desirable that it should be followed, it is only equitable that adherents accept such a position in the union as they are entitled to fill and not demand more.

The rules in question are, moreover, simply unworkable when it comes to the payment of the expenses of a bureau, the appointment of officials, and similar tasks. The smaller states simply cannot contribute as heavily as the larger ones. They cannot provide the same number of trained persons for service in the organization. They are not, moreover, interested to the same degree or amount in the services to be rendered by the bureau. Within the confines of the colonial empires are many states in everything but name. The persons engaged in the operation of the administrative bodies are therefore inclined to go upon what seem to them the realities of the case and to ignore the fictions. They are all the more inclined to do this because the rule of unanimity is an almost insuperable obstacle to action in international commissions-or, for that matter, in any other order of commissions.

${ }^{1}$ Dickinson, 280-336. 
A solution has been sought in several ways. In one or two cases schedules have been drawn up indicating classes of members contributing different quotas of the expense of the union and enjoying different voting-powers, and each state is allowed to choose its own degree of power and obligation. ${ }^{1}$ In another case colonial units have been given representation in their own names, the result being to multiply and equalize the states of the world in startling fashion. ${ }^{2}$ Finally, in several cases agreements have been made at the beginning to abide by majority decisions in the course of the operations of the bureau, and thus national sovereignty is saved and the practical needs of the situation are met at the same time. ${ }^{3}$ The behavior of those intimately connected with the promotion of such bodies may be compared to the attitude of the jurists at The Hague in 1907 in their attempt to organize an international court. The greater the attention given to the realities of the case, the greater the effort made to actually accomplish something, just so much less is the attention paid to the fictions of diplomacy and legal theory.

The international administrative bureaus created since 1804 have not been uniformly successful. In addition to the forty-five in operation in 1915, some ten or fifteen others have been established only to fail in actual practice. Such were the Suez Commission (1888) and the Albanian Commission (1913). The causes for the failure of these bodies and other similar organs are variously described. Thus, lack of power, unimportance of the subject matterleading to indifference on the part of the contracting powers -and the impossible situations in point of fact with which certain bureaus have been confronted, have been set forth as causes for certain failures in the past. Likewise, the unanimity rule and the rule of equality have been held responsible for the difficulties and deficiencies of international adminis-

${ }^{1}$ Sayre, 164-165; Conv. Inst. Agr., Arts. III and X.

Sayre, 162-163.

Sayre, 150-158; Conv. Inst. Agr., Arts. V, Par. 4. 
tration. It has been felt that the success attendant upon international administrative organization in the past has been discouraging. ${ }^{1}$

The fundamental difficulty lies deeper. Bureaus are not given adequate power, the situations in which they are placed are beyond their control, and the equality and unanimity rules are insisted upon, because the nations do not see any necessity for acting otherwise. The necessity is present, latent in the situation, but is not recognized. If it is not soon recognized, international social order may very well be wrecked. ${ }^{2}$ The responsibility lies with political thinkers to make clear the need and the solution. Nations and governments will delegate discretionary authority to administrative bodies when convinced of the necessity of doing so, but only when they are so convinced. That they have not done so in the past is due to the absence of such conviction, which, in turn, is due to the weakness of the case made out by advocates of international organization who have talked much of the beauty of peace but little of the substantial economy and advantage of international government. The cause of the deficiencies of international administration is largely the weakness of support given it by those in the best position to support it.

'Sayre, 147-150.

Woolf, especially 179-183. 


\section{CHAPTER XVIII}

\section{PRIVATE INTERNATIONAL ASSOCIATIONS}

7 THE fact that a large number of the existing official 1 international unions and bureaus have originated in private international organizations implies the continued existence of a certain number of private associations which have not been taken over by the states and converted into official bodies. Such, indeed, is the case. In addition to the public international unions with their bureaus and commissions, there have developed in recent years a still larger number of private bodies,-some five hundred or more,-which carry on their activities in the same or closely allied fields of international life. Some of these private bodies are always receiving public approval or support, and are thus approaching ever more closely the status and functions of the official unions. ${ }^{1}$

In a general sense, the private international association is an older institution in world affairs than the official union. Decades, and even centuries, before the national states were willing to join together in common administrative unions, private persons were ready and eager to associate their activities and their interests across national frontiers. Private international financial, scientific, and commercial organizations date back to the early days of modern Europe, not to mention, for the moment, the great

${ }^{1}$ On private international associations see literature cited, below, Appendix B, § 18 . 
religious orders and trading companies of a still earlier period.

In a narrower sense, however, private associations such as are here under discussion have made their appearance in the world more recently and more slowly than the public unions. Not until after 1830 did these private associations begin to multiply in the form in which we now find them. Prior to that time there had been private associations extending over territorial regions occupied by various nations, but these earlier associations were not organized on the international principle. The later associations, while private and unofficial in composition, have taken the national state system as their foundation and structural standard. In this form private international associations are still very new and very tentative things.

Statistical information regarding the exact dates of organization of these associations is lacking. The reason is obvious: in their beginnings these bodies are relatively inconspicuous, unrecognized, and unrecorded. Only at a later stage, when the association has attained a position of power and influence, is it given a place in the annals of international life.

Some figures are available, however, relating to the number of meetings held by these associations during recent years, and these figures reveal the state of affairs in this field with a fair degree of accuracy and completeness. Thus, during the decade 1850-59 there were held some eighteen meetings of private international bodies. During the decade 1880-89 there were over two hundred and seventy such meetings. During the first decade of the present century the number rose almost to the thousand mark, and when war broke out in 1914 meetings were being held at a rate which promised to exceed that of the preceding decade. Such was the volume and force of the tide of private internationalism when the defects of official interna- 
tional organization permitted the breakdown of 1914 to occur and to interrupt the normal course of events. ${ }^{1}$

In a very literal sense it is possible to say that these private associations cover every field, every nook and corner, of human endeavor. To inspect a list of the private international organizations now covering the globe is a revelation. ${ }^{2}$ Science is represented by the International Association of Medicine and the Institute of International Law; art by the International Institute of Public Art; religion by the Y. M. C. A., the World Church Alliance, and other bodies. In different fields we have the Olympic Games Committee, the International Congress for the Protection of Animals, the Interparliamentary Conference, and, in the world of industry and commerce, the International Congress of Chambers of Commerce, the International Association for the Legal Protection of Laborers, varions international labor and socialist bodies, and many private capitalist organizations. If we explore farther we encounter such oddities as the International Petrol Commission, the General Association of Hotel Keepers, the International Congress of the Deaf and Dumb, the International Association of Copper Chemists, and the International Cynological Federation. ${ }^{3}$ No important aspect of human life is unrepresented.

In their general form, most of these private associations resemble the public unions. There is as much variety of

1 Table of meetings of private international organizations since 1840 :

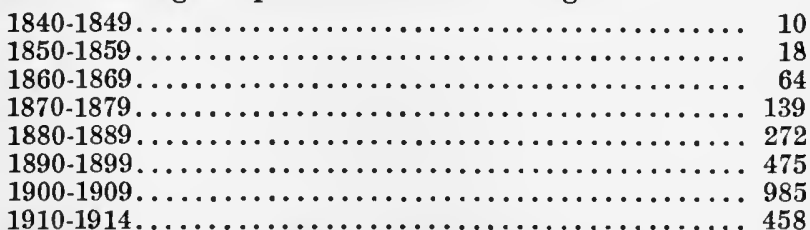

"Historical Light on the League to Enforce Peace"' in W. P. F., Pamph. Ser., Vol. VI, No. 6, 22-23 (December, 1916), and Krehbiel, 136, citing La Vie Internationale, 1908-1909, I, 175.

La Vie Internationale (each number), annexes; Krehbiel, 130-132.

- La Vie Internationale, 1912, Te. II, Fasc. 8, Annex, 1-9. 
form among them as among the public unions, if not more, but two types may be singled out with a fair degree of distinctness, namely, the federalistic Association and the unified business concern.

The federalistic Association is made up of national units, joined in a federal system, under a constitution defining the membership and structure of the Association. The Association holds conferences at intervals of a year or more-sometimes less-attended by delegates representing the national units; papers are read and there is general discussion of various subjects of interest to the members. The results are summed up in a set of printed proceedings, including, perhaps, a set of resolutions, copies of which may be forwarded to various national governments if any purpose is to be served thereby. In addition, the Association usually maintains a central office or bureau to look after its administrative and clerical work.

These wide-spreading Associations built on the federalistic plan are, as has been said, of recent growth. More elementary in form are the great business houses with partners and share-holders in different nations, with branches all over the world, and with activitis extending to all the continents and all the seven seas. ${ }^{1}$ Certain of our great industrial concerns, such as the Standard Oil Company, certain trading companies and export and import houses, and certain of our banking and insurance firms, belong to this class. Here belong likewise the world news agencies, those of the Associated Press, Reuter, Havas, Wolff, and others. The national state system is respected by such organizations in their activities just as far as it is necessary to do so, but it is commonly merely utilized as a convenient tool.

The organization of capitalists and employers into world-wide trusts and syndicates has had its response in the development of the international trade union. Such are the International Metal Workers Federation and the Inter-

2 Woolf, 327-343. 
national Trades Union Congress. It is not for any philosophical or idealistic reason that such bodies are created. No attachment to the abstract or humanitarian idea of international organization caused the employers and the bankers and the manufacturers to combine in one international association or another. International combination was perceived to be good business. So with the international labor bodies; a prosaic calculation of the advantage and benefits to be derived dictated their formation. The testimony here borne to the advantages of international coöperation is especially sincere.

As between the two, the employers and the financial and commercial interests have developed their organizations further and with more conviction than the workers. Nationalism is an affair of the middle classes largely, a bourgeois idea. The great capitalist has little of it to bother him, the common laborer likewise. But the latter may be aroused by appeals to his passions, and the skilled worker is petty bourgeois in his own way. Hence the international labor bodies are not as cohesive and do not run as smoothly as the international banking firms. Furthermore, it is the employers and financial and commercial chieftains who are able to prevail upon the official states to recognize them and to take over their interests. Several of the more recent public international bureaus were formed under the influence of the industrial and commercial community. ${ }^{1}$ Where international government is asked for in the name of labor it is not always regarded as reasonable and practical, but rather utopian. Economic considerations prompt the creation and development of international organization in the first place, and the relative economic power of different interests in society determines the share which each shall enjoy in the development of official international government. ${ }^{2}$

There are no questions of jurisdiction to be raised in

1 Woolf, 269-285.

${ }^{2}$ Same, 285-304. 
connection with the private international organizations. Questions of internal jurisdiction do exist-as between the component national bodies and the international association-but no questions which project themselves into the realm of public law or affect the national states. For these organizations are not official, and they rest, not upon a foundation of public authority, but upon voluntary private cooperation.

There are significant differences of interest among the different classes of private international organizations.

The commercial concerns,-exporters and importers and shipping syndicates,-the international news agencies, and similar bodies, desire to see a rapid and extensive development of free international communication and trade. They thrive in proportion as international trade, travel, and communication are freed from nationalistic restrictions, vexatious discriminations, dangers of interference, and national monopolistic controls in the form of tariffs, exclusive patent and copyright laws, and similar devices.

The international bankers, so-called, are in a similar position. Dealing as they do in international exchange and foreign credit, they desire to see the world credit structure developed and strengthened, and to that end they desire, above all, peace and order among the nations. An attempt has been made to show that certain world banking interests, by stimulating international jealousies, have managed to sell credit to many nations at once to finance war preparations one against another, thus creating an invisible empirc of debt over them all. ${ }^{1}$ This may or may not be true in general and it may have been true in the past. Certainly it can apply to few concerns today; certainly it is not applicable to the great majority of banking concerns dealing in world credit. And even where it is applicable the outbreak of war is not the thing desired, but the preparation for it, and the outbreak might still be dreaded for its effect upon existing national credit. Public financing for

'Jordan, Unseen Empire, entire. 
war and for military preparations is so gigantic today that private concerns do not, and could not, handle it except in a minor and auxiliary fashion. The states prefer to sell bonds in public at lower rates of interest than they would be compelled to pay to private concerns, thus also enlisting popular support and enthusiasm. At all events, everything goes to show that, in actual fact, the international banking houses are now internationalistic in their outlook. $^{1}$

Great manufacturing concerns, drawing upon worldwide sources of supply and selling in world-wide markets, take the same position. Freedom of trade and peace on the seas is their desire.

So for the labor organizations, especially in Europe. To mention but a single consideration, their members may have to depend on temporary migrations from country to country in search of work, and they naturally want international protection in their wanderings.

On the other hand, manufacturing concerns enjoying a national monopoly of one sort or another, labor groups enjoying a similar fixed advantage over other groups, and banking houses confining their activities to national financial activities-in other words, industrial, financial and labor organizations which are not international in their foundations and outlook-are usually active in opposition to the development of internationalism and cosmopolitanism. They oppose free trade, free immigration, and the establishment of international bureaus to control and adjust national competitive activities. International coöperation appears to them to be either positively dangerous or, at least, foolish and unnecessary, depending upon whether their advantage is natural or depends upon national legislation. All they demand in the international field is freedom to sell their goods abroad.

As a matter of fact, this small measure of freedom can hardly be obtained except by international reciprocity

${ }^{1}$ Krehbiel, 127-128. 
and agreement. And, finally, even industries enjoying nationalistic protection find it expensive to pay for such legislative protection and are led to a new manœuvre which eventually lands them in the other camp. By the premises of the problem, there are competitive supplies of material and labor in foreign lands. The simplest remedy is, therefore, to set up a branch in that place and rise superior to the national state system. Indeed, such concerns not infrequently expand in this way and end by becoming powerful enough to dictate to the national governments. Private international organization becomes so complete and adequate as to be able to dispense with official help. Indeed, as will presently appear, it may turn out to be profitable for the concern, because of its peculiar interests, to oppose official internationalism, itself indulging in private internationalism all the while. This is due to the fact that the states have neglected to keep up with the development of world civilization and have forced private interests to launch into the international field independently.

One other form of private international activity deserves passing notice. From time to time since 1850 there have been held at one important city or another a number of international expositions or world fairs, beginning with the exhibition at the Crystal Palace in London in 1851 and continuing at the present time. Paris, Vienna, Philadelphia, Brussels, Melbourne, Chicago, and numerous other cities have been the scenes of these huge international symposiums. ${ }^{1}$ In addition, hundreds and thousands of

A partial table of such expositions follows:

1851 London

1855 Paris

1867 Paris

1873 Vienna

1876 Philadelphia

1878 Paris

1880 Melbourne

1888 Melbourne

1889 Paris

Otlet, 54 .
1893 Chicago

1900 Paris

1901 Buffalo

1904 St. Louis

1905 Liége

1910 Brussels

1915 San Francisco

1915 Seattle 
smaller fairs have been held, especially in the cities of Europe, where exhibits from abroad are invited, although the fair is organized as a national event. Such are the fairs frequently held at Leipzig and Birmingham. ${ }^{1}$ The international expositions proper enjoy a semi-official standing and the national governments send official exhibits and encourage private exhibitors to participate on behalf of the nation. The result is a composite picture of world civilization at the time.

As has been pointed out, the motives underlying the formation of these private international bodies are motives of business advantage and pecuniary benefit. The result is that, once established, such associations make every effort to secure advantages for themselves and to secure satisfaction for the interests which they embody. This means, in most cases, bringing pressure to bear on the official national governments with this in view. The resolutions of the International Congress of Chambers of Commerce are not communicated to the President of the United States purely as a compliment, but in the hope that they may commend themselves to him for support. The international business house does not hesitate to carry its case to the government of the state in which it is located or to the governments of all the states in which it has active interests.

This sort of activity is of great present importance. The foreign policies of national governments are profoundly influenced by the representations and pleadings of special international interests. The policy of the United States toward Turkey and Mexico since 1917 has been influenced to some degree by the international missionary movement, and by the international oil interests. ${ }^{2}$ The American attitude toward Russia since the same year has been influenced by international commercial concerns. Labor

${ }^{1}$ Guaranty Trust Company, Bulletin, 1 January, 1920.

New York Times, 13 December, 1919, p. 3; New Republic, XXIII, 218 (21 July, 1920). 
organizations have not been without their power in the international relations of the past few years.

The most spectacular case of this kind is that of the international armament firms. For a concern to maintain and operate factories for the manufacture of war materials in five or six nations at the same time and to continue to supply these materials to the different national governments while they are at war one with another, distributing the profits among its share-holders of one nationality or another, seems somewhat anomalous. For Englishmen to derive financial profit from shells sold to Germany in 1916 seems dubious. The accusation is raised that war is encouraged by such concerns because of the sales it brings. Englishmen and Germans so interested are accused of bringing on war between their countries for the excess profits obtainable thereby. War scares are, it is said, worked up because of the extra contracts which result therefrom. ${ }^{1}$

A great deal of this criticism is apparently sound, and the private manufacture of arms has been officially recognized as "open to grave objections" on this score. ${ }^{2}$ The most sensational charges have repeatedly been made, seldom denied, and proved to the hilt as far as anything can be proved by circumstantial evidence. ${ }^{3}$ And during the recent World War the French Government practically admitted that it had determined its military policy partly by reference to the representations of certain German-French iron interests holding mineral properties in Lorraine." There is no room for doubt that private international concerns manufacturing arms have impeded the development of international peace, order, and government, in the past.

1 "Syndicates for War," in W.P.F., Pamph. Ser., Vol. I, No. 2 (July, 1911), and Snowden, P., "Dreadnoughts and Dividends" in same, Vol. IV, No. 5 (August, 1914); Hudson, M. O., "Private Enterprise and War," in New Republio, XXVIII, No. 363 (16 November, 1921), Supp., 26.

Treaty of Versailles, Art. VIII, Par. 5, in Sen. Doc. 49, 66 Cong., 1 Sess.

${ }^{2}$ Note 1 above.

"Streit, Where Iron is There is the Fatherland, especially 43-45. 
To say that international peace societies have exerted an opposite influence is not to say very much, for the people engaged in the former sort of activity possess ten times the power and influence possessed by the peace people. Only in a rare case, such as that where the International Federation of Trade Unions compelled the Hungarian Government to change its policy toward labor and the Hungarian Socialists in 1920, do we find labor and the reformers enjoying an influence comparable with that of their opponents. ${ }^{1}$

The activity of private international interests is going on continually. In 1920 and 1921 there appeared to be more activity in this field of international organization than in any other. The Baltic and White Sea Conference of Shipowners met at Copenhagen in June, 1920, and endeavored to reorganize Baltic trade methods after the war. ${ }^{2}$ The International Congress on the Causes of Death and Sickness met for the first time after the war in Paris in November, 1920, and resumed its work. ${ }^{3}$ The Miners International resumed its activity. ${ }^{4}$ An international conference of steel manufacturers was planned. ${ }^{5}$ An international Board of Agriculture was projected by American and Canadian farmers. ${ }^{6}$ The first Pan-Pacific Educational Conference was called in Honolulu. ${ }^{7}$ Various unofficial conferences of diplomatic representatives were held to discuss world trade. ${ }^{8}$ The World's Young Men's Christian Association met in Utrecht. ${ }^{9}$ The International Conference on the White Slave Traffic met and resumed work on the basis of the pre-war conventions. ${ }^{10}$ Finally, an Interna-

${ }^{1}$ Nation (New York), 3 July, 1920, Supp., p. 28; New Republic, XXIII, 136 (30 June, 1920).

New York Times, 10 June, 1920, p. 17.

Same, 14 November, 1920, p. 1.

'Same, 15 November, 1920, p. 14.

Same, 26 February, 1921, p. 2.

- Same, 12 May, 1921, p. 4.

'Same, 4 April, 1921, p. 15.

- Same, 4 April, 1921, p. 22.

- Same, 12 June, 1921, p. 2.

1o Same, 27 June, 1921, p. 15. 
tional Chamber of Commerce was planned, to supplant, perhaps, the older and rather loosely organized International Congress of Chambers of Commerce. ${ }^{1}$ In all directions private international organizations were revived after the war, were carried forward, or were organized to meet some new need.

In several cases the private international activities here described have developed into something quite unlike that from which they started. In all such movements there is present an element which easily constitutes a distinct and in some ways a novel departure. Private international bodies do not have a great deal of patience with the national state system. They tolerate it or utilize it as best they may. They are more concerned with association on the basis of the interest to be served-science, art, religion, business, or what not-and they are inclined to ignore national lines. They are inclined, that is, to develop a distinctly cosmopolitan outlook, which is a decisive turn in events.

This development serves to bring out very clearly the essential relations between internationalism and cosmopolitanism. On one hand private interests demand satisfaction irrespective of national lines, yet they are not averse to obtaining satisfaction through the mechanism of the national governments if this is possible, and they often call upon the latter for recognition, approval, and support, thereby manifesting a willingness to become part of the national and international system. But if satisfaction is denied, the former position is likely to be resumed and the existing national states and governments will probably be ignored and even defied. Cosmopolitanism as a condition is, in point of fact, at once a support and an encouragement to internationalism on one side and a threat and a menace on the other side. So long as the national governments

${ }^{1}$ New York Times, 21 May, 1920, p. 16; 12 June, 1921, § 7, p. 1; 20 June, 1921, p. 21. 
PRIVATE INTERNATIONAL ASSOCIATIONS 301

strive by international coöperation to satisfy the legitimate interests involved, the development of world trade, world science-world civilization, in short-can only stimulate and strengthen the system of national states and the fabric of international relations among them. Let the national governments manifest an obstinate attachment to extreme nationalism, however, and attempt to ignore the facts, arrest the march of political evolution, and shut their eyes to the realities of world life today, and the world's life will simply pass by on its own course. 


\section{CHAPTER XIX}

\section{MODERN COSMOPOLITANISM}

MOST of the activity of the private international or1 ganizations just described touches only remotely the official life of the states; the greater part of private internationalism exists and functions with scant reference to the system of national states. National lines are at times recognized for the sake of mechanical convenience, at times they are simply ignored as irrelevant to the business in hand, and at times they are deliberately set aside as antiquated obstacles to the proper and natural growth of world civilization. In other words, there has developed since the early part of the last century, a cosmopolitanism which differs from the rather impotent cosmopolitanism of Antiquity and the Middle Ages as already studied, and which bids fair to exert a profound influence upon the international relations of the future. ${ }^{1}$

Cosmopolitanism has been defined as the grouping together of people in the world by reference to common interests apart from nationality. It is spiritual unity based on one or more of the elements which, taken together, make up nationality; it is a supernationality. The individuals join together for coöperative action in associations which do not greatly take into account the otherwise distinct nations. Such cosmopolitanism is, of course, quite distinct from internationalism. If completely developed, it would supersede internationalism entirely.

Cosmopolitanism may develop within one nation as well as among or above several nations. Ordinarily cos-

${ }^{1}$ On modern cosmopolitanism see literature cited, below, Appendix B, § 19. 
mopolitanism appears as a union of individuals legally belonging to several distinct states but having interests in common irrespective of their diverse citizenship. In certain cases, however, as where a state diverges from the standard type of national state and embraces within its confines several nationalities, cosmopolitanism may be infra-national, or infra-state. This is notably true in all imperial states. Ancient Rome and the Holy Roman Empire of the Middle Ages, to mention only two illustrations, produced a cosmopolitanism within their bosoms more pronounced and self-conscious than anything of the kind which the world was to know for centuries afterwards. In that cosmopolitanism was found a measure of justification for the imperial domination. Under the sway of the Emperor unity of culture and feeling was achieved and the conflicts of national spirit were quieted. Unfortunately for the picture, however, this imperial cosmopolitanism was not entirely natural and spontaneous, but was imposed by authority from above; and such is commonly the sanction of imperial cosmopolitanism. To be genuine, cosmopolitanism must come by a natural disappearance of nationalism, not by its destruction at the hands of imperial masters.

The cosmopolitanism of our day differs somewhat, as has been said, in its bases and foundations, from that of earlier periods, and the prospects of its continuation and development are affected by that difference.

Greek cosmopolitanism was racial, religious, and linguistic. The people of all the independent city-states were Hellenes and were conscious of their race, in contrast to the outer barbarians. All were embraced in one great religious cult; all worshiped the gods of Olympus, whatever local deities and shrines they might cherish. All spoke one generic tongue, albeit with differing accents and inflections. By virtue of these things they were ultimately Greeks, although they might be primarily Athenians or Spartans. 
Viewed in a larger perspective, this may appear to be Greek nationalism rather than cosmopolitanism. But the Greeks themselves were so attached to their city-states as to make it very difficult for them to attain the idea of political unity when that question was actually raised, and they certainly looked upon Greek unity as a complex and ultimate synthesis based upon much that had gone before, not as a primary national allegiance. ${ }^{1}$

In Rome the elements of imperial cosmopolitanism were more restricted, and were derived from different sources. ${ }^{2}$ Of racial unity there was none. Even the Italians, all Latins though they were, felt their tribal ancestry too strongly in the early period to recognize Italian unity, and when Italian unity was finally attained Italy was no longer the whole state. And the mature empire-where and when alone any cosmopolitanism at all developed- was a congeries of Latins, Gauls, Iberians, Carthaginians, Greeks, Slavs, and peoples of every race and stock. Similarly, in general culture the peoples of the Empire lived divergent lives, following different manners and customs. Such cosmopolitanism as existed was based upon other foundations than race and manners.

Religion and law were the great forces used by Rome to bind her peoples into one society. Above the manifold pagan cults were erected first the worship of the Emperor and later state Christianity. The official faith created some degree of spiritual oneness from the Augustan period to the end of the imperial age. Closely related to the state religion was the public law of the Empire. While allowing the peoples of the outlying regions to retain their local manners and customs and their local private law, Rome insisted upon establishing a single system of constitutional and administrative law in all parts of the state and upon regulating by imperial authority such conflicts as appeared be-

1 Fairbanks, 13-29, 148-164; Murray, Part I.

- Mahaffy, Chaps. V.VIII, X.XVI; Muir, 33-34; Wendland, Chaps. VII-IX. 
tween different local systems of private law, especially where those conflicts arose in the capital city or the great commercial centers. Thus potentially, and, to a large degree, actually, one system of law prevailed from the straits of Gibraltar to the Syrian desert, from the plains of Northern Europe to the valley of the Nile. Though imposed from above by authority, and maintained in part by armed force, the effect was the same. The peoples of the far-flung empire lived and died subject to and participants in the one great and majestic system of the law of imperial Rome.

Medieval cosmopolitanism was broader in its character and more varied in its manifestations. ${ }^{1}$ At bottom Medieval European unity was religious and ecclesiastical. The Church and the Faith of Rome supported and informed men's minds when Rome herself had fallen into disorder. One common inheritance bound the faithful together and preserved a spiritual European unity through centuries of material chaos and ruin. Added to this was the nebulous but thoughtful allegiance in the Empire of the Carolingians and the Hohenstaufens. The ideal membership held by all the peoples of Europe in this theoretical projection of im. perial Rome served to strengthen and enrich the ecclesiastical and religious unity under the Popes. Finally, especially in the later centuries of the Medieval period, the Roman law itself, and Latin literature and the classical cultural inheritance, bound the best people of European society into one spiritual school. One Church and Faith, one Empire, and one body of neo-classical enlightenmentsuch was cosmopolitan Europe in the later Middle Ages.

Then came the dissolution. In political power, in ecclesiastical organization, in dogma and ritual, one after another, the Church was shaken from end to end. The Babylonian Captivity, the Great Schism, and the Protestant Reformation worked out their disintegrating effects from 1309 to 1555 , and the religious and ecclesiastical unity of

1 Muir, 124-126. 
Europe was destroyed. The Empire had already fallen into anarchy, and the feudal princes of Germany, the free cities of Italy, and the national kingdoms of Western Europe-Portugal, Spain, France, England, and other states-rose in the place of the Emperor. Feudal allegiance to the successor of the Cæsars gave place to allegiances, more immediate and more real, to local city, prince, or king. Finally, the cultural revival soon developed in such a way that not unity but variation was the result, and, other things being as they were, that variation fell out upon lines of nationality. Turning from classical art and literature directly back to nature itself, men's individual tastes and faculties emerged, and this meant that national peculiarities and national characteristics were revealed. By the middle of the sixteenth century Europe was a maelstrom of the most varied religious beliefs, political allegiances, and cultural aims and ideals.

For more than three centuries this state of affairs persisted. It is true that during a brief period extending from the early part of the eighteenth century down to the French Revolution a sham theoretical cosmopolitanism developed among the intellectuals, among the literary and philosophical devotees of the salons. At the same time a process of intermarriage and inheritance had brought the royalty and aristocracy of the states of Western Europe into a closely knit family. But this eighteenth century cosmopolitanism was superficial. It came at a time when the colonial and commercial competition of the European states was most bitter and when conditions in the world of real facts were such that no deep or lasting unity was possible among the peoples of Europe. The barriers to free communication, free personal development, and that spiritual breadth of vision without which real cosmopolitanism is impossible, were still too great. Hence the effect of the French Revolution and subsequent events was to disperse very quickly such misty unity as existed. The Revo- 
lution itself was but a culminating manifestation of the deep and abiding change which came over Europe between 1300 and 1700; the Renaissance had merely got down to the people. But it was sufficient to dispel the illusion of European unity created by the litterateurs and illuminati of the age of Voltaire and Goethe.

Modern cosmopolitanism is built upon more solid foundations. Some of the older elements remain, but, in general, the world civilization of today is unlike that of Antiquity or the Middle Ages, and equally unlike that of eighteenth-century Europe.

To be sure, the sunity of Christendom" still means something, at least in continental Europe and Latin America. In Great Britain and North America it is felt to a less degree, as the religious temper becomes milder and secular ideals replace the old feelings of piety and devotion. A similar phenomenon-a religious cosmopolitanism- exists in the Mohammedan world and in Buddhist Asia. But the distinct existence of these three great groups, and of the great subdivisions in the Christian world-Orthodox, Roman, and Protestant-lowers the importance of this effect. Religion is hardly strong enough, and certainly not sufficiently unified, in this day and age to produce a world society. Indeed, such cosmopolitanism as exists is somewhat cynical and skeptical of the religion which is too often tribal and nationalistic in its origin and employment.

Of legal unity Europe still knows something, at all events continental Europe west of Budapest. The Civil Law,the law of Rome in modern guise,-obtains in Madrid and Paris alike, in Berlin and in Bern, in Brussels and in Rome. Similarly, the Civil Law governs private rights and obligations in all of Latin America, in Louisiana, in Quebec. This, however, is only part of the story. As in the field of religion, so here it is necessary to note that Great Britain and North America are under the English Common Law, that Eastern Europe lives under Slavic law, and that Asia 
and Africa possess many indigenous legal systems of their own. Added to this is the fact that even where supposedly common legal systems exist the practice of constituent and statutory law-making has so worked upon and made over the historically received private law as to produce endless variations among the nations. And it is curious to notice that it is in connection with this particular legislative activity, which has largely destroyed the inherited cosmopolitanism based on the Civil Law, that a new legal cosmopolitanism may be expected as a result of deliberate imitation and concurrent legislative action. This leads us forward to the true bases of modern cosmopolitanism.

The principal element in modern cosmopolitanism, as it has developed since 1850, is a common economic and scientific culture.

The facts are familiar to every observer. ${ }^{1}$ With the introduction of steam and electricity, travel and the transportation of goods have become enormously easier, cheaper, and more rapid. The communication of information by post, telegraph, and telephone and the shipping of printed matter has been expanded and speeded up to a point unimagined a half-century ago. The commercial market of even the small manufacturer has become a world-market. Raw materials and labor come from places where they are plentiful to lands where exists the capital to put them to use; or capital, increasingly mobile in the hands of the international banking organizations, is transmitted in vast amounts to places where the materials and labor already exist. The manufactured product is carried by a world transportation system to all corners of the globe, so standardized and labeled that a merchant in Calcutta whose credit is attested by the credit agencies, and who probably maintains relations with an American house in New York, may buy automobiles in Detroit by post or telegraph and rely on the results of his action with some confidence. This means a new world, as compared

' Clark, Unifying the World, 9-51; Woolf, 181-183. 
with the world of the twelfth century, or even the world of the seventeenth.

The basic causes for this commercial revolution, comparable only with the commercial revolution of the thirteenth, fourteenth, and fifteenth centuries, are scientific inventions, such as steam locomotion on sea and land, and the electric telegraph. The railroad, the steamship, and the telegraph have reorganized the world.

With these must be grouped several other devices, of less importance by themselves, but influential as subsidiaries of the major inventions of Watt and Edison. Such are the decimal metric system, the standardization of time on the basis of Greenwich, England,- - a result accomplished by formal international treaty, it may be noted,the perfection of a system of maritime signals, and so on. The Gregorian calendar, long used generally in Europe and America, has finally been adopted in Russia and is establishing itself in Asia. The English, German, Spanish, and French languages, especially English and Spanish, are making great headway in all parts of the world as the commonly accepted languages of commerce. These scientific devices, and numerous others, all contribute to the support of a world economy possible only with free and complete communication and intercourse.

The results are manifest in many quarters, and are recognized by the most careful and competent authorities. ${ }^{1}$ The private scientific and economic associations just reviewed are based upon this foundation as are the official administrative organizations previously studied. As a result of these forces many private organizations and corporations are being recognized in public international law and treaty agreements and become units in the official international system. ${ }^{2}$ These acts of recognition in their turn help to intensify modern cosmopolitanism; the recog-

'Guaranty Trust Company, Bulletin, "Effect of War on Neutrals," 15 December, 1919 , especially p. 5 .

"See fuller description in Hicks, 280-292; for law see conflicting views in Oppenheim, I, §63. 
nition of such world unity as exists leads to steps which increase that unity, and thus the process is accelerated.

There is, however, another form in which modern cosmopolitanism is made manifest, a form which has received a name recognizing in so many words the character of the phenomenon it describes: cosmopolitan law-making. ${ }^{1}$ It would probably be more accurate to speak of this activity as concurrent uniform national legislation, ${ }^{2}$ but a detailed account of just what has been done is probably the best explanation and definition.

Uniformity of national legal systems is needed in the whole range of commercial law, regarding bills of exchange, commercial contracts, and the thousand and one details of business law. Uniformity is needed in the field of admiralty or maritime law, in the field of labor and labor protection, and in all fields where a world activity has developed. The need of uniformity in patent and copyright law to protect inventors and authors from pirate manufacturers and printers is especially grave. ${ }^{3}$

The object to be accomplished is clear, but the methods to be adopted are hard to find. A treaty alone would hardly satisfy the needs of the case except in those few nations where a treaty becomes a law to be enforced in the courts on a par with statute law. Some more subtle procedure is necessary. The result has been a novel experiment in international government, dating only from 1880; and, although the resulting action is of such nature as to fall outside the category of international administration, it may be briefly described here, for the action escapes the classes of international diplomatic treaty negotiation, arbitration and conference alike.

What happens is that a model code is drafted by an

1 Woolf, 266-310.

2 Hicks, 242-243.

- See the importance attached to this subject as indicated in the preparations made for the Peace Conference in 1918-19; Langner and White, Patent Laws. 
international committee or convention, and then efforts are made to secure its adoption in different states as national legislation. Thus, an International Maritime Committee was established in 1898, composed of experts in that field, acting as delegates of seventeen national associations of shipping interests, and this Committee has succeeded in securing the adoption of several items in a potentially complete code of maritime law. ${ }^{1}$ Questionnaires are sent out to member associations; the replies-relating to the existing state of the national law and suggestions for a uniform code-are scanned; a model code is drawn up and recommended to the individual national legislatures. The obstacles to acceptance are many: national habit and tradition-"our way of doing things"-and competitive advantages enjoyed by certain national groups by one accident of fate or another. There is, of course, no supernational legislature to act. International uniformity must make its way on its merits. Treaties alone would be inadequate. The only recourse is to persuade national legislatures to adopt these model statutes for the sake of the advantages of uniformity and certainty in world business. This is not international action, properly speaking, but concurrent national action. The result, however, is felt directly in the field of international life. It is legislative cosmopolitanism.

Similar action was taken more or less successfully in the field of patent law and copyright law in 1883 and 1886, respectively, and in subsequent years. Some fifteen nations-among which the United States is not conspicuoushave unified their national laws on the question of copyright, and patent and trade-mark laws have been similarly

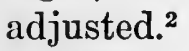

An attempt to accomplish the same result in the field of labor legislation may be studied for what it indirectly

${ }^{1}$ Woolf, 269-285.

Same, 304-310. 
reveals regarding the motives of the parties in interest. ${ }^{1}$ Speaking generally, the employers in the individual nations are opposed to labor legislation. The menace of foreign competition is raised as an argument against such legislation. ${ }^{2}$ Therefore concurrent international action has been proposed to meet the situation.

An International Association for Labor Legislation was formed in 1900, after the futile conference at Berlin in 1890 of which Kipling once wrote so tellingly. The Association is made up. of several national sections. It maintains an International Labor Office at Bern and has attempted to secure concurrent national legislation in the interests of labor but has made little headway. The philanthropic reformers in charge have been able to accomplish little, and organized labor has not given consistent support to its activities. The real reason for the association's comparative failure, however, is the character, not of its support, but of the opposition. The employers have leagued themselves together-French and German and British, irrespective of nationality - to oppose the labor people, who were likewise associated together irrespective of nationality. ${ }^{3}$ This is the very essence of cosmopolitanism. German and British capitalists have fought the German and British labor organizations hand in hand. What headway has been made has been made by compromises not so much between nations as between the two social groups running through the several nations.

From this state of affairs it is not a far step to the Socialist International and the International Workers of the World. The world capitalists, whose activities have already been reviewed, are confronted by the world proletariat. The cry goes out for the workers of the world to unite-even as the owners of the world, the manufacturers,

Woolf, 285-304, and Lowe, entire.

2 Woolf, at 289.

same, 296. 
the traders, the bankers, have already united. This is cosmopolitanism with a vengeance. Unfortunately also, the national states, as has been mentioned, pay more heed and give more recognition and support, both in national and in international affairs, to the latter groups, with the result that international organization,-that is, organized coöperation by the existing national states,-appears to the proletariat as organized exploitation by capitalist class governments. ${ }^{1}$ Hence they withhold from it their support. The one class most interested collectively and individually in providing a substitute for unrestricted international war opposes the one feasible solution of the problem. An attempt has recently been made to remedy this by the labor clauses of the Treaty of Versailles, which will presently receive attention. But if internationalism cannot be made attractive to the workers, world unity will come by the path of cosmopolitanism; for the future of government, national and international, certainly belongs-whether we like it or not-to that class in society. Whether internationalism or cosmopolitanism wins depends upon the speed with which the national governments become subject to the power of the workers, and the workers thus nationalized.

It should be noted that the legislation here under examination is markedly different from legislation adopted by the individual states to carry out their duties one to another under public international law, as already described, or regulating subjects rising in their official relations one with another. Uniform laws regarding naturalization, citizenship, and extradition are desirable and serve to regularize the relations of individuals to the national states and the international state-system. ${ }^{2}$ But they are not a manifestation of cosmopolitanism, as are uniform codes of private international law regarding marriage and divorce, property, and the subjects just described.

${ }^{1}$ New York Times, 25 and 26 August, 1919, p. 1.

2 Hicks, 245-254, and references on 255. 
The cosmopolitanism of our day is always making its appearance at unexpected places. Thus, it has recently appeared that, the financial situation of the world being what it is, American bankers will necessarily have the final word on the size of the reparation fund paid by Germany to the Allies, through the market price which they set upon the reparations bonds. ${ }^{1}$ It has also developed that, the commercial situation of the world being what it is, American industry and commerce are largely dependent upon European industrial and commercial recovery for their own prosperity. ${ }^{2}$ It has been discovered that our manufacturers and inventors face huge losses unless the American Congress acts to put us again in a position to enjoy the protection of international patent agreements. ${ }^{3}$ In all directions this new cosmopolitanism of travel, communication, industry, commerce, and finance is developing and establishing a control over the international relations of the world. It is bound to go on increasing, as the means of communication become farther perfected and the interchange of ideas and the generalization of world culture are intensified. It provides a firm basis for international cooperation. It also constitutes a threat that, failing international coöperation, the nations will be overrun against their will by a unified world civilization. ${ }^{4}$ Eventually, the cosmopolitanist is heard to say, there will no longer be any "nations," even as there were none in Medieval Europe. If this is chimerical or undesirable, the alternative is international coöperation,-which itself, however, helps to develop cosmopolitanism!

${ }^{1}$ New York Times, 2 February, 1921, p. 2, and 7 May, 1921, p. 1.

'Same, first citation.

Same, 30 January, 1921, § 2, p. 1.

- Compare what is happening in the matter of personal movement among the nations today. The states possess and exercise the right to control emigration from, and immigration into, their territories, and the device employed for this purpose is the passport system, but today the demand goes up from commercial bodies that this restriction on free world travel shall be abolished. See Wilson and Tucker, §62, for law, and New York Times, 29 May, 16 October, 21 November, 1921, pp. 5, 20, 10, respectively. 
PART VI

INTERNATIONAL CONFERENCES AND CONGRESSES 



\section{CHAPTER XX}

\section{INTERNATIONAL CONFERENCES IN TIME OF PEACE; THE HAGUE CONFERENCES}

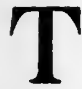

THE most valuable feature of the League of Nations as organized in 1919 is felt to be its provision for a continuous series of international conferences. It was the failure of the efforts of Sir Edward Grey in July and August, 1914, to secure the consent of Germany, Austria, and Russia to the holding of an international conference on the Serbian question that finally allowed the great catastrophe to come upon Europe. The most vital defect in the international organization of the past has been the difficulty of securing international conference where, and especially when, it was needed. This form of world government will therefore demand our best attention.

International conference may be defined as joint consideration and discussion by representatives of two or more states of matters of interest common to both. Whenever the representatives of two states meet together to settle an international difference, not by the arbitral or judicial process but by discussion and mutual agreement, we have the phenomenon for which we are now looking. Conferences of two nations, however, naturally give way to conferences of several nations, as the problems of international life become generalized and expanded so that they affect more than two states. Eventually we reach the conference in which thirty or forty independent nations, perhaps the states of the whole world, participate. Bi-party conferences become tri-party and multi-party conferences 
as the interests of all states become further and further interwoven.

International conference in its simplest form is merely personal diplomacy as already studied. Whenever the Ambassador of a foreign state visits for business purposes the Minister for Foreign Affairs in the capital where he is stationed we have an international conference. The action takes on its full significance, however, when the conference is specially arranged before it takes place, when the questions for discussion are previously defined, and when the discussions in conference are conducted by representatives specially named for the purpose. If, in addition, the conference includes several nations, as just described, the action is still more significant.

Like personal diplomacy of the simpler form, the international conference may end in one of two ways. A formal international treaty of one type or another may be signed; or the results may be left in the form of memoranda or minutes of the discussions. The more important the conference and the questions there discussed, the more likely is it that a formal treaty will be drawn up and signed. Likewise, where extensive agreements are reached in conference and definite decisions are taken, the results will be put in treaty form. Inconclusive conferences on unimportant topies are recorded only in minutes or memoranda of discussions.

When the treaty form is adopted for expressing the result the conference reaches its highest point of significance, and also the highest point of development possible for any of the special forms of international organization. For this is legislation, constituent or statutory. It is lawmaking. The adjustment of differences by personal negotiations and bargains and compromises is a comparatively simple thing; the conclusion of special contractual agreements regarding international relations, and the development of customary law, carry us but little further; the 
settlement of disputes by arbitration on the basis of existing law, and the administration of international business according to existing law, are not revolutionary, as far as the substance of international rights is concerned. But the revision and amendment of international constitutional and statutory law by deliberate discussion and agreement reaches the most vital point of world government. Petty law-making is to be found in all of the other special fields of international government; here legislation is the principal business, and the practice of diplomacy, the negotiation of treaties, the development of the law of nations, and international arbitration and administration are all, in turn, amenable to its control.

The subjects dealt with by international conferences range over the whole field of international relations. The decisions taken may relate to constitutional questions of deep and lasting moment to all nations, such as the decision to establish a compulsory court of arbitration. At times they relate to comparatively trivial concrete questions affecting two states only, such as the cession of a bit of territory by one state to another. The more important questions, both constitutional and practical, arise in conferences held at the termination of wars, and we shall encounter at that point the whole general problem of peace and war and of the relation between peace and international organization.

No distinction need be made, probably, between the terms "conference" and "congress." 1 It was once felt that a "congress" must be more formal, more important, and more general, than a "conference." But in view of the practice of speaking of the gatherings at The Hague in 1899 and 1907 as the "Hague Conferences" and of the gathering in Paris in 1919 as the "Peace Conference of Paris," this distinction vanishes. No international meetings were ever more formal, more important, or more general than

${ }^{1}$ Satow, $\S \S 439,463,468$. 
these. It sometimes appears that the term "conference" is given to gatherings of diplomats for the discussion of political questions, while the meeting of experts and administrative officials on legal and scientific matters is called a "congress," as in the cases of the Postal Congress and the Pan-American Scientific Congress. Here again, however, the Hague Peace Conferences and the Pan-American Financial Conference rise to confound all attempts at differentiation by reference to the terms actually used in the names of international bodies. Indeed, there seems to be a tendency to get away entirely from the rather flowery and pompous term "congress" and to stick to the simpler, more direct, and more accurate designation.

At times, the term "peace" is also used ambiguously in this connection. A "peace conference" is, curiously enough, a conference which meets in time of war to settle questions connected with the war. It derives its name from its object, which is the reëstablishment of peace. The conferences at The Hague in 1899 and 1907, on the other hand, are commonly referred to as the "Hague Peace Conferences" for this same reason, namely, that they were aimed at the more effective maintenance of peace, although, unlike most "peace conferences," they were not called at the close of hostilities to define the terms of peace between belligerents. Now every international conference is a peace conference, in a sense, for it aims at the maintenance or reëstablishment of international peace. It seems best therefore to classify international conferences more carefully, as conferences in time of peace and conferences for the termination of war.

International conferences in time of peace are relatively new institutions in the field of international government. ${ }^{1}$ Indeed, they are the most recent special form of international governing body. Personal diplomacy of course is older; courts of arbitration are far older; and

${ }^{1}$ On international conferences in time of peace see literature cited, below, Appendix B, \& 20. 
even international administrative bodies are older by some sixteen years. Cosmopolitan law-making is more recent in origin, but no standing international organ of government is there involved.

International conferences in time of peace developed out of conferences for the termination of war. ${ }^{1}$ The latter have held their prominent place in world affairs, at least in their primitive form, from the very earliest times. Down to 1820, however, no international conferences were held which were not connected more or less directly with preparations for waging war or with the termination of war. Even the first conferences held in time of peace, -those held at Troppau in 1820, at Laibach in 1821, and at Verona in 1822,--were not wholly unconnected with the wars which ended in 1815 .

An explanation is found in the fact that international organization was still accidental and passive, rather than deliberate and active. In the absence of any special and unescapable need for a conference, such as the necessity of settling a war, why tempt fate by indulging in useless discussion? Let well enough alone. There being no a priori reason for conferences, they were to be held only when indispensable.

Criticism of this attitude was soon forthcoming. Speaking of the subject in a rather lively vein in 1849 , Cobden inquired whether as good men as Lord Castlereagh could not have been found to settle the matters dealt with at Vienna in 1815 before, as after, twenty years of war. In the same year the King of Portugal touched upon the same problem in an address at the opening of the Cortes and added another element in his treatment of it. He said: "Congresses which assemble in consequence of war only sanction, as a rule, the advantages secured by the strongest; and the treaties which result from such congresses rest on accomplished fact rather than on right. They create

${ }^{1}$ Satow, $\S \S 462-465,468$; the meetings described in $\S \S 439-462$ are to be contrasted, in this connection, with those in $\S \S 463-495$. 
forced situations, ending in general uneasiness, and producing protests and armed demands. A congress before war, and intended to prevent war, is to my mind a generous idea, favoring progress.' 1 There are thus two motives back of the holding of conferences in time of peace: the prevention of war and the superiority in the quality of the settlement which can be obtained in such conferences when compared with the settlement possible of attainment in a conference for the termination of war.

Since 1850 such conferences have increased rapidly,not as rapidly as private international associations and conferences, yet with a regular and firm trend. Seven intermational conferences were held in time of peace between 1820 and 1850, five between 1820 and 1829, and one in each of the two following decades. ${ }^{2}$ All but one of these conferences, however, were more or less connected with the Napoleonic period, and they do not constitute the real beginning of the modern process. There was a decided Iull between 1830 and the middle of the century; when the practice was actually resumed. Two conferences are recorded in the decade 1850-59, and seventy-seven between 1900 and the end of the first decade of the century. ${ }^{3}$ As will shortly appear, there is a partial correlation between the meetings of such conferences and the formation of international administrative bureaus, but this correlation cannot be clearly traced in the data relating either to the

${ }^{1}$ New York Times, 24 January, 1921, p. 10.

2 International conferences in time of peace before 1850:

Date Place Subject

1820

1821

1822

1826

1827

1830

1847

Troppau

Laibach

Peace of Europe

Verona

Same

Panama

Same

London

London

Peace of America

Greek affairs

Belgian affairs

Lima

Peace of America

Satow, $\S \S 462-465 ; 440$, end; 470,471 .

'W.P.F., Pamph. Ser., Vol. VI, No. 6, as eited, 22-23. This list does not include the earlier conferences. Another list (incomplete) in Am. Jour. Int. Law, I, 808. Table below, p. 323 , note 1 . 
frequency of the formation of such bodies or to the frequency of meeting of international conferences.

International conferences in time of peace deal with a multitude of subjects, which may be grouped, roughly, under three heads: political subjects, legal problems, and questions of economics and finance.

International discussions on political questions are older than the conferences on legal or economic questions, for the reason that such a conference is not much more than simple diplomatic negotiation. By the same token, however, such conferences tend to diminish as international relations enter the stage of legal regulation and as more nations are called in to participate in the discussions. The result is that when we reach the later nineteenth century, and the period of multilateral international conferences proper, the meetings which deal with purely political or diplomatic matters are relatively few. ${ }^{1}$ Such, however, were the Conference on Cretan Affairs in 1869 and the Conference of Algeciras in 1906. ${ }^{2}$

1 This may be seen from the following table:

$\begin{array}{ccc}\begin{array}{c}\text { Date } \\ \text { (decade) }\end{array} & \begin{array}{c}\text { Purely Political } \\ \text { Conferences }\end{array} & \begin{array}{c}\text { Total of all } \\ \text { Conferences }\end{array} \\ 1850-59 & 2 & 2 \\ 1860-69 & 4 & 13 \\ 1870-79 & 3 & 29 \\ 1880-89 & 0 & 39 \\ 1890-99 & 0 & 35 \\ 1900-09 & 2 & 77 \\ 1910-14 \text { (half-decade) } & 1 & 38\end{array}$

Total of all

ferences

13

29

39

77

1910-14 (half-decade) 1

2 A list of the political conferences since 1850 follows:

$\begin{array}{ll}\text { Date } & \text { Place } \\ 1855 & \text { Vienna } \\ 1858 & \text { Paris } \\ 1860 & \text { Paris } \\ 1864 & \text { London } \\ 1867 & \text { London } \\ 1869 & \text { Paris } \\ 1871 & \text { London } \\ 1876 & \text { Constantinople } \\ 1878 & \text { Berlin } \\ 1900 & \text { Peking } \\ 1906 & \text { Algeciras } \\ 1913 & \text { London }\end{array}$

Crimean War (mediation attempted)

Danubian Principalities

Syrian question

Schleswig and Holstein

Question of Luxembourg

Question of Crete

Black Sea question

Balkan question

Same

Chinese affairs

Morocean question

Balkan affairs

Satow, $\S \S 472,474,476,479,481,484,485,487,467,491,493,496$, respectively. 
Frequently, especially since the development of "public international law," such questions take on also a legal aspect. Thus, the conference held at London in 1871 regarding the Black Sea question issued a declaration concerning the inviolability of treaties. ${ }^{1}$

More frequently, however, legal questions arise in connection with the details of current international practice, and a conference must be held to revise and codify the rules of international law relating to the conduct of war, the treatment of wounded in time of war, or the neutralization of certain sections of territory or certain bodies of water. It is worth noting that most of the early conferences on legal subjects dealt with the laws of war, just as the first treatises on the law of nations dealt with this subject. The reason is the same in both cases, namely, that war is the earliest and most critical form of international contact. The question of neutralization, again, harks back rather directly to the political sphere, inasmuch as the proposal to neutralize a given body of water can hardly be based on any established legal grounds and inevitably affects one nation or another adversely. Thus the neutralization of Belgium and Luxembourg resulted from the actions of the conferences, political in character, convened at London in 1830 and 1867. The Hague Conferences of 1899 and 1907 were conferences on legal subjects, as also were the London Naval Conference in 1909, the Conference of Brussels in 1874 , and others. ${ }^{2}$

Finally, economic and financial questions have become so prominent in international relations in recent years that several international conferences have been held to deal with them. Such was the Conference of Peking, in 1900, which dealt with claims for compensation for damages suffered by Europeans during the Boxer uprising in China, although at this meeting political and diplomatic

1 Satow, § 485.

'Same, $\S \S 471,481,486,490,494,495$. 
questions arising out of the quasi-war occupied the attention of the delegates in large measure. Such was the Conference on the Scheldt Dues in 1863, and such was the Conference of Algeciras in 1906, in so far as it dealt with questions of trade rights in Morocco. ${ }^{1}$

It is quite common, as this mention of the Conference of Algeciras shows, and as is also indicated by the comments on the Conference of Peking, for political, legal, and economic problems to arise for treatment in the same conference.

Speaking broadly, the last-named problems yield solutions more satisfactory from all points of view than the first two, and the second better results than the first. Economic questions can be subjected to statistical treatment and the knowledge and opinions of business men can be utilized; moreover, business is business, and neither eternal wrangling nor false pride nor national sentiment count as heavily in the business world as in the world of diplomacy. Legal questions might possibly be treated in a scientific manner, also, and professional lawyers and jurists might be called in for assistance. But the definition of general rules to govern all cases arising in the future is a delicate task for an international conference, and hence legal problems are not as easy of approval as they might be expected to be. When we get back into the world of political and diplomatic relations conditions are still worse. There are no fixed points to go upon, no generally accepted principles to apply, and not only is every man an expert-in his own estimation-but national desire, rather than inherent reason and right or the general interest, governs the outcome. In the fields of law and economies national greed is not unknown, but neither are considerations of common benefit, mutual protection. and good business for all.

The form given to the results of the conference varies

${ }^{1}$ Satow, $\S \S 478,491,493$. 
with the subjects discussed, as well as with the extent and definiteness of the conclusions reached. Legal problems are commonly disposed of by an international convention, which constitutes for the future a code of the law of nations on the subject with which it deals. Such were the Hague Conventions relating to the Rules of War. ${ }^{1}$ Economic and political problems are frequently settled by treaty agreements, and in such cases the whole body of theory applying to the negotiation and conclusion of treaties is applicable.

As has been said, the settlement in such cases may be a specific bargain for territory or an indemnity payment, or it may consist of the declaration of a general principle. The former type,-a mere contractual bargain,--resulted from the Conference at Hanover in 1861 regarding the Stade Toll. ${ }^{2}$ The latter type of settlement resulted from the Conference in London in 1871 respecting the Inviolability of Treaties and Navigation of the Black Sea. ${ }^{3}$ Such treaties or declarations as the latter, dealing with political problems, and at the same time attempting to provide a permanent rule of public law as a solution to govern similar cases in the future, represent the acme of difficulty and importance in the field of international legislation. They constitute international constitution-making. The one thing more important and more difficult is the closely allied task of establishing international governing bodies to exercise authority over the states in the future according to principles now defined in advance. Such action followed from the Hague Conferences and from the numerous conferences for the creation of international administrative bureaus. ${ }^{4}$ Practically all of the forty or fifty administrative bureaus now in existence have been created in this way.

It will be apparent that single international conferences

1 Malloy, 2259 and following.

2 Satow, § 476.

a Same, § 485, especially at 131 .

- Malloy, 1924, 2220. 
may well perform various functions. The Congress of Vienna, for example, was primarily a conference for the definitive termination of war, yet it was also a conference in time of peace striving to prevent future war. It dealt with purely legal questions,- -diplomatic rank,-with economic questions, and with political problems. It created an administrative bureau, it defined certain principles of the public law of nations in Europe, and it produced certain political results still evident in the state-system of the Old World. ${ }^{1}$

The form given to the decisions of the international conference is not the only thing influenced by the nature of the problems discussed. The organization and methods of action of the conference are subject to the same influence. This will appear as we examine the way in which the conference meets and sets about its work.

International conferences meet only upon invitation. ${ }^{2}$ There are no regular or automatic sessions, as in the case of national legislative bodies. There is no presumption that a conference will be held at any time. In the normal course of events no conferences meet at all. The burden of proof is upon any one suggesting a conference at any time, because of the absence of any conviction that a continuous series of regular conferences is needed. No state has any recognized right to call the nations to a conference and the family of nations has no recognized right to summon its members to an assembly. The proposal made at the conference at The Hague in 1899 that such conferences should meet continuously at regular intervals in the future was considered a radical proposition.

This situation gives the nation which initiates the conference an enormous tactical advantage. ${ }^{3}$ The agenda or

Satow, §461.

'Oppenheim, $\$ 484$; Proposals for Hague Conference of 1907, below, Appendix A, Documents No. 8a, 8b, and 8c, cited hereafter as Props. Hague Conf., a, b, or c.

${ }^{3}$ Lansing, 12-16. 
program of discussions at the conference must be decided. What shall be discussed and what shall not be discussed depends in the first instance upon the proposal of the "august initiator" of the conference. ${ }^{1}$ Frequently the acceptance or rejection by other nations of the invitations issued to them by the nation suggesting the conference depends upon the views held by the former as to the general advisability of the meeting and as to their own advantage in discussing the subjects proposed. Frequently they will make reservations concerning the proper range of discussion in the forthcoming conference, thereby excluding certain topics from its jurisdiction. Frequently the agenda as originally proposed will be modified, in view of preliminary objections from the nations invited to attend the conference, and in order to obtain their consent to participate.

This power of defining the agenda before the beginning of the conference also gives great prestige and influence to the nation initiating the conference, an advantage enhanced by the fact that the conference will usually be held in the territory, and at the seat of government, of this state. It is likewise an occasion of suspicion. If a certain nation moves for a conference on a certain subject it may be assumed that it is for certain definite national advantages that the move is made. So Napoleon III was continually under suspicion because of his frequent suggestions for European conferences; he was suspected not only of having an axe to grind in each particular case but of desiring to secure a sort of diplomatic domination over Europe as a whole. The other nations, therefore, come prepared to combat the äemands of the nation which is chiefly sponsoring the conference. Because of the way in which the agenda is drawn up, there can hardly be a set of openly competing programs when the conference meets; and this is an unhealthy thing in itself. Furthermore, competition or opposition which is stifled makes itself felt in a silent

${ }^{1}$ Props. Hague Conf., b and c. 
suspicion and mistrust and an opposition "on general principles." Where preliminary national views have been canvassed fully in advance, something like competing party programs exist at the outset, and it is generally agreed that such a procedure helps enormously, for the members do not then need to lose time in discovering each other's beliefs and demands.

The nation holding the conference is free, in the nature of the case, to invite such other states as seems best, subject to the danger of giving offense by failing to invite this or that state, and to the danger of opposition to the results of the conference from non-participants. A nation initiating a conference on maritime law and failing to invite Great Britain would encounter both British resentment and futility of results. In such a case, other states would in all probability refuse to attend, for the same reasons.

Membership in the conference itself is limited to accredited representatives of states which have been invited to attend and which have accepted. This limitation is enforced through a system of credentials. Delegates carry commissions and powers identifying them as representatives of this or that nation, and these credentials are inspected by a credentials committee at the beginning of the conference. ${ }^{1}$

The membership of the conference having been decided, it remains to select the presiding officials and the secretariat. Here again the state holding the conference has an enormous advantage, for that bane of international relations, precedence and dipiomatic courtesy, decrees that the presiding officer and the chief secretary shall be chosen from among the representatives of the local state. ${ }^{2}$ When the deliberations of the conference are also conducted in the language of that nation the result is complete. The secretarial force, working with all the conveniences which

1 Oppenheim, § 485 .

'Same, at 512 . 
the local government can place at its disposal, largely controls the agenda and the record of the conference, and the chief secretary controls the secretarial force. Even where no effort is made to abuse its power, the state holding the conference exerts an enormous influence on the conference through these simple facts.

The conference meets in full session at the beginning and may hold plenary sessions thereafter as often or as seldom as seems best. It ordinarily closes with one or more plenary sessions. In the intervals come many sittings of committees and commissions, in which experts are heard and matters are thrashed out in detail for reference to full sessions of the conference for final decision later. ${ }^{1}$ The conferences on legal and economic questions employ the committee system and make use of experts more extensively than do those on political and diplomatic problems; in the latter the principal delegates insist on keeping things strictly in their own hands. It is for this reason that there seems to be some ground for speaking of the former bodies as "congresses" and the latter as "conferences."

Debate is, of course, far freer in the committees than in the full sessions, especially among the experts in attendance at committee meetings, who are interested in the subject-matter under debate and have few scruples about international delicacy and sensitiveness. Speeches at the plenary meetings are stilted, formal, flowery. The real argumentation in the conference, so far as there is any at all, comes in committee meetings. Steam-roller methods are not uncommonly employed in the plenary sessions to put through bargains made outside, either in committees or still further out in the corridors of the conference chambers. This is especially true where the plenary sessions are public and where committee meetings are-as is commonly the case-confidential. This may not be true where the conference is concerned with legal problcms, where committee meetings have been public, and where a fight in

'Hershey, § 293. 
committee crops out again on the floor in plenary session. All of this is quite like the situation in national legislative bodies, only in greater degree. To criticize the methods of doing business in international conferences is, of course, to criticize the common methods of legislation in all ranks of political organization-international, national, provincial, and municipal. That criticism may, however, be applied to international conferences with special aptitude. There seems to be something in the nature of the subject matter and in the traditions of the profession which encourages this particular sort of thing in international bodies.

Members of the conference are not ordinarily free to vote according to their best judgment on proposals coming before them but are bound by restrictions from their home governments. They are instructed delegates, not discretionary representatives. As a further result, the votes are not so much counted as weighed. That is, the vote of a delegate is not regarded simply as one vote, but as evidence of the support of his government, whatever that be, great or small, strong or weak. The vote, moreover, is not given so much upon the basis of arguments or facts brought out in the conference as upon grounds of national policy maintained and asserted by the home government, not present at the conference at all.

This is made easier by the rule of unanimity which invariably prevails, as far as final decisions are concerned, at such conferences. ${ }^{1}$ After all, this is at bottom the negotiation of a treaty, the making of a contract. The consent of each participating state is therefore necessary to give binding force to the result. The doctrine of sovereignty admits national consent alone as the basis of national obligations. Even without any formal doctrine of sovereignty, however, the result would be the same. There are no $a$ priori grounds on which any nation or nations can claim as of right to impose obligations upon another.

${ }^{1}$ Hershey, § 293, and note 10. 
This requirement weakens the value and effect of committee decisions unless all members of the conference are represented on all committees. In that case the value of committee work is lowered by being made more cumbersome and difficult. The committee becomes a miniature conference, with all the power-potentially-and all the difficulties of a conference. The only solution is a prior agreement among the nations in conference to be bound by a majority or a two-thirds vote on decisions to be taken in the course of the conference. Such a vote would preserve the doctrine of consent and at the same time remove the necessity for unanimity at every step and on every point in the discussion. Whether the nations are ready for such a step, and whether, on the whole, it would be wise, are other questions. Its effect on the procedure of international conferences cannot be doubted.

A similar result flows from the doctrine of state equality as applied in international conferences. ${ }^{1}$ The smaller states would generally refuse to go into conference with the larger ones if they were compelled to admit that the larger states possess some degree of jurisdiction over themselves as of right. Yet nothing could be more unjust and unscientific than to give the few thousand citizens of Panama equal power in international legislation with the hundreds of millions of subjects of the British Empire. And in actual practice, of course, the votes of different nations count differently in the results in the sessions of the conference. What is needed is a theory of national representation in international bodies which will rest on facts, not upon an outworn metaphysic of public corporations. ${ }^{2}$

The conference ends with the signing and sealing of the treaty, as described in connection with treaty negotiation. The fact that only signatories are bound by the treaty

1 Oppenheim, §484, end; also Dickinson, 281-283.

'Dickinson, 286-292, and Myers, "Representation in Public International Organs," in Am. Journ. Int. Law, VIII, 81-108 (January, 1914). 
derogates somewhat from its legislative character. But for those who sign, and in so far as the signers do not impose reservations upon their signatures, the effect is to legislate into existence new rules of international law, assuming, of course, as we must assume, that the national states will ratify the actions of their agents. The delegates accept the new statute for their constituents as do members of legislative bodies in the national states, at least in national states where legislation is subject to referendum. This is the most vitally important process in international control.

Among all the international conferences in time of peace during the last hundred years the Hague Peace Conferences are the most famous. Yarious comments have already been made upon them, but it may not be superfluous, in spite of the amount of attention bestowed on these conferences in the literature of international organization in the past fifteen years, ${ }^{1}$ to summarize here some of the more important observations to be made concerning them.

The conferences of 1899 and 1907 were held on the invitation of Russia and the Netherlands. The coöperation of the latter was made necessary as the conference was to meet in Dutch territory. The conference was to discuss a list of topics suggested by Russia. ${ }^{2}$ Proposals from other nations were brought forward with more or less hesitation. The conferences were attended by thirty or forty independent states of the world and dealt with legal questions entirely, questions ranging from the details of the conduct of war to constitutional principles concerning the organization of tribunals of arbitration. Great difficulties-apart from national opposition on political grounds-were encountered. Plenary sessions were frequently held, and also sessions in committee, where the main work was done, largely by expert jurists and lawyers.

${ }^{1}$ Scott, Conferences, I, as cited, below, Appendix B, $\S 20$

${ }^{2}$ Props. Hague Conf., below, Appendix A, as cited, b and c. 
The equality of states was formally recognized, and likewise the principle of unanimous consent, thus badly crippling the work except where considerations of power and influence served to correct that dogma in the interests of realistic truth. The results were put in the form of conventions, which were signed in the usual treaty form for subsequent ratification by the home governments.

The object of all of the work of the conferences was to prevent war, to limit its application, to regulate its conduct. It was hoped that the common interest of Europe might prevail to some extent, in spite of national policies, military and naval programs, and diplomatic considerations, and, in a certain measure, this hope was gratified The chief results of the conferences were to encourage this general type of international practice; to establish a court of arbitration which, as has been seen, settled several international disputes of considerable importance before 1914, and is still in active operation; to begin the work of codifying international law; and to reveal the limitations of international organization at the time and the source of the most determined opposition to its improvement, namely, Germany. Other conferences have accomplished far more in definite effective and constructive work; none have influenced public opinion so strongly in favor of international conferences as such. In many directions the conferences at The Hague asked more questions than they answered. Their chief value was neither to ask questions nor to answer them, but to assert the feasibility of international constituent and legislative assemblies.

After all is said of the work of the past, however, the fight for the principle of international discussion and agreement is yet to be won. The nations do not fully admit that international conference is a natural and normal action. They have not seriously set themselves to the task of solving the problems of procedure connected therewith - the problems of representation, of majority rule, of rati- 
fication, and others-because they have expected to be able to dispense with conferences except in abnormal times. The great value of the Hague Conferences was that they inaugurated what was by implication to be a continuous and permanent series of such conferences. The interruption of 1914 would constitute a tremendous catastrophe indeed if it had not led to a resumption of the process of conference in a fashion and on a scale more significant even than the activities of the nineteenth century and the Hague Conferences themselves. To this matter we shall presently return. ${ }^{1}$

${ }^{1}$ Below, Chaps. XXI, XXVII-XXIX. 


\section{CHAPTER XXI}

\section{PEACE CONFERENCES; THE CONFERENCE OF PARIS}

$7 \mathrm{HE}$ origin of international conferences in time of 1 peace was found to lie in deliberate efforts to take thought for the morrow and to preserve the peace in the future by international arrangements made in advance of the actual need for them. Conferences for the termination of war are quite different. Such conferences, called "peace conferences" by reason of the object directly in view, namely, the restoration of peace, are actually held in time of war and originate in the practical necessity for clearing up the problems at issue between or among two or more states whose interests have clashed and whose peaceful relations have actually been interrupted by the outbreak of war. ${ }^{1}$

It would be possible, of course, for belligerents merely to stop fighting, and to go on into the future without concluding a formal treaty of peace, and this has happened several times in the modern history of international relations. $^{2}$ Such a method of terminating war, known as "simple cessation of hostilities," is, however, very unsatisfactory to all concerned. The belligerents themselves are left in doubt regarding each other's intentions. Hostilities may be resumed without warning. A constant attitude of defense and suspicion is rendered inevitable. Neutrals, again, or states which would be neutral if war really ex-

${ }^{1}$ On peace conferences see literature cited, below, Appendix B, $\S 21$.

3 Phillioson, Termination of War, 3-8. 
isted, are left uncertain regarding their rights and duties toward the belligerents.

Finally, the status of occupied territory is ambiguous. The termination of war by the conquest or complete subjugation of one party by the other might leave no room for doubt. ${ }^{1}$ Even here, however, both logic and convenience require some formal notice to the world by the conquering power declaring its intention respecting the conquered territory. And where merely a portion of the territory of an opposing belligerent has been occupied it is doubly desirable for the status of that territory to be defined and made known to all the members of the society of nations. Where hostilities have long ceased and positive acts of peaceful intercourse have been performed by the recent enemies, third states must conclude that the war is over and, according to the rule of uti possidetis, that the occupied territory has passed under the sovereignty of the state whose forces are in possession at the termination of hostilities. Obviously, however, it would be better for all concerned if the belligerents would clear up all questions outstanding between them in a formal and explicit agreement or treaty of peace. The superior convenience of such a settlement has led to the practice of conference for the termination of war.

As has been pointed out, such conferences are far older than conferences in time of peace. Indeed, they are as old as international relations themselves, since war and the termination of war are equally as old. From the immemorial dawn of tribal and interstate conflict belligerents have met together, quite naturally and simply at first, deliberately and ceremoniously later, to patch up the broken fabric of their normal relations one with another. ${ }^{2}$ And in spite of the knowledge that the peace to be made will not, in

1 Phillipson, Termination of War, 9-19.

See treatment of jus fetiale in Phillipson, II, Chap. XXVI, and 320-321; also Bouché-Leclereq, 541-543. 
all probability, be permanent, in spite of the memories and feelings of war which still dominate men's minds, such meetings have never failed to appeal mightily to the peoples suffering from the hostilities, and in some degree even to the cynical professional diplomat who could but suspect that this was only. one of the many pacifications hailed as complete and definitive at the time, only to be proved hollow and transitory in the event. The outburst of feeling throughout Western Europe and the United States on 11 November, 1918, may be recalled in this connection.

Certain notable changes have, however, come over the typical peace conference in the past century. Of these, three deserve notice here.

First, there has occurred what might be described as a generalization of the peace conference in respect to the parties who are concerned and who are therefore invited to participate. Originally the peace conference included only the belligerents, and in the great majority of cases only two belligerents. This form of peace conference still persists, of course, and is illustrated best by a case where the belligerents come in contact and conduct their conference to a successful conclusion without aid from any third state, as happened at the end of the war between France and Germany in 1871. ${ }^{1}$ In later times, however, there has appeared a tendency to expand the peace conference to include several, and indeed many, powers. This has been due partially to a second tendency, discernible still farther beneath the surface of events, whereby wars have changed from "special" wars between two parties to "general" wars involving several parties. This has resulted, in the main, from the increased degree to which the interests of all nations are interwoven in modern times, and, more especially, from the practice of forming alliances for the furtherance of these interests. So long as all of the participants in the peace conference are belligerents, there is 1 Phillipson, Termination, 60. 
no sharp break with the traditional theory. Very early in modern international relations, however, it was felt to be advisable to call in states which had been neutral in the war, in view of the extent to which their interests were involved in the general settlement. This happened at Westphalia in 1648, at Vienna in 1815, and again at Paris in 1856 , to name only three famous general peace conferences, and it marks a new stage in international constiti:tional development. ${ }^{1}$

In like manner the questions treated in peace conferences have been generalized. Originally the questions at issue between the belligerents in the war were, alone, put in discussion. With the expansion of the area of conflict, however, the necessity for keeping in view many collateral questions affecting the belligerents, and also states with whom the belligerents were in mutual relationships, became evident. Inasmuch as the object of peace conferences soon came to be that of making a permanent peace, and not merely patching up the current dispute, this necessity grew greater. In the end what was involved was a general review and settlement of all outstanding international disputes, a general pacification. The peace conference thus approached more nearly the nature of the conference in time of peace, that is, an international constituent assembly of general jurisdiction. ${ }^{2}$ The traditional rule to the effect that only questions at issue between the belligerents come within the jurisdiction of the conference is still put forward by neutrals desiring to block consideration of questions affecting them and by belligerents desiring to avoid certain embarrassing problems. None the less the tendency described is unmistakable in practice, and in view

${ }^{1}$ Westphalia: Satow, II, $\S 441$, especially $7-8$; Vienna: same, 77 ( $\left.\$ 461\right)$; Paris: Phillipson, 120.

"See Satow's distinction between "Congresses"; and "Conferences" in Chaps. XXV and XXVI; see also the anxiety of the Powers in 1818 to prevent other states from thinking that the forthcoming meeting at Aix-la-Chapelle was to be a Congress and thus prevent "the intervention of other princes and cabinets" (Satow, § 462). 
has led not only to the holding of conferences in time of peace to devise in advance a settlement of better quality than that of a settlement to be attained at the end of a possible war, but also to the holding of conferences in the ensuing state of peace to revise settlements already made at the end of a preceding war. Such was the Congress of Aix-la-Chapelle in 1818; such, more clearly, was the Congress of Berlin in 1878; and the action of Russia, Germany, and France in 1895, regarding the Treaty of Shimonoseki between China and Japan, is of the same type. ${ }^{1}$ It was largely the failure of the Powers to take such action respecting the Balkan settlement of 1913 that prepared the ground for the events of $1914 .^{2}$ The peace of 1919 was subjected to revision by Inter-Allied conferences during the whole of 1920 and 1921. Considering this development along with the establishment of the conference in time of peace to prevent war, it is possible to say that peace conferences are being generalized, not only as to parties involved and questions discussed, but also as to the time when they are held. In addition, it may be observed that such conferences for revision of peace settlements attest further the interest taken by states not parties to the war, especially the Great Powers, where a settlement has been made by minor powers which appears to them defective from the point of view of their own interests or the balance of power and the general peace.

In organization and procedure, peace conferences do not differ materially from conferences in time of peace, and a brief review of the subject will therefore be sufficient.

A peace conference convenes as the result of either direct negotiations between the belligerents or action by a third state in providing a means of bringing the belligerents into conference. ${ }^{3}$ Participation is, of course, wholly

'Satow, $\S \S 462,467$; Seymour, 128.

Seymour, 243.

Phillipson, 75-93. 
voluntary, and depends upon calculations of the results which it may be possible to obtain from such a conference in contrast to those to be obtained by continuing the war. ${ }^{1}$

The membership of the peace conference has already been discussed. It should be recalled that at times the conference is attended by the mediator, if it happens that the war has been brought to an end through the offices of a mediator. ${ }^{2}$ This is very likely to happen where the mediator has been led to take action in order to defend certain national interests, and especially where the mediation has been performed by one or more of the Great Powers in defense of their own interests or the general welfare, and where the small powers, belligerents in the war, have been compelled to accept such mediation. ${ }^{3}$ In all cases, however, the belligerents must be present; a peace conference without them, even with mediators or conciliators present, would be "Hamlet" without the Prince.

The range of subjects discussed, or the jurisdiction of the conference, has also been described in another connection. ${ }^{4}$ A further set of considerations must, however, be added here.

It should be noted, first, that the jurisdiction of a peace conference must be defined in terms of subjects or questions, not in terms of parties or territory. The conference has no legal power over any territory or property, nor has it authority over any persons or states. More important still, the powers victorious in the war do not gain thereby any degree of legal authority over the vanquished nor over his possessions.

In the second place, the territory of one belligerent occupied by another is not thereby acquired in full sovereignty, even where the whole of the territory of the enemy is so

1 Example in Seymour, 229-230.

Attendance of French mediator at conference near Belgrade in 1739 at end of Turko-Austrian war; Satow, § 634.

The Great Powers were in complete control in the Conference of London in 1913 for the termination of the first Balkan war; same, $\S 496$.

Above, 323-327. 
occupied. ${ }^{1}$ In this case only a cessation of resistance and an at least tacit consent-albeit "forced" consent-to annexation or absorption in the conquering state, accompanied, probably, by a proclamation of the annexation by the latter or some overt act testifying to the same intent, will be effective in the eyes of other states. In the former case, only cession in an international agreement or consent to the retention of the partially occupied territory by the state at the time in possession will be effective. This is one of the chief reasons for holding a conference between the belligerents at the end of a war.

Military victory, moreover, gives to the successful belligerent no legal authority to dictate terms to his defeated enemy. It is doubtful whether peace can ever be successfully founded upon dictation; it is certain that a treaty cannot, in its very nature, be dictated by one state to another. Not only must the conquered be taken into conference, but his consent must be secured, to render valid any changes which affect his rights under the status quo ante. ${ }^{2}$ A state may find it necessary to accept certain changes and to agree to certain terms of peace, in order to avoid certain other results, such as military occupation of its territories, massacre, or what not. But, after all, some alternative is present in such a situation, and freedom of choice, in a sense necessary to satisfy the doctrine of sovereignty, is preserved. Nor is this merely an imaginary freedom, for a state might prefer to go on with the war; cases have been known in which states have refused to bow the knee even when all seemed lost. The choice of agreeing to the proffered terms or continuing to resist is always present, at least in form.

From a strictly mechanical viewpoint, peace conferences are ordinarily organized much as are conferences in

${ }^{1}$ Phillipson, 9.

'See recognition of this by Allies in 1921; New Fork Times, 30 January, $1921, \S 1$, p. 1 . 
time of peace. They are based on credentials and fullpowers and, ordinarily, upon the principles of equality of representation and voting power, and they operate by unanimous consent-the consent of all allies must be obtained as well as that of all enemies. ${ }^{1}$ Presiding officers and secretaries are chosen, plenary sessions and sessions in committee are held, and the results are put in the form of a treaty and signed.

However, peace conferences are not usually as well organized or as well conducted as are conferences in time of peace. They are composed of diplomats in the narrowest sense of that word, and the personal element plays a very great part in the negotiations. They are smaller in membership; they do not make use of committees and commissions as fully as do the conferences in time of peace; they operate more secretly; they go less upon grounds of law and economics and statistical data generally, and more upon grounds of "policy," national ambition, and the personal opinions of the negotiators. There is more dickering behind the scenes, extra-conference agreements are more numerous, ${ }^{2}$ and there is more subterranean "accommodation" all along the line. Not common and permanent advantages, but exclusive, direct, and immediate, even if temporary, national advantages, are pursued. There is no fixed program or agenda to be followed and everything depends on the turns in the negotiations from day to day. The result is that the atmosphere is very unwholesome and not conducive to the production of a sound settlement. Indeed, the questions are not commonly approached as problems to be settled by joint efforts to discover sound solutions, but as contests in which each nation must seek to outwit the other in securing satisfaction. ${ }^{3}$ Another way

\footnotetext{
${ }^{1}$ Phillipson, 111-129; also literature cited, below, Appendix B, § 21, espeeially Satow, Conferences.

${ }^{2}$ Satow, $\S 497$, gives a record of the conference at Bukarest in 1913 where this appears very clearly.

Herbert Adams Gibbons, writing in 1917 of the possibility of a peace based wholly on the military situation at the (prospective) end of the war,
} 
in which this may be viewed is to note that there is no one present to represent the general interest of the society of nations. In conferences in time of peace, consideration of the general welfare need not be, and is not, entirely forgotten. In the diplomatic contests in a peace conference it usually is. ${ }^{1}$

The Peace Conference of Paris in 1919 is the last great peace conference on record, and it may profitably be studied in the light of previous conferences of the same type. ${ }^{2}$

The Conference was brought on by the mediation of the United States, a belligerent state, undertaken at the request of Germany, an enemy state, to secure an armistice on certain terms from its co-belligerents, unusual as such a step may seem to be. The United States being one of the belligerents, this might be regarded as a case of direct negotiations between belligerents without the interposition of an outside power; such a conclusion must be qualified in view of the fact that Germany communicated her request to the United States "to take steps for the restoration of peace" and "to bring about the immediate conclusion of a general armistice" through the good offices of Switzerland. ${ }^{3}$ Both the good offices of one power and the mediation of another (one of the belligerents) were, therefore, employed. Moreover, the basis of the requested mediation was to be a set of statements. of peace terms already put forward by the mediating enemy belligerent. The United States, furthermore, became a participant in the Conference itself as much in the rôle of mediator as in that of enemy. In the course of the Conference, the United States

said: "For there will (in such a case) be no peace problems. The victors will refuse to consider problems" (my italies); New Map of Africa, 481.

${ }^{2}$ For atmosphere and attitude of parties at great peace conferences in the past see Hazen, entire (Vienna, Paris, Berlin), and Hill, II, 592-607 (Westphalia). B, $\$ 21$.

${ }^{2}$ On the Peace Conference of Paris see literature eited, below, Appendix

Documents in Temperley, I, 448. 
played the rôle of mediator at times very strongly; at other times it played the rôle of enemy.

The Conference included as contracting parties not merely enemy belligerent states, but states not enemies in the war, states not belligerents, and belligerents and enemies not entitled to be regarded as states stricto jure. The Conference recognized as participants autonomous colonies, "states in process of formation," states which had merely severed diplomatic relations one with another, and entirely neutral powers. ${ }^{1}$ The basis of participation was interest, not status in reference to the war. Neutral powers and states in process of formation participated, it is true, not as of right, but upon the invitation of the Principal Allied and Associated Powers. Nevertheless, the resulting treaties were signed by certain of the latter, including neutral powers "in a state of diplomatic rupture" with the Central Powers, ${ }^{2}$ and even the lesser belligerent nations were dependent for their share in the Conference upon the will of the Great Powers. Moreover, the fact that all these powers did actually participate in the deliberations and settlement is more important than the decision of a hypothetical legal question whether and by whom they might have been excluded if it had been desired to do so. The result was a general world congress, not merely a peace conference. Westphalia and Vienna were repeated, on an enlarged scale, covering Europe, Asia, the Americas, Africa, and Australasia.

The many participants were grouped in the Conference into two groups: powers with general interests, and powers with particular interests, not to mention further the powers not strictly belligerent. ${ }^{3}$ These groups and the members thereof were unequally represented, as a result of the decisions of a self-appointed Supreme Inter-Allied

1 Documents in Temperley, I, 247.

Same, III, 105.

s Paris Peace Conference Regulations prescribing organization and work of the Conference, Art. I, below, Appendix A, Document No. 10. 
Council, eomposed of those Great Powers which were determined to insist on this arrangement and upon having the largest numbers of delegates under it. At the same time the delegations voted as units-as a result of unescapable political forces-and the number of delegates counted chiefly as a matter of prestige and influence. ${ }^{1}$

The rule of unanimous consent was, of course, respected in form. ${ }^{2}$ At the same time, individual states voluntarily "yielded," as they sometimes said, "to the majority." 3 More important still, the smaller Allied states were in no position to challenge the decision of the Principal Allied and Associated Powers from the point of view of either physical power or reason and justice, seeing that all power and responsibility was inevitably concentrated upon the Great Powers in point of fact, and both sides were thoroughly well aware of this. ${ }^{4}$ It was said by one eritic, half in jest, but half in earnest, that the peace was dictated not only to Germany but to the lesser Allied and Associated Powers. At all events, the rules of equality and unanimity were not effective in fact, except, in a mild way, among the Great Powers themselves. The United States,-Great Britain, France, Italy, and Japan,-particularly the first three, controlled the Conference.

It is, however, necessary at this point to examine more precisely the way in which certain of the participating powers did-and did not-make their appearance in Paris toward the end of 1918 and the beginning of 1919, and the effect which this behavior had upon the Conference.

When the German request of 6 October, 1918, for an armistice and a peace conference was submitted to the

1 Temperley, I, 248.

'Same.

${ }^{3}$ Clemenceau is quoted as having said to Mr. Wilson and Mr. Lloyd George at one time: "Since I am in a minority I must bow to your decision." New York Times, 18 September, 1921, § 7, p. 8.

${ }^{4}$ See the protest of the smaller powers in the plenary session of 25 January, and the reply thereto of President Clemenceau, in New York Times, 26 January, 1919 , pp. 1-2. 
Allies by the United States, it was necessary for the Allies, including the United States, to discuss that request. The request was therefore taken up by the Inter-Allied Supreme War Council, a body created by and among the Allies in November, 1917, for coöperation in the conduct of the war, and consisting of the "Heads of State" of the four Great Powers (Allies) and the Foreign Ministers or their representatives, in each case, assisted by "Military Advisers." 1 The German request was granted by the Allies upon the advice of that body, and the armistice was concluded under the control of that body on 11 November. ${ }^{2}$ There followed an interval of two months during which slow, irregular, and informal steps were taken in bringing the Conference into being. No official invitation or call to the Conference was, apparently, sent out. The Supreme Inter-Allied Council, acting in part as the War Council, in part as a new body for the maintenance and supervision of the armistice and for the establishment of the Peace Conference, continued to function during the whole of the period of the Conference in this capacity. " "Meanwhile," as it is casually described in the most authoritative history of the Conference, "there gradually assembled at Paris the host of Delegates and Officials who were to constitute the Conference." 4 Plans for the organization and procedure of the Conference were worked out, under pressure of the situation as it developed, by the Supreme InterAllied Council according to the views and policies of the five Great Powers, and these were communicated to one another through oral conferences among representatives on the ground in Europe or through the ordinary diplomatic channels.

One of the earliest decisions taken was that the Con-

"'The Supreme War Council," in League of Nations, I, 388 (Oetober, 1918), especially note 1 .

2 Temperley, I, 457, 458.

Same, $279-357$.

- Same, 243. 
ference about to open should not include representatives from the Central Powers. ${ }^{1}$ The Conference as it convened in January, 1919, was, therefore, a "Preliminary Inter-Allied Conference" on the conditions of peace, whose object was to draft a proposed treaty for submission to the enemy. It was, nevertheless, the real Peace Conference in many respects, in that the principal conditions of peace were determined and the bulk of the work in formulating the terms of the treaty of peace was done there. Moreover, President Poincaré, in opening the sessions, on $18 \mathrm{Janu}-$ ary, described the meeting as "the Conference of Paris" 2 and the "Regulations" governing the work of the Conference were so phrased as to indicate that there was to be only the one (preliminary) conference, whose task would be to frame a treaty to be signed by the enemy. ${ }^{3}$

The reasons for this step and its results were manifold.

In the first place, there were so many powers and so many problems involved on the side of the Allies alone that it was feared that dissensions might arise which would be dangerous to the interests of individual Allied Powers, to the common cause of the Allies, and to the general peace, unless questions at issue among them were composed by a conference unhampered by the presence of enemy delegates. Attempts had already been made by the four leading Allied Powers to come to an understanding on the desirable terms of peace in conferences held in London on 4-6 December, 1918, but with no great success. ${ }^{4}$ The bulk of the negotiating to be done in Paris therefore was to be done by and among the Allies. Moreover, as the choice of Paris rather than Geneva or some other neutral city as the scene of the Conference indicates, Allied opinion was averse to a free debate with Germany on the terms of peace.

${ }^{1}$ Same, 241-242, 248.

'International Conciliation, No. 139 (June, 1919), 813.

${ }^{3}$ Paris Peace Conference Regulations, as eited, Arts. I, V.

${ }^{4}$ See Woolf, 55, on significance of these preliminary conferences. 
The results of this step were unfortunate. While President Wilson had insisted upon an agreement by Germany that nothing was to be open for negotiation but the "practical details of the application" of the principles embodied in the Fourteen Points and other speeches of the President on the terms of peace, he clearly had in mind a full discussion of those details. ${ }^{1} \mathrm{He}$ accordingly opposed, although ineffectively, the exclusion of German representatives from what was in effect the real conference, just as England had opposed, in this case with success, the proposal to exclude France from the discussions at Vienna in $1815 .^{2}$ The treaty as framed, on the other hand, had the appearance of a peace dictated to Germany, even in the details. The element of dictation was greater than it had been in the settlements of 1815 and 1871, or, indeed, in any modern case. Moreover, in the discussions attendant upon the formulation of the treaty there was lacking, in the absence of enemy delegates, that competition and balance of ideas and demands which alone can insure sound and just conclusions, no matter how wise and righteous the representatives of any one party to a controversy. This judgment has since been confirmed in many ways. ${ }^{3}$ And if it be admitted, as it probably must be, that any other course was impossible in the circumstances, this merely confirms the conclusion that it is impossible to secure sound and just settlements of international affairs in conferences during, or at the conclusion of, war. This is particularly true when national propaganda is employed as extensively as it is today with the object and result of stimulating public feeling and opinion against the enemy to a point where full and free conference is impossible.

The Conference among the Allies proceeded in its work

${ }^{1}$ Notes of 8 and 23 October, 1918; Temperley, as cited, 450, 455.

2 Satow, $\S 461$, at 76 .

Thus, it was discovered, in 1920, that the reparations question could only be satisfactorily treated by oral conferences with the Germans; New York Times, 5 July, 1920, p. 4. 
during most of the time from 18 January to 7 May, 1919, when the draft treaty was handed to the Germans. ${ }^{1}$ Preliminary discussions among the Principal Allied and Associated Powers had resulted in a set of "Regulations" governing the organization and work of the Conference, ${ }^{2}$ based originally upon a French memorandum which was submitted on 12 January to the Supreme Inter-Allied Council, ${ }^{3}$ -known from now on as the Council of Ten, two Japanese representatives being added to the original eight on 13 January. These regulations provided for representation in the Conference, as already described. In addition, provisions were made for precedence in the Conference "according to alphabetical order in French" of the names of the Powers. ${ }^{4}$ It provided for the opening meeting, verification of credentials, choice of permanent officers, a secretariat, the sessions of the Conference, procedure, and the making and publication of records. ${ }^{5}$

The regulations implied that plenary sessions were to be the rule, committee work the exception. ${ }^{6}$ In the event the Conference actually met in plenary session but six times prior to a meeting with the Germans on 7 May. $^{7}$ This was due to the same causes which led to the decision to hold a preliminary Inter-Allied conference in the first place, to the increasing need for speed in the work of making peace, to the difficulty anticipated by all of maintaining secrecy under such conditions, and to the desire of the Great Powers to keep matters in their own hands for settlement.

Work by committees and commissions and the Supreme Council therefore became the usual thing, plenary sessions

1 Temperley, I, 252-268.

Above, p. 346, note 3 .

Temperley, as cited, 247.

- Regulations, Art. IV.

-Same, Arts. V-XV.

- Same, Arts. X and XIV.

- Temperley, as cited, 249. 
the exception. The bulk of the work was done oy the Supreme Council, at first a Council of Ten, later a Council of Five, when the Foreign Ministers were separated into a Council by themselves to act as an auxiliary to the Council of Five, later a Council of Four, when the Japanese ceased to attend, and at one time a Council of Three, while the Italians were out of the Conference. ${ }^{1}$ The three leading members of the Conference-Clemenceau, who had been elected "President of the Conference" and who was also "President" of the Supreme Council in its many forms, ${ }^{2}$ Wilson, and Lloyd George-thus controlled the decisions of the Conference as a whole.

The many committees and commissions, sub-committees and sub-commissions, of the Conference, appointed in part by the plenary Conference, in part by the Supreme Council, and dealing with the many subjects in debate, met continuously. $^{3}$ They were assisted by the "experts" attached to the various delegations, ${ }^{4}$ and they prepared data and recommendations for the Supreme Council and the Conference. It is still impossible to describe with accuracy and assurance the full array of these bodies. Their work, moreover, was always subject to the decisions of those whom they served, and it is to be noted that their reports were in most cases turned over to the Secretariat for such use as the Supreme Council might choose to make of them.

The rules of procedure set forth in the Regulations were severely enforced in the plenary sessions-with such alterations as circumstances seemed to him to require-by M. Clemenceau as President. ${ }^{5}$ They had no application, how-

1 Temperley, 249, 263, 268; as a matter of terminology it should be noted that the Council of Foreign Ministers was called the "Council of Five" and that the Council of Heads of States was never known as a council of five inas. much as the Japanese representative dropped out simultaneously with the separation of the Ten into two bodies. Temperley, as cited, 499.

2 On Clemenceau's position see Lansing, R., 10-36, especially 16, 25.

Temperley, I, 500.

- Same, 244.

- Lansing, as cited, 110. 
ever, in the work of the Councils and the commissions, and are therefore of little or no importance. ${ }^{1}$

The work of the Secretariat, including the really marvelous performance of the official interpreter, needs only to be mentioned. ${ }^{2}$ The keeping of records was rendered a stupendous task by the decentralization of the Conference, but the French Foreign Office, with an eye for the value of such records of what was going on day by day, was indefatigable in this direction. ${ }^{3}$

In keeping with the irregular and informal way in which the members of the Conference assembled, the verification of credentials was delayed until a late date, contrary to usual practice. ${ }^{4}$ The sum and substance of this was that political power and influence, rather than legal authority, determined the place occupied by individual delegates in the rather amorphous conference going on in hotels and offices all over Paris.

The problem of publicity in international conferences has already been fully discussed. ${ }^{5}$ Next to the exclusion of the German delegates, the partly successful attempt to prevent any real publicity regarding the discussions in process probably exerted more influence upon the character of the result than any other one thing, apart, of course, from the national demands and personal influences operating in the negotiations themselves. The discussions did not enjoy the benefit of any wide scrutiny until they had emerged in the form of a treaty too complicated and extensive to be substantially changed. Moreover, the Allies actually attempted to keep the text of the Treaty of Versailles secret, while issuing an official summary of it, after it was handed

1 They are not printed at all in Temperley.

Temperley, I, 250.

Lansing, as cited, 113.

- The matter was not taken up until the signing of the German treaty became imminent. It is noteworthy that the subject is nowhere treated in Temperley.

See Temperley, I, 254, for a temperate statement of the problem in connection with the Paris Conference. 
to the Germans on 7 May. ${ }^{1}$ The intention, doubtless, was to make the treaty public only after signature, pending ratification. In a narrow sense of the phrase this would have satisfied the requirement for open covenants openly arrived at, because the critical step of approval and consent to ratification would, in such circumstances, be taken in the open, but only in that very narrow sense.

The Germans were told on 7 May that they would have three weeks in which to make "observations" in writing upon the provisions of the proposed treaty, but that oral discussions would not be permitted. ${ }^{2}$ What was wanted were merely "practical suggestions" regarding the application and enforcement of the terms. Premier Briand said in a statement upon a similar occasion some two years later that it must be well understood that by proposals, he meant "acceptance pure and simple" of the Allied terms as well as "an arrangement of the methods and manner" of performance. ${ }^{3}$ Such was the case in 1919.

Upon this action the same comments must be made as have been made upon the exclusion of German representatives from the preliminary discussions connected with the framing of the treaty. The method of written discussion, if it may be so called, considered in conjunction with the short time available,-even when the three weeks allowed were extended to six, - was totally inadequate to the needs of the case. Indeed, the Allies did not intend to negotiate a treaty of peace at all, but to dictate a settlement. They conceived of themselves as acting on behalf of international society in punishing a convict. Yet they possessed no legal jurisdiction over, and therefore were compelled to secure the consent of, Germany, and this made a treaty necessary, at least in form. ${ }^{4}$ Moreover, the moral or psychological

1 Temperley, I, 270.

2 Same.

New York Times, 2 May, 1921, p. 2.

- See admission of this in securing changes in the reparations plan in 1921, New York Times, 30 January, 1921, $\$ 1$, p. 1, and, in contrast, the expression 
value of a signed "agreement" was not to be despised. The Germans, their feelings aggravated by the methods used in drafting the treaty, quite apart from its contents-and this was a needless obstacle which the Allies frequently raised up for themselves-criticized the treaty bitterly and extensively in the next six weeks, but in the end accepted the terms, which were substantially unchanged as a result of the "discussions" of May and June, and on 28 June, 1919, signed the Treaty of Versailles. ${ }^{1}$

The objects of the Conference as it met in January, 1919, had been three: to revise the peace settlements made in 1918 between the Central Powers on one side and Russia and Roumania on the other ; ${ }^{2}$ to make peace with the Central Powers; and to create an international organization of some sort to maintain the peace when it had been made. The creation of the League of Nations, an attempt to attain the final purpose of the Conference, will be discussed in the next chapter. The first object was accomplished as part of the second, namely, through treaties of peace with the Central Powers of which the Treaty of Versailles was the first. ${ }^{3}$ During the remainder of 1919 and the whole of 1920 the Peace Conference, reduced to its essential organ, the InterAllied Council, ${ }^{4}$ with the delegations of other interested powers in irregular attendance, maintained the armistice and attempted to keep Europe in order ${ }^{5}$ while drafting treaties with Austria, Bulgaria, Hungary, and Turkey, and these treaties were signed at St. Germain-en-Laye, Neuillysur-Seine, the Trianon palace at Versailles, and Sèvres, on 10 September and 27 November, 1919, and 4 June and 10 August, 1920, respectively. ${ }^{6}$ During the later stages the of Briand, in speaking of the question of reparations in May, 1921: "Germany must yield or be in a state of rebellion," same, 6 May, 1921, p. 1.

1 Temperley, I, 271.

- Texts in same, III, 42, and, with other documents, in Roumanian Peace, Russian Peace, Ukraine Peace, as cited, below, Appendix B, §21.

- For example, Treaty of Versailles, Art. 292, in Temperley, I, 253.

- Now the Council of Five Foreign Ministers; same, I, 499.

- Same, I, 279-357.

- Same, III, 28, 36, 41. 
Conference degenerated even further into irregular, informal, and ineffective negotiations of very ambiguous types.

The conclusion of this study of the Peace Conference of Paris is simple, although the explanation is highly complicated. The Conference of 1919 was far inferior in organization and methods to the meetings at Berlin in 1878 and Paris in 1856, not to mention such conferences in time of peace as those at The Hague in 1899 and 1907. The performance at Vienna in 1815 was probably a little worse. But when we examine the Regulations which embody the original ideas of the leading Powers regarding the way in which the Paris Conference should be organized and operated, we realize the extent of the débacle of the succeeding months. This collapse of method was due primarily to the intensity of national and personal demands and feelings, to political and economic exigencies and desires, inflamed by war and propaganda. To a certain extent the situation was hopeless, as it must be in all such cases. The collapse was due, in the second place, to the immaturity of the art of international government. Here was a need for a set of forms and procedure capable of receiving and reconciling and satisfying all the contending forces at play in the scene, as legislative forms and procedure serve to resolve similar conflicts among contending interests in the state. Nothing adequate was available. Having been unable, for lack of adequate international governmental methods, to prevent the war, the world was unable for the same reasons to bring it to a firm conclusion. Having been unable to preserve international law and order in 1914, the world was, in 1919 and 1920, unable to contrive a firm peace. 


\section{CHAPTER XXII}

\section{THE PROBLEM OF PEACE AND ITS RELATION TO INTERNATIONAL ORGANIZATION}

T $\mathrm{T}$ has not been a very long time since any person who 1 confessed to an interest in the problems of international organization was in grave danger of being regarded as a pacifist and lumped indiscriminately in a group with those timid souls who demanded peace at any price. International organization was regarded as a proposed reform, designed to eliminate war and bring peace to the world, and it was presumably to be studied, if at all, because of this potential service. Now as we have seen, international organization is not merely a reform to be accomplished in the future but an established phase of the actual historical development of the world, and is entitled to attention as a part of present political reality on a par with national, state or provincial, and local or municipal government. It is, nevertheless, closely related to the creation and maintenance of world peace, also, and we must now examine the precise nature of that "peace" which is so much discussed and so little understood, and its relation to international government. ${ }^{1}$

Peace may be conceived entirely as a negative thing, as the condition which exists when there is no war. Even this simple description, however, requires some analysis, for "war" also is a concept not commonly analyzed and defined with precision. War may be defined as general military action by an organized group of people, ordinarily forming a state, undertaken for the purpose of vindicating

${ }^{1}$ On peace movements see literature cited, below, Appendix B, § 22. 
what it believes to be its public rights against another state or other states. ${ }^{1}$ Direct action of a limited sortretorsion, reprisals-may be undertaken for the defense of certain limited rights without bringing on a state of war in the full sense of the term. Military action may be undertaken by certain individuals or groups for private rights without the result of creating a state of public war. Finally, if joint military action is taken by several states not for the purpose merely of protecting their own rights directly but also common international law or the general peace, we have something which does not deserve to be regarded as "war" in the usual sense of the term."

Peace, then, while excluding international war proper, does not necessarily exclude all military action. The occurrence of sporadic outbursts of individual violence, of piratical marauding or civil rioting, does not disturb the peace from an international viewpoint. Likewise, the military action of an international organization for the enforcement of international law would not amount to a breach of the peace. On the contrary, such action would in reality constitute a step taken for the maintenance of ulti. mate peace.

Let us see how this comes to be. If the absence of international war would mean peace, then, obviously, peace might conceivably be brought about by each nation voluntarily abstaining from the use of military action to vindicate its rights, preferring peace to justice. Such a peace of inaction, of weakness, of resignation, deserves all the scorn heaped upon it-or upon peace in general-by the militarist and the jingo nationalist. ${ }^{3}$ The peace of the cemetery, the

${ }^{1}$ See discussions of the nature of war in Hall, $\S \S 15,16$, and the cases of Gray v. United States, 1886, 21 Ct. of Cls., 340; Hooper v. United States, 1887, $22 \mathrm{Ct}$. of Cls., 408 .

"Hall, $\$ 95$. No claim is made that such action is taken for "altruistic" reasons, nor is it necessary for the conclusion, so long as the interests defended be common interests.

"A just war is, in the long run, far better for a nation's soul than the most prosperous peace obtained by an acquiescence in wrong or injustice." 
peace of death, has no claim to respect. The peace movement has been injured by nothing else as much as by the spread of a concept of peace typified by a milk-white dove bearing inanely before it a silly twig of olive leaves.

A nation, like an individual, may, of course, calculate that the inconvenience and expense of enforcing its rights will be greater than the values to be obtained by that step, and decide to refrain from action. This may go the length of deciding that war is, in general, a method of action so terrible and expensive that no values which can be obtained through its use can conceivably compensate for the suffering and cost which it entails. ${ }^{1}$ To make war would then be weakness and folly. That is not what is in mind here. The undesirable thing is an attitude in making the foregoing calculation which gives undue weight to inconvenience and expense and trouble, which unduly fears the harsh realities of conflict and undervalues the interests of right and justice.

We encounter at this point the vast polemical literature for and against war, describing it as useful, beneficial, and inevitable, or the opposite. ${ }^{2}$ That war is inevitable so long as certain conditions of mind and certain international political conditions persist is certain. The former are, however, changing notably in recent times; ${ }^{3}$ the latter, as we now see, may soon be changed radically in certain particulars. As for the utility of war, that also must be considered not by itself but in relation to the alternatives available, in particular the alternatives in international procedure about to be described.

Granting, then, that the effect produced by a general

Roosevelt, Message to Congress, 4 December, 1906, Ho. Doc. 1, 59 Cong. 2 Sess., LV.

The commendation of war in general and the condemnation of peace in general ("Wars are terrible, but necessary, for they save the state from social putrefaction and stagnation"') is a different thing, of course.

1 Angell, Great Illusion, 28-49.

Krehbiel, 16-35 (bibliography).

Angell, 155-221. 
willingness on the part of the nations to obtain peace by sacrificing their rights would be demoralizing, how is the enforcement of those rights to be reconciled with the maintenance of peace? Granting, further, as we must grant, that, even if peace by inaction were desirable, the nations are unwilling to surrender their rights generally for the sake of peace, how may the same problem be solved? There is presented here a task of political engineering deserving serious study. Peace cannot be attained by aspiration merely, by crying "let us have peace"; for, contrary to the old adage, it only takes one state to make war but it takes two, three-all-to keep the peace. It must be attained by international organization for the definition, administration, and enforcement of the rights of individual states so as to relieve them of the necessity of self-help in this regard. Peace must be attained indirectly, and international organization may be regarded as the means to the end. ${ }^{1}$

With this in mind, peace becomes not a weak condition of inaction and dissolution, but a condition where the adequate power of the community maintains the common law and common justice, and public order reigns. The peace of the court room is the peace to be sought and, if possible, obtained by international government. These general principles remain, however, to be worked out in detail, and it is most convenient to make the beginning in connection with the international conferences discussed in the last two chapters.

It has been seen that war may be terminated by a simple cessation of hostilities or by treaty. It was noted that the former method left matters in an inconvenient state of uncertainty. More important here is the fact that it leaves open many questions likely to lead to a renewal of 'war. For that reason the method of concluding war by treaty is of much greater value for preserving the peace, in that

${ }^{2}$ Krehbiel, 150-165, on types of pacifism. 


\section{PEACE AND INTERNATIONAL ORGANIZATION 361}

it provides for the mutual satisfaction of claims outstanding between the parties.

When this task is undertaken the peace conference is led, first of all, to revert to the causes which originally brought on the war. The discussion of international relations must be resumed where the discussion, and where those relations, speaking generally, were broken off by the event of war.

The most natural question suggested by this obvious but commonly neglected fact is the question why, if this be so, the discussion was broken off originally, and what assistance has been derived from the intervening war in the settlement of the issues at stake. The reply is extremely complicated and varies with the nature of the issues.

In general terms, it may be said that diplomatic discussions are broken off and military action begun in such cases because of a failure on the part of the parties to come to agreement, or, more specifically, the failure of one party to secure from the other a satisfactory degree of compliance with its demands by the use of diplomatic argument. But what is that "argument" the failure of which brings war? It is the presentation of alternatives from which the other state will, it is claimed, suffer as a result of refusing the demands of its neighbor. Those argumentative alternatives may be of many forms, such as warnings of the loss of reputation or the loss of favor in the eyes of the state making the demand, and of other states, resulting indirectly in material loss; physical attack by the state making the demand (or by others, or both), with the object of seizing the object of the demand, if that be feasible, or other things to be held for exchange; or with the object of securing power over the state resisting the demandover its property, territory, people, and government-in order to demand satisfaction as the price of continued free existence. And, the arguments being unconvincing, the 
action threatened is taken in fact. So far as war does not come about merely from excitement and confusion, this is the rational theory of the event. ${ }^{1}$

It will be noted, however, that the value of war in the settlement of the current dispute is as remote from view as ever. When we examine the case again we find that what the first state has done is to take action having no bearing at all upon the merits of the issue in dispute. So far as that state is victorious in war, it secures satisfaction for its demands without reference to the merits of the issue; the issue is therefore not "settled" in any rational sense, but remains in dispute in the minds of the parties; for the second party has yielded, not from conviction on the merits of the issue, but as a price of existence. If the second party is victorious the same result follows: the original demand is refused, with as little reference to the merits as in the preceding case. Now if the war should be a drawn battle, the only recourse is to resume negotiations where they were dropped, for no new factors have entered the situation at all. Where, as most often happens, there is a partial victory for one party, the situation is a mixture of cases one, two, and three, but in none of these cases does the war facilitate in any way the solution of the dispute on the merits.

It is partly for this reason that peace conferences, held at the conclusion of war, are of little value for the cause of international peace and justice. The atmosphere and temper of the time is, of course, bad. But more important is the fact that such conferences are based upon the status quo at the time. They treat the disputes between the parties by reference to the perhaps temporary preponderance of military force of one power at the time, not by reference to the permanent conditions of power between, and the rela-

${ }^{1}$ For description of the law and practice relating to the beginning of war see Wilson and Tueker, $\S 97$, and Prize Cases, 67 U.S. 635; also Hershey, $\S \S 338-342$, with references. 
tive needs of, the two states. The result may easily be the reverse of what it should be in the interests of the common welfare, of justice, and, therefore, of permanence. They produce artificial solutions capable of being maintained only by the constant use of military force. They do not deal with the issue as it stood on the merits at the outbreak of war.

It is obvious, therefore, that the critical point, the point upon which attention must be focused in an effort to find a method of really solving international disputes, is the point where negotiations were broken off. New issues arise during the war, partly connected with the conduct of the war, and partly independent of it. But when these issues come to be discussed in the peace conference it is similarly true that the subsequent conduct of the war has no more bearing upon the merits of those issues than upon the original issues. In attempting to deal with the problem of war or national action by military force to vindicate national rights we must revert to the nature of those rights or demands, or, in familiar terms, the causes of war.

The causes of war are, of course, too complicated. for complete analysis here, but they may be described as falling under one or the other of two heads, either violations of legal rights or actions not covered by international law at all. The former may take the form of maltreatment of citizens abroad, violation of territorial sovereignty, and many other actions. The latter are still more varied, consisting in commercial rivalry, political rivalry, and what not. The conclusions significant for our purpose flow from the twofold classification itself, not from the detailed description of the two classes.

What are the outstanding features of these two forms of the causes of war? The first is the failure to define

${ }^{2}$ On causes of war see literature cited, below, Appendix B, $\S 22$; see also, for the legal aspect, Hall, §16, Par. 2. 
legally the interests included in the latter group of causes, thus leaving great discretion to the individual state in its decision regarding supposed violations of its "rights." It is a testimony to the respect for law among the nations that the "rights" demanded are invariably portrayed as legal rights wherever possible, but this effort is not in most cases very successful. The second is the freedom left to individual states even to decide whether their legal rights have been violated. The third is a failure to provide the state with any means of enforcing its rights except selfhelp in carrying out the law and securing justice according to its own opinion. ${ }^{1}$ It is to these features of the situation that international government must be applied if it is to accomplish anything for the cause of peace.

In accordance with this conclusion, the conferences held in time of peace with the purpose of preventing war turn first to the definition of the rights of the states participating in them. Such conferences have a greater chance of success than conferences at the end of war because the temper of the time is better, the alignment of the forces in the scene is normal, and the common interest may conceivably be kept in view. National advantage is here sought through the common advantage, benefit is now sought not at once but in the long run, and all attention is directed to the origin of disputes, not to the results thereof, as is not true in conferences in time of war. By treaty agreements the rights of the parties regarding territory, commercial privileges, and all the interests at stake in the situation, are defined. The next step is the provision of machinery for adjudication upon those rights, in the form of arbitration. The third step would be to provide for enforcement by the community of nations participating in the plan, in place of enforcement by the individual state.

Historically, something, but not a great deal, has been done on the first point, in formally defining international

'Hall, as cited, Par. 1. 
rights. For the most part, international law has been allowed to grow up by itself, and the task of recording and codifying it has been left to private scholars. Only in the last fifty years have official conferences for the statement of the law met with any frequency, ${ }^{1}$ and these have dealt principally with the conduct of war. By far the greater part of the law of normal intercourse, covering the period when war is not being carried on, yet in which it originates, is left untouched. The reason for this, as well as the reason for the same action by private scholars in recording first the common international law of war, is that the law has been set down, not so much deliberately with the object of effecting a world government and preventing war in the future, as with the object of recording retrospectively the methods of making war, of avoiding disputes concerning these methods, and, if possible, of ameliorating these methods. ${ }^{2}$ At present, the great need for an effort to set forth the law of international relations in complete and official form is being realized. ${ }^{3}$

Provisions for the adjudication of disputed rights have also been made in the past, as the history of arbitration shows, and the steps taken in this direction, although not very well coördinated before the end of the last century, have been more numerous and consistent than those taken for the definition of the law. This has been due to the fact that it has seemed simpler to reconcile such a proceeding with the idea of state independence than the declaration of law binding for the future, and to the greater intrinsic difficulty of the latter task. It is intrinsically difficult to find legal formulas capable of doing justice to all parties, and a law which works injustice is worse than

2 Above, Chap. XII.

'On law regarding conduct of hostilities see Wilson and Tucker, $\S \S 101$. $116,127-140$; also Hershey, $\S \S 351-444,448-515$, with references; also Baker and Crocker, Land Warfare, and Martin and Baker, Maritime Warfare, as cited, below, Appendix B, $\S 12$.

"See criticism of the League of Nations because it neglects this task, in Hill, Present Problems, 120-124. 
a political bargain which does not. This is the fundamental human obstacle to the development of international law, the lack of such knowledge of international relations as would enable us to write fairly and completely the law of those relations. ${ }^{1}$ But the movement for the judicial settlement of international legal disputes is now well on its feet.

The last step to be taken in providing for peaceful world government is to provide for community enforcement of international rights, and not much has been done in this direction in the past. A state could look only to its own right arm for the enforcement of its rights under international law; to such an extent was this true that the normal attitude to be taken by third states in the face of a dispute between two others was that of neutrality. ${ }^{2}$ The reason for this is that such action demands a degree of international organization not deemed practicable or desirable, in view of the doctrine of state sovereignty and independence. ${ }^{3}$ The actions of the Concert of Europe between 1825 and 1860 provide the best-and almost the only -illustration in history of such a procedure. We are now coming to new proposals leading in this direction which promise greater results. This will form the subject of the remaining chapters.

For if community enforcement of international rights is to be established, such action must be provided through the creation of an international federation of some type. The states of the world, working as individuals, might, and indeed have, generated a rather extensive system of common international law. The states of the world, acting by twos and threes, might, and have, elaborated a rather ex-

${ }^{1}$ See Prince von Bülow's remark: "Germany has not found any formula that will meet the great diversity which characterizes the geographical, the economic, the military, and the political positions of the various countries," in reference to the proposals at the Hague in 1907 for obligatory arbitration, made in an address in the Reichstag, 30 April, 1907; see, above, Chap. XVI, 277, 256-258.

'Theory in Hershey, $\S \$ 445-447$, with referenees; practice and allegations of principles in Neutrality Proclamations, eited, below, Appendix B, $\$ 22$.

See, also, above, at 256 , and note 3 . 
tensive body of treaty law. They could, and did, develop the practice of arbitration very far in the same simple manner, by bilateral agreements. But community enforcement could come only by multi-party combinations, and in its full sense only by a combination of substantially all of the members of the society of nations. Moreover, the processes of stating and adjudicating international rights, while they could be carried on in an elementary way without such a general organization, would gain greatly in the breadth and stability of their foundation and in their influence upon international life by being performed under the auspices of a general international league.

For this there are highly specific reasons, revealed by the history of international relations in all modern times. Special and temporary conferences and acts of adjudication must be replaced with general and continuous conferences and courts.

Special conferences are defective in two ways. They deal only with one or more limited topics, whereas the actual state of affairs demands attention to a considerable range of questions at once. In modern times specific problems in international relations, affecting two states immediately, are found, upon examination, to ramify into many collateral questions and to affect many nations at once. Special conferences of two states to deal with limited questions therefore become increasingly inadequate. ${ }^{1}$

In the same manner, temporary conferences, called on the spur of the moment, are inadequate. The process of international life is continuous; the process of international government must be equally continuous to be effective. Disputes arise constantly, and if no conference is in session

${ }^{1}$ When it was proposed to call a conference on the limitation of naval armaments in Washington in 1921 attended by the United States, Great Britain, France, Italy, and Japan, it was discovered that Pacific problems and land armaments would also have to be taken up and perhaps the status of the League of Nations, and that Portugal, Belgium, the Netherlands, and perhaps other powers, must needs be invited. New York Times, September-October, 1921, especially 5 October, 1921, p. 17. 
it is difficult to convene one. Moreover, even if a conference is in session it will have been called for some other purpose and will not, as things now stand, possess any jurisdiction over the new dispute. A new conference, or a new grant of authority to the old one, would be necessary in any case. And just that task of securing a conference after the dispute has arisen is the most difficult task of presentday diplomacy; as has already been pointed out, it was failure just here that brought war in $1914 .^{1}$

The position is the same regarding arbitration. It is difficult to secure agreement to arbitrate after the dispute has arisen, because of the state of feelings aroused, because the disadvantage of losing seems more vivid when the concrete case has emerged, and because at least one party probably has reason to be mistrustful of the outcome. It is more difficult to get agreement to arbitrate in the future all cases as they arise, or all cases of a certain type. Likewise, it has been more difficult still to secure agreement to a standing conference which shall have jurisdiction over all questions arising in the future or over all questions of a certain type. This is because of the desire to preserve the sovereign independence of the state in point of principle, to the amount of the concrete loss which might be sustained in the future by defeat in the deliberations of the conference, and also to the fact that the risk of defeat seems great in advance. But in both cases the difficulty of securing consent in advance to conferences and courts has resulted in a more fundamental sense from the fact that the question has been studied entirely with reference to specific disputes, actual or potential. When the general desirability of conference and adjudication in place of war, from sheer practical considerations of profit and loss, is realized, as it is coming to be realized today, the demand arises for

2 Above, Chap. $\mathrm{XX}$; - it may also be noted that the Peace Conference of Paris has been prolonged into 1921 by the continued meetings of the Supreme Council. 
arrangements prior to the appearance of the dispute, to avoid delay and possible collapse at the time of the crisis, in other words, for continuous courts and conferences.

It is obvious that such defects can be cured and such remedies provided only by some general and permanent international organization. At whatever point the problem of international government is opened for examination, the indications all point in one direction, toward the creation of a permanent world-wide federation of states for the performance of the minimum services of definition, adjudication, and enforcement of national rights in international relations. In no other way can law and order, peace and justice, be secured.

At this point a question may be raised which refers back to an earlier stage of the discussion and again forward to. the idea of the enforcement of international rights. Stated very simply, the question runs thus: if war is the result of the use of armaments by nations, would not a destruction of armaments, would not disarmament, pure and simple, bring peace? Stated more subtly, it is asked whether, seeing that great armaments lead to an excessive boldness and to excessive demands on the part of the nations possessing them, a limitation of armaments would not be beneficial all round. This view is usually combined with the theoretical attack upon war as such, bitterly criticizing its alleged utility, and representing its cost and its sorrow at their maximum. The literature of the peace movement deals, not so much with the practical methods of political engineering which may be taken to reduce the chances of war, as with the beauty of peace and the ugliness of war. A reproduction of the picture "The Spirit of '76" is placed beside a photograph of the mutilated and gangrened face and jaws of a wounded soldier and the title "The Glory of War' is placed under the two. ${ }^{1}$ To such an atti-

${ }^{1}$ Crile, Mechanistic View of War and Peace, 100, 102. 
tude the reply is direct: peace will not come and war will not disappear by wishing it so, by dwelling on the beauty of peace and the horror of war. More effective steps must be taken than mere aspiration.

The second question is, would disarmament or limitation of armament be effective in the desired direction? Suppose that the nations were to abandon all military armaments at a stroke, would the result be peace? The result would, on the contrary, be the outbreak of piracy at sea and disorders on the land on the part of anti-social individuals and groups with which the community would be impotent to deal. So long as this sort of violence is latent in society, and it is impossible to conceive of such a complete destruction of engines of violence that some weapons-clubs, knives, explosives-would not be available, or that persons ready to use them would be entirely absent, some degree of armament for the protection of the peaceful and orderly individual members of society is essential. Moreover, disarmament would be most difficult to carry out in precisely the cases of those most likely to misuse the arms which they were able to retain. This applies among individuals in society. It also applies among the nations. Disarmament would be most difficult to obtain from imperialistic powers. The result is that any attempt at disarmament must hamper the better elements in international society in dealing with the worse elements. The nations loving peace and justice would thus abandon all possible means of upholding law and order in the world. Furthermore, it is simply impossible at the present time to secure a general consent to disarmament, and this means that disarmament, if undertaken at all, would have to be undertaken by those individual nations most attached to the ideal of peace, with the result just described.

Even these more enlightened nations are not, however, willing to take such a step. This, perhaps, is due in part to their sense of responsibility for the maintenance of peace 
and order in the world. It results, more specifically, from their unwillingness to put themselves at the mercy of the more designing ones, and this brings us to the reason for the general unwillingness to disarm. That reason is found in the fact that national rights are still ill-defined, that no sure method of adjudication upon those rights except self-adjudication is available, and no method of enforcement but self-enforcement. ${ }^{1}$ We are back to the deficiencies of international government as the chief cause of huge armaments. The only method available for producing a state of mind in the nations such that they will be willing to disarm is to provide them with a system for securing definition, application, and enforcement of their rights without arms. It need not be pointed out again that this can only be done by a general international organization for the purpose.

If we return to the proposal for a mere limitation of armaments, the same conclusions apply, with even greater cogency. The amount of reduction possible would depend upon the forces needed to maintain peace and order on the seas and in civil society. The amount of reduction for each power would have to be carefully calculated in order to prevent many undesirable possibilities. Those states most willing to accept limitations would be precisely the ones which should not be asked or allowed to take such action. The states upon which the most severe limitations should be placed are the ones which it would be most difficult to persuade to accept any limitations at all. Finally, these facts are all accentuated because the deficiency of international government is felt, not in defining the maximum size of forces needed to preserve domestic peace, a matter in which the peaceful nation needs powers as great as any, but in deciding upon the possibility of any curtailment at

${ }^{1}$ See the reason assigned by the United States for taking up Pacific and Far Eastern questions in the conference on limitation of armaments in the third paragraph of the official invitation of Secretary Hughes to this conference, 11 August, 1921, in New York Times, 12 August, 1921, p. 1. 
all, just the point where the peaceful nation has the weakest case.

What is probably the greatest difficulty, however, would arise after it is agreed to accept some limitation of armaments. How great shall the reduction be? Shall it be the same for all states? How shall it be enforced? If the reduction is to be the same in all cases it must be less than the size of the armament of that one of the present powers whose armament is smallest; otherwise some state will be left without any forces for preserving domestic peace. In a general agreement for the limitation of armaments intended to include all nations this procedure would, of course, be ridiculous in its application to the Great Powers -another evidence of the unwholesome effect on international relations of the existence of inequality among the nations. Evidently, reductions must be unequal or the action must be confined to the Great Powers. But it is often the smaller powers with armaments excessive for their size, with less sense of responsibility, which precipitate international conflict; they are, moreover, among the states in position to gain most by the saving incident to limitation of armaments. ${ }^{1}$ Hence it appears that the proposed reductions may have to be unequal, a thing hard to present in an acceptable light to those powers now in a position of relative supremacy regarding their armed strength.

The whole matter is, moreover, very difficult to reduce to exact figures, and, of course, it must be reduced to exact figures, for after a certain stage general considerations are of absolutely no use. Probably the only sure basis for computing the armaments needed by individual powers is the force needed to maintain domestic law and order. ${ }^{2}$ Even here the relative state of society in one nation and another makes the adoption of a uniform standard im-

See debates at Second Assembly of League of Nations and views of France and Great Britain; New York Times, 3 October, 1921, p. 1.

2 This is also the conclusion of Col. Vestal in his work on the Maintenance of Peace, end. 
possible, though the experience of the past and the judgment of those responsible for the performance of the task are substantial foundations to build on. ${ }^{1}$ All of this assumes-an assumption justified with difficulty in view of the facts-that a reliable unit of computation can be found. Perhaps a complex unit can be devised, a unit made up from the number of persons in the armed forces of a state, the number and caliber of arms in stock, the amount of ammunition on hand, the number and tonnage of vessels in commission, and other factors.

It is obviously impossible to settle such questions here. It is not difficult, however, to discover the truth that the very complexity of the problem makes a certain method of procedure inevitable. Some sort of a conference is needed to secure the primary adoption of any plan, as joint action is essential in the nature of the case. Careful conference is necessary for the selection of the particular plan to be utilized, and for the construction or selection of a unit of computation to be employed. Finally, joint administration and enforcement are needed if the plan is to be carried out successfully. Inevitable ambiguities which will develop in the process of execution must be interpreted, attempts at evasion must be detected, and the whole matter must be watched over from the very beginning. If the administrative experience of national governments in similar situations is any guide, partial limitation of armaments would need such supervision even more than complete disarmament because it would be more complicated and easier to evade. $^{2}$ Moreover, the work would never be entirely completed and such supervision would have to be maintained permanently. If any changes were to be made in the ratios of reduction, if any further progress in limitation of armaments were desirable and feasible, they could only

${ }^{1}$ See the fixing of such figures for Germany in the Treaty of Versailles, Arts. 159-213.

${ }^{2}$ Hall, Constitutional Law, § 169. 
be had by the same process of conference and coöperation which was necessary at first. And it does not need to be repeated that for the limitation, as for the abandonment, of armaments, a definition of national rights is essential to prepare the ground, and that such a result can only be had by conference. Moreover, when we reflect that some joint enforcement of international rights would, on the one hand, be necessary to secure any consent to a limitation of national armaments for national use, and that it would, on the other hand, mean military coöperation for this purpose, it is not wholly fanciful to say that, when worked out in actual practice, national disarmament really becomes a pooling of armaments, or the internationalization of armaments.

It may appear that the subject has been argued over much. If so, it will be useful to note, on one side, that peace is desired by the peoples today as never before, that disarmament is demanded as never before in modern times, and, on the other hand, that nationalism and resistance to international supervision were never more pronounced, in spite of external appearances to the contrary. The situation is one of the great internal conflicts of history: the desire for international peace against the assertion of national power. The conflict is real, and a choice must be made; either common peace or individual power may be enjoyed, not both.

The discussion of the proposals for disarmament has, however, thrown the emphasis where it does not belong. The principal conclusion to be drawn in this chapter has been stated already, namely, that permanent peace is, in its essence, and depends for its existence upon, the definition and satisfaction of national rights through common international action by the creation of an international organization to perform the functions of legislation, adjudication, administration, and enforcement on behalf of all members of the society of nations. That such a step would 
also be essential for the successful working of any plan for partial disarmament is collateral evidence of the soundness of this conclusion. If space permitted it would be simple to demonstrate that the attempt made so earnestly during the years $1860-1910$ to mitigate the severity of war and restrict its incidence was largely unsuccessful because it needed for its success precisely the method of procedure described for the effective limitation of armaments and was deprived of that procedure. That movement sometimes received the scorn of the pacifists who declared that war could not be tamed but must be destroyed. This resulted partly from their desire to accomplish the greater good and partly from a reluctance to take the procedural steps necessary to the end in view. This reluctance, further, was dictated somewhat by temperament, but also by an unwillingness to be mixed up in international politics which was quite innocent and understandable in many ways but wholly irreconcilable with the end in view. Nothing is more ridiculously inept than the combination of pacifism or opposition to war and national armaments, on one side, and a refusal to participate in international coöperation on the other. And, while international organization and international order probably will come as a result both of the negative movement for disarmament and peace and the affirmative movement to prevent the outbreak of war by settling international disputes likely to lead to war, it will certainly not come solely from the efforts to secure disarmament or restrict war on the part of those who dwell on the beauties of peace and the horror of war without provision for practical conference and coöperation for that end. 

PART VII

INTERNATIONAL FEDERATION 



\section{CHAPTER XXIII}

\section{THE JURISTIC THEORY OF INTERNATIONAL FEDERATION}

U $\mathrm{P}$ to this point attention has been directed to the way in which the modern state-system has been formed, to its nature, and to six special forms of international organization, namely, diplomacy, treaty-negotiation, international law, arbitration, international administration, and international conferences. Some attention has been given to the relations which exist among different members of this series, as, for example, between treaty-negotiation and international administration. But it has been found that, except by the accidents of history, or by virtue of the way in which they are employed, these practices are not coördinated into any one system of international government. They are, indeed, coördinated and employed by the foreign offices of individual nations as one body of diplomatic practice, capable of serving the national interests. When so used, however, they constitute an arm of national service, not a system of international government. Only by deliberately assuming the world point of view ean they be so regarded.

To gather these activities together into one system of international government is, therefore, the first step forward. To do this it is necessary to gather the national states upon which these practices at present rest into one federal system and thereby unify the activities of these states in their relations one with another. This is international organization, in the most precise and significant 
meaning of that phrase. This is the final step in the process of creating international government.

Such a step, however, raises the fundamental question of the nature of the national state and of the juristic nature of the relations among the national states today. It brings us in touch with the most difficult problem in international organization, namely, the reconciliation of international organization with national sovereignty. To that problem we now turn. ${ }^{1}$

Much effort is being expended today in attempting to evade or circumvent the classical doctrine regarding the sovereignty of the state. These efforts are being put forth, first, by those persons who desire to curb the state in its relations with individual citizens and groups of citizens within the state, and who are impatient with severe theory at any point and feel that all rigid and simple doctrines in political science belie the rich complexity of life. Such are the pluralists in the political philosophy of constitutional government. These efforts are also being made by people who desire to curb the state in its relations with other states, and who believe that the classical doctrine is untenable in view of actual practice and the facts of contemporary world relations. Such are the internationalists and the pacifists of all types, emotional or scientific, practical or theoretical.

It is doubtful whether all this expenditure of energy is entirely justified. The classical doctrine of state sovereignty must either be met directly and those who hold it satisfied by direct replies, or the theory must be simply ignored. If it is mentioned at all in relation to international federation, it must be given an adequate hearing; to mention it only to evade the issue is worse than to ignore it entirely.

It is plain, however, that the issue cannot safely be

${ }^{1}$ On juristic theory of international federation see literature cited, below, Appendix B, § 23. 


\section{THEORY OF INTERNATIONAL FEDERATION 381}

ignored. For practical political reasons this is impossible in view of the fact that those in power in all the leading states of the world adhere to the orthodox theory and are supported in their position by the peoples of those states. In the immediate future, at least, the idea of national sovereignty will not be scrapped and must be met by anyone who proposes to create an international federation. Among European states at the present time the need for such a federation is so great, and is felt so keenly, and the influence of abstract forms of political theory in everyday governmental life is so weakened by the practice of parliamentary government, that not much is said or heard regarding state sovereignty as an obstacle to international organization. In Asia and Africa, and Latin America likewise, the issue is not sharply raised. But in the United States the issue is sharply raised and must be met, whether the reasons for raising it have been sincere or insincere, flowing from partisan politics or from patriotic solicitude for the national welfare. Moreover, the issue, so long as it is not definitely settled, might be raised by politicians elsewhere whenever the tactics of the diplomatic battle demanded it.

Evasion is the less justifiable when the path of direct attack seems plain. It does not appear to be at all impossible to reconcile the concepts of international federation, international federal government, world government, world state, super-state-making the concept as strong as possible-with the concept of state sovereignty, as long as we keep scrupulously in mind the exact steps in the process of creating such an international federation or world state.

It will be profitable to begin by reverting to the most elementary stages in the development of international organization, the stages of personal diplomacy and the negotiation of treaties. In those early phases two or more states, none of which owe any degree of allegiance one to another or to any state or body of states, enter into a practice of discussing matters of common interest through the 
medium of personal agents. Disputes are settled and arrangements made for the future by voluntary agreements recorded in more or less formal diplomatic documents, the most formal of which is the treaty proper. Such agreements derive their authority from the voluntary participation of the two or more states entering into them.

These elementary proceedings are not felt to constitute a violation of state sovereignty, as is shown by the fact that they are entered into continually by states which at the same time do not concede any loss of sovereignty and are not regarded by others as having suffered such loss. And rightly so. The action of making a diplomatic agreement or concluding a treaty is sometimes described as the acceptance of a self-imposed limitation upon sovereignty. No state may dictate the terms of a settlement or a treaty to another, and consent alone can create a binding diplomatic agreement. The treaty is, therefore, certainly not more than a self-imposed limitation. It is, indeed, only partially that. It is at least as much a positive action of sovereignty in asserting a demand and securing recognition of it. If the act be regarded as a unit, it must be considered an act of self-expression or self-direction as much as an act of self-limitation. The very common rule that only independent sovereign states may conclude treaties may be mentioned in partial confirmation of the tacit acceptance of this position in international law. ${ }^{1}$

The case of the state "compelled" to accept a treaty "by force" has already been discussed." Here, as in all similar situations in human affairs where it is said that we do not wish to do a certain thing but that we must, what we really mean is that we would not wish to do a certain thing if things were not as they are, but that, things being as they are, we do, after all, prefer to sign on the dotted line. We have a choice which any reasonable person, living

${ }^{1} \mathrm{Hall}, \S 108$.

${ }^{2}$ Above, Chap. $X$. 


\section{THEORY OF INTERNATIONAL FEDERATION 383}

under the common conditions of human life, would, indeed, decide in only one way, but his decision would be needed to make the choice; if conditions varied from the normal the decision also would vary. The freedom of consent is there in ample degree to satisfy the doctrine of sovereignty.

When the treaty has been concluded, however, and after it has continued in operation for some time, the situation appears, superficially, to have changed. When a state is held to performance of a treaty obligation incurred twenty or thirty years before, it appears-to that state, and to some presumably disinterested students of the matter-that state sovereignty has been lost.

To such a conclusion there are several replies.

First, as in the initial negotiation of the treaty, so here, it is to be noted that all states come to stand, in the course of events, in precisely this position, and yet their public representatives do not consider that they have lost their sovereignty, nor are they considered by the public officials of other states to have suffered such impairment. This certainly proves that such a conclusion is not warranted in the minds of the high priests of state sovereignty themselves.

Again, it is to the source and creation of the current obligation that we must look, not to its incidence. The obligation flows, and can only flow, from the original act of consent of the state; it can be traced to no other state or body of states. This, by itself, is sufficient to satisfy the doctrine of sovereignty. The state may appear to be bound to act against its present will; if so, it is a case of one act of the state's own will, made at a previous point in time, overriding a later act of will, and the doctrine of sovereignty certainly does not pretend to bar such a process within the area of operations of the will of a single state.

Third, it is not even accurate to say that a state is bound against its present will. What happens is that the state acts upon the dictates of a general policy, rather than 
those of a specific policy. It wills to act to uphold the sanctity of treaties, rather than to express a policy of commercial discriminations. Or it acts upon the will to preserve the friendship of the cosignatory party, or the will to secure advantages corresponding to the concessions rendered, or upon some similar ground. Again, it is one act of the state's own will overriding another; but both are acts of will of the same state.

Finally, although this it not essential to the validity of our conclusion, the state is not bound by its original act of consent except in so far as the conditions which led to that original consent persist and thereby justify the assumption that that act of consent is continued. In so far as conditions change and render the arrangement unjust, there arises a right of denunciation for the state suffering from the effect of the alteration of circumstances, apart from any explicit provision in the treaty for denunciation upon notice. Such action may precipitate a discussion of the question of fact as to whether this principle of rebus sic stantibus is really applicable, that is, whether conditions have, in point of fact, so changed as to render denunciation permissible, but that does not affect the validity of the principle. Indeed, the principle is so firmly established that the effect is rather to weaken unduly the obligation of treaties; there certainly is no room for a contention that sovereignty is lost by the conclusion of a binding treaty. ${ }^{1}$

Suppose, however, that conditions have not changed, yet one of the states party to the treaty desires to denounce the treaty, and, not acting upon any higher will of this or any previous period (such as a provision in the treaty for denunciation on notice, or a new agreement to supersede the treaty in question), denounces the treaty or proclaims that national safety compels it to disregard its obligations under the treaty. What is to be said in such circumstances?

For one thing, whatever else is true, the state in question ${ }^{1}$ On the rule of rebus sic stantibus see Moore, Digest, $\S 772$. 
has not lost its sovereignty. It may be claimed that the state had no right to act in such a manner, and this is true, for reasons soon to appear. The action does not, however, evidence any greater limitation upon sovereignty than the actions already examined-which was none at all; for action in excess of one's own legal rights is certainly no greater evidence of loss of sovereignty than action in accordance with those rights. In reality, both are irrelevant to the existence of the rights or their absence.

The state whose rights under the treaty have been denied is in a different position. Without action and without consent on its part, its rights are denied satisfaction. The important point, however, is that they are not destroyed. In many cases this may even be admitted by the state refusing to carry out the terms of the treaty, or, at all events, not explicitly denied; the principal point of the recalcitrant state in the situation now under discussion is that, although it is under certain legal obligations, it cannot safely perform them. If it did not, at least by inference, admit the validity of the obligations, there would be no cause for taking the position described. In any event, the rights which are unsatisfied remain intact, and if they cannot at present be enjoyed or exercised, this is due to a deficiency of international government, not of legal right. It is not sovereignty and legal rights, but courts and executives for the enforcement of those rights, that are inadequate.

If, now, we turn to the third and succeeding stages in the development of international organization these conclusions will be applicable to the end.

From diplomatic settlements and treaties at large customary or common international law was steadily developed by the states of Western Europe in the years after 1648, and this law has been extended to America, Asia, and Africa in more recent times. This common international law is held to be binding upon the individual state. Is this not a loss of sovereignty? 
Once more the test of usage is to be applied. The states, or those in a place to speak for them, while recognizing the binding force of common international law, do not admit a loss of sovereignty thereby. Nay, they do not even suggest that there might be any such result. Sovereignty does not preclude subjection to law. It precludes only subjection to law made by another, to law dictated from an external source, subjection to the will of another.

Such subjection is not present in common international law. That law is based upon the consent of the members of the society of nations as evidenced by the diplomatic records, treaties, arbitral decisions, and so on, which they have left behind. ${ }^{1}$ Even national judicial decisions-in cases in prize, admiralty, criminal, civil, and constitutional law-and also national diplomatic and legal instructions and opinions, are valuable as showing the consent or agreement yielded by the states to various rules of the law.

When a rule which has received the specific consent of a certain state is invoked against that state, the case is, therefore, entirely simple; the binding force of the rule is in the prior consent, and no sovereignty is impaired. Suppose, however, that a commonly accepted rule is invoked against a state which has not specifically consented to it or has definitely repudiated it.

In the first alternative, the rule is binding and derives its binding effect from the action of the state in joining the society of nations. The state sought, received, and accepted admission into that international community under the commonly accepted standards of admission. One of these is responsibility under common international law to the other members of the community of nations. The new state is now bound by that law as a result of its own conscious assumption of the obligation covering all the commonly accepted rules of the law.

In the second alternative, the rule is also binding. The

${ }^{1}$ The Antelope, 1825, 23 U.S. 66, 120-122. 
reasoning is the same as in the previous case up to the point where the state in question attempts to repudiate the rule. If the state had simply refused to act in accordance with the rule, while not denying its binding force, nothing would be proved one way or another, as was seen in the case of the treaty whose terms were defied by a signatory party. If, however, the state yields "unwilling" obedience to the rule, while denying its legal validity, the case is on a par with that of the treaty obeyed under similar circumstances. If we agree with the state's own contention that the rule is not binding, no problem of loss of sovereignty is, of course, left. If we deny that contention, our denial will be based upon the reasoning of the preceding paragraph. If we attend simply to the action of the state alone, it might appear at first that we have "unwilling obedience," a supposedly sovereign state constrained to act against its will. The reality of the matter is that the state does desire, does will, to obey the rule-in order either to keep in line on the general issue of obedience to international law or to avoid retaliation or for other purposes. This is not a "fiction" as it has been called; the fiction is the "unwillingness" which in fact does not prevent the action. Obedience proves consent; action is more decisive evidence than protestation.

It ought not to be overlooked that the idea that a state is "compelled" to do a given thing is susceptible of infinite variation to suit the needs of the moment. In the simplest situation confronting a state, where an opportunity is presented to the state to secure a great advantage at little cost, the diplomats will often say "we were compelled to take advantage of the opportunity," or "we were compelled to act quickly," or something of the same sort. The compulsion in such cases is not fanciful. It is just as real as the compulsion bearing upon an individual to protect himself from the rain, a compulsion to act for one's best interests. But it does not derive from any particular outside human 
source; it derives from the general posture of affairs, human, political, or natural and non-political, and, more specifically, from the reaction of the individual or state to that situation. The same is true when "we are compelled" becomes an excuse for demanding what is expected to be an unwelcome act, as when a state says: "We are compelled to insist upon satisfaction of our claims." The reality is that we will to do thus and so, and we hope you will appreciate the reasons why and will yield gracefully.

In like manner, the effort to get back of a prior act of consent is often real, sincere, and deserving of respect. But it does not affect our argument. A state may wish that it had not become party to a certain prior agreement, and may be unable to get out of it. That means only that acts of will are often the result of poor judgment or ignorance and that, nevertheless, the hands of the clock cannot be turned back. The binding force and the unwelcome effect is in the march of events and in the part in that process played by this state as the result of a decision made some time ago, not in the will of the other state which is now in position to profit by present conditions. The doctrine of sovereignty does not pretend to stay the march of time.

When international arbitration and administration and conference are reached the process becomes still more complicated, yet it is no less clear. Let us state the conclusions briefly for each of these forms of international government in turn.

Where two or more states agree to submit a dispute to arbitration and to abide by the result, the result is binding because of the original agreement. ${ }^{1}$

Where two or more states agree to create an administrative commission and to abide by its actions, in practice the binding force of the subsequent action of the commission derives from the original convention creating the commission and giving it authority.

${ }^{1}$ The La Ninfa, 1896, 75 Federal Reporter, 513: "The award is to be construed as a treaty which has become final." 


\section{THEORY OF INTERNATIONAL FEDERATION 389}

Where two or more states agree to a conference wherein decisions shall be taken by majority vote, the binding force of the decisions taken flows indirectly from the original agreement.

In no instance is there any loss of sovereignty. These cases are vivid because of the fact that the representatives of a given state may vote openly for one thing and the arbitral decision, the administrative ruling, or the settlement actually reached by the conference, may be exactly the opposite. The state is then bound, not in the absence of any expression of will, but, apparently, in spite of a clear expression of will. Yet there is no loss of sovereignty, for the binding force of the decision flows not from any legal authority inhering in the wishes of the majority by virtue of its own existence, but in the agreement originally made to use the device of the majority vote to decide questions in the court, the commission, or the conference. Without such agreement, the majority vote would have no value. Given that agreement, the majority vote takes on a value it would not otherwise have. The clear expression of the present will of this state must be checked up against the equally clear expression in the past of a general will still operative in the present case.

If all this be true, there is no obstacle in national sovereignty to the creation of an international federation with legislative, executive and judicial functions, for that result would be obtained by merely gathering together into one system the various organs or institutions of international government already existing on independent foundations. To effect this integration is, indeed, the immediate end for which an international league is desirable today. From this action to the extension of the machinery and the powers of the league to any desired extent by the creation of new organs of government and the delegation of new powers to these new organs or to organs already in existence, is merely a matter of quantitative expansion. So long 
as the process of expansion and intensification goes on by means of the original form of action, the consent by all members of the league, the power of the league may be increased indefinitely without violating the sovereignty of any state. By what may be called the doctrine of the original agreement, we may reconcile national sovereignty and the world state. If this appears to reduce sovereignty to a vassal condition, if it appears to amount to the subjugation of sovereignty, the phenomenon is startling only because of a common neglect to observe the things which sovereignty may, and often does, do with or to itself, and because of failure to realize that what we have here is merely a case of sovereign power acting upon itself.

At this point three supplementary questions will naturally be raised, and all deserve attention. First, have we not committed ourselves to the principle of unanimity, and is that not an almost unsurmountable handicap to effective international federal government? Second, why is this concession necessary? Finally, is the doctrine of original agreement powerful enough to support the creation of a fixed or perpetual union?

The necessity for unanimity lies in the fact that, in their original condition, states stand toward each other in a state of entire independence. In the absence of any agreement among them, no state has any right or jurisdiction over another. There are no natural grounds of superiority or supremacy giving any state the right to lay down the law for another. This condition is often described by saying that all states are equal, and in this sense the principle is sound, and has received universal assent. ${ }^{1}$ It may be maintained that there is a common bond of humanity and natural justice connecting the states of the world. It may also be argued that reasons of natural justice imply or demand the supremacy of greater and more advanced

'Classical statement by Marshall, in The Antelope, as cited: "No principle of general law is more universally acknowledged than the perfect equality of nations. Russia and Geneva have equal rights. It results from this equality that no one can rightfully impose a rule on another.", 
nations over lesser and backward ones. It is still true that until the principles of that natural justice are recognized and defined by agreement among the states, it can have no effective contact with human affairs, no binding force upon international relations; and in this process of defining natural justice, and until it is defined, no state has any particular ground for jurisdiction over another.

This means, indeed, that the initial establishment of any international government, and the initial creation of any bonds of authority among the nations, demands unanimous consent, and that any international federation must lack all jurisdiction over the nations which do not participate in its formation. ${ }^{1}$ This is unescapable, in the nature of the case, whether it be bad or good. It may also be suggested that too much impatience is at times manifested in this connection by persons who desire to make headway quickly, without being required to secure from all concerned consent for the schemes or actions which they propose. The real trouble is not so much in the unanimity rule as in the inability or unwillingness of the peoples to come to accord on subjects of common interest. In other walks of life much "unanimous consent business" is carried along successfully. Unanimous consent at the initial stage is neither an unreasonable nor an impossible requirement.

Where the need for unanimity is an intolerable burden is in the later operation of international government, in its application to concrete questions. But the necessity for an initial unanimity does not involve a like necessity beyond that point. There is no reason in law or jurisprudence why the members of a group of states should not provide by original agreement for the operation of any organs of the federation which they are in the act of creating by threefourths votes, two-thirds votes, or simply majority votes. ${ }^{2}$ Thereafter the decisions of the league need not be unani-

\footnotetext{
${ }^{1}$ Compare Covenant of League of Nations, Art. XXVI, below, Appendix A, Document No. 15.

${ }^{2}$ Examples of such procedure in Sayre, 155-157.
} 
mous; yet all members will be bound thereby, and, at the same time, no violation of state sovereignty will take place, because of the continuing effect of the original agreement, which is an integral element in the authority of each subsequent decision.

Suppose, however, that the federal agreement is made for an indefinite period, and that no method is provided for withdrawal from the league or for amendment of its terms. Does not this result in a loss of sovereignty by the member states? 1

To this there are many replies.

In the first place, it may be observed that many simple treaties have been concluded in the past without any provision for a definite period of operation and without any provisions for withdrawal or denunciation. ${ }^{2}$ Yet they have not usually been regarded as involving a loss of sovereignty.

In the second place, we must not forget that such treaties are susceptible of denunciation by the principle of altered circumstances, and there is no juristic reason why that process could not justifiably be applied to a treaty creating a federal league. ${ }^{3}$ If the Constitution of the United States had been solely a treaty among states, acting in that capacity, denunciation or secession would have been juristically feasible. It was the fact that the Constitution was not solely a treaty among states, but also a fundamental law resting upon the action of the people of the United States as a unit,-in other words, it was the unitary element in the foundation of the Constitution,-which placed that instrument beyond the action of single states. ${ }^{4}$

${ }^{1}$ Hall, $\S 4$; note that Hall protects his statement by stipulating that the union shall "subject the external action of a state to direction by a will other than its own."

'So the international administrative unions generally; see, for example, the Sanitary Convention of 1905, Malloy, 2144.

So the action of the United States in 1921 in denouncing this Convention.

- See the statement of this dual character of the Union in The Federalist, No. 39; Marshall's exposition of the national element in the Union in $M c C u l l o c h v$. Maryland, 1819, 17 U.S. 316; and the application of this doctrine to the problem of secession in Texas $v$. White, 1869, 74 U.S. 724 . 


\section{THEORY OF INTERNATIONAL FEDERATION 393}

Third, it is not to be overlooked that, even if there were a loss of sovereignty, it would be a voluntary surrender of sovereignty, not its destruction or violation at the hands of another state or states. Now the doctrine of sovereignty does not insist that all sovereign states which ever come into being shall remain in existence forever. It merely requires that so long as a state exists as such, and desires to continue to exist as such, it shall be free from outside interference. Voluntary surrender of sovereignty is therefore entirely compatible with the doctrine of sovereignty. It has been said that slavery is no less slavery because entered willingly. If we set aside the emotional nuance surrounding such a declaration, it will appear that the essence of slavery is precisely the element of compulsion, and that where freedom of choice exists in taking up certain duties-indefinite in extent, and, perhaps, running into an indefinite future,-precisely that element of compulsion is lacking. It may also be added that such a voluntary surrender not only escapes the description "violation of sovereignty" at the time. It also makes impossible any violation of sovereignty in the future by bringing about the consolidation of that sovereignty, or, rather, by merging it, in practice, in the common power of the league.

The issue must, however, be met still more directly. Does such an agreement really involve a loss of state sovereignty, irrespective of past opinion, disregarding the rule of rebus sic stantibus, and admitting that surrender, not violation, is in question? It does not seem so, for various reasons.

It should always be remembered that the critical stage at which the test must be made is not the resultant situation, but the stage of the original agreement. Why? Because the whole question relates to the origin, source, or basis of authority, and that can be discovered only by going back to the process of creation. Without such a method of analysis, the simplest treaty or diplomatic agree- 
ment would be susceptible of being interpreted as a destruction or loss of sovereignty, the simplest contract as slavery. And when such a method is employed, the voluntary character of the original agreement covers and obliterates any apparent compulsion emerging at a later stage-even into a perpetual future.

A most illuminating and vivid, yet very simple, example is to be found in the case of an international agreement, without time limits, not to exercise the treaty power, not to make a certain sort of treaty, such as a treaty of peace. Such agreements are common in the history of international relations. Both of the objectionable elements are present: permanence, and, apparently, a surrender of a peculiarly essential sovereign power. Yet such agreements have not been regarded as destructive of the sovereignty of the contracting parties or as involving a loss or surrender of that sovereignty. ${ }^{1}$

Furthermore, the unalterable character of the agreement, and not merely the content of the agreement which is made unalterable, is itself the result of the will of the state. The element of irrevocability and permanence, like a specific promise to pay money, derives its juristic reality from the continuing sovereign power of the state which for its own self wrote that element into the agreement. It cannot then result in a loss of that sovereign power, for such a result would deprive the agreement of its own authority upon this particular point. The permanence of the arrangement depends upon the persistence of sovereignty in the states which decree that it shall be permanent.

Finally, the unalterable membership in the union and the unalterable specific terms of union, the duties assumed by the member state, are likewise embodiments of the

${ }^{1}$ For an old example where a sovereign power is contracted away by pledges not to exercise the treaty-making power see Treaty of Alliance between United States and France, 1778, Art. VIII, in Malloy, 481; for recent examples see the Inter-Allied Pact of London, of 1914, whereby the signatory parties promised not to make peace separately, and the Covenant of League of Nations, Art. XX, below, Appendix A, Document No. 15. 
sovereignty of that state, not acts of surrender. Construe them as such, and all the foundation for their future authority is destroyed. What the state has done is to perform a permanent action of sovereign power, to achieve a perpetual act of sovereignty, as when an individual chooses to become a lawyer or teacher or member of some other profession or association. Other states have done the same thing, and these simultaneous acts bring into existence as a joint product a federal league wherein are funded and exercised for the future the united sovereign powers of all the constituent states.

At times it appears that it is precisely this process of practical coöperation which is really opposed by the supporters of the doctrine of state sovereignty; sometimes it seems that the doctrine is used merely to cloak with an ideal moral value a policy of opposition to international coöperation, of national action for immediate and exclusive national advantage. For this reason it has seemed necessary to argue the case on the issue of national sovereignty. It might occur to some students of the problem that if the advantages and benefits of international organization in the concrete are such as to justify its adoption, then any conflict which is apparent between such a step and the preservation of national sovereignty shows that the latter is a useless, and even harmful, doctrine. As we have seen, however, neither the violation of national sovereignty by others nor the voluntary surrender of sovereignty by the state itself is involved in the creation of a federal union. The original agreement, on the contrary, preserves, during the term of its life, the sovereignty of the state which enters the league. 


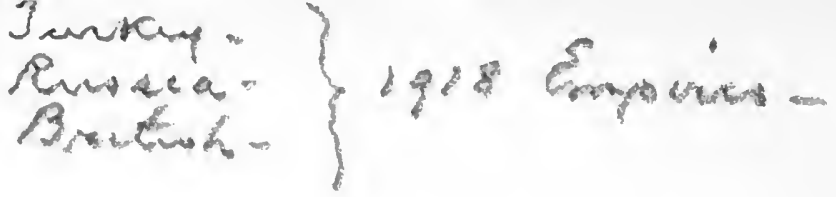

CHAPTER XXIV

EMPIRE, DEFENSIVE ALLIANCES, AND THE BALANCE OF POWER

A the beginning of this study the development of the and the state-system of 1648 was described as the foundation for the slow growth of international organization from that time onward. ${ }^{1}$ It is now desirable to review briefly the principal events in the development of the modern state-system between 1648 and 1918, as a foundation for a study of attempts to create a new and more elaborate international organization for the future. We shall begin with a review of attempts at empire since the Renaissance.

During the fourteenth and fifteenth centuries, as has been seen, there was a lull in the story. The Papacy and the Holy Roman Empire had been shattered, and no other imperial structures had risen to take their places. The new national states of Western Europe were still busy consolidating, or attempting to consolidate, their internal strength for the new age. England was passing through the Wars of the Roses, after having been forced, as a result of the Hundred Years War, to withdraw from her continental possessions in France. France herself was slowly recuperating from the long struggle with England, and Louis XI was engaged in the final attempt to exclude Charles of Burgundy from interference in the kingdom. Germany was in a state of anarchy. The historic effort to erect imperial structures by military force was left to be resumed anew by other states in other quarters of Europe. ${ }^{2}$

${ }^{2}$ Chaps. II-IV, above.

'On the state-system of Europe in this period see Schevill, 11-24. 
From the ancient seat of the Eastern Roman Empire came the first modern imperial movement, under the leadership of the Ottoman Turks. Capturing Constantinople in 1453, the Turks added to their older possessions in Asia Minor new conquests in Syria and Northern Africa and great stretches of Southeastern Europe up to the very gates of Vienna. The Ottoman Empire did, indeed, begin to lose ground after the great period of Sulieman the Magnificent (1520-1566). Various territories were lost to foreign powers,-Hungary to Austria in 1699, Tripoli to Italy in 1912, Egypt to Great Britain in 1914. Others were lost as the result of movements for national independence -Greece in 1830, Serbia in 1878, and so on. Nevertheless, in 1918 the Ottoman state was still great in its extent and of the typical imperial form.

To the north of the Turkish domains rose the Russian Empire, beginning at Moscow, the ancient seat of the family of Romanoff, as a center, and spreading gradually in all directions, partly by the process of natural growth, but also largely by means of military conquest. As Byzantium had claimed to succeed Rome after the barbarian invasions in the West, so Russia claimed to succeed Byzantium, after the Turkish conquest, as the legitimate seat of the Church and the Empire. Ivan IV, "the Terrible," formally took the imperial title of Tsar (Cæsar) in 1547. Bordering peoples in Finland, Poland, Ukrania, Georgia, and central Asia were brought under subjection to a despotic imperial power which stretched over vast areas of territory and millions of subjects until well into 1918. ${ }^{2}$

The only other empire in existence in 1918 of a similar type was the British. Having recovered her power in the later sixteenth century, Britain began to establish herself

1 On the rise and development of the Turkish Empire see Thorndike, 554559, Schevill, 13, 14 (note 1), 42, 43, 59, 64-65, and. Maps Nos. 1, 4-8, and Shepherd, 93, 124, 164.

'On the development of the Russian Empire see. Schevill, 215-229, 400-407, and Shepherd, 138, 170. 
in America, in India, in Africa and Australasia. Long before the Congress of Vienna, and reaching down to our own day, her power extended into all the five continents and all the seven seas. It must be clearly noted, however, that Britain differed greatly from Turkey and Russia in the methods pursued in achieving empire, although, superficially, the result was the same. In a few cases-South Africa and Ireland among them-the method of conquest was employed. But the bulk of the British imperial dominions came by movements of exploration and settlement of not only an innocent but an admirable type. More important, so far as the result is concerned, Great Britain had, in 1918, gone far to develop schemes of local autonomy within the Empire calculated ultimately to destroy the normal effect of empire upon the state system of the world. Finally, the British Empire has been a maritime empire, composed, not of subject continental states, but of transoceanic colonies, and has thereby constituted less of a threat to the European state-system than would otherwise have been the case. ${ }^{1}$

Another empire of the same type was that of Spain prior to the time of Charles V. As a result of the work of her explorers and colonizers, Spain gained dominion over vast areas in the Americas and in further Asia. These she held more or less firmly until well into the nineteenth century. But it was not for her transmaritime colonies that Spain was regarded as a threat to the liberties of European states. In the last century even those colonies were lost, to take their places in the modern state-system in their own names. ${ }^{2}$

The real dangers to the liberties of the European states in the past four centuries have come principally from two

${ }^{1}$ On the development of the British Empire see Schevill, 163-199, 248-263, and Shepherd, 128, 136, 170. On devolution in the Empire with reappearance of independent states see Keith, Imperial Unity, entire, especially 510-529; also works cited, below, Appendix B, § 24.

On the Spanish Empire see Schevill, 21-22, 59-67, 102-116, and Shepherd, $128,136$. 
other sources. Russia and Turkey threatened and subjugated only peoples who were, relatively, backward in their growth and who dwelt upon the fringes of Europe. Britain and Spain built empires beyond the seas. In the main, it was not these, but other, imperial efforts which were the objects of resistance on the part of the nations seeking to preserve their freedom. The imperial menace in the heart of Europe in recent times came from Austria, from Germany, and from France.

The Hapsburg Charles I of Spain, heir to the domains of Ferdinand and Isabella, was chosen in 1519, as Charles V, to rule over the Holy Roman Empire. ${ }^{1}$ The Empire had recovered some unity and power under his immediate predecessors, and Charles claimed to rule over not only Spain and her world-wide colonies, but the Empire in Central Europe, the Netherlands, Naples, and Sicily. From this time onward for four centuries the house of Hapsburg maintained its claim to imperial power. The Protestant Reformation in Germany made upon the imperial unity deep inroads which ended only in the Peace of Augsburg and the failure and abdication of Charles in 1555 and 1556; but his son Philip II of Spain took up the task in Spain, and his brother Ferdinand in Central Europe. Until the defeat of the Armada the Spanish effort threatened to be successful, and the Austrian Hapsburgs built up an empire in the valley of the Danube which held in subjection Poles and Czechs, Magyars and Rumanians, Italians and Southern Slavs, down to the end of $1918 .^{2}$

The French threats to European national liberty were made under two great rulers, Louis XIV and Napoleon. The former, during the years from 1667 to 1714 , attempted to conquer additional dominions for France in the Netherlands and in the valley of the Rhine. More important still,

See table in Schevill, 435.

${ }^{2}$ On the Hapsburg Empire see Schevill, 40-41, 43-46, 141-160, and elsewhere, and Shepherd, 119, 131, 155, 167. 
he attempted with some success to secure for France a political hegemony in Europe which amounted to an empire of influence and power, if not of possession. ${ }^{1}$ Napoleon, a century later, capitalized the fervor of the Revolution, and the resentment against those powers which had attempted to suppress that movement, for his imperial purposes, and embarked on a dazzling career of conquest. There were suggestions of national liberty and free international federation to come, when hostile and reactionary dynasties had been destroyed. But at the time his performance resembled nothing in the minds of European statesmen so much as that of Charles V, Philip II, and Louis XIV, and the end was St. Helena. ${ }^{2}$

The latest imperial movement came from Hohenzollern Prussia. Beginning as a rather small state built up chiefly by military measures on the sandy plains of North Central Europe, progressing through a very skilful and, on the whole, admirable movement for the unification of the scattered fragments of Germany North and West of the Erzgebirge, Prussian Germany emerged in the end as a very formidable embodiment of the imperial idea. Territories were taken from Denmark, Austria was expelled from influence in that section of Europe where the new Empire was to be established, and the preliminary work was consummated with the defeat of France and the annexation of Alsace-Lorraine. The remaining period down to 1918 was filled with renewed efforts at expansion in Europe, in Asia Minor-in coöperation with imperial Austria-and in the African colonial world. In 1918 Germany was the center of what appeared to be, notwithstanding democratic opposition at home and Russian, French, and British competition in the colonial field, the center of the most powerful imperial impulse in the world. 126.

${ }^{2}$ On the imperial career of Louis XIV see Schevill, 200-214, and Shepherd,

${ }^{2}$ On the Napoleonic Empire see Schevill, 304-332, and Shepherd, 150-157. 
Germany boasted that at home she was a federal state, resting upon the free consent and voluntary leadership of Prussia. It is also true that her empire was, like the British, mainly a colonial empire and did not rest upon subjugated peoples in Europe, as did the Russian, Turkish, and Austrian imperial structures. But, like France under Louis XIV, the tone and attitude of imperial domination were present in all their force.

These successive imperial movements in Europe from the fifteenth to the twentieth centuries constitute one of the two principal threads of development in the history of the modern state-system. ${ }^{2}$ Yet they have all failed. Amerongen, St. Helena, and the Siberian monastery where the last of the Tsars perished,- these are symbols of the defeat of imperial power and pretensions. There are new schemes of empire in the minds of some dreamers still, but in actual fact the world is back where Europe stood in the fifteenth century, and no great strong empire dominates the liberties of the free national states of Europe, nor, indeed, of any part of the world. The explanation lies in the second of the two threads of modern international history, namely, in the development of defensive alliances and of the principle of the balance of power.

If individual man is, in truth, a political or social animal, and by his very nature craves the society of his fellows, it would also appear that collective man, the state, is a social creature, if habitual behavior is any guide. The behavior of states from the time when states first made

${ }^{1}$ On the modern German Empire see Schevill, 230-247, 380-389; Seymour, Chaps. II-V, VII-IX, XI, XII; and Shepherd, 160, 161, 166, 174.

Chronological table:

+ 1453-1918 Ottoman Empire. 1462-1918 Russian Empire. 1603-1918 British Empire. 1516-1918 Hapsburg Empire (Austrian). 1556-1821 Hapsburg Empire (Spanish). 1667-1714 Louis XIV. 1795-1815 Napoleon I. 1618-1918 Prussian German Empire. 
their appearance in the world indicates that they stand in need, and realize that they stand in need, of the society and coöperation of their fellows. Speaking carefully, and weighing not the gross indications of nationalist rhetoric but the net evidence of actual practice, we may say that states have never manifested a desire to live independently in either the economic or political spheres. Some degree of international cooperation is found as far back as we find national independence; the two are correlative modes of national life.

The simplest form of international political union is the alliance, which may be defined as an association of two or more otherwise independent states for a common purpose. ${ }^{1}$ Political units which do not have control of their own international relations, - which are not, in other words, independent states in full right,-have no power in law to conclude alliances, and this rule is observed in actual practice. $^{2}$ Where an alliance does exist the common purpose is usually defined in a treaty of alliance or equally definite diplomatic agreement stating the terms of the coöperation both as to the objects sought and the means to be employed in the process. ${ }^{3}$ In many cases the details regarding military or naval cooperation by the allies are settled in subordinate agreements made to supplement the principal treaty, and these agreements are frequently entrusted to military or naval officers for elaboration. ${ }^{4}$

\section{Two points deserve special notice here.}

In the first place, the alliance is a definite first step in the process of international federation. This is recognized in many notable documents. The Constitution of the United States provides that no state shall make any

1 On alliances in general see literature cited, below, Appendix B, § 24.

- On capacity to contract alliances see Calvo, $\$ \S 1616-1618$, and Hershey,

- Example in the Triple Alliance; text in "The Background of the War," in League of Nations, I, 216 (April, 1918).

- League of Nations, I, 219-220. 
"treaty, alliance, or confederation." 1 The fact is also recognized by Calvo, the great Latin-American jurist, ${ }^{2}$ and by Phillipson, in his study of "Treaties and Alliances" in Greece and Rome. ${ }^{3}$ Indeed, every treaty constitutes an alliance or a confederation pro tanto. The treaty of friendship and commerce concluded in 1778 between the United States and France on the same day which saw the conclusion of the military alliance between those two states spoke of the parties as "the confederates." ${ }_{4}$ An alliance and a treaty are to be distinguished in that ordinarily a simple treaty does not provide for joint action by the parties for execution of the agreement, while an alliance does.

In the second place, the alliance may be distinguished from the federation in the full sense of the word by the fact that there is no common organ of government. The activities of the allies are coordinated but not unified, and they are coördinated, usually, not by a standing body but by diplomatic consultations ad hoc. ${ }^{5}$

The objects of alliances are as manifold as the interests which states may have in common, and, as in the case of the subject matter of treaty-negotiation, no purpose is to be served by a long enumeration of those objects, by the pedantic enumeration of treaties of alliance and guarantee, of treaties of alliance and assistance or subsidy, and so on. ${ }^{8}$ Nor would it be profitable to dwell upon the different varieties of alliances by reference to the motives which lead to their original formation, and to speak of alliances of blood,

${ }^{1}$ Constitution, Art. I, $\S 10$, Par. 1.

${ }^{2}$ Calro avers that offensive and defensive alliances are most frequently found among sovereign states linked by federal bonds as in the case of the United States of America; as cited, $\$ 2008$. He adds that such alliances aro one essential element in any federal union.

International Law and Custom of Ancient Greece and Rome, II, Chaps. XX, XXI.

Art. XXIII, in Malloy 476.

- This may explain the unusual importance attached by Mr. Lloyd George to the formation of the Inter-Allied Supreme Council in November, 1917; quoted in League of Nations, I, 348 (October, 1918). 2013.

Attempt to classify alliances by objects in Calvo, as cited, $\S \S 2006-2008$, 
of faith, of interest. ${ }^{1}$ All alliances are alliances of interest and the interests are too many to be listed singly. A few of the more important and more common objects may be noted, as well as a few general inferences regarding the whole matter.

In the first place, it is an elementary rule of sound policy to provide at the outset a clear and specific statement of the objects sought by the alliance. Alliances in general terms are often called alliances "pure and simple." Such alliances are, on the contrary, neither pure nor simple. They are bound to be sources of continual disagreement between the parties. They are "entangling alliances" par excellence. They are agreements of indefinite liability for the parties and are certain to cause friction and misunderstanding later. Moreover, the objects as stated in a treaty of alliance must in fact coincide with the real interests of the parties, for, otherwise, they will be ineffective when the time comes to invoke the obligations of the pact. The parties will not support with men and money the fanciful objects stated in the text.

The most common purpose of alliances is to provide for military coöperation, defensive or offensive, or both. It is common to deride the idea that an alliance may be purely defensive. As to that, it may be said, first, that, in point of fact, it is not impossible to point out alliances which have operated entirely in that rôle. ${ }^{2}$ Moreover, in so far as defensive alliances tend to become offensive in character this is due to causes much deeper than the alliance itself. Parties to a defensive alliance engage to protect one another in what they believe to be their legitimate rights and interests. That this leads to offensive action at times, and, more commonly still, to stronger action by the parties in defining and pressing for the satisfaction of these ${ }^{1}$ Calvo, as cited, $\S \S 2014,2015,2022,2028$.

- For example, that between Italy and Austria, of 1882; it was an attempt by Austria to use this alliance, as renewed in 1887, 1892, 1903, and 1912, for offensive purposes, that wrecked it in 1914 . 
rights, in reliance upon the support of the alliance, is due to the fact that international government is still so rudimentary as to leave to individual nations almost entirely the business of defining and obtaining satisfaction for their rights. It is this which induces in the defensive alliance its offensive character, just as the same factor tends to make war always offensive in actual fact unless attention is focused on the superficial question as to which party first undertakes military action.

The objects of alliances are commonly stated in the preambles of the treaties creating them. Often there is a profession of solicitude for the maintenance of peace and justice by means of the alliance. ${ }^{\prime}$ This is, in part, but another reflection of the situation just described. It is also true that for the real character of the alliance recourse must be had to the body of the treaty, just as it is true that many treaties, if their texts are examined, prove to be in fact alliances although they are not called so by name. ${ }^{2}$ But it may safely be averred, further, that the professions of solicitude for the maintenance of peace and justice by means of the alliance are entitled to a considerable measure of respect, and this for a very definite reason, namely, that practically every alliance aims at the support of the balance of power, without which there can be, in reality, neither peace nor justice.

Before turning to this subject of the balance of power, however, two other matters are to be considered, namely, the legal aspects of alliances and the question of membership.

In common with all treaties, treaties of alliance involve many questions of law respecting the original power of the signatories to conclude the treaty, the duration and binding effectiveness of the pact, the scope of the obligations as-

1 Example in preamble of treaty eited in note 3, p. 402, above.

Example in the Anglo-French Entente of 1904; in League of Nations, I, 227-233. 
sumed, and the effect of the treaty upon other treaties and other parties. Because of the fact that definite action, and military action at that, is commonly called for, the question of the scope of the obligation of the treaty, of the appearance of the occasion for action under the treaty, called the casus foderis, is especially vital. It is, however, a strictly legal question, and the student must be referred for its adequate treatment, as well as for treatment of all the various legal questions relating to alliances, to the treatises upon international law proper. ${ }^{1}$

As to membership alliances may be bi-lateral or multilateral, dual, triple, quadruple, and so on. They may also be "general"' in form, including, that is, a substantial number of all the states of Europe, or of the world. At this point we begin to reach the final stages of the development of alliances as instruments of international government. It requires a broader, a more general, interest to bind three states together than two four than three, and so on. Likewise, it requires a more permanent interest to create an alliance of long term than an alliance for a short period, and it requires a permanent interest to justify an alliance for an indefinite term. It requires a very general and a very permanent object to establish a permanent general alliance, an international federation. Such an object, again, is found in the maintenance of the balance of power. To that we now turn.

The "balance of power" is a concept respecting the power and alignment of the states in the political scene in Europe, in Asia, or in whatever region it is applied.2 A balance of power would exist where no one state was in a position to dictate to other states according to its will. Out of this concept a rule of law might be made, to the effect that no state may legally claim or hold such a position. Or the matter might be stated as a practical prob-

1 See, for example, Calvo, as cited, and Pradier-Fodéré, $\$ 934$ and following.

${ }^{2}$ On the balance of power see literature cited, below, Appendix B, $\S 24$. 
ability : no state will be allowed to obtain and hold such a position. Finally, we might turn the idea into a statement of policy: no state should be permitted to attain such a position, and such a balance must be preserved as to prevent such a result.

As embodied in a statement of law, the formula leaves much to be desired. It is vague and difficult to apply. It appears to imply that states may not legally expand in power and possessions and political influence, which is not accurate. On the other hand, the formula does reflect a familiar and an accepted principle, namely, that no state may, of right, lay down the law for others. It consists of an attempt to insure the maintenance of that principle by action in the world of physical facts. It is not a principle or rule of law but a rule of action designed to reinforce and vindicate the law from the outside.

The formula as a statement of probability is of more value. Surveying the long course of international relations from Thucydides to Clemenceau, it is clear that the states will not, if they can prevent it, permit such a predominance on the part of one state as will endanger their own liberties. As a scientific statement of habitual and characteristic be-

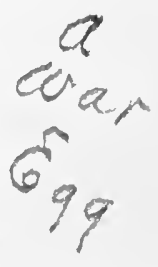
havior, as a law of the descriptive type, it is well supported by the evidence. ${ }^{1}$

It is as a rule of policy, however, that the doctrine may be regarded to best advantage. On the surface it is a rule of national policy, serving as a guide for each individual state. At a second stage it is an international policy, a generally recognized principle of public interest. As both, it has been proclaimed and supported consistently from the earliest times. It is generally felt to be necessary as a practical support for the observance of public law; in the absence of an international police for the vindication of the law, free combinations for security are necessary. ${ }^{2}$

${ }^{3}$ On the balance of power in history see Phillimore, Part IV, Chap. I, § II, and Wilson and Tucker, 82-83.

' Bernard, 97, 99. 
The concept of the balance may take any one of several distinct forms which vary considerably among themselves' in value.

The simplest form of the balance is found where two states are somewhere nearly equal in power and are, by force of circumstances, balanced one against another so that neither possesses a predominance over the other. This form of balance is most unstable and precarious. In its mechanical aspect it resembles a see-saw, or the beam of a pair of scales, which will tip violently if a slight weight is cast into one side of the balance. It is bound to result in an agonizing competition between the parties to prevent one from securing advantages over the other. It leads to the practice of "partition" whereby the rivals, by a "calculus of lands and souls," divide equally the possessions of a weaker neighbor and thus grow in greatness yet preserve the balance. It leads to attempts, on one side and the other, to secure the protection of alliances, counter-alliances, and cross-alliances, resulting in a veritable "nightmare of alliances," haunting the minds of all parties and creating a super-sensitive and suspicious atmosphere among them.

Some improvement is made in the second form of the balance, where a third state, not permanently allied to either of the rivals, holds the balance of power between them. This state, acting from time to time as a makeweight, has the power to exert a moderating influence upon the other parties and to reassure each that he will be protected in his legitimate interests. On the other hand, the situation leads these rivals to curry favor continually with the third state, and it allows the third state itself to maintain its supremacy by dividing the rivals and playing upon their fears, and to assume an attitude of dictation checked only by the possibility that the rivals may make common cause against the dictator. While greatly superior to the primitive form of the balance, in view of the presence at 
the fulcrum of a stabilizing weight which will tend always to redress the balance, it is not entirely satisfactory.

The desirable form of the balance is found where three or more states are substantially equal and are not grouped in any particular or exclusive alliances one with another. This is the mechanical form of the equilateral triangle or, if the comparison is permissible, of the equilateral polygon. There is at once greater stability and greater flexibility in this form of balance than in the simpler forms. It is not so easily upset, because it has the capacity to adjust itself more readily to stresses and strains from without and within. There is a condition not so much of balance as of general equilibrium. Where these conditions exist, among not merely three but four or five or a larger number of states, the ideal condition exists. We then find ourselves back upon the familiar principle that a condition of general equality among the states is what is most to be sought. We also find ourselves demanding that exclusive alliances shall be dropped, as they tend to destroy the general equilibrium. The latter demand, however, leads to a more detailed consideration of the relations between the alliances described in an earlier part of this chapter and the balance of power, and likewise of the part played by these factors in the problem by the imperial movements witnessed in Europe from the fifteenth to the twentieth centuries.

The idea of the balance of power was not unknown in the ancient and medieval periods.

The Greek states lived constantly in a condition of equilibrium such that no single state could secure, or at all events long retain, a predominance over the others. Athens, Sparta, and Thebes were constantly struggling for hegemony, attaining it, and losing it again. The Greeks recognized this condition of affairs and sought to perpetuate it. Thus the growing power of Athens called for opposition from Sparta and other Peloponnesian states in the

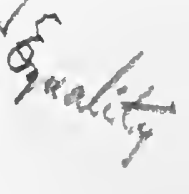


flast half of the sixth century B.C. The power of Sparta was checked by Athens and Thebes, and that of Thebes in turn by Athens and Sparta during the later years of the fourth century.

It has therefore been said that the balance or equilibrium among the Greek states was exceedingly delicate and unstable. By this it is meant that the states were sufficiently unequal to make attempts at conquest possible, yet sufficiently equal to make resistance a hopeful enterprise, and that constant competition was the result. In reality, however, beyond this margin of competition the equilibrium was exceedingly stable, for extensive or permanent upsets were very difficult. The Greeks maintained the struggle among the states as a permanent condition of life. ${ }^{1}$

So successful were the Greeks in this direction, however, that, when Macedon came upon the scene, the independence and self-reliance of the Greek states were too perfectly developed to allow that degree of coöperation which was necessary to repel the invader. It would have been better, where a threat from an external source existed, to forego such an intense application of the principle of balance that no disciplined coöperation could develop. Too great suspicion and jealousy had inhibited the spirit of confidence and mutual help. ${ }^{2}$

Rome was consistently able to escape the operations of the policy of balance and was therefore able to build up her empire successfully. Certain of her victims saw the necessity for coöperation in defense, but saw it too late to persuade others to take effective action. By following a rule later employed by other empire builders with marked success, the rule divide et impera, Rome was able to conquer singly states which might have preserved the balance by making common cause against her. ${ }^{3}$

1 On the balance of power among the Greek states see Phillipson, as cited, II, 101-110.

On the lack of a balance against Macedon see same, 108.

- On the absence of a balance against Rome see same, 110-114. 
From the establishment of the Empire of Rome to the $\alpha$. 2 time of the Renaissance the idea of the balance of power was lost. Empire seemed the natural course of events, and even a desirable condition. Then came the revival of independent statehood and with it a rediscovery of the prin-

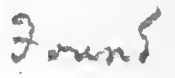
eiple of the balance of power.

It is to Italy that we must turn for this event. The situation in the peninsula was similar to that of ancient Greece: many independent states of substantially equal power existed side by side and were engaged in active relations one with another, and all were anxious to preserve their respective independence. It was quite natural that some keen politician and some wise student of current interstate relations, such as Lorenzo de Medici and the historian Guicciardini, should rediscover and restate the old principle for the new age. ${ }^{1}$

If we turn to Guicciardini's statement we find a elear indication of the function of allianees in preserving the balanee of power against military conquests. Said Guicciardini: "The peace which Italy enjoyed at that time was the effect of different causes, and especially of the cleverness of Lorenzo de Medici.... This celebrated citizen of Florence,...., now governed the Republic ....; a short time back he had conceived the policy of uniting his family by an alliance with Pope Innocent VIII.

For Lorenzo understood ... that it was necessary to oppose the aggrandizement of the prineipal powers of Ifaly and to preserve among them a just balance, as well for the safety of the Republie of Florence as for his own position. The sole means of preserving that equilibrium was to preserve the peace. ..." 2

The operation of this principle from 1500 to 1815 may be briefly outlined.

1 On the rediscovery of the doctrine in fifteenth century Italy see $\mathrm{Nys}$, Origines, 165-168, especially 167.

Quoted in Nys, 167-168. 
needy rival. Beside this, the worst conceivable use of the alliance for the state contemplating alliance, is to become an ally of the stronger of two rivals, for the result would be a victory not greatly due to the assistance rendered by the ally, a victory so decisive as to kill all feelings of moderation in the victor and to relieve him of any feeling of obligation to his friend and helper. If the ally is also weaker than the victor in his triumph, the ally is likely to become merely the next victim of him whom he assisted.

During the first half of the seventeenth century the principle was again embodied in the coalition between France and the Protestant Princes against Ferdinand II, and in the assistance brought by Sweden against the imperial pretensions of the Hapsburgs. ${ }^{1}$ The Peace of Westphalia (1648), the foundation of the modern Euro- pean state-system, constituted a definite recognition of the principle as the corner-stone of modern international relations. ${ }^{2}$ The Italians of the fifteenth century had hoped to preserve the balance by preserving peace and preventing wars for conquest; modern Europe was to preserve peace by preserving the balance. The Empire and the Papacy being no longer available as frames or forms into which the states of Europe might be fitted in orderly peace, this new cadre was adopted for the future. The feudal system had covered all Europe with a fabric of authority which, complicated and irregular as it was, had preserved a semblance of unity among the many petty political units of the time; the balance of power was now to serve to hold in order the more powerful states coming on the scene subject to no unified control such as that of the feudal authority of the previous age. ${ }^{3}$

Peace the balance of 1648 did not bring. The states of Europe were too new and their positions too unsettled to

1 Schevill, 144-156, especially 151, 155.

${ }^{2}$ Phillimore, as cited, § cecxcvii.

' Walker, 141. 
produce a stable alignment. In addition to this, the activities of Louis XIV and the manifold repercussions in Europe of the colonial competition in America and Asia prevented any settled peace. The end of the century saw a succession of coalitions against Louis, as earlier periods had seen successive alliances formed to check Charles, Philip, and Ferdinand. Such were the Triple Alliance of Britain, Sweden, and the Netherlands, in 1667; the alliance of the Emperor, Germany, the Dutch and the Spaniards in 1673 ; the Dutch, Spain, the Emperor, and Britain in 1688; and the Grand Alliance, - Britain, the Dutch, Germany, and the Emperor - of 1701.

The succeeding century witnessed a continuation of the same process; in various treaties the policy was set forth again and again. ${ }^{2}<1814$ a $h$ remmes

At the end of the eighteenth century, and during the years preceding the rapid development in international relations which was to set in after 1815, there appeared a new, factor in the process of preserying the balance of power. This was the practice of agreed partition, which, while it resulted from the common and familiar anxiety of rivals to keep abreast one of another, and has, therefore, already been mentioned in that connection, also involved a new element, the idea of preserving peace and the balance at one and the same time by international agreements to avoid war and secure national advantages by peaceful action.

The most striking example of this was the partition of Poland, in 1772-95. ${ }^{3}$ That action is usually characterized in the most condemnatory terms. Viewed from the standpoint of Poland, it was undoubtedly nothing but imperial conquest by three confederates, and worse than conquest by some single state under which national unity might have been preserved even if independence were lost. It could be

'Schevill, 204-213.

Hassal, entire; Phillimore, as cited, end; for text of treaty of alliance for preserving the balance of power see, below, Appendix A, Document No. 11.

${ }^{3}$ On the partition in general see Schevill, 227-229. 
justified as between the individual despoilers and Poland by no legal or moral right. It was naked physical seizure. ${ }^{1}$ But the action should be viewed from the standpoint of the annexing states also, and from the point of view of Europe as a whole. If the partition had not been made it is highly probable that war would have followed between Austria, Prussia, and Russia, ending in a conquest and division of Poland in any event. For Europe it may have been better done as it was done. Similar actions in a later period have not been regarded in the same light, partly because the direct profits of the participants have been less, the world more accustomed to such action, and solicitude for the general peace greater.

Before following the development of this practice into the Concert of Europe, however, it remains to note that the opening of the last century witnessed another case of alliances and coalitions to preserve and recreate the balance of power in the traditional manner. It was the Grand Alliance of 1814 between Britain, Austria, Prussia, and Russia which finally accomplished the defeat of Napoleon, as another Grand Alliance, also formed under British leadership, a century before, had balked the designs of another French sovereign. ${ }^{2}$

And at Vienna an attempt was made to redistribute the increments or elements of power in Europe so as to create a condition of equilibrium which would serve as a foundation for peaceful international relations in the future. ${ }^{3}$ In that process two fundamental mistakes were made. The experience with French power and French policy in the preceding fifteen or twenty years was allowed to induce the Allies to make, in all their calculations, errors in one direc-

${ }^{1}$ Schevill, 228, gives the familiar characterization.

2 On the action of the Grand Alliance in 1814 see Schevill, 328-332, and document cited, above, in note 2, p. 414 .

"On the balance of power at Vienna see Phillimore, as cited, $\S$ ccexcviii, citing Convention of 1814 among the Allies which defined the purpose of the meeting at Vienna to be that of establishing the peace of Europe "upon a just distribution of power among the states which compose it."

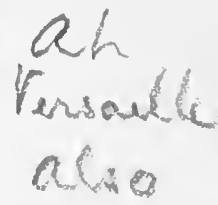


416

INTERNATIONAL ORGANIZATION

timon, namely, errors against France and in favor of themselves, errors which could, in the end, only weaken the settlement. The Allies also performed their calculations solely in terms of land and people and neglected to take into account the spiritual forces of nationality and liberty which had been unleashed by the Revolution. This also weakened their settlement. But the essential fact is that in 1814 and 1815 the defeat of Napoleon and the reconstructimon of the free European state-system were again based, and must have been based, upon an alliance to prevent ioperial conquest and an attempt to provide a condition of equilibrium among the five Great Powers which should insure the liberties of the nations in the future.

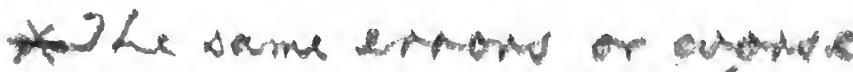

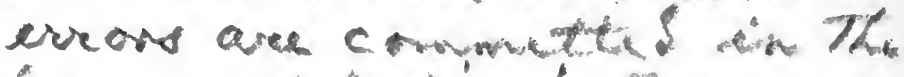

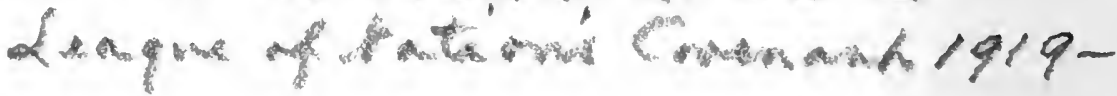
Have war hath

Partition

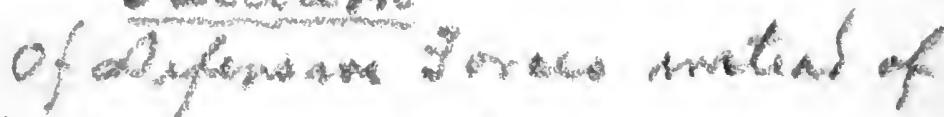

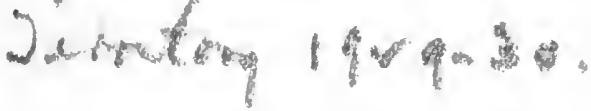




\section{CHAPTER XXV}

\section{THE HOLY ALLIANCE, THE CONCERT OF EUROPE, AND METHODS OF INTER- NATIONAL CONTROL}

THE experience of the Napoleonic period served to 1 reinforce all the convictions concerning the necessity for a just and stable distribution of power in Europe which had been developing since the beginning of modern times. Here was the most elaborate and the most successful effort yet made at universal European empire, and it had been defeated only by a system of defensive alliances which had approximated a league of public safety for the reëstablishment of equilibrium and national freedom in Europe.

Naturally, therefore, as it seems to us now, the Allies of 1814 determined to take care that their work should not have been done in vain; they determined to guard and maintain the newly created equilibrium in the uncertain future. And this was a real step forward. The principle of the balance of power, far from being dropped, was now placed for enforcement and administration in the hands of a permanent organ of international government, instead of being left to individual states or temporary alliances for its defense and support. The result was the Holy Alliance of $1815 .^{1}$

It is the fashion today to criticize and abuse the Holy Alliance and its activities, along with the principle of the balance of power itself. Such criticism must be reëxamined

${ }^{1}$ On the Holy Alliance see literature eited, below, Appendix B, § 25 . On the aims in the formation of the Holy Alliance see Phillips, 148-156, especially 151. For text of the Holy Alliance see, below, Appendix A, Document No. 12. 
here to discover its true value, for the principles of the Alliance and of the balance are present in recent efforts at international government, just as they were a century ago.

It will be noted, first, that opposition to the Alliance and to the balance has usually arisen from hostility to the perversion by the Alliance of the principle of balance to serve the ulterior designs of the individual parties to the Alliance and from aversion to the methods employed by the former for the maintenance of the latter. In the days of the partition of Poland it was the fact that the three Powers took over Polish territory for themselves and that they divided Poland without reference to Polish consent, not the idea of balance, nor the idea of alliance and cooperation to maintain that balance, that roused criticism. So in the case of the Holy Alliance and the balance after 1815, it was the fact that the Allies, particularly Austria, supported dynastic legitimism rather than the principle of international equilibrium itself that has given rise to the criticism of the work of 1815-25, and the fact that they employed military force for the suppression of national aspirations, not the central idea of international equilibrium and international coöperation in support of that equilibrium.

This leads us deeper, however, into the question whether such equilibrium could ever be maintained, and how it could be maintained, without stifling legitimate national activities and national growth. This question will answer itself if we examine more closely the nature of the threats raised against the equilibrium of Europe in the years following 1815 and the nature of the methods employed for its preservation.

There is no need to describe in detail the nationalistic movements of the early nineteenth century. We have seen how the force of nationalism operated in the creation of new states in Europe from the end of the Medieval period 
to the French Revolution. ${ }^{1}$ This principle of action was powerfully reinforced by the doctrines of government by $\mathcal{U}$ S.A consent which were brought forward by the Revolution, and it remained to challenge the work of the Alliance as it had, in an earlier age, challenged the strength of the Empire. In the period from 1789 onward the nationalistic movement appeared to its supporters to be the embodiment of progress and justice struggling against the forces of death and tyranny. To the members of the Holy Alliance it appeared to be a force of anarchy pure and simple. For this reason they employed every available agency against it.

The principal agency of international control used by the Alliance was intervention. ${ }^{2}$ Of course, when any difficulty arose the first step was conference, with or without participation by the offending parties, and conference was followed by a recommendation regarding the action to be taken in the interests of peace and order. Such recommendation, if adopted, could be embodied in an agreement which would settle the matter once and for all. But in the last resort, where voluntary acceptance of the mediatory suggestions was not forthcoming, collective intervention with the use of military or naval force-intervention which might take the simple forms of invasion and occupation, or the more complex form of pacific blockade-was always in the background. ${ }^{3}$ A threat might be sufficient, but whether force was actually employed or only threatened, the juristic nature of the proceeding was the same.

Now according to common or customary international law individual nations are free to follow their own policies in spite of the views of other nations, except in so far as they have limited themselves by the adoption of certain customary or conventional rules and principles for the regulation of international relations. Each state is free

1 Above, Chap. IV.

2 On the methods of the Alliance see Phillips, 159-266. On intervention see Hodges, and Stowell, Intervention, entire.

On pacific blockade see Hogan, entire, as cited, below, Appendix B, § 25. 
to judge for itself of the nature of those limitations and their effect upon its own action. No state may enforce the rules of law upon another, but may only demand voluntary obedience to those rules, threatening various actions if the demand is not met, actions which may vary from economic retaliation to the most serious steps known to international law. The aggrieved state is entitled, in the last resort, to go to war for the satisfaction of its rights, and it can be said that the first state is, from the beginning, under legal obligation to satisfy those rights. ${ }^{1}$ Does this apply to the Alliance and intervention for the maintenance of the balance? Is this, on the other hand, the most that can be said in describing the power and action of the Alliance in the years 1815-25?

It is certainly true that the Alliance enjoyed, and could enjoy, no right of general supervision over the actions of individual states. It could not, as of right, claim any such wide jurisdiction over even its own members. Much less could it claim such jurisdiction over outsiders. Nor could it, a fortiori, claim any general right of intervention to make good such supervisory jurisdiction. On the other hand, in so far as the Alliance or its members merely demanded the observance of established rules of international law, it was wholly within its rights, even when it threatened to back up that demand by physical force. Moreover, the individual states to whom such a demand was addressed were under legal obligation to submit to that demand. It is frequently forgotten that in demanding its rights-providing that what is demanded really is an established right -a state is not assuming to dictate to another, but is simply acting under a system of law deriving its authority from other, broader, sources, including the consent of the state upon whom the demand is made.

In actual historical fact the Holy Alliance was demand-

${ }^{1}$ On methods of securing redress at international law, in general, seo Hall, $\S \S 118-122$. 


\section{HOLY ALLIANCE AND CONCERT OF EUROPE 421}

ing the observance of the principle of legitimacy, of $\checkmark$ hereditary succession to political and territorial sovereignty, and opposing the principle of popular revolution or a claim to a right to set up independent states and governments by force in defiance of accepted constitutional law. It is no great help to say that this meant interference in "domestic" affairs and "constitutional" questions, for at the time under consideration the "law of nations" or "public law of Europe" covered both what we now consider purely international questions and certain subjects among what we now consider purely domestic questions. And surely the question of the recognition of new states was an international question. It is no great help, moreover, merely to say that the Alliance was trying to fly in the face of progress, to strangle at birth the elementary forces of democratic national life. If the Alliance was standing upon the law of nations as it existed at the time, then the Alliance was in the right, from a legal point of view, and its aim was largely that maintenance of international law and order which is not without merit in the eyes of the world today. The Alliance was, in truth, engaged in trying to minimize the use of military force for international reorganization, in a period like our own, when force had already been used too extensively for that purpose.

Does this mean that the maintenance of the international equilibrium inevitably commits us to such action as the suppression of progress, the prevention of growth and change in the state-system? Is not such a task impossible? How can we prevent the increase of power of a progressive state, the break-up of mature or even decrepit states? How can we hope to regulate and control international birth, life, and death in the interest of world peace and order?

If the problem had to be faced in just this form it would be impossible of solution. If order and progress were 
necessarily conflicting elements in the international problem the outcome would be perpetual conflict. National growth must and will go on, and some attempts to preserve order will always be made by those states which stand to benefit by the established order. But if we turn again to the behavior of the Holy Alliance it will appear that the conflict between progress and order in that day was brought about by a refusal on the part of the Alliance to recognize that the existing settlement might be unjust, that it might, in reality, be unstable and unbalanced, not stable and well balanced, and that it could-and even must-be revised while still preserving, and even in order to preserve-a condition of equilibrium in Europe. The real object of the anxieties of the Allies was not, it would appear, the preservation of a condition of equilibrium in Europe but the preservation of that order of things which profited them at the time. Serving that object, they betrayed the cause of peace and order and paved the way for revolution and war. The balance of power or the equilibrium of Europe was sacrificed in an attempt to prevent alterations in the existing status by gradual processes of revision and reorganization.

The solution of the apparent conflict between the ideal of order and equilibrium and the fact of change lies, therefore, in the practice of constant reorganization by consent. Every settlement, every order of things, every status quo, is in some measure unjust, unbalanced, almost as soon as it is made. It must be rectified and the balance corrected by constant revision, not by force so much as by consent applied in the recognition of new and changing facts. In asking whether such a process is feasible and whether such consent is obtainable, we may profitably turn to the efforts made for the preservation of peace and order in Europe after the failure of the Holy Alliance.

The Concert of Europe grew up in the second quarter of the nineteenth century on the ruins of the Alliance and 


\section{$J h x$ \\ " \\ 1825}

HOLY ALLIANCE AND CONCERT OF EUROPE 423

on the basis of the claim put forward by the Alliance to speak in the name of all Europe. ${ }^{1}$ The Concert supervised the liberation of Greece from Turkey ${ }^{2}$ and of Belgium from the unwelcome union with the Netherlands, ${ }^{3}$ and attempted to guide the development of the Eastern question in general from 1825 onward. ${ }^{4}$ After the middle of the century it began to weaken. The Italian problem worked itself out in 1859 with little control by the Concert; here nationalism won without its aid. The Polish question of 1863 was allowed to drift on in its own course; here nationalism lost, with the Concert impotent to prevent that result. Conferences in London in 1852-64 did not prevent Prussia and Austria from taking Schleswig and Holstein from Denmark, nor Prussia from expelling Austria from Germany in $1866 .{ }^{5}$

From this time onward the game was hopeless. The year 1867 saw a successful action by the Concert in the case of Luxembourg, but this is explained by sudden fear of war on the part of France and Prussia, rather than by any great skill or strength on the part of the Concert. ${ }^{6}$ During the years from 1870 to the outbreak of war in 1914 the increasing division of Europe into two hostile alliances wrecked the Concert completely. On the one side, the agreement between England and France controlled the outcome of the Egyptian controversy rather than any views of the Concert as a whole, and the rivalry between France and Germany prevented any really concerted action regarding Morocco. ${ }^{7}$ To the competition of alliances which gradually supplanted the Concert we shall turn in a later chapter. ${ }^{8}$ It remains here to notice why the Concert succeeded where

${ }^{1}$ On the Concert see literature cited, below, Appendix B, § 25, especially Holland, Concert, and Dupuis, 114-513.

2 Holland, 4-33.

Dupuis, 199-230.

- Holland, 4-322.

${ }^{3}$ Dupuis, 291-307, 308-316, 316-329.

- Same, 340-349.

TSame, 411-443, 444-492.

${ }^{8}$ Below, Chap. XXVII. 
the Alliance failed and how, in detail, the Concert actually did its work. Why it also failed will be discovered later.

The Concert succeeded where the Alliance failed because it made provision for changes in the existing statesystem in accord with the needs of the time. Greece and Belgium secured their independence as they could not have done under the principle of the Alliance. Not that there was no war. The prevention of all war is less in point in this question than the promotion of such a development of international relations as will, in the long run and in the balance of calculations, tend to eliminate war and also satisfy the just demands of the states. But can it be maintained either that the Concert preserved the balance of power or that it operated by the method of consent? If a balance existed before the achievement of Greek independence, did not the Concert destroy that balance? If the balance was lacking until the action of the Concert was taken in each case,- and that action was, it may be men-

" tioned, usually undertaken only after the initial movement had been made by an outside state or national group,- - did the Concert not tolerate conditions of instability more frequently than it attempted to remedy them? And can the sort of "consent" yielded by Turkey and the Netherlands be made the basis of any firm assertions or conclusions whatever?

The first question implies a misconception of the nature of the balance or equilibrium of power. What is to be maintained is, not any given status or alignment, but such a status or distribution of power that each state may be in a position freely to live its own life. This means that as time passes a given status-a given distribution of territory or population, of allegiance and sovereignty-may become obsolete and press for change. The balance or equilibrium of things is then to be served, not by a vain attempt to preserve the existing, or, rather, the pre-existing, balance, but by revising the legally established order. What 
the Concert commonly did was to re-define the balance; it did not destroy a condition of balance in favor of a condition of unbalance, but rather it supplanted an increasingly inadequate formula of equilibrium with a new and accurate formula; it did not deliberately tolerate conditions of unbalance, but moved to remedy them when evidence appeared that such conditions existed. The Concert did not, indeed, engage in preventive action as freely as it might have done. This is due mainly to the lack or uncertainty of its jurisdiction and to the tradition that international coöperation should take place only upon direct and immediate provocation, not for general purposes. But when problems had once arisen, it did attempt to devise solutions which would last, and it had the courage and judgment to recognize the facts and act upon them.

This may appear to amount to commending the Concert for accepting every change that came along; it may appear to reduce the task of maintaining the balance of power to the job of keeping pace with the upsets which constantly overtake that mythical condition. In the sense that the decisive facts in the problem are to be found outside the realm of diplomacy, politics, and law, and that the existing political and legal balance is either upset or not upset as a result of economic and social forces working independently of it, this is true. The task of law and government in this problem is to register and embody the forces of a 110npolitical nature, - the growth of population, the increase of wealth, of intelligence, of national feeling. The balance of power in the sense of the actual distribution of power will always be what in fact it is, and no diplomatic legerdemain can alter the facts of nature.

The suggestion is probably true also in another sense. It must, apparently, be admitted that it is finally impossiole to prevent the expansion and development of any given state which is in a natural position to develop its power and might. If the preservation of the international equilibrium 
Eruce \&

Jenkey

\&

concertie Sorce.

depended upon the stifling of natural growth it would be both an unrighteous and a futile task. How then can the equilibrium be preserved? If states are to be allowed to develop as they can, and new states to come into being if natural forces demand it, how can we prevent a disruption of the public peace and order, and consequent danger to the rights and interests of existing states? The answer to these questions may be found by again observing the behavior of the Concert, particularly upon the question of obtaining the consent of the interested states to the necessary changes in the existing state-system.

The consent of the interested states was obtained by the Concert by a process which may be described as the funding or generalization of interests or rights, accompanied by a correlative funding or generalization of power. Turkey would be injured by the creation of independent Greece, would refuse consent, oppose it, and have a right to oppose it, and, probably, would be able to oppose it successfully if the question were allowed to remain a Greco-Turkish question alone. But when it was asserted and recognized that the question of Greek independence, with all that it involved, interested all the Powers and affected their peace and safety and the public peace and justice of Europe generally, the way was open to take care of the problem so as to satisfy all interests and demands. Turkish consent could be obtained-that type of consent which emerges from a balancing of alternatives in all such situations-by bringing forward considerations which would set the Turkish loss in one direction off against gains in another direction, such as continued support from the Powers which would otherwise be lost. Turkish rights must be considered in conjunction with the rights of the Powers to act in defense of their own peace and safety. Turkish power to deny Greek demands must be weighed in conjunction with the power of the whole Concert. ${ }^{1}$

\footnotetext{
A ${ }^{1}$ The Greco-Turkish case is best discussed in Holland, 4-13. The consent
} 
So it is in all cases where a change in the status quo is involved. The case just discussed involved no danger to the existing states except Turkey, apart from the general danger of continued injustice and consequent unrest and war in the Balkans. If the change had involved an expansion of power for one state, such as would have been considered a threat to neighboring states, the same method of generalization of rights and power could be employed to take care of the situation. Thus, assuming that the Concert had been able to function properly in 1908 when Austria-Hungary annexed Bosnia and Herzegovina, what would have happened? The question would have been recognized to be one in which the rights and interests of all the Powers were involved and in whose settlement they therefore had a right to a voice. And if the annexation appeared to be dictated by sound principles of international political relations,-if, for example, it had been based upon the economic interests and the desires of the people of Bosnia and had been recognized and agreed to as such,the consequent expansion of power for Austria-Hungary would have worn a different aspect. Such an expansion with the consent and approval of the Concert would not be the menace which it would be in contrary circumstances. It is arbitrary, artificial, and forced expansions of power that disturb the natural distribution of forces in the statesystem and provide incitement and precedents for similar forced expansions in the future, that are dangerous to the peace and safety of other states. A great state based upon natural facts, not upon dynastic imperialism, composed of contented instead of rebellious peoples, is not a menace to its neighbors. Moreover, the Concert, functioning as such, would be ample enough and powerful enough to assimilate and take up into its complex constitution the expanded

of Turkey was obtained, ostensibly, in 1829 , by military action, war pleno jure, by Russia (Holland, 11); this action must be considered, however, in connection with the activities of France and Britain in conference with Russia.

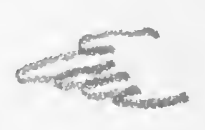


Austria. No such effect could be hoped for if the individual states, or even limited combinations of those states joined in the old type of alliances for mutual defense, were left to face the new Austria depending on their own strength alone. Finally, if the expansion were not dictated by sound principles the Concert would be in a position effectively to veto the expansion where individual states or limited alliances would not be-and in the actual conditions of Europe in 1908 were not-so able. ${ }^{1}$

The final form of international combination for preserving the equilibrium of power is, therefore, the general international concert; and the final form of the equilibrium itself is at the same time to be found in the generalization of power in this international concert.

It has been said that intervention was the method of control commonly employed by the Holy Alliance and that such action could only be justified on other grounds, such as defense of national rights and interests. In the later period, from 1825 to 1865 , there came a change on both of these points. The Concert did not commonly resort to intervention, but more frequently employed other methods of control. Similarly, there developed a general recognition of the claim of the Concert to act as a committee of public safety in Europe-a development which also explains, in part, the fact that the Concert did not, and did not need to, intervene by force as frequently as did the Alliance. At the same time the Concert developed methods of operation deserving attention in their own name.

The initial step taken by the Concert in all cases was discussion or conference, with or without the participation of the state or group involved in the question under examination. The next step was to intervene diplomatically and make recommendations in the premises. ${ }^{2}$

${ }^{1}$ For description of the Bosnian case as it actually worked itself out see Seymour, 179-182.

For a typical act of intervention and recommendation by the Concert see, below, Appendix A, Document No. 13. 
So far the Concert followed the Alliance in its methods. Like the Alliance, it might go on to support its diplomatic intervention by force of arms. This it did not need to do very frequently. But diplomatic intervention, whether or not carried out by force of arms, if successful, must produce certain results in the realm of politics and law, such as consent to a cession of territory, or the granting of certain rights to certain persons. The next step was to attempt to render these results permanent. For this purpose the Powers might resort to the device of the guarantee, embodied in a treaty of guarantee or in a clause in the treaty of settlement. ${ }^{1}$ Such a treaty defines the rights guaranteed,-for example, rights of jurisdiction, commer- $\checkmark$ cial or fishing rights, or dynastic rights and privileges, and the action to be taken for the protection of that guarantee. As in the case of ordinary alliances-for this, in fact, closely resembles an alliance-the execution of the guaranty bond is a delicate and often awkward matter. Much doubt may be raised regarding the obligations of the parties to act under the treaty, and to act singly or in concert; for guarantees may be unilateral or mutual, single or colTective, joint or several. Waiving such questions of application, however, the treaty of guarantee, as used by the Concert, and embodying as it does a clear right to intervene for its execution in the future, is very nearly the last word in the creation of international control. Indeed, one experienced student of international organization appears to consider it-rather extravagantly-the whole story of international government. ${ }^{2}$

If any criticism is to be made of the treaty of guarantee, it is that automatic action for enforcement is not obtainable, and that the enforcement of the guarantee depends upon the interest and willingness of the guarantors to act

${ }^{1}$ On treaties of guarantee see Milovanovitch, entire. For example see, below, Appendix A, Document No. 14.

Sayre, as cited, Chap. I. 
when the time comes, and not upon any broader basis, such as action by all states. For this reason more definite results may be obtained where it is possible to create by an executed agreement a status which then remains fixed as recognized by all the world. The merit of such a step is that an air of accomplished fact is given to the situation and all the world is made party to the settlement. This is peculiarly true where all states derive certain benefits from the status created.

Among the varieties of status which may be created and guaranteed are, first, territorial possessions and independence. Such a guarantee extends only to existing possessions and the existing degree of independence and does not cover new additions of territory or new rights subsequently acquired. It need not prevent voluntary changes in the existing status. It involves an approval of that status, and, indirectly, it implies a ruling upon the proper bases of territorial jurisdiction in general; and it depends for its success in the end upon the justice of the status guaranteed. Yet even a supremely just status needs recognition and support against isolated parties who may oppose it; territory and independence may need defensive action for their protection in the future, for they may be attacked by outside parties, or even by one of the guarantors themselves. If carried to its logical extreme and applied generally, this method would lead to nothing more-and nothing less-than coöperation by all states for mutual defense, a general international guarantee of existing possessions and independence against violent attack.

Where the status created is of a different type, different, and more beneficial, results may be expected. Thus the status of territorial neutrality, which is usually created mainly for the purpose of protecting certain states from attack, may be calculated to enlist at least the defensive efforts of those states. Neutralization as applied to strategic areas, such as Switzerland and Belgium, is a form of 
stabilization which rests upon the real necessities of certain imperiled nations and will enlist their support for its defense. ${ }^{1}$

The most advanced type of status to be guaranteed by the nations,-most advanced because most directly useful and most effective and secure,--is internationalization, or the opening of territory or of certain rights to the use of all nations. Thus the high seas, after being claimed in whole or part by various nations for centuries, are internationalized by common international law and practice, as are the principal international straits. International rivers are being increasingly placed in the same condition by treaty agreements; ${ }^{2}$ the same is true for such canals as those at Kiel, Suez, and Panama. The public maritime highways of the world are thus made a symbol of public international authority. ${ }^{3}$

Similarly, colonial territories are being placed in a condition where all states may enjoy equal opportunities therein for investment and trade. The mandate system established in connection with the League of Nations is a notable embodiment of this idea of the open door and equal opportunity. How this attempt will work out in the future remains to be seen. But, whether or not it is successful as an application of the principle, it constitutes another effort to establish international control in the field of otherwise free international competitive struggle. In all parts of the world to which this treatment is applied the door is declared open and national monopoly forbidden. In these cases, moreover, the parties benefited by the arrangement are so increasingly numerous, and the benefit is so real,

${ }^{1}$ On status in general, and neutralization in particular, see Wicker, entire, especially 70-72; for example of neutralization see, below, Appendix A, Document No. 5.

'See, for example, Chamberlain, Danube, cited below, Appendix B, § 25.

- On freedom of international waterways see Hall, $\S \S 39-42$, and, more generally, Duggan, Chaps. XII and XIV (Chamberlain and Gettell) and references. 
that a violation or overturn of the status created is less and less likely. ${ }^{1}$

It should be noted, in passing, that in the end neutralization and internationalization come to be one and the same thing. Guaranteed neutrality usually involves a surrender of certain rights of offensive and defensive military action by the guaranteed state and an acceptance of protection from the guarantors, that is, a subjection of that state to a more or less limited international control. Moreover, perfect neutralization is obtained only when all states join in the action; and this is, in effect, internationalization. Where the process of neutralization is applied to uninhabited territories, or to bodies of water, it amounts to opening these areas to free international use, which, again, is internationalization. It may also be mentioned that it has been found useful to neutralize certain territories in the process of bringing them under the control of international administration. ${ }^{2}$ The destruction or removal of unilateral national rights over a territory or a water area is almost certain to result in the substitution of affirmative international jurisdiction over it; and as international coöperation develops further and further this type of action will probably be resorted to with increasing frequency.

In the fifty years prior to 1914 the international concert was, in spite of the increasing employment of all these devices, largely ineffective. The agencies of conference and intervention, guarantee, neutralization, and internationalization, were of little use in preserving public order and justice in the world. On one hand, there developed an increasing interest in, and knowledge of, international affairs,

${ }^{1}$ On freedom of access-and the extent to which it exists-see Duggan, Chap. XI (Borchard), and references; for origin of the mandate system and its relation to the open door see Biship, I, 490, 496, 499, and for mandate system in general see Covenant, Art. XXII (below, Appendix A, Document No. 15) and Levermore (texts) 59-69.

'As in the case of the Cape Spartel lighthouse; Sayre, 48. 
and an increasing inclination to accept and promote some form of international concert and control. While the traditional opposition to any general right of intervention, based upon the doctrine of state independence, was maintained, the idea of the responsibility and authority of the leading powers for the peace and order of the world grew stronger and stronger. On the other hand, certain forces came into operation which more than equaled this development and nullified its effects. It remains to examine what, in general, were the forces which defied the best efforts of the Concert and all its agencies of international control.

At the center of the resistance was the simple and familiar force of nationalism which has been encountered so frequently in the course of this study, both as a friend and a foe of international organization. National consciousness and the nationalist spirit are still so strong among the newer states, the experience of independence is still so novel for some nations, that there is often little patience with ideas of the common international welfare, or even with notions of permanent if indirect national benefit as against immediate if temporary advantage; and hence there is little desire for international organization. Contrary to common impressions, it is in the smaller and newer states that nationalism is found in its worst forms. A secure and satisfied nationalism is a stable factor in international relations and a good basis for international cooperation, but an insecure and still sensitive nationalism is not.

The excesses of the nationalistic spirit have led to a reaction against it in the minds of many students of world affairs in recent years. That reaction has already been discussed as it has leaned toward cosmopolitanism. ${ }^{1}$ They have led also to a supersophistical reaction toward empire as a means of bringing peace and order in a too, too nationalistic world. This reaction likewise has been

${ }^{1}$ Above, Chap. I. 
noted. ${ }^{1}$ During the years prior to 1914 both of these reactions found vigorous expression. Suddenly, with the breaking of the spell which had rested upon Europe since 1870 , the force of nationalism burst forth again-with all of its objectionable features present, it is true, but also with all its promise of stability later. In one sense it was the pressure of these nationalities demanding liberation from imperial oppression that gave its tone to the period preceding 1914. The pathos of the situation lies in the fact that the great breakdown came largely because of the necessity for that liberation of suppressed nations which by itself would have made such a breakdown unnecessary if it had been achieved earlier. ${ }^{2}$

The operation of the force of nationalism in bringing on the catastrophe of 1914 was indirect. The war did not come as a direct result of rebellion in Poland or Bohemia or Ireland. It came directly as a result of German imperialism. Yet the latter, in its Prussian and Austrian embodiments, was, on one hand, the product of an earlier nationalistic development and, on the other, was merely given its current form by those in a position to profit from a use of its power in conflict with newer nationalist move-

$\checkmark$ ments which they, in turn, sought to stifle. Germanic nationalism had become nationalistic imperialism. ${ }^{3}$ The monarchs of Berlin and Vienna were attempting to use nationalism for imperialistic objects, as had Napoleon a century before. Ironical and paradoxical as it may seem, empire was to be built upon the foundation of nationalism. Closely allied to this development was the movement of commercial imperialism which bulked so large in the same generation. Commercial imperialism may, of course, be discovered in the colonizing movement of the seventeenth century. But with the increase of population at home, the

${ }^{1}$ Above, Chap. I.

${ }^{2} \mathrm{On}$ nationalism as a cause of the War see Toynbee, entire, especially $1-20,476-500$.

' On national imperialism in Germany see Lair, entire. 


\section{HOLY ALLIANCE AND CONCERT OF EUROPE 435}

improvement of means of transportation, and the development of the machine processes of manufacture, the demand upon the newer territories of the earth for food, raw materials, and markets became so overmastering as to lead to a great wave of commercial imperialism in the years after 1878, such as is best exemplified in the partition of Africa. ${ }^{1}$ An attempt was made at the Berlin Conference in 1884-85 to apply to this movement the methods of concert, and more success was attained than might have been expected,-more, also, than could have been hoped for ten or twenty years later. ${ }^{2}$ Yet the best that can be said is that the precarious balance was preserved by a process of partition without much reference to anything but financial profits and national power. The fundamental forces at the bottom of things were left untouched.

Such empire is better, of course, than empire over advanced peoples. It is even possible to talk with sincerity of carrying civilization to the natives, and to arouse the noblest as well as the lowest minds in the cause. Even the laboring class will respond to the idea of coloring further sections of the map red or white or blue, and popular support may readily be secured for a war to carry democratic liberties and the benefits of progress to oppressed and backward peoples. Something of this motive entered into the American war with Spain. A sort of popular or democratic imperialism may be developed, working upon the basis of the democracy of the Revolution, even as nationalistic imperialism utilizes Revolutionary nationalism as its motive power. ${ }^{3}$

Rising still higher in the scale, nationalism turns into pan-nationalism,-pan-Slavism, pan-Germanism and so on. ${ }^{4}$ Such movements vary from pan-Germanism, with its ad-

1 On the partition of Africa see Gibbons, entire, especially maps at 32,64 .

'Same, 27-33.

"On "democratic imperialism" see Seillière, entire.

'Leger, L.P.M., "Le Panslavisme." Andler, C. (transl. by J. \$.), "PanGermanism.', 
mixture of commercialism, militarism, and dynastic imperialism, to Anglo-Saxonism, with its reliance upon sentiment and voluntary cooperation for mutual assistance. ${ }^{1}$ Yet all alike, in one degree or another, presented difficulties and obstacles to the Concert and have retarded international organization in general. They may offer quicker and more certain returns in the way of international cooperation for those nations and peoples participating in them, but in the end they tend to obstruct general international friendship and coöperation.

No mention has here been made of certain types of state expansion which have grown up along with these principal movements of nationalistic and commercial imperialism, such as the protectorate, the suzerainty, and the sphere of influence; the Monroe Doctrine, and the Japanese policy in the Far East. ${ }^{2}$ All such activities have tended in the past to prevent free international coöperation. Concrete evidence of this is found in the fact that it was felt to be necessary to recognize the Monroe Doctrine, the basis of the mildest of these movements, as an exception to the full application of the Covenant of the League of Nations. ${ }^{3}$ In reviewing the agencies of, and the obstacles to, international organization and international coöperation as they have developed in the past half-century, such devices must be placed in the same class with territorial conquests and imperial domination generally. The Monroe Doctrine escapes from this class in so far as it is merely the proclamation of a policy on the part of the United States to prevent conquest or intervention in Latin America. In so far as it amounts to a claim to a general sphere of interest. in those regions, it is on a par with Japanese hegemony in China or British domination in Southern Asia as a hin-

'Kennedy, S., “The Pan-Angles."

- On protectorates and spheres of influence see Engelhardt, entire; on the Monroe Doctrine, Hart, entire.

- Covenant, Art. XXI, and Duggan, 301-303 (Kimball), and references. 


\section{HOLY ALLIANCE AND CONCERT OF EUROPE 437}

drance to full and free international coöperation. Even so, we may prefer to maintain the Doctrine and let the world and world harmony go by the board. Let us, however, face the problem squarely and settle it with open eyes.

We have now reviewed the nature and development of international alliances and concerts since early modern times, and their more or less ineffective efforts to provide a system of international control. These efforts inevitably suggest the creation of a formal international league or federation, and to that subject we now turn. 


\section{A $x$ EN Moxls Ion't needed \\ a ner I wil Sact to secure Fourtace
onder
Safety}

\section{CHAPTER XXVI}

\section{PROJECTS FOR INTERNATIONAL FEDERATION}

THE repeated proposal of projects for international 1 federation since the dawn of modern times furnishes evidence of a general and persistent conviction that a more comprehensive scheme of international government is needed. The multiplication of such proposals in the nineteenth century and in the opening years of the present century indicates an intensification of that conviction. It is worth while to make an analysis, at this point, of the foundations of that belief and of the purposes of those bringing forward various schemes for international federation. ${ }^{1}$

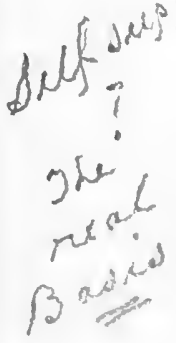

The basic idea underlying all such plans is the simple and elementary truth that the nation is not, as such, a selfsufficient unit, and that there is a constant and general need for international coöperation in all phases of world affairs. That idea is so simple and so commonplace that it is usually passed over in silence. It deserves, however, to be put in the very forefront of any discussion of the problem of international federation.

More specifically, the cause which has led to the elaboration of various schemes for international federation is the insufficiency of the existing system of international government. Even if the need for coöperation among the nations be granted, there would be no occasion for devising and publishing a plan for world federation if the historically existent set of institutions and practices were not

${ }^{1}$ On projects for international federation see literature cited, below, Appendix B, §26. 
inadequate to the needs of the case. The system of international cooperation in the past has been too loose, too disjointed; the world has remained unorganized too long and too widely. The alliances of the sixteenth, seventeenth, and eighteenth centuries, and the system of the balance of power of which they were the embodiment; the Holy Alliance, the Concert of Europe, and even the coöperation of the nations for arbitral and administrative purposes, have been judged and found wanting. By their meager fruits it is known that they have not, and, by their nature it is seen that they cannot, possess the power to provide a wholly satisfactory world government. The alliances of earlier days and the principle of the balance of power did not prevent international relations from breaking down in repeated wars, and they did not provide that state of justice, order, and safety which the world needed. The Holy Alliance constituted a certain slight advance in the right direction, and the Concert of Europe embodied the essential principle which must be acted on if any results are to be had and for some years gave that principle adequate expression in a few rather narrow cases. And the latter part of the past century saw the development of certain organs of government of still greater import. When the situation between Austria and Serbia developed as it did in 1914, however, these steps did not suffice. The critical test of those days in July and August brought out clearly the fact that the existing system of international government was defective and incapable of conducting international relations past such a storm. It is true that the main obstacle to a just and peaceful settlement in 1914, namely, the determination of the Prussian diplomatic and military chiefs to make a bid for imperial conquests, was such that it may appear unduly exacting to demand a system of international control capable of taking care of such a crisis. And yet, after all, the situation does not appear to have been utterly impossible. A solution or a 
method of securing a solution was very nearly obtained at one stage of the crisis. ${ }^{1}$ And the important point is that, whether or not a solution could have been obtained in that crisis or in any similar crisis, in the face of a will to conquest such as that manifested by the Prussian diplomatic and military group, the best and, indeed, the only practicable method for obtaining that solution was not available. The existing scheme of international government was deficient at the most vital point in that it neither provided in advance for any international conference to take up such a conflict as that which arose between Austria and Serbia, nor offered any sure method of obtaining such a conference. The solution was left to depend completely upon the possibility of securing the consent of the parties to the dispute to an international conference on the question after the dispute had arisen and when the atmosphere was of precisely that character to leave the parties least inclined to compromise and conciliation. The proposals for international federation which appeared in 1915 and 1916 reflect this revelation of a condition of international anarchy.

On the other hand, the serious student of the problem of world government realizes that this condition of anarchy can be cured only by taking into consideration the conditions which have produced it. The simplest solution which might suggest itself is the concept of the world state. Yet, except in so far as the proposed world state should be organized in a federal form, such a plan would be fantastic. The nations are too new, too young, too vigorous, people are too firmly attached to their national states to be willing to see them swallowed up in a unified world state. If nationalism is so powerful as to present an obstacle to the simpler forms of international coöperation, how much more of an obstacle does it present, not only to cosmopolitanism, as has been seen, but, a fortiori, to the establishment of a unified and centralized world state! Federation

${ }^{1}$ Seymour, 264-270. 


\section{PROJECTS FOR INTERNATIONAL FEDERATION 441}

is the only practicable form of world political organization. Even that may not be practicable. Certain it is that nothing higher in the scale of state forms would be practicable. Mr. Wells is impatient with a world organization which retains as its foundation the national state-system. ${ }^{1}$ Such a position, it must be said, with all due respect, is sheer nonsense, in so far as it is sincere. To scorn international federation and cry after a unified world state is to deny support to an attainable improvement over the present anarchy, and waste it upon an unattainable ideal.

This, then, is the case for international federation: the nation is insufficient by itself and some system of international coöperation is needed; the previously existing system of international government is inadequate to the needs of the case; a unified world state is impossible. The conclusion is obvious. Yeferation?

Moreover, we have the benefit of much actual historical experience in the practice of international federation. It is possible to review the record of international federation in the past and learn therefrom not only its practicality but its essential prerequisites, its weaknesses and its potentialities for service, and this by itself is a great advantage for this form of political organization. ${ }^{2}$ To such a review we now turn, beginning with Greek experiments in this direction.

As far back as the early part of the fifth century B.C. the Delian Confederacy in Greece, under Athenian leadership, achieved a large measure of success in the field to which it confined its activities. ${ }^{3}$ The succeeding centuries down to the Christian era were filled with activities of a similar character. The Peloponnesian League, the Bœotian League, and the Athenian Confederacy, in turn, played their part in interstate organization among the Greeks in

${ }^{1}$ Salvaging of Civilization, Chap. I.

2 On history of federation see literature cited, below, Appendix B, § 26.

Fowler, 285-286; Greenidge, 189-190; Hart, 30; Phillipson, II, 13-17. 
the period before the Macedonian invasion, ${ }^{1}$ and lasted until the invader arbitrarily dissolved such federal unions as then existed. ${ }^{2}$ After the breakdown of Macedonian control in the third century B.C. the movement was resumed. The Atolian and Achran leagues succeeded the earlier efforts at interstate federation, and the latter reached such a point of development that it remained until the end of the Medieval period the highest form of political organization known in the history of Europe. ${ }^{3}$ A federal foreign policy was evolved by this League, a federal military organization was created, and a federal executive and administrative system, including a federal budget, was instituted. A common scale of weights and measures was adopted and likewise a common currency. There were present also the elements of a federal judiciary.

After the final invasion and conquest of Greece by Rome in 146 B.C. interstate federation suffered a long eclipse. Apart from the feudal system, with its many interstate ties, legal and political, which resembled federalism only very indirectly, we must turn to the modern world for the next period of federal experimentation and federal government. The Swiss Confederation arose in Medieval times, but did not attain great power or prestige until well into the modern period. The Italian leagues of the fourteenth and fifteenth centuries were comparatively petty things. For these reasons, and for other reasons not important enough to be recited here, it is better to turn to the eighteenth century and the experiment begun in Philadelphia in 1774,1781 , and 1789 for the rise of modern federalism.

Since the beginning of the American adventure the spread of federalism has been rapid. Switzerland has developed her federal system since the Napoleonic period. ${ }^{4}$

${ }^{1}$ Fowler, 290-292; Greenidge, 204-207; Phillipson, II, 19-24.

Fowler, 302.

Same, 302-305; Hart, 31-32; Phillipson, II, 26-28.

- Ogg, 559-563. 
Germany found the federal form useful in 1815, again in 1871, and continued under that form when a new constitution was framed in 1919. ${ }^{1}$ In Australia, in South Africa, and in Canada the federal form has proved of great service. ${ }^{2}$ Several Latin American nations are federations of otherwise independent states. ${ }^{3}$ Within the past year the Central American states have attempted to recreate their sorely tried federal union. ${ }^{4}$ Finally, the development of colonial empires has led to the elaboration of systems of state organization which are federal in everything but name. This is especially true where the metropolitan state is itself organized in the federal form, as in the case of the United States and her colonies.

The United States of America still remains the greatest experiment in international or, to be very strict in terminology, interstate federation. Previously independent colonies, later states, combined gradually in 1774, in 1781, and finally in 1789 , first to coöperate without any formal union, then to create and operate a confederacy, and then to create and operate a federal union. Now forty-eight states maintain this union and enjoy the dual advantages to be derived from that form of organization. The legislature, the executive system, and the judiciary all reflect in their composition, their powers, and their procedure, the federal character of the nation. Interstate disputes are settled by a supreme tribunal according to the constitutional law of the union if possible, and according to common international law if need be. The United States thus presents the greatest example of interstate federation in history. ${ }^{5}$

It is commonly objected, when the example of the United

${ }^{1}$ Ogg, 610, 619, 723.

Egerton, entire; for constitutional documents see collection made by the writer in Carnegie Endowment, Division of International Law, Pamphlet No.33.

${ }^{3}$ Macy and Gannaway, Chap. LIX, Rowe, entire.

- New York Times, 11 October, 1921, p. 20. zation.

Scott, The United States of Ameriea: 4 Study in International Organi. 
States is cited in this connection, that we are not here dealing with national differences reconciled by international federation but with something a great deal simpler. That is true in some comparisons; New York and Pennsylvania differed less in 1774, 1781, and 1789, and they differ less today, than do Germany and China. It is untrue in others; Rhode Island and Mississippi, Delaware and Wyoming, differ more than do France and Spain, France and Belgium, not to mention Colombia and Venezuela. Moreover, the important thing at this point is not to decide by the facts upon the feasibility of international federation but to examine the theory of federalism and define the standards to be applied in deciding upon the facts. It is especially useful in this day when international federation is beng proposed right and left to have a clear idea of the circumstances under which federation is proper and desirable. ${ }^{1}$

The most elementary antecedent condition of affairs for such a step is found, of course, where several independent states exist side by side. The question then arises whether or not a federal union shall be created. This question is to be answered in the affirmative only where the mass of interests common to all the states is so great as to demand common organs of government to take care of them. Particular interests must remain in the hands of the local states. The burden of proof is upon anyone proposing federal union, an obligation to show that a central government is needed in addition to the local governments, a central government beyond any coöperative efforts which may be made by concurrent state action, by alliances, or by any form of association short of federal government.

There are no objective mechanical means of measuring this mass of common interest. It is possible for the student to compute the amount of commerce which goes on among the states of the group in question, to record the amount of interstate travel and communication in existence among ${ }^{1}$ On the theory of federation see literature cited, below, Appendix B, § 26. 


\section{PROJECTS FOR INTERNATIONAL FEDERATION 445}

them, and to picture the degree to which a cosmopolitan or interstate life has developed. When that is done some light will, indeed, have been thrown upon the advisability of creating a federal union. The final decision, however, depends upon the judgment of advantage and disadvantage in the minds of those who live in the various states. After all, it is impossible to anticipate exactly the net result of convenience and inconvenience which will flow from creating or failing to create a federal union. Those who are to live under the union must decide, more or less at a venture, as to its probable utility.

Not uncommonly, the decision is made in a fashion far less precise than this. Where a condition of cosmopolitanism has begun to develop among the members of a group of states the simpler forms of interstate association-diplomacy, treaty practice, alliances-will already have made their appearance. The question then presents itself in a familiar form, namely, whether or not the loose forms of association existing shall be converted into a federal union. More frequently still the degree of association increases imperceptibly until federation is reached unconsciously.

The problem then becomes a purely scientific one, namely, to discover whether or not federalism has actually made its appearance. To a certain extent this is wholly a problem of terminology, but it is of a degree of importance not usual in problems of terminology. After all, federalism is the decisive first stage in the organization of a single state and deserves to be marked out carefully as it occurs.

The most useful test which can be employed to discover the existence of a federal union-most useful partially because of its ease of application-is the test of established organs of government. Where there is no established common organ of government there is no federal union of any degree, as in the case of the alliance. Where there is a common organ of government, no matter how limited its power, there exists a federal union for the purposes defined 
by the powers entrusted to the common governmental body. Thus the international administrative union exercising governmental power appears to be a federal state to the extent of the substantive jurisdiction entrusted to its care.

A second test, which serves to mark the passage from a simpler form of federation to federation proper, from confederation to federation itself, is the test of the incidence and source of governmental power. If the authority of the established organ of government falls only upon the states which are members of the union in their official capacity the union has not passed far from the level of the alliance. When the common organs of government operate directly upon the individual members of the states of the union without action by the individual states as such, the last stage of federal development has been reached. So long as the states remain in existence and the authority of the central government rests upon their consent-as revealed by the character of the process in force for amending the federal constitution-the federal character of the union remains. If the central government should, in addition to exercising its power directly upon the people of the union as a whole, draw its power directly from the people of the entire union, irrespective of state lines, the federal character of the union gives way to that of the unified state.

The reassuring thing about all this is that the steps described are all optional, in so far as any steps in human life are optional. All powers enjoyed by a federal government are delegated to it from the members of the union. That is not accidental, nor is it peculiar to one federal system or another. It is necessarily true in the nature of the case. In the beginning there is no central government. It must be created and it must be endowed with life and power. Hence the expansion and intensification of its powers are dependent upon action, upon tacit acquiescence at the very least, by the members of the union. Even if the members should at once by constitutional grant confer 
upon the central government all power in so many words, such a step would still remain an action of delegation and therefore subject to revision or revocation.

Once a federal union has been created by constitutional action, these questions of revision and revocation, of constitutional amendment and withdrawal from membership, become the most critical phases of the problem. The degree of permanence of the union depends, apparently, on a denial of the right of withdrawal. So long as a right of withdrawal upon notice is allowed, the life of the union is potentially limited to the extent of the notice period. The powers enjoyed by the central government are potentially subject to destruction by the action of constitutional revision. A permanent and firmly established federal union should have, apparently, a constitution not subject to amendment and a membership not subject to diminution by withdrawal.

A little reflection, however, will serve to qualify those conclusions. It is, it must be admitted, of great importance in the creation of a federal union to have the processes of constitutional change and of withdrawal clearly defined and not left to interpretation and implication. The United States suffered her greatest misfortune largely through the failure of the fathers to take up and settle explicitly in the text of her fundamental law the vital question of secession. The right should be definitely denied or affirmed and the conditions under which it may be exercised should be explicitly stated. This is very far from saying that, in the interests of permanence, such a right should be denied. To deny such a right is to risk the appearance of converting the federal government from servant into master, as far as the individual state is concerned, albeit a master voluntarily accepted in the first instance. To deny the possibility of constitutional revision appears to convert the government from servant into master for all the members of the union. This may not be wholly disastrous, if the original 
action in creating the federal union and in defining the nature of the government was supremely wise. But it imposes upon the federal state and government the burden of not only the current difficulties of state practice at any one time but the cumulative difficulties of all time, seeing that it is impossible to cure a fault when once that fault arises or escape from its consequences. Besides, where withdrawal is impossible, where even revision in coöperation with other member states is impossible, it is rather hazardous to rely upon the original act of consent as evidence of the voluntary character of the union. The states of the union in such case appear to become not much more than provinces in a state whose power they cannot escape.

Beyond these fundamental problems of structure, however, rise the more practical questions of governmental action from day to day, the question of the distribution of powers. Assuming that the member states retain their discretion in granting or withholding powers from the federal government, the problem of sovereignty is amply cared for. But the various questions of utility and convenience which demand settlement are not to be avoided in any way.

The principle to be followed is as simple as its application is difficult. Such powers are to be given to the central government as will enable it to care for those interests which led originally to the formation of the union. Such matters as the regulation of interstate commerce will thus naturally go to the central government. The remaining subjects-those which do not affirmatively call for regulation from the center-naturally remain where they were in the first place.

It is easy to render this problem of distribution difficult by assuming that it is necessary or desirable to traverse the whole field of governmental power and to decide deliberately in advance upon each item of power, as to whether it should go to the central government or to the states. In 
practice this is not what happens, nor is it necessary or natural. What does happen is that certain powers or subjects cry aloud for transfer to the central jurisdiction, others suggest such a transfer, but merit further study, while still others are by tacit consent allowed to remain within the local jurisdiction. As in the original delegation of power in the abstract, so in the definition of jurisdiction in the concrete, the burden of argument is on him who suggests that a certain power be conferred upon the central government.

That burden will be heavy or light, as the circumstances of the case change with time. The advisability of conferring a given power on the central government changes from decade to decade. In a sense, this development through history is the sum and substance of the problem of the distribution of powers. There seems to be a general tendency, as time passes, - as population increases in each state and in the union, as communication becomes more active and extensive,-for more items of government and power to deserve to be transferred to the central government. The process of centralization seems to be general, continuous, and persistent. History records no example of a federal union in which this process has not manifested itself, or of a given power once entrusted, on reasonable grounds, to the central government which has been returned to the local government.

As may easily be imagined, the definition of jurisdiction cannot be so clear that disputes over jurisdiction between the central government and the local govermments will not arise. Hence the urgent necessity of providing some institution or some method for settling such disputes. In view of the fact that, as time passes, the central government is led constantly to aggrandize itself at the expense of the local governments, this is especially necessary. A court of some sort to decide upon conflicts of authority is mdispensable unless disputes regarding jurisdiction are

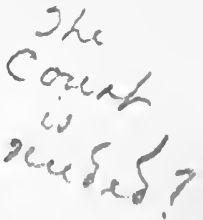


to be threshed out in the field of usage and practice at the risk of great excitement and violent disturbances.

Granted that the federal system is created on due cause, that the power conferred upon the central government is of the proper amount, and that the problems of revision, of withdrawal, and of conflicts are duly cared for, federalism is, considered as a mechanical device, the highest form of state organization. It is more flexible than a unitary form of organization, and it offers the means of greater power than is possible in a unitary state, unless the latter is to become so huge as to become unmanageable. The federal system reconciles local variety and general uniformity. It harmonizes central government and local individuality, power and freedom, unity and multiplicity. It provides the means of marshaling the powers of many states without imperial conquest. It performs in the sphere of interstate relations the great synthesis of authority and liberty which is the heart of the problem of government.

This is not to deny that difficulties are involved. Federalism is a complicated and delicate political form, where it is not positively cumbersome and awkward. A federal state moves slowly and may be disconcerted where a unitary state would be confident. The larger the federation the greater these difficulties. In a competition of wits and strength the unitary state may easily have the best of it at the start and in all the tight places.

This implies, of course, that the unitary state would be more effective as a state, and, judging by absolute standards, this must be admitted at once. The unitary state, where it is feasible, the unitary state in its proper place, is more effective than the federal union. The important thing for us is that international conditions are not ripe for the unitary state. We thus come back to the original proposition. If all variety and local feeling were to vanish, the centralized or unitary state would be in perfect place. With things as they are, it is not only impossible but highly 
(1)

undesirable. Federalism is the only available form of political organization for the world state in our day.

It is not surprising, therefore, that students who have attempted to devise plans for world government in the past have generally adopted the federal form on which to build their plans. Since the thirteenth century, at least, various schemes have been brought forward for leagues and associations of nations, in more or less conscious emulation of the leagues of classical Greece. These schemes may now be briefly examined.

It would be worse than useless, however, to review here the details of the plans of Podiébrad, Crucé, Franklin, Ladd, and others. ${ }^{1}$ In their details these various plans betray the idiosyncrasies of their authors and are based on generous but impractical hopes rather than sound statesmanship and they are deceptive in what they imply regarding the conditions of the problem. Moreover, no single plan is of decisive importance, inasmuch as no one of these various plans has ever been adopted as such by the states. The chief value which these schemes have today for the student of international organization is the light which they shed, in their main outlines, upon the development of the idea of world government since the Renaissance. ${ }^{2}$

These plans have commonly been based upon one or more of four rather distinct foundations, namely, selfish national advantage, historical development in international relations, previous plans of the same sort, and abstract justice. These foundation principles may best be examined in the reverse of the order as named.

Every would-be architect of world government naturally professes to aim at justice and, through justice, peace; and in a large measure every reformer who has suggested a plan for international federation really has tried to serve these

${ }^{1}$ On classic projects see literature cited, below, Appendix B, $\S 26$, especially York, entire.

2 Ter Meulen, entire. 
ends. However, when the ends of justice and peace are c sought directly the result is likely to bo unfortunate. The ideal of peace by itself induces on the part of its possessor a quietism and a willingness to accept almost any settlement for the sake of peace. The ideal of justice, on the other hand, taken by itself, leads to a meddlesome dissatisfaction with all things as they are, which is as bad on its side as is quietism on the other. In the end, plans which attempt to serve these abstract ideals directly are incoherent and unstable.

The simplest method which can be adopted for the correction of such errors is the comparison of plans which other students have worked out in previous ages. In recent years a great deal has been done in collecting, analyzing and collating the classic projects for international federation worked out in the past. A most valuable form of such activity is found in the practice of scrutinizing the plans for international courts and conferences which have previously been proposed or adopted when the occasion arises for creating a new court or conference. Thus, the creation of the Hague Court of Arbitration in 1899 and the revision of the plan in 1907 were both based upon a study of prior courts of arbitration and the working of such courts, including the Hague Court itself between 1899 and 1907,' and both Great Britain and the United States, in preparing for the Peace Conference of 1919 collected much data on international negotiation, administration, and conference in the past. ${ }^{2}$

The action last described carries us over into the second method of drawing up such plans, namely, building the new edifice of international government not upon paper plans, but upon the actual historical development of international federation in the past. Such a method might seem to pro-

${ }^{1}$ Scott, Conferences, I, Chap. VI.

'Such were Chamberlain, Danube; Hershey, Diplomatic Agents; Munro, Berlin Congress; Satow, Conferences; as cited, below, Appendix B, $\S \S 8,20,25$. 
vide no first step in the process, and to make success depend upon something having already been done in the desired direction. When it is recalled, however, that international federation must grow out of spontaneous international coöperation of a simpler sort, this limitation becomes less important, a source of strength, not weakness, and in this late day the objection to confining the process of drafting an international constitution to the reorganization and improvement of institutions which have proved valuable in the past is slight. The results have such a high degree of reliability, in comparison with schemes not based on actual experience, that this method is the only one to be preferred. The development of the Commission of Inquiry in 1899 and 1907 is a cardinal example of this sort of activity. ${ }^{1}$ The best of the private plans which have been put forward in the past, as that of St. Pierre, have, likewise, taken careful account of actual historical development.

To connect the proposed plan too closely with actual political life, however, is to fall again into error. Several plans for international federation proposed in the past have amounted to not much more than schemes for the aggrandizement of the power and prestige of the nation in which they have originated. Such was the-not improperly named - Great Design attributed to Henry IV. It is, of course, not to be assumed that a given plan for international federation is necessarily bad because it peculiarly satisfies the interests of a given nation. No nation will accept such a plan unless it does serve the national interest. The only requirement which can be made is that the national interest which is served shall be a non-competitive interest, one which can be satisfied without injury to other states. But when a plan for international organization is put forth directly with the calculation that it will serve the national interest, the probabilities are that the plan will not

${ }^{1}$ Scott, Conferences, I, 265-273. 
be of great value from the point of view of other states and of the common international welfare.

Beyond the nature of the motives for its formulation, however, the value of any plan for international federation depends also upon the exact provisions which are written into the proposed international constitution. These will presumably reflect one or more of the different foundations upon which the plan may be based. But, after all, it is in the text of the plan that the decisive virtue lies. Here also the projects put forward in the past have varied considerably.

The earlier projects were very simple and highly unified. Later plans have been more compreh mnsive and more analytical. Recent proposals cover, as any feasible proposal must cover, institutions for the making of law, for its administration, and for its interpretation in case of doubt. Conferences, commissions, and courts are essential in any international government. Earlier projects not only contained no separate provisions for such bodies, but ignored the distinction between the different varieties of work to be done by a world government. With the growing understanding of the process of government in general since the seventeenth century plans for international government have similarly improved in quality.

There is still some temptation to visualize world government in terms of some particular form of institutional organization. Thus, a few years ago arbitration or judicial settlement seemed to be the sum and substance of international reform and an international court the equivalent of international government." At another time "the world in alliance" or an international police was regarded as the essence of international coöperation. ${ }^{2}$ In recent years international administrative unions and bureaus were taken

1 Jones, R. L., International Arbitration as a Substitute for War.

'Keen, F. N., The World in Alliance, A Plan for Preventing Future Wars; Nijhoff, War Obviated by an International Police. 
as international governing bodies par excellence. ${ }^{1}$ Later, international conference seemed to be most important. ${ }^{2}$ It cannot be too strongly affirmed that any adequate international association must include organs of all types, constituent and legislative, administrative, and judicial. The most recent projects for international federation respond favorably to this test. ${ }^{3}$

Finally, all recent plans have recognized the need for control in operation and for adaptation as times and circumstances change. Earlier plans pretended to be panaceas to be adopted by the world intact and left as originally framed. In some cases the precious scheme was to be imposed upon the world by autocrats and maintained in place by their authority. Modern plans do not pretend to be infallible and are subject to amendment. They are, in the first place, to be adopted by voluntary action by the states of the world. They are, further, to be operated by responsible officials ; their virtue is to depend on such operation rather than upon any magic quality of the scheme as adopted; and they are to be open to constant revision. ${ }^{4}$

Needless to say, this last view is of great importance. Combined with the other changes in approach just deseribed it has brought the proposal for international federation out of the realms of religion and speculative theory into practical politics. International federation is to be built up gradually, on the basis of what has gone before, to meet the actual needs of this cosmopolitan world, by the voluntary coöperation of the states in the paths of conference, administration, and arbitration, subject always to revision and control as the times require. Such was the approach to the League of Nations as organized in 1919.

1 Reinsch, 186.

${ }^{2}$ Goldsmith, Chaps. IX, X.

Minor reveals the spread of this conviction, ix-xxxiii; also Woolf, 371. 410 , especially $371-375$.

Minor, Chap. XVII.

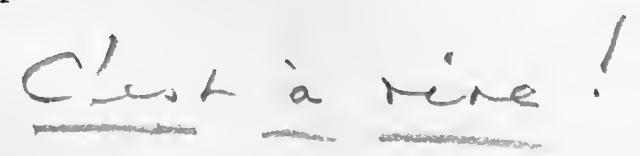




\section{CHAPTER XXVII \\ THE LEAGUE OF NATIONS, 1919}

THE nature of the action taken at the Peace Conference 1 of Paris in 1919 for the creation of a League of Nations was determined by several divergent, if not conflicting, national aims. As has been pointed out, such projects commonly reflect either an idealistic desire for abstract justice, an effort to obtain national advantages under a cloak of international reform, or more general historical development among the family of nations at large. The League of Nations was no exception to this rule. President Wilson and General Smuts, while defending the interests of the United States and South Africa, especially their interests in the maintenance of world peace, were also, and for this very reason, engaged in serving certain general ideals of international coöperation laudable in themselves. Clemenceau, in so far as he supported the program of a League at all, did so to secure protection for France. And beyond these motives and the suggestion of conflict between them lay a more comprehensive aim, shared by all the belligerents, namely, to supplant the inadequate machinery for regulating international relations which had failed in 1914 with a world government capable of insuring that such a thing should not happen again. It was the failure of the Concert of Europe in 1914 that created a demand for the creation of a League of Nations in 1919.

The failure of the Concert of Europe in 1914 and the nature of the result must be studied with reference to the whole of the period from 1862 onward.

The course of events in 1914 was fairly well forecast in 456 
1864 and 1867 and again in 1871. For the greatest single cause of the failure of the Concert in 1914 was the new German Empire, and the new German Empire was built up in the years 1862-1914. ${ }^{1}$ In 1862 Bismarck became Prussian Chancellor. In 1864 Schleswig and Holstein were conquered by Prussia ; in 1867 Austria was excluded from competition with Prussia for control of the new Germany; and in 1871 the Empire was formally and ceremoniously established on the strength of the victory over France.

The years from 1871 to 1914 saw a tremendous development for the new Empire. The disorganization of the latesurviving Medieval anarchy was in a measure replaced by German unity. Industrial and financial and commercial power in the new nation came to full fruition. In the later years German influence in the colonial world grew as German colonies multiplied in Africa, Asia, and the isles of the Pacific. Until the turn of the eentury, and for a little while beyond, Prussian Germany was the dominant power in Europe.

This development was soon followed by the inevitable result, a competition of allianees. ${ }^{2}$ Already in 1879 Germany had attempted to secure herself against possible enemies by an Austrian alliance, defensive in terms but general in its effect. In 1882 Italy was drawn in to eomplete the Triple Alliance. The powers stretehing across the center of Europe formed a firm bloc and, either for good or ill, absolutely dominated the political scene.

British statesmen at length began to feel the danger. But Britain was too completely preoccupied with colonial questions and domestic social and political questions to pay a great deal of attention to the continent. It was, therefore, France who moved first to check Germany. In 1891-92 a defensive alliance with this aim was concluded with

' Best account of diplomatic history prior to 1914 is in Seymour; see especially Chaps. I-III, VII, VIII.

2"The Background of the War; History and Texts," in League of Nations, I, 173-251 (April, 1918). 
Russia. Fifteen years later, after Britain and France had adjusted their colonial rivalry in Africa, these Powers drew together in the cordial understanding of 1904-07. The Entente was further strengthened in 1907 when Russia and Great Britain succeeded in clearing up their mutual relations in the Near and Middle East. Finally, the Triple Entente was strengthened in Asia in 1911 by the renewal of the Anglo-Japanese alliance of 1902 .

The result was a balance of power in its worst form, that of a see-saw. Two great combinations of states faced one another across the heart of Europe, which is the heart of the world, and no detached power pretended to watch over and help maintain that balance. The precarious balance could last only until one party to the system should attempt to force the issue. Then would come a struggle, not so much to regain the position of balance, as to gain a position of dominance. The German dominance of 18711904 had been largely lost, replaced by a balance with the Entente. Then, from 1907 to 1914, Germany might well feel that the balance was going against her and that the Entente was attaining a dominant position. The only remedy, it might well appear, was to force the issue and see to it that the position of dominance of 1871-1904 was regained.

Roughly speaking, that is what happened in 1914, in connection with an indirect attack on Austrian imperial unity by one of the satellites of a member of the Entente. When the Entente, or the leading member thereof, tried to secure a peaceful adjustment of the case Germany forced the issue in war. ${ }^{1}$ Possible methods of adjustment between the Triple Alliance and the Triple Entente and between or among the individual nations members thereof were defeated by Germany, and the gage of battle was thrown down.

It has been seen that the growing danger of the years 1890-1914 had been perceived in Europe and that efforts

${ }^{1}$ Seymour, 265. 
had been made to provide some machinery for regulating international relations peaceably. The conferences at The Hague, trivial and anemic as their results appear when contrasted with the tremendous diplomatic struggle of the alliances with which they were expected to cope, were undoubtedly intended to remedy the existing diplomatic situation. The years from 1900 to 1914, especially, are filled with fear and appeals for reorganization before it should be too late. ${ }^{1}$ As has also been seen, the full success of the Hague Conferences was blocked by German and Austrian opposition. It was German opposition that prevented the adoption of compulsory arbitration at the conference in 1907. Now, in 1914, it was precisely this deficiency in the existing system of international government that allowed Austria to press her attack upon Serbia without fear of being compelled to submit to arbitration at The Hague as Serbia proposed. The ensuing efforts to secure a conference on the issues were failures in the same way and for the same reasons. Germany and Austria took advantage of the lack of any international machinery for compulsory adjudication or compulsory conference to make an attempt to secure again the diplomatic hegemony of Europe by challenging the balance of power in 1914 .

During nearly four years of war the balance remained fixed. Through the last weeks of 1914, through 1915, 1916, 1917, and the first half of 1918, the war was at a stalemate. Both parties won marked victories here and there-in the march into Belgium and France; at the Marne; in Shantung; in East Prussia; and all along the eastern front. At one time and another Bulgaria and Turkey joined the Triple Alliance, Italy and Rumania the Triple Entente. Yet the stalemate remained.

Then, in the end of 1917 and the beginning of 1918, the crisis arrived. Russia went out of the fight, as a result of Czaristic inefficiency, the wastage of war, and Bolshevik

${ }^{1}$ See especially Hanotaux, Politique d'Equilibre, generally. 
policy. The Central Powers were free to turn to the West and hurl all their strength against the British and French lines.

The lines held. A breach on the Western front in the spring of 1918 might not have brought the end at once, but it very possibly would have been the beginning of the end. In the event, however, the German bid for victory failed, as it had failed in 1914, and the balance continued intact.

That the drive of 1918 failed was due in part to the action of the only power capable of turning the scales of the contest. The United States, harassed in her neutral commerce since 1914 by the belligerents on all sides, had been attacked anew by the German submarines in the beginning of 1917. She had declared war, in defense of her maritime rights and of the international law on which those rights were based, and in the hope of securing an improvement of the international political and legal system in general. She was, accordingly, able to help considerably in the war of defense of May and June of 1918, and the balance was thus preserved against the German attack.

In mid-July of 1918, in the face of continued German attacks, the balance was still unbroken. Then came a sharp turn against the Central Powers. Beginning on $18 \mathrm{July}$ the Allies, with American troops forming a substantial part of the spear-head of advance, began the movement which led to the breaking of the stalemate, the destruction of the balance of power, and the signing of the Treaty of Versailles. The Allied troops had been put under a single command largely as a result of American insistence. ${ }^{1}$ The offensive of 18 July was undertaken directly at the suggestion of the American Commander, General Pershing. ${ }^{2}$ And in November, after four months of victory as consis-

${ }^{1}$ New York Times, 23 November, 1918, p. 2, column 8.

'Statement of F. R. Kent in New York Times, 28 November, 1918, p. 2, column 5; Pershing's Report, in same, 5 December, 1918, p. 3, column 2 ("Seizing this opportunity to support my conviction, every division with any sort of training was made available for use in the counter-offensive'"); Grasty in same, 9 March, $1919, \S 4$, p. 12 , column 1 . 
tent in their character as had been the preceding four months of defeat, an armistice was concluded under American mediation which left the Allies absolutely dominating the diplomatic scene. ${ }^{1}$ Never before had one power or one group of powers been placed in a position of such complete dominance in Europe; never before had the balance of power been so completely destroyed.

It was under these circumstances, and as a result of these causes, that the plan of the League was drafted. It remains to review the processes by which the Covenant was drawn up and accepted as the new constitution of the world state.

When the Peace Conference of Paris met in January of 1919 the creation of a League of Nations was felt to be one of the principal tasks to be undertaken. ${ }^{2}$ Accordingly, the three leading Allied Powers came armed with draft p ans for a Leag'ue. President Wilson possessed what must be called the official American plan, and the British and French possessed official plans of their own. General Smuts carried a plan which he had worked out independ- $\checkmark$ ently. ${ }^{3}$ These projects varied considerably in the extent to which they had been worked out in detail. The official British and French plans had been worked out most carefully, while the plans of President Wilson and of General Smuts were still in the form of general principles. ${ }^{4}$ These four projects formed the basis of the work of the Conference on this subject.

On 25 January, 1919, at the second plenary session of the preliminary Inter-Allied Conference, there was appointed a Committee, with President Wilson as chairman, to draft a "constitution" for the League. ${ }^{5}$ The resolution adopted by the Conference did not attempt to guide the

1 Temperley, I, 115-134, 373-386, 459-476.

'Same, III, 56 (Resolution of 25 January, 1919).

s Same, II, 24-25.

¿Same, II, 25, and III, 52-54.

Same, III, 56 (Resolution of Peace Conference), and 54-55 (personnel of Commission). 
Committee in its work beyond the declarations that the League should be "open to every civilized nation which can be relied on to promote its objects," and that "the members of the League should periodically meet in international conference and should have a permanent organization and secretaries to carry on the business of the League in the intervals between the conferences."

Between this date and 3 February President Wilson, General Smuts, M. Bourgeois, and Signor Orlando met informally and drew up a preliminary plan based upon the projects brought to the Conference by various delegates. ${ }^{1}$ This preliminary plan was discussed at daily meetings of the Committee from the time of its first meeting on 3 February until 13 February, when a tentative draft was adopted. ${ }^{2}$ This tentative draft was reported to the third plenary session of the Conference, on 14 February, and at Conce published to the world, in spite of the fact that it had not yet been signed and was still in a very tentative form. ${ }^{3}$ Whether or not the draft of 14 February is now regarded as sound, the circumstances were such at the time that its publication inevitably elicited a flood of enthusiasm and also a hot fire of criticism. While the President made his trip to America and the Committee was inactive the proposed constitution was scrutinized and praised and censured by all sorts of groups and all sorts of persons in all parts of the world. ${ }^{4}$

On 18 March, after the return of the President to Paris, the Committee reconvened and spent some four or five weeks in revising the text of the Covenant, with the more or less willing-but also the more or less reluctant-cooperation of friends of the League of all political factions and parties. ${ }^{5}$ On 28 April the final text of the Covenant was

${ }^{1}$ House and Seymour, Chap. XVII (Miller), 407-412.

${ }^{2}$ Same, 410.

Temperley, III, 12.

- House and Seymour, 412-414; Temperley, II, 28.

- House and Seymour, 414-423; Temperley, II, 28-29. 
submitted to the fourth plenary session of the Conference and at once adopted. ${ }^{1}$ Two months later the Covenant was included in the Treaty of Versailles and, on 28 June, signed as such by the representatives of the Allied and Associated Powers and Germany. ${ }^{2}$ Subsequently the Covenant was included in the treaties signed with Austria, Hungary, Bulgaria, and Turkey. ${ }^{3}$ During the later part of 1919 a number of nations ratified the Treaty of Versailles and thus brought into legal effect the new constitution of the world state. ${ }^{4}$

If we examine the Covenant of the League of Nations as adopted in 1919 we shall find that it corresponds rather indifferently to the purposes of its authors, and that it is related in a rather haphazard way to the historical background on which it must be assumed to have been based.

President Wilson undoubtedly intended to construct a League which should constitute a general concert of the nations in the room of the old balance of power as that balance had existed from 1907 to $1914 .^{5}$ This the League, as created in 1919, does not do. The power was concentrated in the hands of the Allied and Associated Powers to the exclusion of Germany, Austria, Russia, and other states not trusted by the Allies. This was natural and desirable, things being as they were in 1919 ; it would have been sheer madness and betrayal of the cause of international coöperation to have attempted to base such coöperation at that time upon German and Bolshevik participation. Political organization and government must normally be the creations of the dominant group, whether in the nations themselves or among the nations. The result none the less constitutes a divergence from the ideal of the concert of power. The League of 1919 did not accurately reflect

1 Temperley, III, 18.

${ }^{2}$ Same, 111-123.

Scott, Introduction, 212, 229, and following.

4 Temperley, III, 31.

Manchester address of 30 December, 1918; Temperley, III, 59. 
the ideal of a concert, did not even embody the idea of a balance, but rather the idea of a monopoly, of international power. That means that the League, if created in 1919, must necessarily have been little more than a cloak for the victors of 1918 , and must have been so regarded by Germany, Russia, and all excluded powers. ${ }^{1}$

That the League as created did not embody a balance of power was, of course, in keeping with Wilson's desire. In so far as it embodied some degree of a concert among those nations who were admitted to membership, it met his ideal still further. But the exclusion of certain states deprived this last fact of any significance, and since 1919 a balance, or conflict, or, perhaps, several conflicts of power have sprung up within the League itself. This is bound to happen,- - especially when the excluded states are admitted, -and it is desirable that it should happen. It will mitigate or destroy any monopoly of power by certain members, and the general concert will come to rest neither on artificial harmony nor on monopoly partnership, but upon a painstaking and careful harmonization of interests. Until the full development of an equilibrium of power within the League the monopolistic condition of 1919 will persist.

This conclusion may suggest the thought that the League should not have been set up in 1919 at all, but rather in a time of peace, a time when fierce international rivalry and the domination of the victors would not be present to distort the results. In the sense that a better League could have been created in 1907 than was created in 1919, this is probably sound, assuming that any League at all could have been created in 1907, and in the sense that, if created in 1930, the League would be better in form than one created in 1919. The difficulty with such a suggestion is that any attempt to create a League in 1907 would have met with defeat, in the face of the opposition of Germany,

1 "Comments by German Delegation on Conditions of Peace," Part I, Sec. ii, (3), in International Conciliation, No. 143, 1215 (Oetober, 1919). 
inasmuch as the same opposition which defeated the proposals for compulsory arbitration at The Hague would have been used to defeat any plan for a League. Moreover, the effect of the war on public opinion was such in 1919 as to make a League peculiarly desirable at that time-although that effect has so worn off as to make difficult the operation of the League since 1919, and to suggest to some observers that another catastrophic war is needed and needed quickly to convince the peoples and governments of the world once and for all of the need for international government. It would have been risky to deny that demand in 1919; it might not exist in the piping times of peace. Moreover, with a general international resettlement in process there was all the more need for a body to sanctify and guarantee the status created by the treaties.

That work the League might have been given to do, thus making it definitely the embodiment of the power and will of the victors, fulty the French desire for satisfaction and protection. ${ }^{1}$ This conception of the League likewise failed of complete execution. In a number of points the power and support of the League were not placed beneath the treaty settlement, notably in the case of the reparations. In some cases this was due to the desire of President Wilson to prevent the League from being regarded merely as the sheriff of the victorious Powers. In other cases, significantly enough, it was due to the reluctance of France to entrust her interests in the settlement to the League for enforcement. The result is that since 1919 the Supreme Allied Council, the Reparations Commission, and other similar bodies, have continued to function alongside of the League. Failing to constitute a complete concert of power, and failing to restore a balance of power, the League likewise failed to create completely a legal hegemony for the Allies.

The relations between the League and the terms of the

${ }^{1}$ House and Seymour, 412-413. 
treaty settlement are correspondingly ambiguous. On one hand, the League has been hailed as the machinery for revising the terms of that settlement in so far as they need revision. ${ }^{1}$ On another hand, it has been censured as responsible for unsatisfactory or unjust terms which itpresumably-sanctifies and guarantees. ${ }^{2}$ Still again, it has been lauded as free and untrammeled by the wickednesses of the settlement, the one pure spot in the work of the Conference. ${ }^{3}$

In truth the League is all three of these things, in varying measure. In so far as it becomes the legal and governmental embodiment of the existing society of nations, the League must recognize and protect the existing status. In so far as it has power it may, happily, remedy defects in

( $v$ ) that status, and will be held responsible for inaction in the face of such defects. That the League is hampered in such action by the rule of unanimity is part of the general handicap of international procedure as we know it; it is a price paid for support which could not be had for a League permitted to operate by less than unanimous consent. The League in its relations to the settlement, as in its member-

(3) ship, embodies a compromise, or a transitory treatment of problems which will have to be dealt with definitely be. fore the League will be on firm ground. The problems and alignments of the war must be superseded, the settlements of the peace must be rendered fair and therefore acceptable and accepted by all parties, before the League can be free to go forward with its own work.

An examination of the final text of the Covenant and a comparison of that Covenant with the tentative draft of 14 February will reveal the main outlines of the League as created in 1919. The League was to be composed originally

${ }^{3}$ Scott, Introduction, 282; statement of General Smuts in Temperley, III, at 75.

Keynes, 259-260.

' Harris, 209. 
of the signatories of the treaty containing the Covenant. ${ }^{1}$ At the same time, certain friendly or neutral states were invited to accede to the Covenant-not to the whole treatyand all of these accepted the invitation. ${ }^{2}$ Membership in the League was left open to all the states of the world, including, it should be noted, autonomous colonies. ${ }^{3}$ Mem- $\checkmark$ bership was, however, made to depend on election at the hands of the states already members, and a two-thirds vote is needed in the electing body. ${ }^{4}$ Moreover, guarantees of good faith respecting outstanding international obligations might be required as conditions of election, and limitations might be imposed upon the armaments of the new member. ${ }^{5}$

These provisions reflect an intention to restrict rather severely admission to the League of former enemy states and of Russia, including new states made from parts of the territory of the former Russian empire. The required guarantees will probably never be asked for formally, and the limitation of armaments here mentioned logically depends on prior action for disarmament among the existing members of the League. But election of outsiders will, nevertheless, proceed slowly.

Members might, it was declared, withdraw on two years notice, provided all outstanding international obligations are fulfilled up to date. ${ }^{6}$ The decision upon whether this proviso has been satisfied must, presumably, be left to the remaining members of the League. No provision for withdrawal appeared in the tentative draft; on the other hand, it is worthy of note that in the tentative draft of 14 February the members of the League were described as "signatory parties," while in the Covenant they are called

${ }^{1}$ Covenant, below, Appendix A, Document No. 15, Art. I, Par. 1, and Annex to Covenant, part first.

Same, and Annex, part second.

${ }^{8}$ Covenant, Art. I, Par. 2.

- Same.

- Same.

- Same, Par. 3. 
"members," a much more fixed and stable concept. ${ }^{1}$ A state might be declared to have forfeited its membership in the League if it violated any article of the Covenant. ${ }^{2}$

The League was to act through a Council, an Assembly,

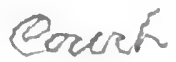
a Secretariat, a Court, and two or more Commissions. ${ }^{3}$ The Court was not created directly by the Covenant. Instead, a plan for a Court was to be worked out and adopted later. ${ }^{4}$ The Commissions were likewise created only by authorization. ${ }^{5}$

By another part of the Treaty of Versailles there was created an International Labor Office and this body was to be a "part of the organization of the League." 8 The members of the League were to be members of a union maintaining the Labor Office, although the union was to have a Conference distinct from the Assembly of the League. ${ }^{7}$ The Secretariat of the League was to assist the Labor Office wherever possible. ${ }^{8}$

The most powerful body in the League as created was the Council. This body was to be composed at the start of five Allied Powers of first rank and four friendly powers of second rank, the former holding their seats permanently, the latter until changed by the Assembly. ${ }^{9}$ The Council might, with the approval of the Assembly, increase the numbers of both these categories. ${ }^{10}$ The Council should meet at least annually; each member of the Council possessed one vote, thus recognizing a principle of political equality after neglecting it in the original act of constructing the Council. ${ }^{11}$

${ }^{1}$ Arts. I, II, III of draft of 14 February, in Sen. Doc. 46, 66 Cong., 1 Sess.; Art. III of Covenant.

${ }^{2}$ Covenant, Art. XVI, Par. 4.

Same, Arts. II, IX, XIV, XXII, XXIV.

Art. XIV.

- Arts. IX, XXII, XXIV.

- Treaty of Versailles, Part XIII, Section I, Preamble, and Arts. 387, 392, in Temperley, III, 314-315, 316.

'Same, Árts. 387, 388, 392.

Same, Art. 398.

- Covenant, Art. IV, Par. 1.

${ }^{10}$ Same, Par. 2.

12 Same, Art. IV, Pars. 3 and 6. 
The Assembly of the League was to be composed of representatives of all members of the League, to meet regularly, and to act by votes, where the principle of equality should be observed. ${ }^{1}$

In all voting, except in questions of procedure, decisions must be made by the unanimous consent of those present. Apparently the absentees were bound by the decision of those present. ${ }^{2}$

The Secretariat, under the Secretary-General, was to act as a secretarial and administrative office, and to maintain its bureau at Geneva, Switzerland, which was designated as the seat of the League. ${ }^{3}$

The chief function of both the Council and the Assembly is to be that of discussing current international problems, whether or not these problems have emerged in the form of international eonflicts, and to try to suggest methods of settlement. Thus the Council was authorized to devise a new plan for a Court of Justice and submit it to the members, to devise plans for disarmament and submit them to the members, and to advise the members regarding the control of the armament industry. ${ }^{4}$ In cases of international disputes the Council is to act as a Commission of Inquiry and a Council of Conciliation. ${ }^{5}$ The chief defeet in the practice of inquiry, good offices, and mediation in the past was, as we have seen, their intermittent eharacter; the Council is to act as an organ for continuous inquiry, good offices, and mediation. It has power to make its inquiry and recommendations on the motion of one of the disputants, and its findings and recommendations are to be published. If it so desires the Council may refer the dispute to the Assembly and, in turn, either one of the parties may demand such action. Even where the Council acts to se-

${ }^{1}$ Covenant, Art. III, Pars. 1, 2, and 4.

Same, Art. V, Par. 1.

Same, Arts. VI and VII.

- Same, Art. VIII, Pars. 2 and 4.

- Art. XV. 
cure coöperation of the members in coercing a state which has refused to abide by certain articles in the Covenant, it may only "advise" what action is to be taken." It may listen to complaints and may discuss problems and disputes at will; it cannot settle anything. It may recommend executive action by the members; it cannot itself make and carry into execution any decision or rule.

(The point at which the Council comes nearest to the exercise of real discretionary power is to be found in its power to refuse to excuse a member from an armament limitation which that member has itself previously adopted. ${ }^{2}$ Even here the source of the binding force of the limitation is the prior decision of the state itself. So in several other places, the states pledge themselves to submit disputes to inquiry, or arbitration, to abide by awards, to respect each other's territorial integrity, to use an embargo of commerce and military force where necessary, against a recalcitrant member, to reduce their armaments, to exchange data regarding armaments, and to permit the passage of League troops through their territory. ${ }^{3}$ But no League body, not even the Council, can itself enforce such pledges.

On the other hand, the Council may make certain decisions of a purely administrative character, and so, indeed, may the Secretary-General himself. Clerical staff appointments may be confirmed, the seat of the League moved, expenses fixed and regulated, and so on. ${ }^{4}$ The Secretary-General may likewise summon a meeting of the Council, publish treaties registered with the League, and perform several similar functions. ${ }^{5}$ These activities, however, though discretionary, do not normally carry any political consequences and so need little attention.

${ }^{1}$ Covenant, Art. $\mathrm{X}$.

2 Art. VIII, Par. 4.

Arte. VIII, X, XII, XIII, XVI.

- Arts. V, VI, VII.

Arts. XI, XVIII. 
The Assembly bears still more of the character of a debating society Given power, like the Council, to take up and discuss any subject of international interest, it has no power at all to act, except in the election of members of the League, members of the Council, and members of the Secretariat. ${ }^{1}$ It may advise the reconsideration of treaties or conditions threatening the peace of the world, but this is about as far as it can go. ${ }^{2}$

The Court planned for establishment under the League likewise, as has been seen, depends entirely on the consent of the parties for its jurisdiction. The Council, adhering strictly to the text of the Covenant, refused to accept and transmit to the members of the League the plan of the Committee of Jurists providing for obligatory arbitration.

With the consent of the nations supporting the existing international administrative bureaus and commissions, the League may take over the forty or fifty international bodies of this type, adding them to the armaments commission, the mandates commission, and various committees which the Council and the Assembly may create for purposes of investigation and report on special topies. International bureaus and commissions to be created in the future are to be placed under the League in like manner. ${ }^{3}$

The position of the administrative bodies just mentioned is somewhat similar to that of the already existing diplomatic and consular systems, the practice of treaty negotiation, the existing network of treaties, the body of common international law, and existing courts of arbitration or treaties providing for the same. All of these standing institutions of international government are to continue to operate as before, more or less in connection with, and more or less independent of, the League, as circumstances determine. Thus the Covenant assumes the continuation

${ }^{3}$ Covenant, Arts. I, IV, VI.

Art. XIX.

Art. XXIV. 
of sovereignty could hardly have been dangerous for the United States. If the motive was to preserve American isolation, so-called, that is another matter. The only thing to be said in such a case is that in point of fact we are not isolated but tied up very closely with Europe in trade and finance, and, therefore, in potential political interest. It may be added, moreover, that by the Covenant we surrender no single item of discretion; we put ourselves in position to be subjected to no single rule or decision to which we have not specifically consented by our own vote.

No penalties are provided and nothing remotely resembling coercion is provided in the Covenant until we reach the subject of international disputes. Penalties are then prescribed in eight distinct cases where the members disregard promises made in the Covenant. Those promises are the pledges to respect the territorial integrity and political independence of other members, to refrain from war at the outbreak of an international dispute and submit the dispute to inquiry by the Council or to arbitration by a court acceptable to both parties, to refrain from war for three months after the report of the Council or the award of the court, to accept the award of the court, or, at least, not to go to war either to enforce a demand against which the report of the Council is unanimous, the parties to the dispute excepted, or to enforce a demand in opposition to the arbitral award. ${ }^{1}$ Penalties are also provided for disregard of the Covenant in general. ${ }^{2}$ In the last case forfeiture of membership alone is inflicted as a penalty. ${ }^{3}$ In the first case the Council is merely to advise the members what to do, and that amounts to saying that the members will do what seems best to them, deriving no specific authority from the Covenant for any coercion they may take, which leaves matters precisely where they were before the

${ }^{1}$ Covenant, Arts. VIII, X, XII, XIII, XVI.

2 Art. XVI.

Same, Par. 4. 


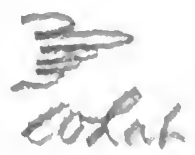

atru

tace

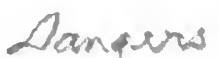

Langers

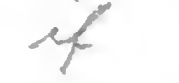

aing
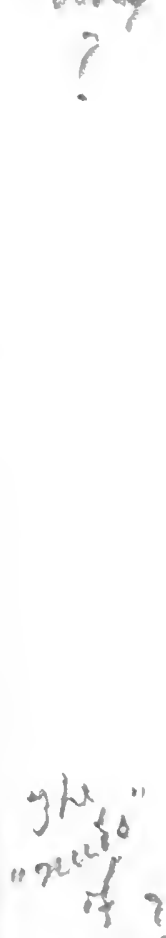

?

-

Covenant and the famous Article $\mathrm{X}$ were concluded. In all other cases the offending members will have to suffer the severance of commercial and financial intercourse with the other members, and eventually military coercion if the other members are willing to exercise such power on the advice of the Council. To what end? That the aforesaid pledges may be carried out. Nothing more. At no point is there mediation or arbitration without voluntary action by the state involved. At no point can Council or Court decide on the merits of the dispute, so as to give the decision a binding effect unless the state has itself voluntarily accepted arbitration. At no point does the League or any body of the League have any authority over the subject matter of the national interests of its members except such as is given to it at the time by the free consent of those states.

It may well be said, however, that, in view of this state of affairs, the thing to be feared is not judgment and execution, but the influence or indirect control to be exerted by the League through the Council and the Court, by means of inquiry, report, mediation, and publicity. This is exactly the case. But it reveals the true spirit and the ultimate futility of the opposition to such a body as the League. The real power of the League, as of every political and legal institution, lies in the extent to which it reflects reality and the actual interests and influences of political life, not in the literal terms of the law on which it is based. It will be successful and powerful only in proportion as it reflects such reality; but in so far as it does correspond to the real needs of the time it will control, even beyond the letter of the Covenant. Any League, be the Covenant ever so restricted and limited in its definition of power, will, so long as it effectively creates a central body for inquiry, conference, advice and publicity, govern the world because just such a body and just such a procedure is precisely what the world most needs. 
One of the principal tests to be applied to any federal constitution in order to discover its true character relates to the method of amendment. The Covenant, being a treaty agreement, may only be altered effectively by unanimous consent. It is true that amendments may be adopted by the consent of the Powers whose representatives at the time compose the Council, acting together with a majority of the states possessing members in the Assembly, ${ }^{1}$ but it is also provided that dissenting members shall not be bound by such changes although they shall, if they persist in dissenting from the changes, lose membership in the League. ${ }^{2}$ This gives to the Great Powers and the few Powers of Second Rank represented on the Council a powerful veto over all amendments. The smaller powers represented in the Assembly may be compelled to accept amendments in many cases in spite of their national wishes or be content to suffer exclusion from the League. Taking the amendment of the Covenant or constitution of the League as the test of the location of sovereignty or control within the League, it is clear enough that that control lies in the Council or, rather, in the Powers represented in the Council, limited by their ability to secure the concurrence of enough smaller states to control a majority in the Assembly, and by the power of a single member to escape from the terms of an amendment and from the League itself by persistent defiance of the former.

Such being the Covenant and the League as projected in 1919, a few general conclusions at once emerge. The system created by the Covenant is comprehensive and symmetrical, complete and adequate in range and scope. The historical institutions of international government-diplomacy, treaty-negotiation, and arbitration, including good offices and mediation-are gathered together and carried forward into the future in close coördination one with

1 Covenant, Art. XXVI, Par. 1.

'Same, Par. 2. 
another and with a new system of conferences and congresses more ample and more comprehensive than anything in existence before. The League is provided with characteristic constituent, legislative, administrative, and judicial organs. It is capable of expansion, and its framework is not unsuited to the development of all varieties of committees and commissions acting under the Secretariat, the Council, and the Assembly.

Admirable in organic structure, the League is, however, in a dubious position as far as its membership and powers are concerned. Its membership still shows the effect of the war and reveals the League as largely a league of victors for perpetuating a position of diplomatic dominance won in battle, rather than a general concert of power for common benefits. So long as this condition of affairs continues, as it must until the legacies of the war are liquidated, its outlook and activities must necessarily be partial, if not partisan. This phenomenon is simply one angle of the manner in which war tends to wreck the nascent fabric of international organization. When the problems of the war are settled the League may turn to other things. It is to be hoped that the rather perplexing definition and allotment of powers in the Covenant may then be cleared up. Is the Assembly merely a debating society?. To what extent is the Council in control? Is there no more power of compulsion vested in the League than such as rests on political and moral influence? Can the nations be brought to face the conditions of the world more squarely and courageously? Such are the problems left open by the Covenant. The Covenant was devised in a few weeks in 1919. It may be revised through decades of international constitutional history.

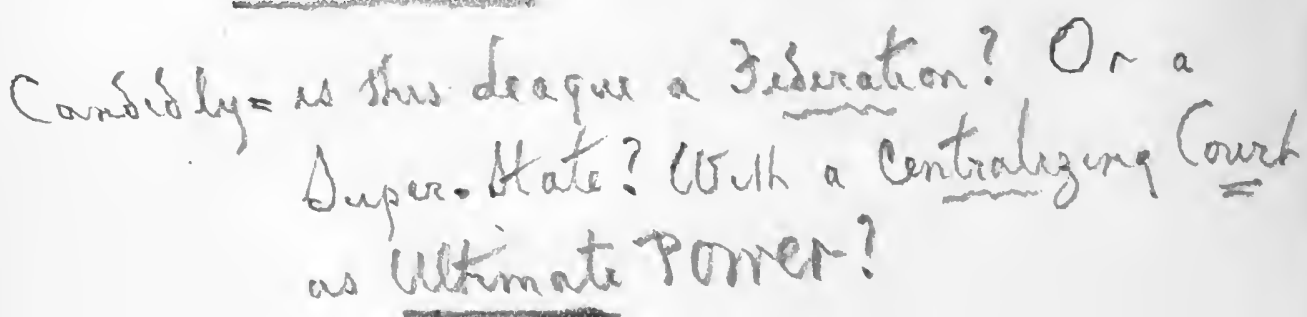


PART VIII

INTERNATIONAL ORGANIZATION IN 1920-1921 



\section{CHAPTER XXVIII}

\section{THE ESTABLISHMENT OF THE LEAGUE OF NATIONS AND THE RESUMPTION OF INTERNATIONAL GOVERNMENT}

TTHE Treaty of Versailles having been ratified in the closing months of 1919 by a sufficient number of the signatory parties to render it effective, an exchange of ratifications took place in Paris on 10 January, 1920. Three days later the first meeting of the Council of the League was summoned by President Wilson, acting under Article $\mathrm{V}$ of the Covenant, and on 16 January the League was formally established by a meeting of the Council in Paris. ${ }^{1}$

The first meeting of the Council had been preceded by a considerable amount of work by an Organization Committee and the Secretary-General.

The Organization Committee had been created by a resolution adopted by the Peace Conference on 28 April, 1919. Starting its work on 5 May the Committee continued to function until the formal establishment of the League, its task being to supervise the organization of the Secretariat and prepare for the meeting of the Council.

The Secretary-General had been named in an appendix to the text of the Covenant. He immediately began to act in accordance with the intentions of the Covenant, although that pact was not yet in force. Temporary offices were established in London. Certain undersecretaries were chosen. The collection of books and papers for a library for the Secretariat was begun. In these actions the Organization

1 Official Journal, I, No. 1, 12, 17, 18. On the early history of the League see literature cited, below, in Appendix B, § 28 . 
Committee participated to the extent of giving advance approval and confirmation. Indeed, the Secretary-General, in all of his preliminary work, acted entirely as a result of a resolution adopted by the Organization Committee on 5 May empowering him to appoint a staff and establish an office, and temporarily fixing his salary.

By the beginning of 1920 plans for the organization of the Secretariat had been thoroughly developed. Delay in the ratification of the Treaty of Versailles allowed the plans of the Secretariat to run ahead of the formal establishment of the League. By the time the Council met, therefore, the Secretariat had devised a plan for many "Sections" and "Commissions" in the permanent structure of the League which could only be definitely created when the constituent or legislative organs of the League, the Council and Assembly, should authorize them.

While this general preparatory work was being carried out by the Organization Committee and the SecretaryGeneral, there was established, in accordance with Part XIII of the Treaty of Versailles, the International Labor Organization described therein. ${ }^{1}$

The International Labor Organization, as has been seen, was to be an association of nations separate from the League, although composed of the same members, and was to operate through its own Governing Body, General Conference, International Labor Office and Director, and a Commission of Inquiry. When the Treaty of Versailles was framed all parties expected that it would be ratified promptly. It was therefore provided that a temporary Organization Committee should begin work at once in preparation for the active operation of the Labor Organization. In the treaty itself it was stipulated that President Wilson should call the first meeting of the General Conference for October, 1919, in Washington. ${ }^{2}$ As things worked out,

${ }^{1}$ Treaty of Versailles, Arts. 387-427.

Same, Arts. 424-426, and Annex. 
these provisions brought about the meeting of the Conference created by the Treaty before the Treaty itself was effective!

The Conference met, nevertheless, at the appointed time, and carried on its deliberations with the result that six draft labor conventions and six recommendations were made and referred to the constituent nations. The Governing Body of the Labor Organization was also established, and likewise the International Labor Office with its Director. ${ }^{1}$ The offices of the Labor Organization had been set up at first in London. They were temporarily moved to Washington in the end of 1919, but were returned to London later. In accordance with the Treaty, close relations of coöperation were at once established between the Secretary-General of the League and the Director of the Labor Office, and it soon appeared that the Labor Organization as such was simply the League in another capacity and that, as the Treaty stipulated should be the case, the Labor Office was fast becoming part of the nascent organization of the League.

With the opening of 1920 , the ratification of the Treaty of Versailles, the formal establishment of the League, and the meeting of the Council in Paris, these preliminary activities of the Secretary-General and the Labor Organization took their legitimate places in the scheme of the League. They did not, however, diminish in importance, but continued during the year 1920 to develop in their own way.

The Secretary-General was now allowed to continue his work of organization unhindered. Even after the beginning of the meetings of the Council he was allowed to proceed largely according to his own lights. Not until May, 1920, when the Council met in Rome for its fifth session, did the plan of organization devised by the Secretary-General come

${ }^{1}$ Official Journal, I, No. 1, 26. 
up for approval, and even at that time his work did not receive any very elaborate discussion. ${ }^{1}$ The Secretary-General was therefore able, all through the first year of the League,- the most important year, for this purpose,- to organize matters as he thought best. While changes may be made in the future, the League was, by the freedom given to the Secretary-General in 1919 and 1920, committed to the plan by him first created and established.

That plan consisted of some ten "Sections," as follows:

Political Section: a bureau of correspondence for members of the League on all political problems,--such as those referred to in Article XI of the Covenant,-and a research bureau in this field for the League itself.

Legal Section: a corps of expert advisers dealing with legal problems arising in the work of the Secretariat, the Council, and the Assembly, or in the relations of the members of the League to each other as members, and to the League itself by virtue of either the Covenant or other international treaties.

Economic and Financial Section: to deal with international commercial and financial problems by collecting data and statistics relating thereto for the information of the members and governing bodies of the League, and by holding general international conferences to deal with such questions.

Administrative Commissions Section : to coördinate and supervise the various commissions created or authorized by the Treaty of Versailles and the other treaties of 1919-20 where the League is involved in the execution or administration of these treaties, such as the commissions dealing with the Saar region and Danzig; to watch over the execution of the provisions of the treaties respecting the protection of minorities.

Transit and Communications Section: to serve the

${ }^{1}$ Official Journal, I, No. 4, 115. 
League in connection with its duties in the field of international communications by providing the Council and the Assembly with data on the subject, making recommendations, and watching over the execution of the peace treaties as far as this topic is concerned:

Information Section: the publicity bureau of the League, the office from which information would be sent out to the world through the press.

Mandates Section: a correspondence bureau between the League and mandatory powers respecting their mandate territories; to provide the League with data to facilitate the performance of the duties of the League under Articles XXII and XXIII of the Covenant.

International Bureaus Section: to constitute the link to connect the League with such of the forty or fifty international administrative bureaus as are placed under the League in accordance with Article XXIV of the Covenant and such administrative bureaus, not otherwise provided for, as shall be created in the future in connection with the League.

Registration of Treaties Section: to receive and register treaties transmitted to the League by members in pursuance of Article XVIII of the Covenant, and provide the texts from which these treaties would later be published by the League.

Health Section: the central office for such organizations as are created by the League to deal with health and morals under Article XXIII of the Covenant or brought under the League from among the already existing international conferences and associations dealing with such subjects.

In addition to these Sections for special work, the Secretariat soon came to possess a clerical staff, a distribution office for routing incoming work to the appropriate Sections, and a library of its own. It took charge of all buildings and offices of the League at Geneva, and began to manage the publications of the League. These publications

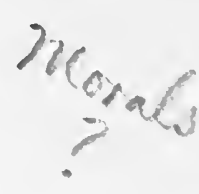


soon included the Official Journal, Special Supplements thereto, the Treaty Series, Reports of the Work of the Council, the records of the meetings of the Assembly of the League, a Monthly Summary of the activity of the League, and certain miscellaneous documents relating to the Permanent Court of International Justice, the International Financial Conference, and the Secretariat itself. The records of the First Assembly as issued at the time consisted of a Journal, a Provisional Verbatim Record of the Plenary Sessions of that body, Procès-Verbaux of the meetings of Committees, and hundreds of Documents laid before the Assembly. ${ }^{1}$

After the adjournment of the Washington conference, the International Labor Organization continued to operate through 1920 chiefly by means of its permanent organs, the Labor Office and the Director. Two additional conferences were held, however, one at Genoa in June and July, dealing with the labor of seamen, and a smaller conference on the same subject at Geneva in November. The headquarters of the Labor Office were moved to Geneva in accordance with the terms of the Treaty, and the Labor Organization thus placed in its proper relationship to the League and, particularly, the Secretariat. ${ }^{2}$

When the first meeting of the Council of the League was held in January, 1920, it was hailed with far more enthusiasm by supporters of the League than had been bestowed upon the inauguration and development of the work of the Secretariat in 1919. In one way this was very unfortunate and quite unjustified. The value to the cause of international coöperation of the unostentatious and prosaic work of the Secretariat is very possibly greater than

${ }^{1}$ Lists of publications are given in the Official Journal. The definitive edition of the records of the First Assembly omits the Journal and Documents, as such.

${ }^{2}$ Official Journal, I, No. 6, 377-388, and Report by the Secretary General to the First Assembly of the League on the Work of the Council, being Document No. 37 of the First Assembly, 17; cited hereafter as Report to First Assembly. 
that of the Council, and it would be well for the standing of the League in public estimation if more attention could be drawn to its more stable and less sensational aspects. In another sense, however, this reaction was faithful to the facts in the case, for the League did not come into legal existence until after the exchange of ratifications of 10 January, 1920, and the first meeting of the Council signalized the beginning of the career of the most powerful organ of the League.

Between 16 January, 1920, and the end of the year the Council met in independent sessions ten times. ${ }^{1}$ An additional meeting was held in November and December in conjunction with the meeting of the First Assembly. ${ }^{2}$ The work of the Council for the year 1920 may be apprehended by means of an examination of the records of these meetings. ${ }^{3}$

The Council met first at Paris. Subsequent sessions were held at London in February; at Paris again in March and again in April; at Rome in May; at London in June and again in July; at San Sebastian (Spain) in August; at Paris in September; and at Brussels in October. The final meeting, in connection with the sessions of the First Assembly, was, naturally, held at Geneva. The first session occupied only one day, while the seventh session occupied a period of twelve days. The Council remained in Geneva, in more or less active session, during the whole of the period of the meetings of the First Assembly, from 15 November to 18 December. At the first session one item of business was taken up, while at the tenth session some twenty-two items were dealt with, and during the Geneva meetings the whole field of the work of the League was up for review and action.

${ }^{1}$ Report to First Assembly, 7, 53-59.

2 Official Journal, II, No. 1, 5-27.

- The following account is based on Report to First Assembly, 53-59. 
The work of the Council during the first year may be divided, as to its subject matter, into three classes, namely, work in connection with the organization and administration of the League itself, political and legal matters, and humanitarian work, including action for the promotion of international coöperation independent of the League.

In League organization and administration, the Council had at first a relatively free hand and a relatively severe task. As in the case of the Secretariat, the structure and methods of the League, so far as they related to the Council, had to be planned and created entirely on the meager basis of the text of the Covenant. The earlier meetings of the Council were therefore taken up largely with such questions. Throughout the meetings down to May, 1920, the Council occupied itself with such problems as the appointment of commissions, rules of procedure, the organization of the Court under the League, accessions to the League, the budget of the League, the first meeting of the Assembly, and the organization and work of the Secretariat. Until the very end of the first year such questions were specially prominent in the order of business of the Council.

The result was a rather irregular growth of subordinate administrative bodies under the Council, some temporary and some permanent, some large and some small, some deliberative and advisory, some of the nature of investigating commissions or administrative boards. ${ }^{1}$ Certain of the temporary bodies, such as the Committee of Jurists appointed in February to draft a plan for the Court to be created under the League, either completed their work before the end of 1920 and passed out of existence, or would shortly do so. This was equally true of certain of the larger bodies such as the International Financial Conference, although in this case and in one or two others, a permanent or, at least, a temporarily continuing, body was created as

${ }^{1}$ Report to First Assembly, 11, 13, 19, and following. 
a result of the Conference. For these reasons it is almost impossible and rather unprofitable to try to define the exact structure of the League at the end of 1920.

There appeared, naturally, a great degree of similarity between the jurisdiction of the organs subordinate to the Council and that of the Sections of the Secretariat. Thus, the International Financial Conference, the Advisory Financial Commission created in October at the Brussels meeting of the Council to carry out the recommendations of the Conference, and the International Credits Commission, plans for which were approved by the Council in December, correspond with the Economic and Financial Section of the Secretariat. A danger that the structure and work of Council and Secretariat would duplicate one another in this way made its appearance, but if the Secretariat remains a merely clerical branch of the League this danger will be avoided and the correlation between organs of the Council and Sections of the Secretariat develop quite naturally and helpfully.

Certain of the administrative tasks of the Council led it into matters outside its jurisdiction. Thus, the practice of obligatory arbitration in the organization of the Court under the League had been definitely ruled out by the terms of the Covenant, and the Council found itself restricted in its activities by that fact. ${ }^{1}$ The preparation for the work of the Assembly had to be made by the Council with thought not only for the terms of the Covenant but also for the fact that the Assembly might itself have certain ideas regarding its own organization and procedure when it convened, and, as the Council was in part subject to removal or renewal by the forthcoming Assembly, this meant that the Council must act with serious consideration for its relations to the Assembly. As we shall see, the Council did not escape all embarrassment on that score.

${ }^{1}$ Covenant, Art. XIV. 
Furthermore, certain of the actions of the Council in the field of administrative organization were preseribed for it by the Treaty of Versailles outside of the Covenant, and led into the field of political and legal problems. Thus, the first official action of the Council, taken at Paris in January, 1920, was to appoint three members of a Saar Basin Delimitation Commission as prescribed by Article 48 of the Treaty of Versailles. At the February meeting, in London, the Council named a Governing Commission for the Saar Basin and a High Commissioner of the League at Danzig, both according to terms of the Treaty. ${ }^{1}$ These organs correspond to the fourth Section of the Secretariat, illustrate the way in which the Council is implicated in part in the execution of the Treaty, and lead us into the political work of the Council.

The work of the Council in the political field has attracted most attention because of its dramatic quality and because it is here that what appear to be the greatest powers of the Council are to be exercised. Questions such as those of territorial sovereignty, and jurisdiction over peoples and races, are felt, and rightly felt, to be dynamic and significant in a peculiar degree.

Such questions increased in number in the work of the Council as the year 1920 wore on. ${ }^{2}$ Apart from questions of this type referred to the Council by the Treaty of Versailles or the other treaties of 1919-20, the first of such problems to be dealt with were discussed at the meeting in Paris in March of 1920, namely the protection of racial groups in Turkey, the protection of Armenia, and the Russian question. By the end of the year the Council was concerned with not only these problems, but also the Persian situation, the Aaland Islands case, the Vilna episode, and several others.

Some danger is involved in this development, and yet a

1 Report to First Assembly, 21-25, 53.

'Same, 25-40,53, 54, and following. 
danger difficult to avoid. On the one hand, such questions as these, arising in those ranges of international relations where generally accepted legal principles are almost entirely lacking, must be settled by the Council either by negotiating a compromise between the disputants or dictating a settlement based on rather general ideas of equity and common sense. In either case the Council is bound to suffer some hostility and criticism; in one case because the substance of the settlement will appear to flow, not from any wisdom or power of the Council, but from the willingness of the parties to keep the peace by compromise, and in the second case because the losing party will dispute the inherent justice and reason of the settlement, while the Council will have no accepted legal rule on which to rely for justification. Yet, as the Supreme Council of the Allies gradually ceases to function,- - and, after all, the war and the alignments and groupings of the war will be over some day,-more political problems, not fewer, will come before the Council. The Assembly would have the right to take up and discuss such questions, but would have little success in handling them because of the infrequency of its meetings, its size and general deliberative character, and its lack of concentrated power and influence. The Court of the League would only be able to deal with such questions by consent of the parties, and not only will it be difficult to secure such consent in the case of these political or nonjusticiable questions, but the Court would merely step into the difficulties of the Council if such consent were obtained. The whole situation shows clearly what a menace to general organized coöperation is to be found in the all too numerous phases of international relations for which no commonly accepted principles and rules have been found. The development of such legal standards and their application by a Court is the only permanent relief to be obtained from this dilemma.

Contrasting strongly with this activity in political ques- 
tions, and less likely to be the subject of hostile criticism, was the humanitarian relief work fathered by the Council. ${ }^{1}$ A campaign against typhus in Poland was organized and conducted, relief work in Central Europe was promoted, and war prisoners in large numbers were repatriated from Russia. This work might be, and in actual execution largely was, undertaken by private agencies, but the activities of such agencies must be coördinated and distributed. Private international organization or a separate official organization might do even that, but if the principle of Article XXIV of the Covenant is sound these activities might better be conducted under the League once and for all.

The Council also took steps in 1920 to encourage international coöperation outside of the League or in only indirect connection with it. ${ }^{2}$ The Council put itself in touch with several already existing official international organizations such as the Health Commission and the Union for Suppression of the Traffic in Opium. It also sent a representative to meet with the General Conference of Red Cross Societies in Geneva and, at its eighth session, voted to assure the International Committee of the Red Cross of its complete moral support in all relief work. The Union of International Associations in Brussels, the organization which acts as a central office for some three hundred private international associations, was granted a subsidy in support of its publication of a compendium of the resolutions adopted from time to time by international congresses. The Federation of National Associations in Support of the League of Nations was given a message of sympathetic encouragement at its meeting in Milan in the Autumn of 1920 .

For many students of the League the Assembly remains, however, its principal organ of government. They point out that the Covenant provides for an "Assembly and a

1 Report to First Assembly, 45-51.

'Same, 51. 
Council," implying, so it is said, that the former is to be the first or primary organ of the League and the Council a subordinate body. ${ }^{1}$ They point out that the principal duties of the Council as specified in the Covenant are administrative or ministerial in character, while the Assembly is left to discuss and, presumably, decide, questions of policy. ${ }^{2}$ The Council contains representatives from eight or nine members of the League only, the Assembly is representative of the full membership. ${ }^{3}$

However the case may stand on the merits, the founders of the League decided otherwise, and no meeting of the Assembly was called until the Council had held its first ten sessions and had thus secured a decided handicap on the Assembly in the possible contest for control of the League. There is no reason why this should necessarily have happened. Indeed, certain provisions of the Covenant, ${ }^{4}$ and the plans made in 1919 for the establishment of the League in the expected event of early American ratification, ${ }^{5}$ all imply that it was the Assembly which was to meet first, and to meet thereafter most frequently. The Council was to meet "at least once a year," the Assembly "at stated intervals." "The trouble was that no one had stated. the intervals, and the Assembly therefore waited, perforce, until it was called into being. The result was that the Assembly came to be regarded as an annual legislative or constituent body, the Council more or less as a ministry.

Yet such a description, if left to stand alone, would be somewhat misleading. The Council does not depend upon the support of the Assembly for its power or position. No egislative power rests in the Assembly. The Council and

${ }^{1}$ Covenant, Art. II.

Same, Arts. VIII, XIV, and XV, XIX.

Same, Arts. III, IV.

Same, Arts. II, III, VI.

- Resolution of Peace Conference of 28 April, 1919, and letter from Clemenceau to House, dated 4 September, 1919, quoted in "Three Months of the League of Nations," in League of Nations, III, 1-96 (February-April, 1920), 12, 35.

'Covenant, Arts. III, IV. 
Assembly each possess powers which are derived directly from the Covenant and which at times exactly overlap, at times overlap in part, at times are quite different and distinct. No more could the Assembly and the Council be regarded as lower and upper houses of a legislature, because of differences of power too numerous to escape notice. As soon appeared, when the question was later discussed by the Assembly, the solution of this problem of the relative natures of and relations between the Council and the Assembly must be sought in practice by reference to the Covenant, the general principles of international law, and the convenience of the case. ${ }^{1}$ What happened in 1920 was that the delegates of European Governments, accustomed to government by Ministers, with the support and advice of Parliament, naturally expected the Assembly to take that attitude, and no more than that attitude, toward the Council.

It is well to note that the Council did not take as hostile an attitude as it might have taken toward the Assembly in regard to the respective powers of the two bodies. In two or three cases, indeed, the Council took conciliatory action not strictly required under the Covenant. Thus, the draft plan for the Court of the League was submitted to the Assembly for approval, when such action was not called for by any provision of the Covenant and when the approval of the Assembly could have no legal effect at all. ${ }^{2}$ Again, the budget of the League was submitted to the Assembly and approved in the same manner, and with like effect. $^{3}$ Where a dispute did arise between the two bodies, - over a demand by the Assembly to be allowed to see the draft plans for the forms of Mandate C-it was due to a feeling on the part of the Council that certain members of the Assembly were anxious to curb the Council contrary

Documents 15, 16, 159 of the First Assembly.

- Covenant, Art. XIV; Procès-Verbaux, No. 15, 4.

- Verbatim Record, 29th Plenary Session. 
to the explicit terms of Covenant. ${ }^{1}$ In view of the dictatorship of the Great Powers represented in the Council, and in view of the long handicap enjoyed by the Council in 1920, this was a natural attitude on the part of the members of the Assembly, but it could hardly be expected to encounter any reception other than that which it did encounter, and cannot be very helpful or effective in the future.

The First Assembly held some thirty plenary sessions between 15 November and 18 December, 1920. Forty-one states were members of the League at the time of the meeting of the Assembly and the number of delegates sent to Geneva was approximately one hundred, although the total number of persons connected with the meeting of the Assembly was double this figure. ${ }^{2}$

The Assembly was provided by the Council with a temporary chairman, and provisional rules of procedure were suggested to it from the same source. The Assembly did not feel inclined to take any different action of its own at the beginning and, while electing the President of the Swiss Republic Honorary President, proceeded to elect the President of the Council President of the First Assembly and to accept the code of rules of procedure as suggested by the Council as its own, pending action by a committee entrusted with the task of drafting a permanent set of rules. $^{3}$

The First Assembly then proceeded to select six Committees to deal with the following problems: constitutional organization; technical bodies attached to the League; creation of the Court of Justice; Secretariat and budget; admission to the League; and the reduction of armaments, the use of economic coercion under the Covenant, and mandates. Each committee was composed of representatives from all the states represented in the Assembly, in order

${ }^{2}$ Verbatim Record, 30th Plenary Session; Mr. Balfour, although speaking as a member of the Assembly, was really voicing the opinion of the Council.

${ }^{2} V$ erbatim Record, Plenary Meetings; also Levermore, 127.

'Official Journal, I, Special Supplement, January, 1921, 6, 7, 9. 
that the views and, if possible, the consent, of each nation might be obtained on each question in the committee stage. Each committee elected its own chairman, and these six chairmen, with the President and Honorary President of the Assembly, and six additional Vice Presidents, elected directly by the Assembly, composed the General Committee. ${ }^{1}$

The question of publicity in connection with meetings of the Assembly and its committees arose at a very early point in the proceedings. The Council had carried on most of its discussions in private. Was the Assembly, and were its committees, to do likewise, and, if so, was this desirable? Apparently there was no question about plenary meetings; it was assumed without discussion that these were to be public. One of the chief functions of the Assembly was precisely that of serving as a public forum; beside this, it would have been impossible to preserve any valuable degree of secrecy among over one hundred delegates. The committees, on the other hand, were free to do as they pleased. After some argument back and forth setting out the familiar advantages and disadvantages of publicity and secrecy, the Assembly decided to permit the committees to meet and deliberate in private but required a record of their debates and decisions to be kept, which should be always available to members of the Assembly and should be published as soon as possible. ${ }^{2}$ As the Assembly did not positively prohibit public committee sessions, the meetings of the Sixth Committee were frequently open to the public. The minutes of the meetings of the other committees were published almost immediately after the meetings. $^{3}$ The principal consideration leading to the decision to permit private discussions in committee was that the

1 Official Journal, I, Special Supplement, January, 1921, 5.

2 Verbatim Record, 3d Plenary Session.

'Procès-Verbaux, Second Committee, First Session; Fourth Committee, Third Session; Sixth Committee, First Session. 
reports of the committees would, in any event, come up for public discussion later in the Assembly.

The First Assembly dealt with many subjects, which may be arranged as subjects having primary importance, subjects given secondary consideration, and miscellaneous topics. ${ }^{1}$ In the first class came the review of the work of the Council; relations between the Assembly and the Council; the technical organizations of the Council and the Secretariat; the Court of International Justice to be created under the League; amendments to the Covenant; and the admission of new states. In the second rank came the questions of disarmament; mandates; economic coercion; and the protection of Armenia. Among miscellaneous details which came to the attention of the Assembly were the proposed use or encouragement of Esperanto, racial equality, and others. On the last two classes of questions nothing much could be or was done; indeed, it was this aspect of practicality, rather than the intrinsic importance of the subjects, that placed them in second and third place in the work of the Assembly. ${ }^{2}$ In connection with economic coercion, where as decisive action was taken as in any case in these classes, the result was only to diminish the amount of control and power exercised by the League under the Covenant. Even on questions of first importance many of the decisions were inconclusive. It was recognized that the Covenant needed revision, but it was felt that the time was not yet ripe for amendments, and there was some doubt as to the proper procedure in the proposed action. ${ }^{3}$ The organizations of the Council and the Secretariat were given approval, but doubts were felt and changes suggested. ${ }^{4}$ So for relations between Council and Assembly; as has been seen, no sharp conclusion was reached or at-

${ }^{1}$ Official Journal, I, Special Supplement, January, 1921, 9-34.

${ }^{2}$ See record of resolutions and decision of First Assembly, Official Journal, as just cited, especially the wording of the resolutions on 12-22.

same, 4.

'Same, 24. 
tempted. Six new states, namely, Albania, Austria, Bulgaria, Costa Rica, Finland, and Luxembourg, were admitted to the League in 1920; but the vital cases of America, Russia, and Germany could not be solved. ${ }^{1}$ The plan for the Court was approved, reluctantly-in view of the absence of obligatory jurisdiction-although such approval could have no legal effect. ${ }^{2}$

What then, did the First Assembly accomplish? It accomplished the principal task to be accomplished by the first meeting of the Assembly: it established its claim to existence, it took on a fixed form, it became an historical fact. The Assembly was to constitute the first permanent, continuous, regular conference of the nations in time of peace having general jurisdiction. Such an organ of international government the world had long needed. The Assembly supplied that need.

On the other hand, the Assembly in 1920 was "ineffectual" - so far as this characterization is accurate at allbecause the function of the Assembly is not to be effectual but deliberative, not to make decisions but to canvass the issues, reflect opinion, and provide for an expression of national feeling on the issues of international life. It appeared "ineffectual" in comparison with the Council because the latter is supposed to be effective in action and really to do things, and because the Council had been in action for ten months before the Assembly met. It appeared "ineffectual" in the larger world problems, as, for that matter, does the Council, because of the continued existence and activity of the Supreme Allied Council, dealing with the major questions of the war and the peacereparations, Silesia, and so on.

Such a conclusion suggests a further observation. While the League was coming into being and into active Sessions.

1. Official Journal, as cited, 28; Verbatim Record, 25th and 29th Plenary Official Journal, I, Special Supplement, January, 1921. 
operation in 1920 the standing institutions of international government outside the League, all of which may eventually be absorbed by the League, but which continue at present fo function independently, were beginning again to operate in their normal manner. International organization in 1920 was not entirely a matter of the League and will not be for some years to come.

Thus, the Supreme Council of the Allies continued to meet during 1920-at San Remo in April; at Spa in July; at London in November. The Council of Ambassadors, auxiliary body to the Supreme Council, and descendant of the Council of Foreign Ministers which split off from the Council of Ten during the Peace Conference, continued to meet in Paris and deal with such matters connected with the peace settlement as were referred to it by the Supreme Council. The Reparation Commission, created by the Treaty of Versailles to supervise the execution of the clauses relating to reparations by Germany, met continuously to perform its task. An Inter-Allied Communications Conference met in Washington in October to discuss the disposition of German cables taken from Germany by the Treaty of Versailles. ${ }^{1}$ And out beyond these inner councils the ordinary diplomatic and consular services were resuming and even expanding their normal activity, and the practice of treaty negotiation was again going forward-as was indicated by the sixty or seventy treaties registered with the Secretariat of the League and published in the first numbers of the Treaty Series of the League. ${ }^{2}$ Administrative bureaus were continuing their partially interrupted activities; private international associations resuming their meetings; and the whole machinery of international political life commencing to operate again after the anarchical paralysis of 1914-19.

1 For meetings of these bodies during 1920 see Levermore, 4, 6, 7, 9, 10, 16,25 , and elsewhere.

Treaty Series, I. 


\section{CHAPTER XXIX}

\section{INTERNATIONAL ORGANIZATION IN 1921}

\section{ATER the meeting of the First Assembly of the A League in December of 1920 there followed a period}

of nine or ten months in the history of international organization, ending in the meeting of the Assembly at Geneva in September and October, 1921, which assumed a character of its own. On one hand, the work of the I eague was carried on continuously by the organs established in 1919 and 1920. ${ }^{1}$ These organs had acquired a feeling of security and stability and routine. They had cleared out of the way the preliminary work of organization, as well as a number of troublesome special questions which would not recur. On the other hand, public attention began to drift away as the novelty of the League wore off, and the work in 1921 sometimes seemed to suffer from public indifference and neglect. Moreover, in certain problems the League had begun to reach below the easy first stages of generalities and to come in contact with the contentious questions beneath. Fewer questions were before the League but these were more difficult to handle than those already settled.

The Secretariat continued to be the backbone of the League. ${ }^{2}$ Its organization remained substantially as it had been created in 1919-20. Its staff was expanding slowly, checked here and there by complaints that too many British or too many French names appeared upon its lists. In-

${ }^{1}$ Report to the Second Assembly of the League on the Work of the Council, being Document No. A.9. 19.21 of the Second Assembly, dated 18 August, 1921, cited hereafter as Report to Second Assembly; and Proceedings of Second Assembly.

- Report to Second Assembly, 83; see also interesting articles by Wambaugh, S., in New York Times, 14 and 21 August, and 4 September, 1921, Section VII, p. 2, in each case. 
dividuals of all nationalities, including several Americans, were to be found at work in the Sections. The correspondence of these Sections increased fivefold over that of the previous year. ${ }^{1}$ Some estimate of the relative importance of the work of the Secretariat may be made on the basis of the fact that the expenses of the Secretariat for 1922 were expected to amount to one-third of the total expenditure of the League. ${ }^{2}$ Council and Assembly, Labor Organization and Permanent Court, all cluster about this extremely useful branch of the League organization.

The Labor Organization, like the Secretariat, has become a permanent, non-political department of the League. The third General Conference of the organization was held in 1921 at Geneva. The Labor Office continued to collect and distribute information and to attempt to supervise international labor conditions. It has prepared one or two questions for consideration by the Permanent Court when that body shall meet. But it is handicapped by the fact that the states have not acted with any great eagerness upon the Draft Conventions signed at Washington in 1919 and at Geneva in 1920, and by the present abnormal industrial conditions. At the same time it may be noted that the expenses of the Labor Organization, which are paid by the League, amount to another third of the expenditure of that organization, or the same amount as those of the Secretariat, or those of the Council, Assembly and other departments combined. ${ }^{3}$

The Council of the League met three times in 1921 before the second meeting of the Assembly, as follows: twelfth session, at Paris, in February and March (ten days); thirteenth session, at Geneva, in June (eleven days); fourteenth session, at Geneva, in August and September (thirty-five days), in conjunction with the second

Report to Second Assembly, 83.

- Official Journal, Special Supplement No. 6, October, 1921, 30.

- Same. An audit of accounts for 1920 is to be found in Official Journal, II, No. 4, 377-379. 
session of the Assembly. ${ }^{1}$ The Council thus met much less frequently than in 1920. On the other hand, its meetings lasted longer each time, the work was better prepared before the meeting, and the transactions in the meeting were carried out with a greater dispatch and effectiveness. The Council is to meet hereafter exclusively at Geneva, as a result of a request of the Assembly in 1920; the meeting at Paris in February, 1921, was a special exception to this rule.

The Council has made an effort to give greater publicity to its deliberations hereafter. ${ }^{2}$ Beginning with the Paris meeting just mentioned, complete minutes of each session have been published, and since the thirteenth session many public meetings have been held not for ceremonial purposes but where questions of special public interest have been discussed. The Assembly was quick to recognize this action in suitable terms when it met in October. ${ }^{3}$

The composition of the Council remained during 1921 as fixed by the Assembly in December, 1920, China taking the place of Greece, along with Belgium, Brazil, and Spain, as a rotating member, and France, Great Britain, Italy, and Japan still making up the permanent membership. The Chairmanship of the Council regularly passes about from the chief representative of one state to that of another, session after session. The only questions still open are those concerning a possible standardization of changes among the rotating members, and the addition of new permanent members. The former has been taken up by the Assembly-for the Assembly has power to select these rotating members according to its own best judgment-the latter will be taken up when Russia, Germany, and the United States approach the pale.

During 1921 the Council dealt with a large number of

1 Official Journal, II, Nos. 2, 7, 8.

Report to Second Assembly, 51-52.

Official Journal, Special Supplement No. 6,

40. 
subjects, as in $1920 .{ }^{1}$ But there appeared a tendency for the agenda of the Council to become stereotyped. Certain subjects appeared on the program regularly at every session. This was true especially among the first and third groups of subjects, as already described-matters of administrative organization and humanitarian questions. ${ }^{2}$ Appointments to, and reports from, various commissions; mandates; and minorities;- - these administrative questions came up at every session, as did the opium traffic, typhus, and relief work in general. It was also true of certain subjects which bulked so large in the work of the Council in 1921 as to deserve to be regarded as a separate group, namely, economic and financial questions. ${ }^{3}$ As the economic and financial restoration of Europe and the world became increasingly important, the Council was compelled to give more and more attention to that problem. And if the matter of reparations had been given to the League, as it logically should have been, instead of to a special Reparations Commission, this effect would have been still clearer.

The political problems of the Council did not diminish in numbers in 1921, nor did they increase, despite the fact that gradually, one after another, certain political problems arising out of the war were finally settled, and notwithstanding, on the other hand, the fact that the Supreme Council still met. The former cause was approximately neutralized by a tendency on the part of the powers to seek the aid of the League rather than that of the Supreme Council, and by the action of the latter in turning the Silesian matter over to the Council itself. ${ }^{4}$

Altogether, it may be said that in the field of political problems the Council was more successful as time went on, and that the danger which was at first feared in this connection did not materialize. In spite of lack of power to

1 Report to Second Assembly, 6-82.

Same, 6-16, 34-38, 41-47, 49, 50, 51, 71, 73, 82.

- Reports of Sessions in Official Journal, II, Nos. 2, 7, 8.

- Report to Second Assembly, 17-34, 74. 
compel obedience to its decisions, and notwithstanding that this condition was a matter of common knowledge, the Council made great progress toward the settlement of the Aaland Islands case and the cases of Vilna, Albania, and Silesia. ${ }^{1}$ This seemed to be due to the fact that the most powerful sanction available-the most powerful when effectively marshaled and applied,-namely, public opinion, was given its chance to operate by the action of the Council in taking up for discussion the contentious problems in dispute. What was needed was a forum, a jurisdiction, rather than a sanction. The Council provided the hearing and the forces of opinion and economic convenience compelled a settlement.

For the rest, the Council undertook or encouraged such humanitarian work as it could, and lent such moral support as it was able to private international projects of promise. $^{2}$

Just how much the Council accomplished by these humanitarian activities is difficult to measure. The number of prisoners repatriated may be numbered in hundreds of thousands, but that tells little of the ultimate value of the work in misery and death avoided. The relief work in Austria and Poland is likewise hard to appraise. All that can be said is that such work should by all means be done, and that if the League accomplished the task effectively it performed a valuable work.

Indeed, such an estimate must still be accepted for most of the work of the Council. The value of the administrative work of that body obviously depends on ulterior results in the months and years to come. Its work in promoting internationalism apart from the League depends for its value in part upon the value of internationalism as such -a question independent of the value of the Council and the League-and upon the extent to which the Council suc-

1 Report to Second Assembly, 17, 20, 29.

'Same, 34-38, 49. 
ceeded in promoting such a movement. The work of the Council in the political sphere can, as such, hardly be assessed at all. The real point of the matter is that international government of this general type is needed and that the work which the Council is doing seems to be eminently suitable for performance by the Council within its general field, with the possible exception of the support of propaganda in favor of the League itself, and with a reservation as to the amount of attention which can profitably be devoted to political questions as such. Only when more time shall have elapsed will a judgment, not upon the general issues but on the specific content of the work of the Council, be possible.

When the Assembly met for its second session in September, 1921, thirty-nine members answered the roll call; of nine absentees, three appeared during the session; three new members added in the course of the session brought the total attendance to forty-five. ${ }^{1}$ It may not be without significance that the absentees-Argentina and Peru, Guatemala, Honduras, Nicaragua, and Salvador-were all from South and Central America.

The members soon found that much work had been prepared in advance, in contrast to conditions of the year before. Besides the official call and agenda sent forth by the Council, there were various matters to come up from the year before or from the Council under the terms of the Covenant. The result was that the Second Assembly was a harder working body than the First.

A further result was a diminution of the number of plenary sessions and of general debate in the Assembly and an increase in committee work. The Assembly created six committees, as in 1920, although one of the committees of 1920 had dealt with the Permanent Court and was not needed in 1921. Its place was taken by a Committee on Humanitarian and Social Questions, not appearing in the

${ }^{1}$ Monthly Summary, No. 6, 106. 
1920 list. Otherwise the list was substantially unchanged. ${ }^{1}$ In spite of the reduction of the plenary sessions and the increase of committee work, less protest was heard concerning secrecy than in 1920, partly because the critics were not quite so sensitive on the subject in regard to this, the second, meeting as they had been with respect to the first, partly because the matters to be discussed had been rather fully considered in the period before the Assembly met, but chiefly because of a factor noted in connection with the First Assembly, namely, the knowledge that all matters must, in any event, come up for debate in the Assembly before final action.

The attention of the Second Assembly ranged over a very wide field. The matters discussed and acted upon may be grouped under the same heads as those used to describe the work of the Council; questions of organization and administration in the League, political questions, and humanitarian questions, with economic and financial questions a possible fourth group. We may review briefly what the Second Assembly accomplished under these different headings.

In the matter of amendments the Second Assembly appeared to be as bold as the First had been timid. ${ }^{2}$ Many proposals had been made in the First Assembly and, in writing, to a Committee on Amendments, which had sat during the year and was now ready to report. Most of the proposals were fully discussed by the Second Assembly and some twelve distinct resolutions were adopted, by threefourths votes in each case, proposing to the Members of the League changes in the Covenant. These proposals related to Article XXVI itself and aimed to make the text of that article less ambiguous ; ${ }^{3}$ to Article IV, with a view to defining more clearly the power of the Assembly over

${ }^{1}$ Monthly Summary, No. 6, 7-8.

2 Official Journal, Special Supplement No. 6, October, 1921, 9-15.

same, 9. 
the choice of the rotating members of the Council $;^{1}$ to Article VI, in order to increase the power of the Assembly over the amounts to be paid by members in defraying the League expenses and to redefine those contributions; ${ }^{2}$ to Articles XII, XIII, and XV, so as to provide for the addition of the Permanent Court to the means of settlement available to Members; ${ }^{3}$ and to Article XVI, so as to give the Council considerable power to invoke the economic weapon of the League (blockade) when necessary, and to supervise and regulate its application. ${ }^{4}$ At the same time the Assembly refused to accept the radical amendment of Argentina relating to membership in the League, ${ }^{5}$ as well as less radical but very important Scandinavian proposals relating to the plan of conciliation under the League. ${ }^{\circ}$ Finally, the Committee on Amendments was instructed to continue its work and further consideration was to be given at the next Assembly to proposals for amending Article X. Evidently, and this is a hopeful sign, the Covenant is to be thoroughly revised from time to time if the Assembly can have its way. It will be interesting to note the reception accorded these proposals by the Members of the League to whom they are referred for ratification.

One of these proposals, it will be noted, relates to the power of the Assembly over the composition of the Council. During the debate it was quite evident that the Second Assembly intended to exercise its power under the Covenant to the full extent, and in reëlecting Belgium, Brazil, China, and Spain as rotating member of the Council the Assembly took an attitude which left no doubt as to who was master in the situation. ${ }^{8}$ Yet it must be said that, in

${ }^{1}$ Official Journal, Special Supplement No. 6, October, 1921, 10.

Same, 11.

Same, 12.

- Same, 13-15.

- Same, 10.

- Same, 10, 14.

' Same, 12, 15.

- Same, 18. 
general, the relations between Assembly and Council were better in 1921 than in 1920, again due to a diminution of the sensitiveness of all concerned, and to the coöperation of the preceding months. The Assembly made certain recommendations to the Council, ${ }^{1}$ but no open dispute appeared similar to that of 1920 over mandates.

On many matters the Assembly was impotent to take any decisive action and could only make suggestions to the Council or adopt pious resolutions of hope. ${ }^{2}$ In one or two cases such as the problem of the relation of petty states, of the type of Monaco and Andorra, to the League, the Assembly could not act for lack of data and understanding. In regard to the technical organizations of the Council or Secretariat, such as the Economic and Financial Commission, and the Health Organization, nothing could be done by the Assembly because no decisions were due to be made or action taken in any case. In regard to the work of the Armaments Commission fundamental political facts precluded any action by the Assembly. In regard to Russian relief, in the Albanian question, and in several other cases, the Assembly could but hope that those immediately in charge would succeed in settling the difficulty. Only where it was given definite power to act-as in the election of Members to the League and to the Council-could the Assembly strike out with confidence. ${ }^{3}$

It was in the exercise of its power of election that the Second Assembly performed its next most important task in helping to create the Permanent Court of International Justice. ${ }^{4}$ When it became apparent that the Statute of the

Official Journal, Special Supplement No. 6, October, 1921, 19-22, 28-34.

Same, entire, for resolutions of Second Assembly.

The Second Assembly pretended to rule upon certain purely legal questions. In this connection it may be doubted whether the Assembly could claim formal legislative power; only the future will reveal the force of the Assembly's dicta that Article XVI of the Covenant does not mean that a state of war automatically supervenes in the case described, and that domicile, not nationality, is the test to be employed in interpreting the first paragraph thereof; Official Journal, as cited, 24, 26.

"Same, 41. 
Court would be ratified by a number of states sufficient to insure its effectiveness, the Council had called upon the nations to nominate candidates for the Court and these nominations were in readiness in September. ${ }^{1}$ Coöperating with the Council, meeting at the time across the Lake, and in constant telephonic communication with it, the Assembly now helped to elect the eleven judges and four deputy judges required under the Statute of the Court. ${ }^{2}$ As was inevitable, political and national considerations were important in determining the voting. In the result, the Spanish element became very prominent in the Court-a phenomenon noted by some in the League as a whole-and the British Dominions did not secure representation on the bench at all, while both Roumania and Jugoslavia did so. On the other hand, substantially every important legal system and legal tradition was included. The possible disagreement between Assembly and Council already noted ${ }^{3}$ appeared at the very end, in the choice of the fourth deputy. It was not wholly an accident that the contest lay between Alvarez of Chile and Descamps of Belgium, or that the matter was settled, by means of the Committee of Mediation provided in the Statute, by electing Beichmann of Norway. Thus the Assembly and Council accomplished what the Second Hague Conference could not do; it chose a selected group of jurists to act as a world court.

Again exercising its powers of election the Second Assembly admitted Esthonia, Latvia, and Lithuania to the League, thereby bringing the membership up to fifty-one. ${ }^{4}$

It will be noted that the Assembly performed its most useful work in the field of organization. That is accountable partly by the fact that the Assembly was created primarily to act as a constituent body, as the lower houses of

Official Journal, II, No. 5-6, 418.

- For the text of the Statute as finally ratified see Same, II, No. 1, 14-25 (January-February, 1921).

Above, Chap. XVI, pp. 260-261.

- Official Journal, as cited, 35. 
parliaments act in Europe today, and partly by the fact that it has no executive arms. It was also due to the fact that the League is still young and problems of organization still bulk large in the work of the League and in the work of all of its branches.

During 1921 the practice of international government by bodies outside the League continued to regain its normal scope and power.

The Supreme Council of the Allies met at Paris in January and February, at London in February and March, at London again in April and May, and again at Paris in August. ${ }^{1}$ The principal subjects of discussion were the disarmament of Germany, the payment of reparations by Germany, the Greco-Turkish war, Austrian financial conditions, Silesia, and Russian relief. An agreement was reached on the first subject in January and the agreement put into effect through the Commission in charge of enforcing the disarmament clauses of the Treaty of Versailles. The reparations problem was not given even a semblance of effective treatment until the third conference, and by the end of 1921 even the London agreement of May, 1921, began to appear of doubtful value and finality. The Silesian problem was finally turned over to the Council of the League for settlement, and no effective settlements were reached with regard to Turkey, Russia, or Austria. The Supreme Council naturally lost credit somewhat during this succession of conferences, and the League tended to gain credit by contrast, partly because of its successful handling of the Silesian question, and partly because it appeared to be free from the political handicaps which prevented effective action by its rival.

The Council of Ambassadors continued to meet and deal with different phases of various questions, such as Silesia, German disarmament, Albania, the Baranya, and

${ }^{1}$ New York Times, 8 January, 8 February, 26 January, 21 March, 20 April, 6 May, 5-13 August, 1921. 
others, which were turned over to it by the Supreme Council, or-in the case of Albania-by the Council of the League. ${ }^{1}$ The Council of Ambassadors was still unimportant in comparison with the two greater councils, the $\mathrm{Su}$ preme Council and the Council of the League, and in those cases where it was found to be specially useful this resulted from its resemblance to the latter rather than to the former.

The Reparation Commission and other bodies created by the Treaty of Versailles continued to carry on their work, partly in coöperation with the League, partly in competition with it. In October, 1921, it was still true that several problems left over by the World War continued to demand special attention and continued to exert their distracting influence upon normal international coöperation.

At the same time, severe general international conferences were held, one at Washington, to deal with the subject of international cable communications-a continuation of the conference begun in October, 1920-; one at Barcelona, to deal with various questions connected with land transportation in Europe; and one at Geneva, to deal with the white slave traffic. The last two conferences were held on the initiative of the League. ${ }^{2}$

Finally, the ordinary processes of treaty negotiation and diplomacy continued to gain momentum as war conditions died away and normal relations were resumed. In spite of all the instability and uncertainty, the want and distress still surviving as a legacy of the War, the practice of international government continued to regain its full stature and to expand still further, both through the League and apart from that organization. And as 1921 drew to a close there convened in Washington a conference which might open an entirely new chapter in the development

${ }^{1}$ New York Times, 1, 4, 8 January; 10 May; 26, 27 June; 21 July; 18 August, 1921.

'Same, 5 February, 19 March, 1921; Official Journal, II, No. 3, 290, and No. 7,697 ; No. 5-6, 596 . 
510

INTERNATIONAL ORGANIZATION

of general international organization, whether under the auspices of the League, or apart from it but in cooperation with it, or, finally, by way of supplanting it with some other form of international association. The outcome must be left to the future.

3 he

4 


\section{APPENDIX A}

\section{DOCUMENTS ILLUSTRATING THE DEVELOPMENT OF INTERNATIONAL ORGANIZATION.}

\section{No. 1. Consular Convention between the United States and Sweden, $1910 .^{1}$}

The President of the United States of America and His Majesty the King of Sweden, being mutually desirous of defining the rights, privileges, and immunities of consular officers of the two countries, and deeming it expedient to conclude a consular convention for that purpose, have accordingly named as their Plenipotentiaries:

The President of the United States of America, Philander C. Knox, Secretary of State of the United States of America; and

His Majesty the King of Sweden, Herman Ludvig Fabian de Lagercrantz, his Envoy Extraordinary and Minister Plenipotentiary at Washington;

Who, after having communicated to each other their respective full powers, found to be in good and proper form, have agreed upon the following articles:

\section{Article I.}

Each of the High Contracting Parties agrees to receive from the other consuls-general, consuls, vice-consuls-general, vice-consuls, deputy consuls-general, deputy consuls, and consular agents in all its ports, cities, and places, except those where it may not be convenient to recognize such officers. This reservation, however, shall not apply to one of the High Contracting Parties without also applying to every other power.

\section{Article II.}

The consuls-general, consuls, vice-consuls-general, vice-consuls, deputy consuls-general, deputy consuls, and consular agents of each

${ }^{1}$ U. S. S. L., XXXVII, 1479; see, above, text, Chap. VI. 
of the two High Contracting Parties shall enjoy reciprocally, in the States of the other, all the privileges, exemptions, and immunities that are enjoyed by officers of the same rank and quality of the most favored nation. The said officers, before being admitted to the exercise of their functions and the enjoyment of the immunities thereto pertaining, shall present their commissions in the forms established in their respective countries. The Government of each of the two High Contracting Parties shall furnish the necessary exequatur free of charge, and, on the exhibition of this instrument, the said officers shall be permitted to enjoy the rights, privileges, and immunities granted by this Convention.

\section{Article III.}

Consuls-general, consuls, vice-consuls-general, vice-consuls, deputy consuls-general, deputy consuls, and consular agents, citizens of the State by which they are appointed, shall be exempt from arrest except in the cases of offenses which the local legislation qualifies as crimes and punishes as such; they shall be exempt from military billetings, service in the Regular Army or Navy, in the militia, or in the national guard; they shall likewise be exempt from all direct taxes-national, State, or municipal-imposed upon persons, either in the nature of a capitation tax or in respect to their property, unless such taxes become due on account of the possession of real estate, or for interest on capital invested in the country where said officers exercise their functions, or for income from pensions of a public or private nature enjoyed from said country. This exemption shall not, however, apply to consuls-general, consuls, vice-consuls-general, vice-consuls, deputy consuls-general, deputy consuls, or consular agents engaged in any profession, business, or trade; but the said officers shall in such ease be subject to the payment of the same taxes that would be paid by any other foreigner under the like circumstances.

\section{Article IV.}

When in a civil case a court of one of the two countries shall desire to receive the judicial declaration or deposition of a consulgeneral, consul, vice-consul, or consular agent, who is a eitizen of 
the State which appointed him, and who is engaged in no com-. mercial business, it shall request him, in writing, to appear before it, and in case of his inability to do so it shall request him to give his testimony in writing, or shall visit his residence or office to obtain it orally, and it shall be the duty of such officer to comply with this request with as little delay as possible; but in all criminal cases, contemplated by the sixth article of the amendments to the Constitution of the United States, whereby the right is secured to persons charged with crimes to obtain witnesses in their favor, the appearance in court of said consular officers shall be demanded, with all possible regard to the consular dignity and to the duties of his office, and it shall be the duty of such officer to comply with said demand. A similar treatment shall also be extended to the consuls of the United States in Sweden, in the like cases.

\section{Article V.}

Consuls-general, consuls, vice-consuls-general, vice-consuls, deputy consuls-general, deputy consuls, and consular agents may place over the outer door of their offices the arms of their nation, with this inseription: Consulate-General, or Consulate, or ViceConsulate, or Consular Agency of the United States or of Sweden.

They may also raise the flag of their country on their offices, except in the capital of the country when there is a legation there. They may in like manner raise the flag of their country over the boat employed by them in the port and for the exercise of their functions.

\section{Article VI.}

The consular offices shall at all times be inviolable. The local authorities shall not, under any pretext, invade them. In no case shall they examine or seize the papers there deposited. In no case shall those offices be used as places of asylum. When a consular officer is engaged in other business, the papers relating to the consulate shall be kept separate. Nor shall consular officers be required to produce the official archives in court or to testify as to their contents. 


\section{Article VII.}

In the event of the death, incapacity, or absence of consulsgeneral, consuls, vice-consuls-general, vice-consuls, and consular agents, their chancellors or secretaries, whose official character may have previously been made known to the Department of State at Washington or to the Ministry for Foreign Affairs in Sweden, may temporarily exercise their functions, and while thus acting shall enjoy all the rights, prerogatives, and immunities granted to the incumbents.

\section{Article VIII.}

Consuls-general and consuls may, so far as the laws of their country allow, with the approbation of their respective Governments, appoint vice-consuls-general, deputy consuls-general, viceconsuls, deputy consuls, and consular agents in the cities, ports, and places within their consular district. These agents may be selected from among citizens of the United States or of Sweden, or those of other countries. They shall be furnished with a regular commission, and shall enjoy the privileges stipulated for consular officers in this convention, subject to the exceptions specified in Article III.

\section{Article IX.}

Consuls-general, consuls, vice-consuls-general, vice-consuls, and consular agents shall have the right to address the authorities whether, in the United States, of the Union, the States, or the municipalities, or in Sweden, of the State, the Provinces, or the commune, throughout the whole extent of their consular district in order to complain of any infraction of the treaties and conventions between the United States and Sweden, and for the purpose of protecting the rights and interests of their countrymen. If the complaint should not be satisfactorily redressed, the consular officers aforesaid, in the absence of a diplomatic agent of their country, may apply directly to the Government of the country where they exercise their functions.

\section{Article $\mathbf{X}$}

Consuls-general, consuls, vice-consuls-general, vice-consuls, deputy consuls-general, deputy consuls, and consular agents of the 
respective countries may, as far as may be compatible with the laws of their own country, take at their offices, their private residences, at the residence of the parties concerned, or on board ship, the depositions of the captains and crews of the vessels of their own country and of passengers thereon, as well as the depositions of any citizen or subject of their own country; draw up, attest, certify, and authenticate all unilateral acts, deeds, and testamentary dispositions of their countrymen, as well as all articles of agreement or contracts to which one or more of their countrymen is or are party; draw up, attest, certify, and authenticate all deeds or written instruments which have for their object the conveyance or encumbrance of real or personal property situated in the territory of the country by which said consular officers are appointed, and all unilateral acts, deeds, testamentary dispositions, as well as articles of agreement or contracts relating to property situated or business to be transacted in the territory of the nation by which the said consular officers are appointed; even in cases where said unilateral acts, deeds, testamentary dispositions, articles of agreement, or contracts are executed solely by citizens or subjects of the country within which said consular officers exercise their functions.

All such instruments and documents thus executed and all copies and translations thereof, when duly authenticated by such consul-general, consul, vice-consul-general, vice-consul, deputy consul-general, deputy consul, or consular agent under his official seal, shall be received as evidence in the United States and in Sweden as original documents or authenticated copies, as the case may be, and shall have the same force and effect as if drawn up by and executed before a notary or public officer duly authorized in the country by which said consular officer was appointed; provided, always, that they have been drawn and executed in conformity to the laws and regulations of the country where they are intended to take effect.

\section{Article XI.}

The respective consuls-general, consuls, vice-consuls-general, vice-consuls, deputy consuls-general, deputy consuls, and consular agents shall have exclusive charge of the internal order of the 
merchant vessels of their nation, and shall alone take cognizance of any differences which may arise, either at sea or in port, between the captains, officers, and crews, without exception, particularly in reference to the adjustment of wages and the execution of contracts. The local authorities shall not interfere, except when the disorder that has arisen is of such a nature as to disturb tranquillity and public order on shore or in the port, or when a person of the country or not belonging to the crew shall be concerned therein.

In all other cases the aforesaid authorities shall confine themselves to lending aid to the said consular officers, if they are requested by them to do so, in causing the arrest and imprisonment of any person whose name is inscribed on the crew list whenever, for any cause, the said officers shall think proper.

\section{Article XII.}

The respective consuls-general, consuls, vice-consuls-general, vice-consuls, deputy consuls-general, deputy consuls, and consular agents may cause to be arrested the officers, sailors, and all other persons making part of the erews in any manner whatever, of ships of war or merchant vessels of their nation, who may be guilty, or be accused, of having deserted said ships and vessels, for the purpose of sending them on board or back to their country. To this end they shall address the competent local authorities of the respective countries, in writing, and shall make to them a written request for the deserters, supporting it by the exhibition of the register of the vessel and list of the crew, or by other official documents, to show that the persons claimed belong to the said ship's company. Upon such request thus supported, the delivery to them of the deserters can not be refused, unless it should be duly proved that they were citizens of the country where their extradition is demanded at the time of their being inscribed on the erew list. All the necessary aid and protection shall be furnished for the pursuit, seizure, and arrest of the deserters, who shall even be put and kept in the prisons of the country, at the request and expense of the consular officers, until there may be an opportunity for sending them away. If, however, such an opportunity should not present itself within the space of two months, counting from 
the day of the arrest, the deserters shall be set at liberty, nor shall they be again arrested for the same cause.

If the deserter has committed any misdemeanor, and the court having the right to take cognizance of the offense shall claim and exercise it, the delivery of the deserter shall be deferred until the decision of the court has been pronounced and executed.

\section{Article XIII.}

All proceedings relative to the salvage of vessels of the United States wrecked upon the coasts of Sweden, and of Swedish vessels wrecked upon the coasts of the United States, shall be directed by the consuls-general, consuls, vice-consuls-general, and vice-consuls of the two countries, respectively, and until their arrival by the respective consular agents, wherever an agency exists. In the places and ports where an agency does not exist, the local authorities until the arrival of the consular officer in whose district the wreck may have occurred, and who shall be immediately informed of the occurrence, shall take all necessary measures for the protection of persons and the preservation of wrecked property. The local authorities shall not otherwise interfere than for the maintenance of order, the protection of the interests of the salvors, if these do not belong to the crews that have been wrecked, and to carry into effect the arrangements made for the entry and exportation of the merchandise saved. It is understood that such merchandise is not to be subjected to any custom-house charges, unless it be intended for consumption in the country where the wreck may have taken place.

The intervention of the local authorities in these different cases shall occasion no expense of any kind, except such as may be caused by the operations of salvage and the preservation of the goods saved, together with such as would be incurred under similar circumstances by vessels of the nation.

\section{Article XIV.}

In case of the death of any citizen of Sweden in the United States or of any citizen of the United States in the Kingdom of Sweden without having in the country of his decease any known heirs or testamentary executors by him appointed, the competent 
local authorities shall at once inform the nearest consular officer of the nation to which the deceased belongs of the circumstances, in order that the necessary information may be immediately forwarded to parties interested.

In the event of any citizens of either of the two Contracting Parties dying without will or testament, in the territory of the other Contracting Party, the consul-general, consul, vice-consulgeneral, or vice-consul of the nation to which the deceased may belong, or, in his absence, the representative of such consul-general, consul, vice-consul-general, or vice-consul, shall, so far as the laws of each country will permit and pending the appointment of an administrator and until letters of administration have been granted, take charge of the property left by the deceased for the benefit of his lawful heirs and creditors, and, moreover, have the right to be appointed as administrator of such estate.

It is understood that when, under the provisions of this article, any consul-general, consul, vice-consul-general, or vice-consul, or the representative of each or either, is acting as executor or administrator of the estate of one of his deceased nationals, said officer or his representative shall, in all matters connected with, relating to, or growing out of the settlement of such estates, be in such capacities as fully subject to the jurisdiction of the courts of the country wherein the estate is situated as if said officer or representative were a citizen of that country and possessed of no representative capacity whatsoever.

The citizens of each of the Contracting Parties shall have power to dispose of their personal goods within the jurisdiction of the other, by sale, donation, testament, or otherwise, and their representatives, being citizens of the other Party, shall succeed to their personal goods, whether by testament or $a b$ intestato, and they may in accordance with and acting under the provisions of the laws of the jurisdiction in which the property is found take possession thereof, either by themselves or others acting for them, and dispose of the same at their will, paying such dues only as the inhabitants of the country wherein such goods are shall be subject to pay in like cases.

As for the case of real estate, the citizens and subjects of the two Contracting Parties shall be treated on the footing of the most-favored nation. 


\section{Article XV.}

The present convention shall remain in force for the space of ten years, counting from the day of the exchange of ratifications, which shall be made in conformity with the respective Constitutions of the two countries, and exchanged at Washington as soon as possible within the period of one year. In case neither Party gives notice, twelve months before the expiration of the said period of ten years, of its intention not to renew this Convention, it shall remain in force one year longer, and so on, from year to year, until the expiration of a year from the day on which one of the Parties shall have given such notice.

In faith whereof the respective Plenipotentiaries have signed this Convention, and have hereunto affixed their seals.

Done in duplicate at the City of Washington this first day of June, one thousand nine hundred and ten.

No. 2. Regulations of Vienna, 1815, and of Aix-la-Chapelle, 1818, concerning Diplomatic Rank. ${ }^{1}$

In order to prevent in the future the inconveniences which have frequently occurred, and which may still occur, from the claims of Precedence among the different Diplomatic characters, the Plenipotentiaries of the Powers who signed the Treaty of Paris have agreed on the following Articles, and think it their duty to invite those of other Crowned Heads to adopt the same regulations :

\section{Article I.}

Diplomatic characters are divided into three classes:

That of Ambassadors, Legates, or Nuncios.

That of Envoys, Ministers, or other persons accredited to Sovereigns.

That of Chargés d'Affaires accredited to Ministers for Foreign Affairs.

\section{Article II.}

Ambassadors, Legates, or Nuncios only shall have the Representative character.

${ }^{1}$ U. S. Diplomatic Instructions, § 18; sce, above, text, Chap. VIII. 


\section{Article III.}

Diplomatic characters charged with any special mission shall not, on that account, assume any superiority of rank.

\section{Article IV.}

Diplomatic characters shall rank in their respective classes according to the date of the official notification of their arrival.

The present Regulation shall not occasion any change respecting the Representative of the Pope.

\section{Article V.}

There shall be a regular form adopted by each State for the reception of Diplomatic Characters of every class.

\section{Article VI.}

Ties of consanguinity or family alliance between Courts confer no rank on their Diplomatic Agents. The same rule also applies to political alliances.

\section{Article VII.}

In Acts or Treaties between several Powers that admit alternity, the order which is to be observed in the signatures of Ministers shall be decided by ballot.

\section{Article VIII.}

It is agreed between the Five Courts that Ministers Resident accredited to them shall form, with respect to their Precedence, an intermediate class between Ministers of the Second Class and Chargés d'Affaires.

No. 3. American Foreign Service and Foreign Diplomatic and Consular Representatives in the United States, December, 1916.

\section{a. Diplomatic Service of the United States. ${ }^{1}$}

\section{Argentina Buenos Aires A. E. \& P.;2 2 Secs.; C. M. N. Atts.}

${ }^{1}$ Register, 15 December, 1916, 27-31; see, above, text, Chap. VIII.

A. E. and P.: Ambassador Extraordinary and Plenipotentiary. E. E. and M. P.: Envoy Extraordinary and Minister Plenipotentiary. Att.: Attaché. C.: Commercial. C. G.: Consul General. Couns.: Counsellor. M.: Military. N.: Naval. Sec.: Secretary. St. Int.: Student Interpreter. 


$\begin{array}{ll}\text { Austria-Hungary } & \text { Vienna } \\ \text { Belgium } & \begin{array}{l}\text { Brussels } \\ \text { Lolivia } \\ \text { Brazil }\end{array} \\ \begin{array}{l}\text { Rulgaria de Janeiro } \\ \text { Chile }\end{array} & \begin{array}{l}\text { See Roumania } \\ \text { Santiago }\end{array} \\ \text { China } & \text { Peking } \\ \text { Colombia } & \text { Bogota } \\ \text { Costa Rica } & \text { San Jose } \\ \text { Cuba } & \text { Habana }\end{array}$

Denmark Copenhagen

A. E. \& P.; Couns. ; 5 Secs.; M. N. Atts.

E. E. \& M. P. ; Sec.; C. Att. E. E. \& M. P.; Sec.; C. Att. A. E. \& P.; 2 Secs.: C. N. Atts.

A. E. \& P.; 1 Sec.; C. M. Atts.

E. E. \& M.P.; 4 Sees.; C. M. 2 N. Atts. ; 8 St. Ints.

E. E. \& M. P.; Sec.; M. Att. E. E. \& M. P.; Sec.; M. Att. E. E. \& M. P.; 2 Secs.; M. Att.

E. E. \& M. P.; Sec.; C. M. Att.

Dominican Republic Santo Domingo E. E. \& M. P.; Sec.

Ecuador Quito

France Paris

E. E. \& M. P.; Sec.; C. Att.

A. E. \& P. ; Couns.; 4 Secs.; C. M. 2 N. Atts.

German Empire Berlin

Great Britain London

Greece

Guatemala

Haiti

Honduras

Italy

Athens

Guatemala

Port au Prince

Tegucigalpa

Rome

Japan

Tokyo

Liberia

Luxemburg

Mexico

Montenegro

Morocco

Netherlands

Nicaragua

Norway

Panama

Paraguay

Perșia

Monrovia

See Netherlands

Mexico

See Greece

Tangier

The Hague

Managua

Christiania

Panama

Asuncion

Teheran
A. E. \& P.; Couns. ; 6 Secs. ; C. M. 2 N. Atts.

A. E. \& P.; Couns. ; 7 Secs. ; C. 2 M. 3 N. Atts.

E. E. \& M. P.; Sec. ; M. Att. E. E. \& M. P.; Sec.; M. Att. E. E. \& M. P.; Sec.

E. E. \& M. P.; Sec.; M. Att. A. E. \& P.; Couns.; 2 Secs. ; M. N. Atts.

A. E. \& P.; 4 Secs.; 6 M. 2 N. Atts.

Minister Resident \& C. G. ; Sec.; M. Att.

A. E. \& P.; Sec.

E. E. \& M. P.

E. E. \& M. P. ; Sec. ; C. M. N. Atts.

E. E. \& M. P.; Sec. ; M. Att. E. E. \& M. P.; Sec.; C. M. Atts.

E. E. \& M. P.; Sec.

E. E. \& M. P.; Sec.; C. Att.

E. E. \& M. P.; Sec. 


\begin{tabular}{|c|c|c|}
\hline Peru & Lima & E. E. \& M. P.; Sec. ; C. Att. \\
\hline Portugal & Lisbon & E. E. \& M. P.; Sec.; C. Att. \\
\hline Roumania & Bucharest & $\begin{array}{l}\text { E. E. \& M. P.; } 3 \text { Secs.; M. } \\
\text { Att. }\end{array}$ \\
\hline Russia & Petrograd & $\begin{array}{l}\text { A. E. \& P.; Couns. ; } 4 \text { Secs.; } \\
\text { C. M. } 2 \text { N. Atts. }\end{array}$ \\
\hline Salvador & San Salvador & E. E. \& M. P.; Sec. ; M. Att. \\
\hline Serbia & See Roumania & \\
\hline Siam & Bangkok & $\begin{array}{l}\text { E. E. \& M.P.; Sec.; Inter- } \\
\text { preter. }\end{array}$ \\
\hline Spain & Madrid & $\begin{array}{l}\text { A. E. \& P.; Couns. ; Sec. ; C. } \\
\text { M. Atts. }\end{array}$ \\
\hline Sweden & Stockholm & $\begin{array}{l}\text { E. E. \& M. P.; Sec.; C. M. } \\
\text { Atts. }\end{array}$ \\
\hline Switzerland & Berne & $\begin{array}{l}\text { E. E. \& M. P.; Sec.; C.M. } \\
\text { Atts. }\end{array}$ \\
\hline Turkey & Constantinople & $\begin{array}{l}\text { A. E. \& P. ; Couns. ; } 4 \text { Sees. ; } \\
\text { M. Att.; } 2 \text { Stud. Ints. }\end{array}$ \\
\hline Egypt & Cairo & Agent \& C. G. \\
\hline $\begin{array}{l}\text { Uruguay } \\
\text { Venezuela }\end{array}$ & Montevideo & E. E. \& M. P.; Sec. ; C. Att. \\
\hline $\begin{array}{l}\text { Venezuela } \\
\text { Department }\end{array}$ & Caracas & $\begin{array}{l}\text { E. E. \& M. P.; Sec.; M. Att. } \\
4 \text { Secs. }\end{array}$ \\
\hline Unassigned & & 6 persons. \\
\hline
\end{tabular}

b. Foreign Diplomatic Representatives in the United States ${ }^{\text {I }}$
Argentina
Austria-Hungary
A. E. \& P.; ${ }^{2}$ Couns.; 2 Secs. ; M. N. Atts.
Belgium
Bolivia Couns. \& Ch.; 2 Sees.; N. Att.; Att. E. E. \& M. P.; Couns. ; Att.
Brazil E. E. \& M.P.
Bulgaria
Chile
A. E. \& P. ; Couns. ; 3 Secs.
E. E. \& M. P. ; Sec.; Att.
China
Colombia
A. E. \& P.; Couns. \& Ch. ; Sec. ; C. M. N. Atts.
Costa Rica
E. E. \& M. P.; Couns. ; 3 Sees. ; Att.
Cuba
E. E. \& M. P.; Sec
Denmark
E. E. \& M. P.; Sec.
E. E. \& M. P.; 2 Secs.
E. E. \& M. P.; Att.
Dominican Republic E. E. \& M. P.; Sec. Ecuador E. E. \& M. P.; 2 Secs.
1 Register, 1916, 181-185; see, above, text, Chap. VIII.
A. E. and P.: Ambassador Extraordinary and Plenipotentiary. E. E. and M. P.: Envoy Extraordinary and Minister Plenipotentiary. Att.: Attaché. C.: Commercial. Ch.: Chargé d'Affaires. Couns.: Counsellor, M.: Military. N.: Naval. Sec.: Secretary. 
France

Germany

Great Britain

Greece

Guatemala

Haiti

Honduras

Italy

Japan

Netherlands

Nicaragua

Norway

Panama

Paraguay

Persia

Peru

Portugal

Russia

Salvador

Siam

Spain

Sweden

Switzerland

Turkey

Uruguay

Venezuela
A. E. \& P.; Couns. ; 3 Secs. ; C. M. N. Atts. ; Att.

A. E. \& P.; 2 Couns.; 2 Secs. ; C. Att. ; Att.

A. E. \& P.; Couns.; 6 Secs.; M. 2 N. Atts. ; 2 Atts.

Ch.; Sec.

E. E. \& M. P.; Sec.

E. E. \& M. P.; Sec.

E. E. \& M. P.; Sec.

A. E. \& P.; Couns. ; 2 Sees. ; C. Att. ; Att.

A. E. \& P.; Couns.; 2 Secs.; M. N. Atts.; 2 Atts.

E. E. \& M. P.; 2 Atts.

E. E. \& M.P.; Ch.

E. E. \& M. P.; Sec.

E. E. \& M. P.; Sec.; Att.

E. E. \& M. P. ; Att.

E. E. \& M. P.; Couns. ; 2 Secs.

E. E. \& M.P.; Ch.

E. E. \& M. P.

A. E. \& P. ; Couns. ; 3 Secs. ; 2 C. M. 3 N. Atts. ; Att.

E. E. \& M. P.; Sec.

E. E. \& M. P.; Sec.; 2 Atts.

A. E. \& P. ; Couns. ; Sec. ; M. Att.

E. E. \& M. P.; Couns.; Sec.

E. E. \& M. P.; Sec.

A. E. \& P.; Sec. \& Ch.; Sec.

E. E. \& M. P.; Sec.

E. E. \& M. P.; Sec.

\section{c. Consular Service of the United States. ${ }^{1}$}

5 Consuls General at Large

For: North America; South and Central America; Western Europe; Eastern Europe, Asia Minor, and Africa; and the Far East.

\section{Argentina}
Buenos Aires
Rosario
C. G. $;^{2} 3$ V.C.
C.; V. C.

1 Register, 1916, 41-59; see, above, text, Chap. VI.

2 C. G.: Consul General. C.: Consul. V. C.: Vice Consul. Agt.: Consular Agent. Mar.: Marshal. St. Int: Student Interpreter. 


\section{Austria-Hungary}

Budapest, Hungary

Carlsbad, Bohemia, Austria

C. G.; C.; V. C.

Fiume, Hungary

C.; V. C.

Prague, Bohemia, Austria

Reichenberg, Bohemia, Austria

Trieste, Coastland, Austria

Vienna, Lower Austria

C.; V.C.

C.; V.C.

C.; V.C.

C.; V. C.

C. G.; 2 V. C.

Belgium

Antwerp

Brussels

C. G.; V. C.

Ghent

C. G.; V.C.

Liege

C.; V. C.

C.; V.C.

\section{Brazil}

Bahia

Para

Pernambuco

Rio de Janeiro

Rio Grande do Sul

Santos

São Paulo
C.; V. C.
C.; 2 V. C. ; 3 Agts. ${ }^{1}$
C.; V. C.
C. G.; 2 V. C. ; Agt.
C.
C. ; V. C.
C.; V. C.

\section{Bulgaria}

Sofia

C. G.

\section{Chile}

Antofagasta

Punta Arenas

Valparaiso
C. ; 2 V. C. ; 2 Agts.
C.; V. C.
C. G.; 2 V. C. ; 4 Agts.

\section{China}

\section{Amoy \\ Antung \\ Canton}

C. ; V. C. ; Mar.

C. ; V. C.; St. Int.

C. G. ; 2 V. C. ; Mar. ; Interpreter.

* Consular Agents are stationed at outlying points and report to the consular officers at a central point. Thus, the three Agents reporting to the Consul at Para are stationed at Cears, Manaos, and Maranhăo, the agents reporting to the Consul at Calais, France (below), are stationed at Boulogne and Dunkirk, and so on. In this way consular representatives are stationed in many more cities than those actually named in these tables. For details see Register, as cited, 
Changsha

Chefoo

Chungking

Foochow

Hankow

Harbin

Mukden

Nanking

Shanghai

Swatow

Tientsin

Barranquilla

Cartagena

Port Limon

San Jose

Cienfuegos

Habana

Santiago de Cuba
C.

C.; V. C. ; Mar.; Interpreter.

C.; V. C.

C.; V. C.

C. G. ; 2 V. C. ; Mar. ; Interpreter

C.; V. C.

C. G. ; V. C.

C.; V. C.

C.G.; 7 V.C. ;Mars. ; Interpreters.

C. ; V. C. ; Interpreter

C. G. ; 3 V. C. ; Mar. ; Interpreter.

Colombia

2 C.; 3 Agts.

C.; V. C.

Costa Rica

C.; V. C.

C.; V. C. ; Agt.

\section{Cuba}
C.; V. C.; 2 Agts.
C. G.; 4 V. C.; 3 Agts.
C.; V. C. ; 4 Agts.

\section{Denmark and Dominions}

Copenhagen

St. Thomas, West Indies
C. G.; V. C.

C.; V. C.; Agt.

Daminican Republic

Puerto Plata

Santo Domingo

\section{Ecuador}

Guayaquil

$$
\text { C. G. ; V. C. ; } 2 \text { Agts. }
$$

\section{France and Dominions}

Algiers, Algeria

Bordeaux

Calais

Dakar, Senegal
C.; V. C. ; Agt.

C.; 3 V. C. ; Agt.

C.; 2 V. C.; 2 Agts.

C.; V. C. 
Grenoble

Guadeloupe, West Indies

C.; V. C.

Havre

La Rochelle

Limoges

Lyon

Marseille

Martinique, West Indies

C.; V. C.

C.; V.C.

C.; V. C.

C.; V. C.

C.; V. C. ; Agt.

C. G.; V. C. ; 2 Agts.

C.; V. C.

Nantes

C.; V. C. ; Agt.

Nice

Paris

C.; V. C.

Rouen

Saigon, French Indo-China

C. G.; C.; 3 V. C.

C. ; V. C. ; Agt.

C.; V. C.

St. Etienne

St. Pierre-Miquelon

Tahiti, Society Islands

Tananarivo, Madagascar

Tunis, Tunis

C.; V. C.

C.; V. C.

C.; V. C.

C.; V. C.

C.

\section{German Empire}

5 C. G.; 18 C.; 28 V. C.; 5 Agts.; stationed at following points 、 Aix la Chapelle, Prussia

Apia, Samoa

Barmen, Prussia

Berlin, Prussia

Bremen

Breslau, Prussia

Chemnitz, Saxony

Cologne, Prussia

Dresden, Saxony

Erfurt, Prussia

Frankfort on the Main, Prussia Hamburg

Hanover, Prussia

Kehl, Baden

Leipzig, Saxony

Madgeburg, Prussia

Mannheim, Baden

Munich, Bavaria

Nuremberg, Bavaria

Plauen, Saxony

Stettin, Prussia

Stuttgart, Wurttemberg

Tsingtau, China

\section{Great Britain and Dominions}

12 C. G.; 80 C.; 88 V. C.; 54 Agts.; 1 Interpreter; Commercia] Attaché; stationed at following points :

Aden, Arabia

Auckland, New Zealand

Barbados, West Indies

Belfast, Ireland

Belize, British Honduras

Birmingham, England

Bombay, India
Bradford, England

Bristol, England

Caleutta, India

Calgary, Alberta, Canada

Campbellton, New Brunswick

Cape Town, Cape of Good Hope

Cardiff, Wales 
Charlottetown, P. E. I.

Colombo, Ceylon

Cork (Queenstown), Ireland

Cornwall, Ontario

Dublin, Ireland

Dundee, Scotland

Dunfermline, Scotland

Durban, Natal

Edinburgh, Scotland

Fernie, British Columbia

Fort William and Port Arthur, Ontario

Georgetown, Guiana

Gibraltar, Spain

Glasgow, Scotland

Halifax, Nova Scotia

Hamilton, Bermuda

Hamilton, Ontario

Hobart, Tasmania

Hongkong

Huddersfield, England

Hull, England

Johannesburg, Transvaal

Karachi, India

Kingston, Jamaica

Kingston, Ontario

Lagos, Nigeria

Leeds, England

Liverpool, England

London, England

Madras, India

Malta, Maltese Islands

Manchester, England

Melbourne, Australia

Mombasa, British East Africa

Moncton, New Brunswick

Montreal, Quebec
Nassau, N. P., Bahamas

Newcastle, N. S. W., Australia

Newcastle-on-Tyne, England

Niagara Falls, Ontario

Nottingham, England

Ottawa, Ontario

Plymouth, England

Port Antonio, Jamaica

Port Elizabeth, Cape of Good Hope

Prescott, Ontario

Prince Rupert, British Colum. bia

Quebec, Quebec

Rangoon, India

Regina, Saskatchewan

Riviere du Loup, Quebec

St. John, New Brunswick

St. John's, Newfoundland

St. Stephen, New Brunswick

Sarnia, Ontario

Sault Ste. Marie, Ontario

Sheffield, England

Sherbrooke, Quebec

Singapore, Straits Settlements

Southampton, England

Stoke-on-Trent, England

Swansea, Wales

Sydney, Australia

Sydney, Nova Scotia

Toronto, Ontario

Trinidad, West Indies

Vancouver, British Columbia

Victoria, British Columbia

Windsor, Ontario

Winnipeg, Manitoba

Yarmouth, Nova Scotia

\section{Greece}

C. G.; 2 C.; 4 V. C.; 2 Agts.; at:

Athens

Saloniki

Patras

Guatemala

Guatemala

C. ; 3 V. C. ; 3 Agts. 


\section{Haiti}

2 C.; 2 V. C̣.; 6 Agts.; at:

Cape Haitien

Port au Prince

\section{Honduras}

3 C.; 3 V. C. ; 6 Agts.; at:

Ceiba

Puerto Cortes

Tegucigalpa

\section{Italy}

C. G. ; 10 C.; 14 V. C. ; at:

Catania

Florence

Genoa

Leghorn

Milan

Naples

Palermo

Rome

Turin

Venice

\section{Japan}

2 C. G. ; 4 C. ; 8 V. C. ; 4 Interpreters, 2 St. Ints.; 2 Agts.; at:

Dairen, Manchuria

Kobe

Nagasaki

Seoul, Chosen

Taihoku, Taiwan

Yokohama

\section{Kongo}

Boma

C. G.; V. C.

\section{Liberia}

Monrovia
C. G.; V. C.

Mexico

2 C. G.; 20 C.; 25 V. C. ; 10 Agts.; at:

Acapulco, Guerrero

Aguascalientes, Aguascalientes

Chihuahua, Chihuahua

Ciudad Juraez, Chihuahua

Durango, Durango

Frontera, Tabasco

Guadalajara, Jalisco

Hermosillo, Sonora

Manzanillo, Colima

Matamoros, Tamaulipas

Mazatlan, Sinaloa
Mexico, Mexico

Monterey, Nueva Leon

Nogales, Sonora

Nuevo Laredo, Tamaulipas

Piedras Negras, Coahuila

Progreso, Yucatan

Salina Cruz, Oaxaca

Saltillo, Coahuila

San Luis Potosi, San Luis Potosi

Tampico, Tamaulipas

Vera Cruz, Vera Cruz 


\section{Morocco}

Tangier

C. G.; V.C.; 2 Agts.; Interpreter

Netherlands and Dominions

C. G.; 3 C.; 5 V. C.; 6 Agts.; at:

Amsterdam

Batavia, Java
Curacao, West Indies Rotterdam

Nicaragua

2 C.; 2 V. C.; 2 Agts.; at:

Bluefields

Corinto

Norway

C. G.; 2 C.; 3 V. C.; 2 Agts.; at:

Stavanger

Bergen

Christiania

$$
\begin{gathered}
\text { Panama } \\
\text { C. G.; C.; } 2 \text { V. C.; Agt.; at: }
\end{gathered}
$$

Colon

$$
\text { Panama }
$$

Paraguay

Asuncion

$$
\text { C.; V. C. }
$$

\section{Persia}

2 C.; V. C.; Interpreter; at:

Tabriz

$$
\text { Teheran }
$$

\section{Peru}

Callao-Lima

C. G.; 2 V. C. ; 4 Agts.

Portugal and Dominions

C. G.; 2 C.; 3 V. C.; 5 Agts.; at:

Lisbon

Lourenço Marques, East Africa
St. Michaels, Azores 
Russia

Moscow

Odessa

Petrograd

Riga

San Salvador

C. G.; 8 C.; 7 V. C.; 3 Agts.; at:

Tiflis

Vladivostok, Siberia Warsaw

\section{Salvador}
Belgrade
Bangkok
Barcelona
Bilboa
Madrid
Malaga

Basel

Goteborg

Berne

Geneva

Serbia
C. G.; V. C.

C.; V.C.

Siam

$$
\text { V.C. }
$$

Spain and Dominions

C. G.; 6 C.; 8 V. C.; 10 Agts.; at:

Seville

Teneriffe, Canary Islands

Valencia

Sweden

C. G.; C.; 2 V. C. ; 2 Agts. ; at:

Stockholm

\section{Switzerland}

$$
\text { C. G.; } 4 \text { C.; } 7 \text { V. C.; } 2 \text { Agts.; at: }
$$

St. Gall

Zurich

Turkey and Dominions

4 C. G.; 9 C. ; 16 V. C. ; 13 Agts. ; 9 Interpreters; 1 St. Int. ; at:

Aleppo, Syria

Alexandria, Egypt

Bagdad

Beirut, Syria

Cairo, Egypt

Constantinople
Harput

Jerusalem, Palestine

Mersina

Smyrna

Trebizond 


\section{Uruguay}

Montevideo

$$
\text { C.; V. C. }
$$

Venezuela

3 C. ; 3 V. C. ; 2 Agts.; at:

La Guaira

Puerto Cabello

Maracaibo

\section{d. Foreign Consular Officers in the United States. ${ }^{1}$}

$$
\text { Argentina }
$$

\begin{tabular}{|c|c|c|}
\hline State & \multicolumn{2}{|l|}{ City } \\
\hline Alabama & Mobile & V. C. ${ }^{2}$ \\
\hline California & Los Angeles & V.C. \\
\hline & San Francisco & V.C. \\
\hline Florida & Apalachicola & V.C. \\
\hline & Fernandina & V.C. \\
\hline & Pensacola & V.C. \\
\hline Georgia & Brunswick & V.C. \\
\hline & Savannah & V. C. \\
\hline Illinois & Chicago & V. C. \\
\hline Louisiana & New Orleans & V.C. \\
\hline Maine & Portland & V. C. \\
\hline Maryland & Baltimore & V.C. \\
\hline Massachusetts & Boston & V. C. \\
\hline Missouri & St. Louis & V.C. \\
\hline New York & New York City & C. G.; C. \\
\hline Pennsylvania & Philadelphia & V.C. \\
\hline Philippine Islands & Manila & V. C. \\
\hline Porto Rico & San Juan & V.C. \\
\hline Texas & Port Arthur & V.C. \\
\hline Virginia & Newport News & V.C. \\
\hline & Norfolk & C.; V. C. \\
\hline Washington & Tacoma & V.C. \\
\hline
\end{tabular}

Register, 1916, 186-217; see, above, text, Chap. VI.

2 C. G. : Consul General. C.: Consul. V. C.: Vice Consul. C. A.: Consular Agent. A. C. A.: Acting Consular Agent. D. C. A.: Deputy Consular Agent. 


\section{Austria-Hungary}

California

Colorado

Florida

Georgia

Hawaii

Illinois

Louisiana

Maryland

Massachusetts

Minnesota

Missouri

New York

Ohio

Pennsylvania

Philippine Islands

Porto Rico

Texas

Virginia

West Virginia
San Francisco

Denver

Pensacola

Savannah

Honolulu

Chicago

New Orleans

Baltimore

Boston

St. Paul

St. Louis

Buffalo

New York City

Cleveland

Philadelphia

Pittsburgh

Uniontown

Wilkes-Barre

Manila

San Juan

Galveston

Richmond

Charleston
C.

C.

V. C.

V.C.

C.

C. G.

C.

C.

C.

C.

C.

A. C. A.

C. G.

C.

C. G.

C.

D. C. A.

D. C. A.

C.

C.

C.

C.

C.
Belgium

41 Consular officers in 35 cities in 18 states and the island possessions.

\section{Bolivia}

13 Consular officers in as many cities.

\section{Brazil}

34 Consular officers in 20 cities.

\section{Bulgaria}

Consul General in New York City.

\section{Chile}

15 Consular officers in as many cities.
China

6 Consular officers in 6 cities.

\section{Colombia}

19 Consular officers in 16 cities.

Costa Rica

18 Consular officers in 15 cities.

\section{$C u b a$}

36 Consular officers in 34 eities.

\section{Denmark}

38 Consular officers in 35 cities. Dominican Republic

20 Consular officers in 18 cities. 
Ecuador

Netherlands

14 Consular officers in 14 cities. Officers in 33 cities.

France

Nicaraguid

47 Consular officers in 42 cities. Officers in 14 cities.

German Empire

35 Consular officers in 34 cities. Officers in 53 cities.

Norway

Panama

92 Consular officers in 58 cities. Officers in 24 cities.

\section{Greece}

Paraguay

11 Consular officers in 11 cities. Officers in 12 cities.

\section{Guatemala}

Persia

20 Consular officers in 19 cities. Officers in 6 cities.

$$
\text { Haiti }
$$

Officers in 9 cities.

Honduras

Officers in 12 cities.

\section{Italy}

Officers in 65 cities.

$$
\text { Japan }
$$

Officers in 13 cities.

\section{Liberia}

Officers in 10 cities.

\section{Mexico}

Officers in 24 cities.

Monaco

Officers in 2 cities.

Montenegro

Consul in New York City.
Peru

Officers in 25 cities.

Portugal

Officers in 21 cities.

Russia

Officers in 16 eities.

Salvador

Officers in 7 cities.

Serbia

Consul General in New York City. .

Siam

Officers in 3 eities.

Spain

Officers in 35 cities.

Sweden

Officers in 33 cities. 


\section{Switzerland}

Officers in 14 cities.

Turkey

Officers in 5 cities.

\section{Uruguay}

Officers in 27 cities.

Venezuela

Officers in 17 cities.

\section{No. 4. Arbitration Convention between the United States and Great Britain, $1908 .^{1}$}

Preamble

Parties

Purpose

Agents

Body

General Article
The President of the United States of America and His Majesty the King of the United Kingdom of Great Britain and Ireland and of the British Dominions beyond the Seas, Emperor of India, desiring, in pursuance of the principles set forth in Articles 15-19 of the Convention for the Pacific Settlement of International Disputes, signed at The Hague July 29, 1899, to enter into negotiations for the conclusion of an Arbitration Convention, have named as their Plenipotentiaries, to wit:

The President of the United States of America, Elihu Root, Secretary of State of the United States, and

His Majesty the King of the United Kingdom of Great Britain and Ireland and of the British Dominions beyond the Seas, Emperor of India, The Right Honorable James Bryce, O. M., who, after having communicated to one another their full powers, found in good and due form, have agreed upon the following articles :

\section{Article I.}

Differences which may arise of a legal nature or relating to the interpretation of treaties existing between the two Contracting Parties and which it may not have been possible to settle by diplomacy, shall be referred to the Permanent Court of Arbitration established at The Hague by the Convention of the 29th of July, 1899, provided, nevertheless, that they do not affect the vital interests,

${ }^{1}$ U. S. S. L., XXXV, 1960; see, above, text, Chaps. X, XI, XIV. 
APPENDIX A

535

the independence, or the honor of the two Contracting States, and do not concern the interests of third Parties.

Special Articles

\section{Procedure}

Ratification

Exchange

Effectiveness

\section{Duration}

Place

Date

Signatures and Seals

\section{Article II.}

In each individual case the High Contracting Parties before appealing to the Permanent Court of Arbitration, shall conclude a special Agreement defining clearly the matter in dispute, the scope of the powers of the Arbitrators, and the periods to be fixed for the formation of the Arbitral Tribunal and the several stages of the procedure. It is understood that such special agreements on the part of the United States will be made by the President of the United States, by and with the advice and consent of the Senate thereof; His Majesty's Government reserving the right before concluding a special agreement in any matter affecting the interests of a self-governing Dominion of the British Empire to obtain the concurrence therein of the Government of that Dominion.

\section{Article III.}

The present Convention shall be ratified by the President of the United States of America by and with the advice and consent of the Senate thereof, and by his Britannic Majesty. The ratifications shall be exchanged at Washington as soon as possible, and the Convention shall take effect on the date of the exchange of its ratifications.

\section{Article IV.}

The present Convention is concluded for a period of five years, dating from the day of the exchange of its ratifications.

Done in duplicate at the City of Washington, this fourth day of April, in the year 1908. 


\section{a. Resolution of the Senate of the United States Consenting to the Ratification of a Treaty by the President. ${ }^{1}$}

$$
\text { Tuesday, January 22, } 1901 .
$$

Mr. Lodge submitted the following resolution for consideration:

Resolved (two-thirds of the Senators present concurring), That the Senate advise and consent to the ratification of the treaty between the United States and Spain signed at Washington November 7, 1900, providing for the cession to the United States of any and all islands of the Philippine Archipelago lying outside of the lines described in Article III of the treaty of peace of December $10,1898$.

On the question to agree to the resolution,

It was decided in the affirmative, two-thirds of the Senators present having voted in the affirmative; yeas, 38 ; nays, 19.

Ordered, That the Secretary lay the said resolutions before the President of the United States.

\section{b. Act of Ratification of a Treaty. ${ }^{2}$}

The executive authority of the Dominican Republic.

To all to whom these presents shall come, greeting:

Whereas a convention was signed in the city of Santo Domingo on the eighth day of February, one thousand nine hundred and seven, by the plenipotentiaries of the Dominican Republic and the United States of America, a true copy of which convention, in Spanish and English, is word for word as follows:

(Here follows copy of convention, in Spanish and English.)

And whereas by a resolution of the third of May of the present year the national congress approved said convention, the executive authority of the Republic confirms and ratifies the aforesaid convention in all and every one of its stipulations, as above written, and promises that every article and clause thereof will be inviolably observed.

In testimony whereof these presents are executed, sealed with the seal of the Republic, and signed and countersigned in the city

1 Journals of the Executive Proceedings of the Senate, XXXII, 646; see, above, text, Chap. $\mathrm{X}$.

${ }^{2} U$. S. Foreign Relations, 1907, 316; see, above, text, Chap. X. 
of Santo Domingo the nineteenth day of June, in the year of our Lord 1907.

Countersigned :

Ramon Caceres,

President of tine Republic.

E. Tejera, (Seal)

Minister of Foreign Relations.

\section{c. Protocol of an Exchange of Ratifications. ${ }^{1}$}

The undersigned plenipotentiaries having met with the object of exchanging the ratifications of the convention signed between the Dominican Republic and the United States on February 8, 1907, providing for the assistance of the United States in the collection of the customs duties of the Dominican Republic and the application of the said customs duties, and the ratifications of said convention having been carefully compared and having been found to exactly conform one with the other, the exchange was to-day affected in the usual form.

In testimony whereof this protocol of exchange is signed and sealed.

Done in Washington the 8th day of July, 1907.

\section{Emilio C. JouberT}

ROBERT BACON.

\section{d. Proclamation of a Treaty by the President. ${ }^{2}$}

By the President of the United States of America

\section{A Proclamation.}

Whereas an Arbitration Convention between the United States of America and the United Kingdom of Great Britain and Ireland was concluded and signed by their respective Plenipotentiaries at Washington, on the fourth day of April, one thousand, nine hun. dred and eight, the original of which Convention is word for word as follows:

\section{(Text of Convention)}

And whereas the said Convention has been duly ratified on both parts and the ratifications of the two governments were exchanged in the City of Washington, on the fourth day of June, one thousand, nine hundred and eight;

${ }^{1}$ U. S. Foreign Relations, 1907, 316; see, above, text, Chap. X.

'U. S. S. L., XXXV, 1960; see, above, text, Chap. X. 
Now, therefore, be it known that I, Theodore Roosevelt, President of the United States of America, have caused said Convention to be made public, to the end that the same and every article and clause thereof may be observed and fulfilled with good faith by the United States and the citizens thereof.

In testimony whereof, I have hereunto set my hand and caused the seal of the United States to be affixed.

Done at the City of Washington this fifth day of June, in the year of our Lord one thousand, nine hundred and

(SEAL) eight, and of the Independence of the United States of America the one hundred and thirty second.

By the President:

Euinu Root,

Theodore Roosevelt.

Secretary of State.

No. 5. Treaty of Peace, Signed at Paris, $30 \mathrm{March}$, 1856, and Declaration of Paris, adopted by signatories thereto.

2. Treaty of Paris, 30 March, $1856 .^{1}$

In the Name of Almighty God.

Their Majesties the Queen of the United Kingdom of Great Britain and Ireland, the Emperor of the French, the Emperor of all the Russias, the King of Sardinia, and the Emperor of the Ottomans, animated by the desire of putting an end to the calamities of war, and wishing to prevent the return of the complications which occasioned it, resolve to come to an understanding with His Majesty the Emperor of Austria as to the bases on which peace might be reëstablished and consolidated, by securing, through effectual and reciprocal guarantees, the independence and integrity of the Ottoman Empire.

For this purpose Their said Majesties have named as their Plenipotentiaries, that is to say:

(Names of plenipotentiaries.)

Which Plenipotentiaries, assembled in Congress at Paris, An understanding having been happily established between them, Their Majesties the Queen of the United Kingdom of Great Britain and Ireland, the Emperor of Austria, the Emperor of the French, the Emperor of all the Russias, the King of Sardinia, and the Emperor of the Ottomans, considering that in the interest of Europe, His Majesty the King of Prussia, a signing Party to the "Convention of the 13th of July, 1841, should be invited to partici-

${ }^{3} B$. \& F., XLVI, 8-26; see, above, text, Chaps. XI, XIII, XXI, 
pate in the new arrangements to be adopted, and appreciating the value that the concurrence of His said Majesty would add to a work of general pacification, invited him to send Plenipotentiaries to the Congress,

In consequence, His Majesty the King of Prussia has named as His Plenipotentiaries, that is to say :

(Names of plenipotentiaries.)

The Plenipotentiaries, after having exchanged their full powers, found in good and due form, have agreed upon the following Articles:-

\section{Article I.}

From the day of the exchange of the ratifications of the present Treaty, there shall be peace and friendship between Her Majesty the Queen of the United Kingdom of Great Britain and Ireland, His Majesty the Emperor of the French, His Majesty the King of Sardinia, His Imperial Majesty the Sultan, on the one part, and His Majesty the Emperor of all the Russias, on the other part; as well as between their heirs and successors, their respective dominions and subjects, in perpetuity.

$$
\text { * * * * }
$$

\section{Article VII.}

Her Majesty the Queen of the United Kingdom of Great Britain and Ireland, His Majesty the Emperor of Austria, His Majesty the Emperor of the French, His Majesty the King of Prussia, His Majesty the Emperor of all the Russias, and His Majesty the King of Sardinia, declare the Sublime Porte admitted to participate in the advantages of the public law and system (concert) of Europe. Their Majesties engage, each on his part, to respect the independence and the territorial integrity of the Ottoman Empire; guarantee in common the strict observance of that engagement; and will, in consequence, consider any act tending to its violation as a question of general interest.

\section{Article VIII.}

If there should arise between the Sublime Porte and one or more of the other signing Powers, any misunderstanding which might endanger the maintenance of their relations, the Sublime Porte, and each of such Powers, before having recourse to the use of force, shall afford the other Contracting Parties the opportunity of preventing such an extremity by means of their mediation. 


\section{Article IX.}

His Imperial Majesty the Sultan, having, in his constant solicitude for the welfare of his subjects, issued a Firman which, while ameliorating their condition without distinction of religion or of race, records his generous intentions towards the Christian populations of his Empire, and wishing to give a further proof of his sentiments in that respect, has resolved to communicate to the Contracting Parties the said Firman emanating spontaneously from his sovereign will.

The Contracting Powers recognize the high value of this communication. It is clearly understood that it cannot, in any case, give to the said Powers the right to interfere, either collectively or separately, in the relations of His Majesty the Sultan with his subjects, nor in the internal administration of his Empire.

\section{Article X.}

The Convention of the 13th of July, 1841, which maintains the ancient rule of the Ottoman Empire relative to the closing of the Straits of the Bosphorus and of the Dardanelles, has been revised by common consent.

The Act concluded for that purpose, and in conformity with that principle, between the High Contracting Parties, is and remains annexed to the present Treaty, and shall have the same force and validity as if it formed an integral part thereof.

\section{Article XI.}

The Black Sea is neutralized: its waters and its ports, thrown open to the mercantile marine of every nation, are formally and in perpetuity interdicted to the flag of war, either of the Powers possessing its coasts, or of any other Power, with the exceptions mentioned in Articles XIV and XIX of the present Treaty.

\section{Article XII.}

Free from any impediment, the commerce in the ports and waters of the Black Sea shall be subject only to regulations of health, customs, and police, framed in a spirit favorable to the development of commercial transactions.

In order to afford to the commercial and maritime interests of every nation the security which is desired, Russia and the Sublime Porte will admit Consuls into their ports situated upon the coast of the Black Sea, in conformity with the principles of international law. 


\section{Article XIII.}

The Black Sea being neutralized according to the terms of Article XI, the maintenance or establishment upon its coast of military-maritime arsenals becomes alike unnecessary and purposeless; in consequence, His Majesty the Emperor of all the Russias and His Imperial Majesty the Sultan engage not to establish or to maintain upon that coast any military-maritime arsenal.

\section{Article XIV.}

Their Majesties the Emperor of all the Russias and the Sultan having concluded a Convention for the purpose of settling theo force and the number of light vessels, necessary for the service of their coasts, which they reserve to themselves to maintain in the Black Sea, that Convention is annexed to the present Treaty, and shall have the same force and validity as if it formed an integral part thereof. It cannot be either annulled or modified without the assent of the Powers signing the Present Treaty.

\section{Article XV.}

The Act of the Congress of Vienna having established the principles intended to regulate the navigation of rivers which separate or traverse different States, the Contracting Powers stipulate among themselves that those principles shall in future be equally applied to the Danube and its mouths. They declare that this arrangement henceforth forms a part of the public law of Europe, and take it under their guarantee.

The navigation of the Danube cannot be subjected to any impediment or charge not expressly provided for by the stipulafions contained in the following Articles: in consequence, there shall not be levied any toll founded solely upon the fact of the navigation of the river, nor any duty upon the goods which may be on board of vessels. The regulations of police and of quarantine to be established for the safety of the States separated or traversed by that river shall be so framed as to facilitate, as much as possible, the passage of vessels. With the exception of such regulations, no obstacle whatever shall be opposed to free navigation.

\section{Article XVI.}

With the view to carry out the arrangements of the preceding Article, a Commission, in which Great Britain, Austria, France, Prussia, Russia, Sardinia, and Turkey, shall each be represented by one delegate, shall be charged to designate and to cause to be

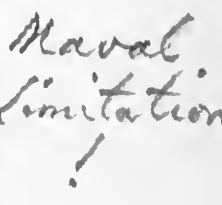


executed the works necessary below Isaktcha, to elear the mouths of the Danube, as well as the neighboring parts of the sea, from the sands and other impediments which obstruct them, in order to put that part of the river and the said parts of the sea in the best possible state for navigation.

In order to cover the expenses of such works, as well as of the establishments intended to secure and to facilitate the navigation at the mouths of the Danube, fixed duties, of a suitable rate, settled by the Commission by a majority of votes, may be levied, on the express condition that, in this respect as in every other, the flags of all nations shall be treated on the footing of perfect equality.

\section{Article XVII.}

A Commission shall be established, and shall be composed of delegates of Austria, Bavaria, the Sublime Porte, and Würtemberg (one for each of those Powers), to whom shall be added Commissioners from the three Danubian Principalities, whose nomination shall have been approved by the Porte. This Commission, which shall be permanent: 1 . Shall prepare regulations of navigation and river police; 2 . Shall remove the impediments, of whatever nature they may be, which still prevent the application to the Danube of the arrangements of the Treaty of Vienna; 3 . Shall order and cause to be executed the necessary works throughout the whole course of the river; and 4, Shall, after the dissolution of the European Commission, see to maintaining the mouths of the Danube and the neighboring parts of the sea in a navigable state.

\section{Article XVIII.}

It is understood that the European Commission shall have completed its task, and that the Riverain Commission shall have finished the works described in the preceding Article, under Nos. 1 and 2, within the period of two years. The signing Powers assembled in Conference having been informed of that fact, shall, after having placed it on record, pronounce the dissolution of the European Commission, and from that time the permanent Riverain Commission shall enjoy the same powers as those with which the European Commission shall bave until then been invested.

\section{Article XIX.}

In order to insure the execution of the regulations which shall have been established by common agreement, in conformity with the principles above declared, each of the Contracting Powers shall have the right to station, at all times, two light vessels at the mouths of the Danube. 


\section{Article XXII.}

The Principalities of Wallachia and Moldavia shall continue to enjoy, under the suzerainty of the Porte, and under the guarantee of the Contracting Powers, the privileges and immunities of which they are in possession. No exclusive protection shall be exercised over them by any of the Guaranteeing Powers. There shall be no separate right of interference in their internal affairs.

\section{Article XXXIV.}

The present Treaty shall be ratified, and the ratifications shall be exchanged at Paris in the space of four weeks, or sooner if possible.

In witness whereof the respective Plenipotentiaries have signed the same, and have affixed thereto the seal of their arms.

Done at Paris, the thirtieth day of the month of March, in the year one thousand eight hundred and fifty-six.
Clarendon.
COWLEY.
Buol-Schauenstein.
HÜBNER.
A. WALEWSKI.
Bourqueney.
MaNTEUFFel.
C. M. D'HatzFeldt.
ORLOFF.
BrunNow.
C. Cavour.
De Villamarina.
AALI.
Mehemmed DJemiL.

\section{b. Declaration of Paris, $1856 .^{1}$}

Considering :

That maritime law, in time of war, has long been the subject of deplorable disputes:

That the uncertainty of the law and of the duties in this same matter gives occasion to differences of opinion between neutrals and belligerents which may cause serious difficulties and even conflicts :

That it is consequently advantageous to establish a uniform doctrine on so important a point:

${ }^{1} B . \& F$., XLVI, 26-27; see, above, text, Chaps. X, XI, XII. 
That the Plenipotentiaries assembled at the Congress of Paris cannot better respond to the intentions by which their Governments are animated than by seeking to introduce into international relations fixed principles in this respect:

The above-mentioned Plenipotentiaries, being duly authorized, resolved to concert among themselves as to the means of attaining this object; and, having come to an agreement, have adopted the following solemn Declaration :-

1. Privateering is and remains abolished:

2. The neutral flag covers enemy's goods, with the exception of contraband of war:

3. Neutral goods, with the exception of contraband of war, are not liable to capture under enemy's flag:

4. Blockades, in order to be binding, must be effective; that is to say maintained by a force sufficient really to prevent access to the enemy's coast.

The Governments of the undersigned Plenipotentiaries engage to bring the present Declaration to the knowledge of the States which have not been called upon to take part in the Congress of Paris, and invite them to accede to it.

Convinced that the maxims which they now proclaim cannot but be received with gratitude by the whole world, the undersigned Plenipotentiaries doubt not that the efforts of their Governments to obtain the general adoption thereof will be erowned with full success.

The present Declaration is not and shall not be binding except between those powers who have acceded or shall accede to it.

\section{No. 6. Convention for the Pacific Settlement of Internationa] Disputes signed at The Hague, 1907.1}

His Majesty the German Emperor, King of Prussia; [etc.] :

Animated by the sincere desire to work for the maintenance of general peace;

Resolved to promote by all the efforts in their power the friendly settlement of international disputes;

Recognizing the solidarity uniting the members of the society of civilized nations;

Desirous of extending the empire of law and of strengthening the appreciation of international justice;

Convinced that the permanent institution of a tribunal of arbi. tration, accessible to all, in the midst of independent Powers, will contribute effectively to this result;

Having regard to the advantages attending the general and regular organization of the procedure of arbitration;

${ }^{1}$ U. S. S. L., XXXVI, 2199 ; see, above, text, Chap. XV. 
Sharing the opinion of the august initiator of the International Peace Conference that it is expedient to record in an international agreement the principles of equity and right on which are based the security of States and the welfare of peoples;

Being desirous, with this object, of insuring the better working in practice of commissions of inquiry and tribunals of arbitration, and of facilitating recourse to arbitration in cases which allow of $a$ summary procedure,

Have deemed it necessary to revise in certain particulars and to complete the work of the First Peace Conference for the pacific settlement of international disputes;

The high contracting Parties have resolved to conclude a new Convention for this purpose, and have appointed the following as their plenipotentiaries :

(Here follow the names of plenipotentiaries.)

Who, after having deposited their full powers, found in good and due form, have agreed upon the following:

\section{Part I.-The Maintenance of General Peace.}

Article 1.

With a view to obviating as far as possible recourse to force in the relations between States, the contracting Powers agree to use their best efforts to insure the pacific settlement of international differences.

\section{Part II.-Good Offices and Mediation.}

\section{Article 2.}

In case of serious disagreement or dispute, before an appeal to arms, the contracting Powers agree to have recourse, as far as circumstances allow, to the good offices or mediation of one or more friendly Powers.

\section{Article 3.}

Independently of this recourse, the contracting Powers deem it expedient and desirable that one or more Powers, strangers to the dispute, should, on their own initiative and as far as circumstances may allow, offer their good offices or mediation to the States at variance.

Powers strangers to the dispute have the right to offer good offices or mediation even during the course of hostilities.

${ }^{1}$ Italics indicate changes in the Convention as drawn in 1907. 
The exercise of this right can never be regarded by either of the parties in dispute as an unfriendly act.

\section{Article 4.}

The part of the mediator consists in reconciling the opposing claims and appeasing the feelings of resentment which may have arisen between the States at variance.

\section{Article 5.}

The functions of the mediator are at an end when once it is declared, either by one of the parties to the dispute or by the mediator himself, that the means of reconciliation proposed by him are not accepted.

\section{Article 6.}

Good offices and mediation undertaken either at the request of the parties in dispute or on the initiative of Powers strangers to the dispute have exclusively the character of advice, and never have binding force.

\section{Article 7.}

The acceptance of mediation can not, unless there be an agreement to the contrary, have the effect of interrupting, delaying, or hindering mobilization or other measures of preparation for war.

If it takes place after the commencement of hostilities, the military operations in progress are not interrupted in the absence of an agreement to the contrary.

\section{Article 8.}

The contracting Powers are agreed in recommending the application, when circumstances allow, of special mediation in the following form:

In case of a serious difference endangering peace, the States at variance choose respectively a Power, to which they intrust the mission of entering into direct communication with the Power chosen on the other side, with the object of preventing the rupture of pacific relations.

For the period of this mandate, the term of which, unless otherwise stipulated, can not exceed thirty days, the States in dispute cease from all direct communication on the subject of the dispute, which is regarded as referred exclusively to the mediating Powers, which must use their best efforts to settle it. 
In case of a definite rupture of pacific relations, these Powers are charged with the joint task of taking advantage of any opportunity to restore peace.

\section{Part III.-International Commisstons of Inquiry}

\section{Article 9.}

In disputes of an international nature involving neither honor nor vital interests, and arising from a difference of opinion on points of fact, the contracting Powers deem it expedient and desir. able that the parties who have not been able to come to an agreement by means of diplomacy, should, as far as circumstances allow, institute an international commission of inquiry, to facilitate a solution of these disputes by elucidating the facts by means of an impartial and conscientious investigation.

Article 10.

International commissions of inquiry are constituted by special agreement between the parties in dispute.

The inquiry convention defines the facts to be examined; it determines the mode and time in which the commission is to be formed and the extent of the powers of the commissioners.

It also determines, if there is need, where the commission is to sit, and whether it may remove to another place, the language the commission shall use and the languages the use of which shall be authorized before it, as well as the date on which each party must deposit its statement of facts, and, generally speaking, all the conditions upon which the parties have agreed.

If the parties consider it necessary to appoint assessors, the convention of inquiry shall determine the mode of their selection and the extent of their powers.

\section{Article 11.}

If the inquiry convention has not determined where the commission is to sit, it will sit at The Hague.

The place of meeting, once fixed, can not be altered by the commission except with the assent of the parties.

If the inquiry convention has not determined what languages are to be employed, the question shall be decided by the commission.

\section{Article 12.}

Unless an undertaking is made to the contrary, commissions of inquiry shall be formed in the manner determined by Articles 45 and 57 of the present Convention. 


\section{Article 13.}

Should one of the commissioners or one of the assessors, should there be any, either die, or resign, or be unable for any reason whatever to discharge his functions, the same procedure is followed for filling the vacancy as was followed for appointing him.

Article 14.

The parties are entitled to appoint special agents to attend the commission of inquiry, whose duty it is to represent them and to act as intermediaries between them and the commission.

They are further authorized to engage counsel or advocates, appointed by themselves, to state their case and uphold their interests before the commission.

Article 15.

The International Bureau of the Permanent Court of Arbitration acts as registry for the commissions which sit at The Hague, and shall place its offices and staff at the disposal of the contracting Powers for the use of the commission of inquiry.

\section{Article 16.}

If the commission meets elsewhere than at The Hague, it appoints a secretary general, whose office serves as registry.

It is the function of the registry, under the control of the president, to make the necessary arrangements for the sittings of the commission, the preparation of the minutes, and, while the inquiry lasts, for the charge of the archives, which shall subsequently be transferred to the International Bureau at The Hague.

\section{Article 17.}

In order to facilitate the constitution and working of commissions of inquiry, the contracting Powers recommend the following rules, which shall be applicable to the inquiry procedure in so far as the parties do not adopt other rules.

\section{Article 18.}

The commission shall settle the details of the procedure not covered by the special inquiry convention or the present Convention, and shall arrange all the formalities required for dealing with the evidence. 


\section{Article 19.}

On the inquiry both sides must be heard.

At the dates fixed, each party communicates to the commission and to the other party the statements of facts, if any, and, in all cases, the instruments, papers, and documents which it considers useful for ascertaining the truth, as well as the list of witnesses and experts whose evidence it wishes to be heard.

Article 20.

The commission is entitled, with the assent of the Powers, to move temporarily to any place where it considers it may be useful to have recourse to this means of inquiry or to send one or more of its members. Permission must be obtained from the State on whose territory it is proposed to hold the inquiry.

\section{Article 21.}

Every investigation, and every examination of a locality, must be made in the presence of the agents and counsel of the parties or after they have been duly summoned.

\section{Article 22.}

The commission is entitled to ask from either party for such explanations and information as it considers necessary.

\section{Article 23.}

The parties undertake to supply the commission of inquiry, as fully as they may think possible, with all means and facilities necessary to enable it to become completely acquainted with, and to accurately understand, the facts in question.

They undertake to make use of the means at their disposal, under their municipal law, to insure the appearance of the witnesses or experts who are in their territory and have been summoned before the commission.

If the witnesses or experts are unable to appear before the commission, the parties will arrange for their evidence to be taken before the qualified officials of their own country.

\section{Article 24.}

For all notices to be served by the commission in the territory of a third contracting Power, the commission shall apply direct to the Government of the said Power. The same rule applies in the case of steps being taken on the spot to procure evidence. 
The requests for this purpose are to be executed so far as the means at the disposal of the Power applied to under its municipal law allow. They can not be rejected unless the Power in question considers they are calculated to impair its sovereign rights or its safety.

The commission will equally be always entitled to act through the Power on whose territory it sits.

\section{Article 25.}

The witnesses and experts are summoned on the request of the parties or by the commission of its own motion, and, in every case, through the Government of the State in whose territory they are.

The witnesses are heard in succession and separately, in the presence of the agents and counsel, and in the order fixed by the commission.

Article 26.

The examination of witnesses is conducted by the president.

The members of the commission may however put to each witness questions which they consider likely to throw light on and complete his evidence, or get information on any point concerning the witness within the limits of what is necessary in order to get at the truth.

The agents and counsel of the parties may not interrupt the witness when he is making his statement, nor put any direct question to him, but they may ask the president to put such additional questions to the witness as they think expedient.

\section{Article 27.}

The witness must give his evidence without being allowed to read: any written draft. He may, however, be permitted by the president to consult notes or documents if the nature of the facts referred to necessitates their employment.

\section{Article 28.}

$A$ minute of the evidence of the witness is drawn up forthwith and read to the witness. The latter may make such alterations and additions as he thinks necessary, which will be recorded at the end of his statement.

When the whole of his statement has been read to the witness, he is asked to sign it. 


\section{Article 29.}

The agents are authorized, in the course of or at the close of the inquiry, to present in writing to the commission and to the other party such statements, requisitions, or summaries of the facts as they consider useful for ascertaining the truth.

\section{Article 30.}

The commission considers its decisions in private and the proceedings are secret.

All questions are decided by a majority of the members of the commission.

If a member declines to vote, the fact must be recorded in the minutes.

\section{Article 31.}

The sittings of the commission are not public, nor the minutes and documents connected with the inquiry published except in virtue of a decision of the commission taken with the consent of the parties.

\section{Article 32.}

After the parties have presented all the explanations and evidence, and the witnesses have all been heard, the president declares the inquiry terminated, and the commission adjourns to deliberate and to draw up its report.

\section{Article 33.}

The report is signed by all the members of the commission.

If one of the members refuses to sign, the fact is mentioned; but the validity of the report is not affected.

\section{Article 34.}

The report of the commission is read at a public sitting, the agents and counsel of the parties being present or duly summoned.

$A$ copy of the report is given to each party.

\section{Article 35.}

The report of the commission is limited to a statement of facts, and has in no way the character of an award. It leaves to the parties entire freedom as to the effect to be given to the statement. 
Article 36.

Each party pays its own expenses and an equal share of the expenses incurred by the commission.

\section{Part IV.-International Arbitration}

Chapter I.-The System of Arbitration

Article 37.

International arbitration has for its object the settlement of disputes between States by judges of their own choice and on the basis of respect for law.

Recourse to arbitration implies an engagement to submit in good faith to the award.

Article 38.

In questions of a legal nature, and especially in the interpretation or application of international conventions, arbitration is recognized by the contracting Powers as the most effective, and, at the same time, the most equitable means of settling disputes which diplomacy has failed to settle.

Consequently, it would be desirable that, in disputes about the above-mentioned questions, the contracting Powers should, if the case arose, have recourse to arbitration, in so far as circumstances permit.

\section{Article 39.}

The arbitration convention is concluded for questions already existing or for questions which may arise eventually.

It may embrace any dispute or only disputes of a certain category.

\section{Article 40.}

Independently of general or private treaties expressly stipulating recourse to arbitration as obligatory on the contracting Powers, the said Powers reserve to themselves the right of concluding new agreements, general or particular, with a view to extending compulsory arbitration to all cases which they may consider it possible to submit to it. 


\section{Chapter II.-The Permanent Court of Arbitration.}

Article 41.

With the object of facilitating an immediate recourse to arbitration for international differences, which it has not been possible to settle by diplomacy, the contracting Powers undertake to maintain the Permanent Court of Arbitration, as established by the First Peace Conference, accessible at all times, and operating, unless otherwise stipulated by the parties, in accordance with the rules of procedure inserted in the present Convention.

\section{Article 42.}

The Permanent Court is competent for all arbitration cases, unless the parties agree to institute a special tribunal.

Article 43.

The Permanent Court sits at The Hague.

An International Bureau serves as registry for the Court. It is the channel for communications relative to the meetings of the Court; it has charge of the archives and conducts all the administrative business.

The contracting Powers undertake to communicate to the Bureau, as soon as possible, a certified copy of any conditions of arbitration arrived at between them and of any award concerning them delivered by a special tribunal.

They likewise undertake to communicate to the Bureau the laws, regulations, and documents eventually showing the execution of the awards given by the Court.

\section{Article 44.}

Each contracting Power selects four persons at the most, of known competeney in questions of international law, of the highest moral reputation, and disposed to accept the duties of arbitrator.

The persons thus selected are inscribed, as members of the Court, in a list which shall be notified to all the contracting Powers by the Bureau.

Any alteration in the list of arbitrators is brought by the Bureau to the knowledge of the contracting Powers.

Two or more Powers may agree on the selection in common of one or more members.

The same person can be selected by different Powers.

The members of the Court are appointed for a term of six years. These appointments are renewable. 
Should a member of the Court die or resign, the same procedure is followed for filling the vacancy as was followed for appointing him. In this case the appointment is made for a fresh period of six years.

\section{Article 45.}

When the contracting Powers wish to have recourse to the Permanent Court for the settlement of a difference which has arisen between them, the arbitrators called upon to form the tribunal with jurisdiction to decide this difference must be chosen from the general list of members of the Court.

Failing the direct agreement of the parties on the composition of the arbitration tribunal, the following course shall be pursued:

Each party appoints two arbitrators, of whom one only can be its national or chosen from among the persons selected by it as members of the Permanent Court. These arbitrators together choose an umpire.

If the votes are equally divided, the choice of the umpire is intrusted to a third Power, selected by the parties by common accord.

If an agreement is not arrived at on this subject each party selects a different Power, and the choice of the umpire is made in concert by the Powers thus selected.

If, within two month' time, these two Powers can not come to an agreement, each of them presents two candidates taken from the list of members of the Permanent Court, exclusive of the members selected by the parties and not being nationals of either of them. Drawing lots determines which of the candidates thus presented shall be umpire.

Article 46.

The tribunal being thus composed, the parties notify to the Bureau their determination to have recourse to the Court, the text of their compromis, and the names of the arbitrators.

The Bureau communicates without delay to each arbitrator the compromis, and the names of the other members of the tribunal.

The tribunal assembles at the date fixed by the parties. The Bureau makes the necessary arrangements for the meeting.

The members of the tribunal, in the exercise of their duties and out of their own country, enjoy diplomatic privileges and immunities.

Article 47.

The Bureau is authorized to place its offices and staff at the disposal of the contracting Powers for the use of any special board of arbitration. 
The jurisdiction of the Permanent Court may, within the conditions laid down in the regulations, be extended to disputes between non-contracting Powers or between contracting Powers and non-contracting Powers, if the parties are agreed on recourse to this tribunal.

\section{Article 48.}

The contracting Powers consider it their duty, if a serious dispute threatens to break out between two or more of them, to remind these latter that the Permanent Court is open to them.

Consequently, they declare that the fact of reminding the parties at variance of the provisions of the present Convention, and the advice given to them, in the highest interests of peace, to have recourse to the Permanent Court, can only be regarded as friendly actions.

In case of dispute between two Powers, one of them can always address to the International Bureau a note containing a declaration that it would be ready to submit the dispute to arbitration.

The Bureau must at once inform the other Power of the declaration.

Article 49.

The Permanent Administrative Council, composed of the diplomatic representatives of the contracting Powers accredited to The Hague and of the Netherland Minister for Foreign Affairs, who will act as president, is charged with the direction and control of the International Bureau.

The Council settles its rules of procedure and all other necessary regulations.

It decides all questions of administration which may arise with regard to the operations of the Court.

It has entire control over the appointment, suspension, or dismissal of the officials and employees of the Bureau.

It fixes the payments and salaries, and controls the general expenditure.

At meetings duly summoned the presence of nine members is sufficient to render valid the discussions of the Council. The decisions are taken by a majority of votes.

The Council communicates to the contracting Powers without delay the regulations adopted by it. It furnishes them with an annual report on the labors of the Court, the working of the administration, and the expenditure. The report likewise contains a résumé of what is important in the documents communicated to the Bureau by the Powers in virtue of Article 43, paragraphs 3 and 4. 
Article 50.

The expenses of the Bureau shall be borne by the contracting Powers in the proportion fixed for the International Bureau of the Universal Postal Union.

The expenses to be charged to the adhering Powers shall be reckoned from the date on which their adhesion comes into force.

\section{Chapter III.-Arbitration Procedure}

\section{Article 51.}

With a view to encouraging the development of arbitration, the contracting Powers have agreed on the following rules, which are applicable to arbitration procedure, unless other rules have been agreed on by the parties.

\section{Article 52.}

The Powers which have recourse to arbitration sign a compromis, in which the subject of the dispute is clearly defined, the time allowed for appointing arbitrators, the form, order, and time in which the communication referred to in Article 63 must be made, and the amount of the sum which each party must deposit in advance to defray the expenses.

The compromis likewise defines, if there is occasion, the manner of appointing arbitrators, any special powers which may eventually belong to the tribunal, where it shall meet, the language it shall use, and the languages the employment of which shall be authorized before it, and, generally speaking, all the conditions on which the parties are agreed.

\section{Article 53.}

The Permanent Court is competent to settle the compromis, if the parties are agreed to have recourse to it for the purpose.

It is similarly competent, even if the request is only made by one of the parties, when all attempts to reach an understanding through the diplomatic channel have failed, in the case of-

1. A dispute covered by a general treaty of arbitration concluded or renewed after the present Convention has come into force, and providing for a compromis in all disputes and not either explicitly or implicitly excluding the settlement of the compromis from the competence of the Court. Recourse can not, however, be had to the Court if the other party declares that in its opinion the dispute does not belong to the category of disputes which can 
be submitted to compulsory arbitration, unless the treaty of arbitration confers upon the arbitration tribunal the power of deciding this preliminary question.

2. A dispute arising from contract debts claimed from one Power by another Power as due to its nationals, and for the settlement of which the offer of arbitration has been accepted. This arrangement is not applicable if acceptance is subject to the condition that the compromis should be settled in some other way.

\section{Article 54.}

In the cases contemplated in the preceding article, the compromis shall be settled by a commission consisting of five members selected in the manner arranged for in Article 45, paragraphs 3 to 6 .

The fifth member is president of the commission ex officio.

\section{Article 55.}

The duties of arbitrator may be conferred on one arbitrator alone or on several arbitrators selected by the parties as they please, or chosen by them from the members of the Permanent Court of Arbitration established by the present Convention.

Failing the constitution of the tribunal by direct agreement between the parties, the course referred to in Article 45, paragraphs 3 to 6 , is followed.

\section{Article 56.}

When a sovereign or the chief of a State is chosen as arbitrator, the arbitration procedure is settled by him.

\section{Article 57.}

The umpire is president of the tribunal ex officio.

When the tribunal does not include an umpire, it appoints its own president.

\section{Article 58.}

When the compromis is settled by a commission, as contemplated in Article 54, and in the absence of an agreement to the contrary, the commission itself shall form the arbitration tribunal.

$$
\text { Article } 59 .
$$

Should one of the arbitrators either die, retire, or be unable for any reason whatever to discharge his functions, the same procedure 
is followed for filling the vacancy as was followed for appointing him.

Article 60.

The tribunal sits at The Hague, unless some other place is selected by the parties.

The tribunal can only sit in the territory of a third Power with the latter's consent.

The place of meeting once fixed can not be altered by the tribunal, except with the consent of the parties.

\section{Article 61.}

If the question as to what languages are to be used has not been settled by the compromis, it shall be decided by the tribunal.

\section{Article 62.}

The parties are entitled to appoint special agents to attend the tribunal to act as intermediaries between themselves and the tribunal.

They are further authorized to retain for the defense of their rights and interests before the tribunal counsel or advocates appointed by themselves for this purpose.

The members of the Permanent Court may not act as agents, counsel, or advocates except on behalf of the Power which appointed them members of the Court.

\section{Article 63.}

As a general rule, arbitration procedure comprises two distinct phases: pleadings and oral discussions.

The pleadings consist in the communication by the respective agents to the members of the tribunal and the opposite party of cases, counter-cases, and, if necessary, of replies; the parties annex thereto all papers and documents called for in the case. This communication shall be made either directly or through the intermediary of the International Bureau, in the order and within the time fixed by the compromis.

The time fixed by the compromis may be extended by mutual agreement by the parties, or by the tribunal when the latter considers it necessary for the purpose of reaching a just decision.

The discussions consist in the oral development before the tribunal of the arguments of the parties. 


\section{Article 64.}

A certified copy of every document produced by one party must be communicated to the other party.

\section{Article 65.}

Unless special circumstances arise, the tribunal does not meet until the pleadings are closed.

\section{Article 66.}

The discussions are under the control of the president.

They are only public if it be so decided by the tribunal, with the assent of the parties.

They are recorded in minutes drawn up by the secretaries appointed by the president. These minutes are signed by the president and by one of the secretaries and alone have an authentic character.

\section{Article 67.}

After the close of the pleadings, the tribunal is entitled to refuse discussion of all new papers or documents which one of the parties may wish to submit to it without the eonsent of the other party.

\section{Article 68.}

The tribunal is free to take into consideration new papers or documents to which its attention may be drawn by the agents or counsel of the parties.

In this case, the tribunal has the right to require the production of these papers or documents, but is obliged to make them known to the opposite party.

\section{Article 69.}

The tribunal can, besides, require from the agents of the parties the production of all papers, and can demand all necessary explanations. In case of refusal the tribunal takes note of it.

\section{Article 70.}

The agents and the counsel of the parties are authorized to present orally to the tribunal all the arguments they may consider expedient in defense of their case. 


\section{Article 71.}

They are entitled to raise objections and points. The decisions of the tribunal on these points are final and can not form the subject of any subsequent discussion.

\section{Article 72.}

The members of the tribunal are entitled to put questions to the agents and counsel of the parties, and to ask them for explanations on doubtful points.

Neither the questions put, nor the remarks made by members of the tribunal in the course of the discussions, can be regarded as an expression of opinion by the tribunal in general or by its members in particular.

\section{Article 73.}

The tribunal is authorized to declare its competence in interpreting the compromis, as well as the other papers and documents which may be invoked, and in applying the principles of law.

\section{Article 74.}

The tribunal is entitled to issue rules of procedure for the conduct of the case, to decide the forms, order, and time in which each party must conclude its arguments, and to arrange all the formalities required for dealing with the evidence.

\section{Article 75.}

The parties undertake to supply the tribunal, as fully as they consider possible, with all the information required for deciding the case.

\section{Article 76.}

For all notices which the tribunal has to serve in the territory of a third contracting Power, the tribunal shall apply direct to the Government of that Power. The same rule applies in the case of steps being taken to procure evidence on the spot.

The requests for this purpose are to be executed as far as the means at the disposal of the Power applied to under its municipal law allow. They can not be rejected unless the Power in question considers them calculated to impair its own sovereign rights or its safety.

The Court will equally be always entitled to act through the Power on whose territory it sits. 


\section{Article 77.}

When the agents and counsel of the parties have submitted all the explanations and evidence in support of their case the president shall declare the discussion closed.

\section{Article 78.}

The tribunal considers its decisions in private and the proceedings remain secret.

All questions are decided by a majority of the members of the tribunal.

\section{Article 79.}

The award must give the reasons on which it is based. It contains the names of the arbitrators; it is signed by the presidient and registrar or by the secretary acting as registrar.

Article 80.

The award is read out in public sitting, the agents and counsel of the parties being present or duly summoned to attend.

\section{Article 81.}

The award, duly pronounced and notified to the agents of the parties, settles the dispute definitively and without appeal.

\section{Article 82.}

Any dispute arising between the parties as to the interpretation and execution of the award shall, in the absence of an agreement to the contrary, be submitted to the tribunal which pronouncedi it.

\section{Article 83.}

The parties can reserve in the compromis the right to demand the revision of the award.

In this case and unless there be an agreement to the contrary, the demand must be addressed to the tribunal which pronounced the award. It can only be made on the ground of the discovery of some new fact calculated to exercise a decisive influence upon the award and which was unknown to the tribunal and to the party which demanded the revision at the time the discussion was closed. Proceedings for revision can only be instituted by a decision of 
the tribunal expressly recording the existence of the new fact, recognizing in it the character described in the preceding paragraph, and declaring the demand admissible on this ground.

The compromis fixes the period within which the demand for revision must be made.

\section{Article 84.}

The award is not binding except on the parties in dispute.

When it concerns the interpretation of a Convention to which Powers other than those in dispute are parties, they shall inform all the signatory Powers in good time. Each of these Powers is entitled to intervene in the case. If one or more avail themselves of this right, the interpretation contained in the award is equally binding on them.

\section{Article 85.}

Each party pays its own expenses and an equal share of the expenses of the tribunal.

\section{Chapter IV.-Arbitration by Summary Procedure.}

\section{Article 86.}

With a view to facilitating the working of the system of arbitration in disputes admitting of a summary procedure, the contracting Powers adopt the following rules, which shall be observed in the absence of other arrangements and subject to the reservation that the provisions of Chapter III apply so far as may be.

\section{Article 87.}

Each of the parties in dispute appoints an arbitrator. The two arbitrators thus selected choose an umpire. If they do not agree on this point, each of them proposes two candidates taken from the general list of the members of the Permanent Court exclusive of the members appointed by either of the parties and not being nationals of either of them; which of the candidates thus proposed shall be the umpire is determined by lot.

The umpire presides over the tribunal, which gives its decisions by a majority of votes.

\section{Article 88.}

In the absence of any previous agreement the tribunal, as soon as it is formed, settles the time within which the two parties must submit their respective cases to it. 
Article 89.

Each party is represented before the tribunal by an agent, who serves as intermediary between the tribunal and the Government who appointed him.

\section{Article 90.}

The proceedings are conducted exclusively in writing. Each party, however, is entitled to ask that witnesses and experts should be called. The tribunal has, for its part, the right to demand oral explanations from the agents of the two parties, as well as from the experts and witnesses whose appearance in Court it may consider useful.

\section{Part V.-Final Provisions.}

\section{Article 91.}

The present Convention, duly ratified, shall replace, as between the contracting Powers, the Convention for the pacific settlement of international disputes of the 29th July, 1899.

\section{Article 92.}

The present Convention shall be ratified as soon as possible.

The ratifications shall be deposited at The Hague.

The first deposit of ratifications shall be recorded in a procèsverbal signed by the representatives of the Powers which take part therein and by the Netherland Minister for Foreign Affairs.

The subsequent deposits of ratifications shall be made by means of a written notification, addressed to the Netherland Government and accompanied by the instrument of ratification.

$A$ duly certified copy of the procès-verbal relative to the first deposit of ratifications, of the notifications mentioned in the preceding paragraph, and of the instruments of ratification, shall be immediately sent by the Netherland Government, through the diplomatic channel, to the Powers invited to the Second Peace Conference, as well as to those Powers which have adhered to the Convention. In the cases contemplated in the preceding paragraph, the said Government shall at the same time inform the Powers of the date on which it received the notification.

\section{Article 93.}

Non-signatory Powers which have been invited to the Second Peace Conference may adhere to the present Convention. 
The Power which desires to adhere notifies its intention in writing to the Netherland Government, forwarding to it the act of adhesion, which shall be deposited in the archives of the said Government.

This Government shall immediately forward to all the other Powers invited to the Second Peace Conference a duly certified copy of the notification as well as of the act of adhesion, mentioning the date on which it received the notification.

\section{Article 94.}

The conditions on which the Powers which have not beel invited to the Second Peace Conference may adhere to the present Convention shall form the subject of a subsequent agreement between the contracting Powers.

\section{Article 95.}

The present Convention shall take effect, in the case of the Powers which were not a party to the first deposit of ratifications, sixty days after the date of the procès-verbal of this deposit, and, in the case of the Powers which ratify subsequently or which adhere, sixty days after the notification of their ratification or of their adhesion has been received by the Netherland Government.

\section{Article 96.}

In the event of one of the contracting Powers wishing to denounce the present Convention, the denunciation shall be notified in writing to the Netherland Government, which shall immediately communicate a duly certified copy of the notification to all the other Powers informing them of the date on which it was received.

The denunciation shall only have effect in regard to the notifying Power, and one year after the notification has reached the Netherland Government.

\section{Article 97.}

$A$ register kept by the Netherland Minister for Foreign Affairs shall give the date of the deposit of ratifications effected in virtue of Article 92, paragraphs 3 and 4, as well as the date on which the notifications of adhesion (Article 93, paragraph 2) or of denunciation (Article 96, paragraph 1) have been received.

Each contracting Power is entitled to have access to this register and to be supplied with duly certified extracts from it.

In faith whereof the plenipotentiaries have appended their signatures to the present Convention. 
Done at The Hague, the 18th October, 1907, in a single copy, which shall remain deposited in the archives of the Netherland Government, and duly certified copies of which shall be sent, through the diplomatic channel to the contracting Powers.

(Here follow signatures.)

\section{No. 7. Convention for the Creation of an International Institute of Agriculture, 1905. ${ }^{1}$}

In a series of meetings held at Rome, from May 29 to June 6, 1905, the delegates of the Powers convened at the Conference for the creation of an International Institute of Agriculture, having agreed upon the text of a Convention to be dated June 7, 1905, and this text having been submitted for approval to the Governments which took part in the said conference, the undersigned, having been furnished with full powers, found in good and due form, have agreed, in the names of their respective Governments, on what follows:

\section{Article I.}

There is hereby created a permanent international institute of agriculture, having its seat in Rome.

\section{Article II.}

The international institute of agriculture is to be a government institution, in which each adhering power shall be represented by delegates of its choice.

The institute shall be composed of a general assembly and a permanent committee, the composition and duties of which are defined in the ensuing articles.

\section{Article III.}

The general assembly of the institute shall be composed of the representatives of the adhering governments. Each nation, whatever be the number of its delegates, shall be entitled to a number of votes in the assembly which shall be determined according to the group to which it belongs, and to which reference will be made in Article $\mathrm{X}$.

${ }^{1}$ U. S. S. L., XXXV, 1918. Compare, above, Document No. 5, Arts. XVXVIII, pp. 541-542. 


\section{Article IV.}

The general assembly shall elect for each session from among its members a president and two vice-presidents.

The sessions shall take place on dates fixed by the last general assembly and according to a program proposed by the permanent committee and adopted by the adhering governments.

\section{Article V.}

The general assembly shall exercise supreme control over the international institute of agriculture.

It shall approve the projects prepared by the permanent committee regarding the organization and internal workings of the institute. It shall fix the total amount of expenditures and audit and approve the accounts.

It shall submit to the approval of the adhering governments modifications of any nature involving an increase in expenditure or an enlargement of the functions of the institute. It shall set the date for holding the sessions. It shall prepare its regulations.

The presence at the general assemblies of delegates representing two-thirds of the adhering nations shall be required in order to render the deliberations valid.

\section{Article VI.}

The executive power of the institute is intrusted to the permanent committee, which, under the direction and control of the general assembly, shall carry out the decisions of the latter and prepare propositions to submit to it.

\section{Article VII.}

The permanent committee shall be composed of members designated by the respective governments. Each adhering nation shall be represented in the permanent committee by one member. However, the representation of one nation may be intrusted to a delegate of another adhering nation, provided that the actual number of members shall not be less than fifteen.

The conditions of voting in the permanent committee shall be the same as those indicated in Article III for the general assemblies.

\section{Article VIII.}

The permanent committee shall elect from among its members for a period of three years a president and a vice-president, who 
may be reëlected. It shall prepare its internal regulations, vote the budget of the institute within the limits of the funds placed at its disposal by the general assembly, and appoint and remove the officials and employees of its office.

The general secretary of the permanent committee shall act as secretary of the assembly.

Article IX.

The institute, confining its operations within an international sphere, shall-

(a) Collect, study, and publish as promptly as possible statistical, technical, or economic information concerning farming, both vegetable and animal products, the commerce in agricultural products, and the prices prevailing in the various markets;

(b) Communicate to parties interested, also as promptly as possible, all the information just referred to ;

(c) Indicate the wages paid for farm work;

(d) Make known the new diseases of vegetables which may appear in any part of the world, showing the territories infected, the progress of the disease, and, if possible, the remedies which are effective in combating them;

(e) Study questions concerning agricultural coöperation, insurance, and credit in all their aspects ; collect and publish information which might be useful in the various countries in the organization of works eonnected with agricultural coöperation, insurance, and eredit;

(f) Submit to the approval of the governments, if there is occasion for it, measures for the protection of the common interests of farmers and for the improvement of their condition, after having utilized all the necessary sources of information, such as the wishes expressed by international or other agricultural congresses or congresses of sciences applied to agriculture, agricultural societies, academies, learned bodies, etc.

All questions concerning the economic interests, the legislation, and the administration of a particular nation shall be excluded from the consideration of the institute.

\section{Article X.}

The nations adhering to the institute shall be classed in five groups, aecording to the place which each of them thinks it ought to occupy.

The number of votes which each nation shall have and the number of units of assessment shall be established according to the following gradations: 

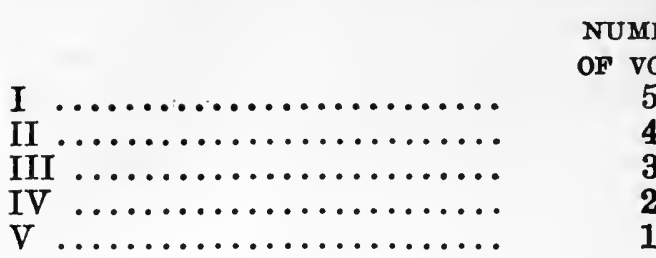

UNITS OF ASSESSMENT.

5

16

48

34

2

11

In any event the contribution due per unit of assessment shall never exceed a maximum of 2,500 francs.

As a temporary provision the assessment for the first two years shall not exceed 1,500 franes per unit.

Colonies may, at the request of the nations to which they belong, be admitted to form part of the institute on the same conditions as the independent nations.

\section{Article XI.}

The present Convention shall be ratified and the ratifications exchanged as soon as possible by depositing them with the Italian Government.

In faith whereof the respective Plenipotentiaries have signed the present Convention and have hereunto affixed their seals.

Done at Rome the 7 th of June one thousand nine hundred and five, in a single original, deposited with the Ministry of Foreign Affairs of Italy, of which certified copies shall be sent through the diplomatic channel to the contracting States.

\section{No. 8. Proposals for The Hague Conference of 1907.'}

8. Memorandum from the Russian Embassy in Washington, handed to the President of the United States, 13 September, 1905, proposing a Second Peace Conference at The Hague.

In view of the termination, with the cordial coöperation of the President of the United States, of the war, and of the conclusion of peace between Russia and Japan, His Majesty the Emperor, as initiator of the International Peace Conference of 1899 , holds that a favorable moment has now come for the further development and for the systematizing of the labors of that international conference. With this end in view, and being assured in advance of the sympathy of President Roosevelt, who has already, last year, pronounced himself in favor of such a project, His Majesty desires to approach him with a proposal to the effect that the Government of the United States take part in a new interna-

2 J. S. For. Rels., 1905, 828; 1906, 1629; see, above, text, Chap. XX. 
tional conference which could be called together at The Hague as soon as favorable replies could be secured from all the other States to which a similar proposal will be made. As the course of the late war has given rise to a number of questions which are of the greatest importance and closely related to the Acts of the First Conference, the plenipotentiaries of Russia at the future meeting will lay before the conference a detailed program which could serve as a starting point for its deliberations.

\section{b. Note from the Russian Ambassador to the Secretary of State, 3 April, 1906.}

Imperial Russian Embassy,

Washington, D. C., April 3, 1906.

Mr. Secretary of State: I have just received from my Government order by telegraph to bring the following to the knowledge of the United States Government:

The Imperial (Russian) Government, in agreement with the Dutch Government, proposes to call The Hague Conference during the first half of the month of July of the present year.

Russia at the same time invites the nations which did not sign the convention relative to the laws of war on land, nor that relative to the adaptation of the Geneva Convention to war at sea, to inform the Royal Government of The Netherlands of their adhesion to these conventions. With regard to further adhesions to the convention concerning international arbitration, the Imperial Government is conferring on this subject with the Governments which signed the acts of 1899 .

I deem it proper at the same time to inclose herewith a summary of the program which the Imperial Government proposes to submit to the Conference at The Hague, and I should thank your Excellency to inform me of the response of your Government to this proposition, in order that I may transmit it to St. Petersburg by telegraph.

Please accept, etc.,

Rosen.

\section{c. Note from the Russian Ambassador to the Secretary of State proposing the Program of the Second Peace Conference 12 April, 1906.}

Imperial Embassy of Russia, Washington, April 12, 1906.

Mr. Secretary of State: When it assumed the initiative of calling a Second Peace Conference, the Imperial Government had 
in view the necessity of further developing the humanitarian principles on which was based the work accomplished by the great international assemblage of 1899.

At the same time, it deemed it expedient to enlarge as much as possible the number of States participating in the labors of the contemplated conference, and the alacrity with which the call was answered bears witness to the depth and breadth of the present sentiment of solidarity for the application of ideas aiming at the good of all mankind.

The First Conference separated in the firm belief that its labors would subsequently be perfected from the effect of the regular progress of enlightenment among the nations and kept abreast of the results acquired from experience. Its most important creation, the International Court of Arbitration, is an institution that has already proved its worth and brought together, for the good of all, an areopagus of jurists who command the respect of the world. How much good could be accomplished by international commissions of inquiry toward the settlement of disputes between States has also been shown.

There are, however, certain improvements to be made in the Convention relative to the Pacific Settlement of International Disputes. Following recent arbitrations, the jurists assembled in court have raised certain questions of detail which should be acted upon by adding to the said Convention the necessary amplifications. It would seem especially desirable to lay down fixed principles in regard to the use of languages in the proceedings in view of the difficulties that may arise in the future as the cases referred to arbitral jurisdiction multiply. The modus operandi of International Commissions of Inquiry would likewise be open to improvement.

As regards the regulating of the Laws and Customs of War on Land, the provisions established by the First Conference ought also to be completed and defined, so as to remove all misapprehensions.

As for maritime warfare, in regard to which the laws and customs of the several countries differ on certain points, it is necessary to establish fixed rules in keeping with the exigencies of the rights of belligerents and the interests of neutrals.

A convention bearing on these subjects should be framed and would constitute one of the most prominent parts of the tasks devolved upon the forthcoming conference.

Holding, therefore, that there is at present occasion only to examine questions that demand special attention as being the outcome of the experience of recent years, without touching upon those that might have reference to the limitation of military or 
naval forces, the Imperial Government proposes for the program of the contemplated meeting the following main points:

1. Improvements to be made in the provisions of the Convention relative to the pacific settlement of international disputes as regards the Court of Arbitration and the International Commissions of Inquiry.

2. Additions to be made to the provisions of the Convention of 1899 relative to the Laws and Customs of War on Land-among others, those concerning the opening of Hostilities, the Rights of Neutrals on land, etc. Declarations of 1899: one of these having expired, question of its being revived.

3. Framing of a convention relative to the laws and customs of maritime warfare, concerning-

The special operations of maritime warfare, such as the bombardment of ports, cities, and villages by a naval force; the laying of torpedoes, etc.;

The transformation of merchant vessels into warships;

The private property of belligerents at sea;

The length of time to be granted to merchant ships for their departure from ports of neutrals or of the enemy after the opening of hostilities;

The rights and duties of neutrals at sea, among others, the questions of contraband, the rules applicable to belligerent vessels in neutral ports; destruction, in case of vis major, of neutral merchant vessels eaptured as prizes;

In the said convention to be drafted, there would be introduced the provisions relative to war on land that would be also applicable to maritime warfare.

4. Additions to be made to the Convention of 1899 for the Adaptation to Maritime Warfare of the Principles of the Geneva Convention of 1864.

As was the case at the Conference of 1899 , it would be well understood that the deliberations of the contemplated meeting should not deal with the political relations of the several States, or the condition of things established by treaties, or in general with questions that did not directly come within the program adopted by the several cabinets.

The Imperial Government desires distinctly to state that the data of this program and the eventual acceptance of the several States clearly do not prejudge the opinion that may be delivered in the conference in regard to the solving of the questions brought up for discussion. It would likewise be for the contemplated meet- 
ing to decide as to the order of the questions to be examined and the form to be given to the decisions reached, as to whether it should be deemed preferable to include some of them in new conventions or to append them, as additions, to conventions already existing.

In formulating the above-mentioned program, the Imperial Government bore in mind, as far as possible, the recommendations made by the First Peace Conference, with special regard to the Rights and Duties of Neutrals, the private property of belligerents at sea, the bombardment of ports, eities, etc. It entertains the hope that the Government of the United States will take the whole of the points proposed as the expression of a wish to come nearer that lofty ideal of international justice which is the permanent goal of the whole civilized world.

By order of my Government, I have the honor to acquaint you with the foregoing, and, awaiting the reply to the Government of the United States with as little delay as possible, I embrace this opportunity to beg you, Mr. Secretary of State, to accept the assurance of my very high consideration.

ROSEN.

\section{No. 9. Final Act of the Second Hague Peace Conference, 1907.1}

The Second International Peace Conference, proposed in the first instance by the President of the United States of America, having been convoked, on the invitation of His Majesty the Emperor of All the Russias, by Her Majesty the Queen of the Netherlands, assembled on the 15th June, 1907, at The Hague, in the Hall of the Knights, for the purpose of giving a fresh development to the humanitarian principles which served as a basis for the work of the First Conference of 1899,

The following Powers took part in the Conference, and ap. pointed the Delegates named below:-

(Here follow the names of the delegates.)

At a series of meetings, held from the 15th June to the 18th October, 1907, in which the above Delegates were throughout animated by the desire to realize, in the fullest possible measure, the generous views of the august initiator of the Conference and the intentions of their Governments, the Conference drew up for submission for signature by the Plenipotentiaries, the text of the Conventions and of the Declaration enumerated below and annexed to the present Act:-

1. Convention for the Pacific Settlement of International Disputes.

2. Convention respecting the Limitation of the Employment of Force for the Recovery of Contract Debts.

${ }^{2}$ U. S. For. Rels., 1907, 1266; see, abore, text, Chaps. XI, XX. 
3. Convention relative to the Opening of Hostilities.

4. Convention respecting the Laws and Customs of War on Land.

5. Convention respecting the Rights and Duties of Neutral Powers and Persons in case of War on Land.

6. Convention relative to the Status of Enemy Merchantships at the Outbreak of Hostilities.

7. Convention relative to the Conversion of Merchant-ships into War-ships.

8. Convention relative to the Laying of Automatic Submarine Contact Mines.

9. Convention respecting Bombardment by Naval Forces in Time of War.

10. Convention for the Adaptation to Naval War of the Principles of the Geneva Convention.

11. Convention relative to certain Restrictions with regard to the Exercise of the Right of Capture in Naval War.

12. Convention relative to the ereation of an International Prize Court.

13. Convention concerning the Rights and Duties of Neutral Powers in Naval War.

14. Declaration prohibiting the discharge of Projectiles and Explosives from Balloons.

These Conventions and Declaration shall form so many separate Acts. These Acts shall be dated this day, and may be signed up to the 30th June, 1908, at The Hague, by the Plenipotentiaries of the Powers represented at the Second Peace Conference.

The Conference, actuated by the spirit of mutual agreement and concession 'characterizing its deliberations, has agreed upon the following Declaration, which, while reserving to each of the Powers represented full liberty of action as regards voting, enables them to affirm the principles which they regard as unanimously admitted :-

It is unanimous-

1. In admitting the principle of compulsory arbitration.

2. In declaring that certain disputes, in particular those relating to the interpretation and application of the provisions of International Agreements, may be submitted to compulsory arbitration without any restriction.

Finally, it is unanimous in proclaiming that, although it has not yet been found feasible to conclude a Convention in this sense, nevertheless the divergences of opinion which have come to light have not exceeded the bounds of judicial controversy, and that, by working together here during the past four months, the colleeted Powers not only have learnt to understand one another and to 
draw closer together, but have succeeded in the course of this long collaboration in evolving a very lofty conception of the common welfare of humanity.

The Conference has further unanimously adopted the following Resolution:-

The Second Peace Conference confirms the Resolution adopted by the Conference of 1899 in regard to the limitation of military expenditure; and inasmuch as military expenditure has considerably increased in almost every country since that time, the Conference declares that it is eminently desirable that the Governments should resume the serious examination of this question.

It has besides expressed the following opinions :-

1. The Conference calls the attention of the Signatory Powers to the advisability of adopting the annexed draft Convention for the creation of a Judicial Arbitration Court, and of bringing it into force as soon as an agreement has been reached respecting the selection of the Judges and the constitution of the Court.

2. The Conference expresses the opinion that, in case of war, the responsible authorities, civil as well as military, should make it their special duty to ensure and safeguard the maintenance of pacific relations, more especially of the commercial and industrial relations between the inhabitants of the belligerent States and neutral countries.

3. The Conference expresses the opinion that the Powers should regulate, by special Treaties, the position, as regards military charges, of foreigners residing within their territories.

4. The Conference expresses the opinion that the preparation of regulations relative to the laws and customs of naval war should figure in the program of the next Conference, and that in any case the Powers may apply, as far as possible, to war by sea the principles of the Convention relative to the laws and Customs of War on land.

Finally, the Conference recommends to the Powers the assembly of a Third Peace Conference, which might be held within a period corresponding to that which has elapsed since the preceding Conference, at a date to be fixed by common agreement between the Powers, and it calls their attention to the necessity of preparing the program of this Third Conference a sufficient time in advance to ensure its deliberations being conducted with the necessary authority and expedition.

In order to attain this object the Conference considers that it 
would be very desirable that, some two years before the probable date of the meeting, a preparatory Committee should be charged by the Governments with the task of collecting the various proposals to be submitted to the Conference, of ascertaining what subjects are ripe for embodiment in an International Regulation, and of preparing a program which the Governments should decide upon in sufficient time to enable it to be carefully examined by the countries interested. This Committee should further be intrusted with the task of proposing a system of organization and procedure for the Conference itself.

In faith whereof the Plenipotentiaries have signed the present Act and have affixed their seals thereto.

Done at The Hague, the 18th October, 1907, in a single copy, which shall remain deposited in the archives of the Netherland Government, and duly certified copies of which shall be sent to all the Powers represented at the Conference.

(Here follow signatures.)

\section{No. 10. Regulations Governing the Organization and Work of the Peace Conference of Paris, 1919. ${ }^{1}$}

\section{Article I.}

The Conference assembled to fix the conditions of peace, first in the preliminaries of peace and then in the definite treaty of peace, shall include the representatives of the belligerent Allied and associated Powers. The belligerent Powers with general interests (the United States of America, the British Empire, France, Italy, and Japan) shall take part in all sittings and commissions. The belligerent Powers with particular interests (Belgium, Brazil, the British Dominions and India, China, Cuba, Greece, Guatemala, Haiti, Hedjaz, Honduras, Liberia, Nicaragua, Panama, Poland, Portugal, Rumania, Serbia, Siam, and the Czecho-Slovak Republic) shall take part in the sittings at which questions concerning thein are discussed. The Powers in a state of diplomatic rupture with the enemy Powers (Bolivia, Ecuador, Peru, and Uruguay) shall take part in the sittings at which questions concerning them are discussed. Neutral Powers and States in process of formation may be heard either orally or in writing when summoned by the Powers with general interests at sittings devoted especially to the examination of questions directly concerning them, but only so far as these questions are concerned.

\footnotetext{
${ }^{1}$ Am. Jour. Int. Law, XIII, No. 2 (April, 1919), Supplement, 109; see, above, text, Chap. XXI.
} 


\section{Article II.}

The Powers shall be represented by Plenipotentiary Delegates to the number of five for the United States of America, the British Empire, France, Italy, and Japan; three for Belgium, Brazil and Serbia ; two for China, Greece, Hedjaz, Poland, Portugal, Rumania, Siam, and the Czecho-Slovak Republic; one for Cuba, Guatemala, Haiti, Honduras, Liberia, Nicaragua, and Panama ; one for Bolivia, Ecuador, Peru, and Uruguay. The British Dominions and India shall be represented as follows: Two delegates each for Australia, Canada, South Africa, and India (including the Native States); one delegate for New Zealand. Although the number of delegates may not exceed the figures above mentioned, each delegation has the right to avail itself of the panel system. The representation of the Dominions (including Newfoundland) and India may besides be included in the representation of the British Empire by the panel system. Montenegro shall be represented by one delegate, but the rules concerning the designation of this delegate shall not be fixed until the moment when the political situation of this country shall have been cleared up. The conditions of the representation of Russia shall be fixed by the Conference at the moment when the matters concerning Russia are examined.

\section{Article III.}

Each delegation of Plenipotentiaries may be accompanied by technical delegates properly accredited and by two stenographers. The technical delegates may be present at the sittings for the purpose of furnishing information which may be asked of them. They shall be allowed to speak for the purpose of giving any desired explanations.

\section{Article IV.}

The delegates take precedence according to the alphabetical order in French of the Powers.

\section{Article V.}

The Conference will be declared open by the President of the French Republic. The President of the Council of French Ministers will be invested temporarily with the Chairmanship. Immediately after this, a Committee, composed of one Plenipotentiary of each of the great Allied or associated Powers, shall proceed at once to the authentication of the credentials of all members present. 


\section{Article VI.}

In the course of the first meeting, the Conference will proceed to appoint a permanent President and four Vice-Presidents chosen from the Plenipotentiaries of the Great Powers in alphabetical order.

\section{Article VII.}

A Secretariat appointed from outside Plenipotentiaries and composed of one representative of the United States of America, one of the British Empire, one of France, one of Italy, and one of Japan, will be submitted to the approval of the Conference by the President, who will be the controlling authority responsible for its operations. This Secretariat will be entrusted with the task of drafting protocols of the meetings, of classifying the archives, of providing for the administrative organization of the Conference, and generally of ensuring the regular and punctual working of the services entrusted to it. The head of the Secretariat will have charge of, and be responsible for, the protocols and archives. The archives will always be open to the members of the Conference.

\section{Article VIII.}

The publicity of the proceedings shall be ensured by official communiqués which shall be prepared by the Secretariat for publication. In case of disagreement as to the drafting of these communiqués the matter shall be referred to the principal Plenipotentiaries or their representatives.

\section{Article IX.}

All documents intended for inclusion in the protocols must be handed in in writing by the Plenipotentiaries presenting them. No document or proposition may be submitted save by one of the Plenipotentiaries or in his name.

\section{Article X.}

Plenipotentiaries wishing to make a proposal unconnected with the questions on the agenda or not arising from the discussion shall give notice of the same twenty-four hours in advance in order to facilitate diseussion. However, exceptions can be made to this rule in the case of amendments or secondary questions, but not in the case of substantive proposals. 


\section{Article XI.}

Petitions, memoranda, observations, or documents forwarded to the Conference by any person other than Plenipotentiaries must be received and classified by the Secretariat. Such of these communications as are of political interest will be briefly summarized in a list to be distributed to all the Plenipotentiaries. This list will be kept up to date as analogous communications are received. All such documents will be deposited in the archives.

\section{Article XII.}

The discussion of the questions to be decided will comprise a first and a second reading. The first will consist of general discussion with the object of obtaining agreement on matters of principle. Subsequently, there will be a second reading for more detailed examination.

\section{Article XIII.}

The Plenipotentiaries shall have the right, subject to the agreement of the Conference, to authorize their technical delegates to submit technical explanations on such points as may be deemed useful. If the Conference thinks it advisable, the technical examination of any particular question may be entrusted to a committee of technical delegates, whose duty it will be to report and suggest solutions.

\section{Article XIV.}

The protocols drawn up by the Secretariat shall be printed and distributed in proof to the delegates in the shortest possible time in order to expedite the work of the Conference. The communication thus made in advance shall take the place of the reading of the protocols at the beginning of each meeting. If no alteration is proposed by the Plenipotentiaries, the text shall be deemed approved and be entered in the archives. If any alteration is proposed, its text shall be read by the President at the beginning of the following meeting. In any case, the protocol must be read out in full at the request of any Plenipotentiary.

\section{Article XV.}

A committee shall be formed for drafting the resolutions adopted. This committee shall concern itself only with questions which have been decided. Its sole duty shall be to draw up the text of the decisions adopted and to present it for the approval of 
the Conference. It shall be composed of five members not forming part of the Plenipotentiary Delegates, and composed of one representative of the United States of America, one of the British Empire, one of France, one of Italy, and one of Japan.

\section{No. 11. Treaty of Alliance for the Preservation of the Balance of Power, 1814. ${ }^{1}$}

In the Name of the Most Holy and Undivided Trinity.

His Majesty the King of the United Kingdom of Great Britain and Ireland, His Imperial and Royal Apostolic Majesty the Emperor of Austria, King of Hungary and Bohemia, His Majesty the Emperor of All the Russias, and His Majesty the King of Prussia, have transmitted to the French Government proposals for concluding a General Peace, and being desirous, should France refuse the Conditions therein contained, to draw eloser the ties which unite them for the vigorous prosecution of a War undertaken for the salutary purpose of putting an end to the miseries of Europe, of securing its future repose, by reëstablishing a just balance of Power, and being at the same time desirous, should the Almighty bless their pacific intentions, to fix the means of maintaining against every attempt the order of things which shall have been the happy consequence of their efforts, have agreed to sanction by a solemn Treaty, signed separately by each of the four Powers with the three others, this twofold engagement.

(Here the plenipotentiaries are named.)

The said Plenipotentiaries, after having exchanged their Full Powers, found to be in due and proper form, have agreed upon the following Articles:

\section{Article I.}

The High Contracting Parties above named solemnly engage by the present Treaty, and in the event of France refusing to accede to the Conditions of Peace now proposed, to apply all the means of their respective States to the vigorous prosecution of the War against that Power, and to employ them in perfect concert, in order to obtain for themselves and for Europe a General Peace, under the protection of which the rights and liberties of all Nations may be established and secured.

This engagement shall in no respect affect the Stipulations which the several Powers have already contracted relative to the number of Troops to be kept against the Enemy; and it is understood that the Courts of England, Austria, Russia, and Prussia,

${ }^{2} B . \& F$., I, 121-129; see, above, text, Chap. XXIV. 
engage by the present Treaty to keep in the field, each of them, one hundred and fifty thousand effective men, exclusive of garrisons, to be employed in active service against the common Enemy.

\section{Article II.}

The High Contracting Parties reciprocally engage not to negotiate separately with the common Enemy, nor to sign Peace, Truce, nor Convention, but with common consent. They, moreover, engage not to lay down their Arms until the object of the War, mutually understood and agreed upon, shall have been attained.

\section{Article V.}

The High Contracting Parties, reserving to themselves to concert together, on the conclusion of a Peace with France, as to the means best adapted to guarantee to Europe, and to themselves reciprocally, the continuance of the Peace, have also determined to enter, without delay, into defensive engagements for the protection of their respective States in Europe against every attempt which France might make to infringe the order of things resulting from such Pacification.

\section{Article VI.}

To effect this, they agree that in the event of one of the High Contracting Parties being threatened with an attack on the part of France, the others shall employ their most strenuous efforts to prevent it, by friendly interposition.

\section{Article VII.}

In the case of these endeavors proving ineffectual, the High Contracting Parties promise to come to the immediate assistance of the Power attacked, each with a body of sixty thousand men.

\section{Article XV.}

In order to render more effectual the Defensive Engagements above stipulated, by uniting for their common defense the Powers the most exposed to a French invasion, the High Contracting Parties engage to invite those Powers to accede to the present Treaty of Defensive Alliance. 


\section{Article XVI.}

The present Treaty of Defensive Alliance having for its object to maintain the equilibrium of Europe, to secure the repose and independence of its States, and to prevent the invasions which during so many years have desolated the World, the High Contracting Parties have agreed to extend the duration of it to twenty years, to take date from the day of its Signature; and they reserve to themselves, to concert upon its ulterior prolongation, three years before its expiration, should circumstances require it.

\section{Article XVII.}

The present Treaty shall be ratified, and the Ratifications exchanged within two months, or sooner if possible.

In witness whereof, the respective Plenipotentiaries have signed the same, and affixed thereto the Seal of their Arms.

Done at Chaumont this 1st of March, in the year of our Lord 1814.
(L. S.) Castlereagh.
(L. S.) Clement Wenceslauus Lothaire, Prince of Metternich.

\section{No. 12. Act of the Holy Alliance, 26 September, $1815 .^{1}$}

In the Name of the Most Holy and Invisible Trinity.

Their Majesties the Emperor of Austria, the King of Prussia, and the Emperor of Russia, having, in consequence of the great events which have marked the course of the three last years in Europe, and especially of the blessings which it has pleased Divine Providence to shower down upon those States which place their confidence and their hope on it alone, acquired the intimate conviction of the necessity of settling the steps to be observed by the Powers, in their reciprocal relations, upon the sublime truths which the Holy Religion of our Saviour teaches:

They solemnly declare that the present Act has no other object than to publish, in the face of the whole world, their fixed resolution, both in the administration of their respective States, and in their political relations with every other Government, to take for their sole guide the precepts of that Holy Religion, the precepts of Justice, Christian Charity, and Peace, which, far from being applicable only to private concerns, must have an immediate influence on the councils of Princes, and guide all their steps, as being the only means of consolidating human institutions and remedying

'B. \& F., III, 211; see, above, text, Chap. XXV. 
their imperfections. In consequence, their Majesties have agreed on the following Articles:

\section{Article I.}

Conformably to the words of the Holy Scriptures, which command all men to consider each other as brethren, the Three Contracting Monarchs will remain united by the bonds of a true and indissoluble fraternity, and, considering each other as fellow countrymen, they will, on all oceasions and in all places, lend each other aid and assistance; and, regarding themselves toward their subjects and armies as fathers of families, they will lead them, in the same spirit of fraternity with which they are animated, to protect Religion, Peace and Justice.

\section{Article II.}

In consequence, the sole principle of force, whether between the said Governments or between their Subjects, shall be that of doing each other reciprocal service, and of testifying by unalterable good will the mutual affection with which they ought to be animated, to consider themselves all as members of one and the same Christian nation; the three allied Princes looking on themselves as merely delegated by Providence to govern three branches of the one family, namely, Austria, Prussia, and Russia, thus confessing that the Christian world, of which they and their people form a part, has in reality no other Sovereign than Him to whom alone power really belongs, because in Him alone are found all the treasures of love, science, and infinite wisdom, that is to say, God, our Divine Saviour, the Word of the Most High, the Word of life. Their Majesties consequently recommend to their people, with the most tender solicitude, as the sole means of enjoying that Peace which arises from a good conscience, and which alone is durable, to strengthen themselves every day more and more in the principles and exercise of the duties which the Divine Saviour has taught to mankind.

\section{Article III.}

All the Powers who shall choose solemnly to avow the sacred principles which have dictated the present Act, and shall acknowledge how important it is for the happiness of nations, too long agitated, that these truths should henceforth exercise over the destinies of mankind all the influence which belongs to them, will be received with equal ardor and affection into this Holy Alliance. 
Done in triplicate, and signed at Paris, the year of Grace 1815, 14/26 September.
(L. S.) Francis.
(L. S.) Frederick William.
(L. S.) Alexander.

\section{No. 13. Program of the Concert of Europe in the Greek Question; Treaty of 6 July, 1827. ${ }^{1}$}

In the name of the Most Holy and Undivided Trinity.

His Majesty the King of the United Kingdom of Great Britain and Ireland, His Majesty the King of France and Navarre, and His Majesty the Emperor of all the Russias, penetrated with the necessity of putting an end to the sanguinary struggle which, while it abandons the Greek Provinces and the Islands of the Archipelago to all the disorders of anarchy, daily causes fresh impediments to the commerce of the States of Europe, and gives opportunity for acts of Piracy which not only expose the subjects of the High Contracting Parties to grievous losses, but also render necessary measures which are burdensome for their observation and suppression.

His Majesty the King of the United Kingdom of Great Britain and Ireland, and His Majesty the King of France and Navarre, having, moreover, received from the Greeks an earnest invitation to interpose their mediation with the Ottoman Porte; and together with His Majesty the Emperor of all the Russias, being animated with the desire of putting a stop to the effusion of blood, and of preventing the evils of every kind which the continuance of such a state of things may produce;

They have resolved to combine their efforts, and to regulate the operation thereof by a formal Treaty, for the object of reëstablishing peace between the contending parties, by means of an arrangement called for, no less by sentiments of humanity, than by interests for the tranquillity of Europe.

For these purposes they have named their Plenipotentiaries to discuss, conclude, and sign the said Treaty, that is to say:- . . .

Who having communicated to each other their full powers, found to be in due and proper form, have agreed upon the following articles.

\section{Article I.}

The contracting Powers shall offer their mediation to the Ottoman Porte, with the view of effecting a reconciliation between it and the Greeks. This offer of mediation shall be made to that Power immediately after the ratification of the present treaty, by

${ }^{1} B$. \& F., XIV, 632; see, above, text, Chap. XXV. 
means of a joint declaration, signed by the plenipotentiaries of the Allied Courts at Constantinople; and, at the same time, a demand for an immediate armistice shall be made to the two contending parties, as a preliminary and indispensable condition to the opening of any negotiation.

\section{Article II.}

The arrangement to be proposed to the Ottoman Porte shall rest upon the following bases:-

The Greeks shall hold under the Sultan as under a Lord paramount; and, in consequence thereof, they shall pay to the Ottoman Empire an annual tribute, the amount of which shall be fixed, once for all, by common agreement. They shall be governed by authorities whom they shall choose and appoint themselves, but in the nomination of whom the Porte shall have a defined right. In order to effect a complete separation between the individuals of the two nations, and to prevent the collisions which would be the inevitable consequence of so protracted a struggle, the Greeks shall become possessors of all Turkish property situated either upon the continent, or in the islands of Greece, on condition of indemnifying the former proprietors, either by an annual sum to be added to the tribute which they shall pay to the Porte, or by some other arrangement of the same nature.

\section{Article III.}

The details of this arrangement, as well as the limits of the territory upon the continent, and the designation of the islands of the Archipelago to which it shall be applicable, shall be settled by a negotiation to be afterwards entered into between the High Powers and the two contending parties.

\section{Article IV.}

The contracting Powers engage to pursue the salutary work of the pacification of Greece, upon the bases laid down in the preceding articles, and to furnish, without the least delay, their representatives at Constantinople with all the instructions which are required for the execution of the Treaty which they now sign.

\section{Article V.}

The contracting Powers will not seek in these arrangements, any augmentation of territory, any exclusive influence, or any commercial advantage for their subjects, which those of every other nation may not equally obtain. 


\section{Article VI.}

The arrangements for reconciliation and peace, which shall be definitively agreed upon between the contending parties, shall be guaranteed by those of the signing Powers who may judge it expedient or possible to contract that obligation. The operation and the effects of such guarantee shall become the subject of future stipulation between the High Powers.

\section{Article VII.}

The present Treaty shall be ratified, and the ratifications shall be exchanged in two months, or sooner if possible.

In witness, \&c.

Done at London, the 6th day of July, in the year of our Lord 1827.

DudLey.

Le Prince de Polignac. LIEVEN.

\section{Additional Article.}

In case the Ottoman Porte should not, within the space of one month, accept the mediation which is to be proposed to it, the High contracting parties agree upon the following measures:-

1. It shall be declared to the Porte, by their representatives at Constantinople, that the inconveniences and evils described in the Patent Treaty as inseparable from the state of things which has, for six years, existed in the East, and the termination of which, by the means at the command of the Sublime Ottoman Porte, appears to be still distant, impose upon the High contracting parties the necessity of taking immediate measures for forming a connection with the Greeks. It is understood that this shall be effected by establishing commercial relations with the Greeks, and by sending to and receiving from them, for this purpose, consular agents, provided there shall exist in Greece authorities capable of supporting such relations.

2. If, within the said term of one month, the Porte does not accept the armistice proposed in the first article of the Patent Treaty, or if the Greeks refuse to carry it into execution, the High contracting Powers shall declare to either of the contending parties which may be disposed to continue hostilities, or to both of them, that the said High Powers intend to exert all the means which circumstances may suggest to their prudence, for the purpose of obtaining the immediate effects of the armistice of which they desire the execution, by preventing, as far as possible, all collision 
between the contending parties; and in consequence, immediately after the above-mentioned declaration, the High Powers will, jointly, exert all their efforts to accomplish the object of such armistice, without, however, taking any part in the hostilities between the two contending parties. Immediately after the signature of the present additional Article, the High contracting Powers will, jointly, transmit to the admirals commanding their respective squadrons in the Levant, conditional instructions in conformity to the arrangements above declared.

3. Finally, if, contrary to all expectation, these measures do not prove sufficient to procure the adoption of the propositions of the High contracting parties by the Ottoman Porte; or if, on the other hand, the Greeks decline the conditions stipulated in their favor, by the Treaty of this date, the High contracting Powers will, nevertheless, continue to pursue the work of pacification, on the bases upon which they have agreed; and, in consequence, they authorize, from the present moment, their representatives at London to discuss and determine the future measures which it may become necessary to employ.

The present additional article shall have the same force and validity as if it were inserted, word for word, in the treaty of this day. It shall be ratified, and the ratifications shall be exchanged at the same time as those of the said treaty.

In witness, \&c.

Done at London, the 6th day of July, in the year of our Lord 1827.

DUdLEY.

Le Prince de Polinac, LIEVEN.

\section{No. 14. Convention of the Concert of Europe providing Guarantees for the Kingdom of Greece, 7 May, 1832. ${ }^{1}$}

The Courts of France, Great Britain, and Russia, exercising the power conveyed to them by the Greek Nation, to make choice of a Sovereign for Greece, raised to the rank of an independent State, and being desirous of giving to that country a fresh proof of their friendly disposition, by the election of a Prince descended from a Royal House, the friendship and alliance of which cannot fail to be of essential service to Greece, and which has already acquired claims to her esteem and gratitude, have resolved to offer the Crown of the new Greek State to the Prince Frederick Otho of Bavaria, second son of His Majesty the King of Bavaria.

His Majesty the King of Bavaria, on his part, acting in the character of Guardian of the said Prince Otho during his minority,

${ }^{1} B$. \& F., XIX, 33; see, above, text, Chap. XXV. 
participating in the views of the three Courts, and duly appreeiating the motives which have induced them to fix their choice upon a Prince of his house, has determined to accept the Crown of Greece for his second son the Prince Frederick Otho of Bavaria.

In consequence of such acceptance, and for the purpose of agreeing upon the arrangements which it has rendered necessary, their Majesties the King of the French, the King of the United Kingdom of Great Britain and Ireland, and the Emperor of all the Russias, on the one part, and His Majesty the King of Bavaria on the other, have named as their Plenipotentiaries, viz.:

Who, after having exchanged their full powers, found to be in good and due form, have agreed upon and signed the following Articles :-

\section{Article I.}

The Courts of Great Britain, France, and Russia, duly authorized for this purpose by the Greek nation, offer the hereditary Sovereignty of Greece to the Prince Frederick Otho of Bavaria, second son of His Majesty the King of Bavaria.

Article II.

His Majesty the King of Bavaria, acting in the name of his said son, a minor, accepts, on his behalf, the hereditary Sovereignty of Greece, on the conditions hereinafter settled.

\section{Article III.} Greece.

The Prince Otho of Bavaria shall bear the title of King of Article IV.

Greece, under the sovereignty of the Prince Otho of Bavaria, and under the guarantee of the three Courts, shall form a monarchical and independent State, according to the terms of the Protocol signed between the said Courts, on the 3rd of February, 1830, and accepted both by Greece and by the Ottoman Porte.

\section{Article V.}

The limits of the Greek State shall be such as shall be definitely settled by the negotiations which the Courts of Great Britain, France, and Russia, have recently opened with the Ottoman Porte, in execution of the Protocol of the 26th of September, 1831. 


\section{Article VI.}

The three Courts having beforehand determined to convert the Protocol of the 3rd of February, 1830, into a definite Treaty, as soon as the negotiations relative to the limits of Greece shall have terminated, and to communicate such Treaty to all the States with which they have relations, it is hereby agreed that they shall fulfil this engagement, and that His Majesty the King of Greece shall become a Contracting Party to the Treaty in question.

\section{Article VII.}

The three Courts shall, from the present moment, use their influence to procure the recognition of the Prince Otho of Bavaria as King of Greece, by all the Sovereigns and States with whom they have relations.

\section{Article XII.}

In execution of the stipulations of the Protocol of the 20th of February, 1830, His Majesty the Emperor of all the Russias engages to guarantee, and their Majesties the King of the United Kingdom of Great Britain and Ireland and the King of the French engage to recommend, the former to his Parliament, the latter to his Chambers, to enable their Majesties to guarantee, on the following conditions, a loan to be contracted by the Prince Otho of Bavaria, as King of Greece:-

1. The Principal of the loan to be contracted under the guarantee of the three Powers shall not exceed a total amount of sixty millions of franes.

2. The said loan shall be raised by instalments of twenty millions of franes each.

3. For the present, the first instalment only shall be raised, and the three Courts shall each become responsible for the payment of one-third of the annual amount of the interest and sinking fund of the said instalment.

4. The second and the third instalments of the said loan may also be raised, according to the necessities of the Greek State, after previous agreement between the three Courts and His Majesty the King of Greece.

5. In the event of the second and third instalments of the above-mentioned loan being raised in consequence of such an agreement, the three Courts shall each become responsible for the payment of one-third of the annual amount of the interest and sinking fund of these two instalments, as well as of the first. 
6. The Sovereign of Greece and the Greek State shall be bound to appropriate to the payment of the interest and sinking fund of such instalments of the loan as may have been raised under the guarantee of the three Courts, the first revenues of the State, in such manner that the actual receipts of the Greek Treasury shall be devoted, first of all, to the payment of the said interest and sinking fund, and shall not be employed for any other purpose, until those payments on account of the instalments of the loan raised under the guarantee of the three Courts, shall have been completely secured for the current year.

The Diplomatic Representatives of the three Courts in Greece shall be specially charged to watch over the fulfilment of the last-mentioned stipulation.

\section{Article XIII.}

In case a pecuniary compensation in favor of the Ottoman Porte should result from the negotiations which the three Courts have already. opened at Constantinople for the definite settlement of the limits of Greece, it is understood that the amount of such compensation shall be defrayed out of the proceeds of the loan which forms the subject of the preeeding Article.

\section{No. 15. Covenant of the League of Nations, $1919 .{ }^{1}$}

The High Contracting Parties,

In order to promote international coöperation and to achieve international peace and security

by the acceptance of obligations not to resort to war,

by the prescription of open, just and honorable relations between nations,

by the firm establishment of the understandings of international law as the actual rule of conduct among Govern- opume erav ments, and

by the maintenance of justice and a scrupulous respect for all treaty obligations in the dealings of organized peoples with one another,

Agree to this Covenant of the League of Nations.

\section{Article I.}

The original Members of the League of Nations shall be those of the Signatories which are named in the Annex to this Covenant and also such of those other States named in the Annex as shall

${ }^{1}$ Sen. Doc. 49, 66 Cong. 1 sess., 8-17; see, above, text, Chap. XXVII. 
accede without reservation to this Covenant. Such accession shall be effected by a Declaration deposited with the Secretariat within two months of the coming into force of the Covenant. Notice thereof shall be sent to all other Members of the League.

Any fully self-governing State, Dominion, or Colony not named in the Annex may become a Member of the League if its admission is agreed to by two-thirds of the Assembly, provided that it shall give effective guarantees of its sincere intention to observe its international obligations, and shall accept such regulations as may be prescribed by the League in regard to its military, naval, and air forces and armaments.

Any Member of the League may, after two years' notice of its intention so to do, withdraw from the League, provided that all its international obligations and all its obligations under this Covenant shall have been fulfilled at the time of its withdrawal.

\section{Article II.}

The action of the League under this Covenant shall be effected through the instrumentality of an Assembly and of a Council, with a permanent Secretariat.

Article III.

The Assembly shall consist of Representatives of the Members of the League.

The Assembly shall meet at stated intervals and from time to time as occasion may require at the Seat of the League or at such other place as may be decided upon.

The Assembly may deal at its meetings with any matter within the sphere of action of the League or affecting the peace of the world.

At meetings of the Assembly each Member of the League shall have one vote, and may not have more than three Representatives.

\section{Article IV.}

The Council shall consist of Representatives of the Principal Allied and Associated Powers, together with Representatives of four other Members of the League. These four Members of the League shall be selected by the Assembly from time to time in its discretion. Until the appointment of the Representatives of the four Members of the League first selected by the Assembly, Representatives of Belgium, Brazil, Spain, and Greece shall be members of the Council.

With the approval of the majority of the Assembly, the Council 
may name additional Members of the League whose Representatives shall always be members of the Council; the Council with like approval may increase the number of Members of the League to be selected by the Assembly for representation on the Council.

The Council shall meet from time to time as occasion may require, and at least once a year, at the Seat of the League, or at such other place as may be decided upon.

The Council may deal at its meetings with any matter within the sphere of action of the League or affecting the peace of the world.

Any Member of the League not represented on the Council shall be invited to send a Representative to sit as a member at any meeting of the Council during the consideration of matters specially affecting the interests of that Member of the League.

At meetings of the Council, each Member of the League represented on the Council shall have one vote, and may have not more than one Representative.

\section{Article V.}

Except where otherwise expressly provided in this Covenant or by the terms of the present Treaty, decisions at any meeting of the Assembly or of the Council shall require the agreement of all the Members of the League represented at the meeting.

All matters of procedure at meetings of the Assembly or of the Council, including the appointment of Committees to investigate particular matters, shall be regulated by the Assembly or by the Council and may be decided by a majority of the Members of the League represented at the meeting.

The first meeting of the Assembly and the first meeting of the Council shall be summoned by the President of the United States of America.

\section{Article VI.}

The permanent Secretariat shall be established at the Seat of the League. The Secretariat shall comprise a Secretary General and such secretaries and staff as may be required.

The first Secretary General shall be the person named in the Annex; thereafter the Secretary General shall be appointed by the Council with the approval of the majority of the Assembly.

The secretaries and staff of the Secretariat shall be appointed by the Secretary General with the approval of the Council.

The Secretary General shall act in that capacity at all meetings of the Assembly and of the Council. 
The expenses of the Secretariat shall be borne by the Members of the League in accordance with the apportionment of the expenses of the International Bureau of the Universal Postal Union.

\section{Article VII.}

The Seat of the League is established at Geneva.

The Council may at any time decide that the Seat of the League shall be established elsewhere.

All positions under or in connection with the League, including the Secretariat, shall be open equally to men and women.

Representatives of the Members of the League and officials of the League when engaged on the business of the League shall enjoy diplomatic privileges and immunities.

The buildings and other property, occupied by the League or its officials or by Representatives attending its meetings shall be inviolable.

\section{Article VIII.}

The Members of the League recognize that the maintenance of peace requires the reduction of national armaments to the lowest point consistent with national safety and the enforcement by common action of international obligations.

The Council, taking account of the geographical situation and circumstances of each State, shall formulate plans for such reduction for the consideration and action of the several Governments.

Such plans shall be subject to reconsideration and revision at least every ten years.

After these plans shall have been adopted by the several Governments, the limits of armaments therein fixed shall not be exceeded without the concurrence of the Council.

The Members of the League agree that the manufacture by private enterprise of munitions and implements of war is open to grave objections. The Council shall advise how the evil effects attendant upon such manufacture ean be prevented, due regard being had to the necessities of those Members of the League which are not able to manufacture the munitions and implements of war necessary for their safety.

The Members of the League undertake to interchange full and frank information as to the scale of their armaments, their military, naval, and air programs and the condition of such of their industries as are adaptable to war-like purposes.

\section{Article IX.}

A permanent Commission shall be constituted to advise the Council on the execution of the provisions of Articles I and VIII and on military, naval, and air questions generally. 


\section{Article X.}

The Members of the League undertake to respect and preserve as against external aggression the territorial integrity and existing political independence of all Members of the League. In ease of any such aggression or in case of any threat or danger of such aggression the Council shall advise upon the means by which this obligation shall be fulfilled.

\section{Article XI.}

Any war or threat of war, whether immediately affecting any of the Members of the League or not, is hereby declared a matter of concern to the whole League, and the League shall take any action that may be deemed wise and effectual to safeguard the peace of nations. In case any such emergency should arise the Secretary General shall on the request of any Member of the League forthwith summon a meeting of the Council.

It is also declared to be the friendly right of each Member of the League to bring to the attention of the Assembly or of the Council any circumstance whatever affecting international relations when threaters to disturb international peace or the good understanding between nations upon which peace depends.

\section{Article XII.}

The Members of the League agree that if there should arise between them any dispute likely to lead to a rupture, they will submit the matter either to arbitration or to inquiry by the Council, and they agree in no case to resort to war until three months after the award by the arbitrators or the report by the Council.

In any case under this Article the award of the arbitrators shall be made within a reasonable time, and the report of the Council shall be made within six months after the submission of the dispute.

\section{Article XIII.}

The Members of the League agree that whenever any dispute shall arise between them which they recognize to be suitable for submission to arbitration and which cannot be satisfactorily settled by diplomacy, they will submit the whole subject-matter to arbitration.

Disputes as to the interpretation of a treaty, as to any question of international law, as to the existence of any fact which if established would constitute a breach of any international obligation, or as to the extent and nature of the reparation to be made 
for any such breach, are declared to be among those which are generally suitable for submission to arbitration.

For the consideration of any such dispute the court of arbitration to which the case is referred shall be the Court agreed on by the parties to the dispute or stipulated in any convention existing between them.

The Members of the League agree that they will carry out in full good faith any award that may be rendered, and that they will not resort to war against a Member of the League which complies therewith. In the event of any failure to carry out such an award, the Council shall propose what steps should be taken to give effect thereto.

\section{Article XIV.}

The Council shall formulate and submit to the Members of the League for adoption plans for the establishment of a Permanent Court of International Justice. The Court shall be competent to hear and determine any dispute of an international character which the parties thereto submit to it. The Court may also give an advisory opinion upon any dispute or question referred to it by the Council or by the Assembly.

\section{Article $X \nabla$.}

If there should arise between Members of the League any dispute likely to lead to a rupture, which is not submitted to arbitration in accordance with Article XIII, the Members of the League agree that they will submit the matter to the Council. Any party to the dispute may effect such submission by giving notice of the existence of the dispute to the Secretary General, who will make all necessary arrangements for a full investigation and consideration thereof.

For this purpose the parties to the dispute will communicate to the Secretary General, as promptly as possible, statements of their case with all the relevant facts and papers, and the Council may forthwith direct the publication thereof.

The Council shall endeavor to effect a settlement of the dispute, and if such efforts are successful, a statement shall be made public giving such facts and explanations regarding the dispute and the terms of settlement thereof as the Council may deem appropriate. If the dispute is not thus settled, the Council either unanimously or by a majority vote shall make and publish a report containing a statement of the facts of the dispute and the recommendations which are deemed just and proper in regard thereto.

Any Member of the League represented on the Council may 
make public a statement of the facts of the dispute and of its conclusions regarding the same.

If a report by the Council is unanimously agreed to by the members thereof other than the Representatives of one or more of the parties to the dispute, the Members of the League agree that they will not go to war with any party to the dispute which complies with the recommendations of the report.

If the Council fails to reach a report which is unanimously agreed to by the members thereof, other than the Representatives of one or more of the parties to the dispute, the Members of the League reserve to themselves the right to take such action as they shall consider necessary for the maintenance of right and justice.

If the dispute between the parties is claimed by one of them, and is found by the Council, to arise out of a matter which by international law is solely within the domestic jurisdiction of that party, the Council shall so report, and shall make no recommendation as to its settlement.

The Council may in any case under this Article refer the dispute to the Assembly. The dispute shall be so referred at the request of either party to the dispute, provided that such request be made within fourteen days after the submission of the dispute to the Council.

In any case referred to the Assembly, all the provisions of this Article and of Article XII relating to the action and powers of the Council shall apply to the action and powers of the Assembly, provided that a report made by the Assembly, if concurred in by the Representatives of those Members of the League represented on the Council and of a majority of the other Members of the League, exclusive in each case of the Representatives of the parties to the dispute, shall have the same force as a report by the Council concurred in by all the members thereof other than the Representatives of one or more of the parties to the dispute.

\section{Article XVI.}

Should any Member of the League resort to war in disregard of its covenants under Articles XII, XIII, or XV, it shall ipso facto be deemed to have committed an act of war against all other Members of the League, which hereby undertake immediately to subject it to the severance of all trade or financial relations, the pronibition of all intercourse between their nations and the nationals of the covenant-breaking State, and the prevention of all financial, commercial, or personal intercourse between the nationals of the covenant-breaking State and the nationals of any other State, whether a Member of the League or not.

It shall be the duty of the Council in such case to recommend
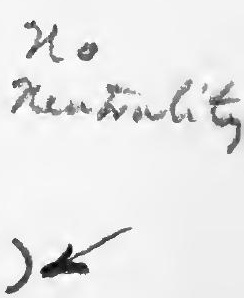
to the several Governments concerned what effective military, naval, or air force the Members of the League shall severally contribute to the armed forces to be used to protect the covenants of the League.

The Members of the League agree, further, that they will mutually support one another in the financial and economic measures which are taken under this Article, in order to minimize the loss and inconvenience resulting from the above measures, and that they will mutually support one another in resisting any special measures aimed at one of their number by the covenant-breaking State, and that they will take the necessary steps to afford passage through their territory to the forces of any of the Members of the League which are coöperating to protect the covenants of the League.

Any Member of the League which has violated any covenant of the League may be declared to be no longer a Member of the League by a vote of the Council concurred in by the Representatives of all the other Members of the League represented thereon.

\section{Article XVII.}

In the event of a dispute between a Member of the League and a State which is not a Member of the League, or between States not Members of the League, the State or States, not Members of the League shall be invited to accept the obligations of membership in the League for the purposes of such dispute, upon such conditions as the Council may deem just. If such invitation is accepted, the provisions of Articles XII to XVI inclusive shall be applied with such modifications as may be deemed necessary by the Council.

Upon such invitation being given the Council shall immediately institute an inquiry into the circumstances of the dispute and recommend such action as may seem best and most effectual in the circumstances.

If a State so invited shall refuse to accept the obligations of membership in the League for the purposes of such dispute, and shall resort to war against a Member of the League, the provisions of Article XVI shall be applicable as against the State taking such action.

If both parties to the dispute when so invited refuse to accept the obligations of membership in the League for the purpose of such dispute, the Council may take such measures and make such recommendations as will prevent hostilities and will result in the settlement of the dispute. 


\section{Article XVIII.}

Every treaty or international engagement entered into hereafter by any Member of the League shall be forthwith registered with the Secretariat and shall as soon as possible be published by it. No such treaty or international engagement shall be binding until so registered.

\section{Article XIX.}

The Assembly may from time to time advise the reconsideration by Members of the League of treaties which have become inapplicable and the consideration of international conditions whose continuance might endanger the peace of the world.

\section{Article XX.}

The Members of the League severally agree that this Covenant is accepted as abrogating all obligations or understandings inter se which are inconsistent with the terms thereof, and solemnly undertake that they will not hereafter enter into any engagements inconsistent with the terms thereof.

In case any Member of the League shall, before becoming a Member of the League, have undertaken any obligations inconsistent with the terms of this Covenant, it shall be the duty of such Member to take immediate steps to procure its release from such obligations.

\section{Article XXI.}

Nothing in this Covenant shall be deemed to affect the validity of international engagements, such as treaties of arbitration or regional understandings like the Monroe doctrine, for securing the maintenance of peace.

\section{Article XXII.}

To those colonies and territories which as a consequence of the late war have ceased to be under the sovereignty of the States which formerly governed them and which are inhabited by peoples not yet able to stand by themselves under the strenuous conditions of the modern world, there should be applied the principle that the well-being and development of such peoples form a sacred trust

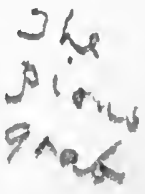
of civilization and that securities for the performance of this trust should be embodied in this Covenant.

The best method of giving practical effect to this principle is that the tutelage of such peoples should be entrusted to advanced 
nations who by reason of their resources, their experience or their geographical position can best undertake this responsibility, and who are willing to accept it, and that this tutelage should be exercised by them as Mandatories on behalf of the League.

The character of the mandate must differ according to the stage of the development of the people, the geographical situation of the territory, its economic conditions, and other simjlar circumstances.

Certain communities formerly belonging to the Turkish Empire have reached a stage of development where their existence as independent nations can be provisionally recognized subject to the rendering of administrative advice and assistance by a Mandatory until such time as they are able to stand alone. The wishes of these communities must be a principal consideration in the selection of the Mandatory.

Other peoples, especially those of Central Africa, are at such a stage that the Mandatory must be responsible for the administration of the territory under conditions which will guarantee freedom of conscience and religion, subject only to the maintenance of public order and morals, the prohibition of abuses such as the slave trade, the arms traffic, and the liquor traffic, and the prevention of the establishment of fortifications or military and naval bases and of military training of the natives for other than police purposes and the defense of territory, and will also secure equal opportunities for the trade and commerce of other Members of - the League.

There are territories, such as South-West Africa and certain of the South Pacific Islands, which, owing to the sparseness of their population, or their small size, or their remoteness from the centers of civilization, or their geographical contiguity to the territory of the Mandatory, and other circumstances, can be best administered under the laws of the Mandatory as integral portions of its territory, subject to the safeguards above mentioned in the interests of the indigenous population.

In every case of mandate, the Mandatory shall render to the Council an annual report in reference to the territory committed to its charge.

The degree of authority, control, or administration to be exercised by the Mandatory shall, if not previously agreed upon by the Members of the League, be explicitly defined in each case by the Council.

A permanent Commission shall be constituted to receive and examine the annual reports of the Mandatories and to advise the Council on all matters relating to the observance of the mandates. 


\section{Article XXIII.}

Subject to and in accordance with the provisions of international conventions existing or hereafter to be agreed upon, the Members of the League:

(a) will endeavor to secure and maintain fair and humane conditions of labor for men, women, and children, both in their own countries and in all countries to which their commercial and industrial relations extend, and for that purpose will establish and maintain the necessary international organizations;

(b) undertake to secure just treatment of the native inhabitants of territories under their control;

(c) will entrust the League with the general supervision over the execution of agreements with regard to the traffic in women and children, and the traffic in opium and other dangerous drugs;

(d) will entrust the League with the general supervision of the trade in arms and ammunition with the countries in which the control of this traffic is necessary in the common interest;

(e) will make provision to secure and maintain freedom of communications and of transit and equitable treatment for the commerce of all Members of the League. In this connection, the special necessities of the regions devastated during the war of 1914-1918 shall be borne in mind;

(f) will endeavor to take steps in matters of international concern for the prevention and control of disease.

\section{Article XXIV.}

There shall be placed under the direction of the League all international bureaux already established by general treaties if the parties to such treaties consent. AII such international bureaux and all commissions for the regulation of matters of international interest hereafter constituted shall be placed under the direction of the League.

In all matters of international interest which are regulated by general conventions but which are not placed under the control of international bureaux or commissions, the Secretariat of the League shall, subject to the consent of the Council and if desired by the parties, collect and distribute all relevant information and shall render any other assistance which may be necessary or desirable. 
The Council may include as part of the expenses of the Secretariat the expenses of any bureau or commission which is placed under the direction of the League.

\section{Article XXV.}

The Members of the League agree to encourage and promote the establishment and coöperation of duly authorized voluntary national Red Cross organizations having as purposes the improvement of health, the prevention of disease, and the mitigation of suffering throughout the world.

\section{Article XXVI.}

Amendments to this Covenant will take effect when ratified by the Members of the League whose representatives compose the Council and by a majority of the Members of the League whose Representatives compose the Assembly.

No such amendment shall bind any Member of the League which signifies its dissent therefrom, but in that case it shall cease to be a Member of the League.

\section{Annex.}

I. Original Members of the League of Nations Signatories of the Treaty of Peace.

United States of America.

Belgium.

Bolivia.

Brazil.

British Empire.

Canada.

Australia.

South Africa.

New Zealand.

India.

China.

Cuba.

Ecuador

France.

Greece.

Guatemala.
Haiti.

Hedjaz.

Honduras.

Italy.

Japan.

Liberia.

Nicaragua.

Panama.

Peru.

Poland.

Portugal.

Roumania.

Serb-Croat-Slovene State.

Siam.

Czecho-Slovakia.

Uruguay. 
States Invited to Accede to the Covenant.

Argentine Republic.

Chile.

Colombia.

Denmark.

Netherlands.

Norway.

Paraguay.
Persia.

Salvador.

Spain.

Sweden.

Switzerland.

Venezuela.

II. First Secretary General of the League of Nations.

The Honorable Sir James Eric Drummond, K.C.M.G., C.B. 


\section{APPENDIX B: BIBLIOGRAPHY.}

It too frequently happens that a bibliography serves no other purpose but to enable others to make further bibliographies. The compilation of book lists seem to have become somewhat of a fad in recent years, and nowhere more than in the field of international relations, where such work has often been substituted for more vital and more effective research and writing. This error the writer desires to avoid. Furthermore, it would be almost impossible to render a bibliography of this subject complete without including vast ranges of material upon all topics in international history, law, and diplomacy, a thing out of question here. The titles found below have been included, therefore, only because they perform one or more of three functions, namely, to indicate the sources most frequently drawn upon for the material used in the text, to indicate the scope of, and direction taken by, the recent literature in this field, and to indicate books specially significant and helpful for further study and reading. Books of the third type are designated by asterisks. No attempt has been made to list completely the many articles to be found in the technical journals of international law and polities, and the general periodicals of public events. For these the student will be better served by himself consulting the indexes of those journals. He will readily be able to amplify the lists of books here given by the use of the bibliographies in Hershey, Krehbiel, Satow, Schücking, and Stowell.

Of all the works cited the general treatises by Hershey, Oppenheim, and Satow deserve special mention for the amount of attention given to all the institutions and practices of international government.

Works are usually cited, in the footnotes above, by the name of the author or by that name and a brief title; where special abbreviations are used they are indicated below. 


\section{GENERAL.}

a. Secondary Materials.

Alvarez, A., Droit International Américain, Paris, 1910.

Atherley-Jones, L. A., Commerce in War, London, 1907.

Bernard, M., Four Lectures on Diplomacy, London, 1868.

Bryce, Viscount J., Holy Roman Empire, new ed., New York, 1919.

Burns, C. D., World of States, London, 1917.

Calvo, C., Droit International, 5th ed., Paris, 1896.

Corwin, E. S., President's Control of Foreign Relations, Princeton, 1917.

Davis, H. W. C., Medieval Europe, New York, 1911.

Dickinson, E. DeW., Equality of States in International Law, Cambridge (Mass.), 1920.

*Duggan, S. P., ed., League of Nations, Boston, 1919.

Duplessix, E., L'Organisation Internationale, Paris, 1909.

- Foster, J. W., Practice of Diplomacy, New York, 1906. Cited:

Foster.

Freeman, E. A., History of Federal Government, 2nd ed., London, 1893.

Garner, J. W., International Law and the World War, New York, 1920.

- Introduction to Political Science, New York, 1910.

Goodnow, F. J., Principles of Administrative Law of the United States, New York, 1905.

Hall, J. P., Constitutional Law, Chicago, 1917.

Hall, W. E., Treatise on International Law, 7th ed., Oxford, 1917. Hart, A. B., Introduction to the Study of Federal Government, Boston, 1891.

*Hershey, A. S., Essentials of Public International Law, New York, 1912.

*Hicks, F. C., New World Order, New York, 1920.

Hill, D. J., History of Diplomacy in the International Development of Europe, New York, 1905. Cited: Hill.

- Present Problems in Foreign Policy, New York, 1919.

Holland, T. E., Elements of Jurisprudence, 11th ed., Oxford, 1910. 
Klüber, J. L., Droit des Gens Moderne de l'Europe, Ott ed., Paris, 1874.

Knox, P. C., "International Unity," in International Conciliation, No. 28 (March, 1910).

*Krehbiel, E., Nationalism, War, and Society, New York, 1916.

Laurent, F., Etudes sur l'Histoire de l'Humanité, Paris, 1865-.

Loria, A., Bases Economiques de la Justice Internationate, New York, 1912.

Macy, J., and Gannaway, J. W., Comparative Free Government, New York, 1915.

Marriott, J. A. E., European Commonwealth, Oxford, 1918.

Martens, F. de, Traité de Droit International (trans. by Leo), Paris, 1883-.

May, T. E., Law, Privileges, Proceedings, and Usage of Parliament, 12 th ed., London, 1917.

Moore, J. B., "International Coöperation," in International Conciliation, No. 100 (March, 1916).

Mowrer, P. S., Balkanized Europe, New York, 1921.

*Muir, R., Nationalism and Internationalism, Boston, 1916.

Nys, E., Droit International, Brussels, 1904.

- Origines de Droit International, Paris, 1894.

Ogg, F. A., Governments of Europe, 2nd ed., New York, 1920.

*Oppenheim, L., International Law, 3rd ed., London, 1921.

Phillimore, Sir R., Commentaries upon International Law, 4th ed., London, 1879.

*Phillipson, C., International Law and Custom of Ancient Greece and Rome, London, 1911. Cited: Phillipson.

Pradier-Fodéré, P. L. E., Traité de Droit International Public, Paris, 1885-.

Quigley, H. S., Immunity of Private Property from Capture at Sea, being Bulletin of the University of Wisconsin, No. 908, Economics and Political Science Series, Vol. 9, No. 2, Madison, 1918.

*Satow, Sir E., Guide to Diplomatic Practice, London, 1917. Cited : Satow.

Seymour, C., Diplomatic Background of the War, New Haven, 1916.

Sidgwick, H., Development of European Polity, London, 1913. 
Taft, W. H., United States and Peace, New York, 1914.

Thorndike, L., History of Medieval Europe, New York, 1917.

Vattel, Emmerich de, Droit des Gens, 1758.

Walker, T. A., History of the Law of Nations, Cambridge (Eng.), 1899.

Wells, H. G., Salvaging of Civilization, New York, 1921.

Wheaton, H., History of the Law of Nations, New York, 1845.

Wilson, G. G., and Tucker, G. F., International Law, 7th ed., New York, 1917.

Woolf, L. S., International Government, New York, 1916.

b. Mixed Treatises.

Bishop, J. B., Theodore Roosevelt and his Time, as told in his correspondence, New York, 1920.

Carnegie Endowment for International Peace, Division of International Law, Recommendations of Habana concerning International Organization Adopted by the American Institute of International Law, 1917, with commentary by Scott, J. B., New York, 1917.

Comité du Livre, Annuaire Générale de la France et de l'Etranger, Paris, 1919-.

Hamilton, A., Madison, J., and Jay, J., The Federalist, Ford ed., New York, 1898. Cited: The Federalist.

Higgins, A. P., Hague Conferences, with texts, Cambridge (Eng.), 1909.

*Scott, J. B., Hague Peace Conferences, with documents, Baltimore, 1909.

Shepherd, W. R., Historical Atlas, New York, 1911.

*Temperley, H. W. V., ed., History of the Peace Conference of Paris, London, 1920.

c. Periodicals.

American Academy of Political and Social Science, Publications, Philadelphia, 1890-.

American Association for International Conciliation, International Conciliation, New York, 1907 . 
American Consular Association, American Consular Bulletin, Long Island City, N. Y., 1919-.

American Historical Association, American Historical Review, New York, 1896-. Cited: Am. Hist. Rev.

American Political Science Association, American Political Science Review, Baltimore, 1894-. Cited: Am. Pol. Sci. Rev. American Society of International Law, American Journal of International Law, Washington, 1907-. Cited: Am. Jour. Int. Law.

Carnegie Endowment for International Peace, Division of International Law, Pamphlet Series, Washington, 1914-.

- Secretary's Office, Year Books of the Endowment, Washington,

1911-. Cited: Carnegie Endowment Year Books.

Guaranty Trust Company of New York, Bulletins, New York.

Minnesota Law Review, Minneapolis, 1917-.

Revue de Droit International et de Législation Comparée, Brussels, 1869-.

World Peace Foundation, Pamphlet Series, Boston, 1911-1918. World Peace Foundation, League of Nations, Boston, 1919-. New Republic, New York, 1914-.

New York Times, New York, 1851-.

\section{d. Documents.}

British and Foreign State Papers, compiled by Librarian of British Foreign Office, London, 1841-. Cited: $B . \& F$. Constitution of the United States.

Great Britain, Foreign Office, Peace Handbooks, London, 1920International Bureau of American Republics, American Constitutions, comp. by Rodriguez, J. I., Washington, 1906-. Cited : Rodriguez.

International Peace Conference (First) at The Hague, 1899, Conférence Internationale de la Paix, The Hague, 1899. Cited: Conférence de la Paix.

International Peace Conference (Second) at The Hague, 1907, Deuxième Conférence Internationale de la Paix, The Hague, 1908. Cited: Deuxième Conférence. 
State of New York, Supreme Court, Reports of cases decided. Cited : New York Reports.

United States, Revised Statutes. Cited: Revised Statutes.

- Statutes at Large. Cited: U. S. S. L.

- Congress, Congressional Documents (Senate or House). Cited: Sen. (or Ho.) Doc. -, - Cong., - Sess.

- Court of Claims, Reports of Cases decided in the Court of Claims. Cited: - Ct. of Cls. - .

- Department of State, Diplomatic Instructions, Washington, 1897. Cited: U. S. Diplomatic Instructions.

- - Foreign Relations of the United States, Washington, 1861-. Cited: U. S. For. Rels.

- - Outline of the Organization and Work of the Department of State, Washington, 1911. Cited: Outline.

- - Register, Washington, 1869-. Cited : Register.

- - Secret Statutes of the United States, by D. H. Miller, Washington, 1918. Cited: Miller, Secret Statutes.

- Federal Courts, Reports of Cases decided. Cited: Federal Reporter.

- House of Representatives, Digest of International Law, by Moore, J. B., being House Document 551, 56 Cong., 2 Sess., Washington, 1906. Cited: Moore, Digest.

- Senate, Journal of Executive Proceedings, Washington, 1828-.

- - Treaties . . . between the United States and Other Powers, 1776-1909 and 1910-1913, comp. by Malloy, W. M., and Charles G., being Sen. Docs. 357, 61st Congress, 2nd Session, and 1063, 62nd Congress, 3rd Session, Washington, 1910, 1913. Cited: Malloy, and Malloy, III (Charles).

- Supreme Court, Reports of Cases decided in the Supreme Court. Cited: - U.S. -

Wilson, G. G., ed., Hague Arbitration Cases, Boston, 1915.

\section{SPECIAL}

\section{$\S 1$}

Terms and Principles

${ }^{*}$ Krehbiel, especially Chaps. I, XV, XXVI. 


\section{$\S 2$ \\ State-Systems of Antiquity}

a. The State-system.

Fairbanks, A., Handbook of Greek Religion, New York, 1910.

*Ferguson, W. S., Greek Imperialism, New York, 1913.

*Fowler, W. W., City State of the Greeks and Romans, New York, 1893.

Francotte, H., Polis Grecque, Paderborn, 1907.

*Frank, T., Roman Imperialism, New York, 1914.

*Freeman, especially 339-374.

Greenidge, A. H. J., Handbook of Greek Constitutional History, New York, 1902.

Huet, P. D., Histoire du Commerce et de la Navigation des Anciens, Lyon, 1763.

*Mahaffy, J. P., Silver Age of the Greek World, Chicago, 1906.

Muirhead, J., Historical Introduction to the Private Law of Rome, 5th ed., London, 1906.

Murray, G., Four Stages of Greek Religion, New York, 1912.

Oliver, E. H., Roman Economic Conditions, Toronto, 1907.

Pelham, H. F., Outlines of Roman History, 4th ed., New York, 1907.

*Phillipson, especially II, Chaps XVI, XVII.

*Shepherd, 10, 14, 26, 30, 34.

Wendland, P., Helenistisch-Römische Kultur, Tübingen, 1907.

*Zimmern, A. E., Greek Commonwealth, 2nd ed., Oxford, 1915.

b. Interstate practices.

Abbott, E. P., Roman Political Institutions, Boston, 1901.

Bouché-Leclereq, A., Manuel des Institutions Romains, Paris, 1886.

Egger, A. E., Traités Publics chez les Grecs et chez les Romains, 2nd ed., Paris, 1866.

Monceaux, P., Proxénies Grècques, Paris, 1886.

Raeder, A. H., Arbitrage International chez les Hellènes, New York, 1912.

Scala, R. von, Staatsverträge des Altherthums, Leipzig, 1898. 


\section{APPENDIX B}

Tod, M. N., International Arbitration amongst the Greeks, Oxford, 1913.

Weiss, A., Droit F'étial, Paris, 1883.

$\S 3$

Medieval State-Systems

a. General.

Adams, G. B., Civilization During the Middle Ages, New York, 1914.

Carlyle, R. W., and A. J., History of Medieval Political Theory in the West, London, 1903-.

Dante Alighieri, De Monarchia.

Gierke, O., Political Theories of the Middle Ages (trans. by Maitland), Cambridge (Eng.), 1900.

*Shepherd, 50, 53, 55, 62-63.

*Thorndike, in general.

*Bryce, entire.

b. Empire.

Fisher, H. A. L., Medieval Empire, London, 1898.

Hartung, J. A., Lehre von der Weltherrschaft im Mittelalter, Halle a. S., 1909.

c. Feudal States.

Seignobos, C., Feudal Régime (trans. and ed. by Dow, E.), New York, 1902.

\section{$\S 4$}

Rise of National States

a. Commercial Revival.

"Day, C., History of Commerce, New York, 1914.

Heeren, A. H. L., Essai sur l'Influence des Croisades, Paris, 1808.

b. Political Evolution.

Heeren, A. H. L., Manual of the History of the Political System of Europe, Oxford, 1834.

*Hill, especially I, end, and II, in general.

Immich, M., Geschichte des Europäischen Staatensystems von 1660 bis 1789, Berlin, 1905. 
*Muir, especially 57-80.

*Thorndike, as cited above, in notes to Chap. IV.

-Walker, same.

\section{c. Modern States.}

*Bowman, I., The New World, Yonkers-on-Hudson, 1921.

Statesman's Year Book, London, 1879-.

Dominian, L., Frontiers of Language and Nationality in Europe,

New York, 1917.

Gooch, G. P., Nationalism, New York, 1921.

Rose, J. H., Nationality in Modern History, New York, 1916.

Seton-Watson, R. W., Rise of Nationality in the Balkans, London, 1916.

*Goebel, J., Jr., Recognition Policy of the United States, New York, 1915. Cited: Goebel.

Holdich, T. H., Political Frontiers and 'Boundary Making, London, 1916.

Carnegie Endowment for International Peace, Division of International Law, Monograph on Plebiscites, by Wambaugh, S., New York, 1920.

*Johns Hopkins University, Studies in Historical and Political Science, XXXVIII Series, No. iii, being Employment of the Plebiscite in the Determination of Sovereignty, by Mattern, J., Baltimore, 1920.

*United States, Department of State, Types of Restricted Sovereignty and of Colonial Autonomy, by Willoughby, W. W., and Fenwick, C. G., Washington, 1919. Cited: Willoughby and Fenwick.

- - Wardships in International Law, by C. G. Fenwick, Washington, 1919. Cited: Fenwick, Wardships.

\section{$\S 5$}

Rise of Consular System

a. Origins of the Consulate.

Borel, F., Origine et Fonctions des Consuls, St. Petersburg, 1807. Capello, Comte M., Consulats et Bailages de Venise, reprinted from Revue de Droit International et de Législation Comparée, XXIX (1897). Brussels, 1897. Cited: Capello. 
*Hershey, § 51.

Laigue, L. de, Origine des Consuls, reprinted from Revue d'Histoire Diplomatique, IV (1890), Paris, 1890.

Leroy, P., Des Consulats, des Legations, et des Ambassades, Paris, 1876.

"Ravndal, G. B., "Origin of the Consular Institution," in American Consular Bulletin, III, Nos. 2, 3, 4 (April, May, and June, 1921), p. 11 in each case.

Salles, G., Institution des Consulats, Paris, 1898.

Schaube, A., Proxénie au Moyen Age, reprinted from Revue de

Droit International et de Legislation Comparée, XXVIII (1896), Brussels, 1896 . Cited: Schaube.

*Sheppard, E. T., American Consular Service, Berkely, 1901.

Warden, D. B., Origin of Consular Establishments, Paris, 1813.

b. Maritime Codes.

Pardessus, I. M., Us et Coutûmes de la Mer, Paris, 1847.

Twiss, Sir T., ed., Black Book of the Admiralty, London, 1871-.

$\S 6$

Consular Organization and Practice

a. Scientific Accounts.

*American Civil Service Reform League, Report on the Foreign Service, New York, 1919. Cited: Report.

Great Britain, Foreign Office, Reports Respecting the Consular Services of Foreign Countries, London, 1872.

*Jones, C. L., Consular Service of the United States, Philadelphia, 1906.

Le Deux, A. B., Caractère Diplomatique et les Immunités des Consuls, Chateauroux, 1905.

Patau, P., Situation Comparée des Ayents Diplomatiques et Consulaires, Toulouse, 1910.

*Stowell, E. C., Le Consul, Paris, 1909.

United States, Library of Congress, List of References on the Consular Service, compiled under the direction of Griffin, A. P. C., Washington, 1905. Cited: Griffin, Consular Service. 
b. Professional Literature.

Borel, F., Formulaire des Consulats, St. Petersburg, 1808.

Clereq, A. de, and Vallat, C. de, Guide Pratique des Consulats, Paris, 1898.

Cussy, F. de, Règlements Consulaires, Leipzig, 1854.

Ferguson, R. E., Manual of International Law for the Use of Navies, Colonies, and Consulates, London, 1884-. Cited: Ferguson, Manual.

McAneny, G., "Organization of the Modern Consular Service," reprinted from the Century Magazine, XXXV, 604 (February, 1899).

Oppenheim, H. B., Praktisches Handbuch der Consulate aller Länder, Erlangen, 1854.

Pillaŭt, J., Manuel de Droit Consulaire, Paris, 1910.

Rosa-Rullo, G. de, Code des Consulats, Naples, 1902-03.

*Stowell, E., Consular Cases and Opinions, Washington, 1909.

Tuson, E. W. A., British Consul's Manual, London, 1856.

United States, Department of Commerce, Commerce Reports, Washington, 1880-. Cited: U. S. Commerce Reports.

- Consular Regulations of Foreign Countries, being Tariff Series, No. 24, 24a, 24b, Washington, 1915-17.

- Department of Commerce and Labor, Diplomatic and Consular Service of the United States, 1903, Washington, 1904.

- Department of State, Consular Regulations, Washington, 1896. Cited: U. S. Consular Regulations.

- - Digest of Circular Instructions to Consular Officers, Washington, 1915.

Senate, Reports from Consular Officers of the United States, being Sen. Doc. 411, 57 Cong., 1 Sess., Washington, 1902.

\section{$\S 7$}

Origin of Modern Diplomacy

a. General Historical Works.

Baschet, A., Diplomatie Venétienne, Paris, 1862.

Flassan, G. de R. de, Histoire de la Diplomatie Française, Paris, 1811. 
Foster, J. W., Century of American Diplomacy, Boston, 1911. Cited: Foster, Century.

- Diplomatic Memoirs, New York, 1910.

*Heatley, D. P., Diplomacy and the Study of International Relations, Oxford, 1919.

Hertslet, Sir E., Recollections of the Old Foreign Office, London, 1901.

*Hill, as cited above, in notes to Chap. VII.

Krauske, O., Entwickelung der Ständigen Diplomatie, Leipzig, 1886.

Löhren, A., Geschichte des Gesandschaftlichen Verkehrs im Mittelalter, Marburg, 1884.

Mackay, B. L., Die Moderne Diplomatie, Frankfurt, 1915.

*Nys, E., Origines de la Diplomatie, reprinted from Revue de

Droit International et de Legislation Comparée, XV and XVI (1883 and 1884). Brussels, 1884. Cited: Nys, Diplomatie. *Walker, 37, 60, 61, 81, 87, 94-96, 131, 135, 143.

b. Historic Treatises.

Bynershoek, C. Van, De Foro Legatorum, Leyden, 1721.

Callières, F. de, De la Manière de Negocier, London, 1750.

Gentilis, A., De Legationibus, 1585.

Paschal, C., Legatus, Amsterdam, 1645.

Wicquefort, A., L'Ambassadeur et ses Fonctions, The Hague, 1680.

\section{$\S 8$}

Diplomatic Organization and Practice

a. General Accounts.

* Bernard, Lecture IV.

*Foster, entire.

Lisboa, H. C. R., Fonctions Diplomatiques, Santiago de Chile, 1908.

Murray, E. C. G., Embassies and Foreign Courts, London, 1855. Paullin, C. O., Diplomatic Negotiations of American Naval Officers, Baltimore, 1912.

${ }^{*}$ Report, in general. 
b. Professional and Official Treatises.

Alt, L., Handbuch des Europäischen Gesandschaftsrechtes, Berlin, 1870.

Clereq, A. J. H. de, and Vallat, C. de, Formulaire des Chancelleries, Paris, 1890.

France, Ministère des Affaires Etrangères, Annuaire Diplomatique, Paris.

Garden, G. de, Traité Complet de Diplomatie, Paris, 1833. Great Britain, Foreign Office, Foreign Office List, London. Martens, K. von, Guide Diplomatique, 5th ed., Leipzig, 1866. Meisel, A. H., Cours de Style Diplomatique, Paris, 1827. Murray, E. C. G., Droits et Devoirs des Diplomates, London, 1853.

Pradier-Fodéré, P. L. E., Cours de Droit Diplomatique, Paris, 1899.

* Satow, in general.

-United States, Department of State, Diplomatic Agents and Immunities, by A. S. Hershey, Washington, 1919. Cited: Hershey, Diplomatic Agents.

- Diplomatic and Consular Service of the United States, Washington, 1920.

- Diplomatic List, Washington.

* _ - Register, entire.

\section{$\S 9$}

\section{Criticism of Diplomacy}

Brailsford, H. N., War of Stecl and Gold, New York, 1915.

Eller, G., Secret Diplomacy, London, 1912.

Hayward, C. W., What is Diplomacy?, London, 1916.

Lippmann, W., Stakes of Diplomacy, New York, 1915.

*Loreburn, Earl, How the War Came, London, 1919.

*Myers, D. P., Control of Foreign Relations, reprinted from Am.

Pol. Sci. Rev., XI, No. 1 (February, 1917), Baltimore, 1917.

- Legislatures and Foreign Relations, reprinted from Am. Pol.

Sci. Rev., XI, No. 4 (November, 1917), Baltimore, 1917.

Neilson, F., How Diplomats Make War, New York, 1915.

* Ponsonby, A., Democracy and Diplomacy, London, 1915.

Young, G., Diplomacy, Old and New, New York, 1921. 


\section{Treaty Negotiation}

${ }^{*}$ Crandall, S. B., Treaties, Their Making and Enforcement, 2nd. ed., Washington, 1916.

*Moore, Digest, as cited, above, in notes to Chap. X.

Roxburgh, R. F., International Conventions and Third States, New York, 1917.

*Satow, as cited, above, in notes to Chap. X.

*United States, Department of State, Treaty-Making Power in Various Countries, Washington, 1919. Cited: Treaty Power.

*-Senate, Ratification of Treaties, being Sen. Doc. 26, 66 Cong., 1 sess., a compilation, Washington, 1919. Cited : Ratification of Treaties.

Weil, B., Mitwirkung der Volksvertretung bei Staatsverträger, Strassburg, 1906.

Wright, Q., Amendments and Reservations to the Treaty, reprinted from Minnesota Law Review, December, 1919, Minneapolis, 1919. Cited: Wright, Amendments.

\section{$\S 11$}

\section{Modern Treaty System}

Argentina, Coleccioon de Tradados celebrados por la Republica Argentina, Buenos Aires, 1863.

Calvo, C., Receuil Complet des Traités de tous les Etats de l'Amérique Latine, Paris, 1862-.

Chile, Coleccion de Tratados celebrados por la Republica de Chile, Santiago, 1857-.

Clereq, A. J. H. de, Recenil des Traités de la France, Paris, 1864-.

Du Mont, Jean, Corps Universel du Droit des Gens (see text, Chap. XI, for full description), Amsterdam, 1726-.

Garden, G. de, Histoire Général des Traités, Paris, 1848-.

Herstlet, L., ed., Complete Collection of the Treaties and Conventions ... between Great Britain and Foreign Powers, London, 1840-.

Koch, C. G., Histoire Abregée des Traités de Paix, Paris, 1817. 
Lagemans, E. G., Receuil des Traités et Conventions conclus par le Royaume des Pays-Bas, The Hague, 1858-.

Lamberty, G. de, Memoires . . contenant . . . Negotiations, Traités et autres Documents, The Hague, 1724-.

* Malloy, entire.

Martens, G. F. de, etc., Receuil des Principaux Traités, etc. (see text, Chap. XI, for full description), Göttingen, etc., 1791-. Oakes, A., and Mowat, R. B., Great European Treaties of the Nineteenth Century, Oxford, 1918.

Rymer, T., Foedera, Conventiones, Literae, et. . . . Acta Publica inter Reges Angliae et Alios . . . Reges . . . et cetera, London, 1726-.

Ribier, G. de, Répertoire des Traités de Paix, etc., Paris, 1895. Tétot, Répertoire des Traités, Paris, 1866-.

*United States, Department of State, Catalogue of Treaties, 18141918, Washington, 1919. Cited: Catalogue of Treaties.

- - Tentative List of Treaty Collections, Washington, 1919. Cited: List.

Wenck, F. A. W., Codex Juris Gentium (see Chap. XI for full description), Leipzig, 1781-.

Wright, Q., Constitutionality of Treaties, reprinted from Am. Jour. Int. Law, XIII, No. 2 (April, 1919), Washington, 1919.

Cited: Wright, Treaties.

\section{$\S 12$}

Treaties and International Law

Bergbohm, C., Staatsverträge und Gesetze als Quellen des Völkerrechts, Dorpat, 1876.

Bex, J., Essai sur l'Evolution du Droit des Gens, Paris, 1910.

Brie, S., Fortschritte des Völkerrechts seit dem Wiener Congress, Breslau, 1890.

Carnegie Endowment for International Peace, Division of International Law, Recommendations on International Law of the Second Pan American Scientific Congress, 1915-1916, ed. by Scott, J. B., New York, 1916.

* - Resolutions of the Institute of International Law, ed. by Scott, J. B., New York, 1916.

Chauveau, E., Introduction au Droit des Gens, Paris, 1891. 
*Crandall, in general.

*Field, D. D., Outlines of an International Code, New York, 1876. Grotius, Hugo, De Jure Belli ac Pacis, 1625.

*Hershey, §§ 16-86.

*Moore, Digest, in general.

Nippold, O., Völkerrechtliche Vertrag, Bern, 1894.

Pillet, A., ed., Les Fondateurs de Droit International, Paris, 1904.

"Root, E., "Effect of Democracy on International Law," in International Conciliation, No. 117 (August, 1917).

"- "Function of Private Codification in International Law," reprinted from Am. Jour. Int. Law, V, 577 (July, 1911).

" - "Outlook for International Law," in International Conciliation, No. 100 (March, 1916).

"Taft, W. H., "Treaty Rights of Aliens," in International Conciliation, No. 116 (July, 1917).

United States, Department of State, Laws of Land Warfare, prepared by Baker, J. R., and Crocker, H. G., Washington, 1919. Cited: Baker and Crocker, Land Warfare.

- - Laws of Maritime Warfare, prepared by Martin, H. H., and Baker, J. R., Washington, 1918. Cited: Martin and Baker, Maritime Warfare.

*Walker, §§ 85-87, 113-120, 126-128, 130-134, 141, 142, 144, 148.

*Wheaton, entire.

Whewell, W., ed. and trans., De Jure Belli ac Pacis of Grotius, q.v., Cambridge (Eng.), 1853.

*Wright, Q., Enforcement of International Law through Municipal Law in the United States, Urbana, 1916. Cited: Wright, Enforcement.

\section{$\S 13$}

Good Offices and Mediation; Commissions of Inquiry

*Hershey, §§ 306-308.

\section{a. General.}

Kamarowsky, Count L., Tribunal International, Paris, 1887. Moore, J. B., History and Digest of International Arbitrations to which the United States has been a Party, Washington, 1898. *Satow, §§ 619-640. 
b. Good Offices and Mediation.

* Carnegie Endowment for International Peace, Division of International Law, Treaties for the Advancement of Peace, with introduction by Scott, J. B., New York, 1920.

Fourchault, C., De la Médiation, Paris, 1900.

Mélik, E, Médiation et les Bons Offices, Paris, 1900.

c. Commissions of Inquiry.

Beaucourt, A., Commissions Internationales d'Enquête, Paris, 1909.

Bokanowski, F., Commissions Internationales d'Enquête, Paris, 1908.

\section{$\S 14$}

History and Theory of Arbitration

André, A., De l'Arbitrage Obligatoire, Paris, 1903.

Barclay, T., New Methods of Adjusting International Disputes, London, 1917.

Carnegie Endowment for International Peace, Division of International Law, Arbitrations and Diplomatic Settlements of the United States, being Pamphlet No. 1 of the Division, Washington, 1914.

*Darby, W. E., International Arbitration; International Tribunals, 4th ed., London, 1904.

Desjardins, A., L'Arbitrage International, Paris, 1892.

Dreyfus, F., L'Arbitrage International, Paris, 1892.

Dumas, J., Sanctions de l'Arbitrage, Paris, 1905.

*Hershey, $\S \S 309-312,318-320$.

Lafontaine, H., Pasicrisie Internationale; Histoire Documentaire des Arbitrages Internationaux, Berne, 1902.

Mérignhac, A., Traité Théorique et Pratique de l'Arbitrage International, Paris, 1895.

Moch, G., Histoire Sommaire de l'Arbitrage Permanent, Monaco, 1905.

*Moore, Arbitrations, V, 4825-4851 (translated from Mérignhac). Perla, L., What is National Honor?, New York, 1918.

Quesada, P. E., Arbitration in Latin America, New York, 1907. 
Redman, J. H., Law of Arbitrations and Awards, London, 1903. *Scott, Conferences, I, 188 and following.

*United States, Library of Congress, List of References on International Arbitration, comp. by Griffin, A. P. C., Washington, 1908. Cited: Griffin, Arbitration.

*Wilson, Cases, entire.

"World Peace Foundation, International Arbitral Law and Procedure, by Ralston, J. H., Boston, 1910.

\section{$\S 15$}

\section{Hague Arbitration System}

*Carnegie Endowment for International Peace, Division of International Law, The International Union of the Hague Conferences, by Schücking, W. (trans. by Fenwick, C. G.), New York, 1918.

"Scott, Conferences, I, Chap. VI and Appendix to Chap. VI.

$\S 16$

Proposed International Courts

Balch, T. W., A World Court in the Light of the United States Supreme Court, Philadelphia, 1918.

Carnegie Endowment for International Peace, Division of International Law, An International Court of Justice, by Scott, J. B., New York, 1916.

- - Hague Conventions and Declarations of 1899 and 1907, ed. by Scott, J. B., Washington, 1915. Cited: Scott, Conventions.

*- - Problem of an International Court of Justice, by Wehberg, H. (trans. by Fenwick, C. G.), New York, 1918.

*- - The Project of a Permanent Court of International Justice and Resolutions of the Advisory Committee of Jurists, by Scott, J. B., being Pamphlet No. 35 of the Division, Washington, 1921.

- Status of the International Court of Justice, by Scott, J. B., New York, 1916. 
*League of Nations, Advisory Committee of Jurists, Documents Relating to Existing Plans for the Establishment of a Permanent Court of International Justice, London, 1921.

- - Procès-Verbaux of the Proceedings of the Committee, The Hague, 1921.

- Council, Documents Concerning the Action taken by the Council under Article XIV of the Covenant, Geneva, 1921. "Scott, J. B., in Car. End., Year Book, 1921, 104-131.

- Conferences, I, Chaps. VII, IX, X, and Appendices thereto.

\section{$\S 17$}

\section{Official International Unions}

"Sayre, F. B., Experiments in International Administration, New York, 1919.

"The Supreme War Council," in A League of Nations, I, 1-416 (October, 1918).

Toll, Baron B. von, Die Internationale Bureaux der Allgemeinen Völkerrechtverwaltungsvereine, Tübingen, 1910.

*World Peace Foundation, Public International Unions, by Reinsch, P. S., Boston, 1911. Cited: Reinsch.

\section{$\S 18$}

\section{Private International Associations}

Fauchille, P., Manuel de la Croix-Rouge, Paris, 1908.

"Hudson, M. O., "Private Enterprise and War," in New Republic,

XXVIII, No. 363 (16 November, 1921) Supp., 26.

Jordan, D. S., Unseen Empire, Boston, 1912.

*Krehibiel, 126-140.

Lange, C. L., "The Interparliamentary Union," in International Conciliation, No. 65 (April, 1913).

Otlet, P., Constitution Mondiale de la Société des Nations, Paris, 1917.

Perris, G. H., The War Traders, London, 1914.

"Profit and Patriotism, and Money-Making and War," in International Conciliation, Special Bulletin, (May, 1913).

Streit, C. K., Where Iron is There is the Fatherland, New York, 1920.

*Vie Internationale, Brussels, 1912-. 
“Who Makes Warq"' in International Conciliation, Special Bulletin, February, 1913.

*Woolf, 266-326.

\section{$\S 19$}

\section{Modern Cosmopolitanism}

a. General.

"Clark, G. N., Unifying the World, New York, 1920.

Claveirole, J., L'Internationalisme, St. Etienne, 1910.

Crafts, W. F., Primer of Internationalism, Washington, 1908.

Faries, J. C., Rise of Internationalism, New York, 1915.

*Krehbiel, as cited, above, § 18.

${ }^{*}$ La Vie Internationale, in general.

Ralston, J. H., "Forces Making for International Conciliation and Peace," in International Conciliation, No. 49 (December, 1911).

*Woolf, as cited, above, § 18.

b. Factors in Modern Cosmopolitanism.

"Butler, N. M., "The International Mind," in International Conciliation, No. 55 (June, 1912).

- "Nationality and Beyond," in International Conciliation, No. 107 (October, 1916).

Haldane, Lord, "Higher Nationality," in International Con- $\checkmark$ ciliation, No. 72 (November, 1913).

Merrill, W. P., Christian Internationalism, New York, 1919.

Mather, F. J., Jr., "Do the Arts Make for Peace?" in International Conciliation, No. 51 (February, 1912).

Mason, D. G., "Music as an International Language," in International Conciliation, No. 67 (June, 1913).

Lodge, O., "Science in the Developing of International Good Will," in International Conciliation, No. 56 (July, 1912).

*Pan American Scientific Congress, 2d., 1915-1916, Final Act and Interpretative Commentary Thereon, prepared by Scott,

J. B., Reporter General of the Congress, Washington, 1916. Showerman, G., "Peace and the Professor," in International Conciliation, No. 25 (December, 1909). 
Wylie, F. J., "Cecil Rhodes and his Scholars as Factors in International Conciliation," in International Conciliation, No. 25 (December, 1909).

Lochner, L. P., "Cosmopolitan Club Movement," in International Conciliation, No. 61 (December, 1912).

Cary, E., "Journalism and International Affairs," in International Conciliation, No. 21 (August, 1909).

Deming, W. C., "The Press and World Peace," in International Conciliation, No. 66 (May, 1913).

Constant, Baron D'E. de, "Woman and the Cause of Peace," in International Conciliation, No. 40 (March, 1911).

Fisk, G. M., International Commercial Policies, New York, 1907. Johnson, A. S., "Commerce and War," in International Conciliation, No. 77 (April, 1914).

Mussey, H. R., "Is Commerce War?", in International Conciliation, Special Bulletin, January, 1916.

Osborne, J. B., "Influence of Commerce in the Promotion of International Peace," in International Conciliation, No. 22 (September, 1909).

Pepper, C. M., "Conciliation through Commerce and Industry in South America," in International Conciliation, No. 34 (September, 1910).

Pratt, S. S., and others, "Finance and Commerce, Their Relation to International Good Will," in International Conciliation, No. 50 (January, 1912).

Lowe, B. E., International Protection of Labor, New York, 1921. Postgate, R. W., Workers' International, New York, 1921.

Weardale, Lord, "First Universal Races Congress," in International Conciliation, No. 42 (May, 1911).

$\S 20$

International Conferences; Hague Conferences

a. General.

*Hershey, § § 292-294.

*Oppenheim, §§ 483-485.

*Satow, Sir E., § § 439-497. 
*Satow, Sir E., International Congresses and Conferences, London, 1921. Cited: Satow, Conferences.

United States, Department of State, Berlin Congress, by H. F. Munro, Washington, 1918. Cited: Munro, Berlin Congress. Woodward, Congress of Berlin, London, 1920.

\section{b. The Hague Conferences.}

* Carnegie Endowment for International Peace, Division of International Law, Proceedings of the Hague Peace Conferences, New York, 1920-21.

Choate, J. H., The Two Hague Conferences, Princeton, 1913.

${ }^{*}$ Hull, W. I., Two Hague Conferences, Boston, 1908.

Lawrence, T. J., International Problems and Hague Conferences, London, 1908.

*Scott, Conferences, I, Chaps. II-IV.

Peace Conferences; Conference of Paris

a. General.

Angeberg, d' (Chodzko, L. J. B.), Congrès de Vienne, Paris, 1864. ${ }^{*}$ Hazen, C. D., and others, Three Peace Congresses, Cambridge (Mass.), 1917.

Phillimore, Lord, Three Centuries of Peace Treaties, London, 1919.

*Phillipson, C., Termination of War and Treaties of Peace, New York, 1916. Cited: Phillipson, Termination of War.

*Satow, references in $\S 20$.

United States, Department of State, Proceedings of the BrestLitovsk Peace Conference, Washington, 1919. Cited: Procs. Brest-Litovsk.

- - Texts of the Roumanian "Peace," Washington, 1918. Cited: Roumanian Peace.

- - Texts of the Russian "Peace," Washington, 1918. Cited: Russian Peace.

- - Texts of the Ukraine "Peace," Washington, 1918. Cited: Ukraine Peace.

Webster, C. K., Congress of Vienna, London, 1919. 
b. Peace Conference of Paris.

Bartlett, V., Behind the Scenes at the Peace Conference, London, 1919.

Dillon, E. J., Inside Story of the Peace Conference, New York, 1920.

Hansen, H., Adventures of the Fourteen Points, New York, 1919. Harris, H. W., The Peace in the Making, New York, 1919.

Haskins, C. H., and Lord, R. H., Some Problems of the Peace Conference, Cambridge, 1920.

House, E. M., and Seymour, C., and others, What Really Happened at Paris, New York, 1921.

Huddleston, S., Peace-Making at Paris, London, 1919.

*Lansing, R., Big Four and Others of the Peace Conference, New York, 1921.

"Organization of the Peace Conference," in International Conciliation, No. 139 (June, 1919).

Peace Conference of Paris, Regulations governing the work of the Conference, Paris, 1919.

*Temperley, I., 236-278, 497-504.

Thompson, C. T., Peace Conference Day by Day, New York, 1920.

\section{$\S 22$}

\section{Peace and International Organization}

a. General.

- Krehbiel, Parts I and III, and the elaborate references to further literature.

Marvin, F. S., Evolution of World Peace, New York, 1921.

b. The Peace Movement.

Butler, N. M., “The Carnegie Endowment for International Peace," in International Conciliation, No. 75 (February, 1914).

Carnegie Endowment for International Peace, Secretary's Office, Epitome of the Purpose, Plans, and Methods of the Endowment, Washington, 1919. 
Fried, A. H., "Pacifism," in International Conciliation, Special Bulletins, March and April, 1915.

-Moritzen, J., Peace Movement of America, New York, 1912.

\section{c. Neutrality.}

Jacobs, A. J., Neutrality versus Justice, London, 1917.

United States, Department of State, Neutrality Proclamations, 1914-1918, Washington, 1919. Cited: Neutrality Proclama tions.

\section{d. War ; Means of Abolishing War.}

Amos, S., Political and Legal Remedies for War, New York, 1880. Angell, N., Great Illusion, New York, 1910.

Anitchkow, M., War and Labor, London, 1900.

Bloch, J. de, Future of War (trans. by Long), New York, 1899. Boas, F., "Anthropologist's View of War," in International Conciliation, No. 52 (March, 1912).

Bryce, J., "War and Human Progress," in International Conciliation, No. 108 (November, 1916).

Clark, J. B., "Economic View of War and Arbitration," in International Conciliation, No. 32 (July, 1910).

Collin, C. C., War against War, with introduction by Archer, W., New York, 1917.

Crane, F., War and World Government, New York, 1915.

Crile, G. W., Mechanistic View of War and Peace, New York, 1916.

Crosby, O. T., International War: Its Causes and Its Cure, London, 1919.

Dickinson, G. L., Causes of International War, New York, 1921. Howe, F. C., Why Warg, New York, 1916.

Johnson, A. S., "War and the Interests of Labor," in International Conciliation, No. 80 (July, 1914).

Morris, R. T., Way out of War; Biology of the Subject, New $\checkmark$ York, 1918.

Novikow, J., Luttes entre Sociétés Humaines, Paris, 1896.

Perris, G. H., War and Peace, New York, 1911.

Powers, H. H., Things Men Fight For, New York, 1916. 
Root, E., "Causes of War," in International Conciliation, No. 18 (May, 1909).

Russell, B. A. W., Why Men Fight, New York, 1917.

e. Peace; Means of Securing Peace.

*Carnegie Endowment for International Peace, Division of International Law, Future of International Law, by Oppenheim, L., being Pamphlet No. 39 of the Division, Washington, 1921.

Duplessix, E., Vers La Paix, Paris; 1903.

Duras, V. H., Universal Peace by International Government, New York, 1908.

Neill, C. P., "Interest of the Wage-Earner in the Peace Movement," in International Conciliation, No. 57 (August, 1912).

*Taft, W. H., and Bryan, W. J., World Peace; A Written Debate, New York, 1917.

Tead, O., People's Part in Peace; Basis for a Sound Internationalism, New York, 1918.

-Veblen, T. B., Nature of Peace, and Terms of its Perpetuation, New York, 1917.

*Vestal, S. C., Maintenance of Peace, New York, 1921.

*World Peace Foundation, New Peace Movement, by Hull, W. I., Boston, 1912.

\section{f. Disarmament.}

Carnegie Endowment for International Peace, Division of International Law, Documents Respecting the Limitation of Armaments, being Pamphlet No. 22 of the Division, Washington, 1916.

* - The Limitation of Armaments, by Wehberg, H., being Pamphlet No. 46 of the Division, Washington, 1921.

Mahan, A. T., Armaments and Arbitration, New York, 1912. "Washington Conference on the Limitation of Armaments," in International Conciliation, No. 169 (December, 1921).

\section{$\S 23$}

Juristic Theory of International Federation

Brie, S., Theorie der Staatenverbindungen, Stuttgart, 1886.

Johns Hopkins University, Studies in Historical and Political Science, XXV Series, Nos. vi-vii, being The State in Con- 
stitutional and International Law, by Crane, R. T., Baltimore, 1907.

*Dickinson, in general.

Garner, Introduction, Chap. VIII, § iii; Chap. V, §§ vi-vii.

\section{$\S 24$}

Empire; Alliances; Balance of Power

a. General.

Schevill, F., History of Modern Europe, New York, 1898.

b. Imperial Organization.

Adams, G. B., British Empire and a League of Peace, New York, 1919.

Carnegie Endowment for International Peace, Division of International Law, Autonomy and Federation within Empire, being Pamphlet No. 33 of the Division, Washington, 1920.

Curtis, L., Problem of the Commonwealth, London, 1917.

"Keith, A. B., Imperial Unity and the Dominions, Oxford, 1916. *"Present Problems of the British Commonwealth of Nations," in International Conciliation, No. 167 (October, 1921).

"Smuts, J. C., "British Commonwealth of Nations," in International Conciliation, No. 120 (November, 1917).

c. Alliances and the Balance of Power.

*Bernard, 61-109.

Carnegie Endowment for International Peace, Division of International Law, The Armed Neutralities of 1780 and 1800, ed. by Scott, J. B., Washington, 1918.

Donnadieu, L., Théorie de l'Equilibre, Paris, 1900.

*Dupuis, C., Principe d'Equilibre et le Concert Européen, Paris, 1909.

*Gentz, F. von, Fragments upon the Balance of Power in Europe (trans.), London, 1806.

Hanotaux, G., Politique de l'Equilibre, Paris, 1914.

Hassall, A., Balance of Power, 1715-1789, New York, 1898.

Hearnshaw, European Coalitions, London, 1920. 
Heeren, A. H. L., Political Consequences of the Reformation, Oxford, 1836.

- Political System of Europe, as cited, above, § 4.

Koumanoudi, K., Traités d'Alliance, Paris, 1901.

"Leckie, G. F., Historical Research into the Nature of the Balance of Power in Europe, London, 1817.

*Phillimore, Commentaries, Part IV, Sec. ii.

Stieglitz, A. de, De l'Equilibre Politique ... et du Principe des Nationalités, Paris, 1893-97.

\section{$\S 25$}

Holy Aliiance and Concert of Europe; Obstacles to, and Agencies of, International Control

a. Holy Alliance.

Heeren, A. H. L., Political System of Europe, as cited, above, § 4.

*Phillips, W. A., Confederation of Europe, London, 1914.

b. Concert of Europe.

*Holland, T. E., European Concert in the Eastern Question, Oxford, 1885.

\section{c. Agencies of International Control.}

Angell, N., The World's Highway, New York, 1915.

Barès, A., Le Blocus Pacifique, Paris, 1898.

Carnegie Endowment for International Peace, Division of International Law, The Consortium, being Pamphlet No. 40 of the Division, Washington, 1921.

Engelhardt, Ed., Fleuves Internationaux, Paris, 1879.

- Histoire du Droit Fluvial Conventionnel, Paris, 1889.

*Hodges, H. G., Doctrine of Intervention, Princeton, 1915.

*Hogan, A. E., Pacific Blockade, Oxford, 1908.

Johns Hopkins University, Studies in Historical and Political Science, XII Series, Nos. xi-xii, being International Beginnings of the Congo Free State, by Reeves, J. S., Baltimore, 1894.

Keeckenbeck, G., International Rivers, London, 1918.

*Milanovitch, M., Traités de Garantie, Paris, 1888.

*Ogilvie, P. M., International Waterways, New York, 1920. 
Stowell, E. C., Intervention in International Law, Washington, 1921.

United States, Department of State, The Danube, by J. P. Chamberlain, Washington, 1918. Cited: Chamberlain, Danube.

Whittuck, E. A., International Canals, London, 1920.

*Wicker, C. F., Neutralization, New York, 1911.

\section{d. Imperialism.}

Abbott, W. C., Expansion of Europe, New York, 1918.

Bülow, B: H. M. K., Imperial Germany, with foreword by Headlam, J. W., New York, 1917.

Despagnet, F., Essai sur les Protectorats, Paris, 1896.

Engelhardt, E., Protectorats, Paris, 1896.

Gibbons, H. A., New Map of Africa, New York, 1917.

Hobson, J. A., Imperialism, London, 1905.

Lair, M., Impérialisme Allemand, Paris, 1902.

Naumann, F., Central Europe, with introduction by Ashley,

W. J. (trans. by Meredith, C. M.), London, 1916.

Ramsay, W. M., Imperial Peace, Oxford, 1913.

Seeley, J. R., Expansion of England, London, 1883.

Seillère, Baron E. A. A. L., Introduction à la Philosophie de l'Impérialisme, Paris, 1911.

Woolf, L. S., Economic Imperialism, New York, 1921.

e. Nationalism in the Nineteenth Century.

*Gooch, Nationalism, as cited, above, § 4 .

Seton-Watson, R. W., Nationality in the Balkans, as cited, above, $\S 4$.

*Toynbee, A. J., Nationality and the War, London, 1915.

\section{f. Pan-national Movements.}

Andler, C., Pan-Germanism (trans. by J. S.), Paris, 1915.

Barrett, J., Pan-American Union: Peace, Friendship, Commerce, Washington, 1911.

Beer, G. L., The English Speaking Peoples, New York, 1917.

Hart, A. R., Monroe Doctrine, Boston, 1916.

Kennedy, S., Pan-Angles, New York, 1915.

Leger, P. L. M., Panslavisme, Paris, 1917. 
Powers, H. H., America and Britain, New York, 1918.

Walston, Sir C., English-Speaking Brotherhood, Cambridge, 1919. Wilson, G. G., "Monroe Doctrine after the War," in A League of Nations, I, 253-305 (June, 1918).

$\S 26$

\section{Projects for International Federation}

a. General Theory.

* Garner, Introduction, as cited, above, in § 23.

*Hart, Introduction, entire.

\section{b. Projects and Schemes.}

Bourgeois, L., Pour la Sociêté des Nations, Paris, 1910.

* Carnegie Endowment for International Peace, Division of International Law, Essay on a Congress of Nations, by Ladd, W., with introduction by Scott, J. B., containing a résumé of other plans, New York, 1916.

Duplessix, E., Loi des Nations, Projet d'un Autorité Internationale, Paris, 1906.

Goldsmith, R., League to Enforce Peace, New York, 1917.

Hooper, C. E., Need of the Nations, an International Parliament, London, 1907.

Jones, R. L., International Arbitration as a Substitute for War, London, 1908.

Keen, F. N., World in Alliance, London, 1915.

La Fontaine, H., "Existing Elements of a Constitution of the United States of the World," an International Conciliation, No. 47 (October, 1911).

*Minor, R. C., Republic of Nations, New York, 1918.

Nijhoff, M., ed., War Obviated by an International Police, The Hague, 1915.

Novikow, J., Fédération de l'Europe, Paris, 1901.

*Phillimore, Lord, Schemes for Maintaining General Peace, London, 1920.

Pollard, A. F., League of Nations in History, New York, 1918.

Schücking, W., Organisation der Welt, Tübingen, 1908.

Ter Meulen, J., Gedanke der Internationalen Organisation in seiner Entwickelung, 1300-1800, The Hague, 1917. 
Trueblood, B. F., Federation of the World, New York, 1899.

World Peace Foundation, World Organization, by Bridgman,

R. L., Boston, 1905.

*York, E., Leagues of Nations, London, 1919.

\section{c. Practice of Federation in the United States and Elsewhere.}

Carnegie Endowment for International Peace, Division of International Law, Debates in the Federal Convention of 1787 which Framed the Constitution of the United States of America, ed. by Hunt, G., and Scott, J. B., New York. 1920.

- Judicial Settlement of Controversies between States of the American Union: Cases Decided in the Supreme Court of the United States, ed. by Scott, J. B., New York, 1918.

- The United States of America: A study in International Organization, by Scott, J. B., Washington, 1920. Cited : Scott, United States.

Carnegie Institution, Federal System of the Argentine Republic, by Rowe, L. S., Washington, 1921. Cited : Rowe.

Egerton, H. E., Federations and Unions in the British Empire, Oxford, 1911.

Poley, A. P., Federal Systems of the United States and the British Empire, Boston, 1913.

\section{$\S 27$}

The League of Nations, 1919

a. Genesis of the War of 1914-1918.

"Background of the War, History and Texts," in A League of Nations, I, 173-251 (April, 1918).

Bernhardi, F. von, Germany and the Next War, New York, 1914. *Bullard, A., Diplomacy of the Great War, New York, 1916.

Carnegie Endowment for International Peace, Division of International Law, Diplomatic Documents Relating to the Outbreak of the European War, New York, 1916.

Cramb, J. A., Germany and England, London, 1914.

*Davis, W. S., Roots of the War, New York, 1918.

Dawson, W. H., Evolution of Modern Germany, New York, 1914. 
"Fried, A. H., "Fundamental Causes of the World War," in International Conciliation, No. 91 (June, 1915).

Gibbons, H. A., New Map of Europe, New York, 1914.

*Headlam, J. W., History of Twelve Days, London, 1915.

*Loreburn, Earl, How the War Came, as cited, above, \$9.

Modern Germany in Relation to the Great War (trans. by Whitelock, W. W.), New York, 1916.

*Schmitt, B. E., England and Germany, Princeton, 1916.

Scott, J. B. (ed.), President Wilson's Foreign Policy, New York, 1918.

* Seymour, entire.

Stoddard, T. L., and Frank, G., Stakes of the War, New York, 1918.

Stowell, E. C., Diplomacy of the War of 1914, Boston, 1915.

Woods, H. C., Cradle of the War: Near East and Pan-Germanism, Boston, 1918.

b. Plans for the Settlement and a League of Nations.

Angell, N., America and the New World State; a Plea for American Leadership in International Organization, New York, 1915.

Barker, E., Confederation of the Nations, Oxford, 1918.

Bassett, J. S., Lost Fruits of Waterloo, New York, 1918.

Bourne, R. S. (comp.), Towards an Enduring Peace, New York, 1916.

Brailsford, H. N., A League of Nations, 2nd ed., London, 1917.

Buxton, C. R. (ed.), Towards a Lasting Settlement, London, 1916. Bryce, J., and others, Proposals for the Prevention of Future

Wars, London, 1917.

Carnegie Endowment for International Peace, Division of International Law, Peace Proposals, 1916-1918, being Pamphlet No. 31 of the Division, Washington, 1920.

Clark, J. B., "Existing Alliances and a League of Peace," in International Conciliation, Special Bulletin, (July, 1915).

Clark University, Problems and Lessons of the War, New York, 1916.

Corbett, J., League of Nations and Freedom of the Seas, New York, 1918. 
Cosmos (pseud.), Basis of a Durable Peace, New York, 1917.

Crozier, A. O., Nation of Nations, Cincinnati, 1915.

Dickinson, G. L., Choice before Us, London, 1917.

- (ed.), Documents Relating to Peace Proposals and War Aims, London, 1919.

- The European Anarchy, London, 1916.

- (ed.), Problems of the International Settlement, New York, 1919.

Eliot, C. W., Road Towards Peace, new ed., Boston, 1915.

Erzberger, M., League of Nations (trans. by Maill, B.), London, 1919.

Fayle, C. E., The Great Settlement, London, 1915.

Garvin, J. L., Economic Foundations of Peace, London, 1919.

Giddings, F. H., "Bases of an Enduring Peace," in International

Conciliation, No. 113 (April, 1917).

Henderson, A., League of Nations and Labor, New York, 1918. Hill, D. J., Rebuilding of Europe, New York, 1917.

Hobson, J. A., Towards International Government, New York, 1916.

Houston, H. S., Blocking New Wars, New York, 1918.

Jastrow, M., War and the Coming Peace, Philadelphia, 1918.

Kallen, H. M., Structure of Lasting Peace, Boston, 1918.

Lange, C. L., Conditions of a Lasting Peace, Christiania, 1917.

Lawrence, T. J., Society of Nations, Past, Present, and Future,

New York, 1919.

Leroy, M., L'Ere Wilson; La Société des Nations, Paris, 1917.

Lippman, W., Stakes of Diplomacy, as cited, above, $\$ 9$.

Lodge, H. C., and Lowell, A. L., "Joint Debate on the Covenant of Paris," in A League of Nations, II, 49 (April, 1919).

Marburg, T. (ed.), Draft Convention for a League of Nations, New York, 1918.

Morrow, D. W., Society of Free States, New York, 1919.

Ollivier, S., League of Nations and Primitive Peoples, New York, 1918.

Otlet, P., Problèmes Internationaux de la Guerre, Paris, 1916.

Powers, H. H., The Great Peace, New York, 1918.

Smuts, J. C., League of Nations: A Practical Suggestion, New York, 1918.

Stallybrass, W. T. S., Society of States, New York, 1919. 
Taft, W. H., and others, "The Covenanter," in A League of Nations, II, 99 (June, 1919).

Tchéou-Weï, S., Essai sur l'Organisation Juridique de la Société Internationale, Paris, 1917.

Toynbee, A. J., The New Europe, New York, 1916.

Wells, H. G., In the Fourth Year. Anticipations of a World Peace, New York, 1918.

Withers, H., League of Nations: Its Economic Aspect, New York, 1918.

Woolf, L. S., Framework of a Lasting Peace, London, 1917.

World Peace Foundation, The Great Solution, by La Fontaine, H., Boston, 1916.

\section{c. The League as Created in $\mathbf{1 9 1 9 .}$}

"Comments by the German Delegation on the Conditions of Peace," in International Conciliations, No. 143 (October, 1919).

"Reply of the Allied and Associated Powers to the Observations of the German Delegation on the Conditions of Peace," in International Conciliation, No. 144 (November, 1919).

*Baker, R. S., "America and the World Peace," in New York Times, 1 January, 1922, and following (Sundays only), New York, 1922.

- What Wilson Did at Paris, New York, 1919.

Brailsford, H. N., The Covenant of Peace, New York, 1919.

Butler, Sir G., Handbook to the League of Nations, London, 1919. Fayle, C. E., The Fourteenth Point, London, 1919.

*Harley, J. E., League of Nations and the New International Law, New York, 1921.

Harris, H. W., Peace in the Making, as eited, above, §21.

*Institute of International Education, International Relations Clubs, Syllabus No. 1, being Outline of the Covenant of the League of Nations, by Manley, L. K., New York, 1920. Cited: Manley.

Kallen, H. M., League of Nations, Boston, 1919.

Marburg, T., League of Nations, New York, 1917-1919.

Pollock, F., The League of Nations, London, 1920.

Scott, A. P., Introduction to the Peace Treaties, Chicago, 1920. 
Taft, W. H., Papers on the League of Nations, ed. by Marburg, T., and Flack, H. E., New York, 1920.

*Temperley, II, 21-31.

United States, Senate, American Draft of the Covenant of the League of Nations, being Sen. Doc. 70, 66th Cong., 1st Sess., Washington, 1919.

- Comparison of the plan for the League of Nations . . . with the Covenant as finally reported and adopted. '. . at the Peace Conference, being Sen. Doc. No. 46, 66th Cong., 1st Sess., Washington, 1919.

- Composite Covenant made by the legal advisers to the Commission on the League of Nations, being Sen. Doc. 74, 66th Cong., 1st Sess., Washington, 1919.

- - Report of the conference between members of the Committee on Foreign Relations and the President, being Sen. Doc. 76, 66th Cong., 1st Sess., Washington, 1919.

\section{$\S 28$}

Establishment of the League of Nations and Resumption of International Government

*Fosdick, R. B., and others, League of Nations Starts, London, 1920.

League of Nations, Official Journal, London, 1920-.

- Treaty Series, London, 1920.

- First Assembly, Documents, Geneva, 1920.

- - Provisional Verbatim Record, Geneva, 1920.

- - Committees, Procès-Verbaux, Geneva, 1920.

*-Information Section, Monthly Summary, Geneva, 1921.

- International Financial Conference, 1920, Proceedings and Documents, Geneva, 1921.

*-Secretary-General, Report to the First Assembly on the Work of the Council, Geneva, 1921.

*Levermore, C. H., What the League of Nations has Accomplished in One Year, Brooklyn, N. Y., 1921.

Sweetser, A., First Year and a Half of the League of Nations, being Publication No. 1534 of the American Academy of Political and Social Science, Philadelphia, 1921. 
Sweetser, A., League of Nations at Work, New York, 1920. "Three Months of the League of Nations," in League of Nations, III, 1-96 (February-April, 1920).

\section{$\S 29$}

International Organization in 1921

League of Nations, Official Journal, *Monthly Summary, and Treaty Series, as cited in $\S 28$, above.

- Council, Minutes of Sessions (Twelfth and following), Geneva, 1921-.

- Second Assembly, Journal, Geneva, 1921.

- - Provisional Verbatim Record, Geneva, 1921.

- Secretary-General, Report to the Second Assembly on the Work of the Council, Geneva, 1921. 


\section{INDEX}

Adhesion and accession to treaty, 150-151

Alliances, device in opposition to empire, 401; definition, 402; relation to international federation, 402 . 403 ; objects, 403-405; offensive and defensive, 404-405; relation to balance of power, 405 ; legal obligations of, 405-406; membership, 406; European 1879-1911, 457458; competition produced World War, 458

Alphabet and alternate, 111

Ambassador-origin of term, 89.

Arbitral awards, sources of international law, 187; acceptance pledged in advance, 222 ; rejection rare, 222-223; void for excess of power, 223

Arbitral clause in treaties in Greece, 216

Arbitration, induced by good offices or mediation, 194; by commission of inquiry, 208; resorted to from defects of mediation, 211-212; is agreed mediation, 212; defined, 212 ; is judicial settlement, 212 213 ; early form of international government, 213 ; bases of decision specified, 213-214; foundation is consent of parties, 214 ; tribunalcomposition, 214; compromis d'arbitrage, 215; arbitration treaty, 215-217; arbitral clause, 216; obligatory arbitration, 217218; questions suitable, 218; honor and vital interests excluded, 218-219; position of third parties, 220-221; agreements for general arbitration, 221; public and private questions, 221-222; no appeal, 222; pledge to accept award, 222 ; rejection of awards rare, 222-223; award void for excess of power, 223 ; history of, 223-226; in ancient Greece, 223; in Roman period, among barbarians, among feudal states, and in Middle Ages, 224 ; in renaissance Italy, 224-
225 ; adopted in northern Europe, 225 ; retarded $1500-1800,225$; revival in nineteenth century, 225226 ; need of reorganization in $1899,226-228$; system set up at The Hague, 229, 232-234; by summary procedure, 233; nature of opposition to, 236-237; by administrative bureaus, 278; needed to maintain peace, 368-369; under League of Nations, 472

Arbitration treaty, form of treaty, 163 ; place in arbitration, 215-217; in Greece and Rome, in Middle Ages, and in modern times, 216; general, 216-217; relation to Hague court, 234

Assembly of League of Nations, position in league, 469; equality and unanimity, 469 ; functions, 471 ; position in league, 490-491; delay in ealling in 1920, 491; relations to council in 1920, 491-493; composition, sessions, and organization of first, 493-494; publicity of meetings, 494-495; scope of work in 1920, 495-496; election of members of council in 1920, 500; election of new members of league in 1920,496 ; verdict on work in 1920 , 496 ; activities in 1921, 503-508; organization in 1921, 503-504; work in 1921, 504-508; suggested changes in covenant in 1921, 504-505; relations of council in 1921, 505-506; ineffectiveness of in 1921, 506; elections of members of permanent court of justice, 506-507; elections of new members of league in 1921, 507 ; importance of work in field of organization in 1921, 507-508.

Balance of power, relation to alliances, 405; definition, 406-407; as law, as policy, and as deseriptive science, 407 ; forms of, 408409 ; general equilibrium, 409 ; history of, 409-416; in Greece and Rome, 410; in Middle Ages, 411; 
renaissance Italy, 411; modern Europe, 412-416; partition as a device for, 414-415; partition of Poland, 414-415; development into holy alliance and concert of Europe, $415-417,422-423$; threats against in $1815-1830,418-419$; feasibility of maintaining, 418 . $421,424-426$; reconciliation with progress, 421-422; basud on generalization of interest, 426-428; worst form of in 1879-1914, 458; not in covenant of league, 463464

Barbarians, invasions, 38 ; state system, 38-39; interstate practices, 39; diplomacy among, 85; arbitration among, 224

Calvo treaty collection, 159

Capitulations, basis of consular jurisdiction, 67 ; basis of exterritoriality, 164 ; military, 164

Cipher writing as aid to diplomacy, 92-93

Collections of treaties, official, 157159 ; private, 157-160; Du Mont, 157-158; Wenek, Martens, 158159 ; Malloy, Calro, special, 159

Colonial territorities opened to international use, 431

Commercial imperialism, 434-435

Commercial revival (1200 and follow. ing), caused by crusades, 43 ; character, 44-46.

Commission of inquiry, theory of, 205-206; a true international organ, 206; description of, 207; origin in mixed commission, 207; function of, 207 ; leads to settlement on merits, 207-208; may act as arbitral tribunal, 208; history of organization, 208-209; reorganized at The Hague, 208-209; improved form used by United States, 209

Compromis d'arbitrage, form of treaty, 163; place in arbitration, 215

Concert of Europe, origin, 422-423; history, 423; reasons for success and failure, 423.424; activity in maintaining equilibrium, 425; based on generalization of interest, 426-428; means of control, 428 . 432; guarantee by, 429.430; creation of status by, 430.432 ; failure in 1860-1914 (causes), 432-436,
456-458; nationalism as obstacle to, 433; commercial imperialism as obstacle to, 434-435; democratic imperialism as obstacle to, 435; pan-nationalism as obstacle to, 435-436

Concordats, 167

Consolate del Mare, origin, 66-67; character, 67 ; spread to northern Europe, 68

Consular body (corpsi), 117-118

Consular conventions, 77

Consular districts, 73

Consular fees, 75

Consular law, 77-78

Consular services (national), possible union with diplomatic, 108; not coördinated with diplomatic, 128

Consular system origins, 63-68; Greek, 63-64; Mediterranean city. states, 64-68; Northern European, 68 ; decline in early modern times, 69 ; modern significance of, 83 ; $\mathrm{re}$ sumption of activity in 1920, 497; expansion in $1921,509$.

Consuls, earliest, 64-68; elective early, 66 ; sent out from home, 64, $65,68,69$; universal use of, 71 ; stationed in commercial centers, 72; qualifications and selection of, 72 ; classes, $72-73$; districts, 73 ; hierarchy and control, 73-74; relations to diplomats, 74 ; paid by salaries, 74-75; fees, treatment (promotion, retirement, pensions), 75; merchant consuls and native consuls, 76; commission and Exequatur, 77; law governing, 77-78; duties and powers, 78-81; judicial work in early times, 65.68 ; diplomatic work in modern times, 79-80; judicial work, 80.81 ; immunities and privileges, 81 ; literature (professional), 81.82; termination of office, 82-83; diplomatic position in early times, 90 ; work contrasted with diplomacy, 123-124.

Convention, treaty form, 163; ad. ministrative union, 281 .

Cosmopolitanism, definition, 14, 302; relations to international organization, $14-16,302$; relations to $\mathrm{na}-$ tional state, $14-16$; relations to empire, 14-16; history of, 16-17, 303307 ; future of, 18-19; under Rome, $31,302-304,303,304-305$; medieval, 17, 302-303, 305; modern, 302 314, esp. 307-314; infra-imperial 
type, 303 ; Greek, 304 ; destruction of in 1250-1550, 305-306; eighteenth contury, 306-307; religion as basis today, 307; laws as basis today, 307-308; economic and seientific basis, 308-309; historic causes for modern, 309 ; manifestations in law and government, 309313 ; concurrent national legislation, 310-311; capital and labor, 312-313; significance and prospects, 314 ; reaction toward (from nationalism), 433.

Council of League of Nations, positions in league, 469 ; equality and unanimity, 469 ; functions, 469 . 470; first meeting called and held, 479-484; significance, 484; sessions in 1920, 485; scope of work in $1920,486.490$; work in organization and administration in 1920 , 486-488; creates subordinate bodies in $1920,486-487$; relations of organs to sections of secretariat, 487 ; political work in 1920,488 489 ; significance and danger of political work, 489 ; humanitarian work, 490 ; relations to assembly in 1920, 491-493; elections of ro. tating members in 1920,500 ; activities in 1921, 499-503; increased publicity in 1921, and election of members in 1921,500 ; scope of work in 1921, 500-502; verdict upon work of, 502-503; relations to assembly in $1921,505.506$; elections of members of permanent court of justice, 506-507.

Court of Arbitral Justice, Draft Convention, provided obligatory jurisdiction, 241; composition of bench, 253-255.

Covenant of League of Nations, procedure in drafting, 461-463; adopted (signed and ratified), 463 ; balance of power, $463-464$; concert of power, 463-464; main outlines of, 466-476; variations from original plans, 472; influence of United States, 472-473; penalties in, 473 . 474; not real test of power of league, 475; comprehensive system of institutions, 475-476; proposed changes in 1921, 504-505.

Credentials, General, 112; international conferences, 329 ; peace conferences, 344; neglected in Peace Conference of Paris, 353.
Crusades, stimulated commercial revival, 43; promoted national unity, 53 ; produced consular system, 64-67.

Declaration (treaty form), 163.

Democratic imperialism, 435.

Diplomacy, meaning of term, 100101, 114; foreign policy and, 101; foreign affairs (relations) and, 101; foreign office and, 101-102; methods of work, 113; style and ceremony, 113-114; documentary composition, 114; language of, 115-116; criticism of, 123-137; contrast with consular practice, 123-124; secrecy intensifies criticism, 124-125; criticised for foreign policies, 125-126; private influences in, 129, 136; popular responsibility for, 133-137; secrecy of and how far necessary, 133-134; tendencies regarding secrecy, 134; public (results of), 134-136; secrecy imperfect, 135-136; partisanship in, 137; failure produces international dispute, 193 ; may settle international dispute, 193; relation to good offices and mediation, 194 ; relation to international conference, 317-318; carried forward under League of Nations, 471.

Diplomatic agents, immunities and privileges early, 95-96; recruitment, 103-108; qualifications, 104 106; changing functions of, 106; rule of personal acceptability, 107 ; aliens as, 107-108; classification and ranks, 108.112; rank and its significance, 109-110; reciprocity of rank, 110; tendencies regarding rank, 111; alphabet and alternat, 111 ; credentials, full-powers, instructions, 112 ; functions, 112.113; methods of work, 113-116; negotiation, 113; style and formality, 113-114; documentary composition, 114 ; language, 115-116; diplomatic corps, 116.117; immunities and privileges, 118, 120-121; agreements for exchange of, 119-120; personal inviolability, and basis of immunities, 120; right to grant asylum, 120-121; termination of mission, 122; unrepresentative, 126 ; incompetent, 126.127 ; negotiate treaties, 143 ; full powers to negotiate treaties, 143-144. 
Diplomatic corps, composition, dean, functions, 116-117.

Diplomatic precedence-early contentions regarding, 94-95.

Diplomatic services (national), possible union with consular, 108; badly organized, 127-128; reforms in recruitment possible, 131. 132.

Diplomatic settlements as sources of international law, 187.

Diplomatic system, origin later than consular, 64; drew strength from consuls, 69-70; Greek and Roman, and among barbarians, 85 ; feudal, 86; Holy Roman Empire, 86-87; Papal, 87-88, renaissance Italian, $88-89$; origins of modern, $88-90$; Northern Europe adopts, 89-90; eauses for establishment, 91, 93; American experience, 92 ; auxiliary services, 92-93; development in $1450-1650,93$; code of procedure early, 93.95; early law regarding, 95-96; development since 1650,97 . 99 ; of Louis XIV, 97; eighteenth century, 98; modern-significance of, $98-99,118$; resumption of activity in 1920, 497; expansion in 1921, 509.

Disarmament, as means of peace, 369-370; relative effect on different states, 370; unacceptable to states, $370-371$; difficult to apply in degrees, 371 ; means of computing, 372 ; need of conference to operate, 373-374.

Du Mont treaty collection, 157-158.

Empire, definition, 14; relations to international organization, to cosmopolitanism, to national state 14-16; history, 16-17; Macedonian, 27-28; Roman, 29-31; Medieral, 34-36; modern history, 396-401; opposed by alliances, 401, 412-416; reaction toward (from nationalism), 433.

Equality of states, International Prize Court, 243; Court of Arbitral Justice, 253-255; comment upon, 253-255; left unsettled in permanent Court of Justice (League), 260-261; in international administrative bureaus, 285 287 ; in international conferences, 332; Hague Conferences, 333; peace conferences, 344 ; Peace Con- ference of Paris, 347; in Assembly and Council of League, 469.

Exchange of ratifications, 150 .

Executive agreements (treaty form), $164,165$.

Feudal state-system, origin and form, 38,40 ; diplomacy in, 85 ; international law of, 179 ; influence on international law, 182; arbitration, 224.

Final Act (treaty form), 165-166.

Foreign affairs (relations), relation to diplomacy, 101.

Foreign Office, relation to diplomacy, 101-102; functions of, 102-103; criticised for isolation, 128-129, 130 ; subject to private influence, 129.

Foreign policy, relation to diplomacy, 101 ; causes criticism of diplomacy, 125-126.

"Full powers," given diplomatic agents, 112; for treaty negotiation, 143-144; pledge ratification of treaty, 144 ; limit scope of treaty, 152; international conferences, 329 ; peace conferences, 344 .

General Conference (Labor Organization), created, 468; established, 480 ; first meeting, $480-481$; meetings in 1920, 484; meetings in $1921,499$.

Germany, Opposition at The Hague in 1899 and 1907, 230-236-237; requested mediation of United States to secure peace conference 1918, 345-346; excluded from oral discussions in Peace Conference of Paris, 348-350; development in modern Eurpoe, 400-401, 457; modern imperialism in, 434, 436, 457; excluded from League, 463 .

Good Offices, relation to diplomacy, 194 ; pave way for arbitration, 194195; distinguished from mediation, 194, 195-196; occasions for and objects of, 195; described, 196; international mandate exists, 197; develop into mediation, 197198 ; organization-history of, 203205; under suspicion early, 203; recognized as legitimate, 203 ; reorganized at The Hague, 204-205; still wholly voluntary, 205.

Governing Body (Labor Organization), established, 480-481. 
Great Schism, 49; Greeco (ancient), state-system, 24-25; interstate practices, 25-26; imperial movements in, 26-29; excessive independence of states, 27-29; Macedonian conquest of, 28; Roman conquest of, 29 ; nationalism in, 52 ; consular system, 63-64; diplomacy, 85; international law, 179 ; arbitral clause and arbitration treaties, 216; arbitration, 224; balance of power, 410; interstate federation, 441-442.

Grotius, on diplomatic representation, 96 ; position in history of international law, 186.

Hague Conferences, good offices and mediation reorganized, 204-205, 228; commission of inquiry reorganized, 208-209; task regarding arbitration, 228 ; system of arbitration created, 229, 232-234; failed to provide obligatory arbitration in 1899, 229-230; bureau of arbitral union, 230-231; signifcance of work regarding arbitration in 1899, 231; Second Conference (1907) plans of, 231; Second Conference (work), 232-233; genoral, 333-335; calling, program, members, scope of action, sessions, committee, experts, unanimity requirement, equality of states, 333 ; results put in treaty form, 334; significance of, 334 .

Hague Court, ereation of, 229; bureau of, $230-231$; significance, in 1899,231 ; reorganized in 1907, 232 ; procedure reformed in 1907, 232-233; summary of the system, 233-234; place in history of arbitration, 234-235; growth in power 1899-1907, 235; criticism of, 238 240; attempted reforms, 240-242; connected with proposed Prize Court, 244.

High Seas, international status of, 431.

Holy Alliance, origin, 417 ; criticism, 417-418; means of control by, 419 421; legitimacy of interventions by, 421.

Holy Roman Empire, creation, 36; theory, 37; struggle with the church, 46-47; diplomacy of, 8687; mediation by, 202; cosmopolitanism under, 17, 305.
Interim commission (administrative union), 281.

International administrative bureau, new type of international institution, 269; theory, 269-270, 282; relation to private internationalism, 270 ; bureaus existing in 1915,270 ; history of growth, 271-273, 279280 ; subjects dealt with, 272-273; cause for creation, 269-270, 273274, 284; functions, 274-280; arbitration by, 278; structure, 280-282; union or confederation, 280 ; convention, interim commission, regulations, 281; directing government, 282 ; non-political character, 283 284 ; supported chiefly by laymen, created from private bodies, 284285 ; attitude of diplomats and laymen, 285 ; state equality in, unauinity requirement, $285-287$; success and failure, 287-288; to be gathered under League, 471 ; resumption of activity in 1920, 497.

International administrative union, 280.

International conference, importance as an international institution, 317, 334; definition, course of development, relation to diplomacy, 317 318 ; treaty concluded by, $318,325-$ $326,332-333$; form of results, development into legislation, 318-319; subjects, $319,323-325$; terms "congress" and "conference," 319 320 ; peace conference and conference in time of peace, 320 ; origin and development of conference in time of peace, $320-323$; changes in subjects, 323-325; meet only on invitation, 327 ; advantages of state calling, 327-329; organization and methods, 327-333; attendance voluntary, 328; composition, 329 ; internal organization, officers, committees, 329-330; credentials, full powers, 329 ; sessions, 330 ; debate, $330-331$; voting, unanimity requirement, 331-332; equality of states in, 332 ; results, significance, 332 333; Hague Conferences, 333-335; peace conferences, 336-356 ; continuous conference needed, 367-368; meetings in 1920, 497; meetings in 1921, 509.

International dispute, result of failure of diplomacy, may be settled by diplomacy, 193; causes need for 
new methods, 193-194; value of war in settling, 361-362; bearing of war on merits, 362 .

International expositions, 296-297.

International federation, leading type of international organization, 19; plan of study, 19 ; administrative union, 280 ; as foundation for peace, 369 ; needed to coördinate international institutions, $379-380$, 389 ; juristic problems involved, 380 ; unanimity necessary in ereating, 390; unanimity not necessary in operation, 391-392; permanent, 392-395; permanence dependent on state sovereignty, 394395 ; motives of opposition, 395 ; relation to alliances, $402-403$; plans, 438-441, 451-455; motives for plans, $438-441,450,451,453$; history, 441-444; United States example, 442-444; Theory, 444-451; proper grounds, 444-445; develops gradually, 445-446, 448-449; stages in development, 446-447; distribution of powers, 448-449; conflicts of jurisdiction, 449-450; amendment and withdrawal, 447-448; characteristics of early plans, 454; bases of plans, $451-454$; later plans better balaneed, 455 .

International institutions, types, 5-6, 63 ; judicial, 5-6; executive, 6; legislative, 6-7; personal agents, 63 ; commission of inquiry, 205. 209 ; court of arbitration, 212-265; administrative bureau, 269-288; administrative union, 280 ; interim commission (Administrative union), 281; international conference, 317-356; conference in time of peace, 317-336; conference a legislative body, 318; peace conference, 336-356; need for co. ordination by federation, 379-380, 389 ; alliances, $402-406$; all necessary types in League, 475-476.

International intercourse, defined, 4; among Greek states, 24-25; in Mediterranean area (early), 29.

Internationalization, type of international status, 431; develops from neutralization, 432 .

International Labor Office and Director, created, 468; established, $480-481$; relations with SecretaryGeneral and League, 481; headquarters (London, Washington and
Geneva), 481-484; activities in 1920, 484; activities in 1921, 499. International Labor Organization, ereated by Treaty of Versailles, 468; established in June-October, 1919, 480-481; Governing Body, General Conference, International Labor Office and Director, 480 ; relations to League, 481, 484, 499; activities in 1920, 484; activities in $1921,499$.

International Law, defined, 4; early maritime codes, 66-67; consular rights and duties, 77-78; early diplomatic law, $95-96$; law of modern diplomacy, 118-122; regarding treaty obligations, 152.153 ; treaty must conform to, 153; seen in treaties, $156-157,172$, 187 ; relation of treaties to, 176-179; declared by legislative treaties, 177 , 190; inferable from treaties, 177, 187 ; treaties making exceptions, 177-178; in Greece and Rome, $\mathrm{Me}$ dieval, 179; origin and development, 179-190; oriental, 180; influences producing (early), 180 . 181; Roman (eivil and canon) law and commercial law in, 181; historical sources, 181-183; feudal law in, 182; influence of state practice (early), 182-183; justice and, 183 ; theory of sources, 183 184; place of state practice in, 184; philosophical and positivist sehools 184-186; position of Grotius, 186; documentary sources, 187 ; scope, 187-188; and international organization, 188 ; codification, 188-190; official codes, privato codes, 189; codified in international conferences, 189-190; codified by treaty negotiation, 190; vagueness kills Prize Court Convention, 247-249; difficulty of formulating, 257-258; legislation by conference, 318; deficiencies cause of war, 363-364; binding force of, 386 ; regarding alliances, 406 ; on intervention, 419-420.

International organization, defined, 3, 5 ; conditions prerequisite, 7-12; relations to empire, to cosmopolitanism, to national state, 14.16; international federation and, 19 ; barbarians, 39 ; Greek, 25-26, 6364; national constitutional obstacles, 252; relation to peace, 357 . 
375, esp. 360 ; Monroe Doctrine, relation to, 436-437; character of morement in 1921,498 ; status at end of 1921 and relation to League and Washington Conference, 509510.

International Prize Court Convention, provided obligatory jurisdiction, 241 ; plan, 243-247; composition of bench, $243-244$; connected with Hague Court, 244; procedure, 244 ; jurisdiction, 244-245; basis of adjudication, form of decision, 245 ; individuals before, 246 ; failure of ratification, 247-251; loss and gain by failure, 250; protocol revising terms, 251.

International rights, definition and enforcement as means to peace, 364; definition bnckward heretofore, $364-365$; adjudication backward heretofore, 365-366; enforcement backward heretofore, 366 ; international federation needed to protect, 366-367.

International rivers and canals, status of, 431.

Intervention, principal agency of Holy Alliance, 419; legal status, 419-420.

Italy, primitive state system, 29; Roman conquest, 30 ; consular activities of Medieval cities, 64-68; renaissance diplomacy, $88-89$; arbitration in Renaissance period, 224-225; balance of power in $\mathrm{Re}$ naissance period, 411.

Judicial settlement, international, forms, 194; value, 194, 247-249, 256-258; not prominent in covenant of League, 255-256.

Law-making treaties, contrasted with other treaties, 168-169; examples, 169 ; increasing in number, 169170 ; tend to be multilateral, 170 ; make international law directly, 177,190 ; codifying international law, 190.

League of Nations, Court of Justice, 258-265; plans for, 461; motives for formation, 456; need for, as revealed in 1862-1914, 456-458, 461; procedure in drafting covenant, 461:463; no balance of power and no concert of power in, 463-464; exclusion of states weakens, 464; advisability of creating in 1919 , 464-465; not wholly a league of vietors, 465-466; membership, 466467 ; withdrawal, 467-468; organs, International Labor Office, Council (structure), 468; assembly (strueture), voting, secretariat, 469 ; functions of council, 469-470; assembly (functions), administrative bureaus and, 471; diplomacy and treaties under, 471-472; arbitration under, 472; real test of power not in Covenant, 474; equipped with all essential institutions, 475-476; need of constant reorganization, 476; relations to International Labor Organization, 481-484; buildings and publications in charge of Secretariat, 483; publications, 483-484; election of new members in 1920,496 ; status in 1921, 498; election of new members in 1921, 507; status at end of 1921 , and relation to Washington Conference, 509-510.

Malloy Treaty collection, 159 .

Mandate system as type of internationalization, 431.

Maritime codes (commercial law), origins, 66-67; contributed to form international law, 181.

Martens treaty collection, 158-159.

Mediation, induces arbitration, 194195; distinguished from good offices, $194,195-196$; relation to diplomacy, 194 ; occasions, 195 ; objects, 195, 203; described, 196197; rôle of mediator, 196-197, 198-203; international mandate exists, 197; grows out of good offices, 197-198; grounds for action in substance, 199-200; no compulsory jurisdiction, 200, 202, 203 ; grounds for (formal), 200-203; by request of parties, or on initiative of mediator, 201; in case of eivil war, 202; history, 202-205; object peace rather than justice, 203, 210; under suspicion early, 203; organization (history of), 203-205; recognized as legitimate, 204 ; reorganized at The Hague, 204-205, 228; still wholly voluntary, 205; shortcomings lead to arbitration, 210-211; agreed mediation is arbitration, 212.

Merchant consuls, 76. 
Middle Ages, state-system, 33, 35-36, $37,38-41$; imperial theory, 34,36 38 ; imperial states, $35-36$; feudal states, 38-41; diplomacy, 86-87; international law, 179; arbitration treaties, 216; arbitration, 224; balance of power, 411 ; interstate federation, 442.

Mixed commission, produced the commission of inquiry, 207; arbitrates private claims, 222.

Monroe Doctrine, relation to international organization, $436-437$.

National honor, question excluded from arbitration, 219; decreasing sensitireness concerning, 219.

Nationalism, conflict with the church, $48-49$; origins, $51-53$; in antiquity, 52 ; obstacle to Concert of Europe, 433; reaction against, 433-434; part in bringing on war in 1914, 434.

National languages adopted in diplomacy, 93.

National law, relation to treaties, 172-176.

National Parliaments, indifferent to international questions, 130 ; badly organized for control of diplomacy, 131; need for watchfulness by, 132-133.

National sovereignty, supposed conflict with international federation, 380 ; doctrine must be met and satisfied, 381 ; not violated in diplomatic settlements, 381-382; not violated in treaty imposed by force, 382-383 ; considered intact by general opinion, 383,392 ; must go to source of obligation for test, 383 , 393 ; case of treaty previously concluded, 383-385; protected by rebus sic stantibus, 384,392 ; violation of treaty leaves rights intact, 385 ; binding foree of international law no violation, $386-387$; not violated in arbitration, nor in international administration, 388 ; not violated in international conference, 389 ; no obstacle to international federation, 389; Constitution of United States, 392; surrender distinguished from violation or loss, 393 ; not lost by pledge not to make peace, 394; motives of supporters, 395.

National states, definition, 13-14; re- lations to international organization, to empire, to cosmopolitanism, $14-16$; victory over the church, 4849 ; origins, $50-51$; development of in 1200-1500, 53-56; aided by crusades, 53; later developments, 56 58 ; list of, as of $1921,58-59$.

Native consuls, 76.

Negotiation, nature of, 113 ; with eneny states excluded at Peace Conference of Paris, 354-355.

Neutralization, type of international status, 430-431; becomes internationalization, 432 .

Obligatory arbitration, described, 217-218; special agreement still necessary, 217-218; not provided by Hague Conference in 1899, 229 230; nature of opposition in 1899 and 1907, 230, 236; opposition of Allies in 1920, 237-238; provided in connection with contract debts, 240-241; provided in plan for International Prize Court, 241, 245, 251 ; provided in plan for Court of Arbitral Justice, 242; Permanent Court of Justice (League), 261-265.

Organization Committee (League), created, 479; work in May-December of $1919,479-480$; relations to Secretary-General, 479-480.

Orient, consular practice (early), 65, note 1 ; international law, 180.

Partition of Poland, characteristic of eighteenth century diplomacy, 98; and balance of power, 414-415; judgment upon, 415, 418.

Pan-nationalism, 435-436.

Peace, relation to international organization, 357-375, esp. 360 ; nature of and relation to war, 357358 ; does not exclude use of force, 358 ; negative type, 357, 358-359; defined, affirmative type, 360 ; relation to termination of war, 360 361 ; means resumption of pre-war relations, 361,363 ; founded on definition and enforcement of international rights, 364 ; continuous conference necessary, 367-368; arbitration by prior agreement necessary, 368-369; international organization necessary for, 369 ; possibility of by disarmament, 369-370; literature, 357, 369-370; conclusion 
regarding means of attaining, 374375.

Peace Conference of Paris, 1919, circumstances of meeting, 345-346, 347-349; membership, 346; voting power, 346-347; Great Powers in, 346-347 ; unanimity requirement, equality of states, 347 ; exclusion of enemy states from oral discussions, $348-350$; organization and procedure, $350-353$; sessions, 351 ; committees, 351-352; Power of President, 352; secretariat, credentials neglected, 353 ; publicity, 353-354; "discussions", with enemy states, 354 ; explanation of attitude regarding negotiation, 354 355; why treaty form used, $354-355$; objects how accomplished, 355; verdict regarding, 356.

Peace conferences, atmosphere bad, $321-322,340-341,344,362$; origin, 336 ; necessity for, $336-337$; history, 337-338; increase in membership, 338-339; recent changes in, 338-341; increase in scope of action, 339-340; decrease in number, 340-341; circumstances of meeting, $341-342$; organization and procedure, 341-345; membership, 342; jurisdiction, $342-343$; authority orer parties, 342-343; dictated settlement, 343 ; credentials, fullpowers, equality of states, unanimity ruled, officials, sessions, com mittees, treaty form used for results, 344 ; compared with conferences in time of peace, 344-345; Peace Conference of Paris in 1919, 345-356; bases of decisions, 362 363.

Permanent Court of Justice (League of Nations), opposition to compulsory jurisdiction, 237-238; created, 258-259 ; composition of bench, 259 261 ; equality of states unsettled, 260-261; bases of decisions, 261; jurisdiction, 261-265; obligatory jurisdiction planned, 262-264; jurisdiction mainly voluntary, 264; obligatory jurisdiction for some states, 265 ; comment on as finally created, 265 ; elections of members in 1921, 506-507.

Permanent embassies, 90, 91, 93, 96.

Personal inviolability of diplomats, among the barbarians, 85 ; in feu- dal period, 86; seventeenth century, 95; modern, 120.

Personality of law, relation to consular system, 66; disappearanceeffect on consuls, 69

Philosophical school of jurists, 184186.

Political independence, guarantee of, 430.

Positivist school of jurists, 184-185, 186.

Postal services as aid to early diplomacy, 92.

Private international associations, general status and numbers, 289 ; history, 289-290; meetings, 290291 ; varieties, 291 ; forms, 291293 ; capitalists and laborers, 292 293 ; interests and programs, 294296, 297-301; international expositions, 296-297 ; armament rings, 298-299; revival of activity in 1920-1921, 299-300, 497; constitute modern cosmopolitanism, 302 .

Protectorates, 436.

Protocol (treaty form), 164.

Ratification of treaty, treaty negotiated subject to, 143; pledged in "full-powers," 144; universality of practice, 145 ; provided by national constitutions, 145-146; theory, 146; significance in control of diplomacy, 146-147; obligation, 147; grounds of refusal, 147-148; provision for in text, 148-149; reservations upon, 149-150.

Reformation, effect on the church, 49 , 50.

Reservations to treaty, 149-150.

Right of legation, 118-119.

Roman Catholic Church (Papacy), establishment, 34, 35-36; theory of (Medieval), 37; struggle with the empire, 46.47; struggle with national states, 48-49; Great Schism, 49 ; reformation, $49-50$; diplomacy, 87-88; mediation by, 202.

Roman law, eontributed to form international law, 181.

Rome, conquests begun, 29-30; maturity of the Empire, 30-31; state autonomy under, 31 ; cosmopolitanism under, 31; disruption of the Empire, 31-32; nationalism in, 52; diplomacy, 85; international law, 179 ; mediation by, 202; arbitration treaties, 216; arbitration un- 
der, 224; balance of power, 410 ; interstate federation, 442.

Secretariat, international conferences, 329 ; peace conferences, 344 ; Peace Conference of Paris 353; League of Nations. See Secretary-General.

Secretary-General (League Secretariat), named, 479; activities in 1919, 479-480; plan for sections in Secretariat, 480 ; relations with International Labor Office, 481, 484; activities in 1920, 481-482; sections of Secretariat, $482-483$; staff, 483 , 498-499; charge of building and publications of League, 483 ; status in League and expansion in 1921, 498-499.

Sources of international law, historical, 181-183 ; philosophical, 183184 ; documentary, 187-188.

State equality, see Equality of states.

State practice, early influence on international law, 182-183; true relation to international law, 184.

States, plurality of necessary, 7; multiplicity of desirable, 7-9; equality desirable, 8,11 ; variety among desirable, homogeneity among desirable, 9 ; stability of desirable, 10-11; Territorial possessions necessary, 11-12; political character necessary, 12; contact among necessary, 12-13; excessive independence of Greek, 27-28, 29.

State-system, Greek, 24-25; early Italian and early Mediterranean, 29; Medieval, 33-41; barbarians, 38 ; modern-origin, 46-56; modern-derelopment, 56-58; modern -form, 58-59.

Status, creation of as device for international control, and varieties, 430-432; territorial integrity, political independence, 430 ; neutralization, 430-431; internationalization, colonial territories, mandate system, high seas, international rivers and canals, 431.

Supreme Council (Inter-Allied), organization and purpose in 1917, 348 ; work in connection with armistice and Peace Conference, 348; meetings in 1920, 497; meetings and loss of prestige in 1921, 508.
Territorial integrity, guarantee of, 430.

Treaties, results of treaty negotiation, 156; exhibit international law, 156-157; collections, 157-160; total numbers, 157-160; classification by form, 160-161, 163-165; executive agreements, 164,165 ; with native tribes, 166 ; concordats, 167 ; classification by subject matter, 167-171; bilateral and multilateral, 170; gencral treaties increasing, 170 ; significance of treaty nexus, $170-171$; relation to national law, 172-176; need legislation for effectiveness, 172-173, 174; need application by national officials, 173-174; position in national courts, 174-176; relation to international law, 176-179; declaring international law, and as evidences of same, 177 ; creating exceptions to international law, 177-178; parties decisive for legislative value, 178 179; codifying international law, 190 ; arbitral clause in, 216 ; of alliance, 405 .

Treaty, objects, 142; concluded by diplomats, 143; negotiated ad referendum, 143; ratification (see), 143-149; exchange of ratifications, 150 ; effect on non-signatories, 150 152 ; adhesion and accession, 150 . 151; scope must conform to fullpower, 152; must conform to international law, 153; modes of obsolescence, 153-155; fulfillment of terms, or expiration of period, 153 154; revision and renewal, or denuuciation, 154; formal definition, 154-155, renunciation, 155 ; analysis of text, 160 ; procedure in concluding, 161-163; concluded in conference, 318 ; form used in results of Hague Conferences, 334; form used in results of peace conferences, 344; why form used at Peace Conference of Paris, 354355 ; basis of alliance, 405 .

Treaty-making power, concept, 146.

Treaty negotiation, development from personal diplomacy, 141.142; objects, 142; approximates legislation, 143 ; by diplomatic agents, 143 ; subject to ratification, 143 ; special full-powers for, 143-144; by special commissioners, 144-145; scope of concept, 145; range of 
subjects, 146; duress and fraud forbidden, 152-153; resultant treaty nexus, 156; procedure in concluding, 162-163; codification of international law, 190; carried forward under League of Nations, 471; resumption of activity in 1920, 497; expansion in 1921,509 .

Treaty of guarantee, used by Concert of Europe, 429; character and value, $429-430$; objects to which applied, 430-432.

Treaty of Versailles, procedure in drafting, 345-355; Covenant of League in, 463; International Labor Organization, 468; ratified and ratifications exchanged, 479 ; effect of delay in ratification, 480 .

Unanimity requirement, international administrative bureaus, 285-287; international conferences, 331-332; Hague Conferences, 333; peace conferences, 344; Peace Conference of Paris, 347 ; in creating international federation, 390-391; not neccssary in operation of same, 391-392; in Assembly and Council of League, 469.

United States, diplomatic history, 92; personal acceptability of diplomats, 107; diplomatic rank, 111; diplomatic costume, 113 ; control of diplomatic appointments, 131; adhesion to rules of Declaration of Paris, 151; executive agreements, 164-165; Indian treaties, 166; mediator between Germany and Allies, 199; attitude on Prize Court Convention, 249 ; mediation be- tween Russia and Japan, 197-198, 201-202; resented mediation in Civil War, 202; improved form of commission of inquiry, 209 ; aid to development of arbitration, 225226 ; part in convening Peace Conference of Paris and rôle in same, 345-346; state sovereignty and the constitution, 392 ; example of interstate federation, 442-444; influence on Covenant of League, 472-473.

Vital interests, question excluded from arbitration, 219-220 ; decreasing concern over, 220.

War, nature and relation to peace, 357-358; literature, 359-369; termination of, relation to peace, 360 361 ; value in settlement of disputes, 361-362; legal status of, 361-362 ; bearing on merits of dis. pute, 362 ; causes and deficiencies of international law as eause, 363 . 364.

Washington Conference (1921-1922), significance and relation to League and international organization in general, 509-510.

Wenck treaty collection, 158.

World War, product of competition of alliances, 458 ; attempts to prevent by international reorganization in $1890-1914,458-459$; stalemate in 1914-1918, 459-460; United States entry, 460; conclusion in Allied success, $460-461$; as prelude to formation of League, 461 . 


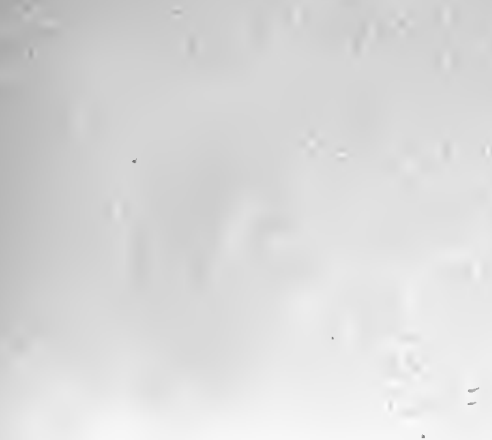

$+$ a

t. 


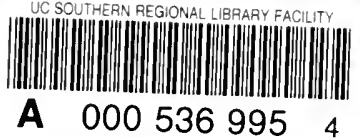


